\title{
Deaminative Chlorination of Aminoheterocycles
}

\author{
Clément Ghiazza, ${ }^{1}$ Teresa Faber, ${ }^{1}$ Alejandro Gómez-Palomino, ${ }^{1}$ Josep Cornella ${ }^{1 *}$ \\ ${ }^{1}$ Max-Planck-Institut für Kohlenforschung, Kaiser-Wilhelm-Platz 1, 45470, Mülheim an der Ruhr, \\ Germany. \\ cornella@kofo.mpg.de
}

\begin{abstract}
Selective modification of heteroatom-containing aromatic structures is in high demand as it permits rapid evaluation of molecular complexity in advanced intermediates. Inspired by the remarkable selectivity of deaminases in Nature, herein we present a simple methodology that enables the $\mathrm{NH}_{2}$ groups in aminoheterocycles to be conceived as masked modification handles; with the aid of a simple pyrylium reagent and a cheap chloride source, $\mathrm{C}\left(\mathrm{sp}^{2}\right)-\mathrm{NH}_{2}$ can be converted into $\mathrm{C}\left(\mathrm{sp}^{2}\right)-\mathrm{Cl}$ bonds. The method is characterized by its remarkable substrate scope and wide functional group tolerance, allowing the modification of $>20$ different classes of heteroaromatic motifs (5- and 6-membered heterocycles), bearing numerous sensitive motifs. The facile conversion of $\mathrm{NH}_{2}$ into $\mathrm{Cl}$ in a late-stage fashion enables practitioners to apply Sandmeyer- and Vilsmeier-type transforms without the burden of explosive and unsafe diazonium salts, stoichiometric transition metals, or highly oxidizing and unselective chlorinating agents.
\end{abstract}

\section{Main text}

Installation and removal of chemical functionalities in complex molecular settings with a high degree of precision still remains a challenging and highly coveted milestone for organic chemists, as it would permit facile decoration of any molecular entity at will. ${ }^{1,2}$ Nature is a clear example of this strategy and has mastered an intricate system of enzymatic biochemical processes to enable the selective modification of specific groups in large chemical systems. In this context, one of the remarkable examples is the conversion of cytidine to uridine via a deaminative process: aided by a $\mathrm{Zn}$ ion in the active site, such deaminases replace the $\mathrm{NH}_{2}$ by a molecule of $\mathrm{H}_{2} \mathrm{O}$ (Fig. 1A). ${ }^{3,4}$ From the chemical point of view, the 
cleavage of a $\mathrm{C}\left(\mathrm{sp}^{2}\right)-\mathrm{N}$ bond is energetically costly $\left(\mathrm{BDE} 102.6 \pm 1.0 \mathrm{kcal} \cdot \mathrm{mol}^{-1}\right)$ and amido groups are extremely poor leaving groups $\left(\mathrm{NH}_{2}{ }^{-}\right)$, with virtually no examples in the synthetic world. ${ }^{5}$ Yet, deaminases overcome these hurdles and enable the process to occur in remarkable efficiency at room temperature. Inspired by this selective deamination process, we hypothesized that a synthetic tool that enables the precise removal of $\mathrm{C}-\mathrm{NH}_{2}$ groups in various complex heterocyclic frameworks beyond nucleobases would be highly desirable. Aminoheterocycles are at the core of many biologically relevant compounds such as fungicides, herbicides, pharmaceutical compounds, natural products, vitamins, DNA, RNA, etc. (Fig. 1B) ${ }^{6,7,8}$ Hence, the conversion of the $\mathrm{NH}_{2}$ group into a modular and versatile leaving group would be highly desirable. In this sense, we turned our attention to heteroaryl chlorides since they have occupied a preferential place in synthetic routes due to the myriad of robust methods available for their chemical modification. ${ }^{9}$

The classical Sandmeyer reaction remains the "textbook" reaction when the conversion of $\mathrm{C}\left(\mathrm{sp}^{2}\right)-\mathrm{NH}_{2}$ into $\mathrm{C}\left(\mathrm{sp}^{2}\right)-\mathrm{Cl}$ is desired. Yet, it still relies on the diazonization of the amine followed by chlorination with $\mathrm{CuCl}$ (Fig. 1C, left). ${ }^{10,11}$ Such protocol has been useful in simple anilines and certain aminoheterocycles. However, the strongly oxidizing and acidic conditions to reveal the diazonium salt present a significant incompatibility when structures contain more sensitive functionalities. More importantly, the formation of nitrogen-rich heteroaryl diazonium salts result in highly energetic compounds, which raise severe concerns about their safe handling. ${ }^{12,13}$ Recently, awareness has also been raised by the use of aqueous nitrite solutions, which can lead to significant levels of carcinogenic $N$ nitrosamines. ${ }^{14}$ Altogether, these setbacks prohibited the translation of such strategy in complex settings and the perception of $\mathrm{C}\left(\mathrm{sp}^{2}\right)-\mathrm{NH}_{2}$ as late-stage functionalization handles was abandoned. With the aim of providing a robust protocol for $\mathrm{C}-\mathrm{Cl}$ bond formation, we drew inspiration from the venerable Vilsmeier reaction (Fig. 1C, right). This powerful transformation has found notorious applications in organic synthesis; yet, the use of highly reactive and unselective $\mathrm{POCl}_{3}$ relegates the Vilsmeier disconnection to the early stages of the synthesis, making it incompatible with late-stage modifications. ${ }^{15,16}$ 
Herein, we present a method that merges the availability of starting materials offered by the Sandmeyer approach with the usefulness of the heteroaryl halides obtained when a Vilsmeier disconnection is desired. The method smoothly converts $\mathrm{NH}_{2}$ groups from heteroaromatic compounds into Vilsmeier products by means of a simple and commercially available pyrylium reagent $\left(\mathrm{Pyry}_{-} \mathrm{BF}_{4}, \mathbf{1}\right)^{17}$ and various chloride sources (Fig. 1D). The method is demonstrated to be applicable to $>20$ distinct types of heterocyclic motifs, including both 5- and 6-membered rings containing N, O and S. Importantly, the protocol is characterized by the broad functional group tolerance, thus permitting the formation of electrophilic $\mathrm{C}\left(\mathrm{sp}^{2}\right)-\mathrm{Cl}$ bonds onto complex pharmaceuticals, agrochemicals and natural products in a late-stage fashion. To contextualize the functional group tolerance of the reported methodology, we benchmarked our system with the state-of-the-art Sandmeyer conditions, demonstrating that our protocol is truly enabling in providing the heteroaryl chloride. 


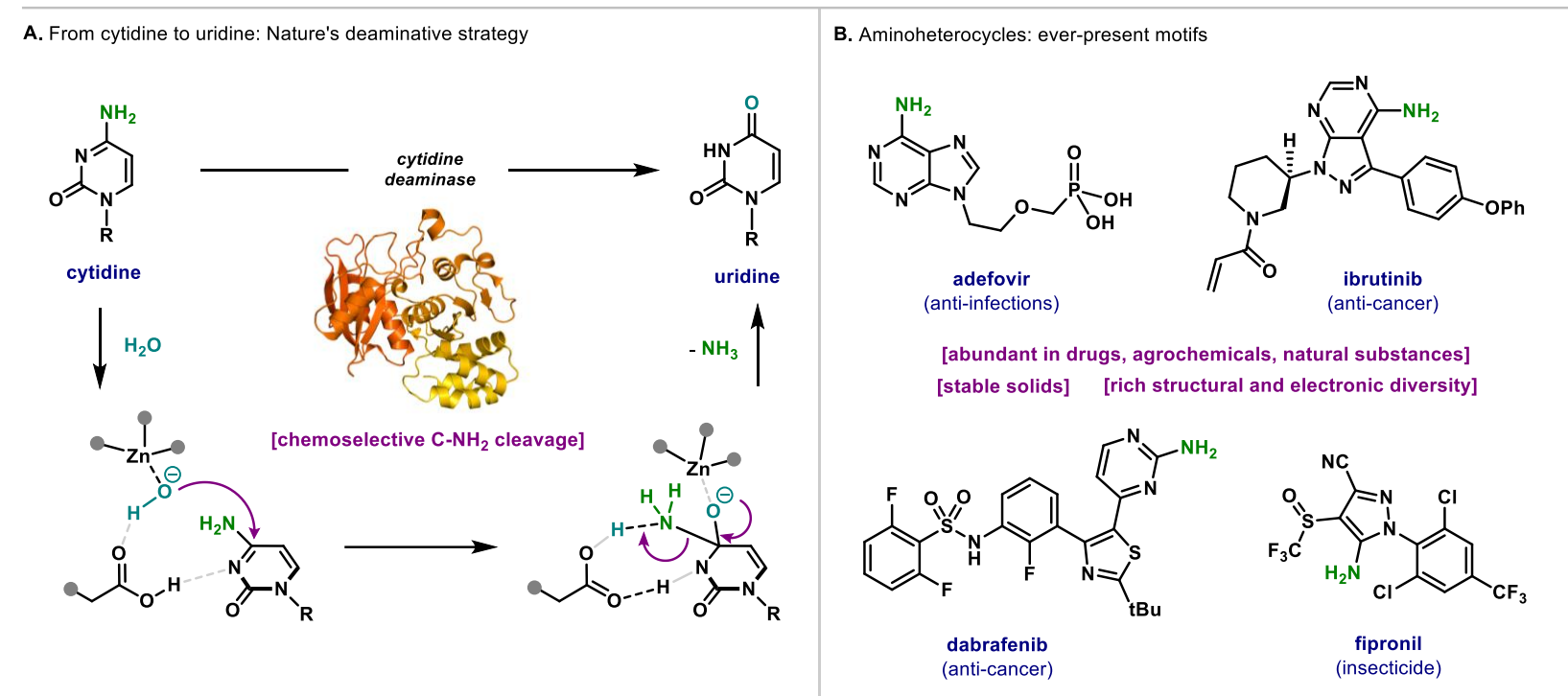

C. The Sandmeyer and Vilsmeier reactions
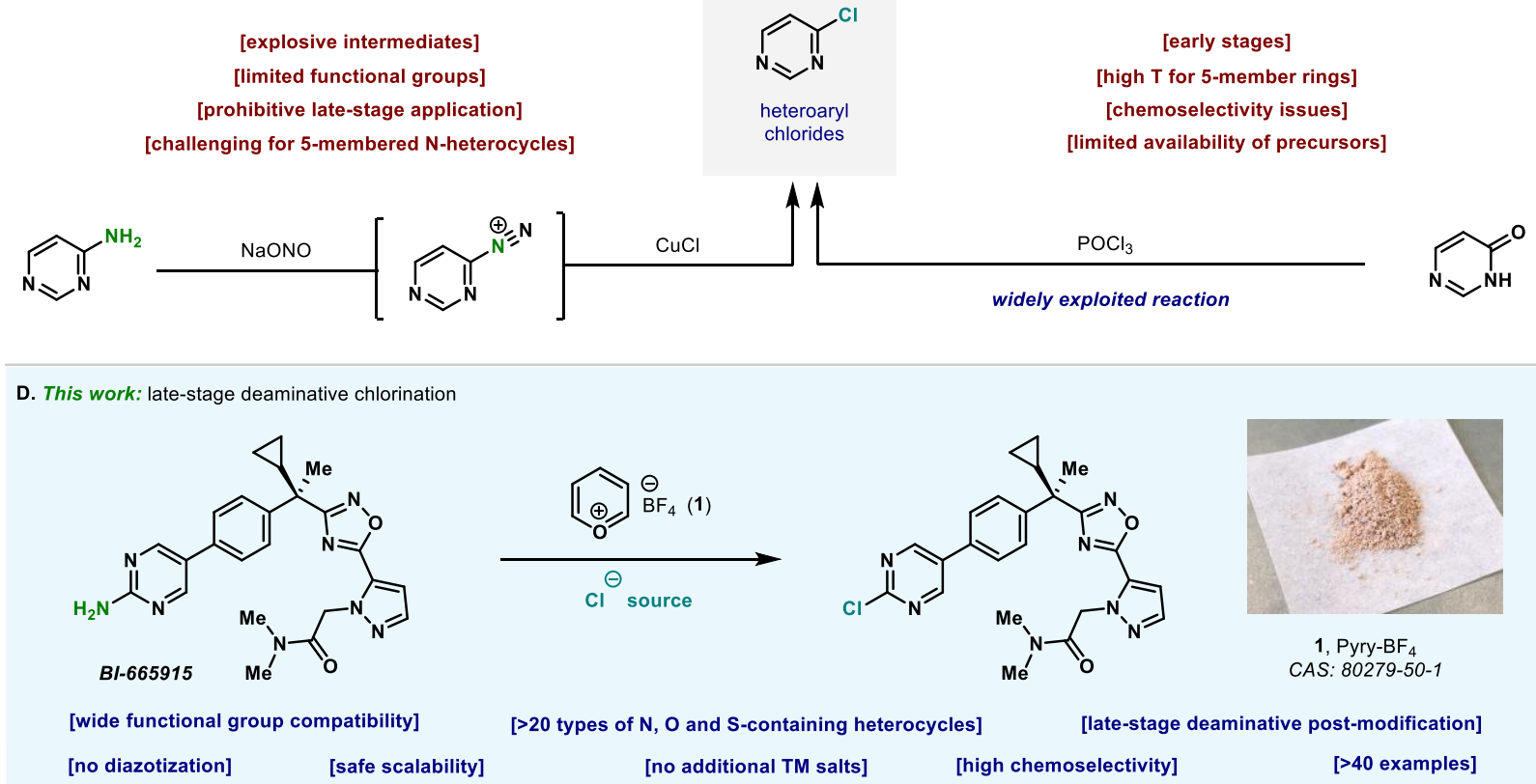

Fig. 1. (A) Deaminases catalyze the conversion of cytidine to uridine by means of a mild and highly selective exchange of $\mathrm{NH}_{2}$ for an $\mathrm{OH}$. Enzyme picture from PDB ID: $6 \mathrm{~K} 63 ;{ }^{18}$ (B) Compounds bearing the $\mathrm{C}\left(\mathrm{sp}^{2}\right)-\mathrm{NH}_{2}$ group are ubiquitous in Nature and are part of many biological compounds; (C) The Sandmeyer and Vilsmeier reactions: inspiration and limitations; (D) Chemoselective deaminative chlorination of aminoheterocycles using Pyry- $\mathrm{BF}_{4} \mathbf{1}$ is applicable to molecular systems bearing various heterocyclic frameworks.

\section{Results}

Our investigations started with an interesting behavior observed for the Zincke salt in solution. When 1-

chloro-2,4-dinitrobenzene (2) is refluxed in the presence of pyridine (3), the Zincke salt precipitates in 
quantitative yields (4) and is easily separated and purified by filtration (Fig. 2A). ${ }^{19}$ Yet, when 4 is dissolved in $\mathrm{CH}_{3} \mathrm{CN}$, partial formation of $\mathbf{2}$ and $\mathbf{3}$ was observed in a 1:1 ratio, suggesting a possible reversibility of the process. Increasing the temperature and diluting the solution led to almost quantitative recovery of the 1-chloro-2,4-dinitrobenzene (2) as well as pyridine (3). Despite the wealth of literature for the reaction of nucleophiles with the Zincke salt, the use of the chloride counter-ion as nucleophile to recover the parent aryl chloride 2 remained largely underexplored. A scrutiny of $S_{N} A r$ reactions revealed that the role of chlorides is vastly relegated to their abilities as leaving group, with only a handful of examples where it is used as nucleophile..$^{20,21}$ Inspired by these observations, we speculated that a similar behavior could be translated to other arylpyridinium chloride systems, namely the product of oxidative dimerization of pyridine (6). ${ }^{22}$ Indeed, when compound 6 is heated in $\mathrm{MeCN}$ at $80{ }^{\circ} \mathrm{C}$ under diluted conditions (0.1 M), almost complete conversion to 4-chloropyridine (7) was observed with concomitant formation of pyridinium hydrochloride $(\mathbf{8})$. This result immediately suggested that this phenomenon is not restricted to activated aryl moieties but also extensive to heteroaromatic substrates. Our group has recently reported on the synthesis and properties of a simple pyrylium reagent $\left(\mathrm{Pyry}_{-} \mathrm{BF}_{4}, \mathbf{1}\right)$, and its capacity to engage certain azines in Zincke-type reactivity; ${ }^{23,24,25}$ although narrow in scope, the Pyry- $\mathrm{BF}_{4}$ displayed high chemoselectivity for amino groups. Then, we envisaged that a merger of the reactivity observed in Figure $2 \mathrm{~A}$ in combination with the selectivity offered by Pyry-BF $\mathrm{B}_{4}$ would provide an opportunity for a broad and chemoselective deaminative chlorination strategy. To test this hypothesis, we subjected oxazole 9 to pyridinium formation with Pyry- $\mathrm{BF}_{4}(\mathbf{1})$, which smoothly afforded pyridinium tetrafluoroborate $\mathbf{1 0}$ (Fig. 2B). At this point, various chloride sources were interrogated in order to effect an anion exchange and trigger the conversion of the $\mathrm{C}-\mathrm{N}$ to a $\mathrm{C}-\mathrm{Cl}$ bond (Fig. 2B, inset Table). When using an etherated $\mathrm{HCl}$ solution, complete chlorination was obtained at room temperature (Fig. 2B, entry 1, inset Table). The use of non-Brønsted acidic counterion such as $\mathrm{MgCl}_{2}$ boded well and smoothly delivered $\mathbf{1 1}$ at $80{ }^{\circ} \mathrm{C}$ (entry 2, inset Table). Noteworthy, 2.0 equivalents of trimethylsilyl chloride (TMSCl) quantitatively furnished the desired oxazolyl chloride 11 under milder conditions (entry 3, inset Table). Anticipating potential issues when translating this methodology to complex molecules bearing acid sensitive functionalities, we tested a 
chloride source bearing a non-coordinating cation. The use of 4.0 equivalents of ${ }^{n} \mathrm{Bu}_{4} \mathrm{NCl}$ displaced the pyridine and forged 11 in excellent yields (entry 4, inset Table). With the aim of providing facile and practical setups, a single-flask operation was established which enables the formation of the pyridinium salt and the subsequent in situ chlorination in high yields (Fig. 2C). This user-friendly protocol can be conducted under regular atmosphere with no special precautions required.

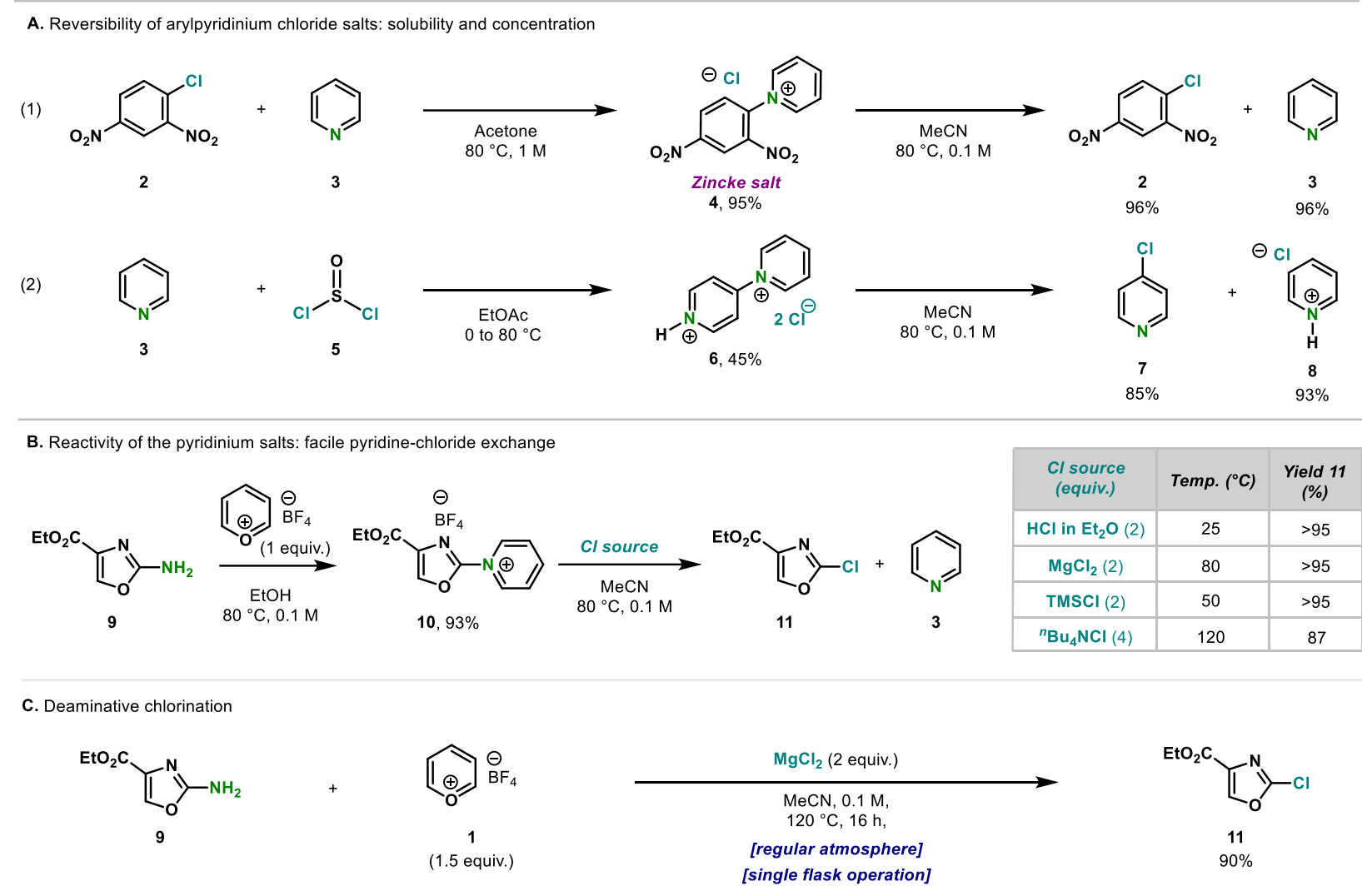

Fig. 2. (A) Unexpected findings on the reversible reactivity of the 1-arylpyridinium chlorides; (B) Development and implementation of a two-step deaminative chlorination of aminoheterocycles using various chloride sources and Pyry-BF 4 ; (C) Conditions for an open-flask one-pot deaminative chlorination.

Having established a protocol using various chloride sources, we turned our attention to explore the scope of the aminoheterocycle (Fig. 3). First of all, we engaged a panel of 4- and 2-aminopyridines (7, 12-20). Tuning the temperature turned out to be crucial to achieve satisfactory yields and accommodate functionalities such as halides $(\mathbf{1 2}, \mathbf{1 4})$, aromatic rings $(\mathbf{1 6}, \mathbf{1 7})$, ester $(\mathbf{1 5})$, morpholine $(\mathbf{1 8})$, nitro (19) or cyano (20). Diazines, including pyrimidine $(\mathbf{2 1}, \mathbf{2 2})$ and pyridazine $(\mathbf{2 3})$, were also smoothly converted to their chlorinated analogs in good yields. When our protocol was applied to herbicide chloridazone, high 
yields of the dichlorinated pyridazone $\mathbf{2 4}$ were obtained. Even the tetralkylated and crowded acrisorcin could be converted in 9-chloroacridine (25) albeit in 36\%. Importantly, fused polycyclic substrates present at the core of biologically relevant molecules such as adenine or remdesivir, were smoothly converted to their chlorinated analog in very good yields (26 and $\mathbf{2 7}$ ). Contrary to most strategies based on the Vilsmeier approach, our protocol boded well with 5-membered heteroaromatic amines. For example, fused triazolopyridine, a motif present in certain Na current inhibitors, smoothly afforded compound $\mathbf{2 8}$ in excellent yields. ${ }^{26}$ Benzo-fused 5-membered rings bearing other heteroatoms, such as benzothiazoles and isobenzothiazoles, which include drugs such as riluzole, boded well with the protocol obtaining excellent yields of the chlorinated analogs (29-31). Simple 5-membered rings bearing sensitive functionalities such ester or oximine were also well tolerated as exemplified by $\mathbf{1 1}$ and $\mathbf{3 2}$. To further study the functional group tolerance, a variety of oxazole-based compounds bearing pendant functionalities were scrutinized. The presence of halogens ( $\mathrm{Cl}, \mathrm{I}, \mathrm{Br}, \mathrm{F})$, pyridine, cinnamyl, cyano, methylsulfone or even aldehyde posed no difficulties for chlorination (33-40). Heterocycles bearing 3 heteroatoms prone to ring-opening such as thiadiazole and oxadiazole $(\mathbf{4 1}, \mathbf{4 2})$ were smoothly chlorinated in high yields. The presence of a free secondary alcohol in $\mathbf{4 3}$ required the use ${ }^{\mathrm{n}} \mathrm{Bu}{ }_{4} \mathrm{NCl}$ to avoid side-reactions through $\mathrm{Mg}$-induced dehydration. Based on the remarkable functional group tolerance observed, we envisaged our protocol to be applicable to more complex and densely functionalized bioactive molecules. Gratifyingly, when the deaminative protocol was applied to hepatitis B pro-drug adefovir diethyl, analog $\mathbf{4 4}$ was obtained in 57\% yield. The anti-inflammatory amlexanox was successfully chlorinated at the 2-position of the pyridine motif (45). Thiazole derivative from amoxapine and paroxetine behaved well and were smoothly converted to the corresponding chloride in high yields $(\mathbf{4 6}, \mathbf{4 7})$. Remarkably, chlorination of the pyrimidine moiety in BI665915 was obtained in 37\% yield (48), tolerating the presence of the rather weak $\mathrm{N}-\mathrm{O}$ bond of oxadiazole, among others. Insecticide fipronil bearing a cyano and a trifluoromethylsulfoxide embedded in a pyrazolyl ring posed no difficulties for chlorination (49). Despite the presence of a Michael acceptor and a piperidinyl moiety, chlorination of the pyrazolopyrimidine core of anti-cancer ibrutinib smoothly occurred in $87 \%$ yield (50). Finally, another anti-cancer such as 
dabrafenib was also subjected to chlorination in a similar manner, obtaining $39 \%$ of $\mathbf{5 1}$. To fully benchmark the usefulness of the protocol developed herein, some of the most critical examples were also tested under state-of-the-art Sandmeyer conditions. Whereas 24, 30 and 32 could be obtained after Sandmeyer, the yields were comparably lower than when our protocol was applied. Although the Sandmeyer conditions were not optimized for each substrate and a general protocol was applied, no product was detected in any of the other 13 challenging substrates tested. Decomposition of the compounds leading to intractable mixtures was the general trend. 


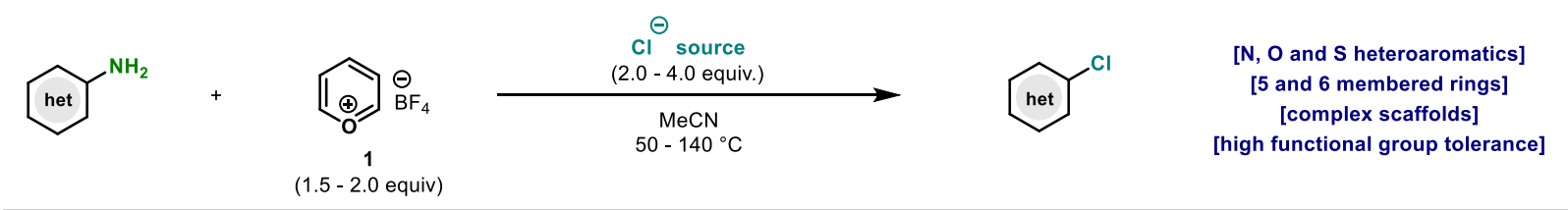
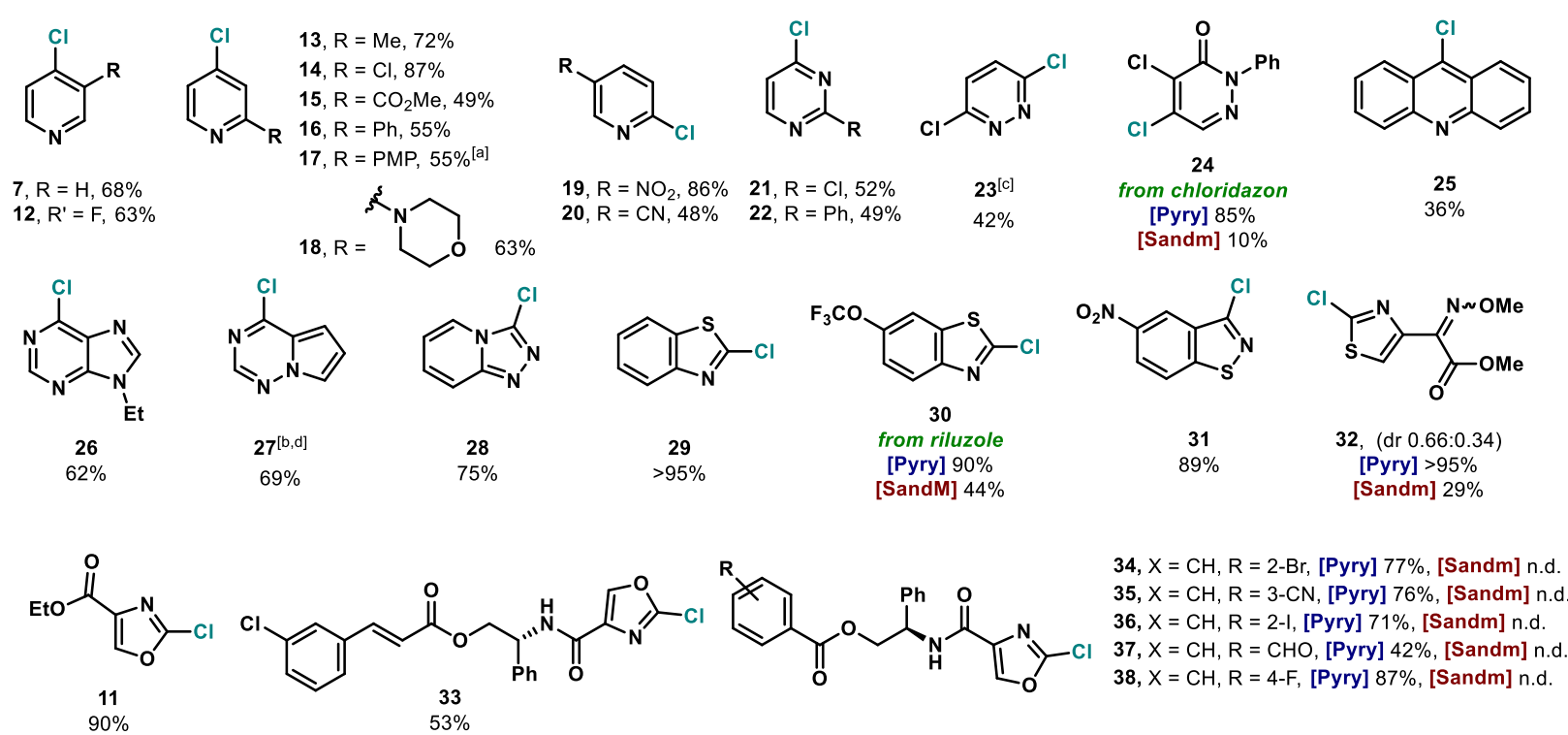<smiles>O=C(OCC(O)NC(=O)c1coc(Cl)n1)c1cccnc1</smiles>
39
[Pyry] 57\%
$[$ Sandm] n.d.<smiles>O=C(N[C@H]1c2ccccc2C[C@H]1O)c1coc(Cl)n1</smiles><smiles>O=C(Cc1csc(Cl)n1)N1CCN(C2=Nc3ccccc3Oc3ccc(Cl)cc32)CC1</smiles><smiles>N#Cc1nn(-c2c(Cl)cc(C(F)(F)F)cc2Cl)c(Cl)c1S(=O)C(F)(F)F</smiles><smiles>[11CH3]</smiles>

from fipronil [Pyry] 83\% [Sandm] n.d.<smiles>COc1ccc(CC(=O)OCC(NC(=O)c2coc(Cl)n2)c2ccccc2)cc1</smiles><smiles>Cc1nnc(Cl)s1</smiles><smiles>Clc1nnc(-c2ccccc2)o1</smiles>
40
$41 \%$ $\mathbf{4 2}$
$72 \%$<smiles>CCOP(=O)(COCCn1cnc2c(Cl)ncnc21)OCC</smiles><smiles>CC(=O)c1cc2c(=O)c3cc(C(C)C)ccc3oc2nc1Cl</smiles><smiles>O=C(Cc1csc(Cl)n1)N1CCC(c2ccc(F)cc2)[C@@H](COc2ccc3c(c2)OCO3)C1</smiles><smiles>CN(C)C(=O)Cn1nccc1-c1nc(C(C)(c2ccc(-c3cnc(Cl)nc3)cc2)C2CC2)no1</smiles>
48 from B/665915 [Pyry] 38\%<smiles>C=CC(=O)N1CCC[C@H](n2nc(-c3ccc(Oc4ccccc4)cc3)c3c(Cl)ncnc32)C1</smiles>

from ibrutinib

[Pyry] 87\%

[Sandm] n.d.

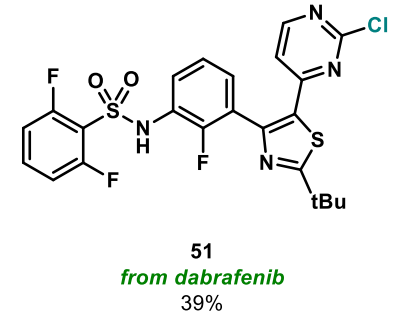


Fig. 3. Exemplification of the deaminative chlorination of aminoheterocycles. Unless otherwise stated, reactions were conducted in a one-step procedure as follows [Pyry]: aminoheterocycle (1 equiv.), 1 (1.5 equiv.), $\mathrm{MgCl}_{2}$ (2.05.0 equiv.), $\mathrm{CH}_{3} \mathrm{CN}(0.1 \mathrm{M}), 50-120^{\circ} \mathrm{C}, 16 \mathrm{~h}$. [Sandm]: Sandmeyer conditions: aminoheterocycle (1 equiv.), $\mathrm{NaONO}$ (1.1 equiv.); $\mathrm{HCl}_{\text {aq }} 37 \%(0.2 \mathrm{M}), 0{ }^{\circ} \mathrm{C}, 15 \mathrm{~min}$; then, $\mathrm{CuCl}(1.3$ equiv. $), 25^{\circ} \mathrm{C}, 3 \mathrm{~h}$. [a] $\mathrm{PMP}=4-$ methoxylphenyl; [b] two-steps procedure: pyridinium formation then chlorination; [c] $\mathrm{CsCl}$ (4 equiv.) instead of $\mathrm{MgCl}_{2}$. [d] $\mathrm{Me}_{4} \mathrm{NCl}$ (4 equiv.) instead of $\mathrm{MgCl}_{2}$. [e] ${ }^{n} \mathrm{Bu} 4 \mathrm{NCl}$ (4 equiv.) instead of $\mathrm{MgCl}_{2}$. n.d. = not detected.

Unlocking a late-stage deaminative chlorination strategy permits the incorporation of all the well-known reactions for aryl halides to be applied in a late-stage functionalization context (Fig. 4). For example, $\mathrm{C}\left(\mathrm{sp}^{2}\right)-\mathrm{C}\left(\mathrm{sp}^{2}\right), \mathrm{C}\left(\mathrm{sp}^{2}\right)-\mathrm{C}\left(\mathrm{sp}^{3}\right)$ as well as $\mathrm{C}\left(\mathrm{sp}^{2}\right)-\mathrm{C}(\mathrm{sp})$ cross-couplings can now be carried out in substrates where such reactivity was limited (Negishi 52, Suzuki 53 and Sonogashira 54). Nucleophilic aromatic substitution, one of the most robust and utilized reactions with aryl halides, is also within reach; aliphatic amines, both primary and secondary including duloxetine, can be incorporated in high yields through simple protocols $(\mathbf{5 5}, \mathbf{5 6})$. Secondary alcohols such as cholesterol can be easily decorated with a benzothiazole in good yield (57). Other nucleophiles, namely fluoride and azide, were also engaged and displaced the $\mathrm{Cl}$ atom leading to valuable products $(\mathbf{5 8}, \mathbf{5 9})$. 


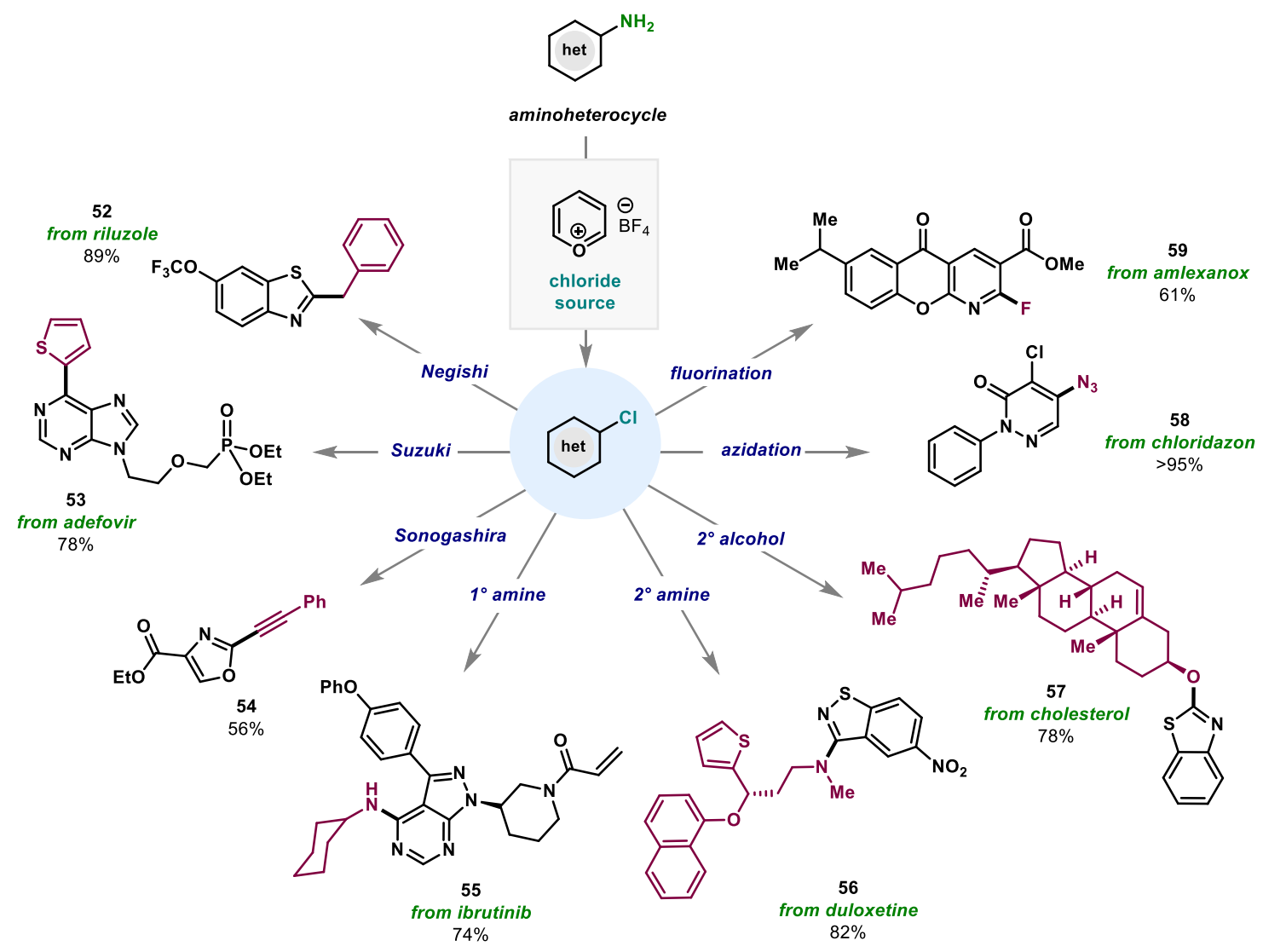

Fig. 4. Deaminative chlorination of drugs and heterocycles opens the door to late-stage functionalization of compounds at positions which were previously inaccessible.

Scalability of the protocol was demonstrated by the gram-scale reaction performed on $\mathbf{6 0}$ without erosion on the yield (32). The deaminative halogenation was also successfully extended to bromides. Both 5- and 6-membered rings afforded good yields of the desired aryl bromide 62 and $\mathbf{6 4}$. Attempts to introduce fluorine atoms through a similar protocol using fluoride anion sources resulted in the isolation of the ringopened compound, which was isolated as the hydrolyzed $\mathbf{6 5} \cdot{ }^{27,28}$ In the case of milder nucleophiles such $\mathrm{Cl}$ or $\mathrm{Br}$, the attack on the pyridinium might be reversible, and occur in both $\mathrm{C} 2$ and $\mathrm{C} 4 .{ }^{29}$ It is not until the ipso position is attacked that the process becomes irreversible and ultimately leads to the formation of pyridine and the aryl chloride. 


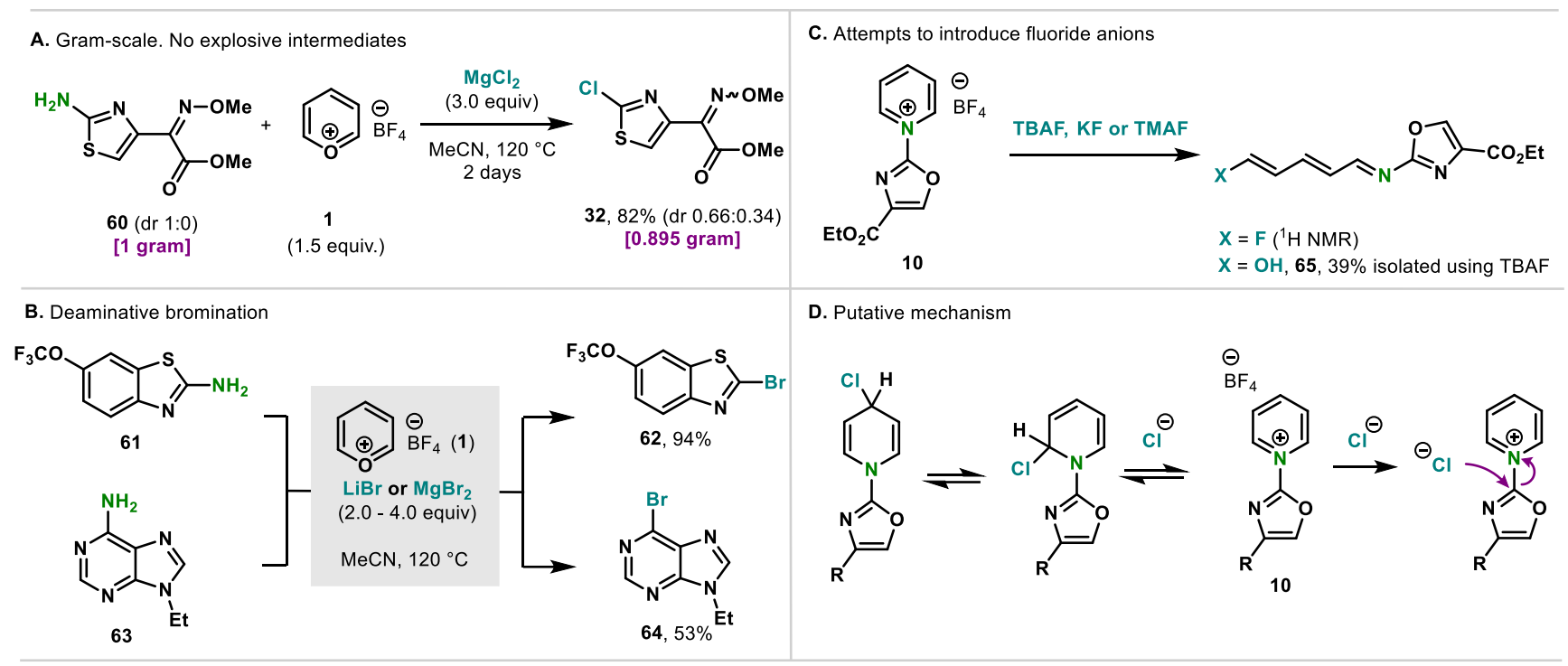

Fig. 5. (A) Scalability of the process; (B) Deaminative bromination: Reaction conditions: aminoheterocycle (1 equiv.), 1 (1.5 equiv.) EtOH ( $1 \mathrm{~mL}) 50-80{ }^{\circ} \mathrm{C}, 16 \mathrm{~h}$; then the solvent is removed and addition of $\mathrm{Br}$ source (4 equiv.), $\mathrm{CD}_{3} \mathrm{CN}(1 \mathrm{~mL}), 50-80{ }^{\circ} \mathrm{C}, 16 \mathrm{~h}$. (C) Ring-opening of the pyridinium intermediate using fluoride salts; (D) Tentative mechanism of the deaminative halogenation.

\section{Conclusions}

Inspired by natural deaminases, we herein report a synthetic tool that enables the conversion of $\mathrm{C}\left(\mathrm{sp}^{2}\right)-$ $\mathrm{NH}_{2}$ groups into $\mathrm{C}\left(\mathrm{sp}^{2}\right)-\mathrm{Cl}$ in high chemoselectivity under mild conditions. The use of the simple Pyry$\mathrm{BF}_{4}$ targets selectively the $\mathrm{NH}_{2}$ attached to a heterocyclic motif and primes it for reactivity by converting it into a pyrydinium intermediate, which further reacts with a chloride source. This protocol merges the potential of the venerable Vilsmeier reaction to decorate aromatic heterocycles, with the ubiquity of aminoheterocycles, resulting in a deaminative chlorination protocol that avoids the use of explosive intermediates or strongly oxidizing reagents. As a result, the high chemoselectivity permits the chlorination of $>40$ compounds containing a myriad of functional groups, embedded in $>20$ different aminoheterocycles including 5- and 6-membered rings. The method is easily scalable, without the need of air-extrusion and without problematic runaway exotherms. Deaminative bromination of the amino group has also been demonstrated with a similar efficiency. More importantly, this deaminative chlorination protocol was applicable to the late-stage chlorination of various drugs and agrochemicals, thus permitting 
post-modification of complex structures beyond the realms of the Sandmeyer reaction. We believe this methodology provides practitioners with a new tool that will permit the scrutiny of new chemical space and ultimately accelerate the drug discovery process.

\section{Data availability}

The Supplementary Information contains all Experimental Procedures and analytical data $\left({ }^{1} \mathrm{H},{ }^{19} \mathrm{~F},{ }^{31} \mathrm{P}\right.$, ${ }^{13} \mathrm{C},{ }^{11} \mathrm{~B}$ NMR, HRMS and crystallographic data) for all new compounds. Crystallographic data for compound 43 (CCDC-2070324) can be downloaded free of charge from the Cambridge Crystallographic Data Center www.ccdc.cam.ac.uk.

\section{References}

1 Blakemore, D. C. et al. Organic synthesis provides opportunities to transform drug discovery. Nat. Chem. 10, 383-394 (2018).

2 Bode, J. W. Chemical Protein Synthesis with the $\alpha$-Ketoacid-Hydroxylamine Ligation. Acc. Chem. Res. 50, 2104-2115 (2017).

3 Ko, T.-P. et al. Crystal Structure of Yeast Cytosine Deaminase. J. Biol. Chem. 278, 19111-19117 (2003).

4 Sklenak, S., Yao, L., Cukier, R. I.and Yan, H. Catalytic Mechanism of Yeast Cytosine Deaminase: An ONIOM Computational Study. J. Am. Chem. Soc. 126, 14879-14889 (2004).

5 Luo, Y. R. Comprehensive Handbook of Chemical Bond Energies. (CRC Press, Boca Raton, FL, 2007).

6 Baumann, M.and Baxendale, I. R. An overview of the synthetic routes to the best selling drugs containing 6-membered heterocycles. Beilstein J. Org. Chem. 9, 2265-2319 (2013).

7 Saini, M. S., Kumar, A., Dwivedi, J.and Singh, R. A review: biological significances of heterocyclic compounds. Int. J. Pharm. Sci. Res. 4, 66-77 (2013). 
8 Vitaku, E., Smith, D. T.and Njardarson, J. T. Analysis of the Structural Diversity, Substitution Patterns, and Frequency of Nitrogen Heterocycles among U.S. FDA Approved Pharmaceuticals. J. Med. Chem. 57, 10257-10274 (2014).

9 Levy, J. N. et al. Selective Halogenation of Pyridines Using Designed Phosphine Reagents. J. Am. Chem. Soc. 142, 11295-11305 (2020).

10 He, L., Qiu, G., Gao, Y.and Wu, J. Removal of amino groups from anilines through diazonium salt-based reactions. Org. Biomol. Chem. 12, 6965-6971 (2014).

11 Mo, F., Dong, G., Zhang, Y.and Wang, J. Recent applications of arene diazonium salts in organic synthesis. Org. Biomol. Chem. 11, 1582-1593 (2013).

12 Firth, J. D.and Fairlamb, I. J. S. A Need for Caution in the Preparation and Application of Synthetically Versatile Aryl Diazonium Tetrafluoroborate Salts. Org. Lett. 22, 7057-7059 (2020).

13 Sheng, M., Frurip, D.and Gorman, D. Reactive chemical hazards of diazonium salts. J. Loss Prev. Process Ind. 38, 114-118 (2015).

14 Ashworth, I. W., Dirat, O., Teasdale, A.and Whiting, M. Potential for the Formation of NNitrosamines during the Manufacture of Active Pharmaceutical Ingredients: An Assessment of the Risk Posed by Trace Nitrite in Water. Org. Progress Res. Dev. 24, 1629-1646 (2020).

15 Su, W. et al. Recent Progress in the Use of Vilsmeier-Type Reagents. Org. Prep. Proced. Int. 42, 503-555 (2010).

16 Joule, J. A.and Mills, K. Heterocyclic chemistry. (John Wiley \& Sons, 2008).

17 Pang, Y., Moser, D.and Cornella, J. Pyrylium salts: selective reagents for the activation of primary amino groups in organic synthesis. Synthesis 52, 489-503 (2020).

18 Liu, W. et al. Biochemical and structural analysis of the Klebsiella pneumoniae cytidine deaminase CDA. Biochem. Biophys. Res. Commun. 519, 280-286 (2019).

19 Michels, T. D., Rhee, J. U.and Vanderwal, C. D. Synthesis of $\delta$-Tributylstannyl- $\alpha, \beta, \gamma, \delta-$ Unsaturated Aldehydes from Pyridines. Org. Lett. 10, 4787-4790 (2008). 
20 Ullmann, F.and Nádai, G. Über die Herstellung von o-nitrierten Aminen aus den entsprechenden Phenolderivaten. Ber. Dtsch. Chem. Ges. 41, 1870-1878 (1908).

21 Fier, P. S. A Bifunctional Reagent Designed for the Mild, Nucleophilic Functionalization of Pyridines. J. Am. Chem. Soc. 139, 9499-9502 (2017).

22 Gurinov, A. A., Lesnichin, S. B., Limbach, H.-H.and Shenderovich, I. G. How short is the strongest hydrogen bond in the proton-bound homodimers of pyridine derivatives? J. Phys. Chem. A 118, 10804-10812 (2014).

23 Gómez-Palomino, A.and Cornella, J. Selective Late-Stage Sulfonyl Chloride Formation from Sulfonamides Enabled by Pyry-BF4. Angew. Chem. Int. Ed. 58, 18235-18239 (2019).

24 Moser, D. et al. Selective functionalization of aminoheterocycles by a pyrylium salt. Angew. Chem. Int. Ed. 57, 11035-11039 (2018).

25 Pérez-Palau, M.and Cornella, J. Synthesis of Sulfonyl Fluorides from Sulfonamides. Eur. J. Org. Chem. (2020).

26 Koltun, D. O. et al. Discovery of triazolopyridine GS-458967, a late sodium current inhibitor (Late INai) of the cardiac NaV 1.5 channel with improved efficacy and potency relative to ranolazine. Bioorg. Med. Chem. Lett. 26, 3202-3206 (2016).

27 Becher, J. Synthesis and Reactions of Glutaconaldehyde and 5-Amino-2, 4-pentadienals. Synthesis 1980, 589-612 (1980).

28 Kearney, A. M.and Vanderwal, C. D. Synthesis of Nitrogen Heterocycles by the Ring Opening of Pyridinium Salts. Angew. Chem. Int. Ed. 45, $7803-7806$ (2006).

29 Sowmiah, S., Esperança, J. M. S. S., Rebelo, L. P. N.and Afonso, C. A. M. Pyridinium salts: from synthesis to reactivity and applications. Org. Chem. Front. 5, 453-493 (2018). 


\section{Acknowledgements}

Financial support for this work was provided by Max-Planck-Gesellschaft, Max-Planck-Institut für Kohlenforschung and Fonds der Chemischen Industrie (FCI-VCI). C. G. thanks the Alexander von Humboldt Stiftung for a Postdoctoral Fellowship. We thank Jennifer Kan for the picture render of the deaminase in Fig. 1A. We are also grateful to the Open Innovation Portal of Boehringer Ingelheim (OpnMe) for providing samples of BI665915. We are thankful to Dr. M. Leutzsch for help in the NMR

and Dr. R. Goddard and Mr. Nils Nöthling for X-ray support. We specially thank Prof. Dr. A. Fürstner for insightful discussions and generous support.

\section{Author Contributions}

C. G. optimized the process, designed the approach, performed the experiments, analyzed the experimental data, prepared the Supplementary Information and helped in the manuscript preparation. $\mathrm{T}$. F. contributed to expand the applicability of the protocol to certain 5-membered rings. A. G. - P. contributed at the initial stages of the project and found conditions in the chlorination and bromination. J. C. conceived the idea, directed the investigations and prepared the manuscript.

\section{Competing interests}

No conflict to declare 


\section{Deaminative Chlorination of Aminoheterocycles}

Clément Ghiazza, ${ }^{1}$ Teresa Faber, ${ }^{1}$ Alejandro Gómez-Palomino, ${ }^{1}$ Josep Cornella ${ }^{1 *}$

${ }^{1}$ Max-Planck-Institut für Kohlenforschung, Kaiser-Wilhelm-Platz 1, 45470, Mülheim an der Ruhr, Germany.

cornella@kofo.mpg.de

\section{Supporting Informations}

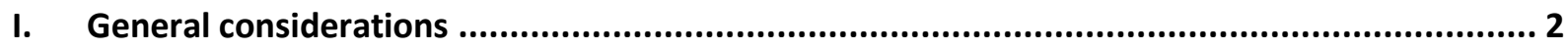

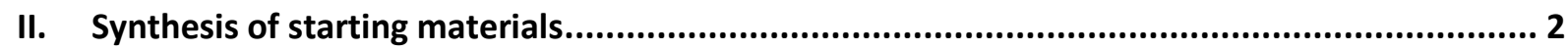

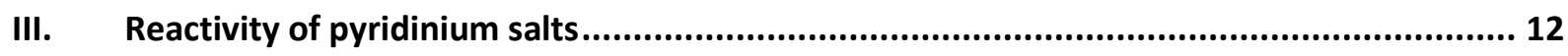

IV. Chlorination reactions and products characterization .................................................. 15

General procedure for the chlorination of amino heteroaromatic compounds......................... 15

General procedure for the Sandemeyer reaction of amino heteroaromatic compounds............ 15

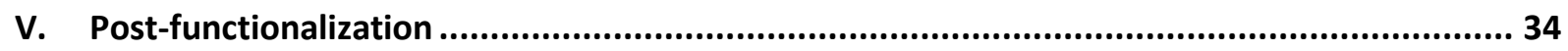

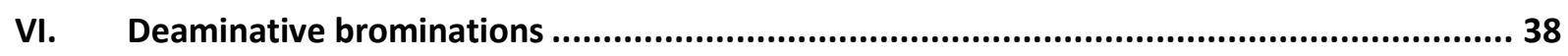

VII. Ring-opening at the 2-position with fluorides.............................................................. 40

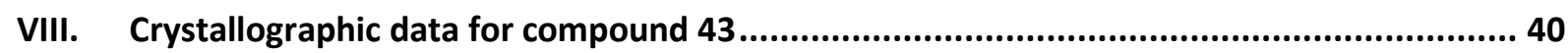

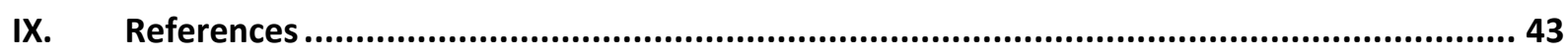




\section{General considerations}

Unless otherwise stated, all manipulations were performed using standard experimental techniques without any specific precautions. Anhydrous solvents were distilled from appropriate drying agents and were transferred under Argon: $\mathrm{CH}_{3} \mathrm{CN}(\mathrm{MS})$, Dioxane (MS), EtOH (Mg, I $\mathrm{I}_{2}$ ), DMSO (MS).

All reagents were used as supplied. Pyrylium tetrafluoroborate 1 (CAS: 80279-50-1) was purchased from SigmaAldrich $\odot$ or prepared according to the reported procedure. ${ }^{1}$ Chemical B/665915 was supplied by Boehringer Ingelheim.

Flash chromatography: Merck silica gel $60(40-63 \mu \mathrm{m})$. MS (EI): Finnigan MAT 8200 (70 eV), ESI-MS: ESQ 3000 (Bruker). Accurate mass determinations: Bruker APEX III FT-MS (7 T magnet) or MAT 95 (Finnigan).

NMR spectra were recorded using a Bruker Avance VIII-300, Bruker Avance III HD $400 \mathrm{MHz}$ spectrometer, Bruker Avance III $500 \mathrm{MHz}$ spectrometer equipped with a $5 \mathrm{~mm}$ BBFO probe. ${ }^{1} \mathrm{H}$ NMR spectra were referenced to the residual protons of the deuterated solvent used. ${ }^{13} \mathrm{C}\left\{{ }^{1} \mathrm{H}\right\}$ NMR spectra were referenced internally to the D-coupled ${ }^{13} \mathrm{C}$ resonances of the NMR solvent. ${ }^{19} \mathrm{~F}$ NMR spectra were referenced externally to the ${ }^{19} \mathrm{~F}$ resonances of $\mathrm{CFCl}_{3}$. ${ }^{31} \mathrm{P}$ NMR spectra were referenced externally to the ${ }^{31} \mathrm{P}$ resonances of $\mathrm{H}_{3} \mathrm{PO}_{4}$. Chemical shifts $(\delta)$ are given in ppm, relative to deuterated solvent residual peak, and coupling constants $(J)$ provided in $\mathrm{Hz}$.

Melting points were recorded on a Büchi@ melting point apparatus, Model B-540 (Büchi, Switzerland) and are uncorrected.

\section{Synthesis of starting materials}

\section{Procedure for cross-coupling reactions with heteroaryl chlorides}

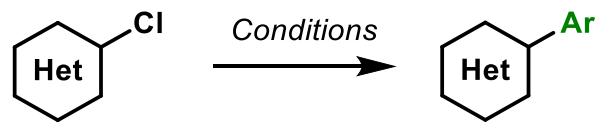

To a flam-dried schlenk flask under $\mathrm{Ar}$ are added $\mathrm{Pd}\left(\mathrm{PPh}_{3}\right)_{4}(225 \mathrm{mg}, 0.195 \mathrm{mmol})$, arylboronic acid $\left(4,675 \mathrm{mmol}\right.$ ), 4-amino-2-chloropyridine ( $500 \mathrm{mg}, 3.889 \mathrm{mmol}$ ), $\mathrm{Na}_{2} \mathrm{CO}_{3} 2 \mathrm{M}$ in water (5 $\mathrm{mL}, 10 \mathrm{mmol}$ ) and toluene $(6.3 \mathrm{~mL})$. The mixture is stirred 16 hours at $100{ }^{\circ} \mathrm{C}$. The reaction is allowed to cool down to room temperature and is partitioned between water and EtOAc. The aqueous layer is extracted with EtOAc $(3 \times 30 \mathrm{~mL})$. The combined organic layers are dried over $\mathrm{Na}_{2} \mathrm{SO}_{4}$, concentrated to dryness and purified on silica gel to afford the desired products SM1 and SM2. 
<smiles>Nc1ccnc(-c2ccccc2)c1</smiles>

White solid, $55 \%$

${ }^{1} \mathrm{H}$ NMR $\left(300 \mathrm{MHz}, \mathrm{CDCl}_{3}\right) \delta 8.32(\mathrm{~d}, J=5.6 \mathrm{~Hz}, 1 \mathrm{H}), 7.91(\mathrm{~m}, 2 \mathrm{H}), 7.44(\mathrm{~m}, 2 \mathrm{H}), 7.39(\mathrm{~m}, 1 \mathrm{H}), 6.96(\mathrm{dd}$, $J=2.3,0.6 \mathrm{~Hz}, 1 \mathrm{H}), 6.50(\mathrm{dd}, J=5.6,2.3 \mathrm{~Hz}, 1 \mathrm{H}), 4.21(\mathrm{bs}, 2 \mathrm{H})$.

Characterization data matched with a previously reported example. ${ }^{1}$

\section{Synthesis of 2-(4-methoxyphenyl)pyridin-4-amine (SM2)}<smiles>COc1ccc(-c2cc(N)ccn2)cc1</smiles>

Yellow solid, $62 \%$

${ }^{1} \mathrm{H}$ NMR $\left(300 \mathrm{MHz}, \mathrm{DMSO}-d_{6}\right) \delta 8.04(\mathrm{~d}, J=5.5 \mathrm{~Hz}, 1 \mathrm{H}), 7.86(\mathrm{~d}, J=8.3 \mathrm{~Hz}, 2 \mathrm{H}), 6.99(\mathrm{~d}, J=8.3 \mathrm{~Hz}, 2 \mathrm{H})$, $6.92(\mathrm{~d}, J=2.2 \mathrm{~Hz}, 1 \mathrm{H}), 6.39(\mathrm{dd}, J=5.5,2.2 \mathrm{H}$

z, 1H), $5.97(b s, 2 H), 3.79(s, 3 H)$.

Characterization data matched with a previously reported example. ${ }^{1}$

\section{Procedure for the SNAr of 2-chloropyridin-4-amine (SM3)}<smiles>Nc1ccnc(Cl)c1</smiles>

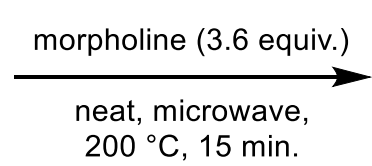<smiles>Nc1ccnc(N2CCOCC2)c1</smiles>

To a microwave reactor are added 2-chloropyridin-4-amine (500 $\mathrm{mg}, 3.89 \mathrm{mmol}$ ) and morpholine $(1.22 \mathrm{~mL}, 14 \mathrm{mmol})$. The mixture is heated at $200{ }^{\circ} \mathrm{C}$ for $15 \mathrm{~min}$. The reaction is allowed to cool down to room temperature and is evaporated to dryness. The residue is then dissolved in saturated $\mathrm{K}_{2} \mathrm{CO}_{3}(40 \mathrm{~mL})$. The aqueous phase is extracted 3 times with $\mathrm{CH}_{2} \mathrm{Cl}_{2}(3 \mathrm{x}$ $40 \mathrm{~mL}$ ). The combined organic layers are dried over $\mathrm{Na}_{2} \mathrm{SO}_{4}$ and concentrated to dryness afford SM3 as a slightly yellow solid (635 mg, $91 \%$ ).

${ }^{1} \mathrm{H}$ NMR $\left(400 \mathrm{MHz}, \mathrm{CDCl}_{3}\right) \delta 7.88(\mathrm{~d}, J=5.6 \mathrm{~Hz}, 1 \mathrm{H}), 6.03$ (dd, $\left.J=5.6,1.9 \mathrm{~Hz}, 1 \mathrm{H}\right), 5.84(\mathrm{~d}, J=1.9 \mathrm{~Hz}$, $1 \mathrm{H}), 4.01$ (bs, $2 \mathrm{H}), 3.81-3.78(\mathrm{~m}, 4 \mathrm{H}), 3.43-3.41(\mathrm{~m}, 4 \mathrm{H})$.

Characterization data matched with a previously reported example. ${ }^{1}$ 
General procedure for the amidation of ethyl 2-aminooxazole-4-carboxylate<smiles>CCOC(=O)c1coc(N)n1</smiles>

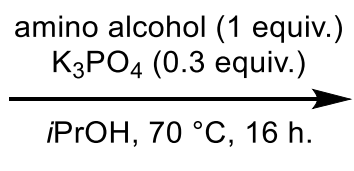<smiles>[R]C(O)C([R])N([R])C(=O)c1coc(N)n1</smiles>

To a flam-dried schlenk flask under $\mathrm{Ar}$ are added $\mathrm{K}_{3} \mathrm{PO}_{4}$ (0.3 equiv.), ethyl 2-aminooxazole-4carboxylate (1 equiv.), amino alcohol (1 equiv.) and $i \operatorname{PrOH}(1 \mathrm{M})$. The mixture is stirred at 70 ${ }^{\circ} \mathrm{C}$ for 16 hours. The reaction is allowed to cool down to room temperature and is partitioned between water and EtOAc. The aqueous layer is extracted with EtOAc. The combined organic layers are dried over $\mathrm{Na}_{2} \mathrm{SO}_{4}$, concentrated to dryness and purified on silica gel (gradient $\mathrm{CH}_{2} \mathrm{Cl}_{2}: \mathrm{MeOH}$ ) to afford the desired products SM6 and SM7. ${ }^{2}$

\section{Synthesis of (R)-2-amino-N-(2-hydroxy-1-phenylethyl)oxazole-4-carboxamide (SM4)}<smiles>Nc1nc(C(=O)NC(CO)c2ccccc2)co1</smiles>

Off white solid (mp: $169.1^{\circ} \mathrm{C}$ )

$16.0 \mathrm{mmol}$ scale, $2.2 \mathrm{~g}, 56 \%$

${ }^{1} \mathrm{H}$ NMR (300 MHz, MeOD) $\delta 7.72(\mathrm{~s}, 1 \mathrm{H}), 7.39-7.22(\mathrm{~m}, 6 \mathrm{H}), 5.11(\mathrm{t}, J=6.0 \mathrm{~Hz}, 1 \mathrm{H}), 3.82$ (dd, $J=6.1$, $2.1 \mathrm{~Hz}, 2 \mathrm{H})$.

Note: The signals for $-\mathrm{NH}_{2}$ and $-\mathrm{OH}$ are not detected due to rapid exchange with MeOD.

${ }^{13} \mathrm{C}$ NMR (75 MHz, MeOD) $\delta$ 163.5, 163.2, 141.0, 136.3, 135.8, 129.5, 128.5, 127.9, 66.1, 56.6.

HRMS (ESI) calculated [M+Na] 270.084910 , measured 270.084710.

Synthesis of 2-amino-N-((1R,2S)-2-hydroxy-2,3-dihydro-1H-inden-1-yl)oxazole-4carboxamide (SM5)<smiles>Nc1nc(C(=O)NC2c3ccccc3CC2O)co1</smiles>

Beige solid (mp: $\left.148.6^{\circ} \mathrm{C}\right)$

$1.6 \mathrm{mmol} \mathrm{scale}, 191 \mathrm{mg}, 46 \%$ 
${ }^{1}$ H NMR (300 MHz, MeOD) $\delta 7.80(\mathrm{~s}, 1 \mathrm{H}), 7.28-7.16(\mathrm{~m}, 4 \mathrm{H}), 5.43(\mathrm{~d}, J=5.1 \mathrm{~Hz}, 1 \mathrm{H}), 4.60$ (td, $J=5.1$, $1.7 \mathrm{~Hz}, 1 \mathrm{H}), 3.18(\mathrm{dd}, J=16.5,5.1 \mathrm{~Hz}, 1 \mathrm{H}), 2.95(\mathrm{dd}, J=16.5,1.6 \mathrm{~Hz}, 1 \mathrm{H})$.

Note: The signals for $-\mathrm{NH}_{2},-\mathrm{NH}$, and $-\mathrm{OH}$ are not detected due to rapid exchange with MeOD.

${ }^{13} \mathrm{C}$ NMR $(75 \mathrm{MHz}$, MeOD) $\delta$ 163.9, 163.1, 142.2, 141.7, 136.3, 135.8, 129.0, 127.9, 126.2, 125.3, 74.0, $58.2,40.8$.

HRMS (ESI) calculated [M+H] 260.102966 , measured 260.103220.

General procedure for the esterification of 2-amino-N-(2-hydroxyethyl)oxazole-4carboxamide<smiles>[R]C(O)C([R])N([R])C(=O)c1coc(N)n1</smiles>

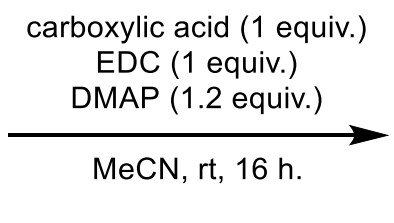<smiles>[R]C(=O)OC([R])C([R])N([R])C(=O)c1coc(N)n1</smiles>

To a round bottom flask are added the starting material $(50.0 \mathrm{mg}, 0.2 \mathrm{mmol})$, carboxylic acid (0.2 mmol), $N$-ethyl- $N$ '-(dimethylaminopropyl)-carbodiimide hydrochloride (38.8 $\mathrm{mg}, 0.2 \mathrm{mmol}$ ), 4 (dimethylamino)-pyridine $(29.6 \mathrm{mg}, 0.24 \mathrm{mmol})$ and acetonitrile $(1.5 \mathrm{~mL})$. The reaction is stirred at $\mathrm{rt}$ for 16 hours. The reaction is partitioned between water and EtOAc. The aqueous layer is extracted with EtOAc $(3 \times 10 \mathrm{~mL})$. The combined organic layers are dried over $\mathrm{Na}_{2} \mathrm{CO}_{3}$, concentrated to dryness and purified on silica gel (gradient $\mathrm{CH}_{2} \mathrm{Cl}_{2}: \mathrm{MeOH}$ ) to afford the desired products SM6 to SM13.

Synthesis of $(R)$-2-(2-aminooxazole-4-carboxamido)-2-phenylethyl (E)-3-(3chlorophenyl)acrylate (SM6)<smiles>Nc1nc(C(=O)NC(COC(=O)/C=C/c2cccc(Cl)c2)c2ccccc2)co1</smiles>

White solid (mp: $152.5^{\circ} \mathrm{C}$ )

$85 \%$

${ }^{1} \mathrm{H}$ NMR $\left(300 \mathrm{MHz}, \mathrm{CDCl}_{3}\right) \delta 7.70(\mathrm{~s}, 1 \mathrm{H}), 7.58(\mathrm{~d}, J=16.0 \mathrm{~Hz}, 1 \mathrm{H}), 7.47(\mathrm{~m}, 1 \mathrm{H}), 7.41-7.26(\mathrm{~m}, 9 \mathrm{H})$, $6.40(\mathrm{~d}, J=16.0 \mathrm{~Hz}, 1 \mathrm{H}), 5.51(\mathrm{td}, J=7.6,4.8 \mathrm{~Hz}, 1 \mathrm{H}), 4.84(\mathrm{~s}, 2 \mathrm{H}), 4.59(\mathrm{dd}, J=11.5,7.1 \mathrm{~Hz}, 1 \mathrm{H}), 4.50$ (dd, $J=11.5,4.8 \mathrm{~Hz}, 1 \mathrm{H}$ ).

${ }^{13} \mathrm{C}$ NMR $\left(75 \mathrm{MHz}, \mathrm{CDCl}_{3}\right) \delta 166.6,160.9,159.5,144.1,138.3,136.2,135.5,135.4,135.1,130.4,130.3$, $129.0,128.2,128.0,126.9,126.5,119.0,66.5,52.1$.

HRMS (ESI) calculated [M+Na] 434.087803 , measured 434.087680. 
Synthesis of $(R)$-2-(2-aminooxazole-4-carboxamido)-2-phenylethyl 2-bromobenzoate (SM7)<smiles>Nc1nc(C(=O)NC(COC(=O)c2ccccc2Br)c2ccccc2)co1</smiles>

White solid (mp: $120.4^{\circ} \mathrm{C}$ )

$77 \%$

${ }^{1}$ H NMR $\left(300 \mathrm{MHz}, \mathrm{CDCl}_{3}\right) \delta 7.72-7.67(\mathrm{~m}, 2 \mathrm{H}), 7.62(\mathrm{~m}, 1 \mathrm{H}), 7.48(\mathrm{~d}, J=8.7 \mathrm{~Hz}, 1 \mathrm{H}), 7.43-7.26(\mathrm{~m}$, $7 \mathrm{H}), 5.59$ (ddd, $J=8.7,6.7,4.6 \mathrm{~Hz}, 1 \mathrm{H}), 4.87(\mathrm{~s}, 2 \mathrm{H}), 4.72(\mathrm{dd}, J=11.4,6.7 \mathrm{~Hz}, 1 \mathrm{H}), 4.62(\mathrm{dd}, J=11.5$, 4.7 Hz, 1H).

${ }^{13} \mathrm{C}$ NMR $\left(75 \mathrm{MHz}, \mathrm{CDCl}_{3}\right) \delta 166.2,161.0,159.9,138.0,135.3,135.1,134.3,132.9,131.7,131.6,128.9$, $128.1,127.2,126.8,121.7,67.4,51.8$.

HRMS (ESI) calculated [M+Na] $]^{+}$452.021650, measured 452.021330.

Synthesis of ( $R$ )-2-(2-aminooxazole-4-carboxamido)-2-phenylethyl 3-cyanobenzoate (SM8)<smiles>N#Cc1cccc(C(=O)OCC(NC(=O)c2coc(N)n2)c2ccccc2)c1</smiles>

White sticky solid (mp: $179.5^{\circ} \mathrm{C}$ )

$82 \%$

${ }^{1} \mathrm{H}$ NMR $\left(300 \mathrm{MHz}, \mathrm{DMSO}-\mathrm{d}_{6}\right) \delta 8.43(\mathrm{~d}, J=9.0 \mathrm{~Hz}, 1 \mathrm{H}), 8.23(\mathrm{t}, J=1.6 \mathrm{~Hz}, 1 \mathrm{H}), 8.14$ (ddt, $J=14.8,7.8$, $1.4 \mathrm{~Hz}, 2 \mathrm{H}), 7.85(\mathrm{~s}, 1 \mathrm{H}), 7.74(\mathrm{t}, J=7.8 \mathrm{~Hz}, 1 \mathrm{H}), 7.50(\mathrm{~m}, 2 \mathrm{H}), 7.37(\mathrm{~m}, 2 \mathrm{H}), 7.30(\mathrm{~m}, 1 \mathrm{H}), 6.83(\mathrm{bs}, 2 \mathrm{H})$, $5.49(\mathrm{td}, J=8.5,5.4 \mathrm{~Hz}, 1 \mathrm{H}), 4.63(\mathrm{~m}, 2 \mathrm{H})$.

${ }^{13} \mathrm{C}$ NMR $\left(75 \mathrm{MHz}\right.$, DMSO-d $\left.d_{6}\right) \delta 163.9,160.9,160.7,139.1,136.7,135.2,134.2,133.4,132.6,130.7$, $130.2,128.4,127.6,127.1,117.8,112.1,67.0,51.0$.

HRMS (ESI) calculated [M+Na] ${ }^{+}$399.106374, measured 399.106750. 
<smiles>Nc1nc(C(=O)NC(COC(=O)c2ccccc2I)c2ccccc2)co1</smiles>

White solid (mp: $136.8^{\circ} \mathrm{C}$ )

$80 \%$

${ }^{1} \mathrm{H}$ NMR (300 MHz, MeOD) $\delta 7.96(\mathrm{dd}, J=8.0,1.1 \mathrm{~Hz}, 1 \mathrm{H}), 7.73(\mathrm{~s}, 1 \mathrm{H}), 7.66(\mathrm{dd}, J=7.8,1.7 \mathrm{~Hz}, 1 \mathrm{H})$, $7.47(\mathrm{~m}, 2 \mathrm{H}), 7.42-7.35(\mathrm{~m}, 3 \mathrm{H}), 7.32(\mathrm{~m}, 1 \mathrm{H}), 7.17(\mathrm{td}, J=7.7,1.7 \mathrm{~Hz}, 1 \mathrm{H}), 5.55(\mathrm{t}, J=6.5 \mathrm{~Hz}, 1 \mathrm{H})$, $4.63(\mathrm{~d}, \mathrm{~J}=6.6 \mathrm{~Hz}, 2 \mathrm{H})$.

Note: The signals for $-\mathrm{NH}_{2}$ and $-\mathrm{NH}$ are not detected due to rapid exchange with MeOD.

${ }^{13} \mathrm{C}$ NMR (75 MHz, MeOD) $\delta$ 168.0, 163.4, 163.2, 142.3, 139.6, 136.8, 136.2, 136.1, 133.9, 131.9, $129.8,129.1,129.1,128.1,94.3,68.3,53.4$.

HRMS (ESI) calculated [M+Na] 500.007772 , measured 500.007860 .

Synthesis of (R)-2-(2-aminooxazole-4-carboxamido)-2-phenylethyl 4-formylbenzoate (SM10)<smiles>Nc1nc(C(=O)NC(COC(=O)c2ccc(C=O)cc2)c2ccccc2)co1</smiles>

White solid (mp: $96.1^{\circ} \mathrm{C}$ )

$60 \%$

${ }^{1} \mathrm{H}$ NMR $\left(300 \mathrm{MHz}, \mathrm{DMSO}-\mathrm{d}_{6}\right) \delta 10.10(\mathrm{~s}, 1 \mathrm{H}), 8.41(\mathrm{~d}, J=9.0 \mathrm{~Hz}, 1 \mathrm{H}), 8.08(\mathrm{~d}, J=8.3 \mathrm{~Hz}, 2 \mathrm{H}), 8.03(\mathrm{~d}, J$ $=8.5 \mathrm{~Hz}, 2 \mathrm{H}), 7.86(\mathrm{~s}, 1 \mathrm{H}), 7.50(\mathrm{~m}, 2 \mathrm{H}), 7.38(\mathrm{~m}, 2 \mathrm{H}), 7.30(\mathrm{~m}, 1 \mathrm{H}), 6.82(\mathrm{bs}, 2 \mathrm{H}), 5.48(\mathrm{td}, J=8.6,5.3$ $\mathrm{Hz}, 1 \mathrm{H}), 4.70-4.57(\mathrm{~m}, 2 \mathrm{H})$.

${ }^{13} \mathrm{C}$ NMR $\left(75 \mathrm{MHz}\right.$, DMSO-d $\left.d_{6}\right) \delta 192.8,164.8,160.9,160.6,139.2,139.2,135.1,134.2,134.2,129.7$, $129.6,128.4,127.5,127.0,66.9,51.0$.

HRMS (ESI) calculated [M+Na] $]^{+}$402.106040, measured 402.106620. 
<smiles>Nc1nc(C(=O)NC(COC(=O)c2ccc(F)cc2)c2ccccc2)co1</smiles>

White solid (mp: $\left.159.4^{\circ} \mathrm{C}\right)$

$86 \%$

${ }^{1} \mathrm{H}$ NMR (300 MHz, MeOD) $\delta 8.00(\mathrm{~m}, 2 \mathrm{H}), 7.73(\mathrm{~s}, 1 \mathrm{H}), 7.47(\mathrm{~m}, 2 \mathrm{H}), 7.37(\mathrm{~m}, 2 \mathrm{H}), 7.31(\mathrm{~m}, 1 \mathrm{H}), 7.15$ (m, 2H), $5.54(\mathrm{dd}, \mathrm{J}=7.8,5.4 \mathrm{~Hz}, 1 \mathrm{H}), 4.61(\mathrm{~m}, 2 \mathrm{H})$.

Note: The signals for $-\mathrm{NH}_{2}$ and $-\mathrm{NH}$ are not detected due to rapid exchange with MeOD.

${ }^{13} \mathrm{C}$ NMR $(75 \mathrm{MHz}, \mathrm{MeOD}) \delta$ 168.9, 165.6, $165.1\left(\mathrm{~d},{ }^{1} J(\mathrm{C}, \mathrm{F})=245 \mathrm{~Hz}\right), 163.2,139.6,136.1,136.1,133.4$ $\left(d,{ }^{3} J(C, F)=10 \mathrm{~Hz}\right), 129.8,129.0,128.0,127.5\left(d,{ }^{4} J(C, F)=3 \mathrm{~Hz}\right), 116.5\left(d,{ }^{2} J(C, F)=22 \mathrm{~Hz}\right), 67.9,53.5$.

${ }^{19} \mathrm{~F}$ NMR $\left(282 \mathrm{MHz}, \mathrm{CDCl}_{3}\right) \delta-105.29(\mathrm{~s}, 3 \mathrm{~F})$.

HRMS (ESI) calculated [M+Na] 392.101704, measured 392.102070.

Synthesis of (R)-2-(2-aminooxazole-4-carboxamido)-2-phenylethyl nicotinate (SM12)<smiles>Nc1nc(C(=O)NC(COC(=O)c2cccnc2)c2ccccc2)co1</smiles>

Beige solid (mp: $\left.100.6^{\circ} \mathrm{C}\right)$

$68 \%$

${ }^{1} \mathrm{H}$ NMR $\left(300 \mathrm{MHz}, \mathrm{CDCl}_{3}\right) \delta 9.19(\mathrm{~d}, J=1.8 \mathrm{~Hz}, 1 \mathrm{H}), 8.76(\mathrm{dd}, J=5.0,1.7 \mathrm{~Hz}, 1 \mathrm{H}), 8.27(\mathrm{~m}, 1 \mathrm{H}), 7.70$ (m, 1H), 7.44-7.26 (m, 7H), $5.60(m, 1 H), 4.74-4.67(m, 4 H)$.

${ }^{13} \mathrm{C}$ NMR $\left(75 \mathrm{MHz}, \mathrm{CDCl}_{3}\right) \delta 165.22$ 161.1, 159.9, 153.5, 151.0, 137.9, 137.3, 135.4, 135.1, 129.0, $128.3,126.9,125.8,123.5,67.2,51.8$.

HRMS (ESI) calculated [M+Na] $]^{+}$375.106374, measured 375.106510. 
Synthesis of $(R)$-2-(2-aminooxazole-4-carboxamido)-2-phenylethyl 2-(4-

(methylsulfonyl)phenyl)acetate (SM13)<smiles>CS(=O)(=O)c1ccc(CC(=O)OCC(NC(=O)c2coc(N)n2)c2ccccc2)cc1</smiles>

White solid (mp: $\left.186.0^{\circ} \mathrm{C}\right)$

$64 \%$

${ }^{1} \mathrm{H}$ NMR $\left(300 \mathrm{MHz}\right.$, DMSO- $\left.d_{6}\right) \delta 8.22(\mathrm{~d}, J=9.0 \mathrm{~Hz}, 1 \mathrm{H}), 7.86(\mathrm{~s}, 1 \mathrm{H}), 7.81(\mathrm{~d}, J=8.1 \mathrm{~Hz}, 2 \mathrm{H}), 7.47(\mathrm{~d}, J$ $=8.1 \mathrm{~Hz}, 2 \mathrm{H}), 7.39-7.25(\mathrm{~m}, 6 \mathrm{H}), 6.84(\mathrm{~s}, 2 \mathrm{H}), 5.28(\mathrm{td}, J=8.5,5.3 \mathrm{~Hz}, 1 \mathrm{H}), 4.45-4.32(\mathrm{~m}, 2 \mathrm{H}), 3.81(\mathrm{~s}$, $2 \mathrm{H}), 3.18(\mathrm{~s}, 3 \mathrm{H})$.

${ }^{13} \mathrm{C}$ NMR $\left(75 \mathrm{MHz}\right.$, DMSO- $\left.d_{6}\right) \delta 170.3,161.0,160.5,140.1,139.3,139.2,135.2,134.3,130.4,128.4$, $127.5,127.0,126.9,66.2,51.0,43.5,39.9$.

HRMS (ESI) calculated [M+Na] 466.104328 , measured 466.103980.

\section{Procedure for the methylation of Amlexanox (SM14)}<smiles>CC(C)c1ccc2oc3nc(N)c(C(=O)O)cc3c(=O)c2c1</smiles><smiles>CCOC(=O)O[Mg]</smiles><smiles>COC(=O)c1cc2c(=O)c3cc(C(C)C)ccc3oc2nc1N</smiles>

To a $50 \mathrm{~mL}$ schlenk flask under normal atmosphere is added Amlexanox (201 mg, $0.67 \mathrm{mmol}$ ) in EtOAc and $\mathrm{MeOH}$ (10 and $4 \mathrm{~mL}$ respectively). The mixture is stirred at $\mathrm{rt}$ and (trimethylsilyl)-

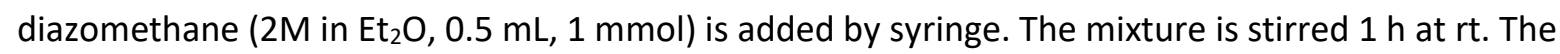
suspension is then filtered and washed with $\mathrm{EtOH}$ and $\mathrm{Et}_{2} \mathrm{O}$ to afford SM14 as a white solid (135 mg, $64 \%)$.

${ }^{1} \mathrm{H}$ NMR $\left(300 \mathrm{MHz}, \mathrm{DMSO}-d_{6}\right) \delta 8.82(\mathrm{~s}, 1 \mathrm{H}), 8.34$ (bs, $\left.1 \mathrm{H}\right), 8.06$ (bs, $\left.1 \mathrm{H}\right), 7.93(\mathrm{~d}, J=2.3 \mathrm{~Hz}, 1 \mathrm{H}), 7.74$ (dd, $J=8.6,2.4 \mathrm{~Hz}, 1 \mathrm{H}$ ), $7.53(\mathrm{~d}, J=8.6 \mathrm{~Hz}, 1 \mathrm{H}$ ), $3.89(\mathrm{~s}, 3 \mathrm{H}), 3.06$ (hept, $J=6.9 \mathrm{~Hz}, 1 \mathrm{H}), 1.26(\mathrm{~d}, J=6.9$ $\mathrm{Hz}, 6 \mathrm{H})$.

Characterization data matched with a previously reported example. ${ }^{3}$ 


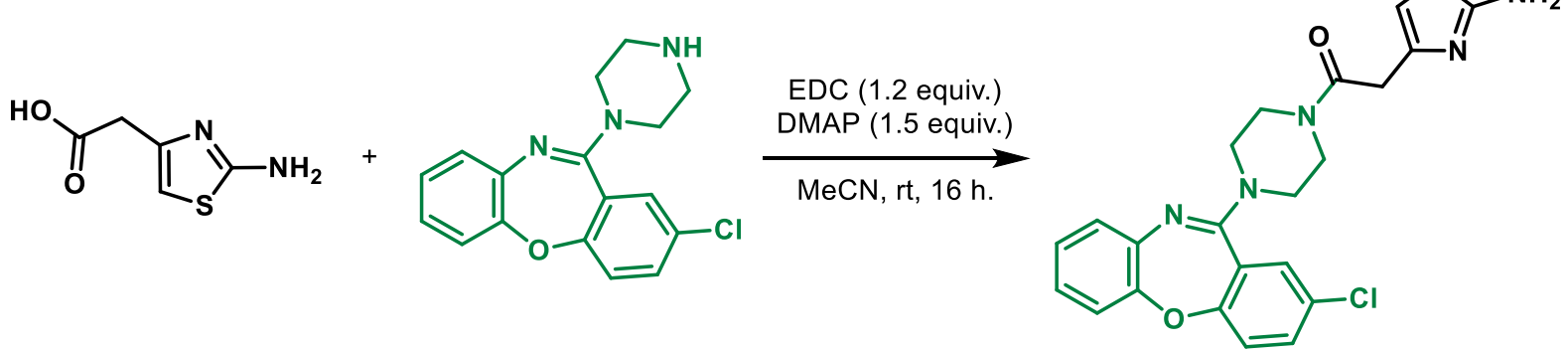

To a round bottom flask are added 2-(2-aminothiazol-4-yl)acetic acid (69.6 mg, $0.44 \mathrm{mmol}$ ), Amoxapine (138.0 mg, $0.44 \mathrm{mmol}), N$-ethyl- $N$ '-(dimethylaminopropyl)-carbodiimide hydrochloride (101.2 $\mathrm{mg}, 0.53 \mathrm{mmol}$ ), 4-(dimethylamino)-pyridine $(80.6 \mathrm{mg}, 0.66 \mathrm{mmol}$ ) and acetonitrile $(2 \mathrm{~mL})$. The reaction is stirred at $\mathrm{rt}$ for 16 hours. The reaction is partitioned between water and EtOAc. The aqueous layer is extracted with EtOAc $(3 \times 10 \mathrm{~mL})$. The combined organic layers are dried over $\mathrm{Na}_{2} \mathrm{CO}_{3}$, concentrated to dryness and purified on silica gel (gradient $\mathrm{CH}_{2} \mathrm{Cl}_{2}: \mathrm{MeOH}$ ) to afford the desired product SM15 as a white solid (200 mg, quant.).

${ }^{1} \mathrm{H}$ NMR $\left(300 \mathrm{MHz}, \mathrm{CDCl}_{3}\right) \delta 7.40$ (dd, $\left.J=8.6,2.6 \mathrm{~Hz}, 1 \mathrm{H}\right), 7.30(\mathrm{~d}, J=2.6 \mathrm{~Hz}, 1 \mathrm{H}), 7.18(\mathrm{~d}, J=8.7 \mathrm{~Hz}$, $1 \mathrm{H}), 7.15-7.05(\mathrm{~m}, 3 \mathrm{H}), 7.00(\mathrm{~m}, 1 \mathrm{H}), 6.30(\mathrm{~s}, 1 \mathrm{H}), 5.20(\mathrm{bs}, 2 \mathrm{H}), 3.83-3.60(\mathrm{~m}, 6 \mathrm{H}), 3.55-3.41(\mathrm{~m}, 4 \mathrm{H})$.

${ }^{13} \mathrm{C} \mathrm{NMR}\left(75 \mathrm{MHz}, \mathrm{CDCl}_{3}\right) \delta 168.7,167.9,159.5,158.8,151.9,145.6,139.9,132.9,130.6,129.0,127.2$, $126.0,124.9,124.8,123.0,120.3,104.9,46.0,41.7,37.5$.

HRMS (ESI) calculated [M+H] $]^{+}$454.109899, measured 454.110070.

Procedure for the amidation of 2-(2-aminothiazol-4-yl)acetic acid with Paroxetine (SM16)

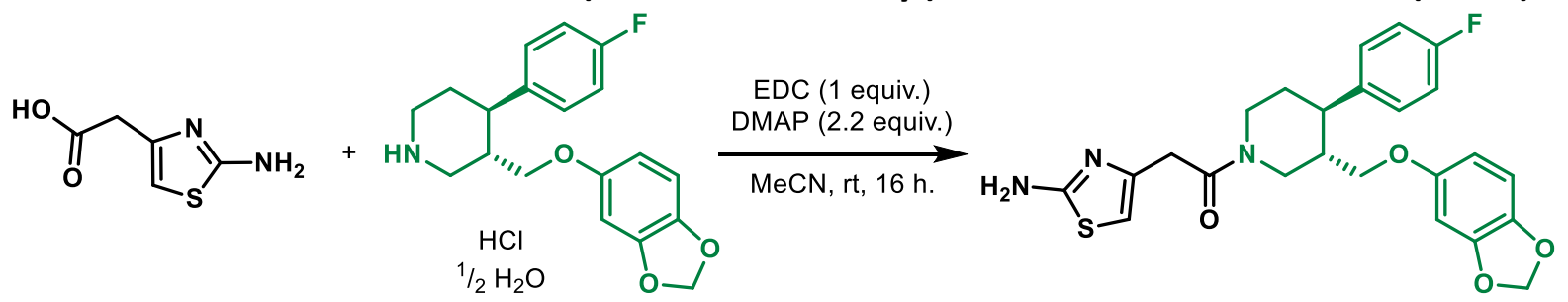

To a round bottom flask are added 2-(2-aminothiazol-4-yl)acetic acid $(52.7 \mathrm{mg}, 0.33 \mathrm{mmol})$, Paroxetine hydrochloride hemihydrate $(125.0 \mathrm{mg}, 0.33 \mathrm{mmol}), \quad N$-ethyl-N'(dimethylaminopropyl)-carbodiimide hydrochloride $(63.9 \mathrm{mg}, 0.33 \mathrm{mmol})$, 4-(dimethylamino)-pyridine $(89.6 \mathrm{mg}, 0.73 \mathrm{mmol})$ and acetonitrile $(2.5 \mathrm{~mL})$. The reaction is stirred at rt for 16 hours. The reaction is partitioned between water and EtOAc. The aqueous layer is extracted with EtOAc $(3 \times 10$ $\mathrm{mL}$ ). The combined organic layers are dried over $\mathrm{Na}_{2} \mathrm{CO}_{3}$, concentrated to dryness and purified on silica gel (gradient $\mathrm{CH}_{2} \mathrm{Cl}_{2}: \mathrm{MeOH}$ ) to afford the desired product SM16 as a white solid (147 mg, 94\%).

${ }^{1} \mathrm{H}$ NMR $\left(300 \mathrm{MHz}, \mathrm{CDCl}_{3}\right) \delta 7.08(\mathrm{dd}, J=8.4,5.3 \mathrm{~Hz}, 2 \mathrm{H}), 6.96(\mathrm{~m}, 2 \mathrm{H}), 6.61(\mathrm{dd}, J=8.4,2.7 \mathrm{~Hz}, 1 \mathrm{H})$, $6.34(\mathrm{~m}, 1 \mathrm{H}), 6.26(\mathrm{~s}, 1 \mathrm{H}), 6.12(\mathrm{ddd}, J=8.3,5.4,2.5 \mathrm{~Hz}, 1 \mathrm{H}), 5.87(\mathrm{~d}, J=2.9 \mathrm{~Hz}, 2 \mathrm{H}), 5.68(\mathrm{bs}, 2 \mathrm{H})$, $4.88(\mathrm{~m}, 1 \mathrm{H}), 4.21(\mathrm{~m}, 1 \mathrm{H}), 3.77-3.51(\mathrm{~m}, 3 \mathrm{H}), 3.42(\mathrm{td}, J=9.9,6.1 \mathrm{~Hz}, 1 \mathrm{H}), 3.08(\mathrm{~m}, 1 \mathrm{H}), 2.83-2.60$ $(\mathrm{m}, 2 \mathrm{H}), 2.03-1.47(\mathrm{~m}, 3 \mathrm{H})$. 
${ }^{13} \mathrm{C}$ NMR $\left(75 \mathrm{MHz}, \mathrm{CDCl}_{3}\right) \delta 168.5-168.4(\mathrm{~m}, 2 \mathrm{C}), 161.7$ (dd, $\left.{ }^{1} J(\mathrm{C}, \mathrm{F})=245 \mathrm{~Hz}, J=2 \mathrm{~Hz}\right), 154.3$ (d, J = 18 $\mathrm{Hz}), 148.3(\mathrm{~d}, J=7 \mathrm{~Hz}), 145.8(\mathrm{~d}, J=2 \mathrm{~Hz}), 141.8(\mathrm{~d}, J=9 \mathrm{~Hz}), 138.8(\mathrm{t}, J=3 \mathrm{~Hz}), 128.9\left(\mathrm{t},{ }^{3} J(\mathrm{C}, \mathrm{F})=7\right.$

$\mathrm{Hz}), 115.7\left(\mathrm{dd},{ }^{2} J(\mathrm{C}, \mathrm{F})=21 \mathrm{~Hz}, J=5 \mathrm{~Hz}\right), 108.0(\mathrm{~d}, J=5 \mathrm{~Hz}), 105.7(\mathrm{~d}, J=9 \mathrm{~Hz}), 104.3(\mathrm{~d}, J=4 \mathrm{~Hz}), 101.2$ $(d, J=6 \mathrm{~Hz}), 98.1(\mathrm{~d}, J=11 \mathrm{~Hz}), 68.7(\mathrm{~d}, J=1 \mathrm{~Hz}), 48.4(\mathrm{~d}, J=217 \mathrm{~Hz}), 45.5-41.9(\mathrm{~m}, 3 \mathrm{C}), 37.8(\mathrm{~d}, J=6$ $\mathrm{Hz}), 33.9$ (d, $J=51 \mathrm{~Hz}$ ).

${ }^{19}$ F NMR $\left(282 \mathrm{MHz}, \mathrm{CDCl}_{3}\right) \delta-115.94(\mathrm{~d}, J=27.0 \mathrm{~Hz}, 1 \mathrm{~F})$.

Note: The 2 conformations of piperidine led to a signal splitting in ${ }^{1} \mathrm{H},{ }^{13} \mathrm{C}$ as well as ${ }^{19} \mathrm{~F} N M R$.

HRMS (ESI) calculated $[\mathrm{M}+\mathrm{H}]^{+} 470.154432$, measured 470.154860.

\section{Synthesis of methyl 2-(2-aminothiazol-4-yl)-2-(methoxyimino)acetate (60)}<smiles>CON=C(Sc1nc2ccccc2s1)c1csc(N)n1</smiles><smiles>CCCCCCCC</smiles><smiles>CON=C(C(=O)OC)c1csc(N)n1</smiles>

To a $18 \mathrm{~mL}$ screw-capped tube under normal atmosphere are added S-(benzo[d]thiazol-2-yl) 2-(2aminothiazol-5-yl)-2-(methoxyimino)ethanethioate $(144 \mathrm{mg}, 0.41 \mathrm{mmol}$ ) and $\mathrm{MeOH}(5 \mathrm{~mL})$. The resulting mixture is stirred 2 days at rt. The solvent was then removed. The crude solid is redissolved in EtOAc $(5 \mathrm{~mL})$ and extracted with $2 \mathrm{M} \mathrm{HCl}(3 \times 5 \mathrm{~mL})$. The combined aqueous phases are neutralized with saturated $\mathrm{NaHCO}_{3}$ and extracted with EtOAc $(3 \times 5 \mathrm{~mL})$. The combined organic layers are dried over $\mathrm{Na}_{2} \mathrm{SO}_{4}$ and concentrated to dryness to afford 60 as a pale yellow solid (72 mg, $81 \%$ ).

${ }^{1}$ H NMR $\left(300 \mathrm{MHz}, \mathrm{DMSO}-d_{6}\right) \delta 7.25$ (bs, 2H), $6.93(\mathrm{~s}, 1 \mathrm{H}), 3.87(\mathrm{~s}, 3 \mathrm{H}), 3.80(\mathrm{~s}, 3 \mathrm{H})$.

Characterization data matched with a previously reported example. ${ }^{4}$

\section{Procedure for the ethylation of adenine (63)}<smiles>Nc1ncnc2[nH]cnc12</smiles>

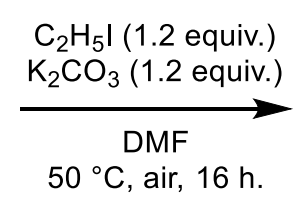<smiles>CCn1cnc2c(N)ncnc21</smiles>

In a $250 \mathrm{~mL}$ round bottom flask are added adenine $(2.26 \mathrm{~g}, 16.7 \mathrm{mmol})$, potassium carbonate $(2.77 \mathrm{~g}, 20.0 \mathrm{mmol})$ and DMF $(15 \mathrm{~mL})$. The mixture is stirred at $\mathrm{rt}$ and iodoethane is added by syringe $(1.61 \mathrm{~mL}, 20.0 \mathrm{mmol})$. The reaction is then heated at $50{ }^{\circ} \mathrm{C}$ overnight. The mixture is then cooled down to $\mathrm{rt}$ and diluted with water/brine $(1: 1,50 \mathrm{~mL})$. The aqueous layer is then extracted as many times as needed with EtOAc $(20 \mathrm{~mL}$ each, extraction of the product monitored by TLC) and the combined organic layers are dried over $\mathrm{Na}_{2} \mathrm{SO}_{4}$. The crude is then concentrated to the minimum amount of solvent and $\mathrm{Et}_{2} \mathrm{O}$ is then added. The precipitate is recovered 
by filtration and washed with the minimum amount of $\mathrm{Et}_{2} \mathrm{O}$ to afford 63 as a pale yellow solid $(1.23 \mathrm{~g}$, $45 \%)$. The filtrate can be concentrated again to repeat this operation.

${ }^{1} \mathrm{H}$ NMR $\left(300 \mathrm{MHz}, \mathrm{DMSO}-d_{6}\right) \delta 8.14(\mathrm{~s}, 1 \mathrm{H}), 8.13(\mathrm{~s}, 1 \mathrm{H}), 7.14(\mathrm{bs}, 2 \mathrm{H}), 4.16$ (q, $\left.J=7.2 \mathrm{~Hz}, 2 \mathrm{H}\right), 1.40$ (t, $J=7.3 \mathrm{~Hz}, 3 \mathrm{H})$.

Characterization data matched with a previously reported example. ${ }^{5}$

\section{Reactivity of pyridinium salts}

Synthesis and reversibility experiments of the Zincke salt (4)

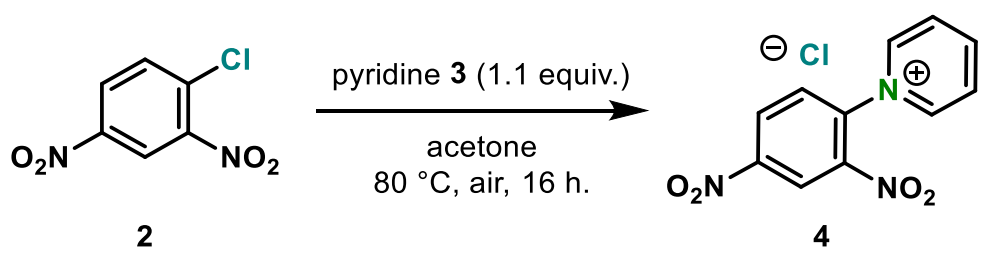

To a $18 \mathrm{~mL}$ screw-capped tube under normal atmosphere are added 1-chloro-2,4-dinitrobenzene 2 (413 $\mathrm{mg}, 2.04 \mathrm{mmol})$, pyridine $3(177 \mathrm{mg}, 2.24 \mathrm{mmol}$ ) and acetone $(2 \mathrm{~mL})$. The colorless mixture is gently stirred at $80^{\circ} \mathrm{C}$ for 16 hours. After cooling down the reaction to rt, acetone $(2 \mathrm{~mL})$ is added to the mixture and the suspension is filtered and washed with acetone to afford 4 as a white solid (532 $\mathrm{mg}, 95 \%)$.

${ }^{1} \mathrm{H}$ NMR $\left(300 \mathrm{MHz}, \mathrm{DMSO}-d_{6}\right) \delta 9.50(\mathrm{~d}, J=5.2 \mathrm{~Hz}, 2 \mathrm{H}), 9.12(\mathrm{~d}, J=2.5 \mathrm{~Hz}, 1 \mathrm{H}), 8.98(\mathrm{~m}, 2 \mathrm{H}), 8.51(\mathrm{~d}, J$ $=8.7 \mathrm{~Hz}, 1 \mathrm{H}), 8.46(\mathrm{~m}, 2 \mathrm{H})$.

Characterization data matched with a previously reported example. ${ }^{6}$

Reversibility experiments. All experiments are conducted in a $18 \mathrm{~mL}$ screw-capped tube under normal atmosphere filled with $0.5 \mathrm{~mL}$ of solvent. The corresponding starting materials $\mathbf{2 + 3}$ or $\mathbf{4}$ (either 0.05 or $0.5 \mathrm{mmol}$ respectively for 0.1 or $1 \mathrm{M}$ ) are dissolved at rt before heating the reaction 16 hours at $80^{\circ} \mathrm{C}$. Yields are determined by ${ }^{1} \mathrm{H}$ NMR with mesitylen (around 1 equiv., amount determined by mass) as internal standard. 


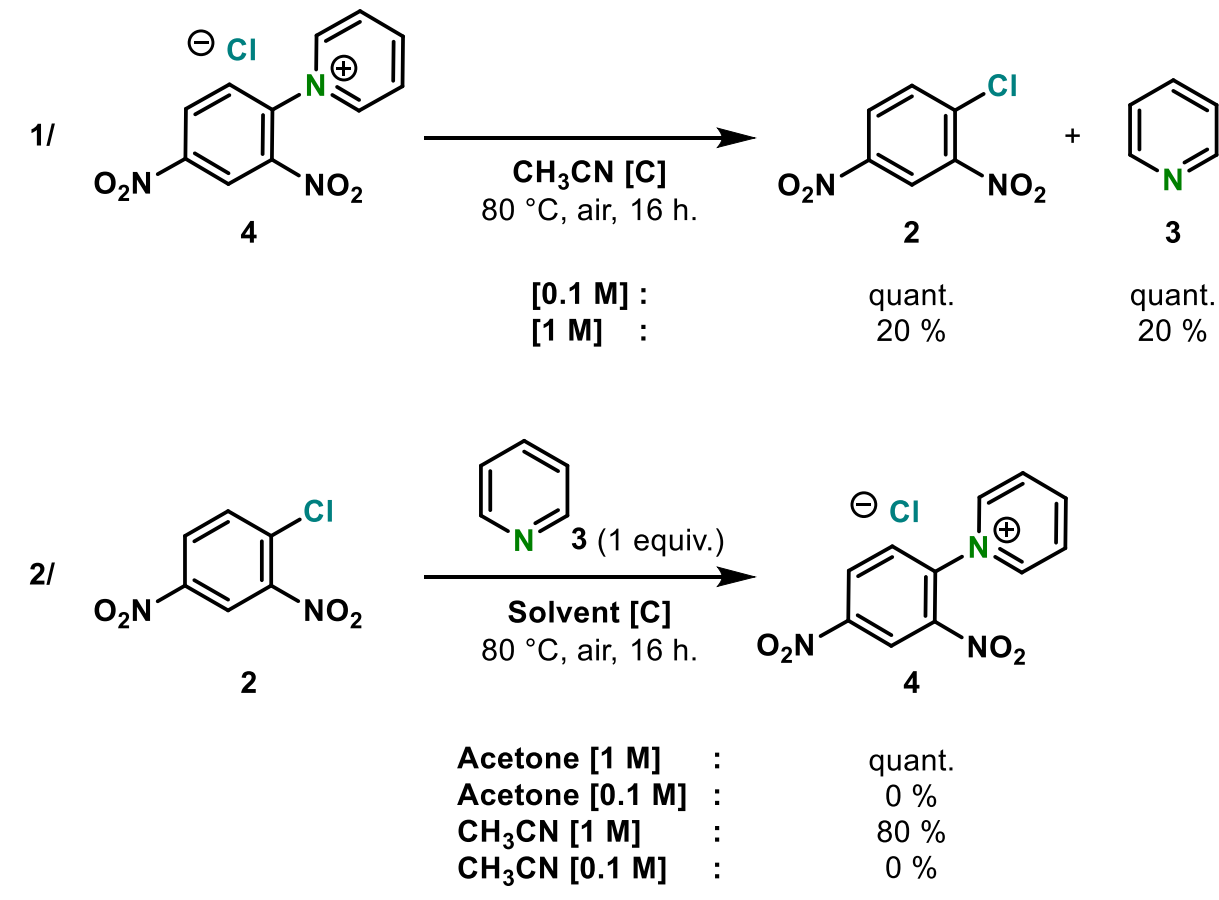

Synthesis and reversibility experiments of 4-[pyridyl]pyridinium chloride hydrochloride (6)

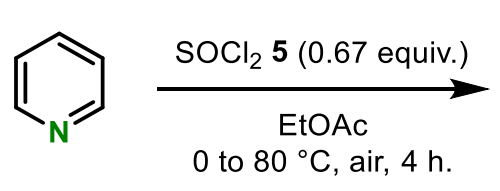

3<smiles></smiles>

6

To a $18 \mathrm{~mL}$ screw-capped tube under normal atmosphere are added pyridine 3 (500 $\mathrm{mg}, 6.32 \mathrm{mmol}$ ) and EtOAc $(300 \mu \mathrm{L})$. The mixture is cooled down to $0{ }^{\circ} \mathrm{C}$ and $\mathrm{SOCl}_{2} 5(310 \mu \mathrm{L}, 4.27 \mathrm{mmol})$ is added dropwise. The reaction is then allowed to reach $\mathrm{rt}$ and finally $80^{\circ} \mathrm{C}$ for 4 hours. The reaction is cooled down to rt and EtOAc as well as remaining $\mathrm{SOCl}_{2}$ as distilled off under high vacuum. The black crude oil is then dissolved in EtOH ( $2 \mathrm{~mL}$ ) and vigorously stirred at $60{ }^{\circ} \mathrm{C}$ for 15 minutes. The mixture is cooled down to rt, filtered and washed with the minimum amount of EtOH and $\mathrm{Et}_{2} \mathrm{O}(2 \times 5 \mathrm{~mL})$ to afford 6 product as a yellow powder ( $230 \mathrm{mg}, 32 \%)$.

${ }^{1} \mathrm{H}$ NMR $\left(300 \mathrm{MHz}, \mathrm{DMSO}-d_{6}\right) \delta 9.46(\mathrm{~d}, J=6.1 \mathrm{~Hz}, 2 \mathrm{H}), 9.01(\mathrm{~d}, J=5.9 \mathrm{~Hz}, 2 \mathrm{H}), 8.87(\mathrm{t}, J=7.8 \mathrm{~Hz}, 1 \mathrm{H})$, $8.38(\mathrm{t}, J=7.1 \mathrm{~Hz}, 2 \mathrm{H}), 8.06(\mathrm{~m}, 2 \mathrm{H})$.

Characterization data matched with a previously reported example. ${ }^{7,8}$

Reversibility experiment. In a $18 \mathrm{~mL}$ screw-capped tube under normal atmosphere are added starting material $(11.5 \mathrm{mg}, 0.05 \mathrm{mmol})$ and $\mathrm{CD}_{3} \mathrm{CN}(0.5 \mathrm{~mL})$. The reaction is stirred 16 hours at $80^{\circ} \mathrm{C}$. Yields are determined by ${ }^{1} \mathrm{H}$ NMR as the ratio between all components (everything was soluble).<smiles></smiles>

6, $15 \%$<smiles>Clc1ccncc1</smiles>

$8,93 \%$ 
Synthesis of ethoxycarbonyloxazole pyridinium tetrafluoroborate (10)

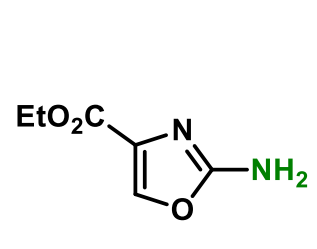

9

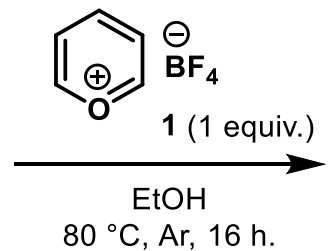

$80^{\circ} \mathrm{C}, \mathrm{Ar}, 16 \mathrm{~h}$.

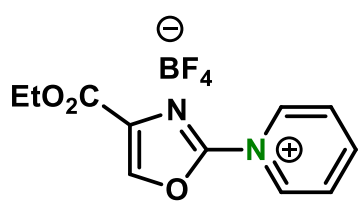

$10,93 \%$

To a flam-dried schlenk under $\mathrm{Ar}$ are added $\mathbf{9}(78.1 \mathrm{mg}, 0.5 \mathrm{mmol})$, pyrylium tetrafluoroborate $\mathbf{1}$ (84 $\mathrm{mg}, 0.5 \mathrm{mmol}$ ) in EtOH ( $5 \mathrm{~mL}$ ). The flask is wrapped in aluminum foil is stirred 16 hours at $80^{\circ} \mathrm{C}$. The reaction is cooled down to $\mathrm{rt}$ and the precipitate is filtered and quickly washed with EtOAc (minimum amount to cover the solid) and $\mathrm{Et}_{2} \mathrm{O}(2 \times 5 \mathrm{~mL})$ to afford 10 as an orange solid (143 mg, $93 \%$ ).

${ }^{1} \mathrm{H}$ NMR $\left(300 \mathrm{MHz}\right.$, DMSO- $\left.d_{6}\right) \delta 9.72(\mathrm{~d}, J=6.2 \mathrm{~Hz}, 2 \mathrm{H}), 9.36(\mathrm{~s}, 1 \mathrm{H}), 8.95(\mathrm{t}, J=7.8 \mathrm{~Hz}, 1 \mathrm{H}), 8.36(\mathrm{t}, J=$ $7.1 \mathrm{~Hz}, 2 \mathrm{H}), 4.39(\mathrm{q}, J=7.1 \mathrm{~Hz}, 2 \mathrm{H}), 1.34(\mathrm{t}, J=7.1 \mathrm{~Hz}, 3 \mathrm{H})$.

${ }^{13} \mathrm{C}$ NMR $\left(75 \mathrm{MHz}, \mathrm{DMSO}-d_{6}\right) \delta$ 159.4, $151.8,151.1,146.9,141.6,133.8,128.3,61.5,14.1$.

${ }^{19} \mathrm{~F}$ NMR $\left(282 \mathrm{MHz}, \mathrm{DMSO}-d_{6}\right) \delta-148.40(\mathrm{~s}, 4 \mathrm{~F})$.

HRMS (ESI) calculated [M-BF $]^{+}$219.076417, measured 219.076560.

Optimization experiments. All experiments are conducted in a $18 \mathrm{~mL} \mathrm{screw-capped} \mathrm{tube} \mathrm{under} \mathrm{normal}$ atmosphere with 10 (15.3 $\mathrm{mg}, 0.05 \mathrm{mmol})$, chloride source and $\mathrm{CH}_{3} \mathrm{CN}(0.5 \mathrm{~mL})$. The reaction is stirred 16 hours at the corresponding temperature. Yields (product 11) are determined by ${ }^{1} \mathrm{H}$ NMR with mesitylen (around 1 equiv., amount determined by mass) as internal standard.

\begin{tabular}{|c|c|c|}
\hline Chloride source (equiv.) & Temperature $\left({ }^{\circ} \mathrm{C}\right)$ & Yield of $11(\%)$ \\
\hline $\mathrm{MgCl}_{2}(2)$ & 120 & $>95$ \\
\hline $\mathrm{MgCl}_{2}(2)$ & 80 & $>95$ \\
\hline $\mathrm{MgCl}_{2}(2)$ & 25 & 50 \\
\hline $\mathrm{MgCl}_{2}(1)$ & 80 & $>95$ \\
\hline $\mathrm{MgCl}_{2}(0.5)$ & 120 & 60 \\
\hline$n \mathrm{Bu}_{4} \mathrm{NCl}(1)$ & 80 & 27 \\
\hline$n \mathrm{Bu}_{4} \mathrm{NCl}(2)$ & 80 & 41 \\
\hline$n \mathrm{Bu}_{4} \mathrm{NCl}(4)$ & 80 & 47 \\
\hline$n \mathrm{Bu}_{4} \mathrm{NCl}(4)$ & 120 & 87 \\
\hline $\mathrm{HCl}$ in $\mathrm{Et}_{2} \mathrm{O}(1)$ & 25 & 90 \\
\hline $\mathrm{HCl}$ in $\mathrm{Et}_{2} \mathrm{O}(2)$ & 25 & $>95$ \\
\hline TMSCl (1) & 50 & 70 \\
\hline $\operatorname{TMSCl}(2)$ & 50 & $>95$ \\
\hline
\end{tabular}




\section{Chlorination reactions and products characterization}

\section{General procedure for the chlorination of amino heteroaromatic compounds}

Unless otherwise specified: a $18 \mathrm{~mL}$ screw-capped tube under normal atmosphere is charged with pyrylium tetrafluoroborate 1 (1.5 equiv.) and $\mathrm{MgCl}_{2}$ (2.0 equiv.). The starting material (1.0 equiv.) is then added and directly followed by $\mathrm{CH}_{3} \mathrm{CN}(0.1 \mathrm{M})$. The resulting mixture is then stirred 5 minutes at room temperature and then 16 hours at $120^{\circ} \mathrm{C}$. The reaction is allowed to cool down to room temperature.

NMR yields: Mesitylen (around 1 equiv., amount determined by mass) is added to the reaction. A sample of the reaction is transferred into a NMR tube and DMSO- $d_{6}(300 \mathrm{~mL})$ is added.

Purification: The crude mixture is partitioned between water and EtOAc. The aqueous layer is extracted with EtOAc $(3 \times 10 \mathrm{~mL})$. The combined organic layers are dried over $\mathrm{Na}_{2} \mathrm{SO}_{4}$, concentrated to dryness and purified on silica gel to afford the desired product.

\section{General procedure for the Sandemeyer reaction of amino heteroaromatic compounds}

The starting heteroaromatic amine $(0.1 \mathrm{mmol})$ is dissolved in concentrated $\mathrm{HCl} 37 \%(0.5 \mathrm{~mL})$ at $0{ }^{\circ} \mathrm{C}$. A solution of $\mathrm{NaONO} 0.11 \mathrm{M}(1 \mathrm{~mL}, 0.11 \mathrm{mmol})$ is added dropwise to the solution. The mixture is stirred 15 minutes at $0^{\circ} \mathrm{C}$. Then, $\mathrm{CuCl}(12.9 \mathrm{mg}, 0.13 \mathrm{mmol})$ is added and the mixture is stirred 3 hours at $r$. The mixture is warmed up at $60{ }^{\circ} \mathrm{C}$ until the end of the bubbling $\left(\mathrm{N}_{2}\right)$. The reaction is carefully quenched with saturated $\mathrm{NaHCO}_{3}$ and extracted with $\mathrm{CH}_{2} \mathrm{Cl}_{2}(3 \times 5 \mathrm{~mL})$. The combined organic layers are dried over $\mathrm{Na}_{2} \mathrm{SO}_{4}$ and concentrated to dryness. Mesitylen (around 1 equiv., amount determined by mass) is added to the crude. A sample of the reaction is transferred into a NMR tube with $\mathrm{CDCl}_{3}$ to determine the dosed yield.

\section{Synthesis of 4-chloropyridine (7)}<smiles>Clc1ccncc1</smiles>

The reaction was performed at $100^{\circ} \mathrm{C}$ instead of $120^{\circ} \mathrm{C}$.

${ }^{1} \mathrm{H}$ NMR - in situ $\left(300 \mathrm{MHz}, \mathrm{DMSO}-\mathrm{d}_{6}\right) \delta 8.86(\mathrm{~d}, J=6.9 \mathrm{~Hz}, 2 \mathrm{H}), 8.13-8.02(\mathrm{~m}, 2 \mathrm{H})^{*}$.

*Note: Overlap with pyridine

Confirmed with the commercially available product [7379-35-3]. 
Synthesis of ethyl 2-chlorooxazole-4-carboxylate (11)<smiles>CCOC(=O)c1coc(Cl)n1</smiles>

No column was required for this compound; characterized after the work up. Slightly yellow liquid ${ }^{1} \mathrm{H}$ NMR $\left(300 \mathrm{MHz}, \mathrm{CDCl}_{3}\right) \delta 8.17(\mathrm{~s}, 1 \mathrm{H}), 4.37(\mathrm{q}, J=7.2 \mathrm{~Hz}, 2 \mathrm{H}), 1.36(\mathrm{t}, J=7.1 \mathrm{~Hz}, 3 \mathrm{H})$.

${ }^{13} \mathrm{C}$ NMR $\left(75 \mathrm{MHz}, \mathrm{CDCl}_{3}\right) \delta 160.1,148.3,145.5,135.2,61.8,14.3$.

HRMS (EI) calculated [M] ${ }^{+}$175.003072, measured 175.003070.

Characterization data matched with supplier data [460081-18-9].

\section{Synthesis of 4-chloro-3-fluoropyridine (12)}<smiles>Fc1cnccc1Cl</smiles>

The reaction was performed at $100{ }^{\circ} \mathrm{C}$ instead of $120^{\circ} \mathrm{C}$.

${ }^{1} \mathrm{H}$ NMR - in situ $\left(300 \mathrm{MHz}\right.$, DMSO- $\left.d_{6}\right) \delta 8.71(\mathrm{~d}, J=1.6 \mathrm{~Hz}, 1 \mathrm{H}), 8.46(\mathrm{t}, J=6.4 \mathrm{~Hz}, 1 \mathrm{H}) *, 7.73(\mathrm{t}, J=$ $5.9 \mathrm{~Hz}, 1 \mathrm{H})$.

*Note: Overlap with impurities

Confirmed with the commercially available product [2546-56-7].

\section{Synthesis of 4-chloro-2-methylpyridine (13)}<smiles>Cc1cc(Cl)ccn1</smiles>

The reaction was performed at $100{ }^{\circ} \mathrm{C}$ instead of $120^{\circ} \mathrm{C}$.

${ }^{1} \mathrm{H}$ NMR - in situ $\left(300 \mathrm{MHz}\right.$, DMSO- $\left.d_{6}\right) \delta 8.70(\mathrm{~d}, J=6.4 \mathrm{~Hz}, 1 \mathrm{H}), 8.16-8.03(\mathrm{~m}, 1 \mathrm{H}) *, 7.95(\mathrm{~d}, J=6.5$ $\mathrm{Hz}, 1 \mathrm{H}), 2.77(\mathrm{~s}, 3 \mathrm{H})$.

*Note: Overlap with pyridine

HRMS (EI) calculated [M] ${ }^{+}$128.026152, measured 128.026220. 
Synthesis of 2,4-dichloropyridine (14)<smiles>Clc1ccnc(Cl)c1</smiles>

The reaction was performed at $100{ }^{\circ} \mathrm{C}$ instead of $120^{\circ} \mathrm{C}$.

${ }^{1} \mathrm{H}$ NMR - in situ $\left(300 \mathrm{MHz}, \mathrm{DMSO}-\mathrm{d}_{6}\right) \delta 8.39(\mathrm{~d}, J=5.4 \mathrm{~Hz}, 1 \mathrm{H}), 7.69(\mathrm{~d}, J=1.8 \mathrm{~Hz}, 1 \mathrm{H}), 7.52(\mathrm{dd}, J=$ $5.4,1.8 \mathrm{~Hz}, 1 \mathrm{H})$.

HRMS (ESI) calculated $[\mathrm{M}+\mathrm{H}]^{+}$147.971530, measured 147.971520.

Synthesis of methyl 4-chloropicolinate (15)<smiles>COC(=O)c1cc(Cl)ccn1</smiles>

The reaction was performed at $80^{\circ} \mathrm{C}$ instead of $120^{\circ} \mathrm{C}$.

${ }^{1} \mathrm{H}$ NMR - in situ $\left(300 \mathrm{MHz}, \mathrm{DMSO}-\mathrm{d}_{6}\right) \delta 8.70(\mathrm{~d}, J=5.2 \mathrm{~Hz}, 1 \mathrm{H}), 8.11(\mathrm{~d}, J=2.1 \mathrm{~Hz}, 1 \mathrm{H}), 7.77(\mathrm{dd}, J=$ $5.3,2.1 \mathrm{~Hz}, 1 \mathrm{H}), 3.94(\mathrm{~s}, 3 \mathrm{H})$.

Characterization data matched with a previously reported example. ${ }^{9}$

Synthesis of 4-chloro-2-phenylpyridine (16)<smiles>Clc1ccnc(-c2ccccc2)c1</smiles>

Colorless oil (volatile)

${ }^{1} \mathrm{H}$ NMR $\left(300 \mathrm{MHz}, \mathrm{CDCl}_{3}\right) \delta 8.59(\mathrm{dd}, J=5.3,0.6 \mathrm{~Hz}, 1 \mathrm{H}), 7.99-7.95(\mathrm{~m}, 2 \mathrm{H}), 7.74(\mathrm{dd}, J=1.9,0.6 \mathrm{~Hz}$, $1 \mathrm{H}), 7.52-7.341(\mathrm{~m}, 2 \mathrm{H}), 7.25(\mathrm{~d}, J=4.9 \mathrm{~Hz}, 1 \mathrm{H})$.

Characterization data matched with a previously reported example. ${ }^{10}$ 
<smiles>COc1ccc(-c2cc(Cl)ccn2)cc1</smiles>

Colorless oil

${ }^{1} \mathrm{H}$ NMR $\left(300 \mathrm{MHz}, \mathrm{CDCl}_{3}\right) \delta 8.54(\mathrm{dd}, J=5.3,0.6 \mathrm{~Hz}, 1 \mathrm{H}), 7.96-7.91(\mathrm{~m}, 2 \mathrm{H}), 7.67(\mathrm{dd}, J=1.9,0.6 \mathrm{~Hz}$, $1 \mathrm{H}), 7.18(\mathrm{dd}, J=5.3,1.9 \mathrm{~Hz}, 1 \mathrm{H}), 7.02-6.97(\mathrm{~m}, 2 \mathrm{H}), 3.87(\mathrm{~s}, 3 \mathrm{H})$.

Characterization data matched with a previously reported example. ${ }^{11}$

Synthesis of 4-(4-chloropyridin-2-yl)morpholine (18)<smiles>Clc1ccnc(N2CCOCC2)c1</smiles>

The reaction was performed at $140{ }^{\circ} \mathrm{C}$ instead of $120^{\circ} \mathrm{C}$.

${ }^{1} \mathrm{H}$ NMR - in situ $\left(300 \mathrm{MHz}\right.$, DMSO- $\left.d_{6}\right) \delta 8.06(\mathrm{~d}, J=6.4 \mathrm{~Hz}, 1 \mathrm{H}), 7.42(\mathrm{~s}, 1 \mathrm{H}), 6.98(\mathrm{~d}, J=6.4 \mathrm{~Hz}, 1 \mathrm{H})$, 3.80-3.70 (m, 8H).

Characterization data matched with a previously reported example. ${ }^{12}$

\section{Synthesis of 2-chloro-5-nitropyridine (19)}<smiles>O=[N+]([O-])c1ccc(Cl)nc1</smiles>

${ }^{1} \mathrm{H}$ NMR - in situ $\left(300 \mathrm{MHz}\right.$, DMSO- $\left.d_{6}\right) \delta 9.23(\mathrm{~d}, J=2.9 \mathrm{~Hz}, 1 \mathrm{H}), 8.60(\mathrm{~m}, 1 \mathrm{H}) *, 7.77(\mathrm{~d}, J=8.8 \mathrm{~Hz}, 1 \mathrm{H})$.

*Note: Overlap with pyridine

Characterization data matched with a previously reported example. ${ }^{13}$ 
Synthesis of 6-chloronicotinonitrile (20)

NC<smiles>Clc1ccccn1</smiles>

The reaction was performed at $140{ }^{\circ} \mathrm{C}$ instead of $120^{\circ} \mathrm{C}$.

${ }^{1} \mathrm{H}$ NMR - in situ $\left(300 \mathrm{MHz}\right.$, DMSO- $\left.d_{6}\right) \delta \delta 8.86(\mathrm{~m}, 1 \mathrm{H})^{*}, 8.30(\mathrm{dd}, J=8.4,2.4 \mathrm{~Hz}, 1 \mathrm{H}), 7.73(\mathrm{~d}, J=8.4$ $\mathrm{Hz}, 1 \mathrm{H})$.

*Note: Overlap with pyridine

HRMS (ESI) calculated $[\mathrm{M}+\mathrm{H}]^{+}$139.005770, measured 139.005750.

Synthesis of 2,4-dichloropyrimidine (21)<smiles>Clc1ccnc(Cl)n1</smiles>

5 equivalents of $\mathrm{MgCl}_{2}$ were used.

${ }^{1} \mathrm{H}$ NMR - in situ $\left(300 \mathrm{MHz}\right.$, DMSO- $\left.d_{6}\right) \delta 8.75(\mathrm{~d}, J=5.3 \mathrm{~Hz}, 1 \mathrm{H}), 7.77(\mathrm{~d}, J=5.3 \mathrm{~Hz}, 1 \mathrm{H})$.

HRMS (EI) calculated [M]+ 147.958954, measured 147.959150.

Synthesis of 4-chloro-2-phenylpyrimidine (22)<smiles>Clc1ccnc(-c2ccccc2)n1</smiles>

Colorless liquid

${ }^{1} \mathrm{H}$ NMR $\left(300 \mathrm{MHz}, \mathrm{CDCl}_{3}\right) \delta 8.67(\mathrm{~d}, J=5.2 \mathrm{~Hz}, 1 \mathrm{H}), 8.46-8.43(\mathrm{~m}, 2 \mathrm{H}), 7.53-4.41(\mathrm{~m}, 3 \mathrm{H}), 7.23(\mathrm{~d}, J=$ $5.3 \mathrm{~Hz}, 1 \mathrm{H})$.

${ }^{13} \mathrm{C}$ NMR $\left(75 \mathrm{MHz}, \mathrm{CDCl}_{3}\right) \delta 165.8,161.7,158.4,136.3,131.7,128.8,128.7,119.5$.

HRMS (EI) calculated [M] 190.029225, measured 190.029520. 
Synthesis of 3,6-dichloropyridazine (23)<smiles>Clc1ccc(Cl)nn1</smiles>

4 equivalents of $\mathrm{CsCl}$ were used instead of $\mathrm{MgCl}_{2}$.

${ }^{1} \mathrm{H}$ NMR - in situ $\left(300 \mathrm{MHz}, \mathrm{DMSO}-d_{6}\right) \delta 8.01(\mathrm{~s}, 2 \mathrm{H})$.

HRMS (ESI) calculated [M+H] ${ }^{+}$148.966778, measured 148.966910.

Synthesis of 4,5-dichloro-2-phenylpyridazin-3(2H)-one (24)<smiles>O=c1c(Cl)c(Cl)cnn1-c1ccccc1</smiles>

Yellow solid

${ }^{1} \mathrm{H}$ NMR $\left(300 \mathrm{MHz}, \mathrm{CDCl}_{3}\right) \delta 7.92(\mathrm{~s}, 1 \mathrm{H}), 7.57(\mathrm{~d}, J=7.2 \mathrm{~Hz}, 2 \mathrm{H}), 7.52-7.40(\mathrm{~m}, 3 \mathrm{H})$.

${ }^{13} \mathrm{C}$ NMR $\left(75 \mathrm{MHz}, \mathrm{CDCl}_{3}\right) \delta 156.3,141.0,136.5,136.2,135.4,129.0,129.0,125.3$.

HRMS (ESI) calculated [M+Na] $]^{+}$262.974938, measured 262.975020.

Synthesis of 9-chloroacridine (25)<smiles>Clc1c2ccccc2nc2ccccc12</smiles>

${ }^{1} \mathrm{H}$ NMR - in situ $\left(300 \mathrm{MHz}, \mathrm{DMSO}-\mathrm{d}_{6}\right) \delta 8.85(\mathrm{~d}, J=8.7 \mathrm{~Hz}, 2 \mathrm{H}), 8.09(\mathrm{~d}, J=8.0 \mathrm{~Hz}, 2 \mathrm{H}) *, 7.99(\mathrm{t}, J=$ $7.7 \mathrm{~Hz}, 2 \mathrm{H}), 7.57(\mathrm{t}, J=7.7 \mathrm{~Hz}, 2 \mathrm{H})$.

*Note: Overlap with pyridine

Confirmed with the commercially available product [1207-69-8]. 
<smiles>CCn1cnc2c(Cl)ncnc21</smiles>

A $18 \mathrm{~mL}$ screw-capped tube under normal atmosphere is charged with pyrylium tetrafluoroborate $1(25.2 \mathrm{mg}, 0.15 \mathrm{mmol})$, aminoheterocycle $63(16.3 \mathrm{mg}, 0.1 \mathrm{mmol})$ and EtOH $(2 \mathrm{~mL})$. The resulting mixture is then stirred 5 minutes at room temperature and then 16 hours at $80{ }^{\circ} \mathrm{C}$ (covered with aluminium foil). The reaction is allowed to cool down to room temperature and the solvent is removed under high vacuum. The crude mixture is then dissolved in $\mathrm{CH}_{3} \mathrm{CN}(2 \mathrm{~mL})$ and $\mathrm{MgCl}_{2}(19.0 \mathrm{mg}, 0.2 \mathrm{mmol})$ is added. The resulting mixture is then stirred 5 minutes at room temperature and then 16 hours at $120{ }^{\circ} \mathrm{C}$. The reaction is allowed to cool down to room temperature and concentrated to dryness. The crude mixture can be purified on a silica pad and washed several times with $\mathrm{CH}_{2} \mathrm{Cl}_{2}$ to afford the desired product as a colorless liquid (11 mg, $60 \%$ ).

${ }^{1} \mathrm{H}$ NMR $\left(300 \mathrm{MHz}, \mathrm{CDCl}_{3}\right) \delta 8.74(\mathrm{~s}, 1 \mathrm{H}), 8.14(\mathrm{~s}, 1 \mathrm{H}), 4.36(\mathrm{q}, J=7.3 \mathrm{~Hz}, 2 \mathrm{H}), 1.58(\mathrm{t}, J=7.3 \mathrm{~Hz}, 3 \mathrm{H})$.

${ }^{13} \mathrm{C}$ NMR $\left(75 \mathrm{MHz}, \mathrm{CDCl}_{3}\right) \delta$ 152.0, 151.2, 144.8, 134.7, 131.9, 39.7, 15.4.

HRMS (ESI) calculated [M+H] ${ }^{+}$183.043198, measured 183.043180.

Synthesis of 4-chloropyrrolo[2,1-f][1,2,4]triazine (27)<smiles>Clc1ncnn2cccc12</smiles>

A $18 \mathrm{~mL}$ screw-capped tube under normal atmosphere is charged with pyrylium tetrafluoroborate $1(25.2 \mathrm{mg}, 0.15 \mathrm{mmol})$, aminoheterocycle $(13.4 \mathrm{mg}, 0.1 \mathrm{mmol})$ and $\mathrm{EtOH}$ $(2 \mathrm{~mL})$. The resulting mixture is then stirred 5 minutes at room temperature and then 16 hours at $80{ }^{\circ} \mathrm{C}$ (covered with aluminium foil). The reaction is allowed to cool down to room temperature and $\mathrm{Me}_{4} \mathrm{NCl}(43.8 \mathrm{mg}, 0.4 \mathrm{mmol})$ is added. The resulting mixture is then stirred 5 minutes at room temperature and then 16 hours at $80^{\circ} \mathrm{C}$. After cooling down the reaction to room temperature, the yield is determined by NMR. Attempts to purify the compound were unsuccessful and led to decompositions.

${ }^{1} \mathrm{H}$ NMR - in situ $(300 \mathrm{MHz}$, DMSO-d 6 ) $\delta 7.76(\mathrm{~d}, J=2.0 \mathrm{~Hz}, 1 \mathrm{H}), 7.52(\mathrm{~d}, J=2.6 \mathrm{~Hz}, 1 \mathrm{H}), 6.86(\mathrm{dd}, J=$ $4.4,1.6 \mathrm{~Hz}, 1 \mathrm{H}), 6.50(\mathrm{t}, J=3.5 \mathrm{~Hz}, 1 \mathrm{H})$.

HRMS (EI) calculated [M] 153.008824 , measured 153.008950. 
Synthesis of 3-chloro-[1,2,4]triazolo[4,3-a]pyridine (28)<smiles>Clc1nnc2ccccn12</smiles>

Colorless liquid

${ }^{1} \mathrm{H}$ NMR $\left(300 \mathrm{MHz}, \mathrm{CDCl}_{3}\right) \delta 8.00(\mathrm{dt}, J=7.0,1.2 \mathrm{~Hz}, 1 \mathrm{H}), 7.75(\mathrm{dt}, J=9.3,1.1 \mathrm{~Hz}, 1 \mathrm{H}), 7.33(\mathrm{ddd}, J=$ 9.4, 6.6, $1.2 \mathrm{~Hz}, 1 \mathrm{H}), 6.97(\mathrm{td}, J=6.8,1.0 \mathrm{~Hz}, 1 \mathrm{H})$.

${ }^{13} \mathrm{C}$ NMR $\left(75 \mathrm{MHz}, \mathrm{CDCl}_{3}\right) \delta 150.7,132.9,127.8,121.9,116.8,114.8$.

HRMS (EI) calculated [M] ${ }^{+}$153.008824, measured 153.009070.

Synthesis of 2-chlorobenzo[d]thiazole (29)<smiles>Clc1nc2ccccc2s1</smiles>

Colorless liquid (volatile)

${ }^{1} \mathrm{H}$ NMR $\left(300 \mathrm{MHz}, \mathrm{CDCl}_{3}\right) \delta 7.95$ (ddd, $\left.J=8.1,1.4,0.6 \mathrm{~Hz}, 1 \mathrm{H}\right), 7.78$ (ddd, $\left.J=7.8,1.4,0.6 \mathrm{~Hz}, 1 \mathrm{H}\right), 7.49$ (td, $J=7.7,1.4 \mathrm{~Hz}, 1 \mathrm{H}$ ), 7.41 (ddd, $J=7.8,7.3,1.3 \mathrm{~Hz}, 1 \mathrm{H}$ ).

Confirmed with the commercially available product [615-20-3].

Synthesis of 2-chloro-6-(trifluoromethoxy)benzo[d]thiazole (30)<smiles>FC(F)(F)Oc1ccc2nc(Cl)sc2c1</smiles>

Colorless liquid (volatile)

${ }^{1} \mathrm{H}$ NMR $\left(300 \mathrm{MHz}, \mathrm{CDCl}_{3}\right) \delta 7.96$ (dd, $\left.J=8.9,0.5 \mathrm{~Hz}, 1 \mathrm{H}\right), 7.66$ (ddd, $J=2.5,1.0,0.5 \mathrm{~Hz}, 1 \mathrm{H}$ ), 7.37 (ddq, $J=8.8,2.5,0.9 \mathrm{~Hz}, 1 \mathrm{H}$ ).

${ }^{13} \mathrm{C} \mathrm{NMR}\left(75 \mathrm{MHz}, \mathrm{CDCl}_{3}\right) \delta 154.3,149.7,147.0\left(\mathrm{q},{ }^{3}(\mathrm{C}, \mathrm{F})=1.7 \mathrm{~Hz}\right), 137.0,124.0,120.8\left(\mathrm{q},{ }^{4} J(\mathrm{C}, \mathrm{F})=\right.$ $0.67 \mathrm{~Hz}), 120.6\left(\mathrm{q},{ }^{1} J(C, F)=258.0 \mathrm{~Hz}\right), 113.9\left(\mathrm{q},{ }^{4} J(C, F)=1.3 \mathrm{~Hz}\right)$.

${ }^{19}$ F NMR $\left(282 \mathrm{MHz}, \mathrm{CDCl}_{3}\right) \delta-58.06(\mathrm{~s}, 3 \mathrm{~F})$.

HRMS (EI) calculated [M] ${ }^{+}$252.957050, measured 252.957470. 
<smiles>O=[N+]([O-])c1ccc2snc(Cl)c2c1</smiles>

Yellow solid

${ }^{1} \mathrm{H}$ NMR $\left(300 \mathrm{MHz}, \mathrm{CDCl}_{3}\right) \delta 8.71(\mathrm{~d}, J=2.3 \mathrm{~Hz}, 1 \mathrm{H}), 8.24(\mathrm{dd}, J=9.7,2.3 \mathrm{~Hz}, 1 \mathrm{H}), 7.86(\mathrm{~d}, J=9.7 \mathrm{~Hz}$, $1 \mathrm{H})$.

${ }^{13} \mathrm{C}$ NMR $\left(75 \mathrm{MHz}, \mathrm{CDCl}_{3}\right) \delta$ 161.5, 155.9, 145.5, 130.9, 123.9, 123.0, 118.0.

HRMS (ESI) calculated [M+H] 214.967653 , measured 214.967750.

Synthesis of methyl (E)-2-(2-chlorothiazol-4-yl)-2-(methoxyimino)acetate and methyl (Z)-2(2-chlorothiazol-4-yl)-2-(methoxyimino)acetate (32a and 32b)<smiles>CO/N=C(/C(=O)OC)c1csc(Cl)n1</smiles><smiles>CON=C(C(=O)OC)c1csc(Cl)n1</smiles>
dr: 0.66:0.34

Colorless liquids

Gram scale experiment: A similar procedure was applied: To a $100 \mathrm{~mL}$ pressure schlenk under normal atmosphere were added pyrylium tetrafluoroborate 1 (1.170 g, $6.97 \mathrm{mmol}), \mathrm{MgCl}_{2}(0.884 \mathrm{~g}, 9.29 \mathrm{mmol})$ and 60 (1.000 g, $4.65 \mathrm{mmol})$ in $\mathrm{CH}_{3} \mathrm{CN}(50 \mathrm{~mL})$. The resulting mixture is then stirred 5 minutes at room temperature and then 2 days at $120{ }^{\circ} \mathrm{C}$ (conversion monitored by crude ${ }^{1} \mathrm{H} N M R$ ). The reaction is allowed to cool down to room temperature. The crude mixture is partitioned between water and EtOAc. The aqueous layer is extracted with EtOAc $(3 \times 100 \mathrm{~mL})$. The combined organic layers are dried over $\mathrm{Na}_{2} \mathrm{SO}_{4}$, concentrated to dryness and purified on silica gel (hexanes:EtOAc, 70/30) to afford the mixed desired products 32 a as pale yellow oil $(0.895 \mathrm{mg}, 82 \%)$..

A) ${ }^{1} \mathrm{H}$ NMR $\left(300 \mathrm{MHz}, \mathrm{CDCl}_{3}\right) \delta 7.50(\mathrm{~s}, 1 \mathrm{H}), 4.04(\mathrm{~s}, 3 \mathrm{H}), 3.94(\mathrm{~s}, 3 \mathrm{H})$.

A) ${ }^{13} \mathrm{C}$ NMR $\left(75 \mathrm{MHz}, \mathrm{CDCl}_{3}\right) \delta 162.7,153.2,145.2,145.2,120.3,63.6,52.9$.

B) ${ }^{1} \mathrm{H}$ NMR $\left(300 \mathrm{MHz}, \mathrm{CDCl}_{3}\right) \delta 8.03(\mathrm{~s}, 1 \mathrm{H}), 4.13(\mathrm{~s}, 3 \mathrm{H}), 3.93(\mathrm{~s}, 3 \mathrm{H})$.

B) ${ }^{13} \mathrm{C}$ NMR $\left(75 \mathrm{MHz}, \mathrm{CDCl}_{3}\right) \delta 163.3,151.2,143.1,141.4,127.8,64.2,53.3$.

HRMS (ESI) calculated [M+Na] ${ }^{+} 256.975812$ measured 256.975680. 
Synthesis of $(R)$-2-(2-chlorooxazole-4-carboxamido)-2-phenylethyl (E)-3-(3-

chlorophenyl)acrylate (39)<smiles>O=C(/C=C/c1cccc(Cl)c1)OCC(NC(=O)c1coc(Cl)n1)c1ccccc1</smiles>

Beige solid (mp: $\left.152.4^{\circ} \mathrm{C}\right)$

${ }^{1} \mathrm{H}$ NMR $\left(300 \mathrm{MHz}, \mathrm{CDCl}_{3}\right) \delta 8.15(\mathrm{~s}, 1 \mathrm{H}), 7.61(\mathrm{~d}, J=16.0 \mathrm{~Hz}, 1 \mathrm{H}), 7.49(\mathrm{~d}, J=2.0 \mathrm{~Hz}, 1 \mathrm{H}), 7.45-7.28$ $(\mathrm{m}, 9 \mathrm{H}), 6.42(\mathrm{~d}, J=16.0 \mathrm{~Hz}, 1 \mathrm{H}), 5.52$ (ddd, $J=8.5,6.9,4.9 \mathrm{~Hz}, 1 \mathrm{H}), 4.62-4.50(\mathrm{~m}, 2 \mathrm{H})$.

${ }^{13} \mathrm{C}$ NMR $\left(75 \mathrm{MHz}, \mathrm{CDCl}_{3}\right) \delta 166.4,158.9,147.2,144.2,143.3,137.8,137.6,136.1,135.1,130.4,130.2$, $129.1,128.3,128.0,126.9,126.5,118.9,66.3,52.3$.

HRMS (ESI) calculated [M+Na] $]^{+}$453.037932, measured 453.038660.

Synthesis of $(R)$-2-(2-chlorooxazole-4-carboxamido)-2-phenylethyl 2-bromobenzoate (34)<smiles>O=C(NC(COC(=O)c1ccccc1Br)c1ccccc1)c1coc(Cl)n1</smiles>

Off-white foam (mp: $151.2^{\circ} \mathrm{C}$ )

${ }^{1} \mathrm{H}$ NMR $\left(300 \mathrm{MHz}, \mathrm{CDCl}_{3}\right) \delta 8.15(\mathrm{~s}, 1 \mathrm{H}), 7.72(\mathrm{~m}, 1 \mathrm{H}), 7.65(\mathrm{~m}, 1 \mathrm{H}), 7.56(\mathrm{~d}, J=8.6 \mathrm{~Hz}, 1 \mathrm{H}), 7.44-7.28$ $(\mathrm{m}, 7 \mathrm{H}), 5.60(\mathrm{~m}, 1 \mathrm{H}), 4.754 .63(\mathrm{~m}, 2 \mathrm{H})$.

${ }^{13} \mathrm{C}$ NMR $\left(75 \mathrm{MHz}, \mathrm{CDCl}_{3}\right) \delta 166.2,158.9,147.2,143.3,137.9,137.6,134.5,133.0,131.9,131.8,129.1$, $128.3,127.4,127.0,121.9,67.4,52.1$.

HRMS (ESI) calculated [M+Na] 470.971780 , measured 470.972260. 
<smiles>N#Cc1cccc(C(=O)OCC(NC(=O)c2coc(Cl)n2)c2ccccc2)c1</smiles>

Beige solid (mp: $\left.101.2^{\circ} \mathrm{C}\right)$

${ }^{1} \mathrm{H}$ NMR $\left(300 \mathrm{MHz}, \mathrm{CDCl}_{3}\right) \delta 8.25(\mathrm{~s}, 1 \mathrm{H}), 8.20(\mathrm{~d}, J=7.9 \mathrm{~Hz}, 1 \mathrm{H}), 8.15(\mathrm{~s}, 1 \mathrm{H}), 7.83(\mathrm{~d}, J=7.8 \mathrm{~Hz}, 1 \mathrm{H})$, $7.56(\mathrm{t}, J=7.8 \mathrm{~Hz}, 1 \mathrm{H}), 7.44-7.31(\mathrm{~m}, 6 \mathrm{H}), 5.61(\mathrm{dt}, J=8.5,6.3 \mathrm{~Hz}, 1 \mathrm{H}), 4.72-4.64(\mathrm{~m}, 2 \mathrm{H})$. ${ }^{13} \mathrm{C}$ NMR $\left(75 \mathrm{MHz}, \mathrm{CDCl}_{3}\right) \delta 164.5,159.0,147.3,143.3,137.5,137.3,136.3,133.9,133.5,131.1,129.7$, $129.3,128.7,126.9,117.9,113.2,67.3,52.2$.

HRMS (ESI) calculated [M+Na] 418.056503 , measured 418.056640.

Synthesis of (R)-2-(2-chlorooxazole-4-carboxamido)-2-phenylethyl 2-iodobenzoate (36)<smiles>O=C(NC(COC(=O)c1ccccc1I)c1ccccc1)c1coc(Cl)n1</smiles>

Off-white foam (mp: $118.3^{\circ} \mathrm{C}$ )

${ }^{1} \mathrm{H}$ NMR $\left(300 \mathrm{MHz}, \mathrm{CDCl}_{3}\right) 8.14(\mathrm{~s}, 1 \mathrm{H}), 7.97(\mathrm{dd}, J=7.9,1.2 \mathrm{~Hz}, 1 \mathrm{H}), 7.71(\mathrm{dd}, J=7.8,1.7 \mathrm{~Hz}, 1 \mathrm{H}), 7.54$ (d, $J=8.6 \mathrm{~Hz}, 1 \mathrm{H}), 7.44-7.29(\mathrm{~m}, 6 \mathrm{H}), 7.14(\mathrm{td}, J=7.7,1.7 \mathrm{~Hz}, 1 \mathrm{H}), 5.61$ (ddd, $J=8.6,6.7,4.7 \mathrm{~Hz}, 1 \mathrm{H}$ ), 4.76-4.62 (m, 2H).

${ }^{13} \mathrm{C}$ NMR $\left(75 \mathrm{MHz}, \mathrm{CDCl}_{3}\right) \delta 166.4,158.9,147.2,143.3,141.4,137.8,137.6,134.9,133.0,131.5,129.1$, $128.4,128.1,127.0,94.2,67.3,52.2$.

HRMS (ESI) calculated [M+Na] ${ }^{+}$518.957902, measured 518.957980. 
Synthesis of $(R)$-2-(2-chlorooxazole-4-carboxamido)-2-phenylethyl 4-formylbenzoate (37)<smiles>O=Cc1ccc(C(=O)OCC(NC(=O)c2coc(Cl)n2)c2ccccc2)cc1</smiles>

Slightly yellow solid (mp: $143.4^{\circ} \mathrm{C}$ )

${ }^{1} \mathrm{H}$ NMR $\left(300 \mathrm{MHz}, \mathrm{CDCl}_{3}\right) \delta 10.09(\mathrm{~s}, 1 \mathrm{H}), 8.15-8.12(\mathrm{~m}, 3 \mathrm{H}), 7.93(\mathrm{~d}, J=8.1 \mathrm{~Hz}, 2 \mathrm{H}), 7.45-7.32(\mathrm{~m}$, $6 \mathrm{H}), 5.62(\mathrm{dt}, J=8.6,6.2 \mathrm{~Hz}, 1 \mathrm{H}), 4.75-4.64(\mathrm{~m}, 2 \mathrm{H})$.

${ }^{13} \mathrm{C}$ NMR $\left(75 \mathrm{MHz}, \mathrm{CDCl}_{3}\right) \delta 191.6,165.5,159.0,147.3,143.3,139.5,137.5,137.5,134.7,130.5,129.7$, 129.2, 128.6, 126.9, 67.1, 52.2.

HRMS (ESI) calculated [M+Na] 421.056169 , measured 421.056580.

Synthesis of (R)-2-(2-chlorooxazole-4-carboxamido)-2-phenylethyl 4-fluorobenzoate (38)<smiles>O=C(OCC(NC(=O)c1coc(Cl)n1)c1ccccc1)c1ccc(F)cc1</smiles>

White solid (mp: $176.8^{\circ} \mathrm{C}$ )

${ }^{1} \mathrm{H}$ NMR $\left(300 \mathrm{MHz}, \mathrm{CDCl}_{3}\right) \delta 8.14(\mathrm{~s}, 1 \mathrm{H}), 8.00(\mathrm{~m}, 2 \mathrm{H}), 7.44-7.30(\mathrm{tt}, \mathrm{J}=13.5,6.4 \mathrm{~Hz}, 6 \mathrm{H}), 7.09(\mathrm{t}, \mathrm{J}=$ $8.6 \mathrm{~Hz}, 2 \mathrm{H}$ ), 5.59 (ddd, J = 8.6, 7.1, 5.3 Hz, 1H), 4.70-4.59 (m, 2H).

${ }^{13} \mathrm{C}$ NMR $\left(75 \mathrm{MHz}, \mathrm{CDCl}_{3}\right) \delta 166.1\left(\mathrm{~d},{ }^{1} \mathrm{~J}(\mathrm{C}, \mathrm{F})=255 \mathrm{~Hz}\right), 165.5,159.0,147.2,143.2,137.8,137.6,132.4$ $\left(d,{ }^{3} J(C, F)=9 \mathrm{~Hz}\right), 129.2,128.5,126.9,126.0\left(d,{ }^{4} J(C, F)=3 \mathrm{~Hz}\right), 115.8\left(d,{ }^{2} J(C, F)=22 \mathrm{~Hz}\right), 66.8,52.3$.

${ }^{19}$ F NMR $\left(282 \mathrm{MHz}, \mathrm{CDCl}_{3}\right) \delta-105.10(\mathrm{~s}, 3 \mathrm{~F})$.

HRMS (ESI) calculated [M+Na] 411.051833 , measured 411.052650. 
Synthesis of (R)-2-(2-chlorooxazole-4-carboxamido)-2-phenylethyl nicotinate (39)<smiles>O=C(OCC(NC(=O)c1coc(Cl)n1)c1ccccc1)c1cccnc1</smiles>

Brown solid (mp: $152.4^{\circ} \mathrm{C}$ )

${ }^{1} \mathrm{H}$ NMR $\left(300 \mathrm{MHz}, \mathrm{CDCl}_{3}\right) \delta 9.16(\mathrm{~s}, 1 \mathrm{H}), 8.76(\mathrm{~d}, J=4.6 \mathrm{~Hz}, 1 \mathrm{H}), 8.24(\mathrm{~d}, J=8.0 \mathrm{~Hz}, 1 \mathrm{H}), 8.14(\mathrm{~s}, 1 \mathrm{H})$, 7.44-7.30 (m, 7H), $5.61(\mathrm{q}, J=6.8 \mathrm{~Hz}, 1 \mathrm{H}), 4.69(\mathrm{~d}, J=6.2 \mathrm{~Hz}, 2 \mathrm{H})$.

${ }^{13} \mathrm{C}$ NMR $\left(75 \mathrm{MHz}, \mathrm{CDCl}_{3}\right) \delta 165.2,159.0,153.8,151.1,147.3,143.3,137.5,137.5,137.3,129.2,128.6$, $126.9,125.8,123.5,67.0,52.2$.

HRMS (ESI) calculated [M+Na] 394.056503 , measured 394.056660.

Synthesis of $(R)-2$-(2-chlorooxazole-4-carboxamido)-2-phenylethyl 2-(4(methylsulfonyl)phenyl)acetate (40)<smiles>COS(=O)(=O)c1ccc(CC(=O)OCC(NC(=O)c2coc(Cl)n2)c2ccccc2)cc1</smiles>

White solid (mp: $\left.116.9^{\circ} \mathrm{C}\right)$

${ }^{1} \mathrm{H}$ NMR $\left(300 \mathrm{MHz}, \mathrm{CDCl}_{3}\right) \delta 8.16(\mathrm{~s}, 1 \mathrm{H}), 7.85(\mathrm{~d}, J=8.3 \mathrm{~Hz}, 2 \mathrm{H}), 7.40(\mathrm{~d}, J=8.1 \mathrm{~Hz}, 2 \mathrm{H}), 7.37-7.20(\mathrm{~m}$, $6 \mathrm{H}), 5.45(\mathrm{dt}, J=8.7,6.1 \mathrm{~Hz}, 1 \mathrm{H}), 4.46(\mathrm{~d}, J=6.1 \mathrm{~Hz}, 2 \mathrm{H}), 3.71(\mathrm{~s}, 2 \mathrm{H}), 3.03(\mathrm{~s}, 3 \mathrm{H})$.

${ }^{13} \mathrm{C}$ NMR $\left(75 \mathrm{MHz}, \mathrm{CDCl}_{3}\right) \delta 170.2,158.9,147.3,143.3,139.9,139.6,137.4,137.4,130.5,129.1,128.5$, $127.8,126.8,66.7,52.0,44.7,41.1$.

HRMS (ESI) calculated [M+Na] 485.054457 , measured 485.055210.

Synthesis of 2-chloro-5-methyl-1,3,4-thiadiazole (41)<smiles>Cc1nnc(Cl)s1</smiles>

${ }^{1} \mathrm{H}$ NMR - in situ (300 MHz, DMSO- $\left.d_{6}\right) \delta 2.72(\mathrm{~s}, 3 \mathrm{H})$.

HRMS (EI) calculated [M] ${ }^{+}$133.969998, measured 133.970270. 
Synthesis of 2-chloro-5-phenyl-1,3,4-oxadiazole (42)<smiles>Clc1nnc(-c2ccccc2)o1</smiles>

Attempts to purify the compound were unsuccessful and led to decompositions.

${ }^{1} \mathrm{H}$ NMR - in situ (300 MHz, DMSO- $\left.d_{6}\right) \delta$ 8.13-7.82 (m, 2H), 7.78-7.45 (m, 3H).

Note: The signals from the product are overlapping with the pyridine. However, the dosed yield remains consistent with both components.

HRMS (EI) calculated [M] ${ }^{+}$180.008490, measured 180.008840.

\section{Synthesis of 2-chloro- $N$-((1R,2S)-2-hydroxy-2,3-dihydro-1H-inden-1-yl)oxazole-4-} carboxamide (43)<smiles>O=C(N[C@H]1c2ccccc2C[C@H]1O)c1coc(Cl)n1</smiles>

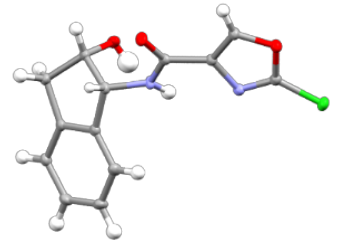

A $18 \mathrm{~mL}$ screw-capped tube under normal atmosphere is charged with pyrylium tetrafluoroborate $1(25.2 \mathrm{mg}, 0.15 \mathrm{mmol}), \mathbf{S M 5}(25.9 \mathrm{mg}, 0.01 \mathrm{mmol})$ and EtOH $(2 \mathrm{~mL})$. The resulting mixture is then stirred 5 minutes at room temperature and then 16 hours at $50{ }^{\circ} \mathrm{C}$ (covered with aluminum foil). The reaction is allowed to cool down to room temperature and the solvent is removed under high vacuum. The crude mixture is then dissolved in $\mathrm{CH}_{3} \mathrm{CN}$ (2 $\mathrm{mL})$ and $n \mathrm{Bu}_{4} \mathrm{NCl}(111.2 \mathrm{mg}, 0.4 \mathrm{mmol})$ is added. The resulting mixture is then stirred 5 minutes at room temperature and then 16 hours at $50^{\circ} \mathrm{C}$. The reaction is allowed to cool down to room temperature and directly purified on silica gel (hexanes:EtOAc, 50:50) to afford the desired product as a colorless oil (16 $\mathrm{mg}, 57 \%$ ).

${ }^{1}$ H NMR $\left(300 \mathrm{MHz}, \mathrm{CDCl}_{3}\right) \delta 8.21(\mathrm{~s}, 1 \mathrm{H}), 7.42(\mathrm{~d}, J=7.4 \mathrm{~Hz}, 1 \mathrm{H}), 7.36-7.20(\mathrm{~m}, 4 \mathrm{H}), 5.52(\mathrm{dd}, J=8.6$, $5.1 \mathrm{~Hz}, 1 \mathrm{H}), 4.73(\mathrm{~s}, 1 \mathrm{H}), 3.23(\mathrm{dd}, J=16.4,5.3 \mathrm{~Hz}, 1 \mathrm{H}), 3.00(\mathrm{~d}, J=16.5 \mathrm{~Hz}, 1 \mathrm{H}), 2.21(\mathrm{~s}, 1 \mathrm{H})$.

${ }^{13} \mathrm{C}$ NMR $\left(75 \mathrm{MHz}, \mathrm{CDCl}_{3}\right) \delta 160.1,160.0,143.3,140.1,140.1,137.7,128.7,127.5,125.6,124.9,73.9$, $57.5,39.9$.

HRMS (ESI) calculated [M+Na] 301.035039 , measured 301.034780.

Synthesis of diethyl ((2-(6-chloro-9H-purin-9-yl)ethoxy)methyl)phosphonate (44)<smiles>CCOP(=O)(COCCn1cnc2c(Cl)ncnc21)OCC</smiles> 
A schlenk under Ar is charged with pyrylium tetrafluoroborate 1 (25.2 mg, $0.15 \mathrm{mmol}$ ), diethylAdefovir ( $32.9 \mathrm{mg}, 0.01 \mathrm{mmol}$ ) and $\mathrm{EtOH}(2 \mathrm{~mL}$ ). The resulting mixture is then stirred 5 minutes at room temperature and then 16 hours at $80^{\circ} \mathrm{C}$ (covered with aluminum foil). The reaction is allowed to cool down to room temperature and the solvent is removed under high vacuum. The crude mixture is then dissolved in $\mathrm{CH}_{3} \mathrm{CN}(2 \mathrm{~mL})$ and $n \mathrm{Bu}_{4} \mathrm{NCl}(111.2 \mathrm{mg}, 0.4 \mathrm{mmol})$ is added. The resulting mixture is then stirred 5 minutes at room temperature and then 16 hours at $80^{\circ} \mathrm{C}$. The reaction is allowed to cool down to room temperature and directly purified on silica gel $\left(\mathrm{CH}_{2} \mathrm{Cl}_{2}: \mathrm{MeOH}, 100: 0\right.$ to $\left.90: 10\right)$ to afford the desired product as an orange oil (20 mg, $57 \%)$.

Note: trace amounts of $n \mathrm{Bu}_{4} \mathrm{~N}^{+}$can sometimes be detected after the column. The resulting mixture can be dissolved in $\mathrm{Et}_{2} \mathrm{O}$, sonicated (orange solution + black solids) and filtered through celite without any loss.

${ }^{1} \mathrm{H}$ NMR $\left(300 \mathrm{MHz}, \mathrm{CDCl}_{3}\right) \delta 8.71(\mathrm{~s}, 1 \mathrm{H}), 8.27(\mathrm{~s}, 1 \mathrm{H}), 4.49(\mathrm{t}, J=4.9 \mathrm{~Hz}, 2 \mathrm{H}), 4.11-4.02(\mathrm{~m}, 4 \mathrm{H}), 3.96$ $(\mathrm{t}, J=5.0 \mathrm{~Hz}, 2 \mathrm{H}), 3.76(\mathrm{~d}, J=8.1 \mathrm{~Hz}, 2 \mathrm{H}), 1.29-1.23(\mathrm{~m}, 6 \mathrm{H})$.

${ }^{13} \mathrm{C}$ NMR $\left(75 \mathrm{MHz}, \mathrm{CDCl}_{3}\right) \delta 151.9,152.0,151.1,146.3,131.6,70.9\left(\mathrm{~d},{ }^{3} \mathrm{~J}(\mathrm{C}, \mathrm{F})=10 \mathrm{~Hz}\right), 65.5\left(\mathrm{~d},{ }^{1} \mathrm{~J}(\mathrm{C}, \mathrm{F})=\right.$ $167 \mathrm{~Hz}), 62.6\left(\mathrm{~d},{ }^{2} J(\mathrm{C}, \mathrm{F})=7 \mathrm{~Hz}\right), 44.1,16.6\left(\mathrm{~d},{ }^{3} J(\mathrm{C}, \mathrm{F})=6 \mathrm{~Hz}\right)$.

${ }^{31}$ P NMR (243 MHz, $\left.\mathrm{CDCl}_{3}\right) \delta 20.21(\mathrm{~s}, 1 \mathrm{P})$.

HRMS (ESI) calculated [M+Na] 371.064641 , measured 371.064630.

Synthesis of methyl 2-chloro-7-isopropyl-5-oxo-5H-chromeno[2,3-b]pyridine-3-carboxylate (45)<smiles>CC(=O)c1cc2c(=O)c3cc(C(C)C)ccc3oc2nc1Cl</smiles>

A schlenk under Ar is charged with pyrylium tetrafluoroborate 1 ( $25.2 \mathrm{mg}, 0.15 \mathrm{mmol}$ ), SM16 ( $31.2 \mathrm{mg}, 0.01 \mathrm{mmol}$ ) and $\mathrm{EtOH}(2 \mathrm{~mL})$. The resulting mixture is then stirred 5 minutes at room temperature and then 16 hours at $80^{\circ} \mathrm{C}$ (covered with aluminum foil). The reaction is allowed to cool down to room temperature and the solvent is removed under high vacuum. The crude mixture is then dissolved in $\mathrm{CH}_{3} \mathrm{CN}(2 \mathrm{~mL})$ and $n B u_{4} \mathrm{NCl}(111.2 \mathrm{mg}, 0.4 \mathrm{mmol})$ is added. The resulting mixture is then stirred 5 minutes at room temperature and then 16 hours at $80^{\circ} \mathrm{C}$. The reaction is allowed to cool down to room temperature and directly purified on silica gel (hexanes:EtOAc, 80:20) to afford the desired product as a white solid (17 mg, $51 \%$ ).

${ }^{1} \mathrm{H}$ NMR $\left(300 \mathrm{MHz}, \mathrm{CDCl}_{3}\right) \delta 9.19(\mathrm{~s}, 1 \mathrm{H}), 8.14(\mathrm{~d}, J=2.3 \mathrm{~Hz}, 1 \mathrm{H}), 7.70$ (dd, $\left.J=8.7,2.3 \mathrm{~Hz}, 1 \mathrm{H}\right), 7.55(\mathrm{~d}$, $J=8.6 \mathrm{~Hz}, 1 \mathrm{H}), 4.01(\mathrm{~s}, 3 \mathrm{H}), 3.07$ (hept, $J=6.9 \mathrm{~Hz}, 1 \mathrm{H}), 1.33(\mathrm{~d}, J=7.0 \mathrm{~Hz}, 6 \mathrm{H})$.

${ }^{13} \mathrm{C} \mathrm{NMR}\left(75 \mathrm{MHz}, \mathrm{CDCl}_{3}\right) \delta 176.4,163.6,160.0,154.5,153.9,146.9,142.5,135.4,123.8,121.5,118.7$, 115.0, 53.2, 33.9, 24.0.

HRMS (EI) calculated [M] 331.060587 , measured 331.060640. 
<smiles>O=C(Cc1csc(Cl)n1)N1CCN(C2=Nc3ccccc3Oc3ccc(Cl)cc32)CC1</smiles>

The reaction was performed at $80^{\circ} \mathrm{C}$ instead of $120^{\circ} \mathrm{C}$. Yellow sticky oil

${ }^{1} \mathrm{H}$ NMR $\left(300 \mathrm{MHz}, \mathrm{CDCl}_{3}\right) \delta 7.40(\mathrm{dd}, J=8.6,2.6 \mathrm{~Hz}, 1 \mathrm{H}), 7.31(\mathrm{~d}, J=2.5 \mathrm{~Hz}, 1 \mathrm{H}), 7.19(\mathrm{~d}, J=8.6 \mathrm{~Hz}$, $1 \mathrm{H})$, 7.17-7.06 $(\mathrm{m}, 4 \mathrm{H}), 7.01(\mathrm{~m}, 1 \mathrm{H}), 3.86(\mathrm{~s}, 2 \mathrm{H}), 3.82-3.68(\mathrm{~m}, 4 \mathrm{H}), 3.65-3.34(\mathrm{~m}, 4 \mathrm{H})$.

${ }^{13} \mathrm{C}$ NMR $\left(75 \mathrm{MHz}, \mathrm{CDCl}_{3}\right) \delta 167.7,159.3,158.5,151.7,151.4,148.7,139.7,132.8,130.4,128.8,127.1$, $125.8,125.0,124.7,122.8,120.1,118.0,47.4,47.4,45.9,41.6,36.7$.

HRMS (ESI) calculated [M+H] ${ }^{+}$473.060028, measured 473.059970.

Synthesis of 1-((3S,4R)-3-((benzo[d][1,3]dioxol-5-yloxy)methyl)-4-(4fluorophenyl)piperidin-1-yl)-2-(2-chlorothiazol-4-yl)ethan-1-one (47)<smiles>O=C(Cc1csc(Cl)n1)N1CCC(c2ccc(F)cc2)[C@H](COc2ccc3c(c2)OCO3)C1</smiles>

The reaction was performed at $80^{\circ} \mathrm{C}$ instead of $120^{\circ} \mathrm{C}$. Yellow sticky oil

${ }^{1} \mathrm{H}$ NMR $\left(600 \mathrm{MHz}\right.$, DMSO- $\left.d_{6}\right) \delta 7.48(\mathrm{dd}, J=3.4,0.9 \mathrm{~Hz}, 1 \mathrm{H}$ ), 7.27 (ddd, $J=10.2,8.7,6.2 \mathrm{~Hz}, 2 \mathrm{H}), 7.12$ $(\mathrm{td}, J=8.8,2.1 \mathrm{~Hz}, 2 \mathrm{H}), 6.72(\mathrm{dd}, J=8.5,1.7 \mathrm{~Hz}, 1 \mathrm{H}), 6.46(\mathrm{dd}, J=10.1,2.5 \mathrm{~Hz}, 1 \mathrm{H}), 6.17(\mathrm{dd}, J=8.5$, $2.5 \mathrm{~Hz}, 1 \mathrm{H}), 5.92(\mathrm{bs}, 2 \mathrm{H}), 4.68(\mathrm{~m}, 1 \mathrm{H}), 4.13(\mathrm{~m}, 1 \mathrm{H}), 3.89(\mathrm{~m}, 2 \mathrm{H}), 3.51(\mathrm{~m}, 2 \mathrm{H}), 3.11(\mathrm{~m}, 1 \mathrm{H}), 2.78$ (dtd, $J=16.0,11.7,3.9 \mathrm{~Hz}, 1 \mathrm{H}), 2.62(\mathrm{~m}, 1 \mathrm{H}), 1.98(\mathrm{dtt}, J=11.1,7.5,3.5 \mathrm{~Hz}, 1 \mathrm{H}), 1.74(\mathrm{dq}, J=13.3,2.9$ $\mathrm{Hz}, 1 \mathrm{H}), 1.61$ (dqd, $J=45.7,12.6,4.3 \mathrm{~Hz}, 1 \mathrm{H}$ ).

${ }^{13} \mathrm{C}$ NMR (151 MHz, DMSO- $\left.d_{6}\right) \delta 166.9(\mathrm{~d}, J=13 \mathrm{~Hz}), 160.9$ (d, $\left.{ }^{1} J(\mathrm{C}, \mathrm{F})=242 \mathrm{~Hz}\right), 153.9,153.8,149.5$ (m), 147.8, 141.2, 139.6, $129.1\left(\mathrm{dd},{ }^{3} J(C, F)=8 \mathrm{~Hz}, J=3 \mathrm{~Hz}\right), 119.7(\mathrm{~d}, J=3 \mathrm{~Hz}), 115.2\left(\mathrm{~d},{ }^{2} J(C, F)=21\right.$ $\mathrm{Hz}), 107.9(\mathrm{~d}, J=7 \mathrm{~Hz}), 105.6(\mathrm{~d}, J=13 \mathrm{~Hz}), 101.0,97.8(\mathrm{~d}, J=10 \mathrm{~Hz}), 68.7(\mathrm{~d}, J=75 \mathrm{~Hz}), 47.4(\mathrm{~d}, J=$ $414 \mathrm{~Hz}$ ), 43.9 (d, J = 232 Hz), $42.5(\mathrm{~d}, J=186 \mathrm{~Hz}), 41.4(\mathrm{~d}, J=106 \mathrm{~Hz}), 36.0$ (d, J=26 Hz), 33.6 (d, $J=$ $109 \mathrm{~Hz})$.

${ }^{19} \mathrm{~F}$ NMR $\left(282 \mathrm{MHz}\right.$, DMSO- $\left.d_{6}\right) \delta-116.45(\mathrm{~d}, J=3.8 \mathrm{~Hz}, 1 \mathrm{~F})$.

Note: The 2 conformations of piperidine led to a signal splitting in ${ }^{1} \mathrm{H},{ }^{13} \mathrm{C}$ as well as ${ }^{19} \mathrm{~F} N M R$.

HRMS (ESI) calculated [M+Na] 511.086506 , measured 511.086620. 
<smiles>CN(C)C(=O)Cn1nccc1-c1nc(C(C)(C)c2ccc(-c3cnc(Cl)nc3)cc2)no1</smiles>

A schlenk under Ar is charged with pyrylium tetrafluoroborate $1(3.4 \mathrm{mg}, 0.02 \mathrm{mmol}$ ) and $\mathrm{MgCl}_{2}$ (4.9 mg, $\left.0.05 \mathrm{mmol}\right) . \mathrm{Bl} 665915(4.7 \mathrm{mg}, 0.01 \mathrm{mmol})$ is then added and directly followed by $\mathrm{CH}_{3} \mathrm{CN}(1 \mathrm{~mL})$. The resulting mixture is then stirred 5 minutes at room temperature and then 16 hours at $120{ }^{\circ} \mathrm{C}$. The reaction is allowed to cool down to room temperature and is concentrated to dryness. The resulting solids were dissolved in the minimum amount of $\mathrm{CH}_{2} \mathrm{Cl}_{2}$ and purified by preparative $\mathrm{TLC}\left(\mathrm{CH}_{2} \mathrm{Cl}_{2}: \mathrm{MeOH}, 90: 10\right)$ to afford the desired product $(1.8 \mathrm{mg}$, $37 \%)$.

${ }^{1} \mathrm{H}$ NMR $\left(600 \mathrm{MHz}\right.$, DMSO- $\left.d_{6}\right) \delta 8.55(\mathrm{~s}, 2 \mathrm{H}), 8.49(\mathrm{~d}, J=0.8 \mathrm{~Hz}, 1 \mathrm{H}), 8.06(\mathrm{~d}, J=0.7 \mathrm{~Hz}, 1 \mathrm{H}), 7.56(\mathrm{~d}, J$ $=8.5 \mathrm{~Hz}, 2 \mathrm{H}), 7.38(\mathrm{~d}, J=8.6 \mathrm{~Hz}, 2 \mathrm{H}), 5.21(\mathrm{~s}, 2 \mathrm{H}), 3.03(\mathrm{~s}, 3 \mathrm{H}), 2.85(\mathrm{~s}, 3 \mathrm{H}), 1.66(\mathrm{~m}, 1 \mathrm{H}), 1.48(\mathrm{~s}, 3 \mathrm{H})$, $0.64(\mathrm{~m}, 1 \mathrm{H}), 0.49(\mathrm{~m}, 1 \mathrm{H}), 0.43(\mathrm{~m}, 1 \mathrm{H}), 0.34(\mathrm{~m}, 1 \mathrm{H})$.

${ }^{13} \mathrm{C}$ NMR $\left(151 \mathrm{MHz}\right.$, DMSO- $\left.d_{6}\right) \delta 175.6,172.3,170.3,165.8,155.8,143.8,138.5,134.0,133.5,127.3$, $125.2,121.7,106.6,53.6,53.25,2.0,1.0$.

Note: Due to the amount of material recovered as well as the presence of several peaks in the aliphatic area, 4 carbons cannot be precisely attributed.

HRMS (ESI) calculated [M+H] 478.175274 , measured 478.174910.

Synthesis of 5-chloro-1-(2,6-dichloro-4-(trifluoromethyl)phenyl)-4((trifluoromethyl)sulfinyl)-1H-pyrazole-3-carbonitrile (49)<smiles>N#Cc1nn(-c2c(Cl)cc(C(F)(F)F)cc2Cl)c(Cl)c1S(=O)C(F)(F)F</smiles>

5 equivalents of $\mathrm{MgCl}_{2}$ were used. Yellow solid

${ }^{1} \mathrm{H}$ NMR $\left(300 \mathrm{MHz}, \mathrm{CDCl}_{3}\right) \delta 7.84$ (bs, 2H).

${ }^{13} \mathrm{C}$ NMR $\left(75 \mathrm{MHz}, \mathrm{CDCl}_{3}\right) \delta 136.1(\mathrm{~d}, J=3 \mathrm{~Hz}) *, 135.9\left(\mathrm{q},{ }^{2} J(\mathrm{C}, \mathrm{F})=35 \mathrm{~Hz}\right), 134.7,134.2(\mathrm{bs}), 128.0$, $126.47\left(\mathrm{qd},{ }^{3} J(\mathrm{C}, \mathrm{F})=4 \mathrm{~Hz}, J=1 \mathrm{~Hz}\right)^{*}, 125.2\left(\mathrm{q},{ }^{1} J(\mathrm{C}, \mathrm{F})=336 \mathrm{~Hz}\right), 121.9\left(\mathrm{q},{ }^{1} J(\mathrm{C}, \mathrm{F})=274 \mathrm{~Hz}\right), 118.5$, 109.3 . 
*Note: A potential steric hindrance impedes a free rotation between the 2 aromatic rings. Therefore, a signal splitting is detected for those signals.

${ }^{19} \mathrm{~F}$ NMR $\left(282 \mathrm{MHz}, \mathrm{CDCl}_{3}\right) \delta-63.38(\mathrm{~s}, 3 \mathrm{~F}),-72.54(\mathrm{~s}, 3 \mathrm{~F})$.

HRMS (ESI) calculated [M+Na] ${ }^{+} 477.878058$, measured 477.877890.

Synthesis of $(R)$-1-(3-(4-chloro-3-(4-phenoxyphenyl)-1H-pyrazolo[3,4-d]pyrimidin-1yl)piperidin-1-yl)prop-2-en-1-one (50)<smiles>C=CC(=O)N1CCC[C@H](n2nc(-c3ccc(Oc4ccccc4)cc3)c3c(Cl)ncnc32)C1</smiles>

A schlenk under $\mathrm{Ar}$ is charged with pyrylium tetrafluoroborate $(25.2 \mathrm{mg}, 0.15 \mathrm{mmol})$, Ibrutinib ( $44.0 \mathrm{mg}, 0.01 \mathrm{mmol}$ ) and $\mathrm{EtOH}(2 \mathrm{~mL})$. The resulting mixture is then stirred 5 minutes at room temperature and then 16 hours at $50{ }^{\circ} \mathrm{C}$ (covered with aluminum foil). The reaction is allowed to cool down to room temperature and the solvent is removed under high vacuum. The crude mixture is then dissolved in $\mathrm{CH}_{3} \mathrm{CN}(4 \mathrm{~mL})$ and $n \mathrm{Bu}_{4} \mathrm{NCl}(111.2 \mathrm{mg}, 0.4 \mathrm{mmol})$ is added. The resulting mixture is then stirred 5 minutes at room temperature and then 16 hours at $50{ }^{\circ} \mathrm{C}$. The reaction is allowed to cool down to room temperature and directly purified on silica gel (hexanes:EtOAc, 20:80) to afford the desired product as a yellow oil (40 mg, $87 \%$ ).

${ }^{1} \mathrm{H}$ NMR $\left(300 \mathrm{MHz}, \mathrm{CDCl}_{3}\right) \delta 8.75(\mathrm{~s}, 1 \mathrm{H}), 7.74(\mathrm{~d}, J=8.7 \mathrm{~Hz}, 2 \mathrm{H}), 7.38(\mathrm{t}, J=7.7 \mathrm{~Hz}, 2 \mathrm{H}), 7.20-6.98$ $(\mathrm{m}, 5 \mathrm{H}), 6.58(\mathrm{dt}, J=25.2,13.6 \mathrm{~Hz}, 1 \mathrm{H}), 6.30(\mathrm{~d}, J=16.1 \mathrm{~Hz}, 1 \mathrm{H}), 5.69(\mathrm{t}, J=14.4 \mathrm{~Hz}, 1 \mathrm{H}), 4.98(\mathrm{bs}, 1 \mathrm{H})$, $4.74(\mathrm{dd}, J=80.5,10.4 \mathrm{~Hz}, 1 \mathrm{H}), 4.13(\mathrm{dd}, J=52.9,13.3 \mathrm{~Hz}, 1 \mathrm{H}), 3.61(\mathrm{dt}, J=111.9,11.9 \mathrm{~Hz}, 1 \mathrm{H}), 3.08$ (dt, $J=92.2,14.0 \mathrm{~Hz}, 1 \mathrm{H}), 2.41(\mathrm{~m}, 1 \mathrm{H}), 2.28(\mathrm{~m}, 1 \mathrm{H}), 2.03(\mathrm{~m}, 1 \mathrm{H}), 1.77(\mathrm{~m}, 1 \mathrm{H})$.

${ }^{13} \mathrm{C}$ NMR $\left(75 \mathrm{MHz}, \mathrm{CDCl}_{3}\right) \delta 165.8,158.8,156.6,154.4,154.1,144.9,131.7,130.0,128.4,127.6,125.9$, $125.7,124.0,119.7,118.2,111.4,54.3(0.5 \mathrm{C}), 53.2(0.5 \mathrm{C}), 50.1(0.5 \mathrm{C}), 46.1(0.5 \mathrm{C}), 46.0(0.5 \mathrm{C}), 42.3$ (0.5 C), 30.3 (0.5 C), 30.1 (0.5 C), 25.3 (0.5 C), 24.0 (0.5 C).

Note: The 2 conformations of piperidine led to a signal splitting in both ${ }^{1} \mathrm{H}$ and ${ }^{13} \mathrm{C} N M R$.

HRMS (ESI) calculated $[\mathrm{M}+\mathrm{H}]^{+}$460.153476, measured 460.153380 . 
<smiles>CC(C)Cc1nc(-c2cccc(NS(=O)(=O)c3c(F)cccc3F)c2F)c(-c2ccnc(Cl)n2)s1</smiles>

A schlenk under Ar is charged with pyrylium tetrafluoroborate $\left(4.0 \mathrm{mg}, 0.02 \mathrm{mmol}\right.$ ) and $\mathrm{MgCl}_{2}$ (9.5 mg, $0.10 \mathrm{mmol})$. Dabrafenib ( $4.7 \mathrm{mg}, 0.01 \mathrm{mmol}$ ) is then added and directly followed by $\mathrm{CH}_{3} \mathrm{CN}(1 \mathrm{~mL})$. The resulting mixture is then stirred 5 minutes at room temperature and then 16 hours at $120^{\circ} \mathrm{C}$. The reaction is allowed to cool down to room temperature and filtered through celite with EtOAc. The resulting mixture is concentrated to the minimum and purified by preparative TLC (hexanes:EtOAC, 50:50) to afford the desired product ( $1.9 \mathrm{mg}, 39 \%$ ).

${ }^{1} \mathrm{H}$ NMR $\left(300 \mathrm{MHz}, \mathrm{CDCl}_{3}\right) \delta 8.30(\mathrm{~d}, J=5.3 \mathrm{~Hz}, 1 \mathrm{H}), 7.75(\mathrm{~m}, 1 \mathrm{H}), 7.51(\mathrm{~m}, 1 \mathrm{H}), 7.34$ (ddd, $J=8.1,6.4$, $1.7 \mathrm{~Hz}, 1 \mathrm{H}), 7.26(\mathrm{~s}, 1 \mathrm{H}),{ }^{*} 7.21(\mathrm{~d}, J=6.6 \mathrm{~Hz}, 1 \mathrm{H}), 6.99(\mathrm{t}, J=8.8 \mathrm{~Hz}, 2 \mathrm{H}), 6.74(\mathrm{dd}, J=5.4,1.1 \mathrm{~Hz}, 1 \mathrm{H})$, $1.48(\mathrm{~s}, 9 \mathrm{H})$.

*Note: Overlap with $\mathrm{CHCl}_{3}$.

${ }^{13} \mathrm{C}$ NMR $\left(151 \mathrm{MHz}\right.$, DMSO- $\left.d_{6}\right) \delta 183.3,160.6,160.5,159.8,158.2,130.5,129.6,128.9,128.2,125.3$, $124.2\left(d,{ }^{3} J(C, F)=9 \mathrm{~Hz}\right), 115.1,112.6\left(d,{ }^{2} J(C, F)=24 \mathrm{~Hz}\right), 37.9,30.2$.

Note: 4 quaternary carbons cannot be detected due to the low amount as well as the C-F couplings.

${ }^{19} \mathrm{~F}$ NMR $\left(282 \mathrm{MHz}, \mathrm{CDCl}_{3}\right) \delta-106.85$ (d, $\left.J=3.7 \mathrm{~Hz}, 2 \mathrm{~F}\right),-129.95$ (bs, 1F).

HRMS (ESI) calculated [M+H] $]^{+}$539.058459, measured 539.058050. 


\section{Post-functionalization}

\section{Negishi coupling of 30}<smiles>FC(F)(F)Oc1ccc2nc(Cl)sc2c1</smiles>

30

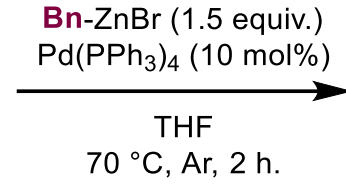

$70{ }^{\circ} \mathrm{C}, \mathrm{Ar}, 2 \mathrm{~h}$

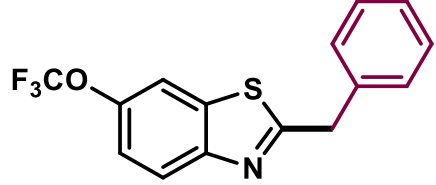

$52,89 \%$

To a flam-dried schlenk under $\mathrm{Ar}$ are added 30 (11 mg, $0.043 \mathrm{mmol}), \mathrm{Pd}\left(\mathrm{PPh}_{3}\right)_{4}(5 \mathrm{mg}, 0.004 \mathrm{mmol})$ and THF $(1 \mathrm{~mL})$. The mixture is stirred at room temperature is $\mathrm{Bn}-\mathrm{ZnBr} 0.5 \mathrm{M}$ in THF ( $130 \mu \mathrm{L}, 0.065 \mathrm{mmol}$ ) is added by syringe. The reaction is then stirred 2 hours at $70^{\circ} \mathrm{C}$. After cooling down, water is added to the reaction $(5 \mathrm{~mL})$ and the aqueous phase is extracted with $\mathrm{Et}_{2} \mathrm{O}(3 \times 5 \mathrm{~mL})$, dried over $\mathrm{Na}_{2} \mathrm{SO}_{4}$ and purified on silica gel ( $n$-pentane:Et ${ }_{2} \mathrm{O}, 100: 0$ to $90: 10$ ) to afford 52 as a colourless oil ( $12 \mathrm{mg}, 89 \%$ ).

${ }^{1}$ H NMR $\left(300 \mathrm{MHz}, \mathrm{CDCl}_{3}\right) \delta 7.99(\mathrm{~d}, J=8.9 \mathrm{~Hz}, 1 \mathrm{H}), 7.65(\mathrm{~m}, 1 \mathrm{H}), 7.37-7.27(\mathrm{~m}, 6 \mathrm{H}), 4.44(\mathrm{~s}, 2 \mathrm{H})$.

${ }^{13} \mathrm{C}$ NMR $\left(75 \mathrm{MHz}, \mathrm{CDCl}_{3}\right) \delta 172.7,151.9,146.4\left(\mathrm{q},{ }^{3} \mathrm{~J}(\mathrm{C}, \mathrm{F})=2 \mathrm{~Hz}\right), 136.9,136.6,129.3,129.1,127.7$, $123.7,120.7\left(\mathrm{q},{ }^{1} J(\mathrm{C}, \mathrm{F})=258 \mathrm{~Hz}\right), 120.1,114.3,40.8$.

${ }^{19} \mathrm{~F}$ NMR $\left(282 \mathrm{MHz}, \mathrm{CDCl}_{3}\right) \delta-58.06(\mathrm{~s}, 3 \mathrm{~F})$.

HRMS (EI) calculated [M] ${ }^{+}$309.042972, measured 309.043220.

\section{Suzuki coupling of 44}<smiles>CCOP(=O)(COCCn1cnc2c(Cl)ncnc21)OCC</smiles>

44

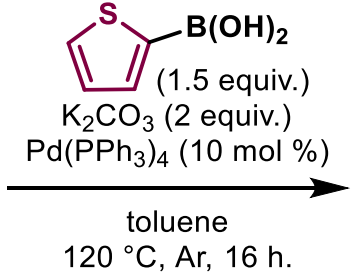

$120^{\circ} \mathrm{C}, \mathrm{Ar}, 16 \mathrm{~h}$.

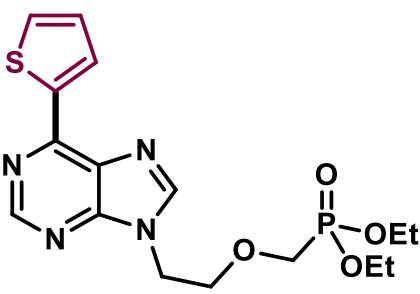

$53,78 \%$

To a flam-dried schlenk under $\mathrm{Ar}$ are added $44(9 \mathrm{mg}, 0.026 \mathrm{mmol}), \mathrm{K}_{2} \mathrm{CO}_{3}(7 \mathrm{mg}, 0.052 \mathrm{mmol})$, $\mathrm{Pd}\left(\mathrm{PPh}_{3}\right)_{4}(5 \mathrm{mg}, 0.004 \mathrm{mmol}), 2$-thiopheneboronic acid $(5 \mathrm{mg}, 0.039 \mathrm{mmol})$ and Toluene $(1.5 \mathrm{~mL})$. The mixture is stirred at $120^{\circ} \mathrm{C}$ for 16 hours. After cooling down, water is added to the reaction $(5 \mathrm{~mL})$ and the aqueous phase is extracted with EtOAc $(3 \times 5 \mathrm{~mL})$, dried over $\mathrm{Na}_{2} \mathrm{SO}_{4}$ and purified on silica gel $\left(\mathrm{CH}_{2} \mathrm{Cl}_{2}: \mathrm{MeOH}, 100: 0\right.$ to $\left.95: 5\right)$ to afford 53 as an orange oil ( $\left.8 \mathrm{mg}, 78 \%\right)$.

${ }^{1} \mathrm{H}$ NMR $\left(600 \mathrm{MHz}, \mathrm{CDCl}_{3}\right) \delta 8.87(\mathrm{~s}, 1 \mathrm{H}), 8.68(\mathrm{dd}, J=3.8,1.2 \mathrm{~Hz}, 1 \mathrm{H}), 8.24(\mathrm{~s}, 1 \mathrm{H}), 7.61(\mathrm{dd}, J=5.0$, $1.2 \mathrm{~Hz}, 1 \mathrm{H}), 7.26(\mathrm{~m}, 1 \mathrm{H}), 4.50(\mathrm{dd}, \mathrm{J}=5.4,4.6 \mathrm{~Hz}, 2 \mathrm{H}), 4.11-4.06(\mathrm{~m}, 4 \mathrm{H}), 3.98(\mathrm{dd}, \mathrm{J}=5.3,4.6 \mathrm{~Hz}$, $2 \mathrm{H}), 3.78(\mathrm{~d}, \mathrm{~J}=8.2 \mathrm{~Hz}, 2 \mathrm{H}), 1.28$ (2t overlap, $\mathrm{J}=7.1,0.4 \mathrm{~Hz}, 6 \mathrm{H}$ ).

${ }^{13} \mathrm{C}$ NMR $\left(151 \mathrm{MHz}, \mathrm{CDCl}_{3}\right) \delta 152.5,152.0,150.2,145.5,140.1,132.8,130.9,128.9,128.9,71.1$ (d, $\left.{ }^{3} J(C, P)=10 \mathrm{~Hz}\right), 65.5\left(d,{ }^{1} J(C, P)=167 \mathrm{~Hz}\right), 62.6\left(d,{ }^{2} J(C, P)=7 \mathrm{~Hz}\right), 43.6,16.6\left(d,{ }^{3} J(C, P)=6 \mathrm{~Hz}\right)$.

${ }^{31}$ P NMR (243 MHz, $\left.\mathrm{CDCl}_{3}\right) \delta 20.31(\mathrm{~s}, 1 \mathrm{P})$.

HRMS (ESI) calculated [M+Na] 419.091336, measured 419.091270. 


\section{Sonogashira coupling of 11}<smiles>CCOC(=O)c1coc(Cl)n1</smiles>

11

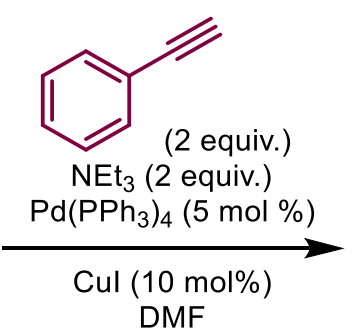

$80^{\circ} \mathrm{C}, \mathrm{Ar}, 16 \mathrm{~h}$.

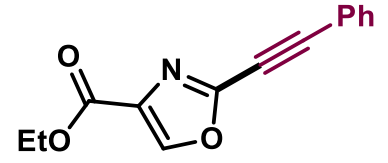

$54,56 \%$

To a flam-dried schlenk under Ar are added 11 (35.1 mg, $0.2 \mathrm{mmol}), \mathrm{Pd}\left(\mathrm{PPh}_{3}\right)_{4}(11.6 \mathrm{mg}, 0.01 \mathrm{mmol})$, Cul (3.8 mg, $0.02 \mathrm{mmol})$, phenylacetylene $(44 \mu \mathrm{L}, 0.4 \mathrm{mmol})$, trimethylamine $(56 \mu \mathrm{L}, 0.4 \mathrm{mmol})$ and DMF (1.5 mL). The mixture is stirred at $80{ }^{\circ} \mathrm{C}$ for 16 hours. After cooling down, aqueous solution of saturated $\mathrm{NaHCO}_{3}$ is added to the reaction $(5 \mathrm{~mL})$ and the aqueous phase is extracted with EtOAc $(3 \times 5$ $\mathrm{mL}$ ), dried over $\mathrm{Na}_{2} \mathrm{SO}_{4}$ and purified on silica gel ( $n$-pentane:Et ${ }_{2} \mathrm{O}, 70: 30$ ) to afford 54 as a brown solid (27 mg, $56 \%$ ).

${ }^{1}$ H NMR $\left(300 \mathrm{MHz}, \mathrm{CDCl}_{3}\right) \delta 8.24(\mathrm{~s}, 1 \mathrm{H}), 7.60(\mathrm{~m}, 2 \mathrm{H}), 7.49-7.36(\mathrm{~m}, 3 \mathrm{H}), 4.42(\mathrm{q}, J=7.1 \mathrm{~Hz}, 2 \mathrm{H}), 1.40$ $(\mathrm{t}, J=7.1 \mathrm{~Hz}, 3 \mathrm{H})$.

${ }^{13} \mathrm{C} \mathrm{NMR}\left(75 \mathrm{MHz}, \mathrm{CDCl}_{3}\right) \delta$ 160.7, 147.4, 144.3, 134.7, 132.4, 130.5, 128.8, 120.2, 92.7, 76.3, 61.6, 14.4.

HRMS (EI) calculated [M] 241.073344, measured 241.073490.

\section{SNAr of 50 with cyclohexylamine}<smiles>C=CC(=O)N1CCC[C@H](n2nc(-c3ccc(Oc4ccccc4)cc3)c3c(Cl)ncnc32)C1</smiles>

50

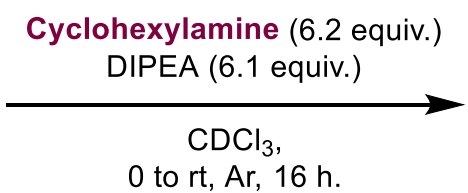

to $\mathrm{rt}, \mathrm{Ar}, 16 \mathrm{~h}$.

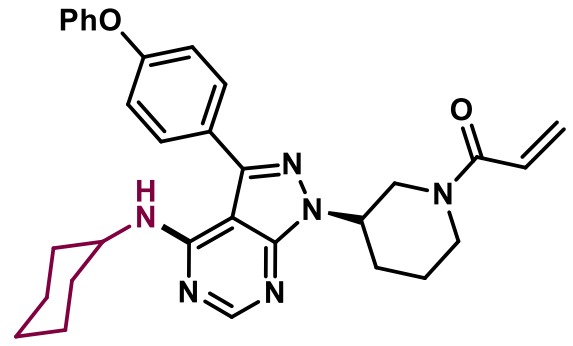

$55,74 \%$

To a flam-dried schlenk under Ar are added $50(13 \mathrm{mg}, 0.028 \mathrm{mmol})$ and cyclohexylamine $(20 \mu \mathrm{L}, 0.175$ $\mathrm{mmol}$ ) in $\mathrm{CDCl}_{3}(1 \mathrm{~mL})$. The mixture is cooled down to $0{ }^{\circ} \mathrm{C}$ and DIPEA ( $30 \mu \mathrm{L}, 0.172 \mathrm{mmol}$ ) is slowly added. The mixture is stirred from $0{ }^{\circ} \mathrm{C}$ to rt during 16 hours (conversion checked by NMR). The product is then directly purified on silica gel $\left(\mathrm{CH}_{2} \mathrm{Cl}_{2}: \mathrm{MeOH}, 100: 0\right.$ to $\left.95: 5\right)$ to afford 55 as a white film (11 mg, $74 \%)$.

${ }^{1} \mathrm{H}$ NMR $\left(600 \mathrm{MHz}, \mathrm{CDCl}_{3}\right) \delta 8.44(\mathrm{~s}, 1 \mathrm{H}), 7.60(\mathrm{~d}, J=8.1 \mathrm{~Hz}, 2 \mathrm{H}), 7.40(\mathrm{~m}, 2 \mathrm{H}), 7.20-7.16(\mathrm{~m}, 3 \mathrm{H}), 7.08$ $(\mathrm{m}, 2 \mathrm{H}), 6.58(\mathrm{~m}, 1 \mathrm{H}), 6.28(\mathrm{t}, J=17.8 \mathrm{~Hz}, 1 \mathrm{H}), 5.68(\mathrm{dd}, J=38.3,10.7 \mathrm{~Hz}, 1 \mathrm{H}), 5.52(\mathrm{bs}, 1 \mathrm{H}), 4.86-4.57$ $(\mathrm{m}, 2 \mathrm{H}), 4.27-4.01(\mathrm{~m}, 2 \mathrm{H}), 3.58(\mathrm{dt}, J=209.9,11.5 \mathrm{~Hz}, 1 \mathrm{H}), 3.04(\mathrm{~m}, 1 \mathrm{H}), 2.35(\mathrm{~m}, 1 \mathrm{H}), 2.25(\mathrm{~m}, 1 \mathrm{H})$, 2.01-1.98 (m, 3H), $1.73(\mathrm{~m}, 1 \mathrm{H}), 1.64-1.60(\mathrm{~m}, 3 \mathrm{H}), 1.51-1.45(\mathrm{~m}, 2 \mathrm{H}), 1.23-1.19(\mathrm{~m}, 3 \mathrm{H})$. 
${ }^{13} \mathrm{C}$ NMR $\left(151 \mathrm{MHz}, \mathrm{CDCl}_{3}\right) \delta 165.9,158.8,156.5,153.5,153.2,144.0,130.1(3 \mathrm{C}), 128.2,127.8(2 \mathrm{C})$, 124.3, 119.6, 119.4, 98.5, 53.7 (0.5C), 52.9 (0.5C), 50.2 (0.5C), 46.2 (0.5C), 46.0 (0.5C), 42.3 (0.5C), 32.8, 30.6 (0.5C), 30.2 (0.5C), 29.9, 25.5, 25.4 (0.5C), 24.3, 24.0 (0.5C).

Note: The 2 conformations of piperidine led to a signal splitting in both ${ }^{1} \mathrm{H}$ and ${ }^{13} \mathrm{C} N M R$.

HRMS (ESI) calculated [M+H] $]^{+}$523.281597, measured 523.281660.

\section{SNAr of 31 with Duloxetine}<smiles>O=[N+]([O-])c1ccc2snc(Cl)c2c1</smiles>

31

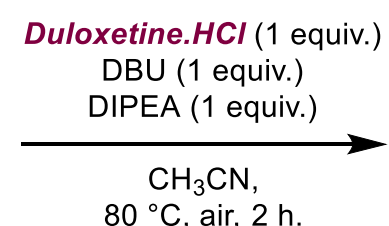

$80^{\circ} \mathrm{C}$, air, $2 \mathrm{~h}$

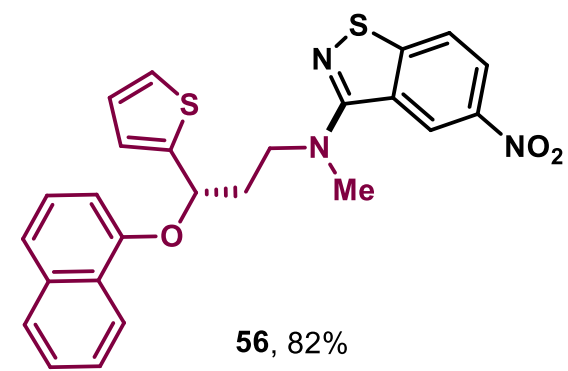

To a first $18 \mathrm{~mL}$ screw-capped tube under normal atmosphere are added Duloxetine. $\mathrm{HCl}$ (24.1 $\mathrm{mg}, 0.072 \mathrm{mmol})$ and $\mathrm{CH}_{3} \mathrm{CN}(0.5 \mathrm{~mL})$. DIPEA $(12.6 \mu \mathrm{L}, 0.072 \mathrm{mmol})$ is then added and the mixture is stirred until it is homogeneous. To a second $18 \mathrm{~mL} \mathrm{screw-capped} \mathrm{tube} \mathrm{under} \mathrm{normal}$ atmosphere are added 31 (15.5 mg, $0.072 \mathrm{mmol})$ and $\mathrm{CH}_{3} \mathrm{CN}(0.5 \mathrm{~mL})$. DBU (10.8 $\mu \mathrm{L}, 0.072$ $\mathrm{mmol}$ ) is then added and a red complex is immediately formed. The first flask is finally added to the second one by syringe and the mixture is stirred at $80^{\circ} \mathrm{C}$ during 2 hours (conversion checked by TLC). The reaction is then allowed to cooled down to room temperature and water $(5 \mathrm{~mL})$ is added to the mixture. The aqueous phase is then extracted with EtOAc $(3 \times 10 \mathrm{~mL})$, dried over $\mathrm{Na}_{2} \mathrm{SO}_{4}$ and purified on silica gel (hexanes:EtOAc, 50:50) to afford $\mathbf{5 6}$ as a red foam (28 mg, $82 \%)$.

${ }^{1} \mathrm{H}$ NMR $\left(300 \mathrm{MHz}, \mathrm{CDCl}_{3}\right) \delta 8.74(\mathrm{~d}, J=2.2 \mathrm{~Hz}, 1 \mathrm{H}), 8.31(\mathrm{~m}, 1 \mathrm{H}), 7.94(\mathrm{dd}, J=9.8,2.2 \mathrm{~Hz}, 1 \mathrm{H}), 7.76$ (m, $1 \mathrm{H}), 7.51-7.45(\mathrm{~m}, 2 \mathrm{H}), 7.41-7.32(\mathrm{~m}, 2 \mathrm{H}), 7.26-7.21(\mathrm{~m}, 2 \mathrm{H}), 7.08(\mathrm{~d}, J=3.5 \mathrm{~Hz}, 1 \mathrm{H}), 6.93(\mathrm{dd}, J=$ $5.1,3.5 \mathrm{~Hz}, 1 \mathrm{H}), 6.79(\mathrm{~d}, J=7.7 \mathrm{~Hz}, 1 \mathrm{H}), 5.79$ (dd, $J=8.1,4.4 \mathrm{~Hz}, 1 \mathrm{H}), 3.96(\mathrm{td}, J=6.9,6.3,1.7 \mathrm{~Hz}, 2 \mathrm{H}$ ), $3.39(\mathrm{~s}, 3 \mathrm{H}), 2.76-2.53(\mathrm{~m}, 2 \mathrm{H})$.

${ }^{13} \mathrm{C}$ NMR $\left(75 \mathrm{MHz}, \mathrm{CDCl}_{3}\right) \delta 178.2,163.0,152.6,143.5,139.9,134.7,127.8,127.1,126.7,125.9,125.7$, $125.7,125.5,125.2,122.3,122.0,122.0,121.7,121.4,106.9,73.7,54.8,43.2,35.6$.

Note: One C signal cannot be found probably due to an overlap.

HRMS (ESI) calculated [M+H] $]^{+}$476.109711, measured 476.109480. 


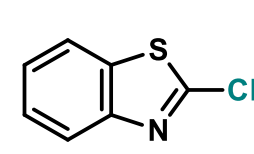

29

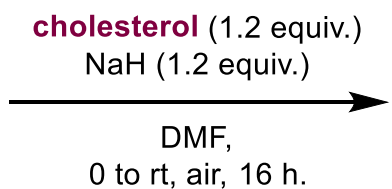

0 to $\mathrm{rt}$, air, $16 \mathrm{~h}$

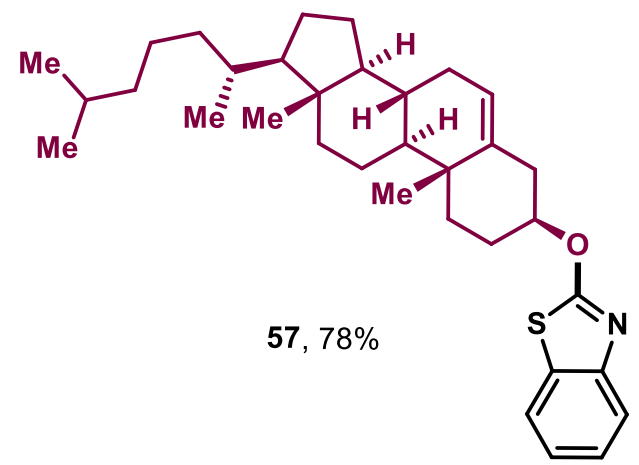

To a $18 \mathrm{~mL}$ screw-capped tube under normal atmosphere are added 29 ( $33.9 \mathrm{mg}, 0.2 \mathrm{mmol}$ ), cholesterol $92.5 \%(100.3 \mathrm{mg}, 0.24 \mathrm{mmol})$ and DMF ( $2 \mathrm{~mL})$. The mixture is cooled down to 0 ${ }^{\circ} \mathrm{C}$ and $\mathrm{NaH}$ (5.8 mg, $0.24 \mathrm{mmol}$ ) is added. The mixture is stirred 5 minutes at $0{ }^{\circ} \mathrm{C}$ and is then allowed to reach room temperature for 16 hours. The reaction is then carefully quenched with water. The aqueous phase is then extracted with EtOAc $(3 \times 10 \mathrm{~mL})$, dried over $\mathrm{Na}_{2} \mathrm{SO}_{4}$ and purified on silica gel (hexanes:EtOAc, 95:5) to afford $\mathbf{5 7}$ as a colorless sticky oil (81 mg, $78 \%$ ).

${ }^{1} \mathrm{H}$ NMR $\left(300 \mathrm{MHz}, \mathrm{CDCl}_{3}\right)$ 8 7.67-7.61 (m, 2H), $7.34(\mathrm{~m}, 1 \mathrm{H}), 7.20(\mathrm{td}, J=7.7,1.2 \mathrm{~Hz}, 1 \mathrm{H}), 5.45(\mathrm{dt}, J=$ 5.6, 1.9 Hz, 1H), $5.02(\mathrm{tt}, \mathrm{J}=11.4,4.8 \mathrm{~Hz}, 1 \mathrm{H}), 2.67$ (ddd, J = 13.0, 5.1, $2.3 \mathrm{~Hz}, 1 \mathrm{H}), 2.50(\mathrm{td}, \mathrm{J}=12.7$, 12.2, $2.7 \mathrm{~Hz}, 1 \mathrm{H}), 2.18(\mathrm{~m}, 1 \mathrm{H}), 2.06-1.89(\mathrm{~m}, 3 \mathrm{H}), 1.88-1.69(\mathrm{~m}, 2 \mathrm{H}), 1.65-0.96(\mathrm{~m}, 23 \mathrm{H})^{*}, 0.93(\mathrm{~d}, J$ $=6.5 \mathrm{~Hz}, 3 \mathrm{H}), 0.89(\mathrm{~d}, J=1.3 \mathrm{~Hz}, 3 \mathrm{H}), 0.86(\mathrm{~d}, J=1.3 \mathrm{~Hz}, 3 \mathrm{H}), 0.70(\mathrm{~s}, 3 \mathrm{H})$.

*Note: This integral should represent $23 \mathrm{H}$ but actually represents $26 \mathrm{H}$ due to complex overlaps between the signals as well as residual grease and water.

${ }^{13} \mathrm{C}$ NMR $\left(75 \mathrm{MHz}, \mathrm{CDCl}_{3}\right) \delta 172.4,149.8,139.6,131.9,126.0,123.4,123.3,121.3,120.8,82.0,56.9$, $56.3,50.3,42.5,39.9,39.7,38.3,37.1,36.8,36.4,36.0,32.1,32.0,28.4,28.2$, 28.0, 24.5, 24.0, 23.0, $22.7,21.3,19.5,18.9,12.0$.

HRMS (ESI) calculated [M+Na] 542.342705 , measured 542.342660.

\section{Azidation of $\mathbf{2 4}$}<smiles>O=c1c(Cl)c(Cl)cnn1-c1ccccc1</smiles>

24

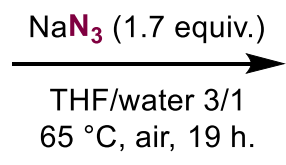

THF/water $3 / 1$
$65^{\circ} \mathrm{C}$, air, $19 \mathrm{~h}$.<smiles>Nc1cnn(-c2ccccc2)c(=O)c1Cl</smiles>

58, $>95 \%$

To a $18 \mathrm{~mL}$ screw-capped tube under normal atmosphere are added 24 (12 mg, $0.05 \mathrm{mmol}$ ) and sodium azide $(5.5 \mathrm{mg}, 0.085 \mathrm{mmol})$ in THF/water $(0.4 \mathrm{~mL}, 3 / 1 \mathrm{v} / \mathrm{v})$. The reaction is stirred 19 hours at $65^{\circ} \mathrm{C}$. The mixture is then cooled down to rt and quenched with water $(5 \mathrm{~mL})$. The aqueous layer is then extracted with EtOAc $(3 \times 5 \mathrm{~mL})$ and the combined organic layers are dried over $\mathrm{Na}_{2} \mathrm{SO}_{4}$ and concentrated to dryness to obtained 58 as a white solid (12 mg, quant.).

${ }^{1} \mathrm{H}$ NMR $\left(300 \mathrm{MHz}, \mathrm{CDCl}_{3}\right) \delta 7.74(\mathrm{~s}, 1 \mathrm{H}), 7.56(\mathrm{~m}, 2 \mathrm{H}), 7.51-7.38(\mathrm{~m}, 3 \mathrm{H})$. 
HRMS (ESI) calculated [M+Na] 270.015306 , measured 270.015370.

Characterization data matched with a previously reported example. ${ }^{14}$

\section{Fluorination of 45}<smiles>COC(=O)c1cc2c(=O)c3cc(C(C)C)ccc3oc2nc1Cl</smiles>

45

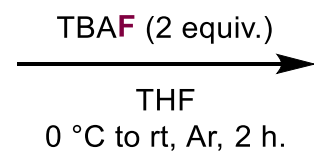

$0{ }^{\circ} \mathrm{C}$ to rt, $\mathrm{Ar}, 2 \mathrm{~h}$<smiles>COC(=O)c1cc2c(=O)c3cc(C(C)C)ccc3oc2nc1F</smiles>

$\mathbf{5 9}, 61 \%$

To a flam-dried schlenk under Ar are added 45 (13 $\mathrm{mg}, 0.039 \mathrm{mmol})$ and THF ( $1 \mathrm{~mL})$. The mixture is cooled down to $0{ }^{\circ} \mathrm{C}$ and TBAF $1 \mathrm{M}$ in THF ( $\left.80 \mu \mathrm{L}, 0.080 \mathrm{mmol}\right)$ is slowly added. The mixture is stirred 1.5 hours at $0{ }^{\circ} \mathrm{C}$ and 30 minutes at room temperature. The reaction is then quenched with water ( 1 $\mathrm{mL})$ and extracted with EtOAc $(3 \times 5 \mathrm{~mL})$ and the combined organic layers are dried over $\mathrm{Na}_{2} \mathrm{SO}_{4}$ and purified on silica gel (hexanes:EtOAc, 8:2) to afford 59 as a white solid ( $7.5 \mathrm{mg}, 61 \%$ ).

Note: the purification is easier once full conversion is reached.

${ }^{1} \mathrm{H}$ NMR $\left(300 \mathrm{MHz}, \mathrm{CDCl}_{3}\right) \delta 9.38\left(\mathrm{~d},{ }^{4} J(\mathrm{H}, \mathrm{F})=9.0 \mathrm{~Hz}, 1 \mathrm{H}\right), 8.16(\mathrm{~d}, J=2.3 \mathrm{~Hz}, 1 \mathrm{H}), 7.70$ (dd, $J=8.6,2.3$ $\mathrm{Hz}, 1 \mathrm{H}), 7.55(\mathrm{~d}, J=8.7 \mathrm{~Hz}, 1 \mathrm{H}), 4.01(\mathrm{~s}, 3 \mathrm{H}), 3.08($ hept $, J=6.9 \mathrm{~Hz}, 1 \mathrm{H}), 1.33(\mathrm{~d}, J=6.9 \mathrm{~Hz}, 7 \mathrm{H})$.

${ }^{13} \mathrm{C}$ NMR $\left(151 \mathrm{MHz}, \mathrm{CDCl}_{3}\right) \delta 176.0,162.9\left(\mathrm{~d},{ }^{1} J(\mathrm{C}, \mathrm{F})=263 \mathrm{~Hz}\right), 162.3\left(\mathrm{~d},{ }^{3} \mathrm{~J}(\mathrm{C}, \mathrm{F})=8 \mathrm{~Hz}\right), 161.0\left(\mathrm{~d},{ }^{3} \mathrm{~J}(\mathrm{C}, \mathrm{F})\right.$ $=18 \mathrm{~Hz}), 153.9,147.0,146.0\left(\mathrm{~d},{ }^{3} J(\mathrm{C}, \mathrm{F})=4 \mathrm{~Hz}\right), 135.2,123.9,121.4,118.6,114.9\left(\mathrm{~d},{ }^{4} J(\mathrm{C}, \mathrm{F})=4 \mathrm{~Hz}\right)$, $111.7\left(d,{ }^{2} J(C, F)=24 \mathrm{~Hz}\right), 53.1,33.9,24.0$.

${ }^{19} \mathrm{~F}$ NMR $\left(282 \mathrm{MHz}, \mathrm{CDCl}_{3}\right) \delta-51.44(\mathrm{~s}, 3 \mathrm{~F})$.

HRMS (EI) calculated [M] 315.090137, measured 315.090100.

\section{Deaminative brominations}

\section{Synthesis of 2-bromo-6-(trifluoromethoxy)benzo[d]thiazole (62)}<smiles>FC(F)(F)Oc1ccc2nc(Br)sc2c1</smiles>

To a $18 \mathrm{~mL}$ screw-capped tube under normal atmosphere are added Riluzole 61 (23.4 mg, 0.1 $\mathrm{mmol}$ ) and pyrylium tetrafluoroborate $1(25.2 \mathrm{mg}, 0.15 \mathrm{mmol})$ in EtOH $(1 \mathrm{~mL})$. The resulting mixture is then stirred 5 minutes at room temperature and then 16 hours at $80{ }^{\circ} \mathrm{C}$ (covered with aluminum foil). The reaction is allowed to cool down to room temperature and the solvent is removed under high vacuum. The crude mixture is then dissolved in $\mathrm{CD}_{3} \mathrm{CN}(1 \mathrm{~mL})$ and $\mathrm{LiBr}$ ( $34.7 \mathrm{mg}, 0.4 \mathrm{mmol}$ ) is added. The resulting mixture is then stirred 5 minutes at room temperature and then 16 hours at $80{ }^{\circ} \mathrm{C}$. The reaction is allowed to cool down to room temperature. The crude mixture is partitioned between water and $\mathrm{Et}_{2} \mathrm{O}$. The aqueous layer is extracted with $\mathrm{Et}_{2} \mathrm{O}(3 \times 10 \mathrm{~mL})$. The combined organic layers are dried over $\mathrm{Na}_{2} \mathrm{SO}_{4}$, 
concentrated to dryness and purified on silica gel (n-pentane:Et ${ }_{2} \mathrm{O}, 100: 0$ to 80:20) to afford the desired product 62 as an off white solid ( $28 \mathrm{mg}, 94 \%$ ).

${ }^{1} \mathrm{H}$ NMR $\left(300 \mathrm{MHz}, \mathrm{CDCl}_{3}\right) \delta 7.99(\mathrm{~d}, J=8.9 \mathrm{~Hz}, 1 \mathrm{H}), 7.68(\mathrm{dt}, J=2.1,1.1 \mathrm{~Hz}, 1 \mathrm{H}), 7.35(\mathrm{~m}, 1 \mathrm{H})$.

${ }^{13} \mathrm{C} \mathrm{NMR}\left(75 \mathrm{MHz}, \mathrm{CDCl}_{3}\right) \delta 151.0,147.0\left(\mathrm{q},{ }^{3} \mathrm{~J}(\mathrm{C}, \mathrm{F})=2 \mathrm{~Hz}\right), 139.9,138.3,123.9,120.7,120.6\left(\mathrm{q},{ }^{1} J(\mathrm{C}, \mathrm{F})\right.$ $=258 \mathrm{~Hz}), 113.6$.

${ }^{19} \mathrm{~F}$ NMR $\left(282 \mathrm{MHz}, \mathrm{CDCl}_{3}\right) \delta-58.05(\mathrm{~s}, 3 \mathrm{~F})$.

HRMS (EI) calculated [M] 296.906547, measured 296.906890.

Characterization data matched with a previously reported example.

\section{Synthesis of 6-bromo-9-ethyl-9H-purine (64)}<smiles>CCn1cnc2c(Br)ncnc21</smiles>

A $18 \mathrm{~mL}$ screw-capped tube under normal atmosphere is charged with pyrylium tetrafluoroborate $1(12.6 \mathrm{mg}, 0.075 \mathrm{mmol})$, aminoheterocycle $63(8.2 \mathrm{mg}, 0.05 \mathrm{mmol}$ ) and $\mathrm{EtOH}(1 \mathrm{~mL})$. The resulting mixture is then stirred 5 minutes at room temperature and then 16 hours at $80{ }^{\circ} \mathrm{C}$ (covered with aluminium foil). The reaction is allowed to cool down to room temperature and the solvent is removed under high vacuum. The crude mixture is then dissolved in $\mathrm{CH}_{3} \mathrm{CN}(1 \mathrm{~mL})$ and $\mathrm{MgBr}_{2}(18.4 \mathrm{mg}, 0.1 \mathrm{mmol})$ is added. The resulting mixture is then stirred 5 minutes at room temperature and then 16 hours at $120^{\circ} \mathrm{C}$. The reaction is allowed to cool down to room temperature and concentrated to dryness. The crude mixture can be purified on a silica pad and washed several times with $\mathrm{CH}_{2} \mathrm{Cl}_{2}$ to afford the desired product 64 as a colorless liquid (12 mg, $53 \%$ ).

${ }^{1} \mathrm{H}$ NMR $\left(300 \mathrm{MHz}, \mathrm{CDCl}_{3}\right) \delta 8.71(\mathrm{~s}, 1 \mathrm{H}), 8.16(\mathrm{~s}, 1 \mathrm{H}), 4.36(\mathrm{q}, J=7.3 \mathrm{~Hz}, 2 \mathrm{H}), 1.59(\mathrm{t}, J=7.3 \mathrm{~Hz}, 3 \mathrm{H})$.

${ }^{13} \mathrm{C}$ NMR $\left(75 \mathrm{MHz}, \mathrm{CDCl}_{3}\right) \delta 152.0,150.6,144.7,143.3,134.4,39.8,15.5$.

HRMS (EI) calculated [M] 225.984870, measured 225.984890. 


\section{Ring-opening at the 2-position with fluorides}

\section{Synthesis of ethyl 2-(((1E,3E)-5-oxopenta-1,3-dien-1-yl)amino)oxazole-4-carboxylate (65)}<smiles>CCOC(=O)c1coc(-n2cccc2Br)n1</smiles>

10

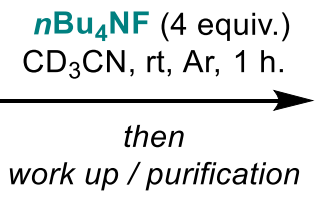

work up / purification<smiles>[X]C=CC=CC=Nc1nc(C(=[X])OCC)co1</smiles>

To a $18 \mathrm{~mL}$ screw-capped tube under Ar atmosphere are added ethoxycarbonyloxazole pyridinium tetrafluoroborate 10 (10 mg, $0.033 \mathrm{mmol}$ ) in $\mathrm{CD}_{3} \mathrm{CN}(0.5 \mathrm{~mL})$. TBAF $1 \mathrm{M}$ in THF (0.131 mL, $\left.0.131 \mathrm{mmol}\right)$ is added. The reaction turned immediately deep green. After 1 hour, the reaction is carefully quenched with water $(2 \mathrm{~mL})$ and extracted with EtOAc $(3 \times 5 \mathrm{~mL})$. The combined organic layers are dried over $\mathrm{Na}_{2} \mathrm{SO}_{4}$ and concentrated to dryness. The redish crude oil is dissolved in the minimum amount of $\mathrm{CH}_{2} \mathrm{Cl}_{2}$ and purified on preparative TLC (hexanes:EtOAc, 50:50) to afford 65 as a dark red oil (3 mg, $39 \%$ ).

${ }^{1} \mathrm{H}$ NMR $\left(500 \mathrm{MHz}, \mathrm{CD}_{3} \mathrm{CN}\right) \delta 9.44(\mathrm{~d}, J=8.1 \mathrm{~Hz}, 1 \mathrm{H}), 8.67(\mathrm{bs}, 1 \mathrm{H}), 7.99(\mathrm{~s}, 1 \mathrm{H}), 7.35-7.28(\mathrm{~m}, 2 \mathrm{H})$, 6.24 (ddd, $J=13.6,11.4,0.6 \mathrm{~Hz}, 1 \mathrm{H}$ ), 6.01 (ddt, $J=15.0,8.1,0.7 \mathrm{~Hz}, 1 \mathrm{H}), 4.28(\mathrm{q}, J=7.1 \mathrm{~Hz}, 2 \mathrm{H}$ ), 1.31 (t, $J=7.1 \mathrm{~Hz}, 3 \mathrm{H})$. $^{*}$

*Note: This integral should represent $3 \mathrm{H}$ but actually represents $4 \mathrm{H}$ due to the small amount of product as well as the presence of grease.

${ }^{13} \mathrm{C}$ NMR $\left(126 \mathrm{MHz}, \mathrm{CD}_{3} \mathrm{CN}\right) \delta 193.9,162.0,157.0,153.7,140.5,137.8,134.0,128.0,109.2,61.7,14.5$.

HRMS (ESI) calculated [M+Na] $]^{+}$259.068926, measured 259.068840.

\section{Crystallographic data for compound 43}

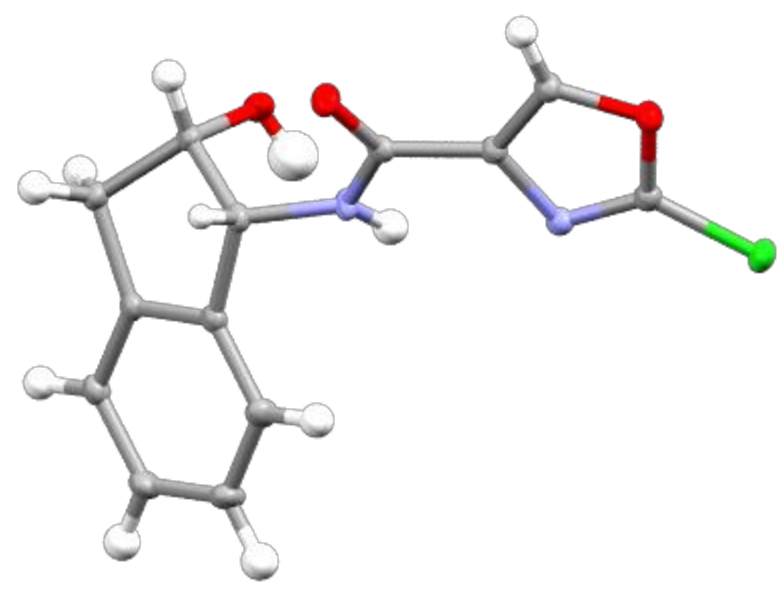

CCDC: 2070324 
Table 1. Crystal data and structure refinement.

Identification code

Empirical formula

Color

Formula weight

Temperature

Wavelength

Crystal system

Space group

Unit cell dimensions

Volume

Z

Density (calculated)

Absorption coefficient

$\mathrm{F}(000)$

Crystal size

$\theta$ range for data collection

Index ranges

Reflections collected

Independent reflections

Reflections with $1>2 \sigma(I)$

Completeness to $\theta=25.242^{\circ}$

Absorption correction

Max. and min. transmission

Refinement method

Data / restraints / parameters

Goodness-of-fit on $\mathrm{F}^{2}$

Final $R$ indices $[\mathrm{I}>2 \sigma(\mathrm{I})]$

$R$ indices (all data)

Absolute structure parameter

Largest diff. peak and hole
13594

$\mathrm{C}_{13} \mathrm{H}_{11} \mathrm{Cl} \mathrm{N}_{2} \mathrm{O}_{3}$

colourless

278.69 g. $\mathrm{mol}^{-1}$

100(2) K

$0.71073 \AA$

ORTHORHOMBIC

P21212, (no. 18)

$a=13.361(2) \AA$

$\alpha=90^{\circ}$.

$\mathrm{b}=18.177(3) \AA$

$\beta=90^{\circ}$.

$c=5.0728(3) \AA$

$\gamma=90^{\circ}$.

4

$1.503 \mathrm{mg} \cdot \mathrm{m}^{-3}$

$0.315 \mathrm{~mm}^{-1}$

576 e

$0.30 \times 0.06 \times 0.04 \mathrm{~mm}^{3}$

2.711 to $33.097^{\circ}$.

$-20 \leq \mathrm{h} \leq 20,-27 \leq \mathrm{k} \leq 27,-7 \leq \mathrm{I} \leq 7$

24317

$4671\left[R_{\text {int }}=0.0464\right]$

4069

$99.8 \%$

Gaussian

0.99 and 0.95

Full-matrix least-squares on $\mathrm{F}^{2}$

4671 / 0 / 188

1.069

$\mathrm{R}_{1}=0.0364$

$w R^{2}=0.0772$

$\mathrm{R}_{1}=0.0478$

$w R^{2}=0.0818$

$-0.02(3)$

0.3 and $-0.4 \mathrm{e} \cdot \AA^{-3}$ 
Table 2. Bond lengths [Å] and angles $\left[^{\circ}\right]$.

\begin{tabular}{|c|c|c|c|}
\hline$C l(1)-C(4)$ & $1.6882(18)$ & $O(1)-C(1)$ & $1.239(2)$ \\
\hline $\mathrm{O}(2)-\mathrm{C}(3)$ & $1.371(2)$ & $\mathrm{O}(2)-\mathrm{C}(4)$ & $1.352(2)$ \\
\hline $\mathrm{O}(3)-\mathrm{H}(3)$ & $0.79(3)$ & $\mathrm{O}(3)-\mathrm{C}(6)$ & $1.420(2)$ \\
\hline $\mathrm{N}(1)-\mathrm{H}(1)$ & $0.84(3)$ & $N(1)-C(1)$ & $1.336(2)$ \\
\hline$N(1)-C(5)$ & $1.451(2)$ & $N(2)-C(2)$ & $1.402(2)$ \\
\hline$N(2)-C(4)$ & $1.286(2)$ & $C(1)-C(2)$ & $1.479(2)$ \\
\hline$C(2)-C(3)$ & $1.350(2)$ & $C(5)-H(5)$ & $0.95(2)$ \\
\hline$C(5)-C(6)$ & $1.563(2)$ & $C(5)-C(13)$ & $1.517(2)$ \\
\hline $\mathrm{C}(6)-\mathrm{H}(6)$ & $0.95(3)$ & $C(6)-C(7)$ & $1.546(2)$ \\
\hline$C(7)-C(8)$ & $1.509(2)$ & $C(8)-C(9)$ & $1.393(3)$ \\
\hline$C(8)-C(13)$ & $1.396(2)$ & $C(9)-C(10)$ & $1.394(3)$ \\
\hline$C(10)-C(11)$ & $1.389(3)$ & $C(11)-C(12)$ & $1.396(3)$ \\
\hline$C(12)-C(13)$ & $1.382(2)$ & & \\
\hline$C(4)-O(2)-C(3)$ & $103.46(14)$ & $\mathrm{C}(6)-\mathrm{O}(3)-\mathrm{H}(3)$ & $107(2)$ \\
\hline$C(1)-N(1)-H(1)$ & 117.0(17) & $C(1)-N(1)-C(5)$ & $122.24(16)$ \\
\hline$C(5)-N(1)-H(1)$ & $120.5(17)$ & $C(4)-N(2)-C(2)$ & $102.73(15)$ \\
\hline $\mathrm{O}(1)-\mathrm{C}(1)-\mathrm{N}(1)$ & $124.37(16)$ & $\mathrm{O}(1)-\mathrm{C}(1)-\mathrm{C}(2)$ & $119.72(16)$ \\
\hline$N(1)-C(1)-C(2)$ & $115.89(15)$ & $N(2)-C(2)-C(1)$ & $123.75(15)$ \\
\hline$C(3)-C(2)-N(2)$ & $109.56(15)$ & $C(3)-C(2)-C(1)$ & $126.65(16)$ \\
\hline$C(2)-C(3)-O(2)$ & 107.93(15) & $\mathrm{O}(2)-\mathrm{C}(4)-\mathrm{Cl}(1)$ & $115.76(13)$ \\
\hline $\mathrm{N}(2)-\mathrm{C}(4)-\mathrm{Cl}(1)$ & $127.89(15)$ & $N(2)-C(4)-O(2)$ & $116.32(16)$ \\
\hline$N(1)-C(5)-H(5)$ & 109.8(13) & $N(1)-C(5)-C(6)$ & $115.44(14)$ \\
\hline$N(1)-C(5)-C(13)$ & $112.54(15)$ & $C(6)-C(5)-H(5)$ & 109.0(13) \\
\hline$C(13)-C(5)-H(5)$ & $107.0(13)$ & $C(13)-C(5)-C(6)$ & $102.56(14)$ \\
\hline$O(3)-C(6)-C(5)$ & $112.06(14)$ & $\mathrm{O}(3)-\mathrm{C}(6)-\mathrm{H}(6)$ & $106.0(15)$ \\
\hline $\mathrm{O}(3)-\mathrm{C}(6)-\mathrm{C}(7)$ & $111.65(16)$ & $C(5)-C(6)-H(6)$ & $112.8(15)$ \\
\hline$C(7)-C(6)-C(5)$ & $102.85(14)$ & $C(7)-C(6)-H(6)$ & $111.6(15)$ \\
\hline$C(8)-C(7)-C(6)$ & $103.25(14)$ & $C(9)-C(8)-C(7)$ & $129.96(16)$ \\
\hline$C(9)-C(8)-C(13)$ & $119.85(16)$ & $C(13)-C(8)-C(7)$ & $110.19(15)$ \\
\hline$C(8)-C(9)-C(10)$ & 118.51(16) & $C(11)-C(10)-C(9)$ & $121.36(17)$ \\
\hline$C(10)-C(11)-C(12)$ & $120.00(17)$ & $C(13)-C(12)-C(11)$ & 118.71(17) \\
\hline$C(8)-C(13)-C(5)$ & $109.81(15)$ & $C(12)-C(13)-C(5)$ & $128.63(16)$ \\
\hline$C(12)-C(13)-C(8)$ & $121.56(16)$ & & \\
\hline
\end{tabular}




\section{References}

1 Moser, D. et al. Selective functionalization of aminoheterocycles by a pyrylium salt. Angew. Chem. Int. Ed. 57, 11035-11039 (2018).

2 Loredo-Calderón, E. L. et al. Synthesis of novel $\alpha$-aminophosphonates under microwave irradiation, biological evaluation as antiproliferative agents and apoptosis inducers. Med. Chem. Res. 28, 2067-2078 (2019).

3 Karimov, R. R., Sharma, A.and Hartwig, J. F. Late Stage Azidation of Complex Molecules. ACS Cent. Sci. 2, 715-724 (2016).

4 Sharif, S. et al. (2Z)-Methyl 2-(2-amino-1,3-thia-zol-4-yl)-2-(methoxy-imino)ethano-ate. Acta Crystallogr. E 65, 01455-01455 (2009).

5 Gelin, M. et al. From Substrate to Fragments to Inhibitor Active In Vivo against Staphylococcus aureus. ACS Infect. Dis. 6, 422-435 (2020).

6 Michels, T. D., Rhee, J. U.and Vanderwal, C. D. Synthesis of $\delta$-Tributylstannyl- $\alpha, \beta, \gamma, \delta-$ Unsaturated Aldehydes from Pyridines. Org. Lett. 10, 4787-4790 (2008).

7 Gurinov, A. A., Lesnichin, S. B., Limbach, H.-H.and Shenderovich, I. G. How short is the strongest hydrogen bond in the proton-bound homodimers of pyridine derivatives? J. Phys. Chem. A 118, 10804-10812 (2014).

8 Alekseev, R. S., Kurkin, A. V.and Yurovskaya, M. A. Use of the Graebe-Ullmann reaction in the synthesis of 8-methyl- - -carboline and isomeric aromatic aza- - -carbolines. Chem. Heterocycl. Compd. 48, 1235-1250 (2012).

$9 \quad$ Ishida, $Y$. et al. Sequence selective dual-emission detection of $(i, i+1)$ bis-phosphorylated peptide using diazastilbene-type Zn(ii)-Dpa chemosensor. Chem. Commun., 2848-2850 (2009).

10 Andersson, H., Almqvist, F.and Olsson, R. Synthesis of 2-Substituted Pyridines via a Regiospecific Alkylation, Alkynylation, and Arylation of Pyridine N-Oxides. Org. Lett. 9, 13351337 (2007).

11 Reeves, E. K., Humke, J. N.and Neufeldt, S. R. N-Heterocyclic Carbene Ligand-Controlled Chemodivergent Suzuki-Miyaura Cross Coupling. J. Org. Chem. 84, 11799-11812 (2019).

12 Sakai, H. A., Liu, W., Le, C. C.and MacMillan, D. W. C. Cross-Electrophile Coupling of Unactivated Alkyl Chlorides. J. Am. Chem. Soc. 142, 11691-11697 (2020).

13 Wang, J. et al. Efficient Phosphorus-Free Chlorination of Hydroxy Aza-Arenes and Their Application in One-Pot Pharmaceutical Synthesis. Org. Progress Res. Dev. 24, 146-153 (2020).

14 Brooke, D. G. et al. Targeting the Warburg Effect in cancer; relationships for 2arylpyridazinones as inhibitors of the key glycolytic enzyme 6-phosphofructo-2-kinase/2,6bisphosphatase 3 (PFKFB3). Biorg. Med. Chem. 22, 1029-1039 (2014). 


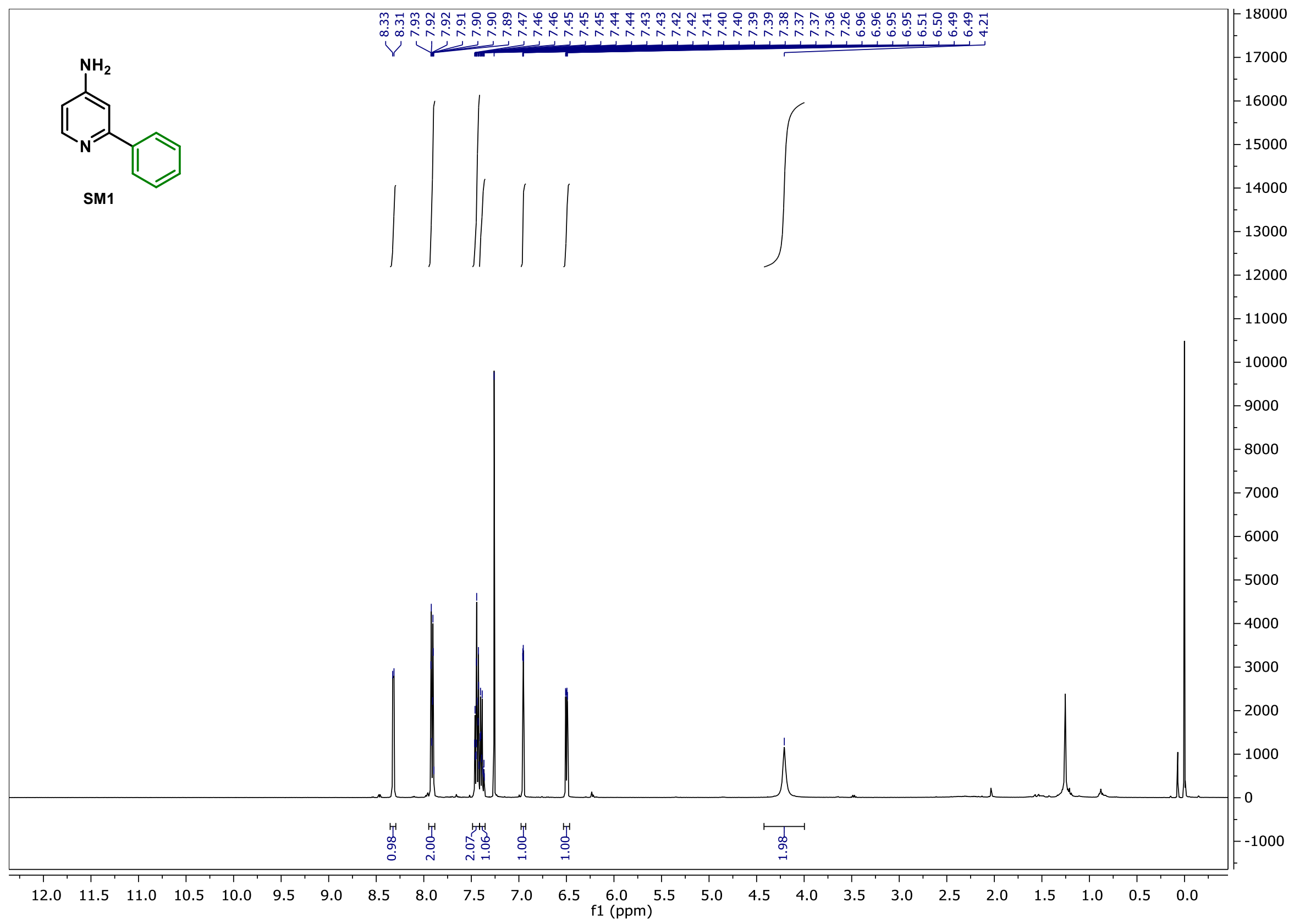


${ }^{1} \mathrm{H}$ NMR

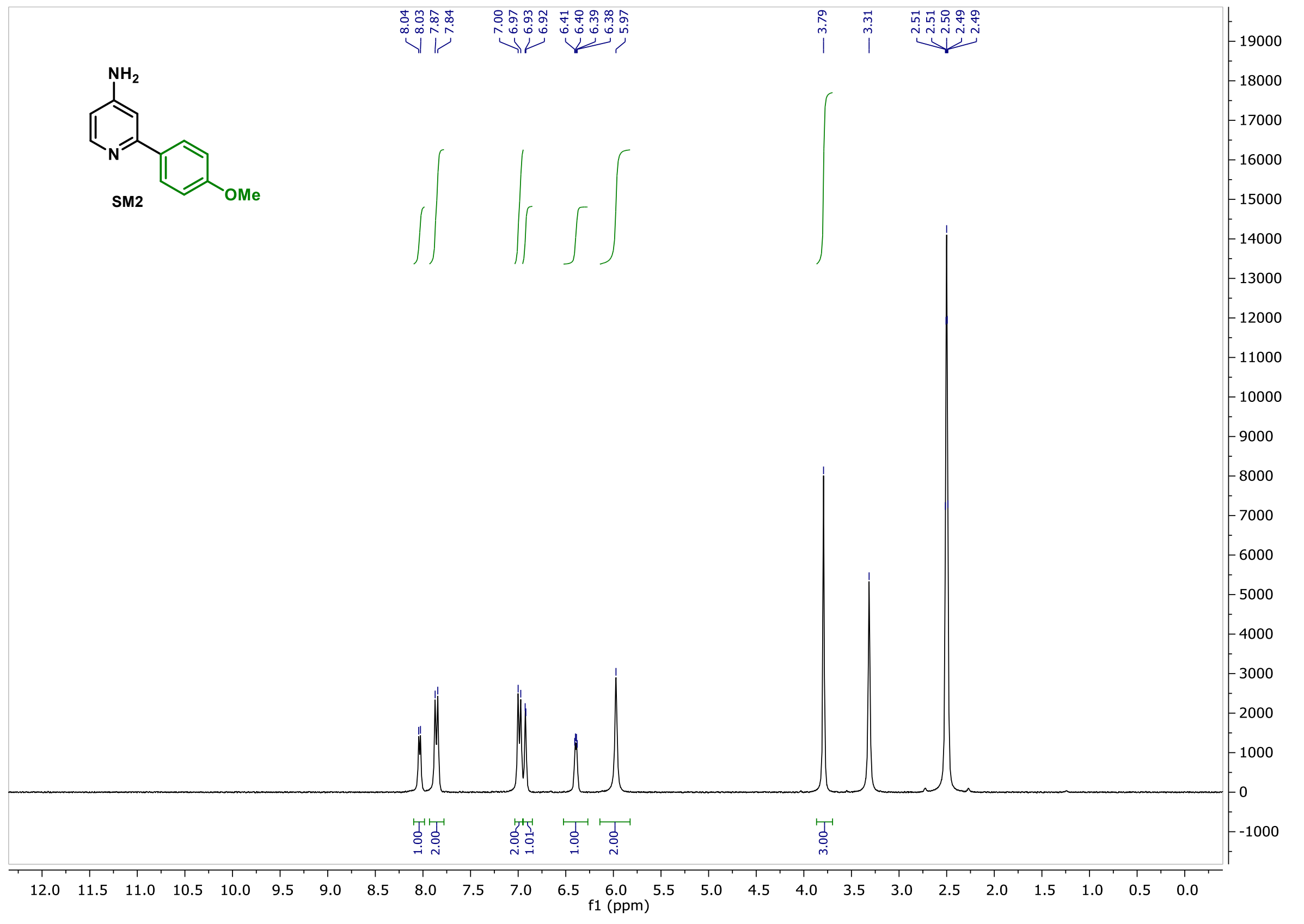


${ }^{1} \mathrm{H}$ NMR

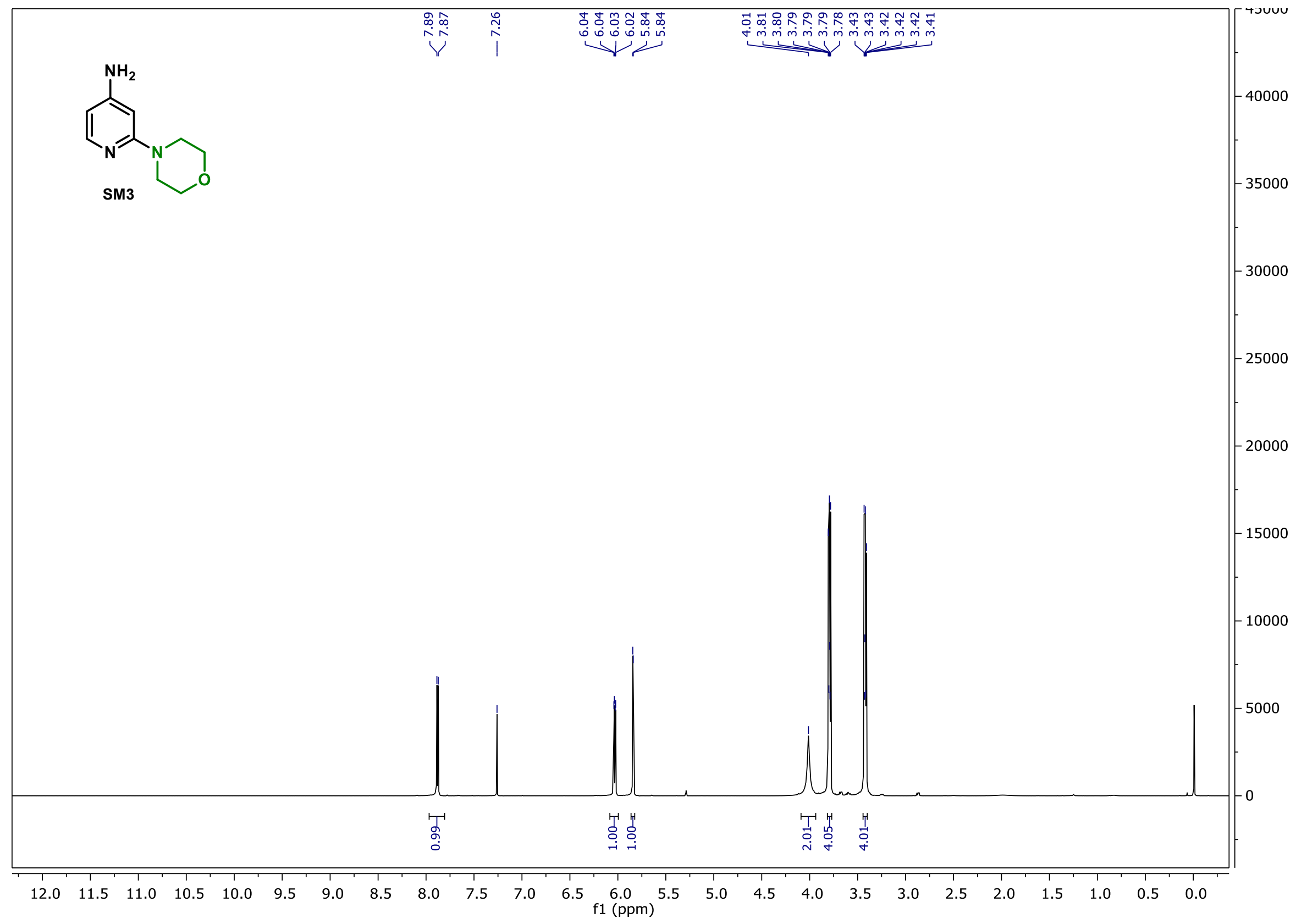




\section{${ }^{1} \mathrm{H}$ NMR}

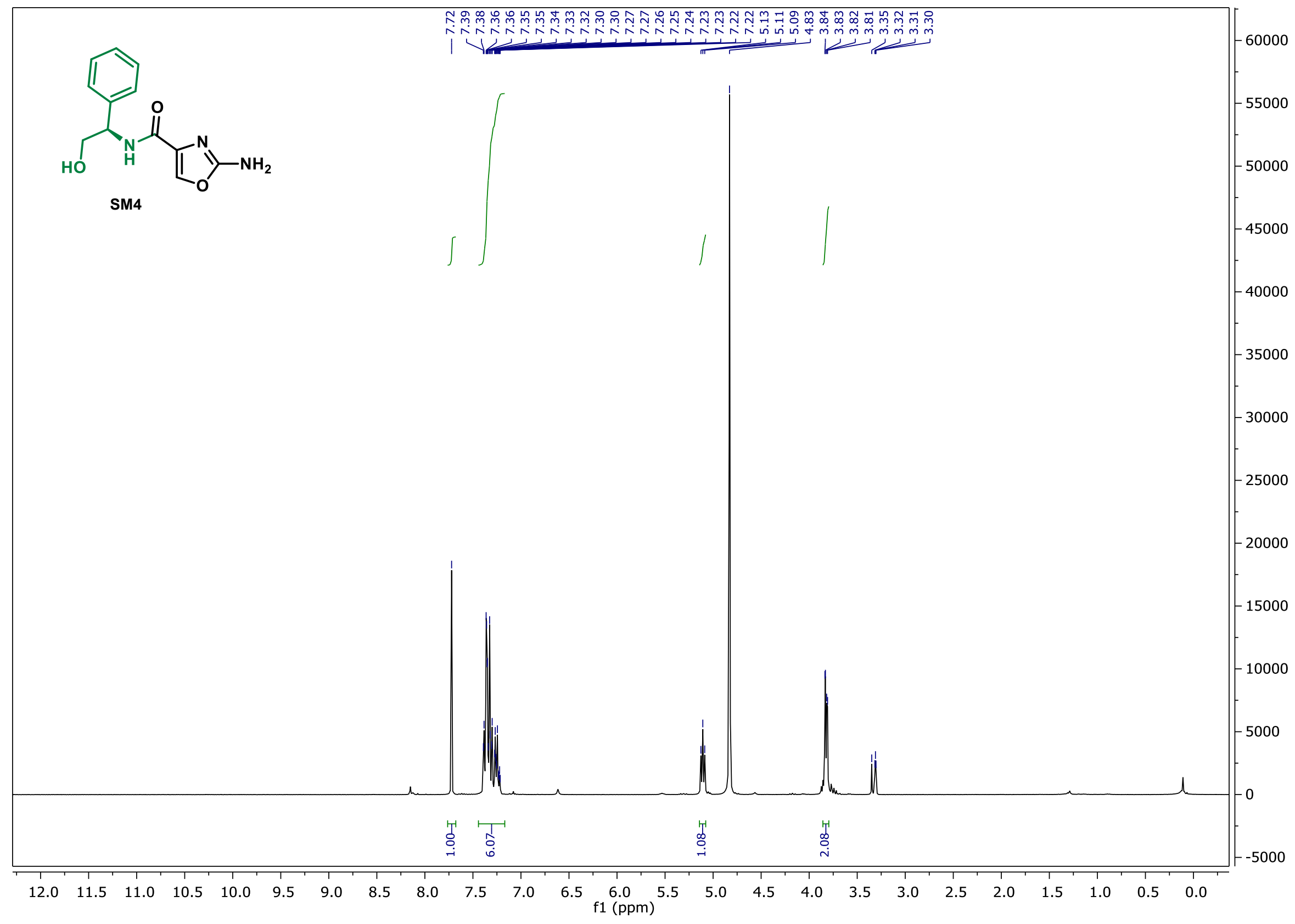


${ }^{13} \mathrm{C}$ NMR

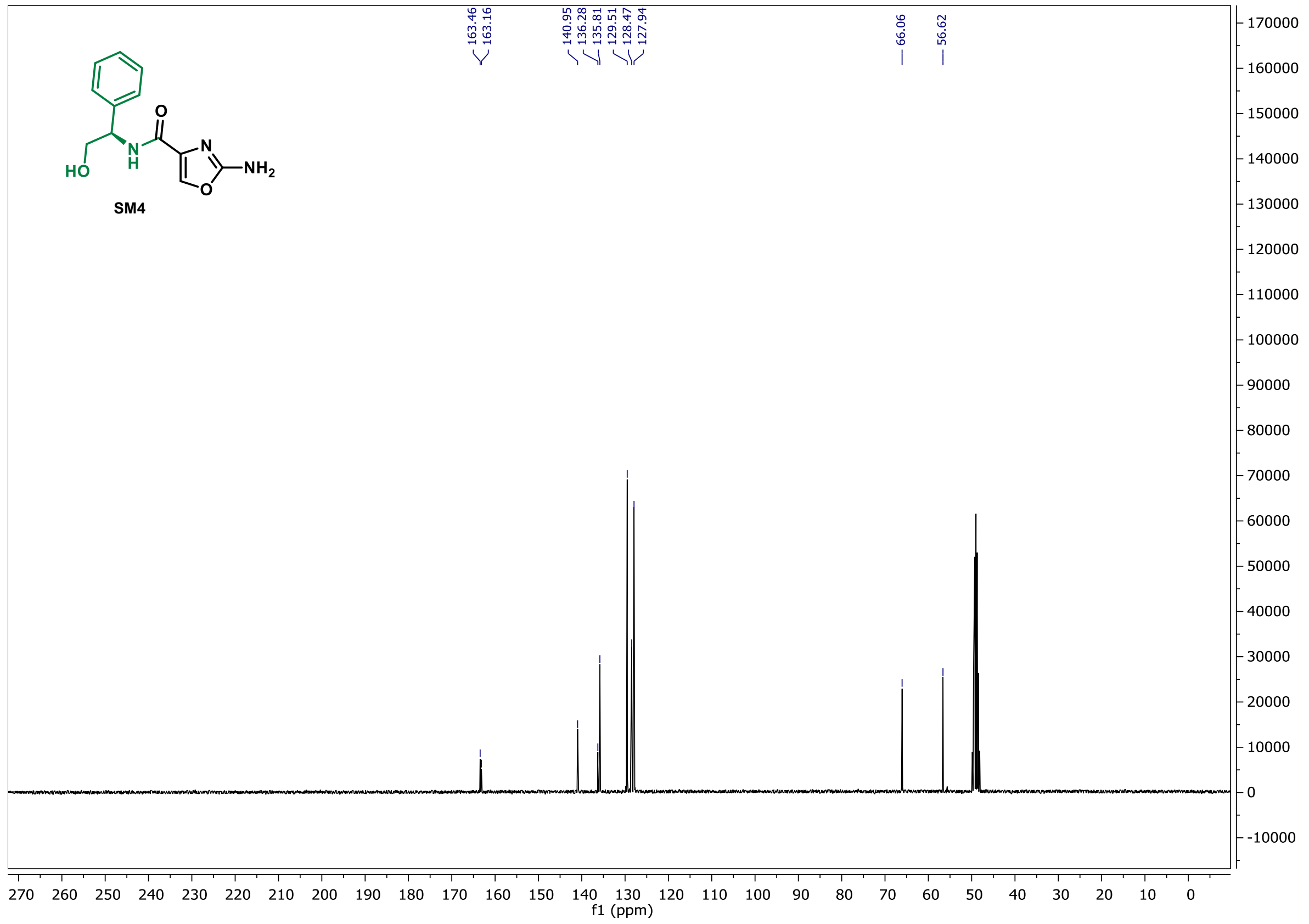


Mass to be matched $(\mathrm{m} / \mathrm{z}): 270.084710$ Charge: 1

Mass Tolerance: \pm 0.005000

Restriction of atom numbers:

$\begin{array}{lllll}\mathrm{C} & \mathrm{H} & \mathrm{N} & \mathrm{O} & \mathrm{Na} \\ 1-100 & 1-100 & 1-3 & \max 10 & 1-1\end{array}$

Number of calculated Formulas: 3

Formula
\begin{tabular}{|lrl|}
\hline C12 H13 N3 O3 Na1 & Diff. (ppm) & theor. m/z \\
\hline C9 H15 N2 O6 Na1 & 0.74 & 270.084910 \\
C17 H13 N1 O1 Na1 & -9.18 & 270.082231 \\
\end{tabular}

\begin{tabular}{ll} 
Datum & 22.09 .2020 \\
Analyse: & $149430 \mathrm{c}-00$ \\
\hline
\end{tabular}

Sigel: GHC-AA-030-01

COP: Dr. Clement Ghiazza

\begin{tabular}{ll} 
Messung: & HRMS \\
Methode: & ESIpos \\
Lösungsmittel: & CH3OH \\
Spektrometer: & Exactive \\
\hline Auswerter: & Kampen (2242)
\end{tabular}

Suggestion:

C12H13N3O3 MW 247

characteristical ion

$270=[247+\mathrm{Na}]+$ 
${ }^{1} \mathrm{H}$ NMR

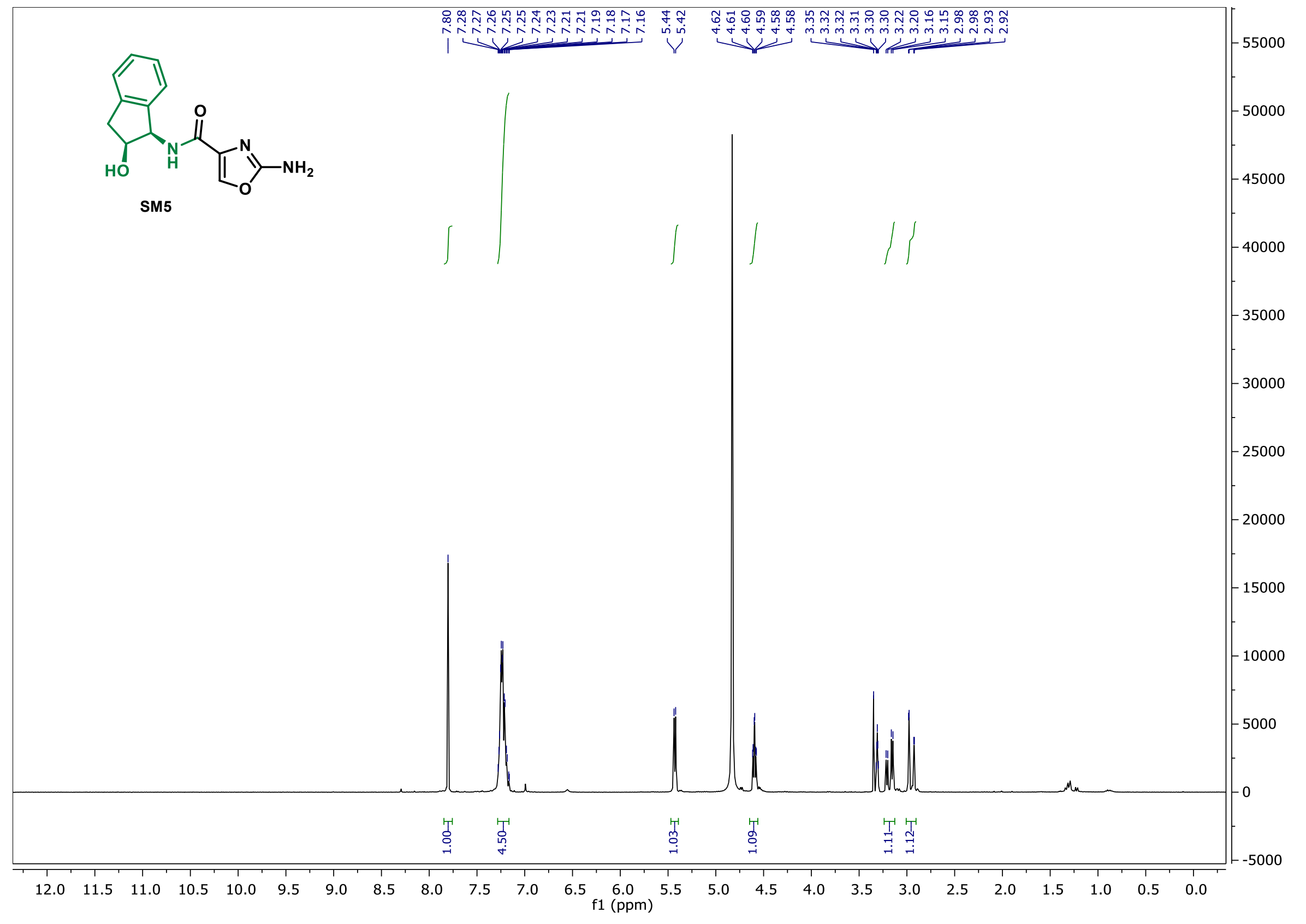




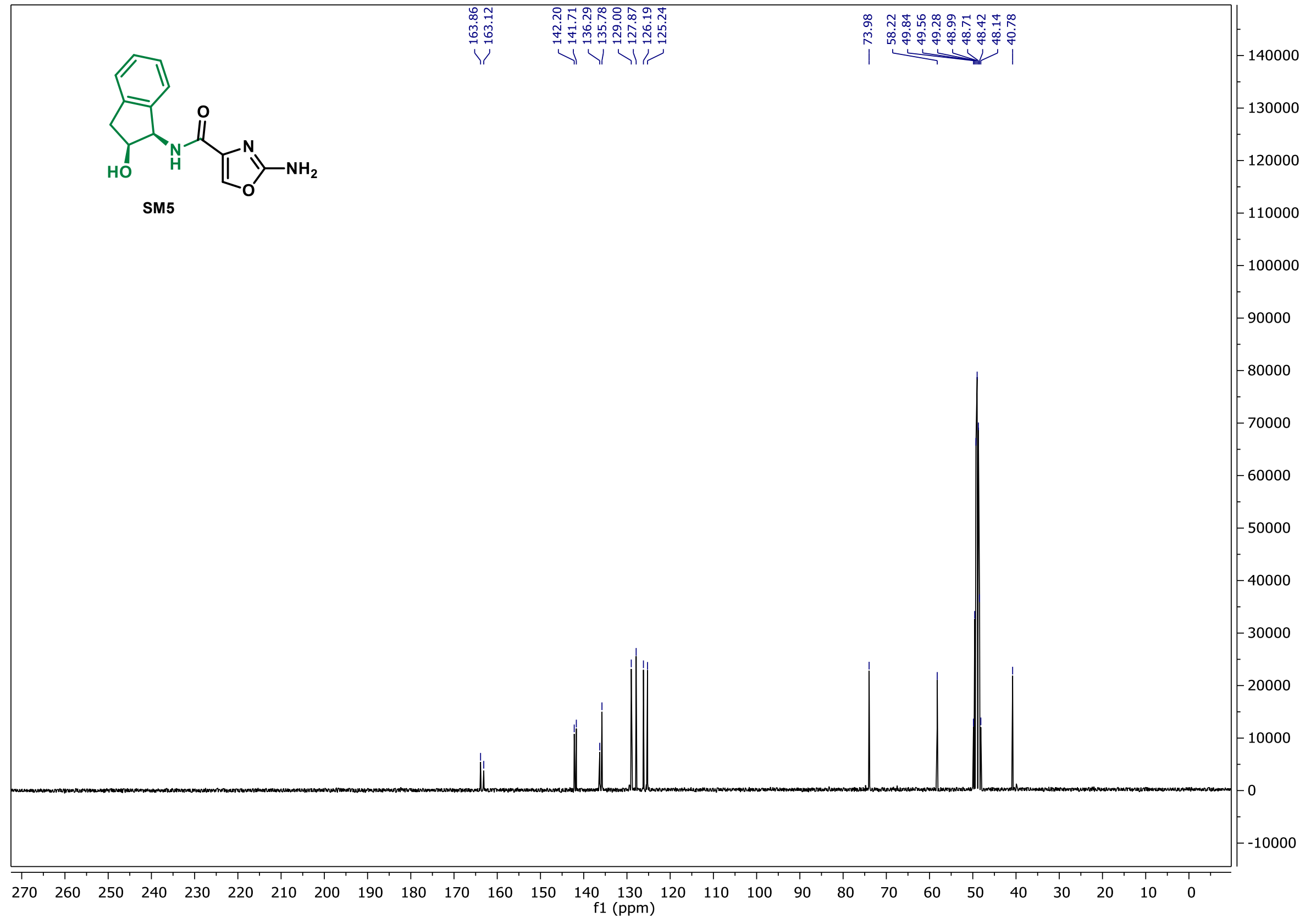


Mass to be matched $(\mathrm{m} / \mathrm{z}): 260.103220$ Charge: 1

Mass Tolerance: \pm 0.005000

Restriction of atom numbers:

$\begin{array}{llll}\mathrm{C} & \mathrm{H} & \mathrm{N} & \mathrm{O} \\ 1-100 & 1-100 & 1-5 & 1-10\end{array}$

Number of calculated Formulas: 4

$\begin{array}{rrrr}\text { Formula } & \text { Diff. (ppm) } & \text { theor } \mathrm{m} / \mathrm{z} \\ \text { C13 H14 N3 O3 } & -0.98 & 260.102966\end{array}$

C10 $\mathrm{H} 16$ N2 $06 \quad-11.27 \quad 260.100287$

$\begin{array}{lllll}\mathrm{C} 18 \mathrm{H} 14 & \mathrm{~N} 1 & \mathrm{O} 1 & 14.49 & 260.106989\end{array}$

C8 H14 N5 O5 $\quad-16.44 \quad 260.098944$

\begin{tabular}{ll}
$\begin{array}{l}\text { Datum: } \\
\text { Analyse: }\end{array}$ & 1.10 .2020 \\
& $49625 \mathrm{C}-00$ \\
\hline Sigel: & GHC-AA-042-01 \\
& COP: Dr. Clement Ghiazza \\
\hline $\begin{array}{l}\text { Method: } \\
\text { Ionis: : }\end{array}$ & HR-MS \\
solvent : & CH2Cl2 + CH3OH \\
Spectrometer: & Exactive \\
\hline Auswerter: & Marcus, Tel:2243
\end{tabular}

suggestion:

C13H13N3O3 MW: 259

Characteristic Ions:

$260=[259+\mathrm{H}]$ 
${ }^{1} \mathrm{H}$ NMR

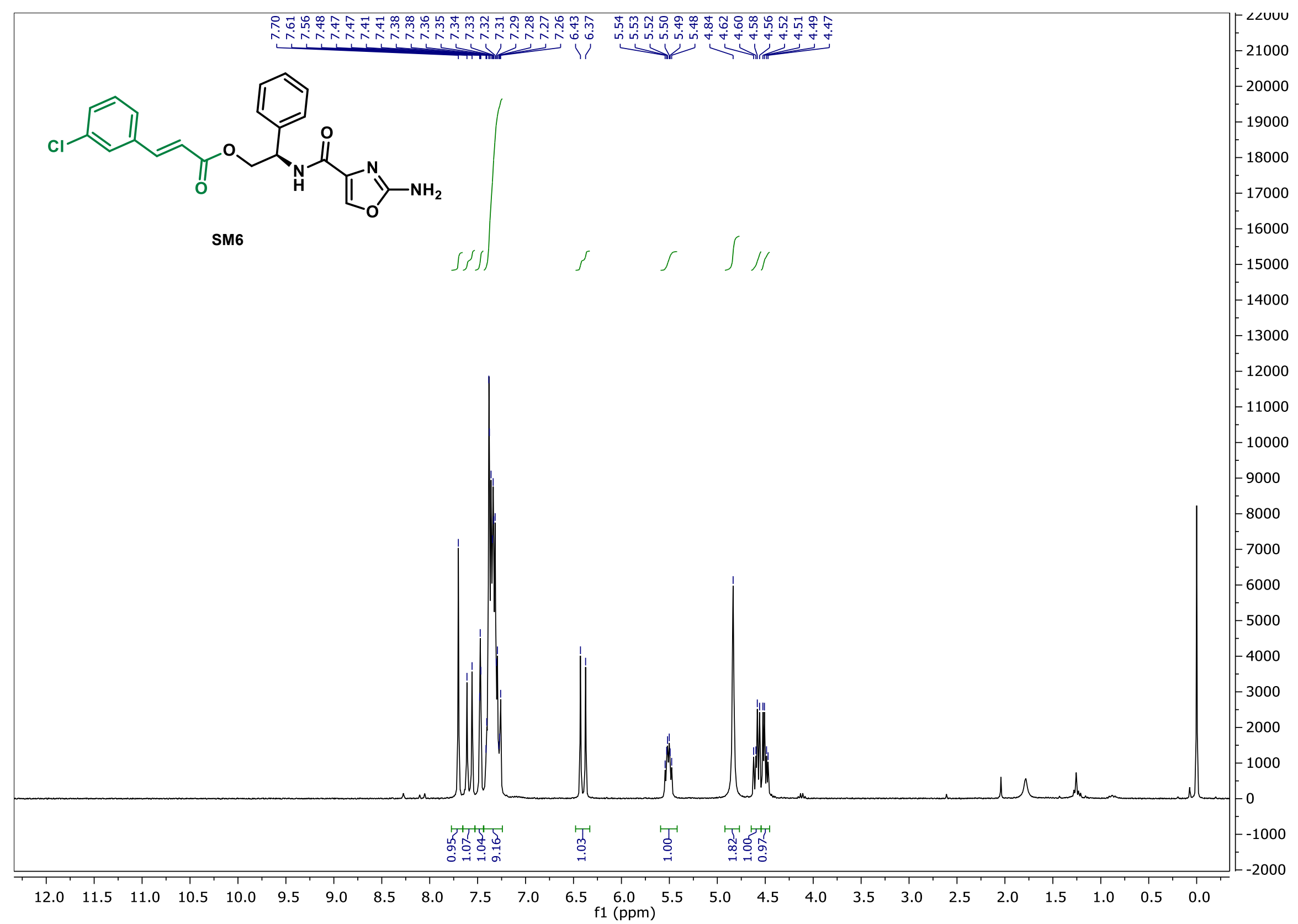




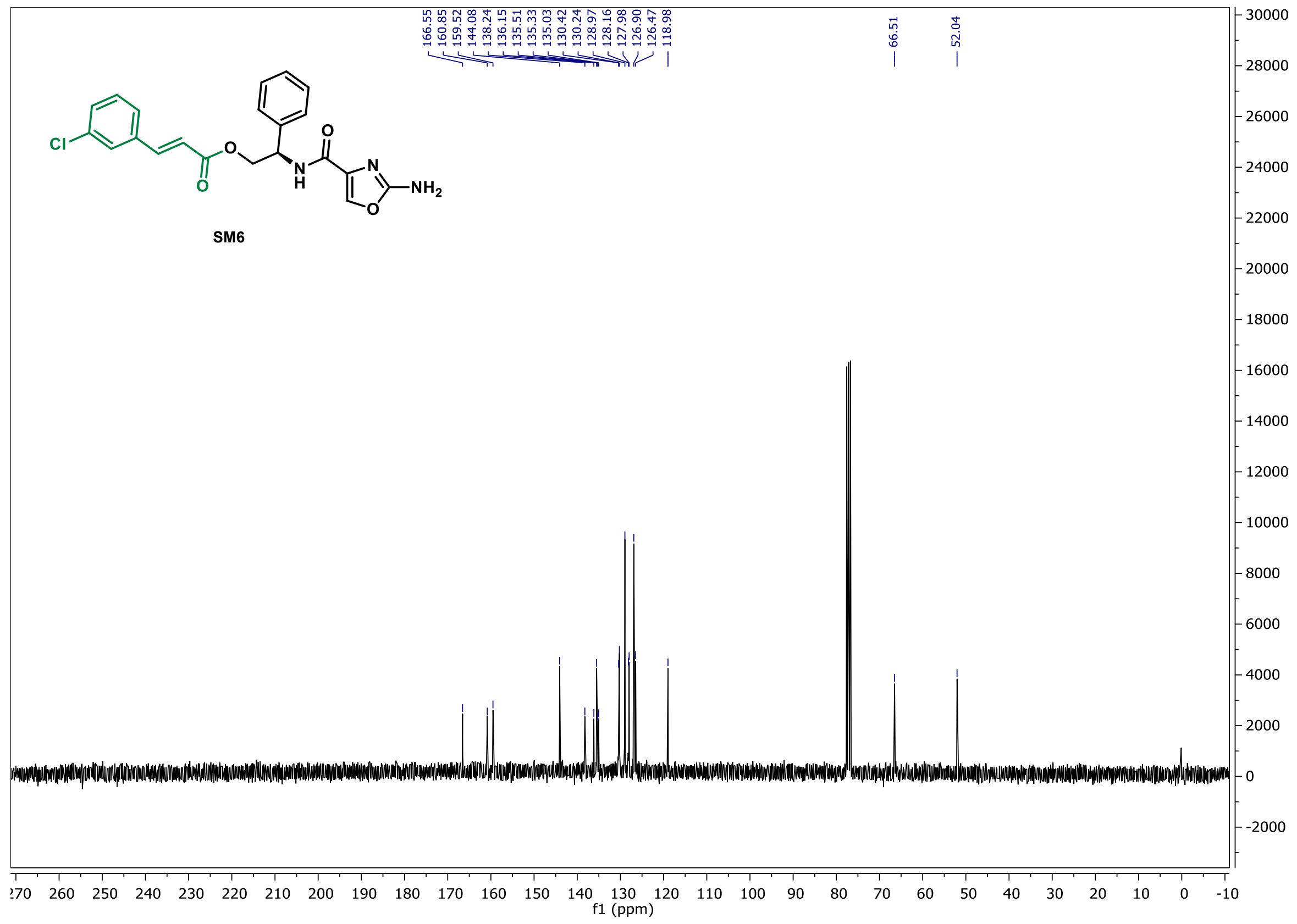


Mass to be matched $(\mathrm{m} / \mathrm{z}): 434.087680$ Charge: 1

Mass Tolerance: \pm 0.005000

Restriction of atom numbers:

$\begin{array}{llllll}\mathrm{C} & \mathrm{H} & \mathrm{Cl} & \mathrm{N} & \mathrm{O} & \mathrm{Na} \\ 1-100 & 1-100 & 1-1 & 1-3 & \max 10 & 1-1\end{array}$

Number of calculated Formulas:

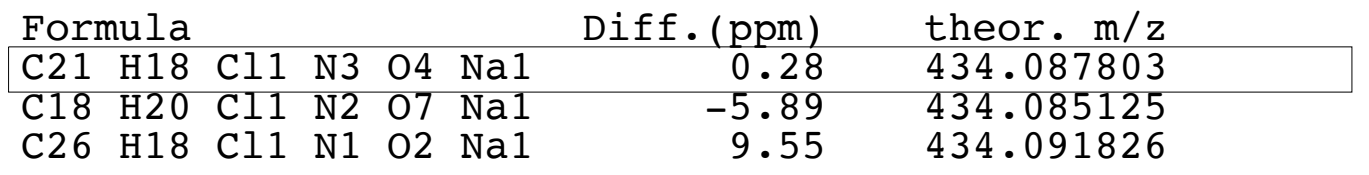

\begin{tabular}{|c|c|}
\hline $\begin{array}{l}\text { Datum } \\
\text { Analyse: }\end{array}$ & $\begin{array}{r}5.10 .2020 \\
149709 \mathrm{c}-00\end{array}$ \\
\hline $\begin{array}{l}\text { Sigel: } \\
\text { COP: Dr. Clement }\end{array}$ & $\begin{array}{l}\text { GHC-AA-044-01 } \\
t \text { Ghiazza }\end{array}$ \\
\hline $\begin{array}{l}\text { Messung: } \\
\text { Methode: } \\
\text { Lösungsmittel: } \\
\text { Spektrometer: }\end{array}$ & $\begin{array}{l}\text { HRMS } \\
\text { ESIpos } \\
\text { CH2Cl2+CH } 30 \mathrm{H} \\
\text { Exactive }\end{array}$ \\
\hline Auswerter: & Kampen (2242) \\
\hline
\end{tabular}

Suggestion :

C21H18Cl1N3O4 MW 411

characteristical ion

$434=[411+\mathrm{Na}]+$ 


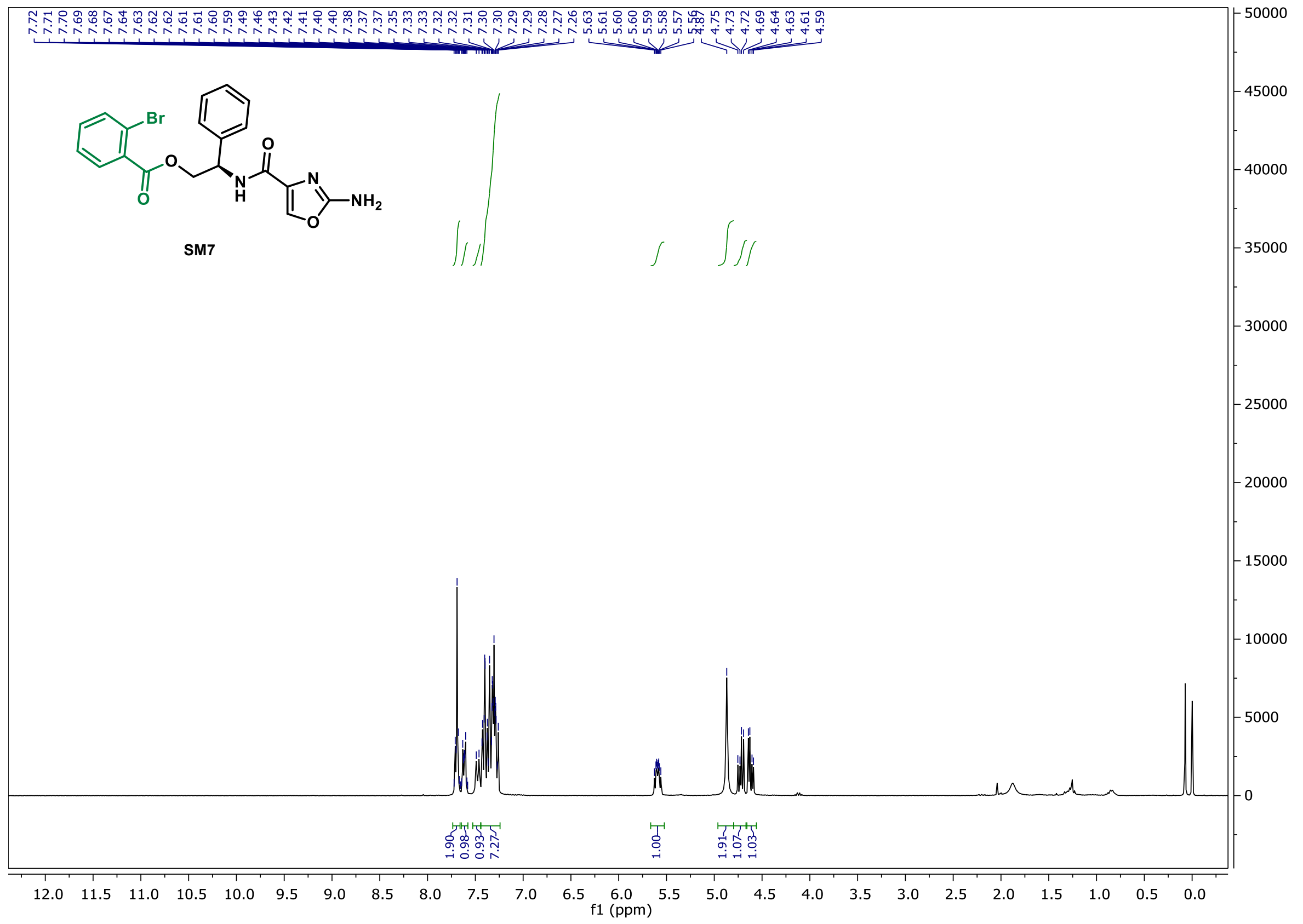




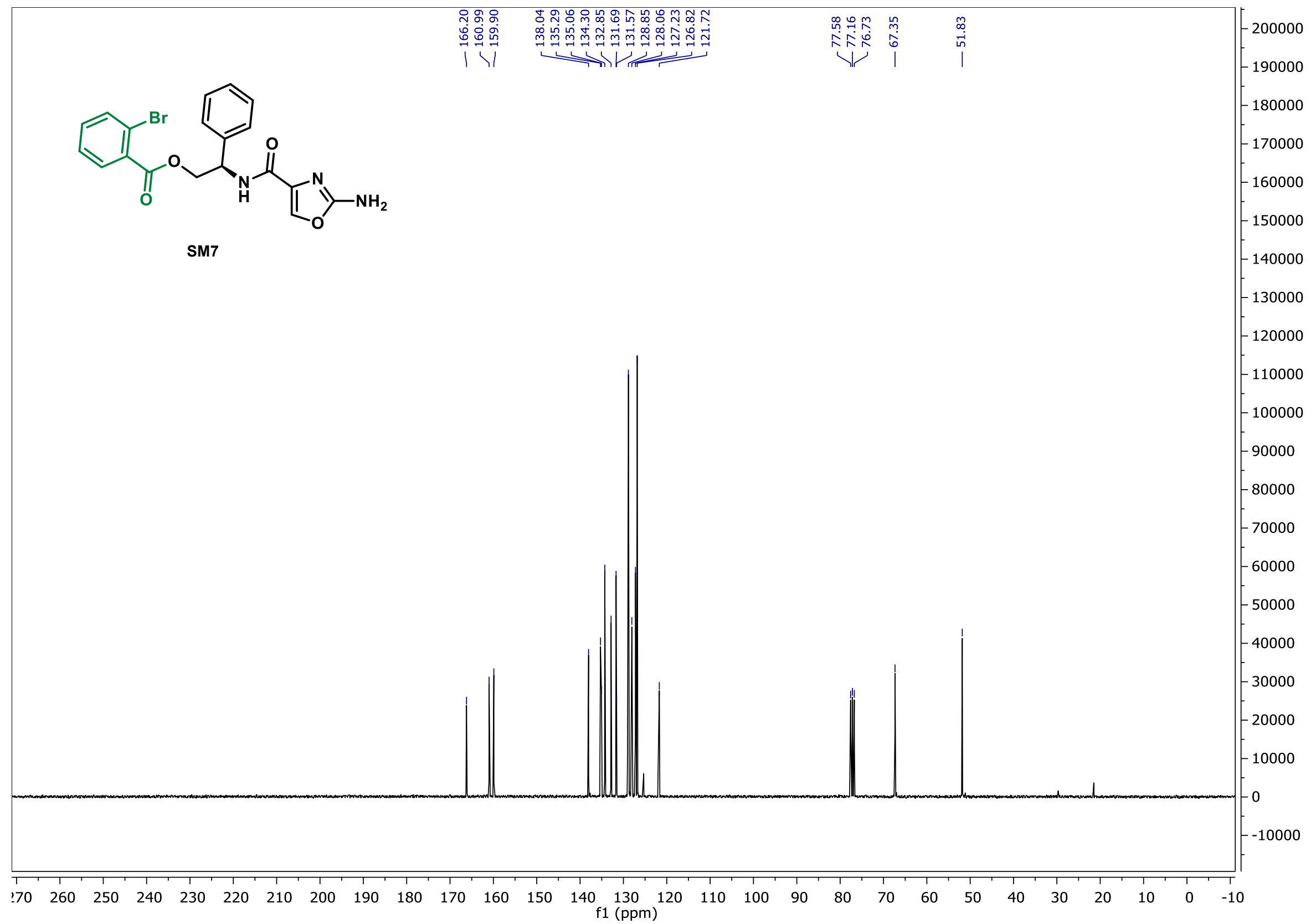


Mass to be matched $(\mathrm{m} / \mathrm{z}): 452.021330$ Charge: 1

Mass Tolerance: \pm 0.005000

09.10 .2020

Restriction of atom numbers:

$\begin{array}{llllll}\mathrm{C} & \mathrm{H} & \mathrm{N} & \mathrm{O} & \mathrm{Br} & \mathrm{Na} \\ 1-110 & 1-100 & 1-3 & 1-4 & 1-1 & 1-1\end{array}$

Number of calculated Formulas: 2

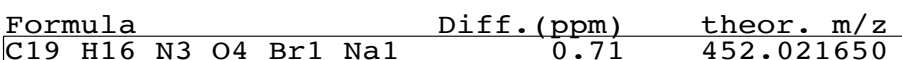

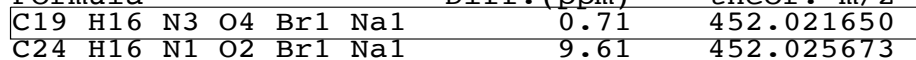

File: $149797 \mathrm{~b}-00$

Analyse: GHC-AA-059-01

COP: Dr. Clement Ghiazza

Messung: HRMS ESIpos

Lösemittel: $\mathrm{CH} 3 \mathrm{OH}$

spektrometer: Exactive

Auswerter: Kohler (2243)

Suggestion:

C19H16N304Br1 Mw 429

Characteristicial ions:

$452=[429+\mathrm{Na}]+$ 


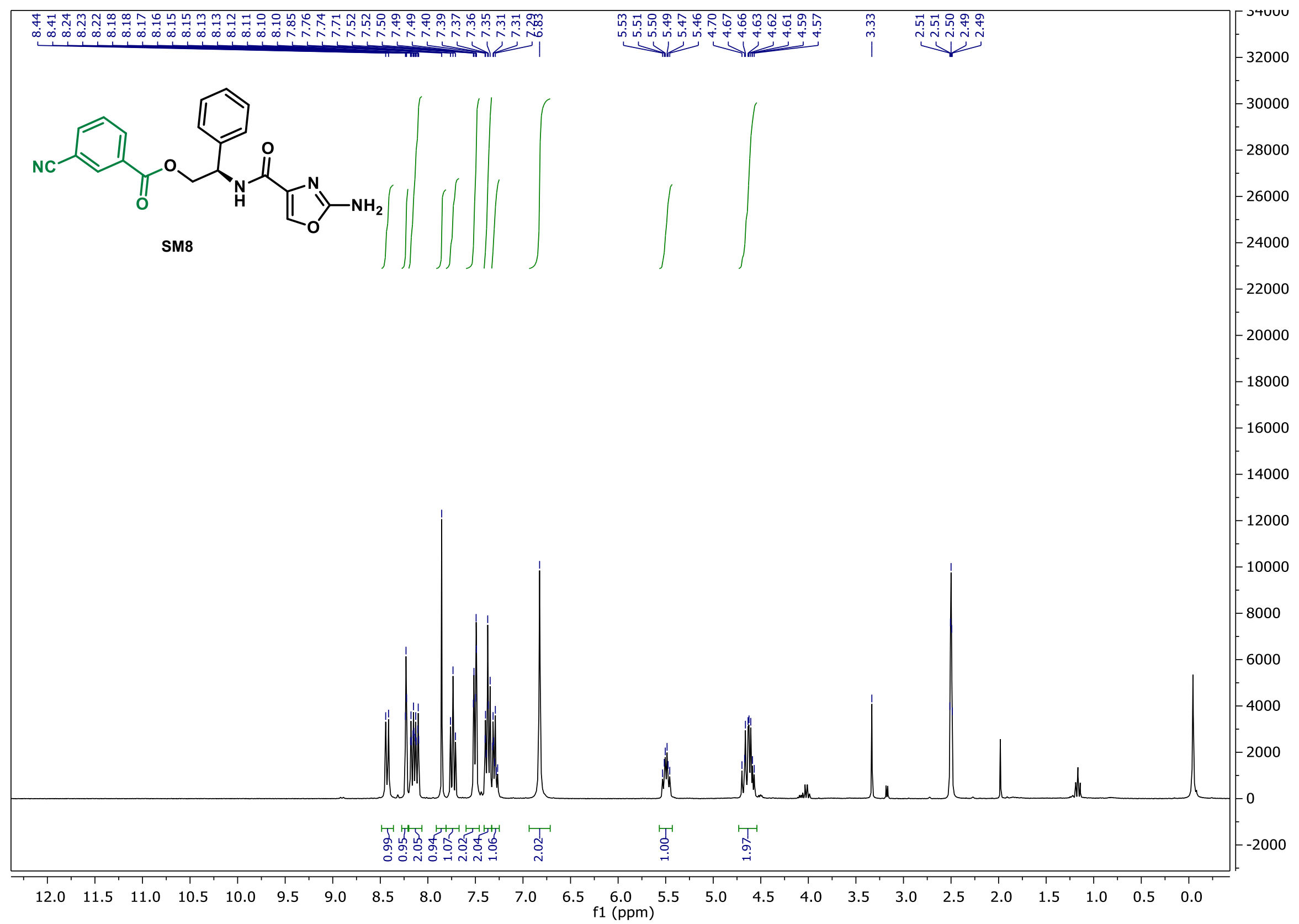




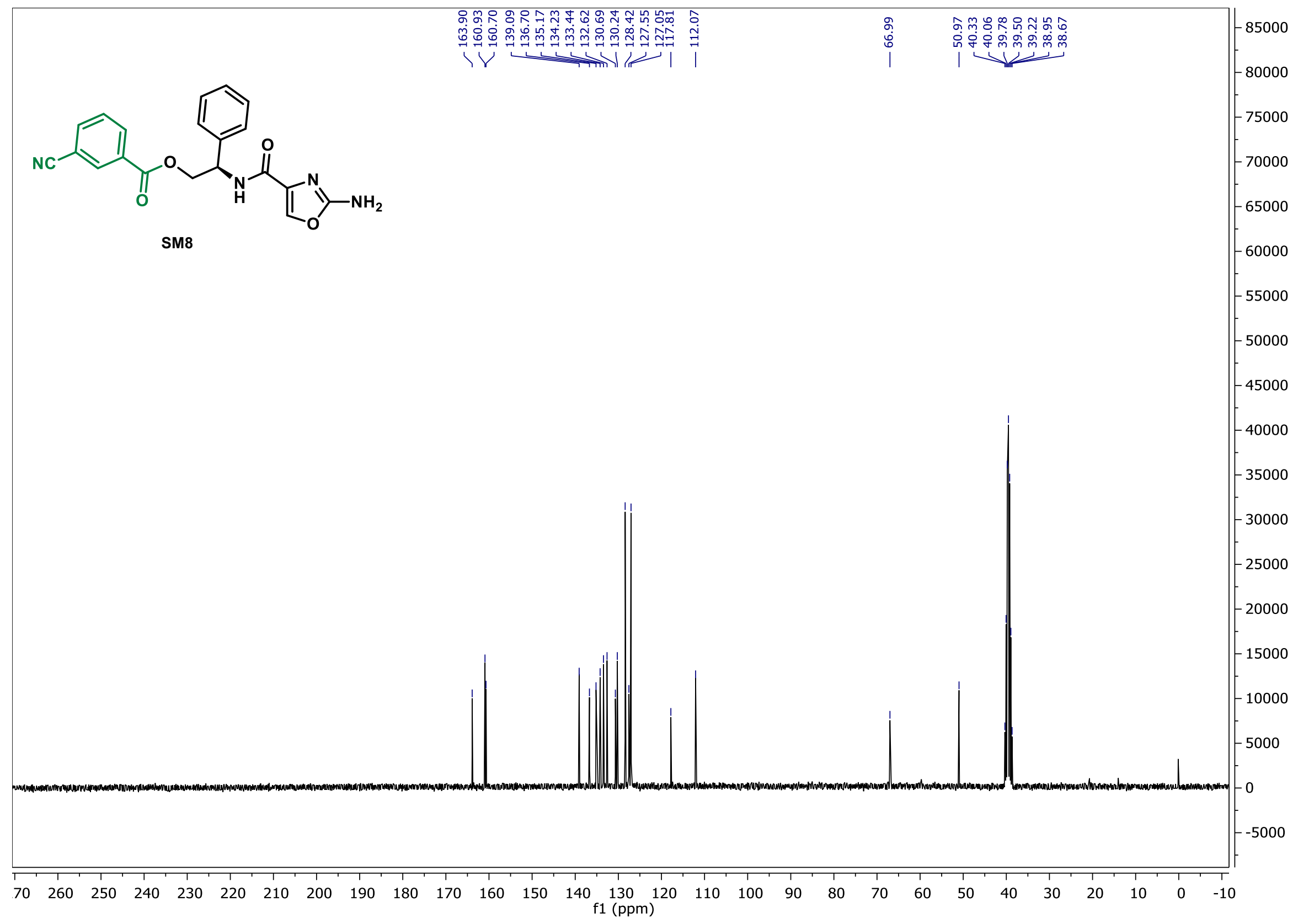


Mass to be matched $(\mathrm{m} / \mathrm{z}): 399.106750$ Charge: 1

Mass Tolerance: \pm 0.005000

Restriction of atom numbers:

$\begin{array}{lllll}\mathrm{C} & \mathrm{H} & \mathrm{N} & \mathrm{O} & \mathrm{Na} \\ 1-100 & 1-100 & 2-4 & \max 10 & 1-1\end{array}$

Number of calculated Formulas: 3

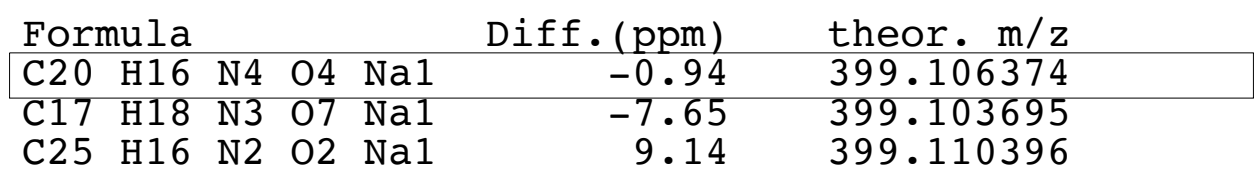

Formula

$\begin{array}{lllll}\mathrm{C} 17 & \mathrm{H} 18 & \mathrm{~N} 3 & 07 & \mathrm{Na}\end{array}$

9.14

399.110396

\begin{tabular}{|c|c|}
\hline $\begin{array}{l}\text { Datum } \\
\text { Analyse: }\end{array}$ & $\begin{array}{r}6.10 .2020 \\
149718 b-00\end{array}$ \\
\hline Sigel: & GHC-AA-049-01 \\
\hline \multicolumn{2}{|c|}{ COP: Dr. Clement Ghiazza } \\
\hline Messung: & HRMS \\
\hline Methode: & ESIpos \\
\hline Lösungsmittel: & $\mathrm{CH} 3 \mathrm{OH}$ \\
\hline Spektrometer: & Exactive \\
\hline Auswerter: & Kampen (2242) \\
\hline
\end{tabular}

Suggestion:

C20H16N4O4 MW 376

characteristical ion

$399=[376+\mathrm{Na}]+$ 


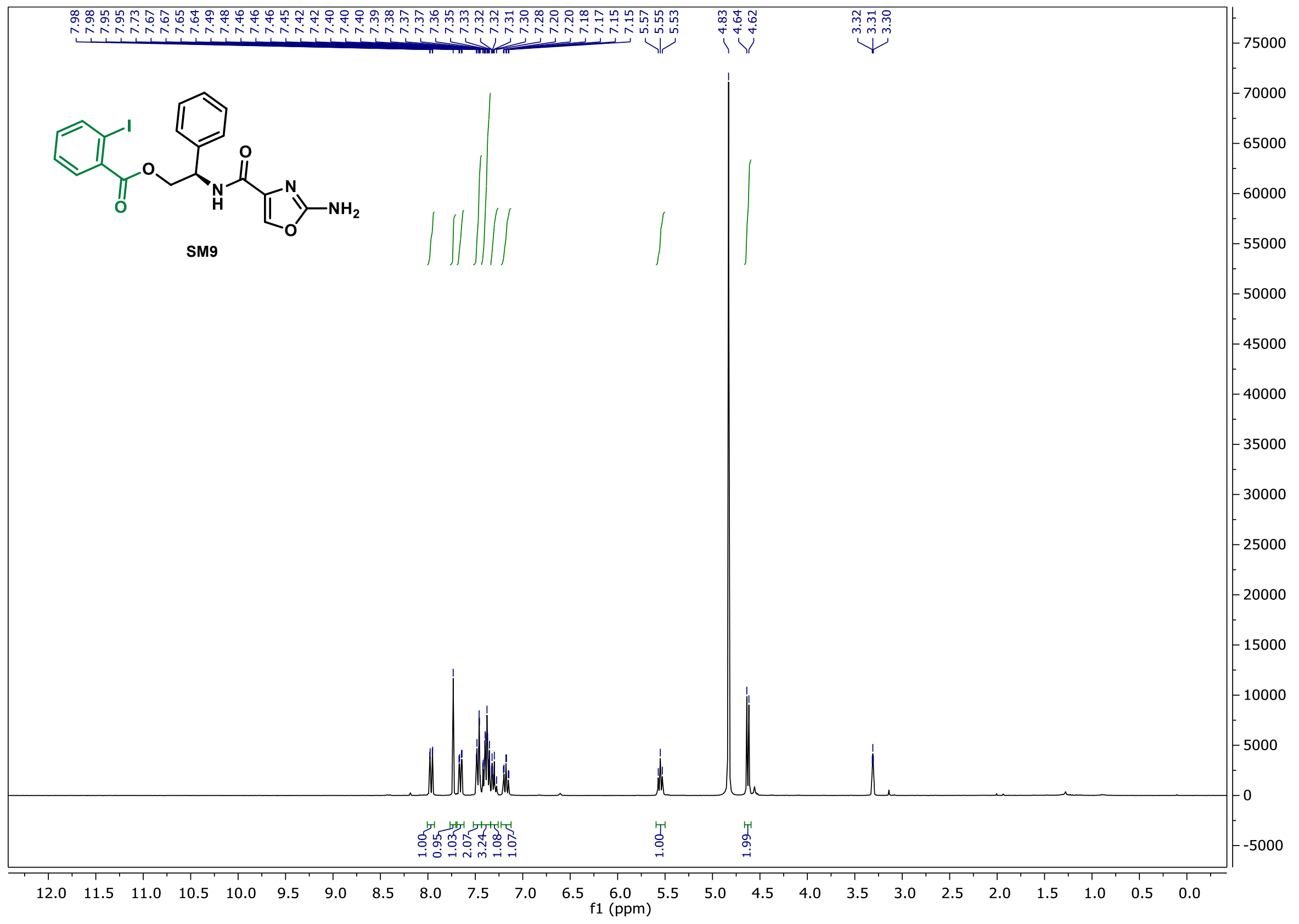




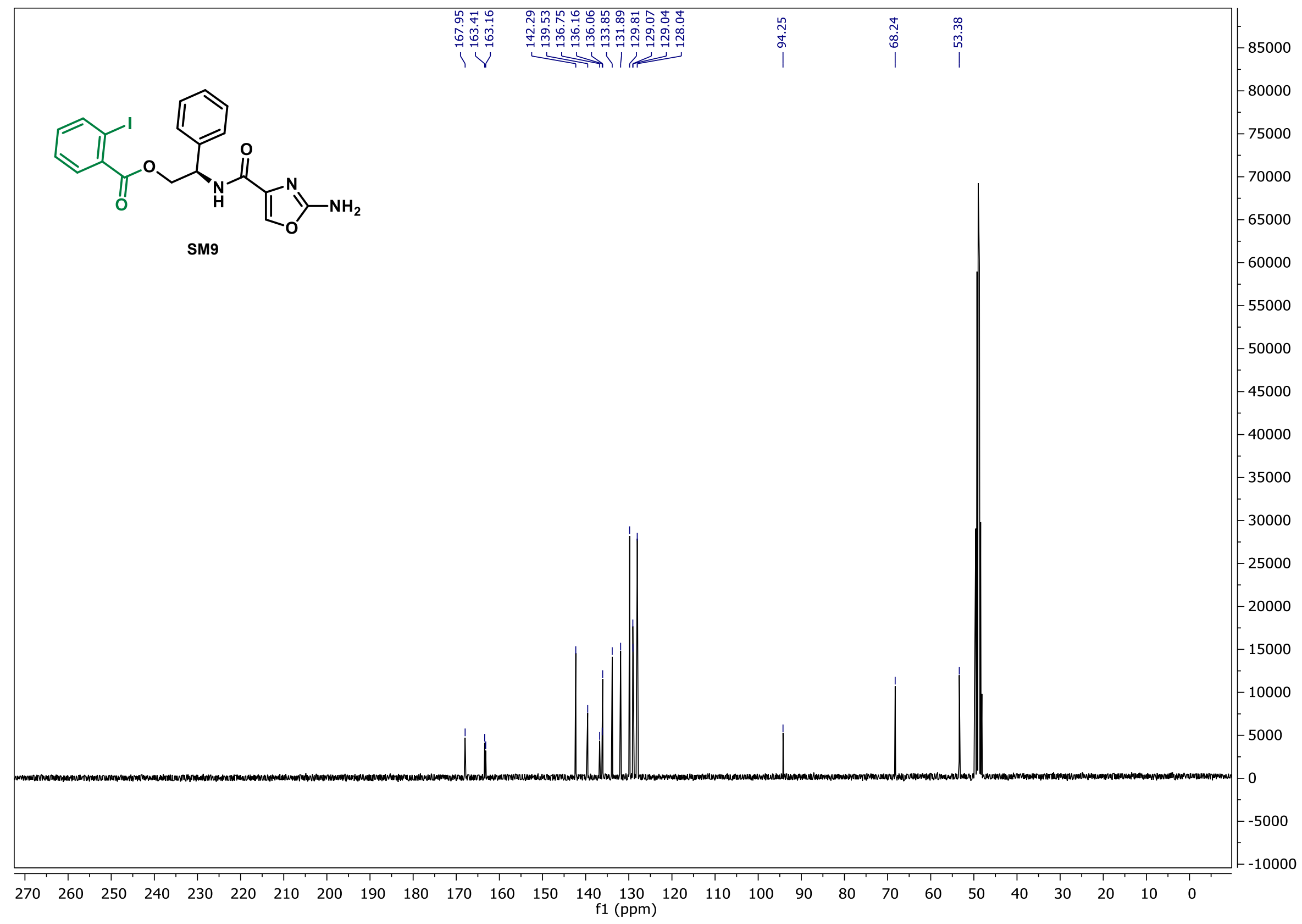


Mass to be matched $(\mathrm{m} / \mathrm{z}): 500.007860$ Charge: 1

\begin{tabular}{lr} 
Datum & 5.10 .2020 \\
Analyse: & $149697 \mathrm{~b}-00$ \\
\hline Sigel: & GHC-AA-043-0
\end{tabular}

Mass Tolerance: \pm 0.005000

Restriction of atom numbers:

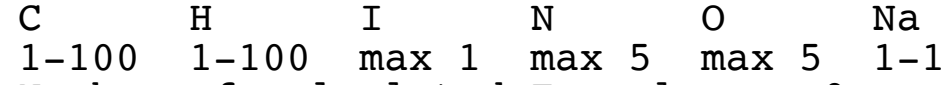

Number of calculated Formulas: 9

Formula
\begin{tabular}{|llrl|}
\hline C19 H16 I1 N3 O4 Na1 & Diff. (ppm) & theor. $\mathrm{m} / \mathrm{z}$ \\
C34 H5 O4 Na1 & -0.18 & 500.007772 \\
C32 H3 N3 O3 Na1 & 0.29 & 500.008004 \\
C21 H18 I1 O5 Na1 & -2.40 & 500.006660 \\
C35 H1 N4 Na1 & 2.51 & 500.009116 \\
C22 H14 I1 N4 O1 Na1 & 2.96 & 500.009339 \\
C37 H3 N1 O1 Na1 & 5.18 & 500.010451 \\
C24 H16 I1 N1 O2 Na1 & 5.65 & 500.010683 \\
C28 H14 I1 Na1 & 7.87 & 500.011795 \\
\end{tabular}

COP: Dr. Clement Ghiazza

Messung: HRMS

Methode: $\quad$ ESIpos

Lösungsmittel: $\mathrm{CH} 3 \mathrm{OH}$

Spektrometer: Exactive

Auswerter: Kampen (2242)

Assumed suggestion based on the reaction of previous samples: C19H16I1N3O4 MW 477

characteristical ion

$500=[477+\mathrm{Na}]+$ 
${ }^{1} \mathrm{H}$ NMR

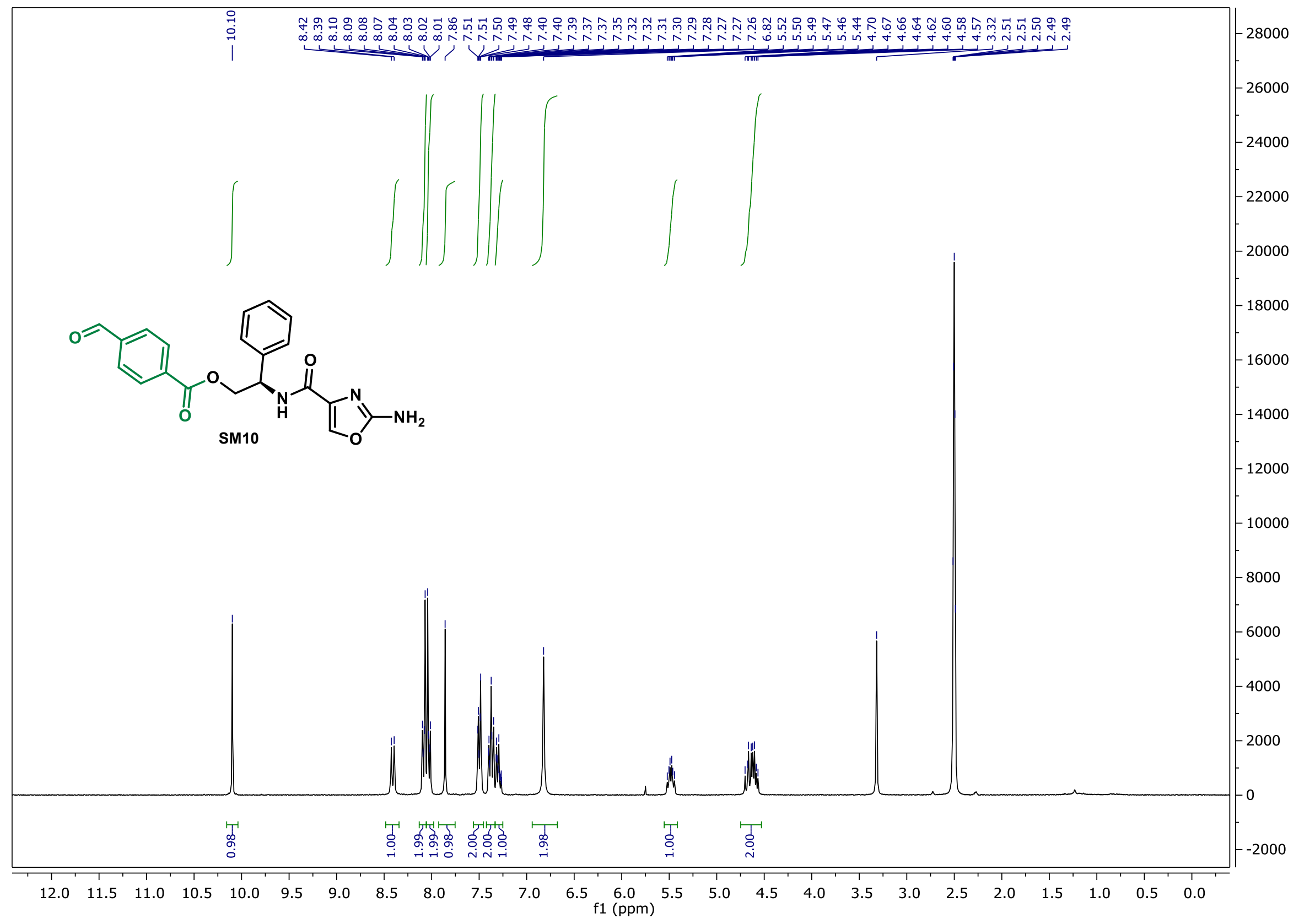




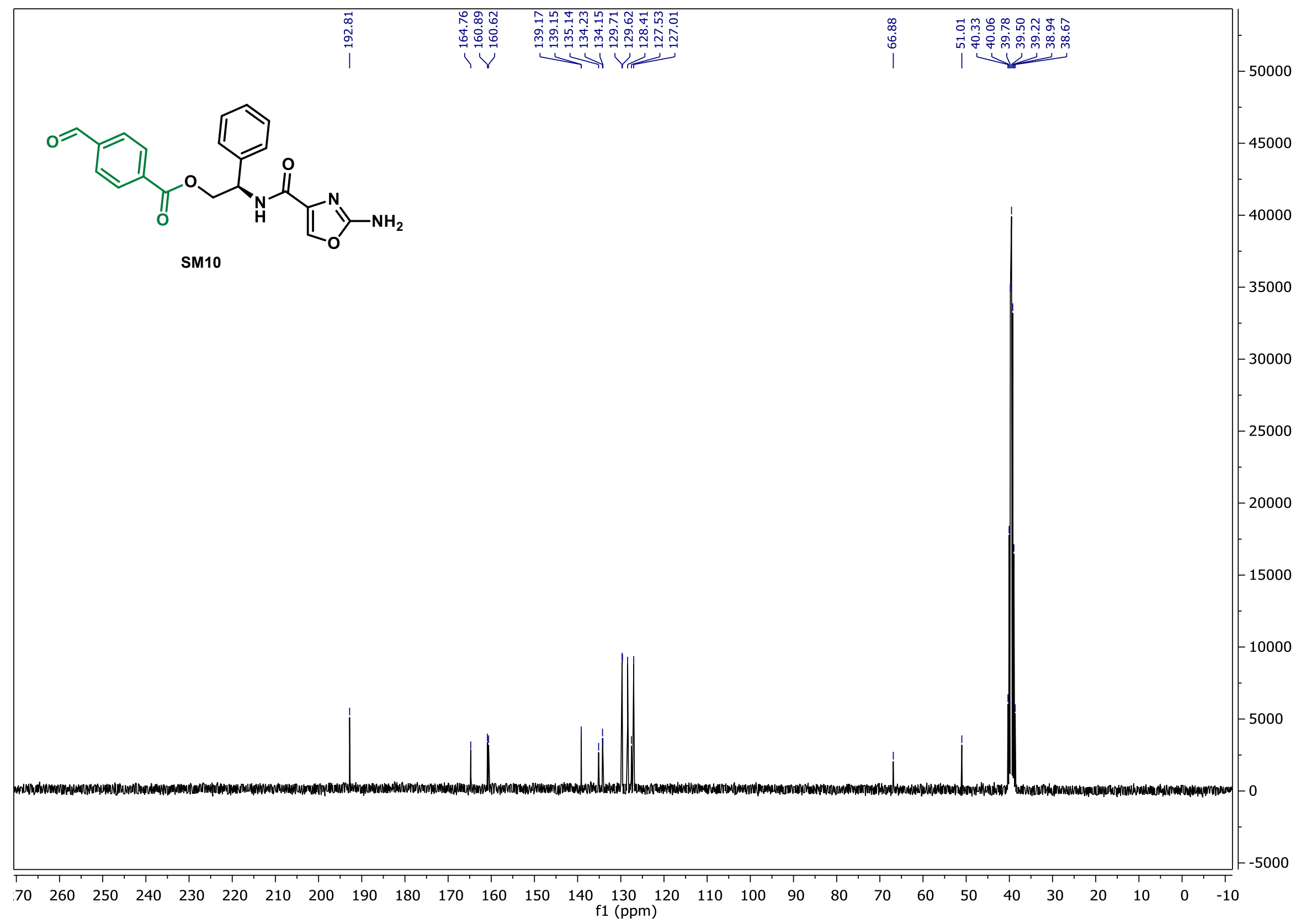


Mass to be matched $(\mathrm{m} / \mathrm{z}): 402.106620$ Charge: 1

Mass Tolerance: \pm 0.005000

Restriction of atom numbers:

$\begin{array}{lllll}\mathrm{C} & \mathrm{H} & \mathrm{N} & \mathrm{O} & \mathrm{Na} \\ 1-100 & 1-100 & 1-5 & 1-10 & 1-1\end{array}$

Number of calculated Formulas: 5

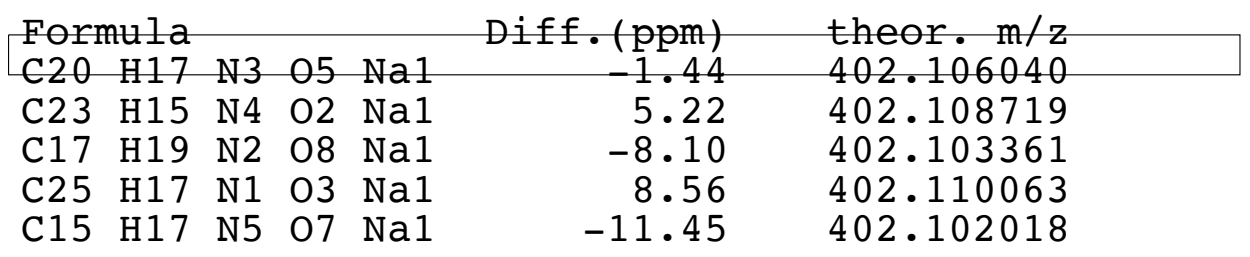

\begin{tabular}{ll}
$\begin{array}{ll}\text { Datum: } \\
\text { Analyse: }\end{array}$ & 15.10 .2020 \\
& $149875 \mathrm{C}-00$ \\
\hline Sigel: & GHC-AA-063-01 \\
& COP: Dr. Clement Ghiazza \\
\hline Method: & HR-MS \\
Ionis: : & ESIPOS \\
solvent : & CH3OH \\
Spectrometer: & Exactive \\
\hline Auswerter: & Marcus, Tel:2243
\end{tabular}

suggestion:

$\mathrm{C} 20 \mathrm{H} 17 \mathrm{~N} 305$

MW : 379

$402=[379+\mathrm{Na}]$ 


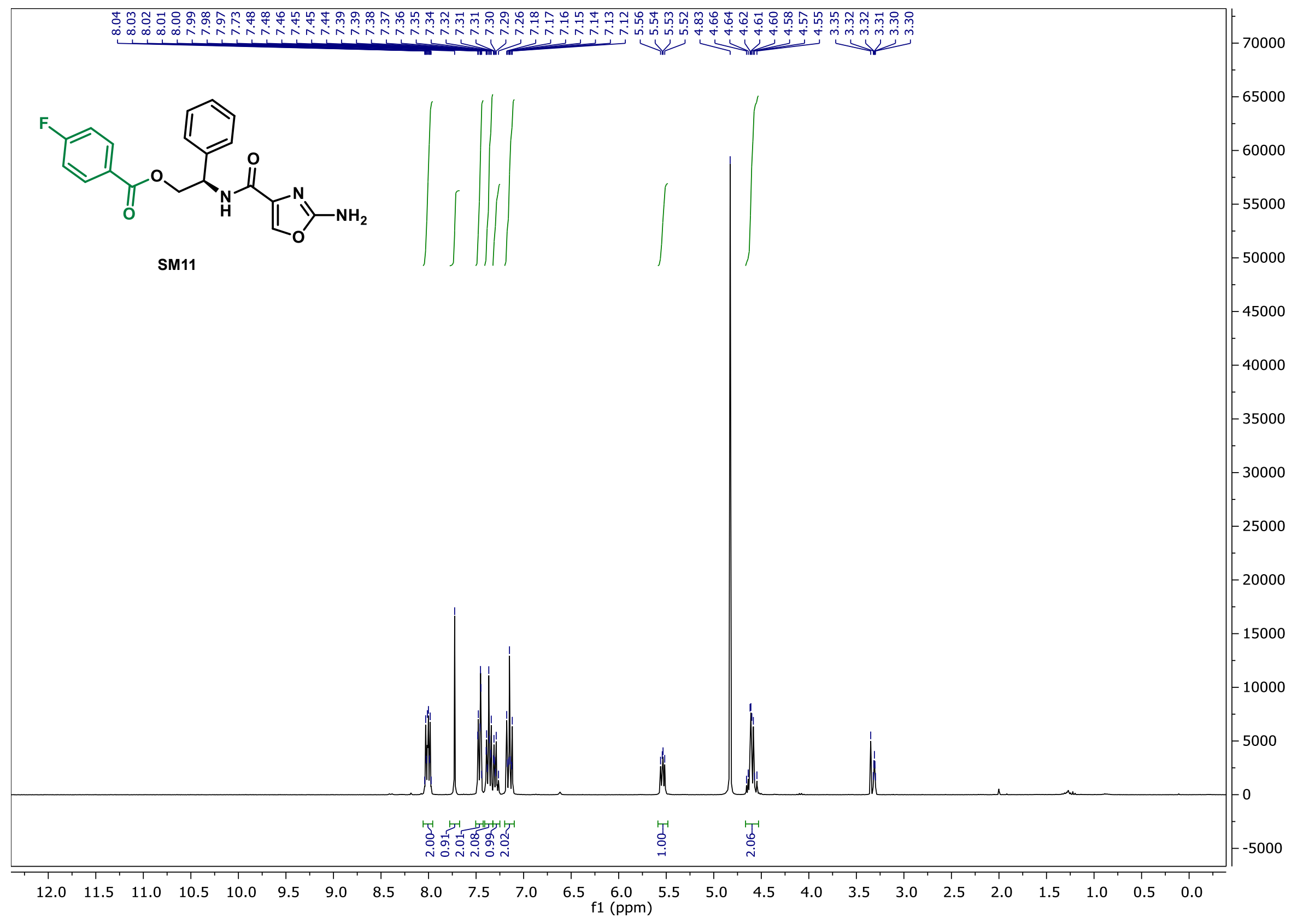


${ }^{13} \mathrm{C}$ NMR

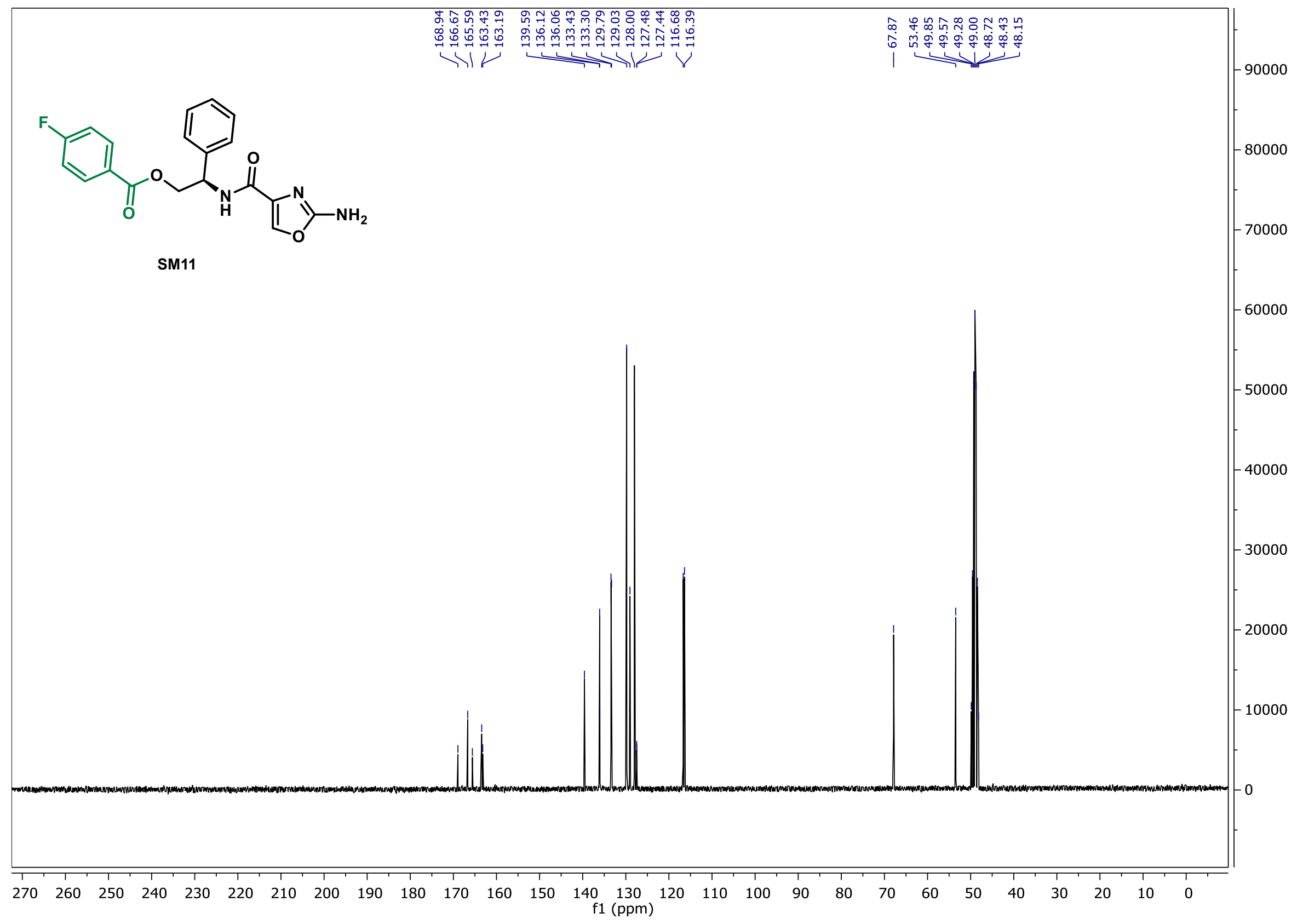




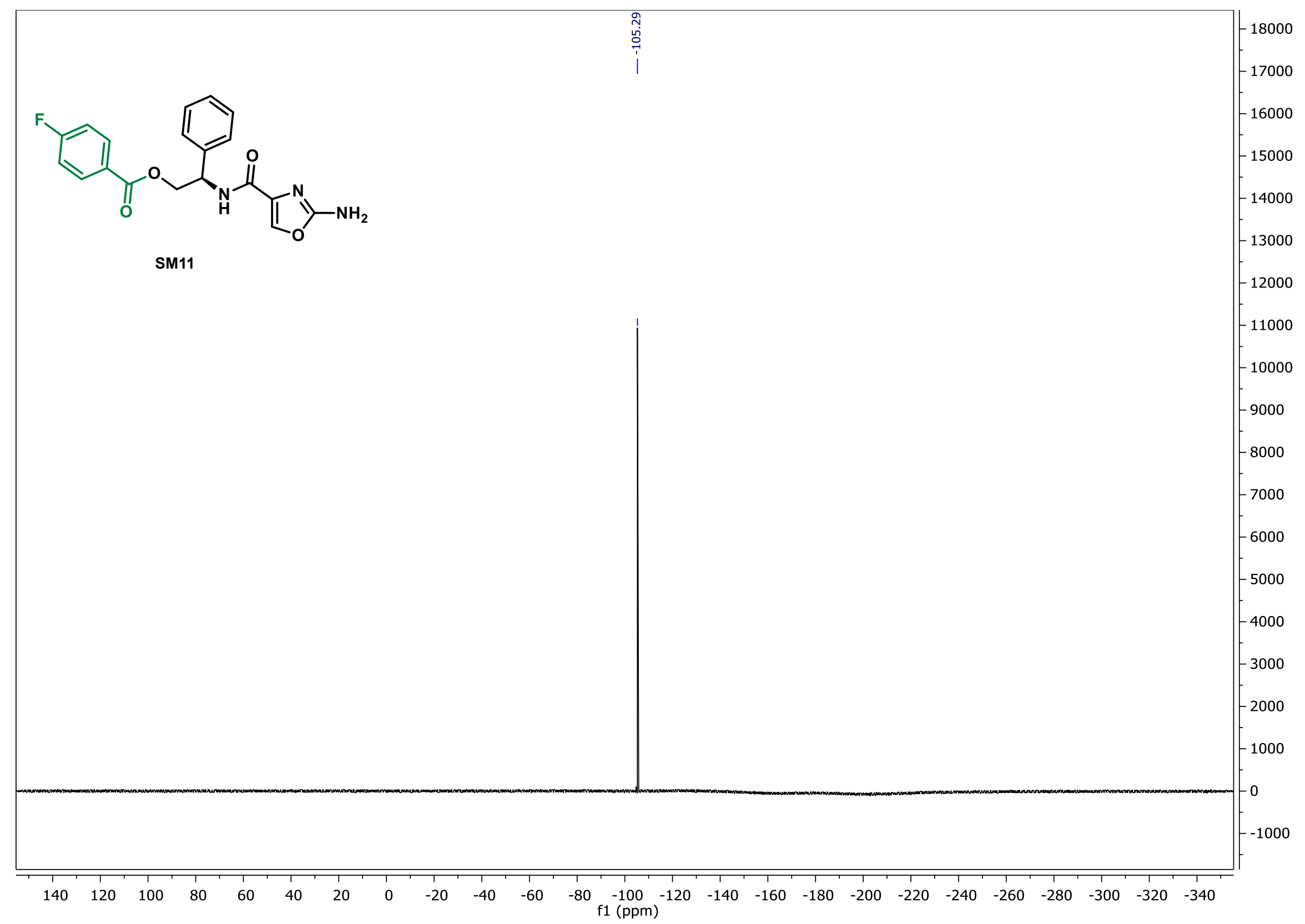


Mass to be matched $(\mathrm{m} / \mathrm{z}): 392.102070$ Charge: 1

Mass Tolerance: \pm 0.050000

Restriction of atom numbers:

$\begin{array}{llllll}\mathrm{C} & \mathrm{H} & \mathrm{N} & \mathrm{O} & \mathrm{Na} & \mathrm{F} \\ 1-100 & 1-100 & 1-3 & 1-4 & 1-1 & 1-1\end{array}$

Number of calculated Formulas: 13

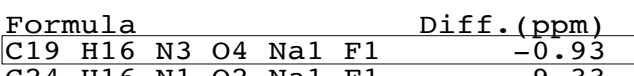
$-0.93$

C24 H16 N1 O2 Na1 F

C23 H14 N2 O2 Na1 F1

C20 H18 N2 O4 Na1 F1

C23 H16 N3 O1 Na1 F1

$\mathrm{C} 22 \mathrm{H} 12$ N3 $\mathrm{O} 2$ Na1 $\mathrm{F} 1$

C21 H20 N1 O4 Nal F1

C24 H18 N2 O1 Na1 F1

C23 H12 N1 O3 Na1 F1

C20 H20 N3 O3 Na1 F1

C25 H20 N1 O1 Na1 F1

C22 H10 N2 O3 Na1 F1

C21 H22 N2 O3 Na1 F1
$-22.75$

31.14

$31 \cdot 1$

37.97

$-54.82$

63.21

70.05

$-83.47$

91.86

102.12

$-115.54$

123.93 theor. $\mathrm{m} / \mathrm{z}$ 392.101704

392.093150

392.114280

392.11428

392.116959

392.080574

392.126856

392.129535

392.138088

392.142111
392.069341

392.056765

392.150665
2.10 .2020

File: $149636 \mathrm{c}-00$

Analysis: GHC-AA-040-01

COP: Dr. Clement Ghiazza

Ionisierung: ESIpos HR-MS

Lösungsmittel: $\mathrm{CH} 2 \mathrm{Cl} 2+\mathrm{CH} 3 \mathrm{OH}$

Spektrometer: Exactive

ELNA :

27611

Auswerter: 


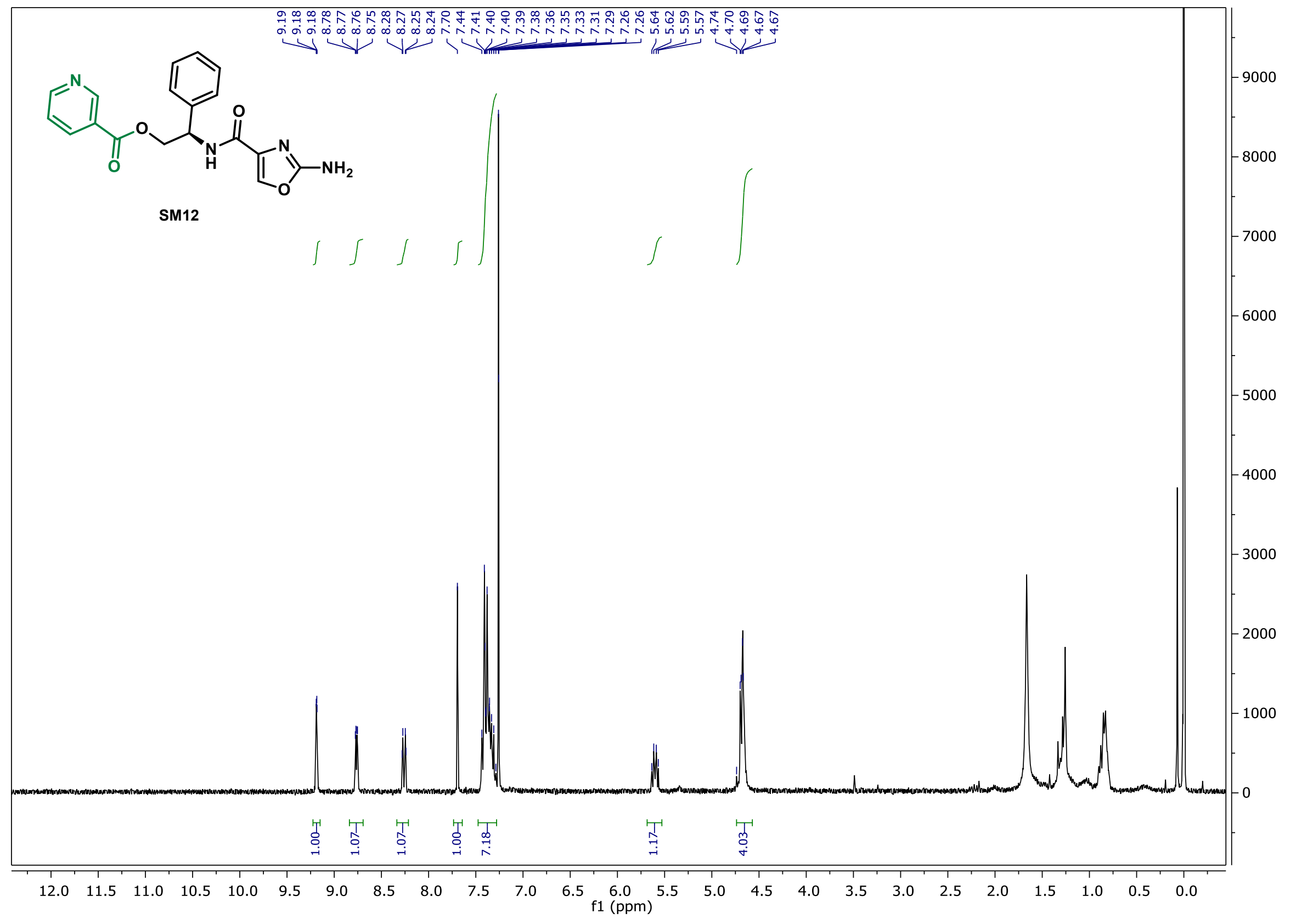


${ }^{13} \mathrm{C}$ NMR

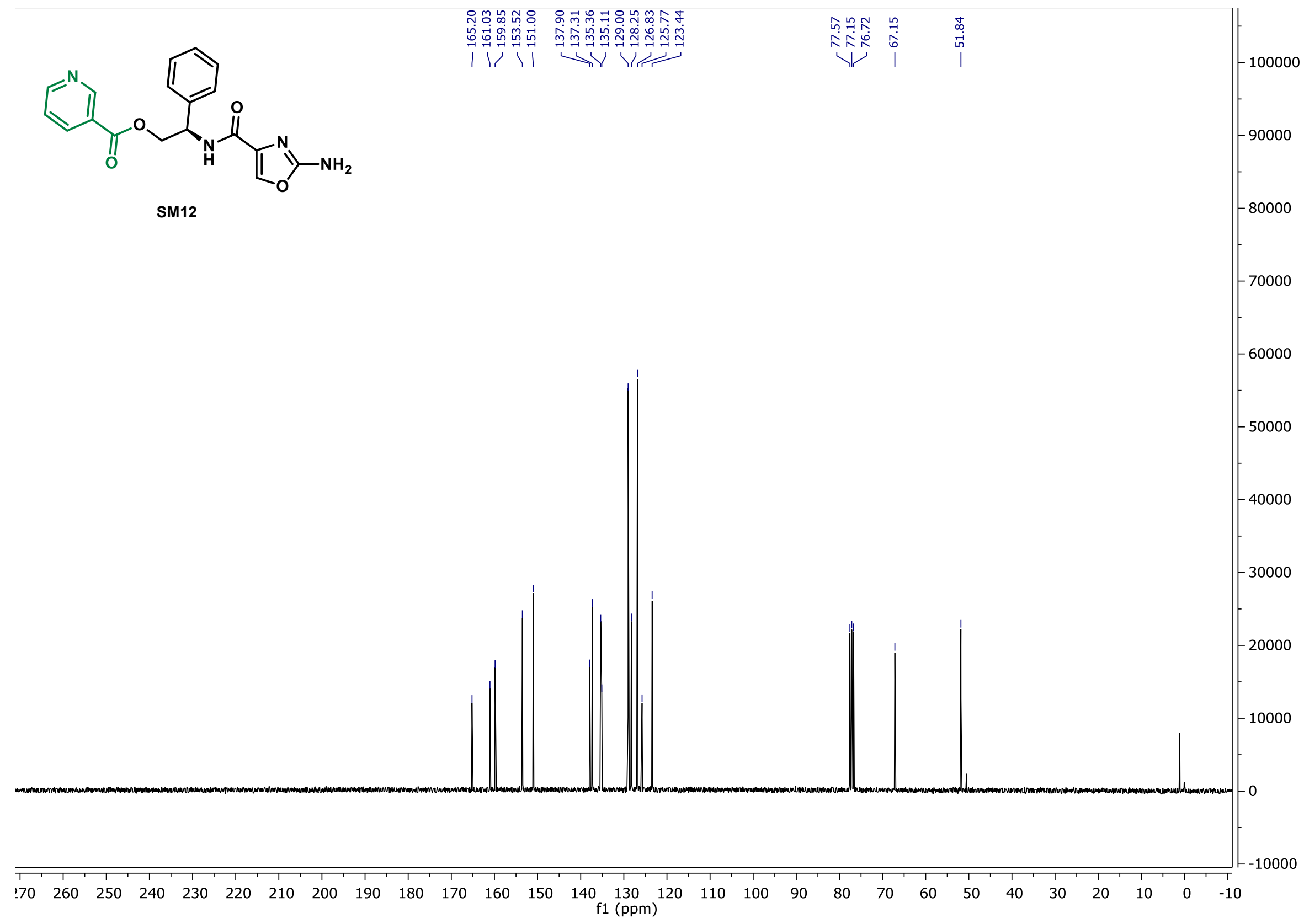


Mass to be matched $(\mathrm{m} / \mathrm{z}): 375.106510$ Charge: 1

Mass Tolerance: \pm 0.005000

Restriction of atom numbers:

$\begin{array}{lllll}\mathrm{C} & \mathrm{H} & \mathrm{N} & \mathrm{O} & \mathrm{Na} \\ 1-100 & 1-100 & 1-5 & 1-10 & 1-1\end{array}$

Number of calculated Formulas: 5

\begin{tabular}{|lrlllrr}
\multicolumn{2}{c}{ Formula } & & & Diff. (ppm) & theor. $\mathrm{m} / \mathrm{z}$ \\
C18 & H16 & N4 & O4 & Na1 & -0.36 & 375.106374 \\
C20 & H18 & N1 & O5 & Na1 & 3.22 & 375.107718 \\
C21 & H14 & N5 & O1 & Na1 & 6.78 & 375.109052 \\
C15 & H18 & N3 & O7 & Na1 & -7.50 & 375.103695 \\
C23 & H16 & N2 & O2 & Na1 & 10.36 & 375.110396
\end{tabular}

\begin{tabular}{ll}
$\begin{array}{ll}\text { Datum: } \\
\text { Analyse: }\end{array}$ & 15.10 .2020 \\
& $149876 \mathrm{C}-00$ \\
\hline Sigel: & GHC-AA-064-01 \\
& COP: Dr. Clement Ghiazza \\
\hline Method: & HR-MS \\
Ionis: : & ESIPOS \\
solvent : & CH3OH \\
Spectrometer: & Exactive \\
\hline Auswerter: & Marcus, Tel:2243
\end{tabular}

suggestion:

C18H16N4O4 MW: 352

Characteristic Ions:

$375=[352+\mathrm{Na}]$ 
${ }^{1} \mathrm{H}$ NMR

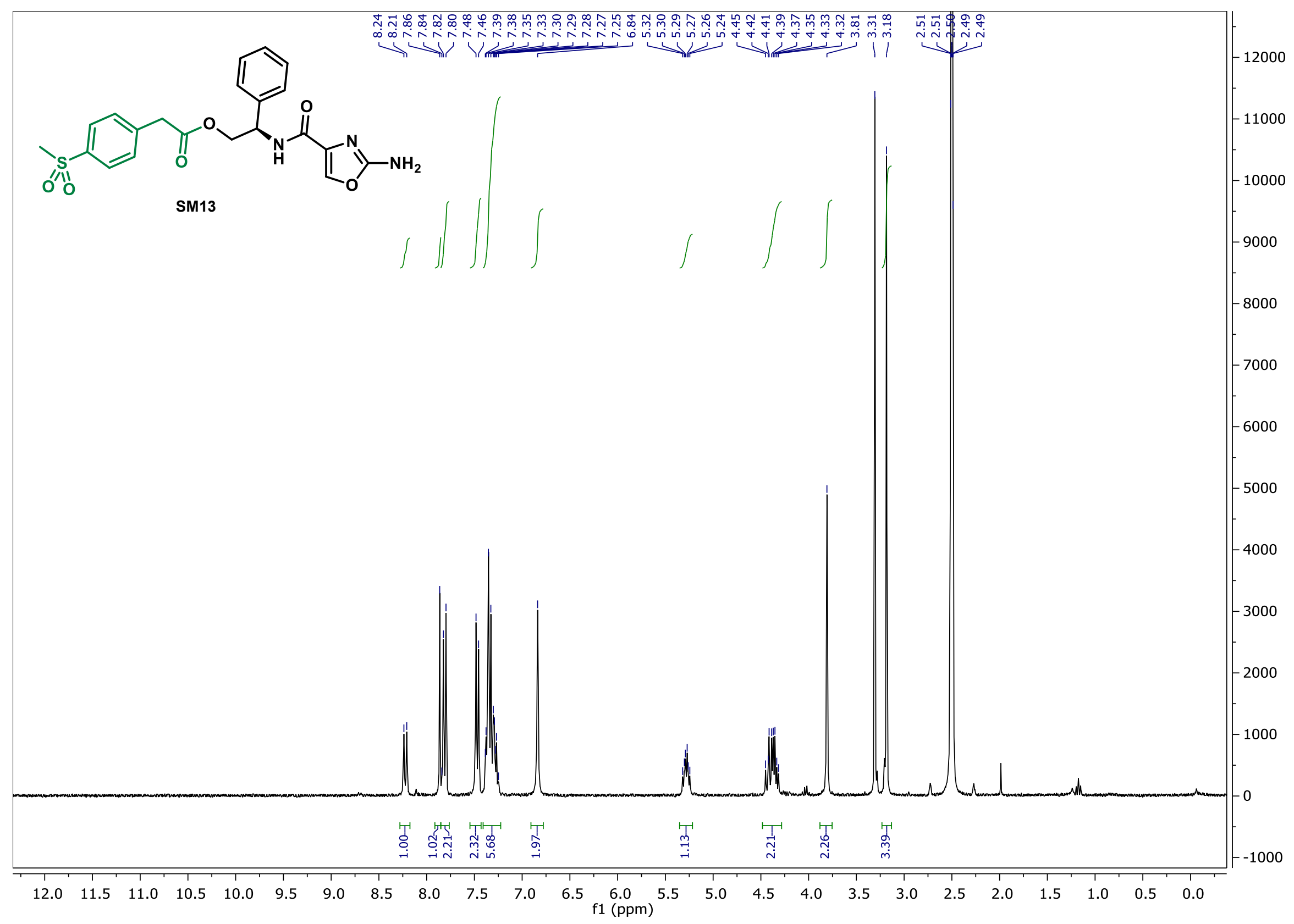




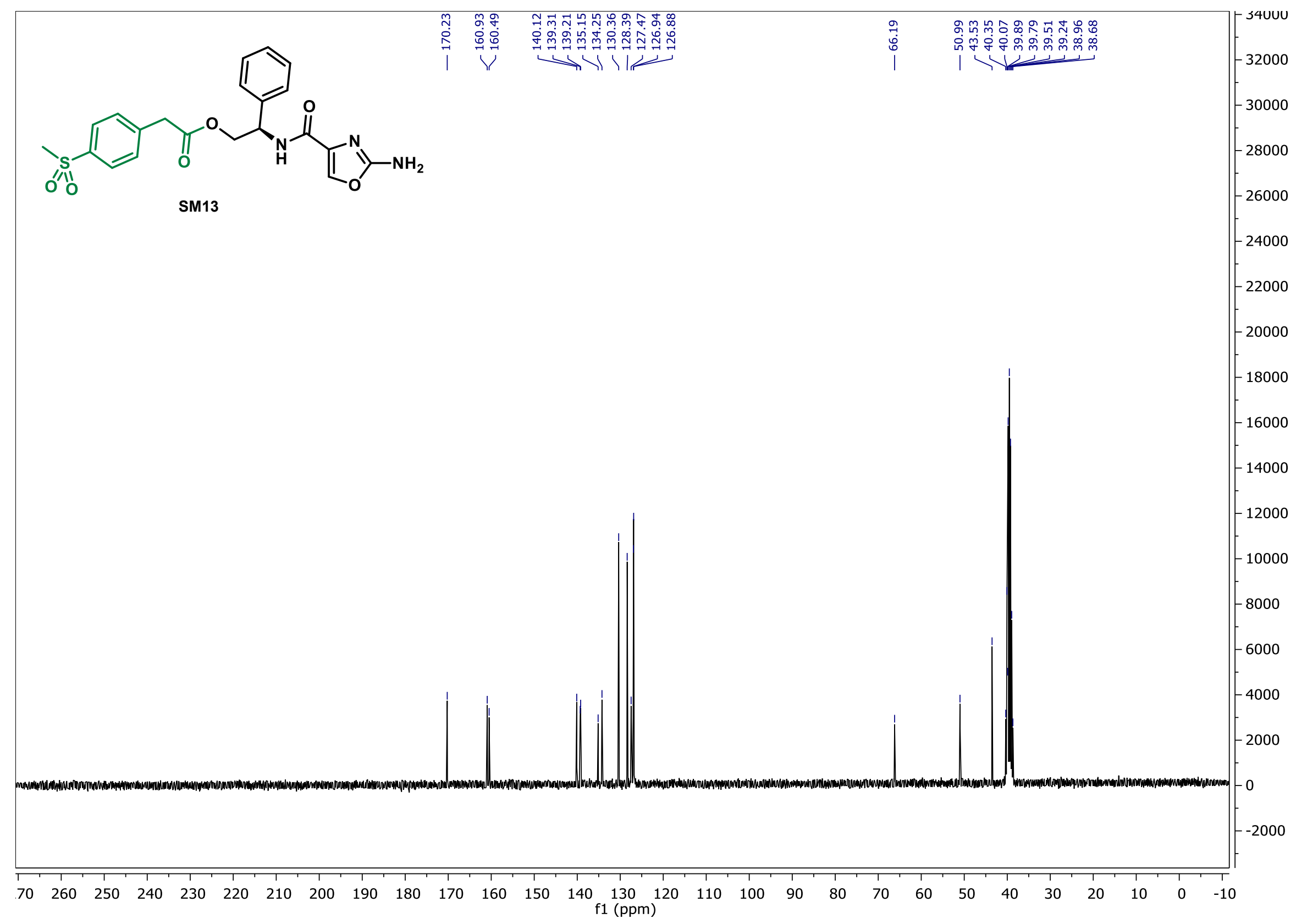




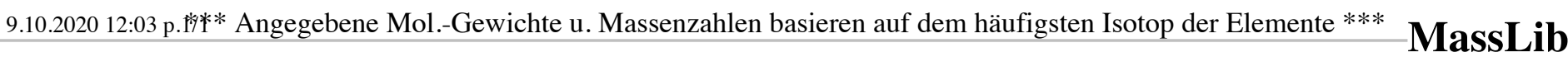

Mass to be matched $(\mathrm{m} / \mathrm{z}): 466.103980$ Charge: 1

Mass Tolerance: \pm 0.005000

Restriction of atom numbers:

$\begin{array}{llllll}\mathrm{C} & \mathrm{H} & \mathrm{N} & \mathrm{O} & \mathrm{S} & \mathrm{Na} \\ 1-110 & 1-100 & 1-3 & 1-6 & 1-1 & 1-1\end{array}$

Number of calculated Formulas: ${ }^{1-1} 2$

\begin{tabular}{|lrrrrr} 
Formula & & & Diff. (ppm) & theor. m/z \\
\hline C21 H21 N3 & O6 & S1 Na1 & 0.75 & 466.104328 \\
\hline
\end{tabular}

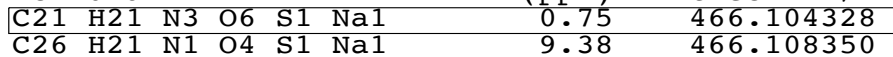

09.10 .2020

File: $149779 \mathrm{~b}-00$

Analyse: GHC-AA-053-01

COP: Dr. Clement Ghiazza

Messung: HRMS ESIpos

Lösemittel : $\mathrm{CH} 3 \mathrm{OH}$

Spektrometer: Exactive

Auswerter: Kohler (2243)

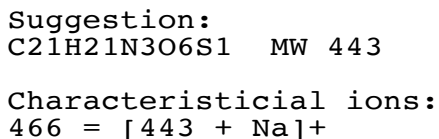

$466=[443+\mathrm{Na}]+$ 
${ }^{1} \mathrm{H}$ NMR

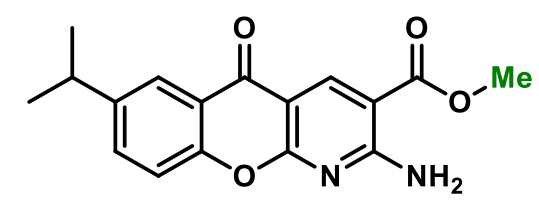

耐

๓

$1 \underbrace{\infty}$

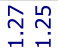

(

50000

SM14
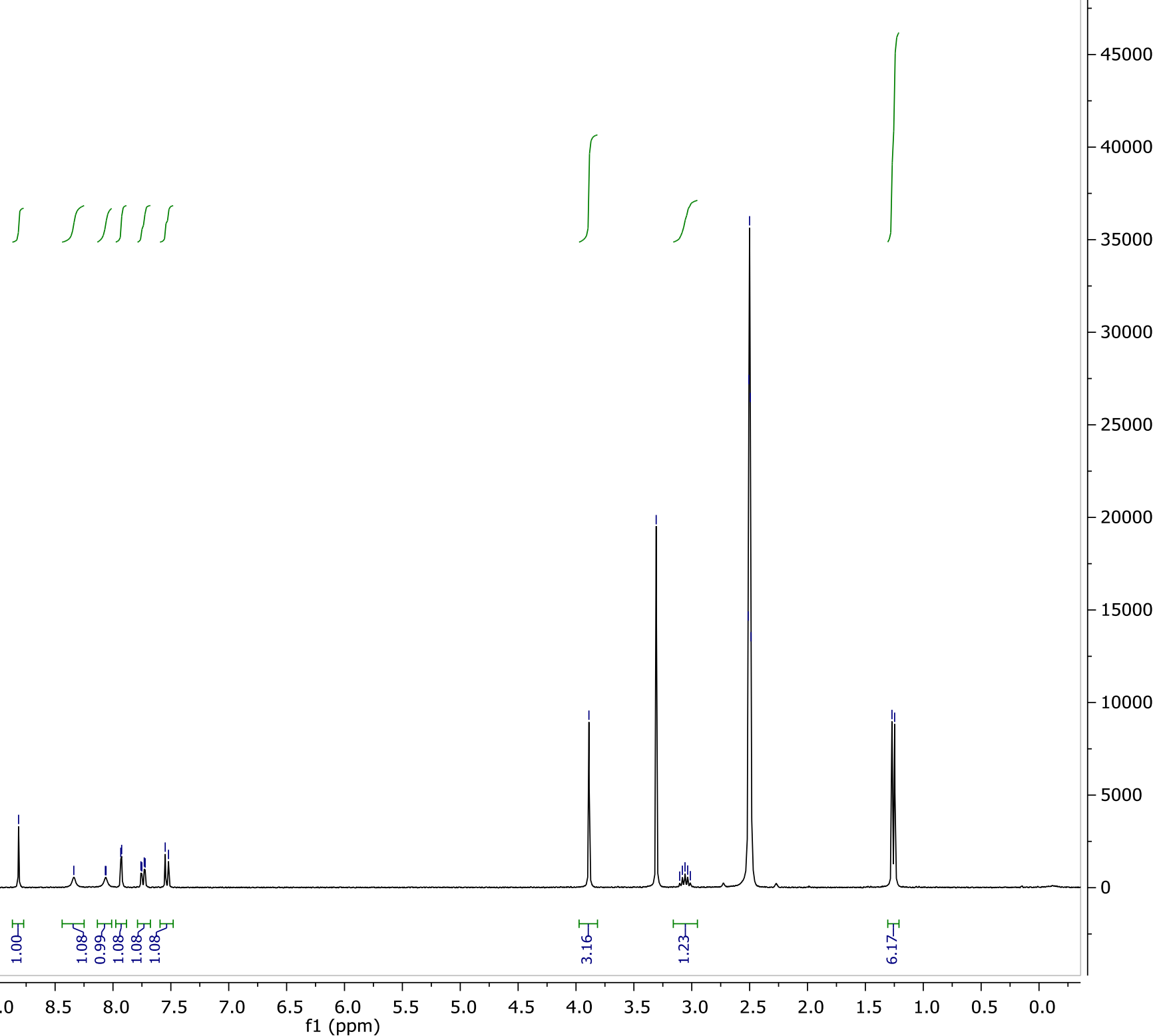
${ }^{1} \mathrm{H}$ NMR

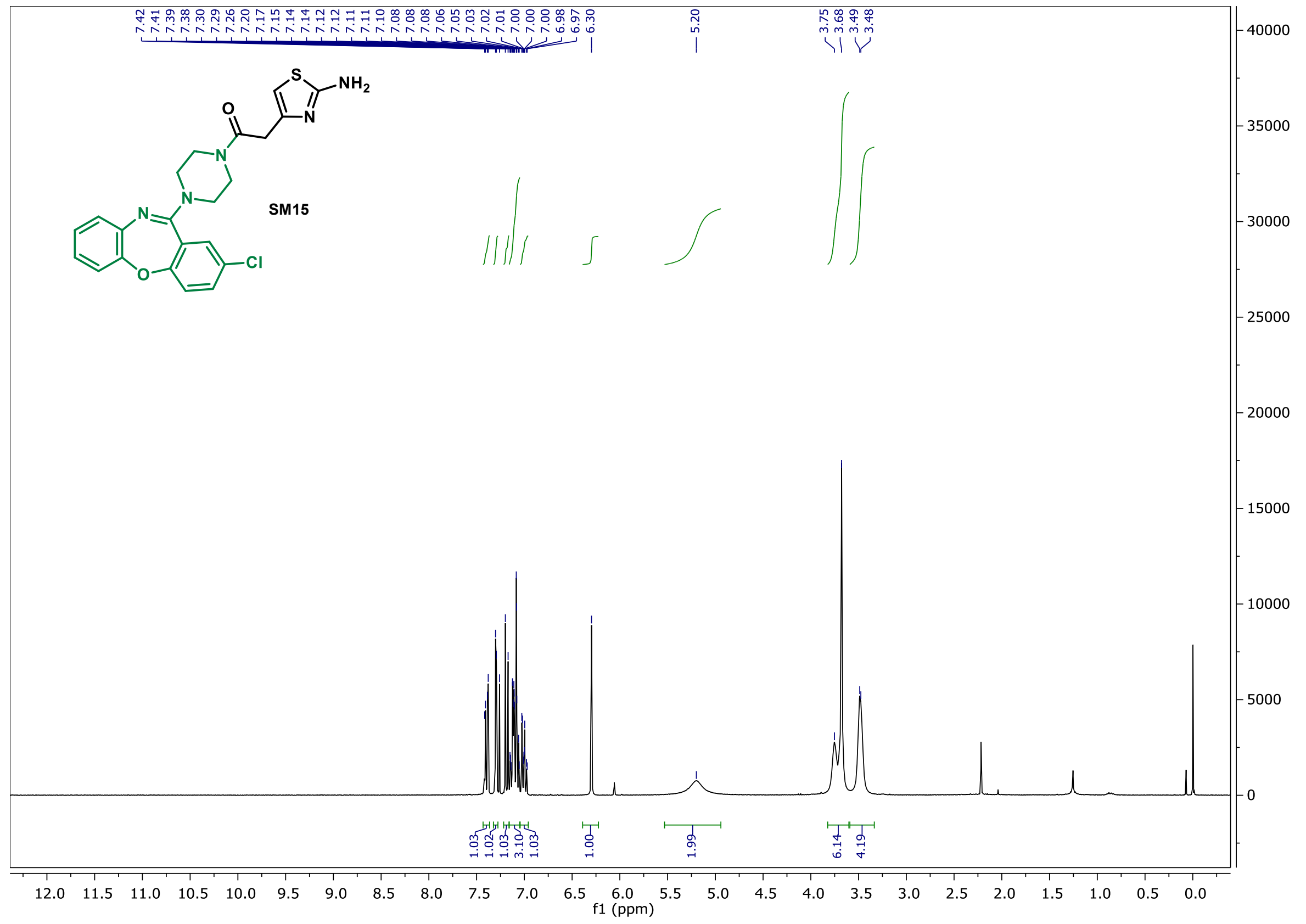




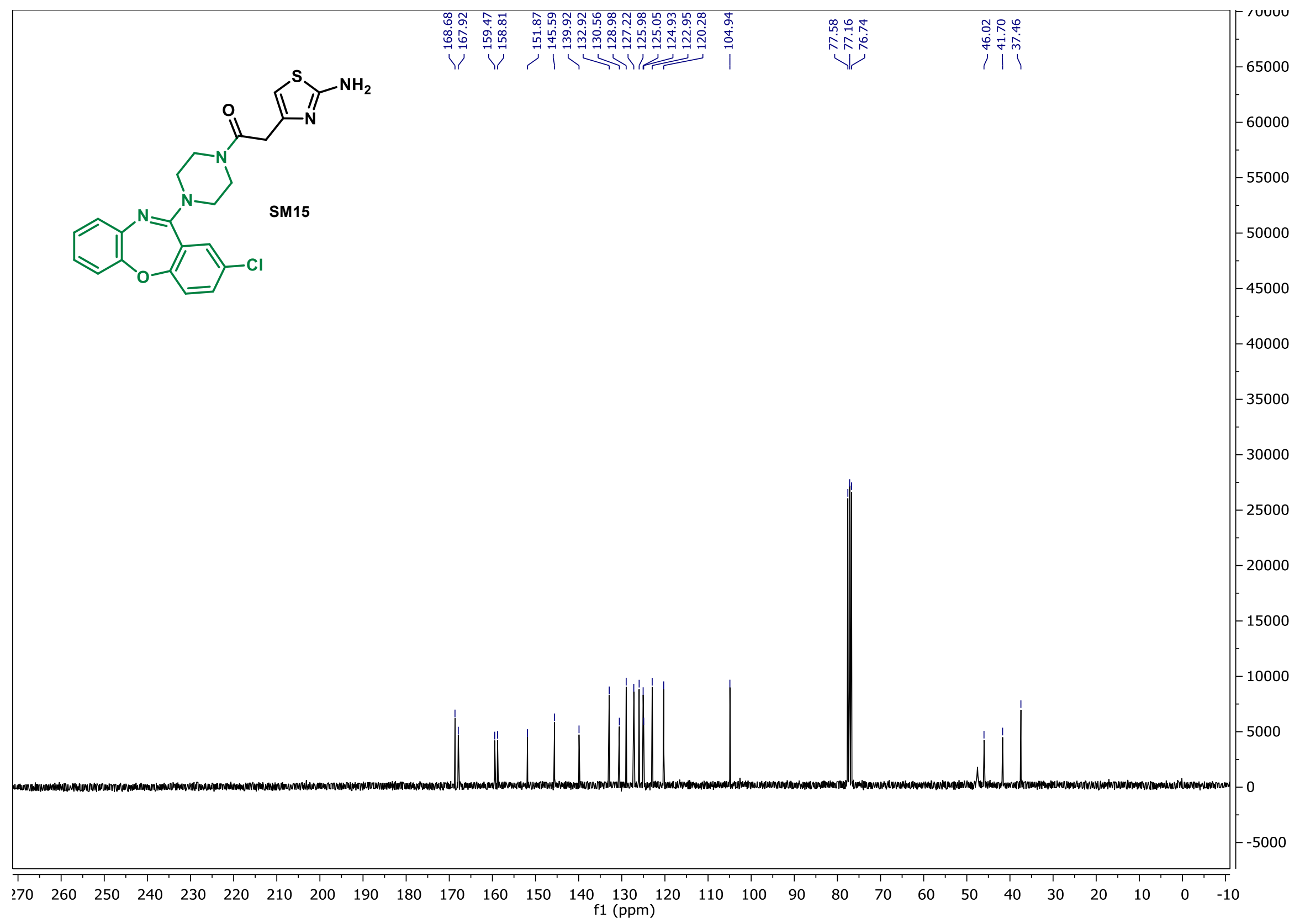


Mass to be matched $(\mathrm{m} / \mathrm{z}): 454.110070$ Charge: 1

Mass Tolerance: \pm 0.005000

Restriction of atom numbers:

$\begin{array}{llllll}\mathrm{C} & \mathrm{H} & \mathrm{N} & \mathrm{O} & \mathrm{S} & \mathrm{Cl} \\ 1-100 & 1-100 & 1-5 & 1-10 & 1-1 & 1-1\end{array}$

Number of calculated Formulas:

\begin{tabular}{|llllllrr|}
\multicolumn{2}{c}{ Formula } \\
C22 & H21 & N5 & O2 & S1 C11 & Diff. (ppm) & theor. $\mathrm{m} / \mathrm{z}$ \\
C24 & H23 & N2 & O3 & S1 Cl1 & -0.38 & 454.109899 \\
C21 & H25 & N1 & O6 & S1 Cl1 & 2.58 & 454.111243 \\
C19 & H23 & N4 & O5 S S Cl Cl & -3.32 & 454.108564 \\
C12 & H27 & N4 & O10 S1 Cl1 & -6.28 & 454.107220 \\
\end{tabular}

\begin{tabular}{|c|c|}
\hline $\begin{array}{l}\text { Datum: } \\
\text { Analyse: }\end{array}$ & $\begin{array}{l}29.10 .2020 \\
150158 c-00\end{array}$ \\
\hline Sigel: & $\begin{array}{l}\text { GHC-GA-406-01 } \\
\text { COP: Dr. Clement Ghiazza }\end{array}$ \\
\hline $\begin{array}{l}\text { Method: } \\
\text { Ionis. : } \\
\text { solvent : } \\
\text { Spectrometer: }\end{array}$ & $\begin{array}{l}\text { HR-MS } \\
\text { ESIpos } \\
\text { CH2Cl2 + } \mathrm{CH} 3 \mathrm{OH} \\
\text { Exactive }\end{array}$ \\
\hline Auswerter: & Marcus, Tel:2243 \\
\hline
\end{tabular}

suggestion:

C22H20N5O2S1Cl1 MW: 453

Characteristic Ions:

$454=[453+\mathrm{H}]$ 
${ }^{1} \mathrm{H}$ NMR

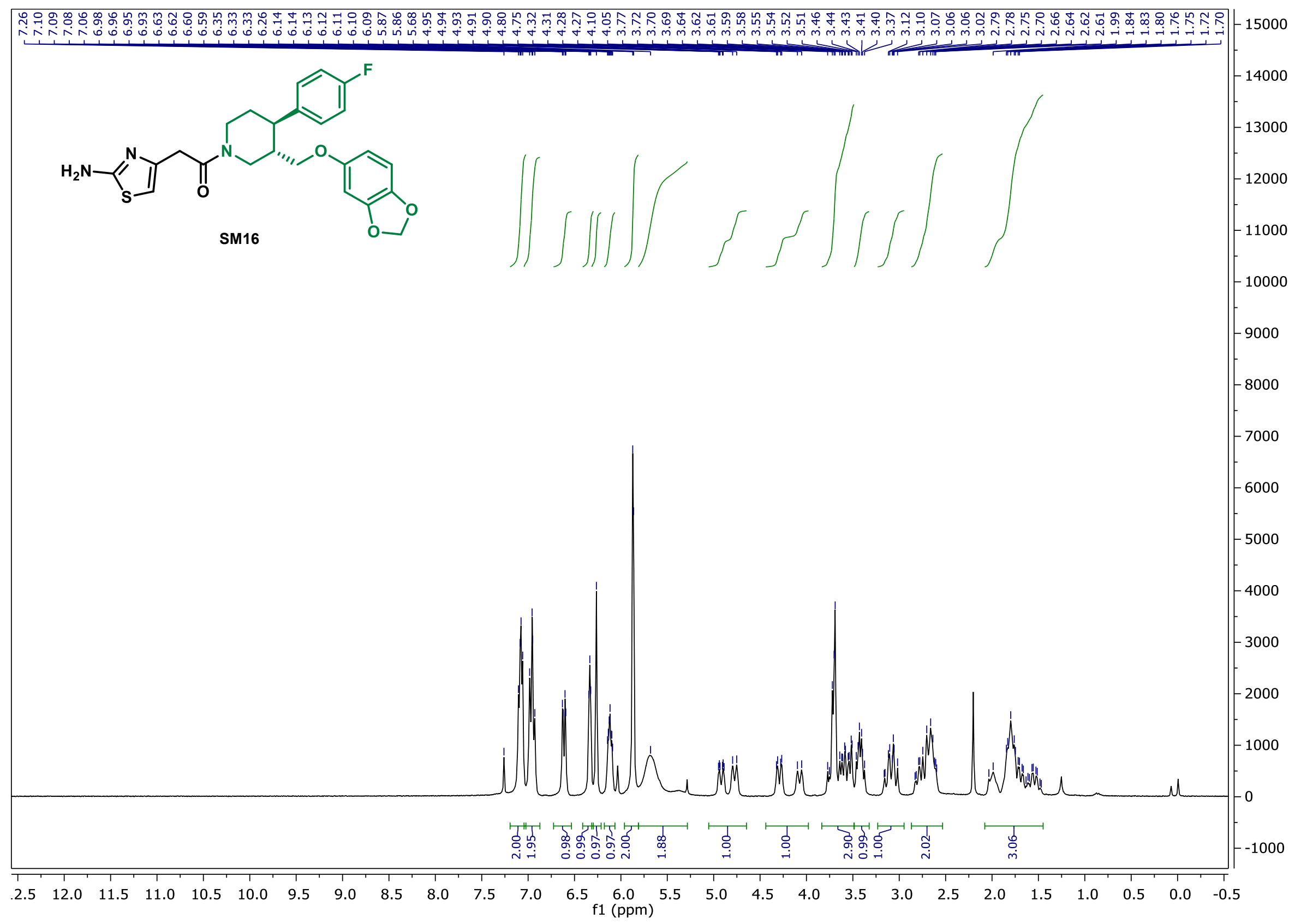




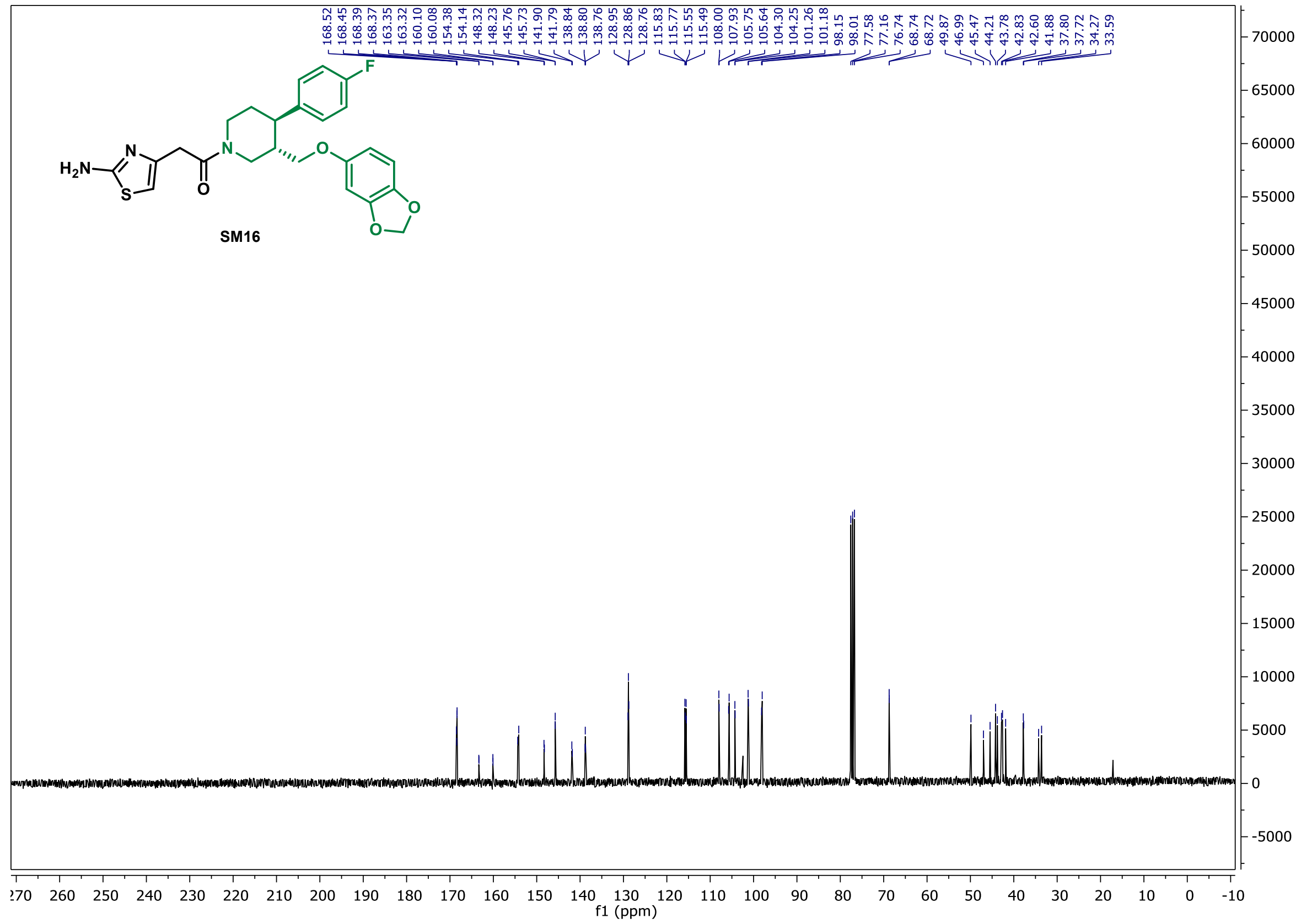


${ }^{19}$ F NMR

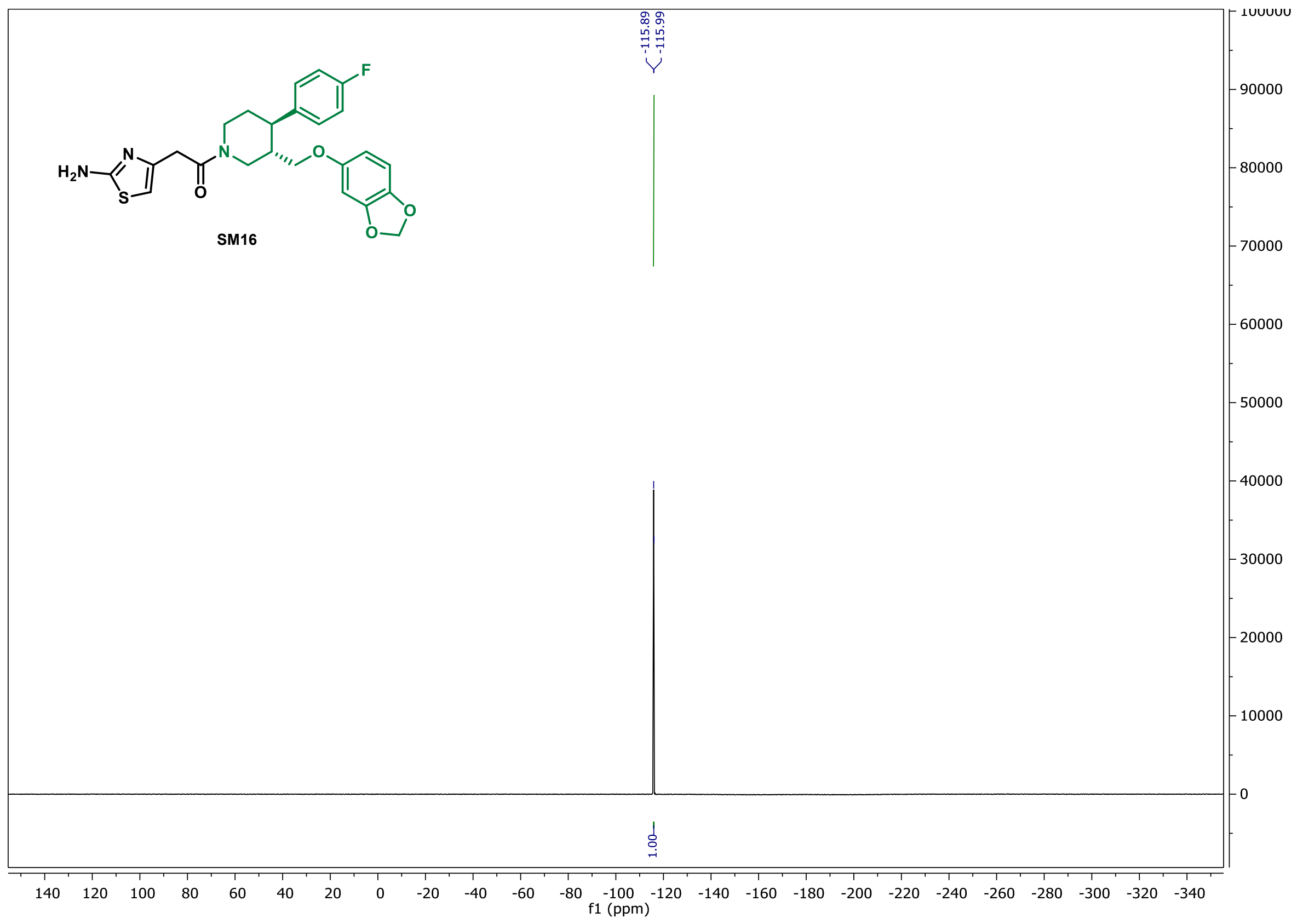


Mass to be matched (m/z): 470.154860 Charge: 1

Mass Tolerance: \pm 0.005000

Restriction of atom numbers:

$\begin{array}{llllll}\mathrm{C} & \mathrm{H} & \mathrm{N} & \mathrm{O} & \mathrm{S} & \mathrm{F} \\ 1-100 & 1-100 & 1-3 & 1-10 & 1-1 & 1-1\end{array}$

Number of calculated Formulas: 3

\begin{tabular}{|lrllllrl|}
\multicolumn{2}{|c}{ Formula } & & & & Diff. (ppm) & theor. $\mathrm{m} / \mathrm{z}$ \\
C24 & H25 & N3 & O4 & S1 & F1 & -0.91 & 470.154432 \\
\hline C21 & H27 & N2 & O7 & S1 & F1 & -6.61 & 470.151753 \\
C29 & H25 & N1 & O2 & S1 & F1 & 7.65 & 470.158455
\end{tabular}

\begin{tabular}{ll}
$\begin{array}{l}\text { Datum: } \\
\text { Analyse: }\end{array}$ & 25.02 .2021 \\
& $151917 \mathrm{~b}-00$ \\
\hline Sigel: & $\begin{array}{l}\text { GHC-GA-615-01 } \\
\text { COP: Dr. Clement Ghiazza }\end{array}$ \\
& HR-MS \\
Method: & ESIpos \\
Ionis: : & CH2Cl2 + CH3OH \\
solvent : & Exactive \\
Spectrometer: & Marcus, Tel:2243
\end{tabular}

suggestion:

C2 4H24N3O4S1F1 MW: 469

Characteristic Ions:

$470=[469+\mathrm{H}]$ 
${ }^{1} \mathrm{H}$ NMR

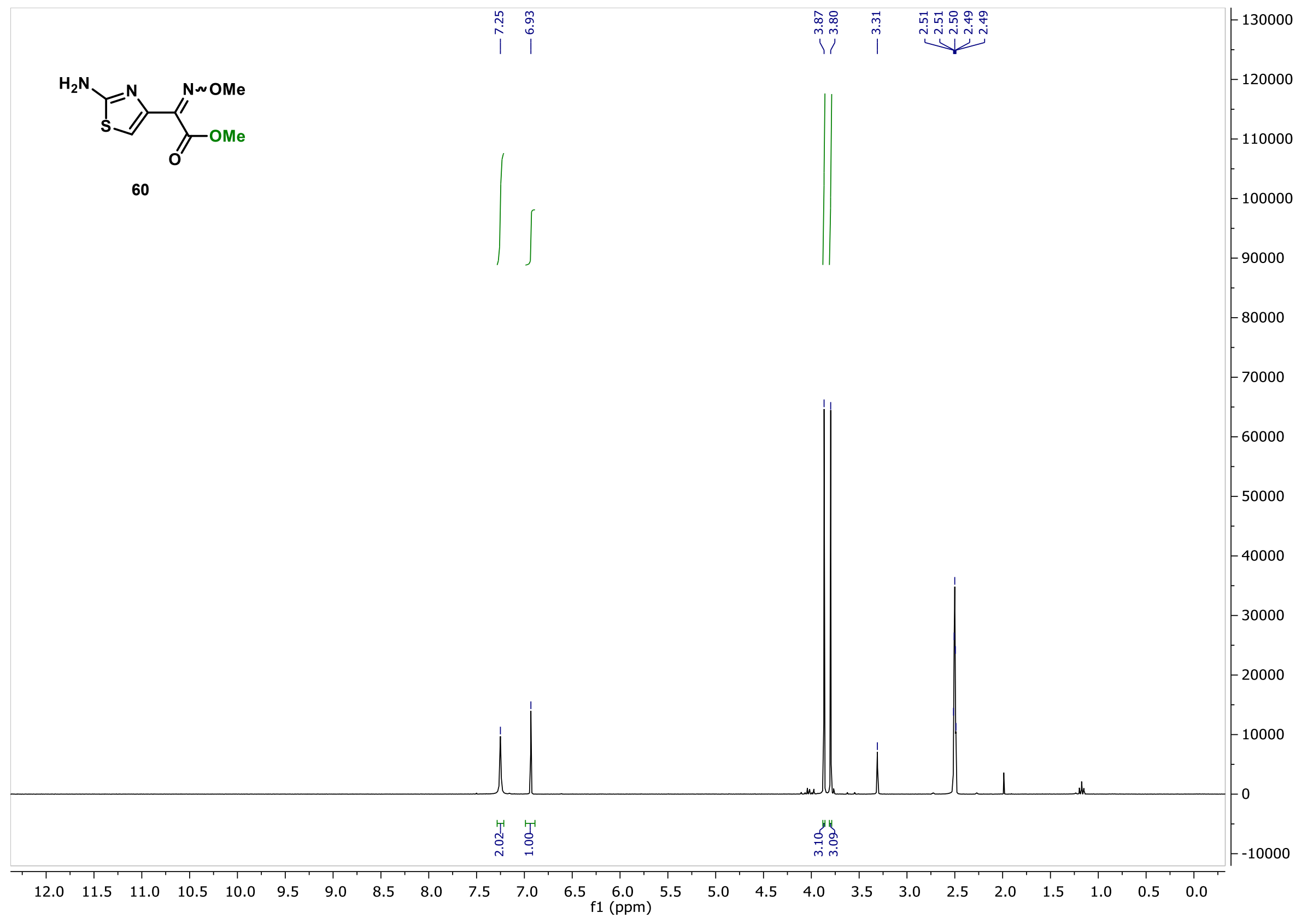


${ }^{1} \mathrm{H}$ NMR

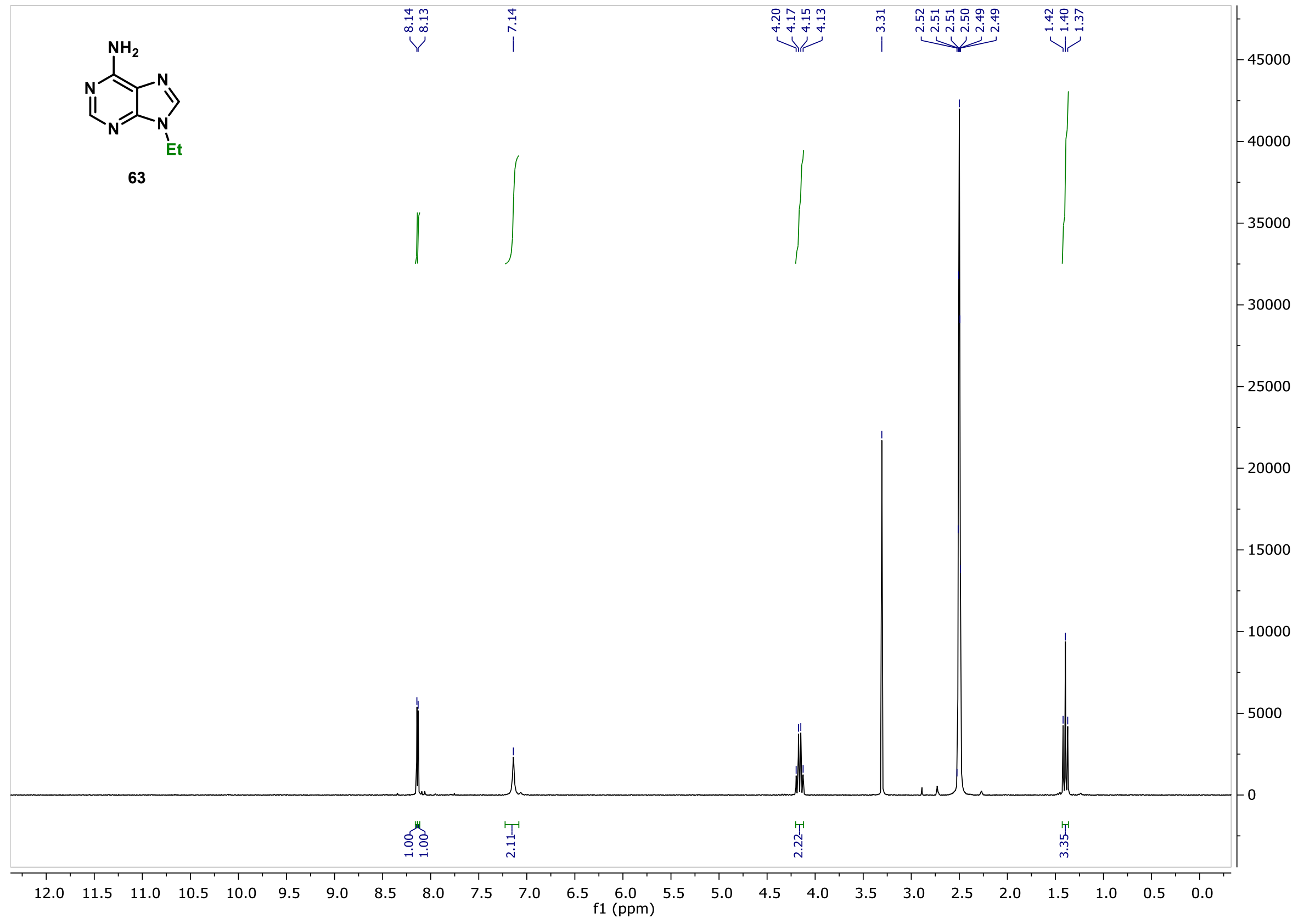




\section{${ }^{1} \mathrm{H}$ NMR}

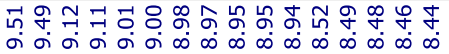

$\infty \infty \infty \infty \infty$

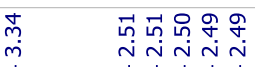

LoUUU

26000
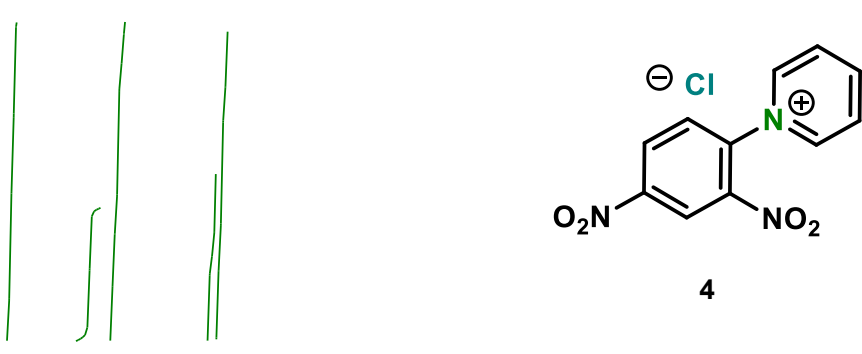

4

24000

22000

20000

18000

16000

14000

12000

10000

8000

6000

4000

2000

0

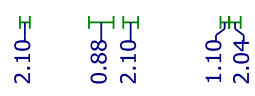

\begin{tabular}{|c|c|c|c|c|c|c|c|c|c|c|c|c|c|c|c|c|c|c|c|c|c|c|}
\hline & $T$ & $T$ & $T$ & $T$ & $T$ & $T$ & $T$ & 1 & $T$ & $T$ & $T$ & $T$ & $T$ & $T$ & $T$ & $T$ & $T$ & $T$ & $T$ & $T$ & $T$ & $T$ \\
\hline 11.0 & 10.5 & 10.0 & 9.5 & 9.0 & 8.5 & 8.0 & 7.5 & 7.0 & 6.5 & 6.0 & $\begin{array}{l}5.5 \\
\mathrm{f} 1(\mathrm{ppm})\end{array}$ & 5.0 & 4.5 & 4.0 & 3.5 & 3.0 & 2.5 & 2.0 & 1.5 & 1.0 & 0.5 & 0.0 \\
\hline
\end{tabular}


${ }^{1} \mathrm{H}$ NMR

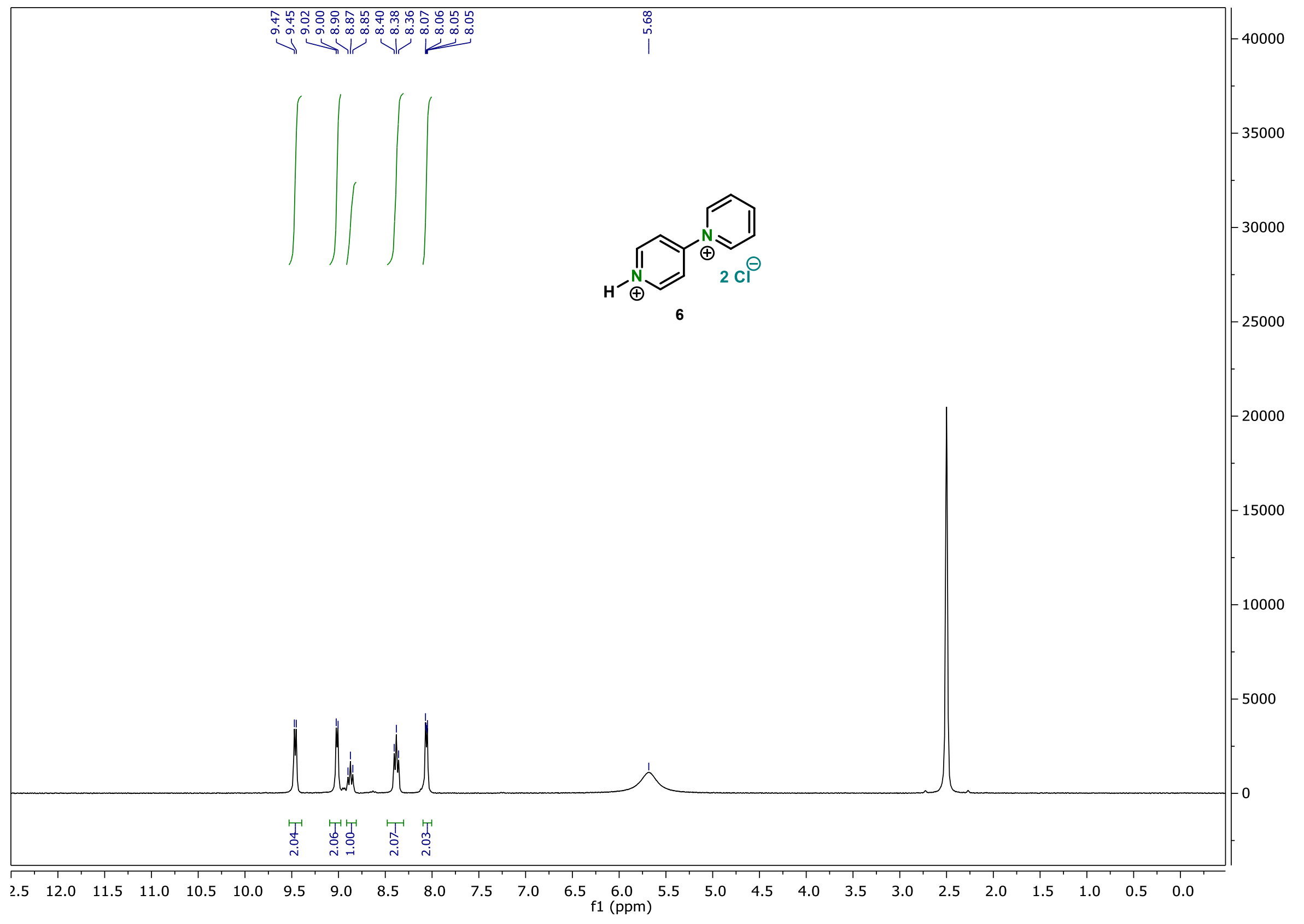


${ }^{1} \mathrm{H} N M R$ - in situ

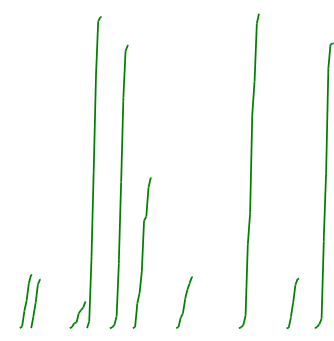<smiles></smiles><smiles>C1=CCCCCC1</smiles>

$\mathrm{CD}_{3} \mathrm{CN}[0.1 \mathrm{M}]$ $80^{\circ} \mathrm{C}$, air, $16 \mathrm{~h}$.

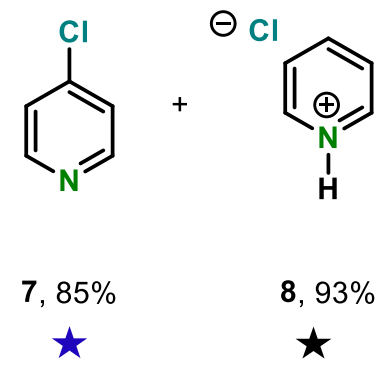

6, $15 \%$

$\star$
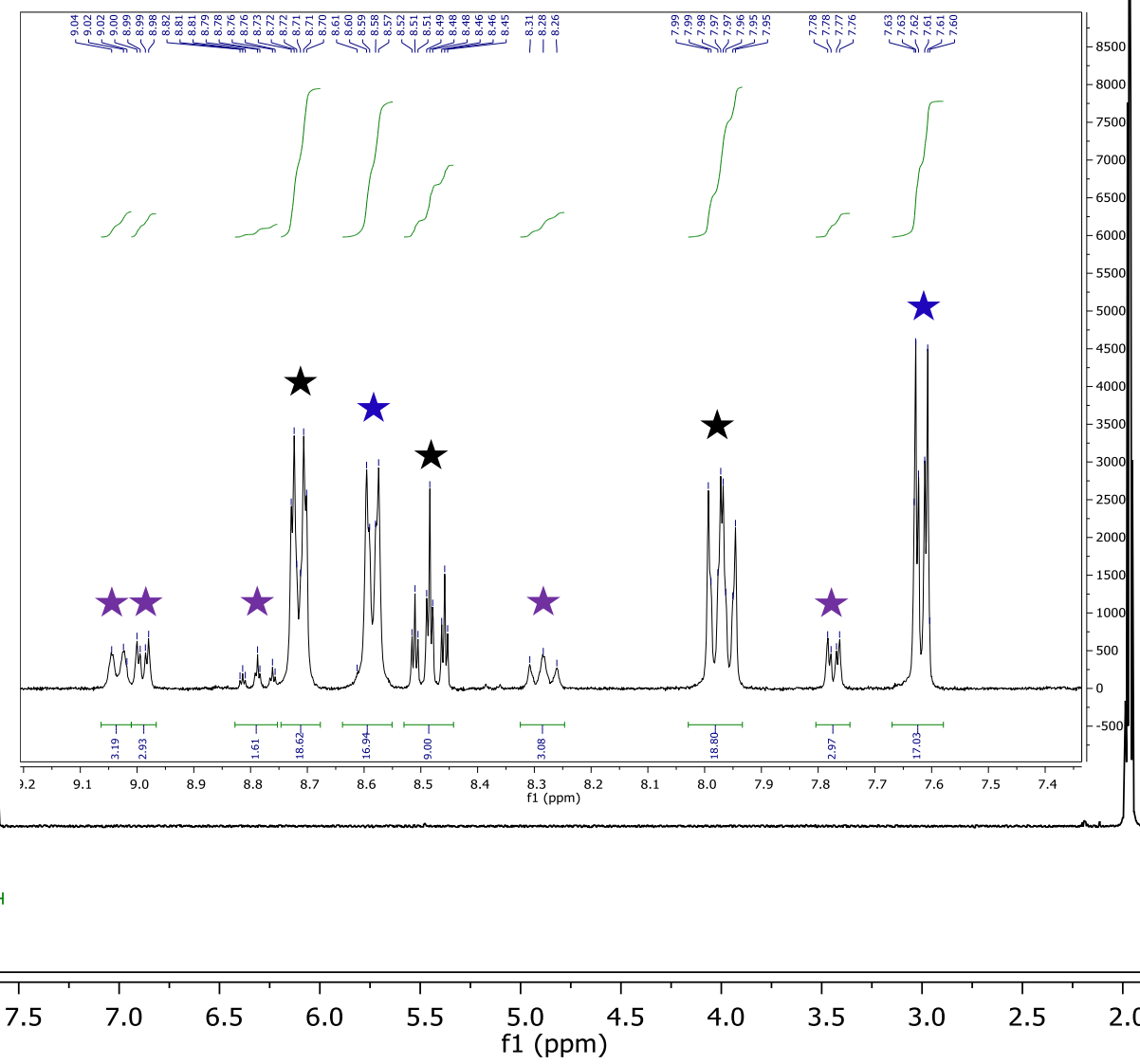
${ }^{1}$ H NMR

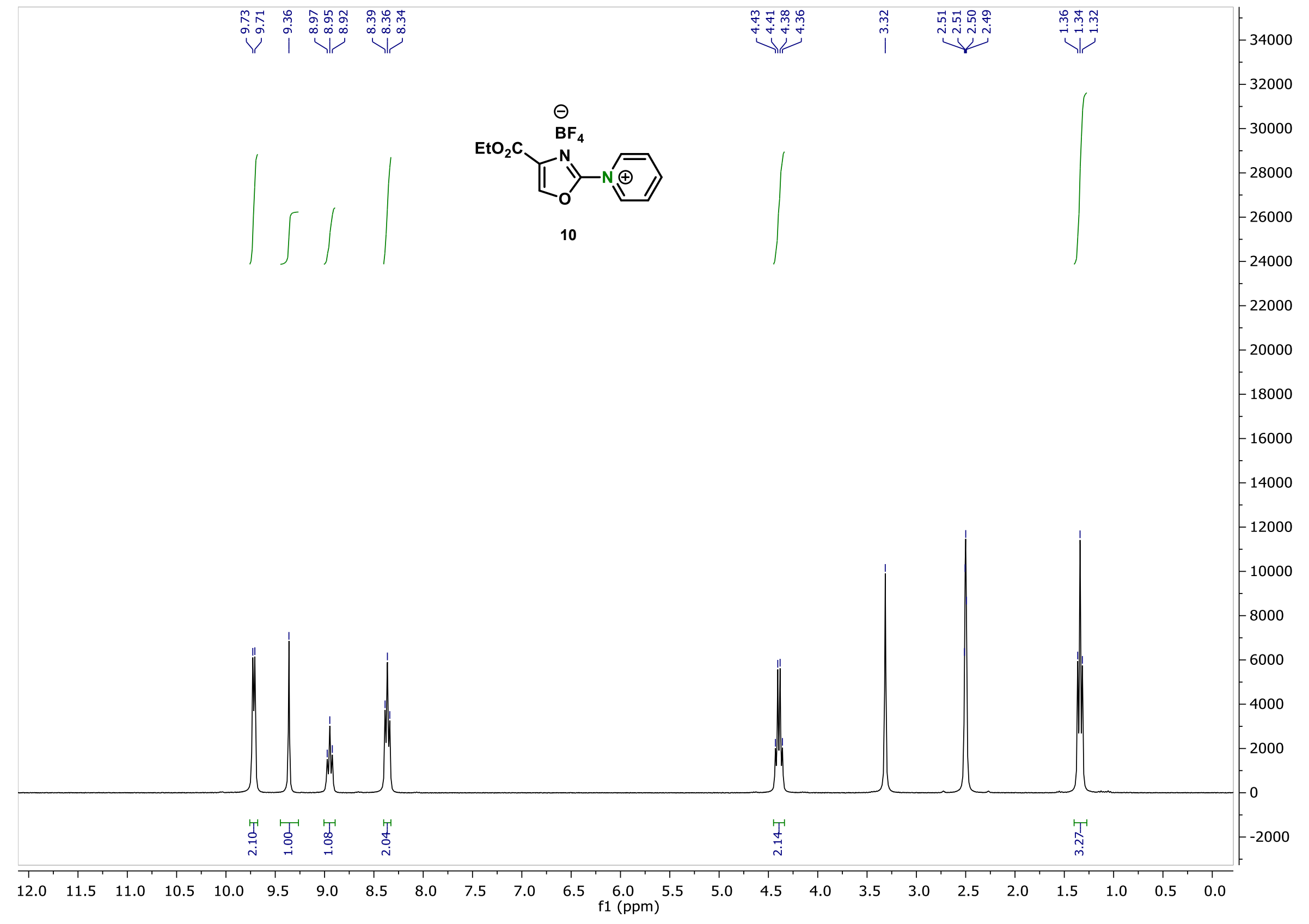


${ }^{13} \mathrm{C}$ NMR

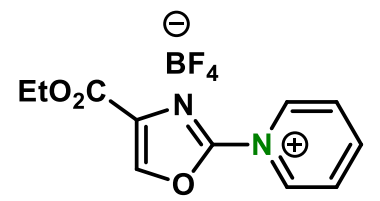

10 
${ }^{19} \mathrm{~F}$ NMR

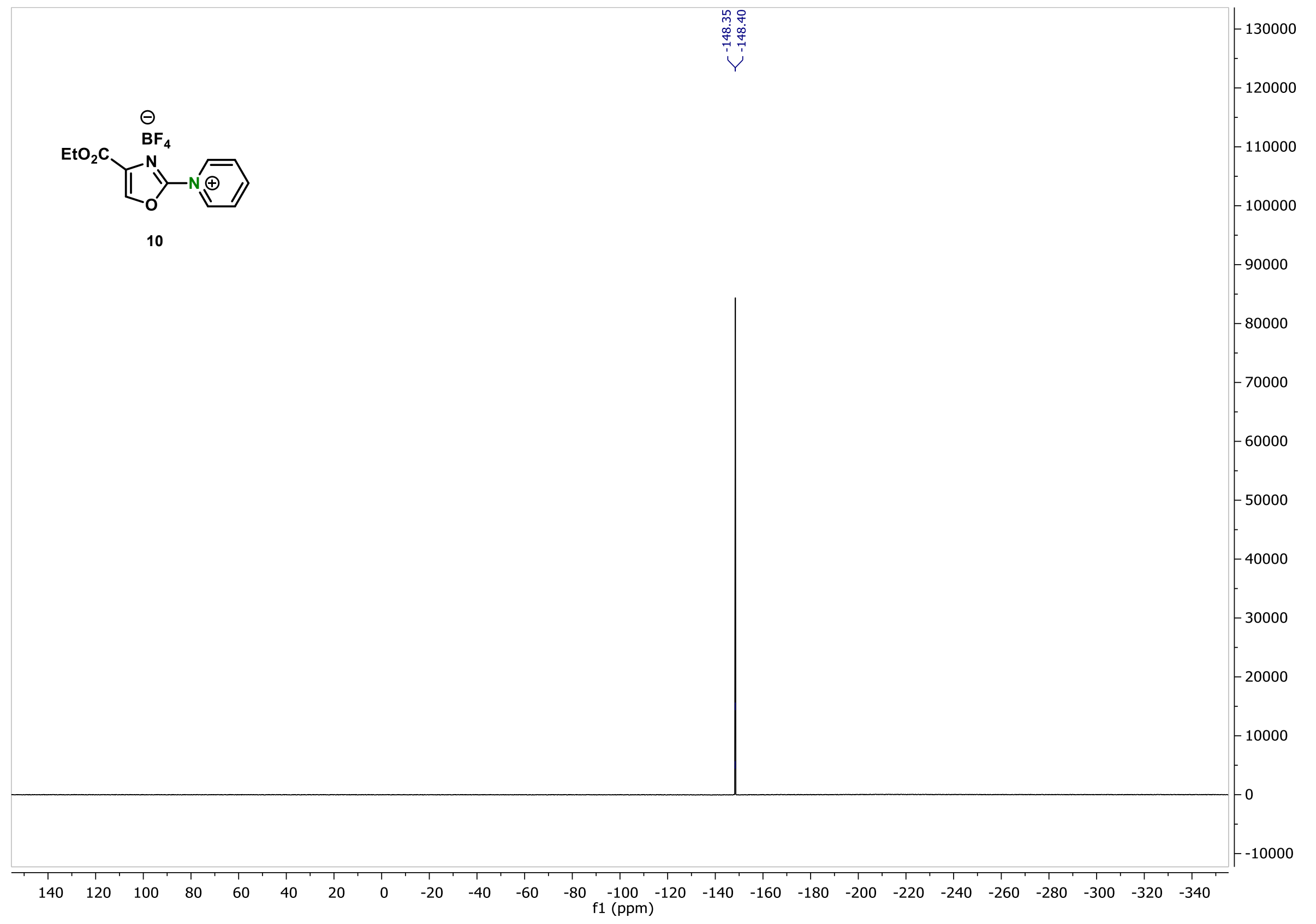




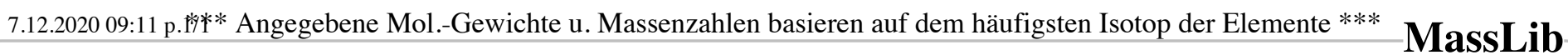

Mass to be matched $(\mathrm{m} / \mathrm{z}): 219.076560$ Charge: 1

Mass Tolerance: \pm 0.050000

Restriction of atom numbers :

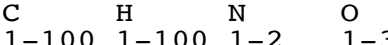

Number of calculated Formulas: 7

Formula

$\begin{array}{llll}\mathrm{C} 11 & \mathrm{H} 11 & \mathrm{~N} 2 & \mathrm{O} 3\end{array}$

C15 H9 N1 O1

$\mathrm{C} 12 \mathrm{H} 13$ N1 O3

C14 H7 N2 O1

$\mathrm{C} 12 \mathrm{H} 15$ N2 O2

C $14 \mathrm{H} 5 \mathrm{~N} 1 \mathrm{O} 2$

$\begin{array}{llll}\mathrm{C} 14 & \mathrm{H} 5 & \mathrm{~N} 1 & \mathrm{O} 2 \\ \mathrm{C} 13 & \mathrm{H} 17 & \mathrm{~N} 1 & \mathrm{O} 2\end{array}$

Diff. (ppm) $-0.65$ $-39.69$

56.75

$-97.10$

165.43

$165 \cdot 43$
$-205 \cdot 78$

$\begin{array}{r}-222.84 \\ \hline\end{array}$

theor. $\mathrm{m} / \mathrm{z}$

219.076417

219.067864

219.088994

219.055287

219.112802

219.031479

219.125379
7.12 .2020

File: 150859b-00

Analysis: GHC-GA-431-01

COP: Dr. Clement Ghiazza

Messung: HR-MS

Ionisierung: ESIpos

Lösungsmittel: $\mathrm{CH} 2 \mathrm{Cl} 2$

Spektrometer: Exactive

ELNA :

28796

Auswerter:

Haupt (2243)

Suggestion:
[C11H11N203]+[BF4]- MW: 306
Characteristic ions:
$219=[306-$ BF4 ]+


${ }^{1} \mathrm{H} N M R$ - in situ

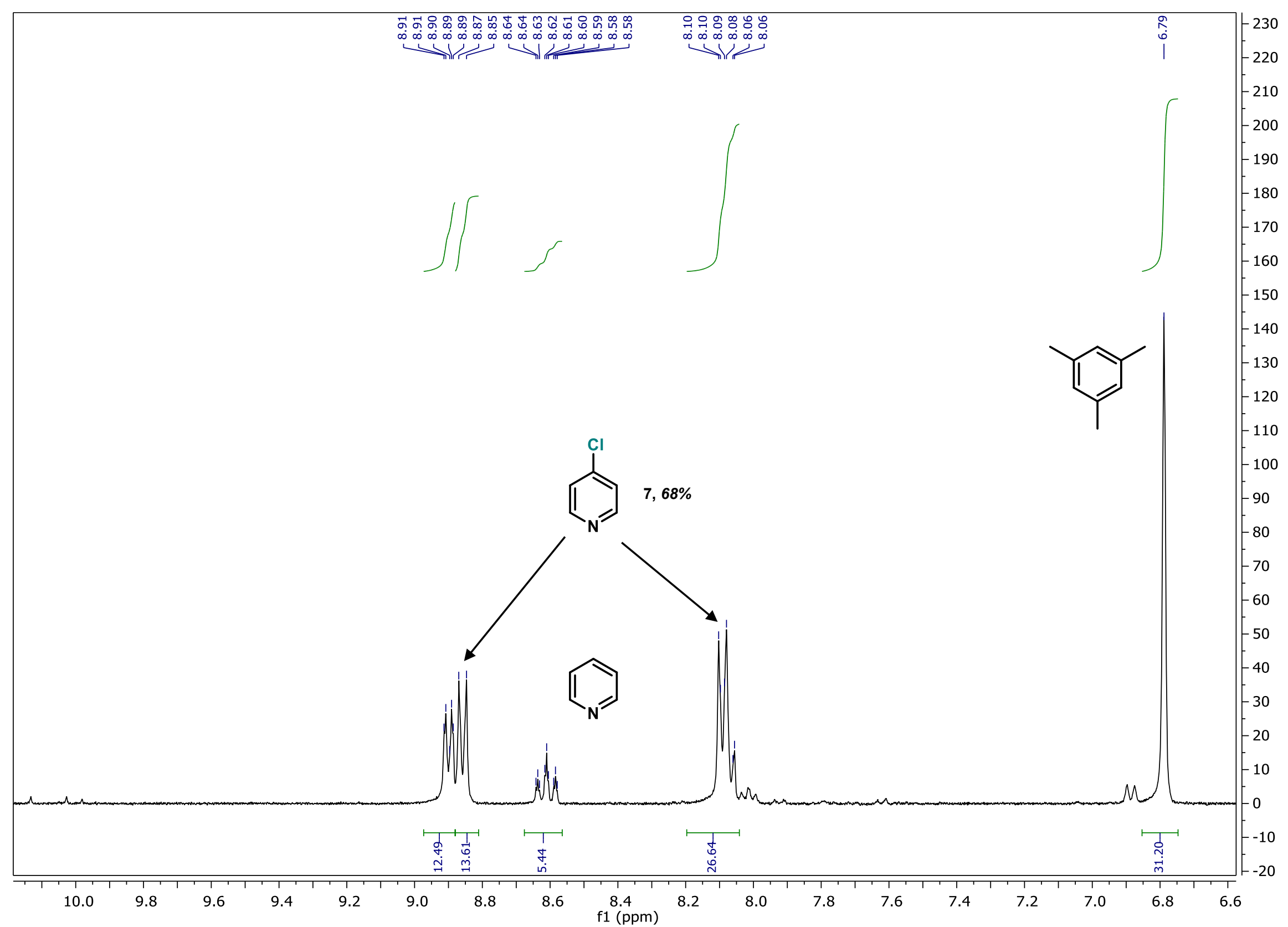


${ }^{1} \mathrm{H}$ NMR

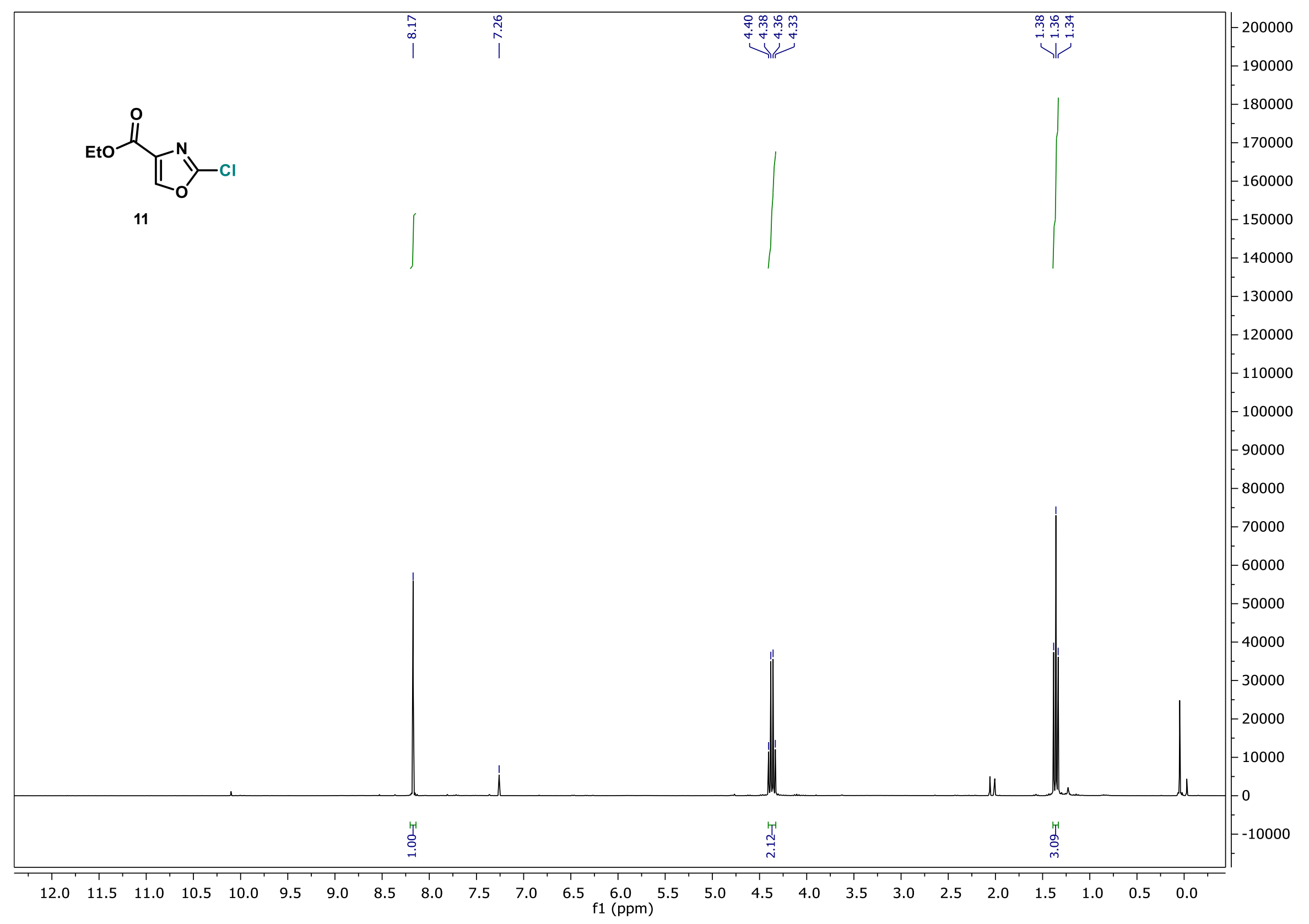


${ }^{13} \mathrm{C}$ NMR

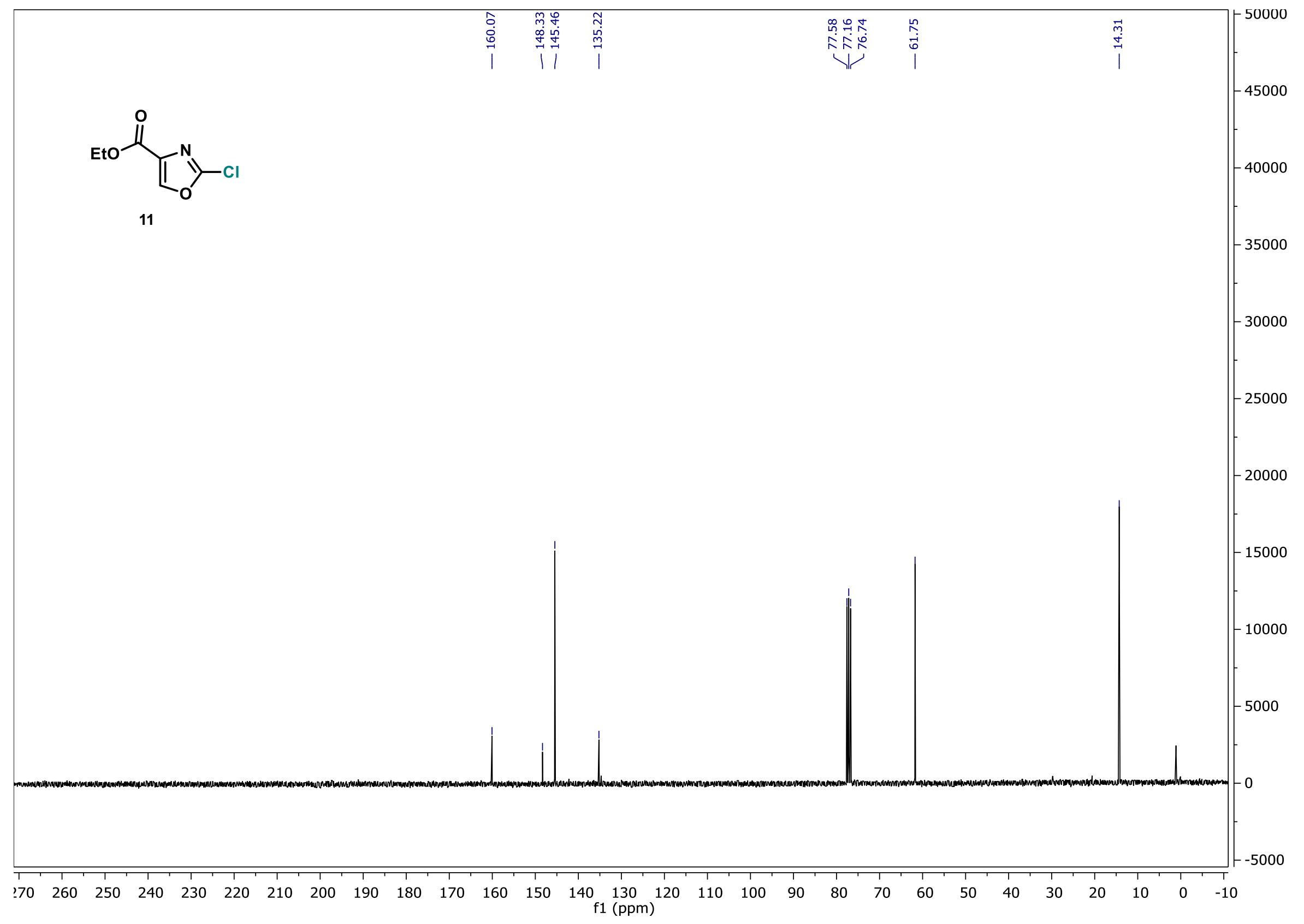


Mass to be matched $(\mathrm{m} / \mathrm{z}): 175.003070$ Charge: 1

Mass Tolerance: \pm 0.050000

Restriction of atom numbers:

$\begin{array}{lllll}\mathrm{C} & \mathrm{H} & \mathrm{N} & \mathrm{O} & \mathrm{Cl} \\ 1-100 & 1-100 & 1-2 & 1-3 & 1-2\end{array}$

Number of calculated Formulas: 12

Formula

\begin{tabular}{|lllll|}
\hline $\mathrm{C} 6$ & $\mathrm{H} 6$ & $\mathrm{~N} 1$ & $\mathrm{O} 3$ & $\mathrm{Cl1}$ \\
$\mathrm{C} 3$ & $\mathrm{H} 9$ & $\mathrm{~N} 2$ & $\mathrm{O} 2$ & $\mathrm{Cl}$ \\
\hline
\end{tabular}

$\begin{array}{llll}\mathrm{C} 5 & \mathrm{H} 4 & \mathrm{~N} 2 & \mathrm{O} 3 \\ \mathrm{Cl}\end{array}$

C4 H11 N1 O2 $\mathrm{Cl}_{2}$

C9 $\mathrm{H} 2 \mathrm{~N} 1 \mathrm{O} 1 \mathrm{Cl} 1$

$\begin{array}{lllll}\mathrm{C} 9 & \mathrm{H} 2 & \mathrm{~N} 1 & \mathrm{O} 1 & \mathrm{Cl} 1 \\ \mathrm{C} 3 & \mathrm{H} 7 & \mathrm{~N} 1 & \mathrm{O} 3 & \mathrm{Cl} 2\end{array}$

$\begin{array}{lllll}\mathrm{C} 6 & \mathrm{H} 8 & \mathrm{~N} 2 & \mathrm{O} 2 & \mathrm{C} 11\end{array}$

C2 $\mathrm{H} 5$ N2 $\mathrm{O} 3 \mathrm{Cl} 2$

$\begin{array}{lllll}\mathrm{C} 7 & \mathrm{H} 10 & \mathrm{~N} 1 & \mathrm{O} 2 & \mathrm{Cl} 1\end{array}$

$\begin{array}{lllll}\mathrm{C} 4 & \mathrm{H} 13 & \mathrm{~N} 2 & \mathrm{O} 1 & \mathrm{Cl} 2\end{array}$

C6 $\mathrm{H} 3 \mathrm{~N} 1 \mathrm{O} 1 \mathrm{Cl} 2$

C5 $\mathrm{H} 15 \mathrm{~N} 1 \mathrm{O} 1 \mathrm{Cl} 2$
Diff. (ppm) 0.01 2.79

$-71.85$

74.66

$-120.73$

$-120.73$

$-133.26$

$-205.12$

207.92

210.70

$-254.00$

282.57 theor. $\mathrm{m} / \mathrm{z}$

175.003072

175.003558

175.016135

175.016135

174.981942

174.979750

175.026880

174.967173

175.039456

175.039943

1773.

175.052520
8.07 .2020

File: 147978b-00.raw

Analyse: GHC-GA-190-01

COP: Dr. Clement Ghiazza

Messung: GC-MS

Ionisierung: GC-EI

Spektrometer: Q Exactive GC Orbitrap

Säule:

MS 75 ZB-5HT $30+5$

Länge: $\quad 30+5$

Temp.: $\quad 35-10-285-5$

$\mathrm{GC}-\mathrm{Nr}$.:

ELNA-Nr.: $\quad 25987$

Auswerter: Haupt (2243) 
${ }^{1} \mathrm{H} N M R$ - in situ

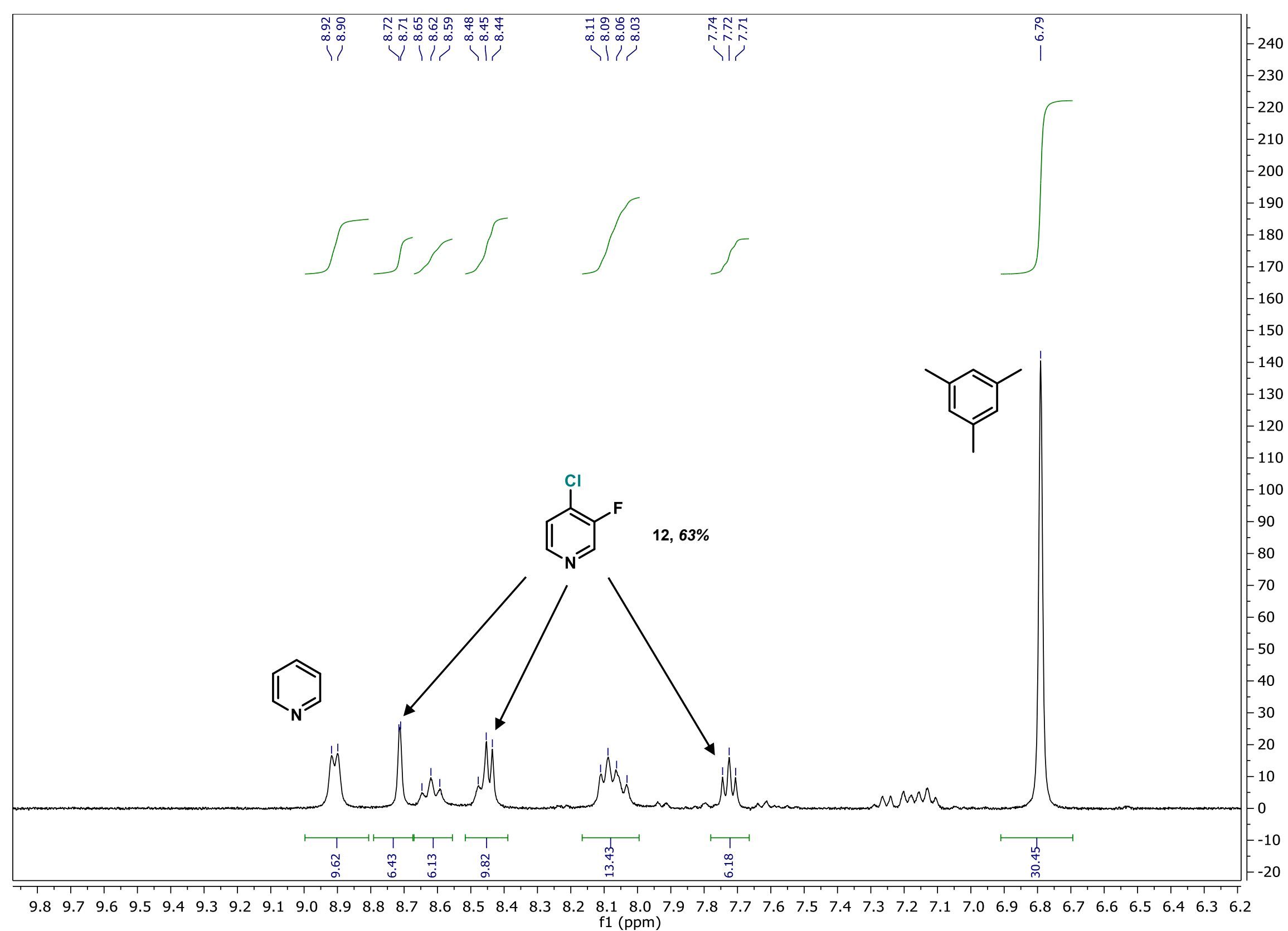


${ }^{1} \mathrm{H} N M R$ - in situ

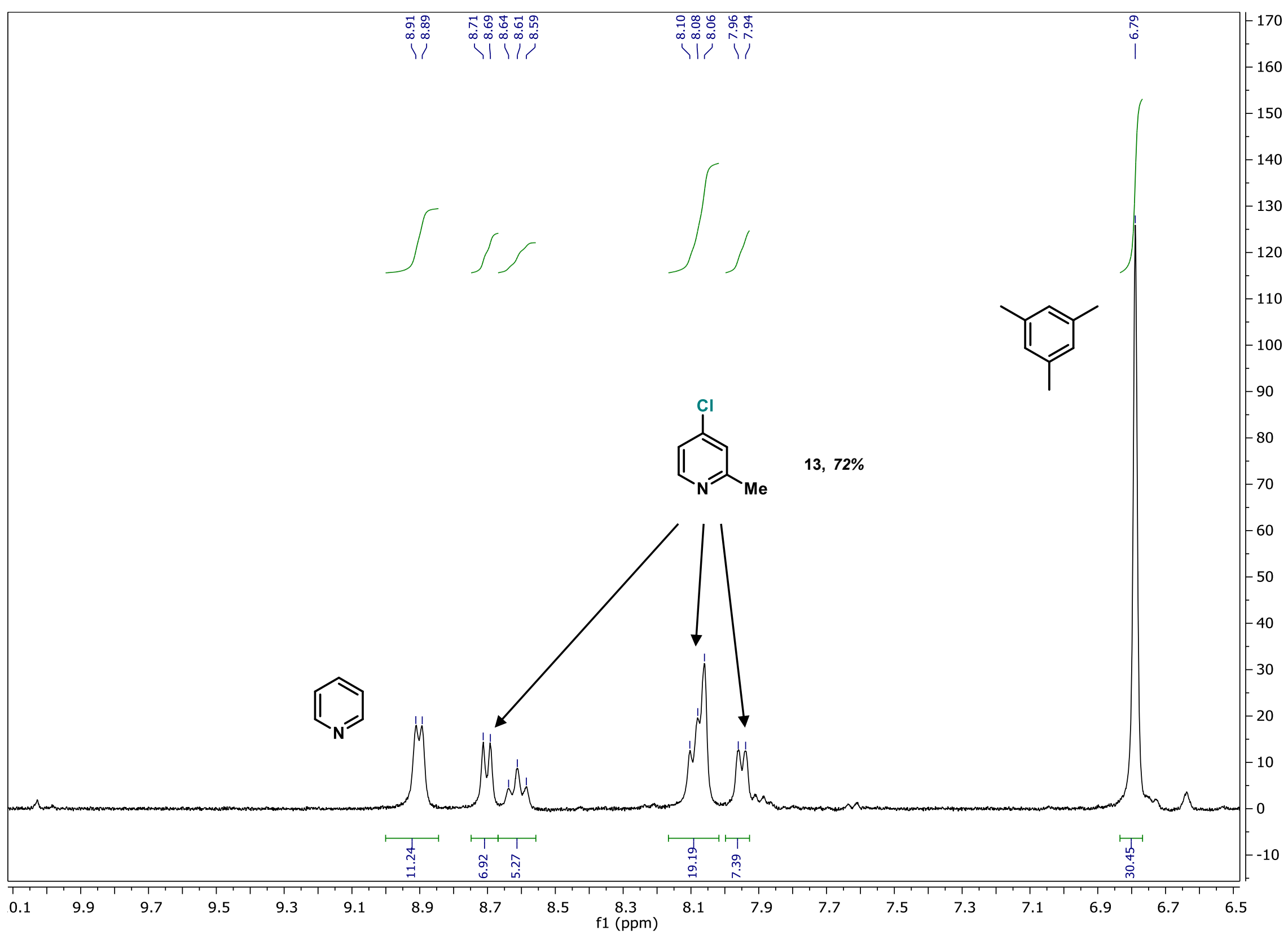


Mass to be matched $(\mathrm{m} / \mathrm{z}): 128.026220$ Charge: 1

\begin{tabular}{ll}
$\begin{array}{ll}\text { Datum } \\
\text { Analyse: }\end{array}$ & 20.07 .2020 \\
& $148239 \mathrm{c}-00$ \\
\hline Sigel: & GOA-GA-386-01 \\
COP: Dr. Gomez, Alejandro \\
\hline Messung: & HRMS \\
Methode: & ESIpos \\
Lösungsmittel: & CH3CN \\
Spektrometer: & Exactive \\
\hline Auswerter: & Kampen (2242)
\end{tabular}

Suggestion:

C6H6Cl1N1 MW 127

characteristical ion

$128=[127+\mathrm{H}]+$ 
${ }^{1} \mathrm{H} N M R$ - in situ

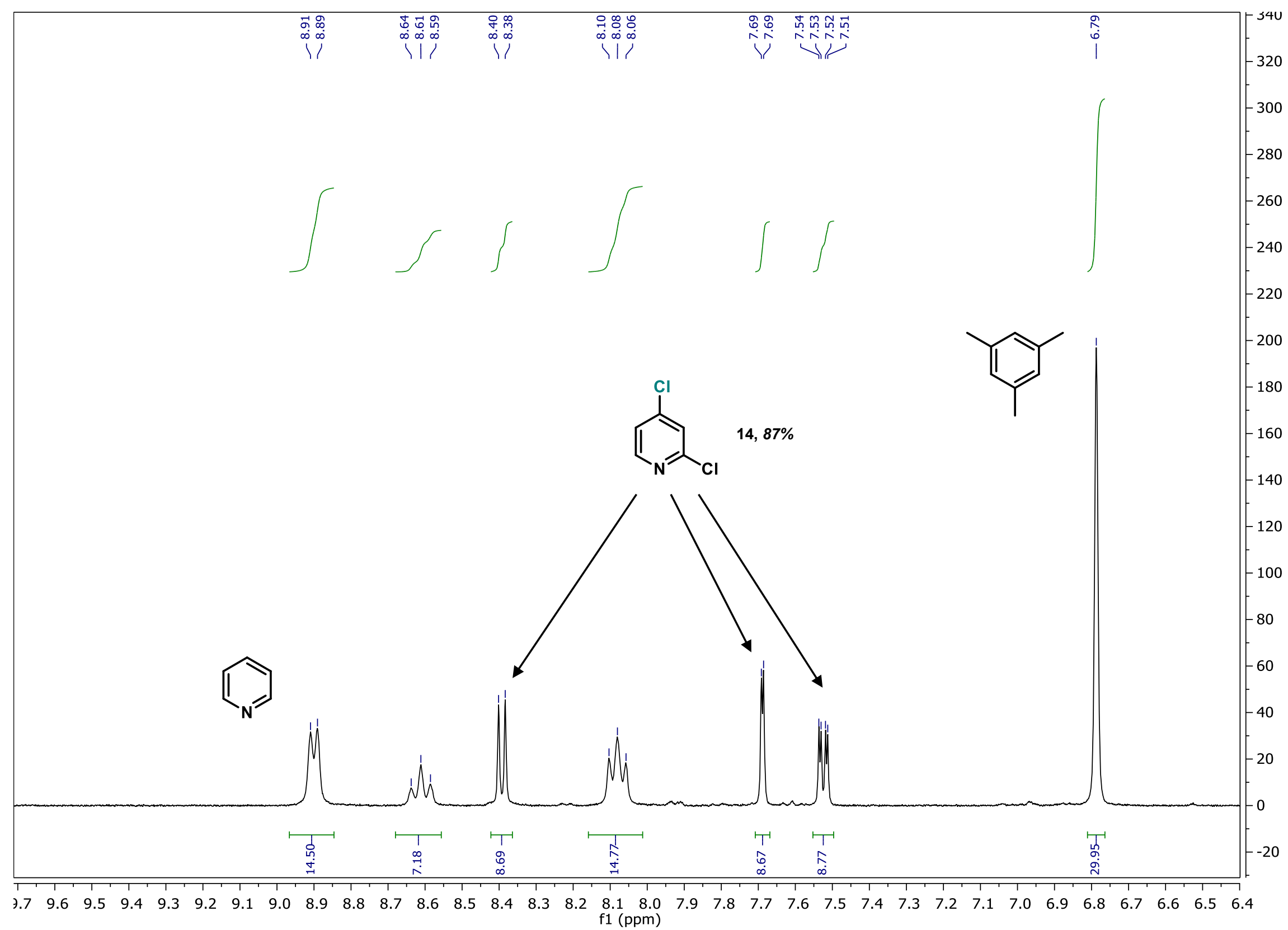


15.06.2020 12:20 p.*炕* Angegebene Mol.-Gewichte u. Massenzahlen basieren auf dem häufigsten Isotop der Elemente ${ }^{* * *}$ MaSSLib

Mass to be matched $(\mathrm{m} / \mathrm{z}): 147.971520$ Charge: 1

Mass Tolerance: \pm 0.005000

15.06 .2020

Restriction of atom numbers:

$\mathrm{C} \quad \mathrm{H} \quad \mathrm{N} \quad \mathrm{Cl}$

$1-110$ 1-100 $1-3 \quad 1-2$
Number of calculated Formulas: 1

File: $147522 \mathrm{~b}-00$

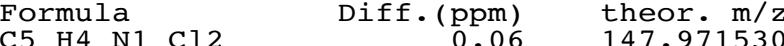

Analyse: GOA-GA-332-01

COP: Dr. Gomez, Alejandro

Messung: HRMS ESIpos

Lösemittel: $\mathrm{CH} 3 \mathrm{OH}$

Spektrometer: Exactive

Auswerter: Kohler (2243)

Suggestion:

C5H3N1Cl2

MW 147

Characteristicial ions:

$148=[147+\mathrm{H}]+$

Mass to be matched $(\mathrm{m} / \mathrm{z}): 191.037120$ Charge: 1

Mass Tolerance: \pm 0.005000

Restriction of atom numbers:

$\begin{array}{llll}\mathrm{C} & \mathrm{H} & \mathrm{N} & \mathrm{Cl} \\ 1-110 & 1-100 & 1-3 & 1-2\end{array}$

Number of calculated Formulas: 1

Formula

Diff. (ppm)

theor. $\mathrm{m} / \mathrm{z}$

C10 H8 N2 Cl1

$-0.36$

191.037050

Suggestion :

[C10H8N2C11]+ [BF4]- MW 278

Characteristicial ions:

$191=[278-\mathrm{BF} 4]+$ 
${ }^{1} \mathrm{H} N M R$ - in situ

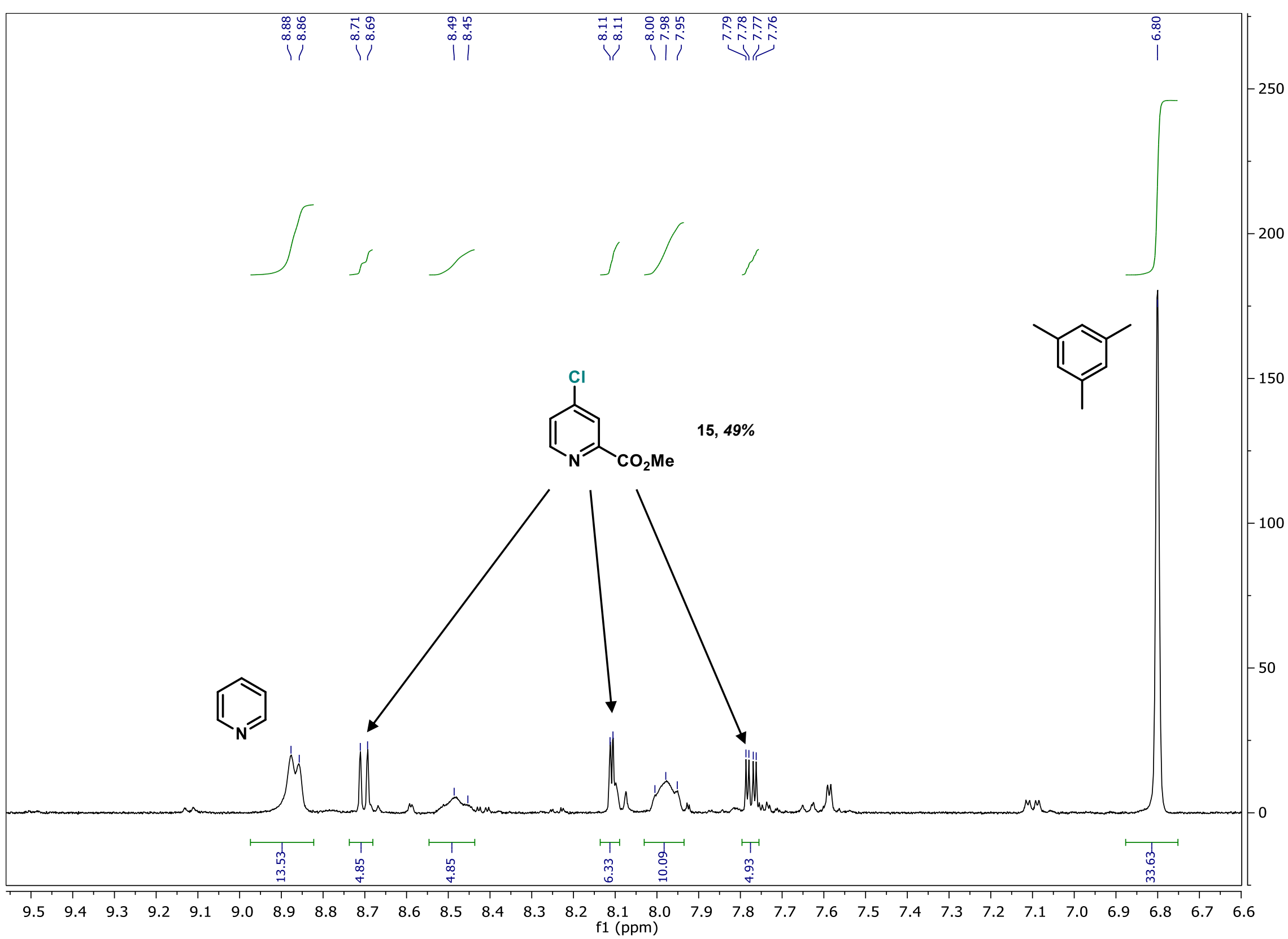




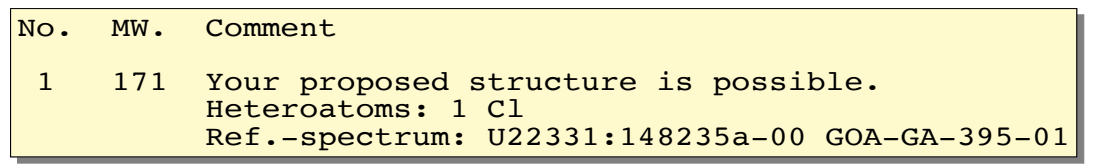

\begin{tabular}{|c|c|c|}
\hline \multirow{2}{*}{\multicolumn{3}{|c|}{20.07 .2020}} \\
\hline & & \\
\hline \multirow{2}{*}{\multicolumn{3}{|c|}{$\begin{array}{l}\text { File: } 148235 a-00 . \text { raw } \\
\text { Analyse: GOA-GA-395-01 }\end{array}$}} \\
\hline & & \\
\hline COP: Dr. Gome & $z$, Alejandro & \\
\hline Messung: & GC-MS & \\
\hline Ionisierung: & $\mathrm{GC}-\mathrm{EI}$ & \\
\hline Spektrometer: & ISQ Series & \\
\hline Säule: & MS 84 TG-5 & SILMS \\
\hline Länge: & 30 & \\
\hline Temp.: & $35-5-285-5$ & \\
\hline $\mathrm{GC}-\mathrm{Nr} .:$ & - & \\
\hline ELNA-Nr . : & 26231 & \\
\hline Auswerter: & Haupt (2243 & \\
\hline
\end{tabular}
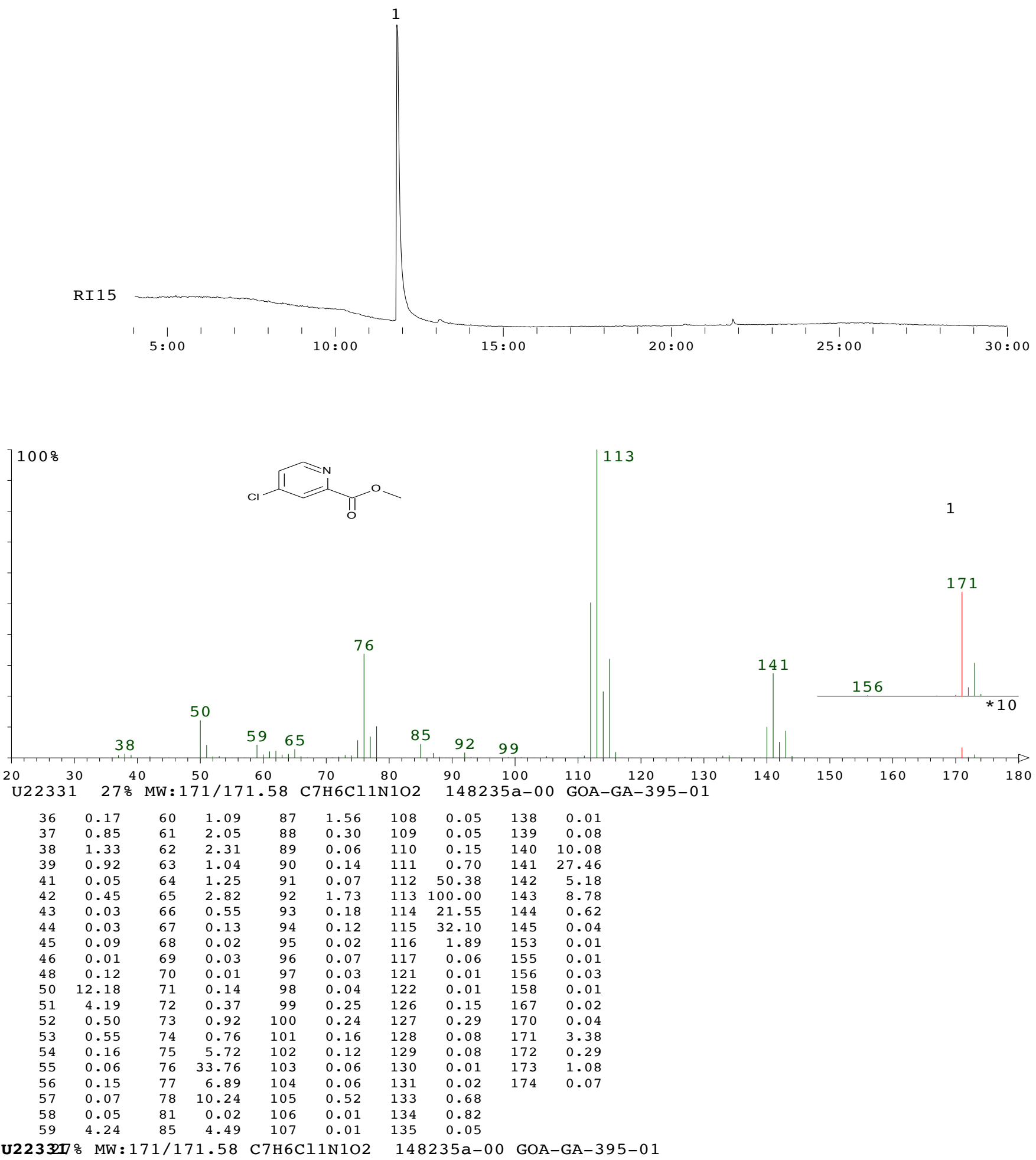
${ }^{1} \mathrm{H}$ NMR

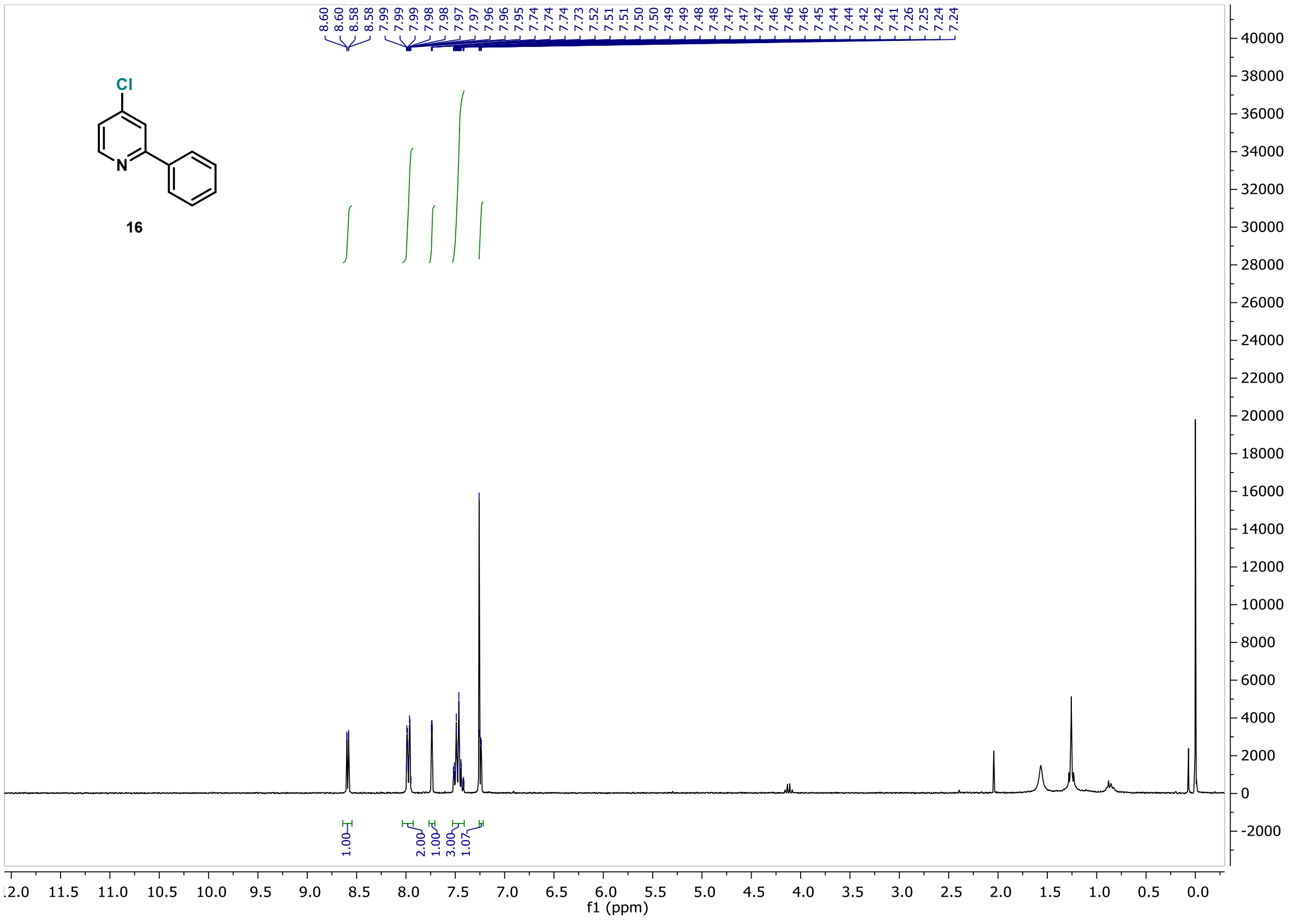


${ }^{1} \mathrm{H}$ NMR

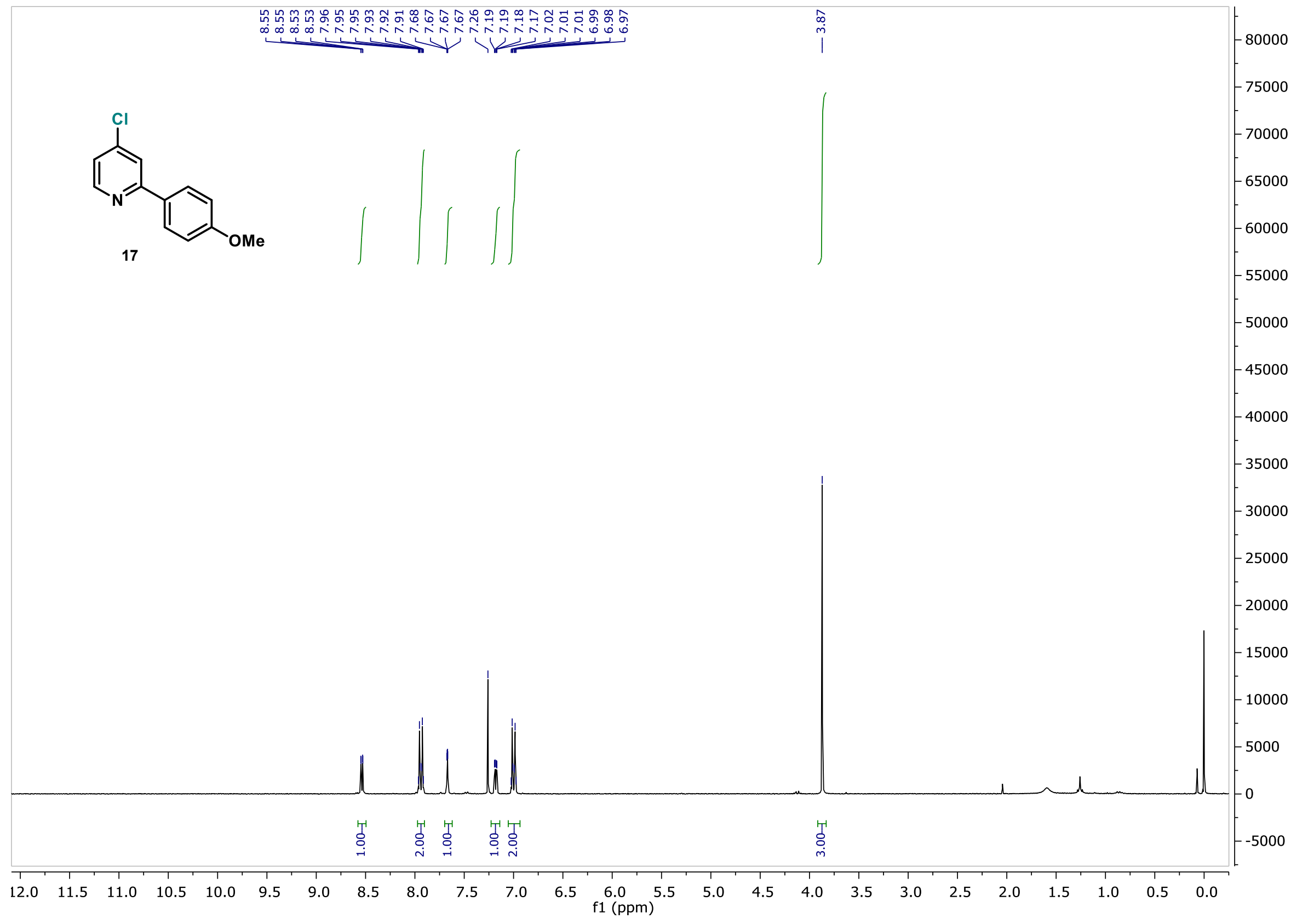


${ }^{1} \mathrm{H} N M R$ - in situ

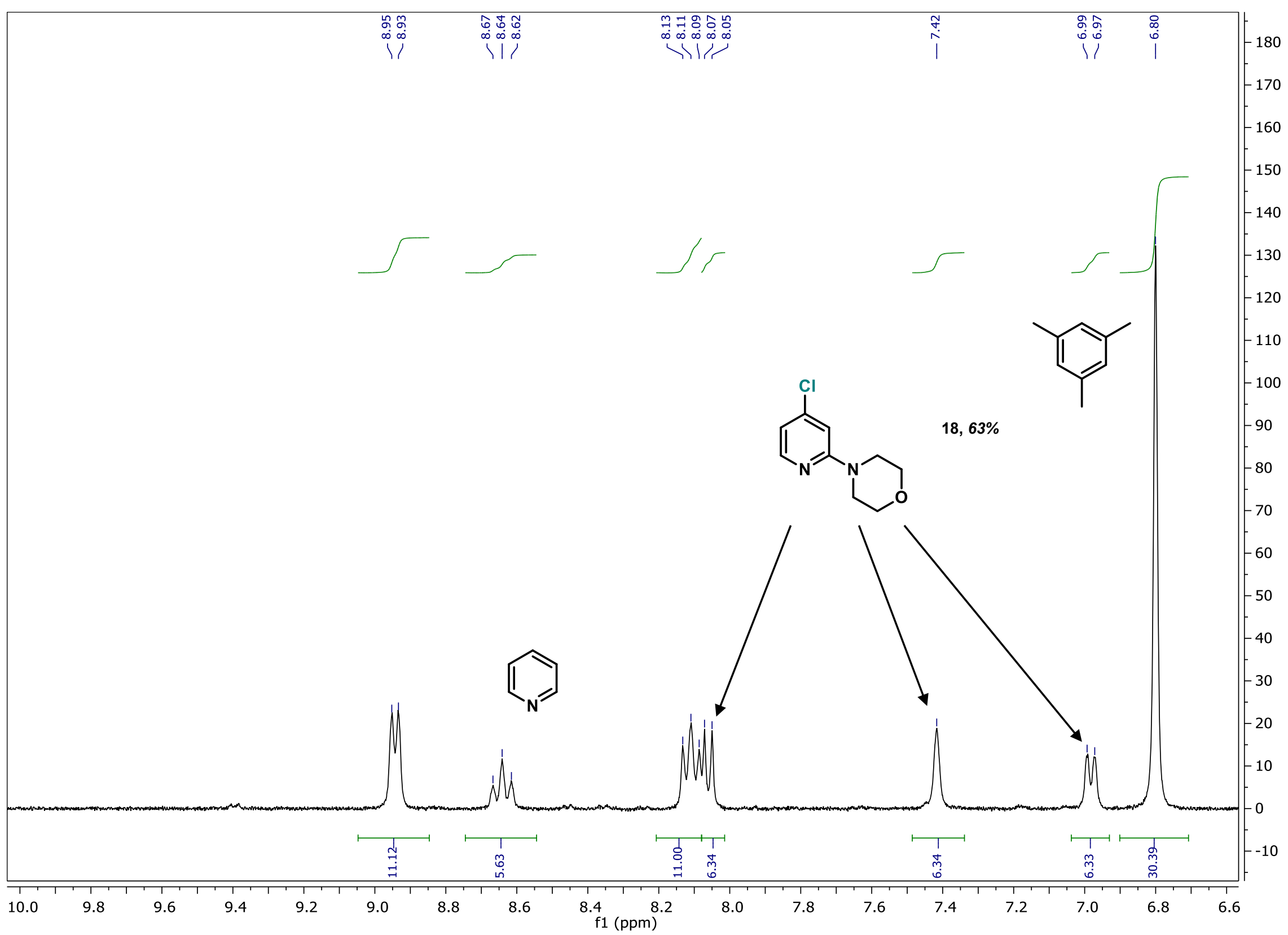




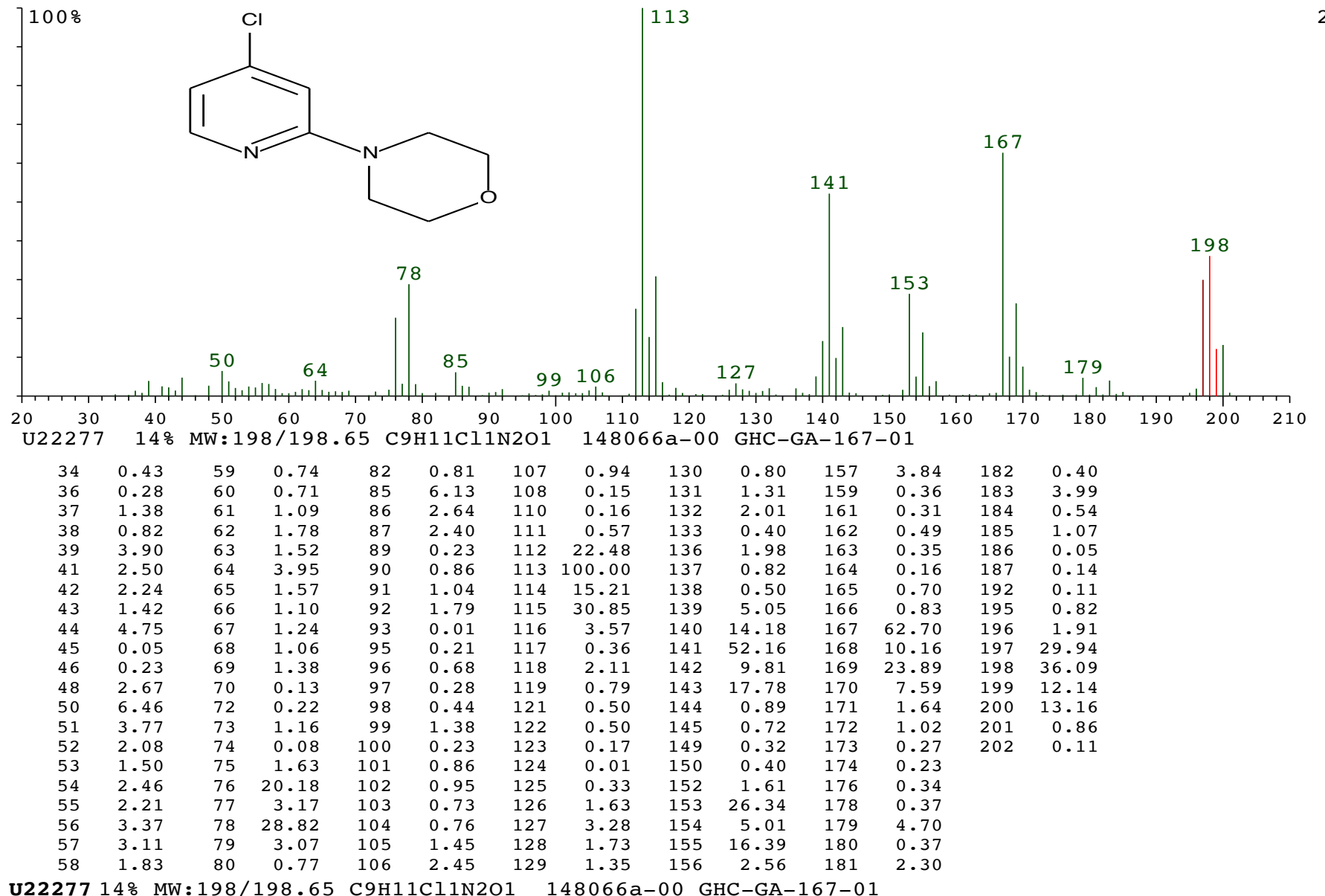


${ }^{1} \mathrm{H} N M R$ - in situ

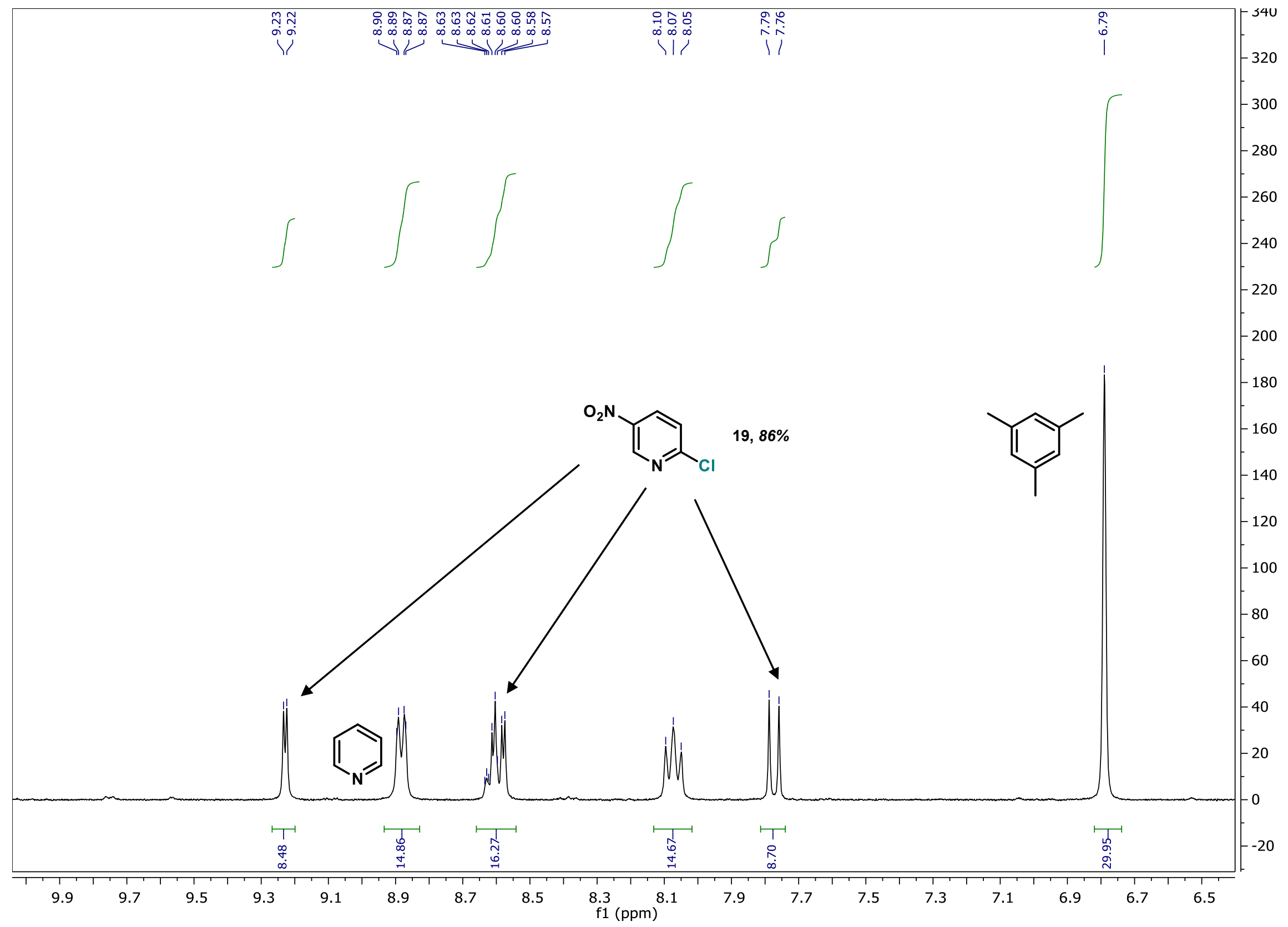




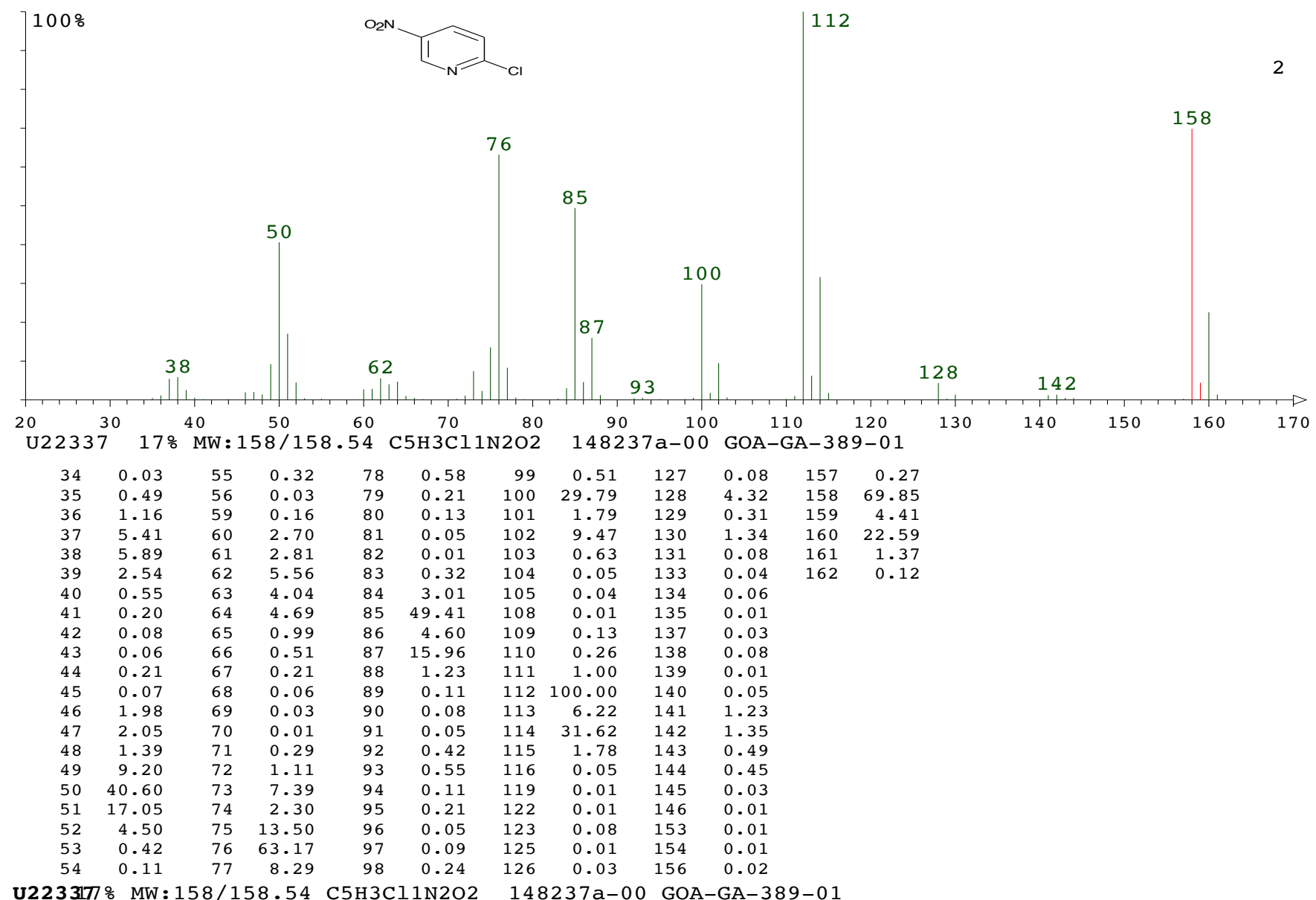


${ }^{1} \mathrm{H} N M R$ - in situ

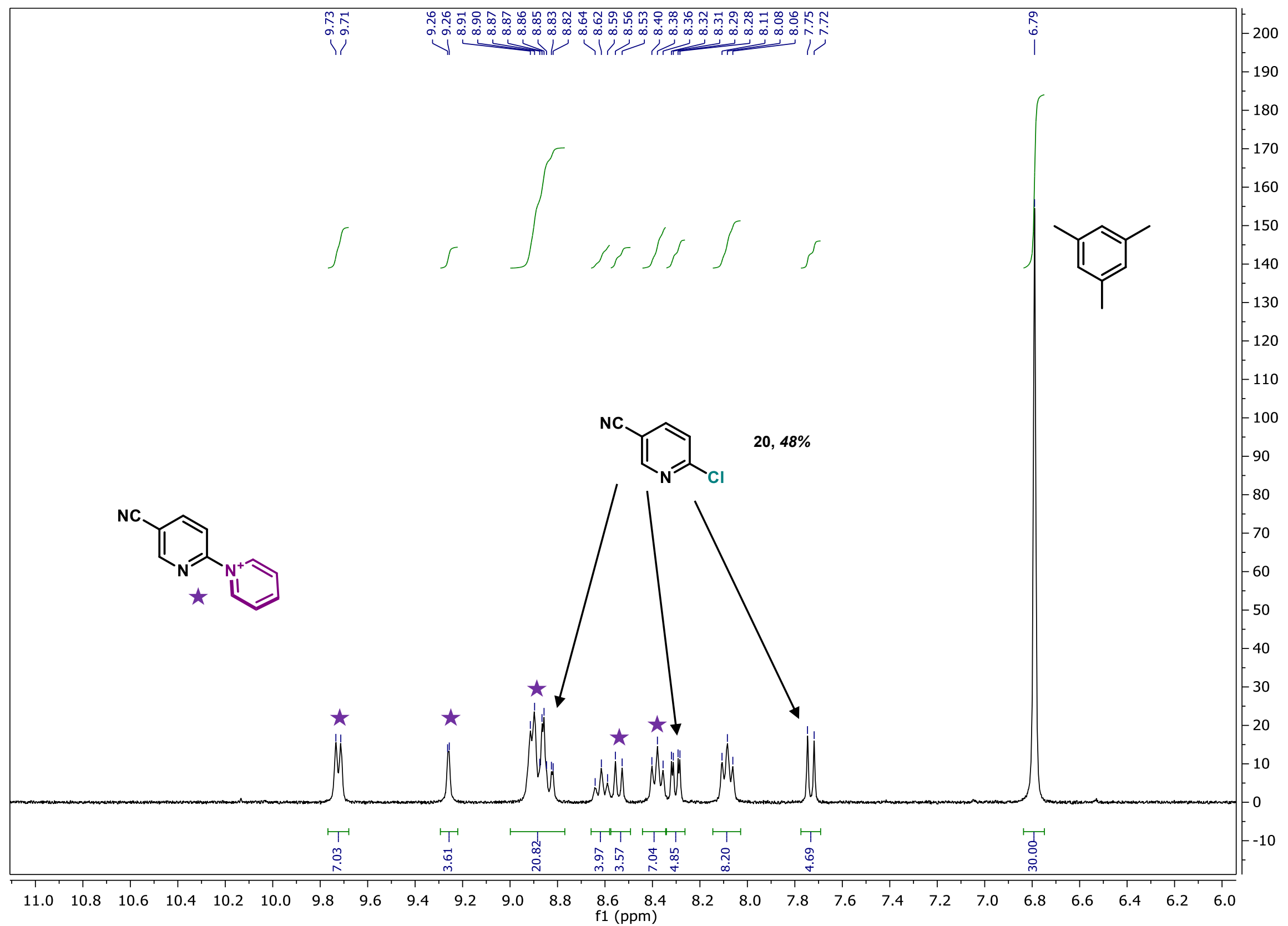


16.06.2020 07:10 p.*炕* Angegebene Mol.-Gewichte u. Massenzahlen basieren auf dem häufigsten Isotop der Elemente *** MassLib

Mass to be matched $(\mathrm{m} / \mathrm{z}): 139.005770$ Charge: 1

Mass Tolerance: \pm 0.005000

15.06 .2020

Restriction of atom numbers:

$\begin{array}{llll}\mathrm{C} & \mathrm{H} & \mathrm{N} & \mathrm{Cl} \\ 1-110 & 1-100 & 1-3 & 1-2\end{array}$

Number of calculated Formulas: 1

$\begin{array}{lrr}\text { Formula } & \text { Diff. (ppm) } & \text { theor. m/z } \\ \text { C6 H4 N2 Cl1 } & -0.14 & 139.005750\end{array}$

15.06 .2020
File: $147526 \mathrm{~b}-00$

Analyse: GOA-GA-337-01

COP: Dr. Gomez, Alejandro

Messung: HRMS ESIpos

Lösemittel: $\mathrm{CH} 3 \mathrm{OH}$

Spektrometer: Exactive

Auswerter: Kohler (2243)
Suggestion:
C6H3N2Cl1 MW 138

Characteristicial ions:

$139=[138+\mathrm{H}]+$

Mass to be matched $(\mathrm{m} / \mathrm{z}): 182.071430$ Charge: 1

Mass Tolerance: \pm 0.005000

Restriction of atom numbers:

$\begin{array}{llll}\mathrm{C} & \mathrm{H} & \mathrm{N} & \mathrm{Cl} \\ 1-110 & 1-100 & 1-3 & 1-2\end{array}$

Number of calculated Formulas: 1

Formula

C10 H13 N1 Cl1

Diff. ( ppm)

theor. $\mathrm{m} / \mathrm{z}$

Suggestion:

[C10H13N1Cl1]+ [BF4]-

MW 269

Characteristicial ions:

$182=[269-\mathrm{BF} 4]+$ 


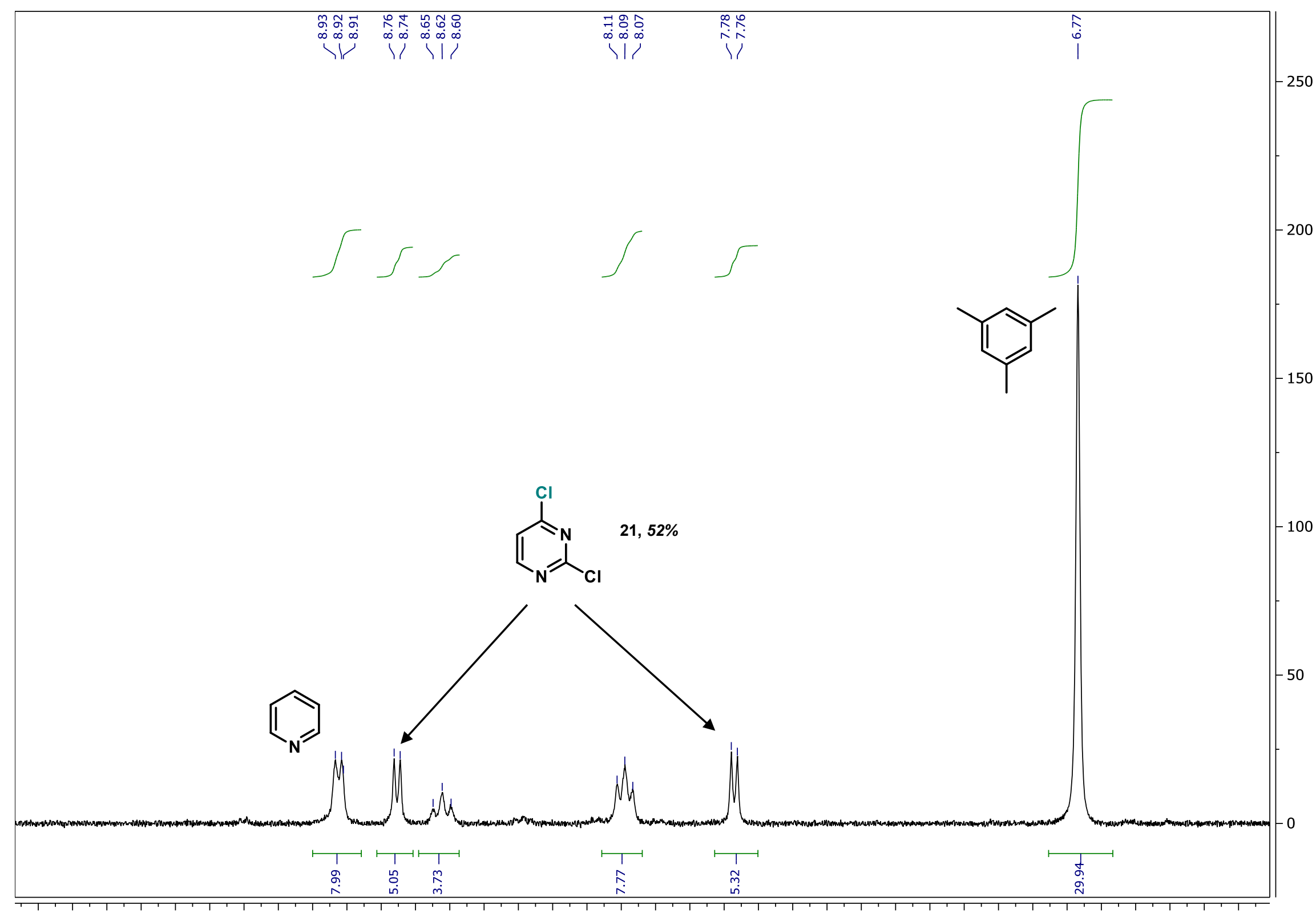

$\begin{array}{lllllllllllllllllllllllllllllllllllllllll}9.8 & 9.7 & 9.6 & 9.5 & 9.4 & 9.3 & 9.2 & 9.1 & 9.0 & 8.9 & 8.8 & 8.7 & 8.6 & 8.5 & 8.4 & 8.3 & 8.2 & 8.1 & 8.0 & 7.9 & 7.8 & 7.7 & 7.6 & 7.5 & 7.4 & 7.3 & 7.2 & 7.1 & 7.0 & 6.9 & 6.8 & 6.7 & 6.6 & 6.5 & 6.4 & 6.3\end{array}$ f1 (ppm) 


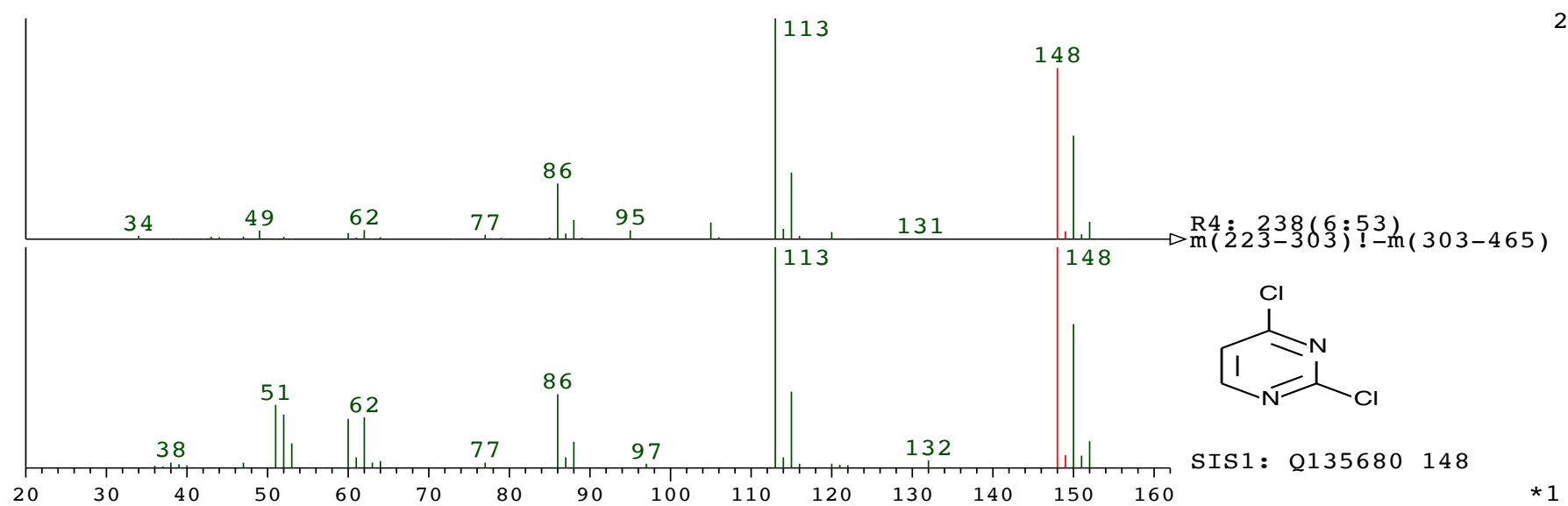

\begin{tabular}{|c|c|c|c|c|c|c|}
\hline 33 & 0.02 & 60 & 2.76 & 96 & 0.12 & 153 \\
\hline 34 & 1.44 & 61 & 0.71 & 105 & 7.54 & \\
\hline 35 & 0.03 & 62 & 4.09 & 106 & 0.87 & \\
\hline 36 & 0.04 & 63 & 0.22 & 111 & 0.02 & \\
\hline 37 & 0.09 & 64 & 0.88 & 113 & 100.00 & \\
\hline 38 & 0.20 & 65 & 0.03 & 114 & 4.70 & \\
\hline 39 & 0.20 & 73 & 0.29 & 115 & 30.17 & \\
\hline 40 & 0.09 & 74 & 0.13 & 116 & 1.44 & \\
\hline 41 & 0.11 & 75 & 0.02 & 117 & 0.12 & \\
\hline 42 & 0.25 & 76 & 0.08 & 119 & 0.03 & \\
\hline 43 & 1.06 & 77 & 1.97 & 120 & 3.22 & \\
\hline 44 & 0.85 & 78 & 0.32 & 121 & 0.11 & \\
\hline 45 & 0.38 & 79 & 0.54 & 122 & 0.24 & \\
\hline 46 & 0.11 & 82 & 0.04 & 125 & 0.00 & \\
\hline 47 & 1.14 & 84 & 0.18 & 131 & 0.01 & \\
\hline 48 & 0.14 & 85 & 0.77 & 147 & 0.02 & \\
\hline 49 & 3.89 & 86 & 25.19 & 148 & 77.49 & \\
\hline 50 & 0.36 & 87 & 2.53 & 149 & 3.59 & \\
\hline 51 & 0.14 & 88 & 8.70 & 150 & 46.88 & \\
\hline 52 & 1.00 & 89 & 0.66 & 151 & 2.18 & \\
\hline 53 & 0.17 & 95 & 3.99 & 152 & 7.86 & \\
\hline
\end{tabular}

Mass to be matched $(\mathrm{m} / \mathrm{z}): 147.959150$ Charge: 1

Mass Tolerance: \pm 0.005000

Restriction of atom numbers:

$\begin{array}{llll}\mathrm{C} & \mathrm{H} & \mathrm{N} & \mathrm{Cl} \\ 1-110 & 1-100 & 1-2 & 2-2\end{array}$

Number of calculated Formulas: 1

Formula

$\mathrm{C} 4 \mathrm{H} 2 \mathrm{~N} 2 \mathrm{Cl} 2$

Diff. (ppm)

theor. $\mathrm{m} / \mathrm{z}$
147.958954
18.01 .2021

File: 151244a-00.raw

Analyse: GHC-GA-535-01

COP: Dr. Clement Ghiazza

\begin{tabular}{ll} 
Messung: & GC-MS \\
Ionisierung: & GC EI \\
Spektrometer: & QExactiveGC \\
Säule: & MS 50 RTX1+VS \\
Länge: & $30+7$ \\
Temp.: & $35-10-285-5$ \\
GC-Nr.: & - \\
MS-Nr.: & 29197 \\
\hline Auswerter: & Margold (2242)
\end{tabular}


${ }^{1} \mathrm{H}$ NMR

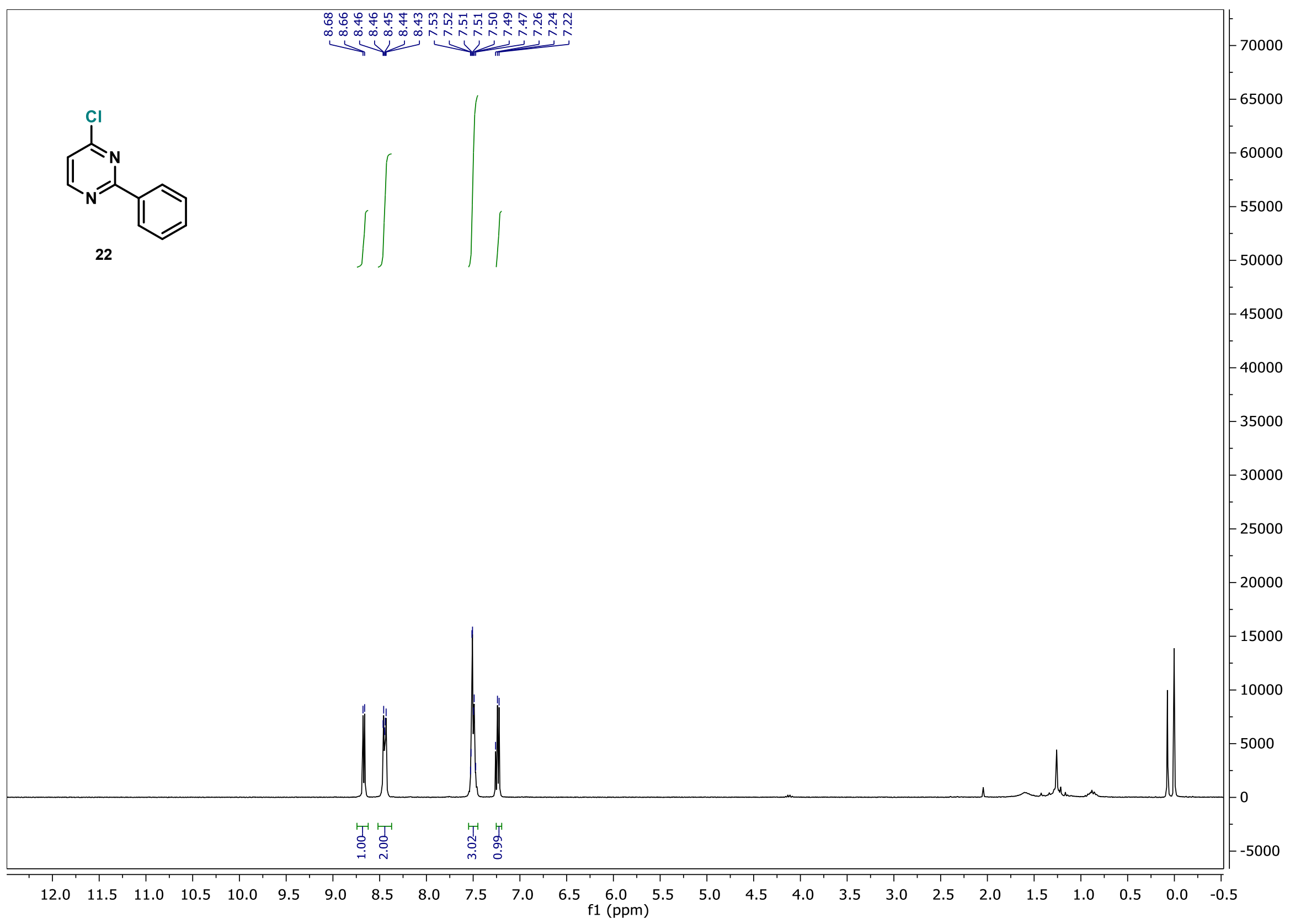


${ }^{13} \mathrm{C}$ NMR

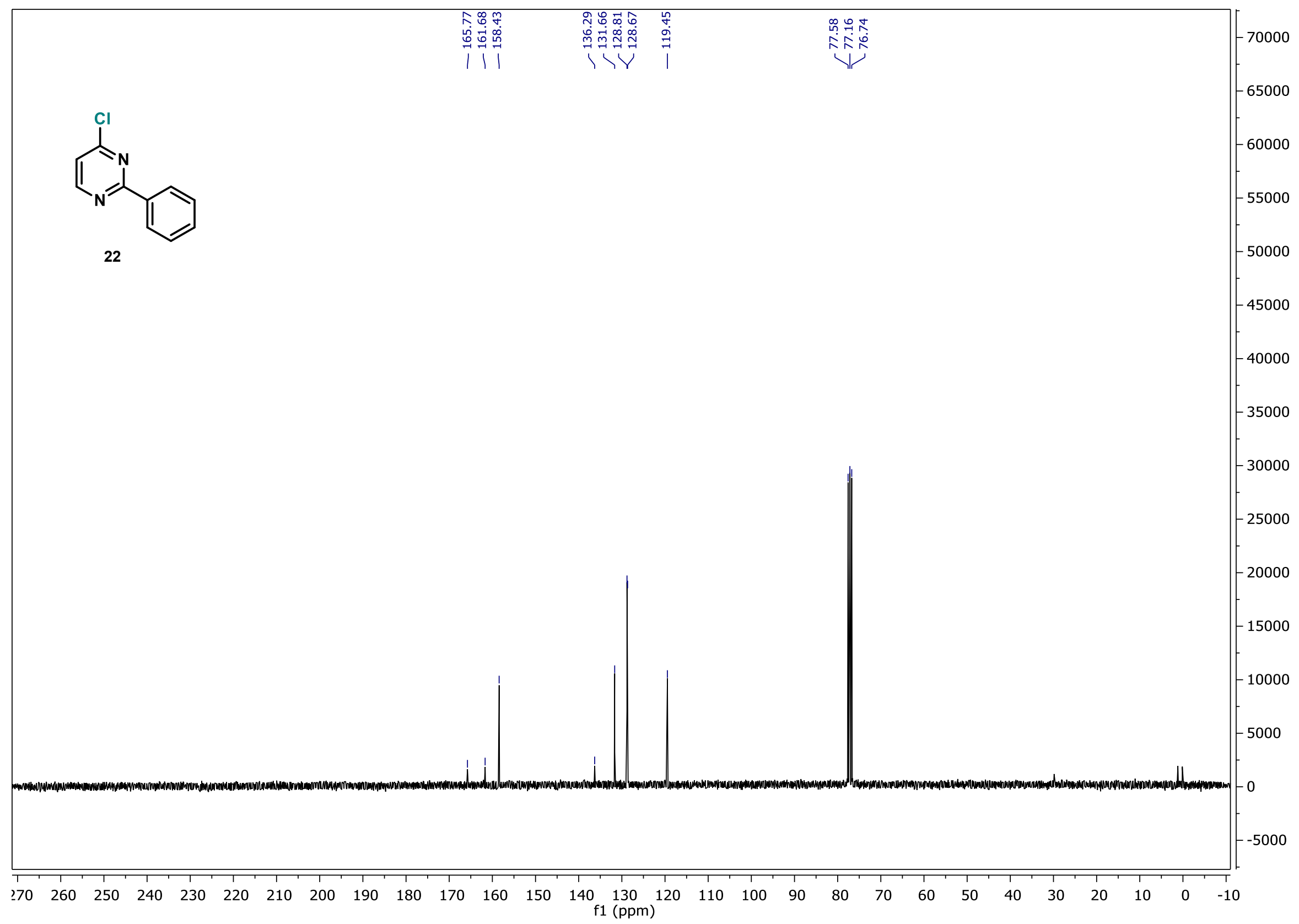


Mass to be matched $(\mathrm{m} / \mathrm{z}): 190.029520$ Charge: 1

Mass Tolerance: \pm 0.050000

Restriction of atom numbers :

$\begin{array}{llll}\mathrm{C} & \mathrm{H} & \mathrm{N} & \mathrm{Cl} \\ 1-100 & 1-100 & 1-2 & 1-2\end{array}$

Number of calculated Formulas: 4

Formula

C10 $\mathrm{H} 7$ N2 $\mathrm{Cl} 1$

C8 H10 N1 Cl2

C11 H9 N1 Cl1

C7 H8 N2 Cl2

$\begin{array}{rl}\text { Diff. (ppm) } & \text { theor. } \mathrm{m} / \mathrm{z} \\ -1.55 & 190.029225 \\ -58.10 & 190.018480 \\ 64.63 & 190.041802 \\ -124.28 & 190.005903\end{array}$

2.10 .2020

File: 149660b-00.raw

Analyse: GHC-GA-361-01

COP: Dr. Clement Ghiazza

Messung: GC-MS

Ionisierung: GC-EI

Spektrometer: Q Exactive GC Orbitrap

Säule:

MS 50 TX $1+\mathrm{VS}$

Länge: $\quad 30+7$

Temp.: 35-10-285-5

$\mathrm{GC}-\mathrm{Nr}$.:

ELNA-Nr.: $\quad 27638$

Auswerter: Haupt (2243) 
${ }^{1} \mathrm{H} N M R$ - in situ

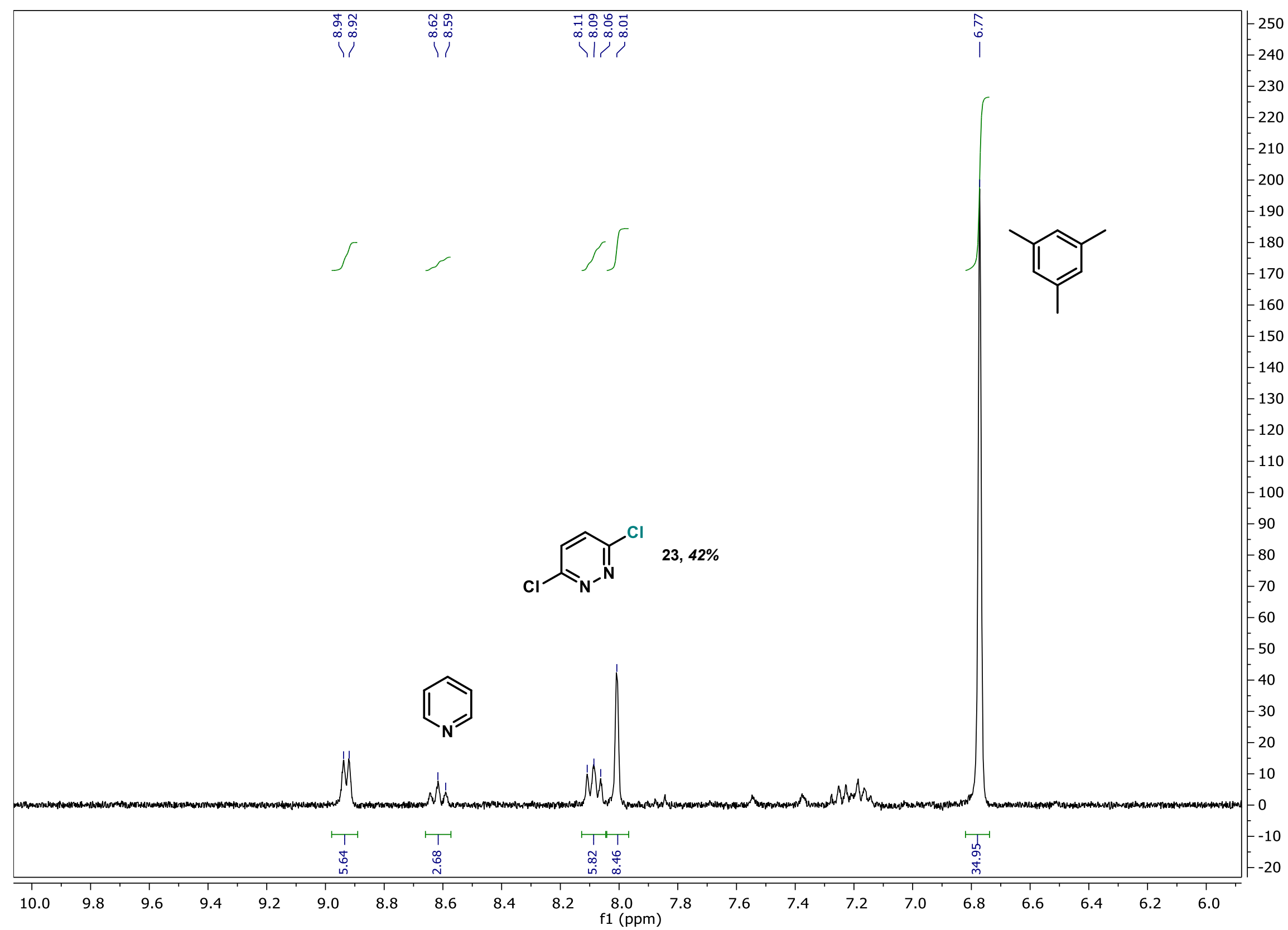


Mass to be matched $(\mathrm{m} / \mathrm{z}): 148.966910$ Charge: 1

Mass Tolerance: \pm 0.020000

Restriction of atom numbers:

$\begin{array}{llll}\mathrm{C} & \mathrm{H} & \mathrm{N} & \mathrm{Cl} \\ 1-100 & 1-100 & 1-5 & 2-2\end{array}$

Number of calculated Formulas: 3

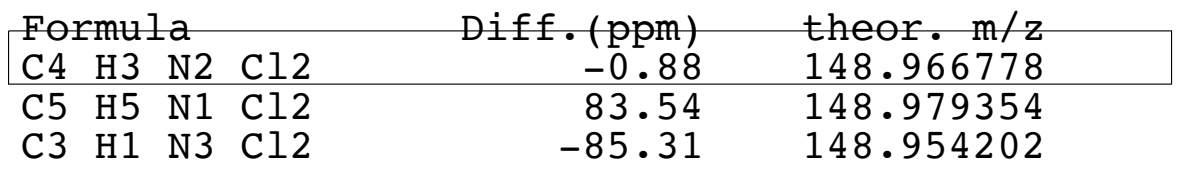

\begin{tabular}{ll}
$\begin{array}{ll}\text { Datum: } \\
\text { Analyse: }\end{array}$ & $\begin{array}{c}3.08 .2020 \\
148468 \mathrm{C}-00\end{array}$ \\
\hline Sigel: & GHC-GA-251-01 \\
& COP: Dr. Clement Ghiazza \\
\hline Method: & HR-MS \\
Ionis. : & ESIpos \\
solvent : & CH2Cl2 + CH3OH \\
Spectrometer: & Exactive \\
\hline Auswerter: & Marcus, Tel:2243
\end{tabular}

\author{
suggestion: \\ C4 H2N2Cl2 MW: 148 \\ Characteristic Ions: \\ $149=[148+\mathrm{H}]$
}


${ }^{1} \mathrm{H}$ NMR

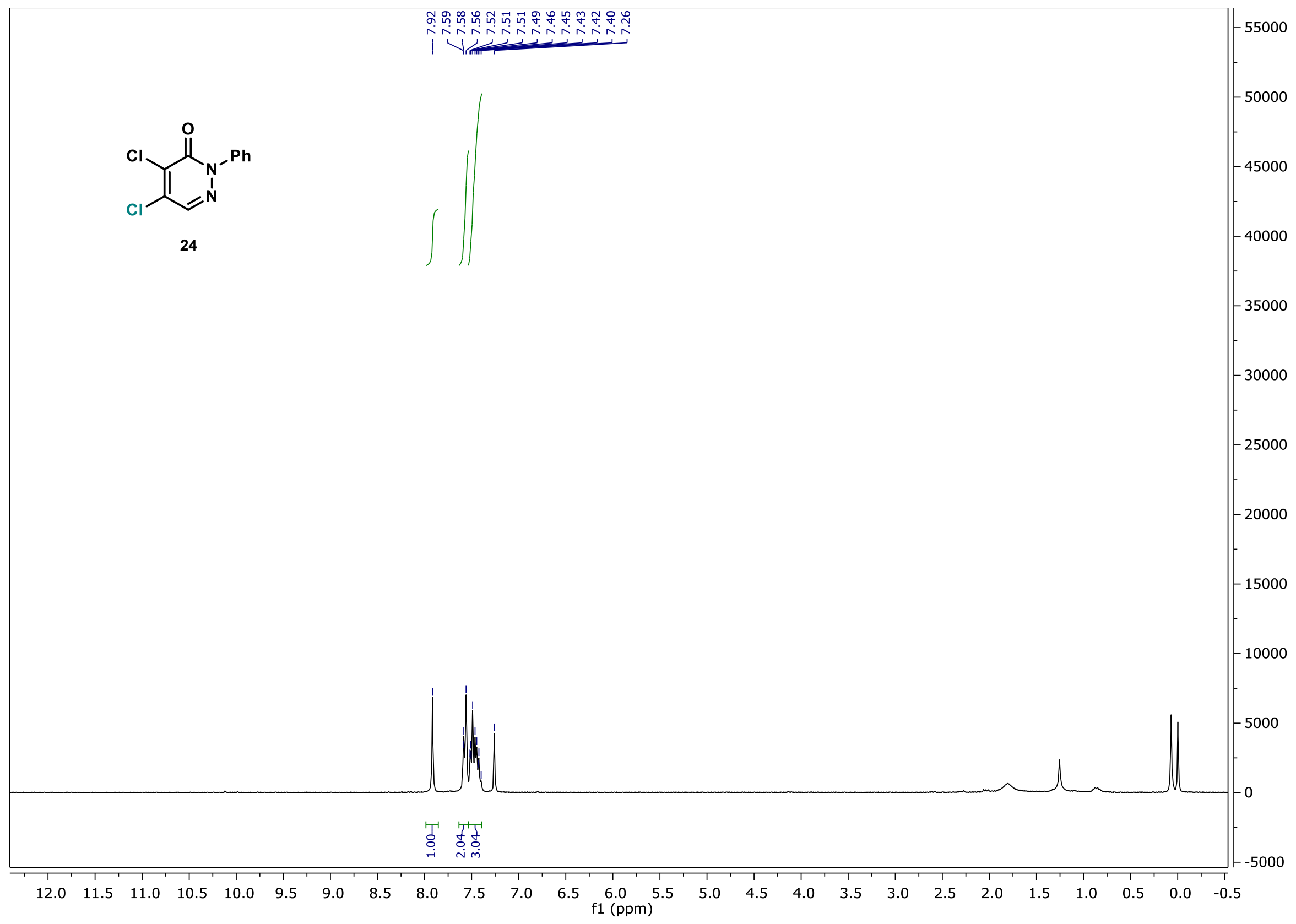


${ }^{13} \mathrm{C}$ NMR

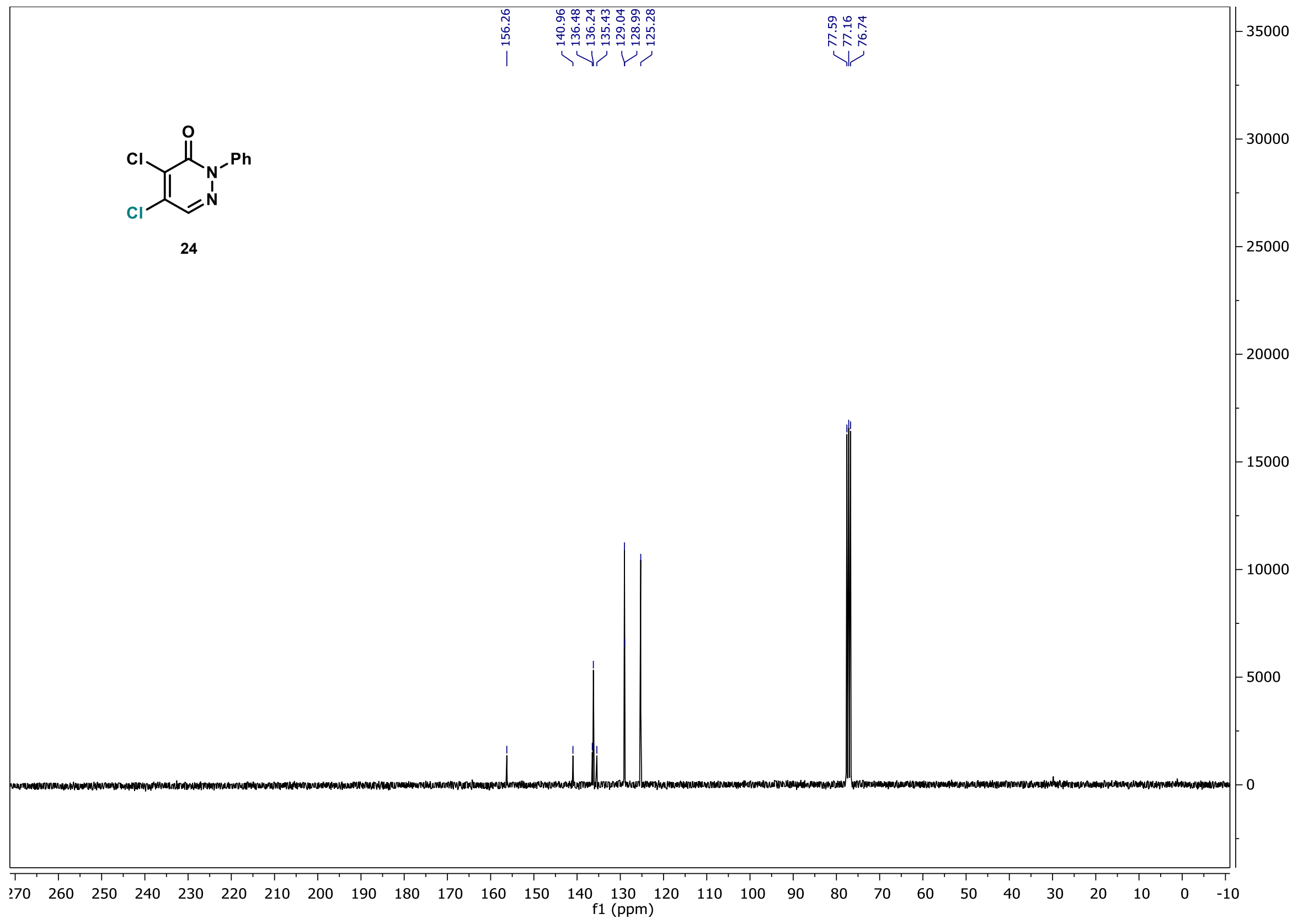


18.08.2020 09:37 p.半为* Angegebene Mol.-Gewichte u. Massenzahlen basieren auf dem häufigsten Isotop der Elemente *** MassLib

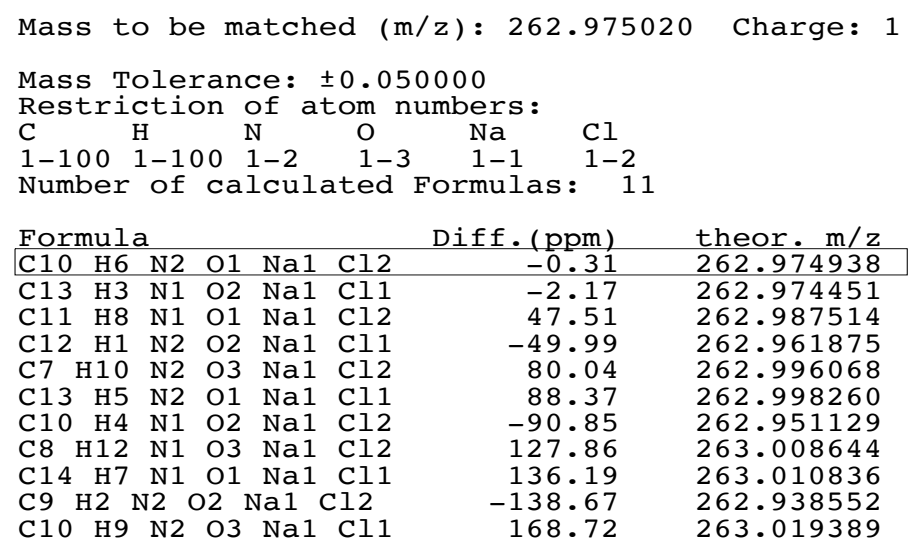

18.08 .2020

File: $148735 f-00$

Analysis: GHC-GA-210-01

COP: Dr. Clement Ghiazza

Messung: HR-MS

Ionisierung: ESIpos

Lösungsmittel: $\mathrm{CH} 2 \mathrm{Cl} 2+\mathrm{CH} 3 \mathrm{OH}$

spektrometer: Exactive

ELNA :

26714

Auswerter:

Haupt (2243) 
${ }^{1} \mathrm{H} N M R$ - in situ

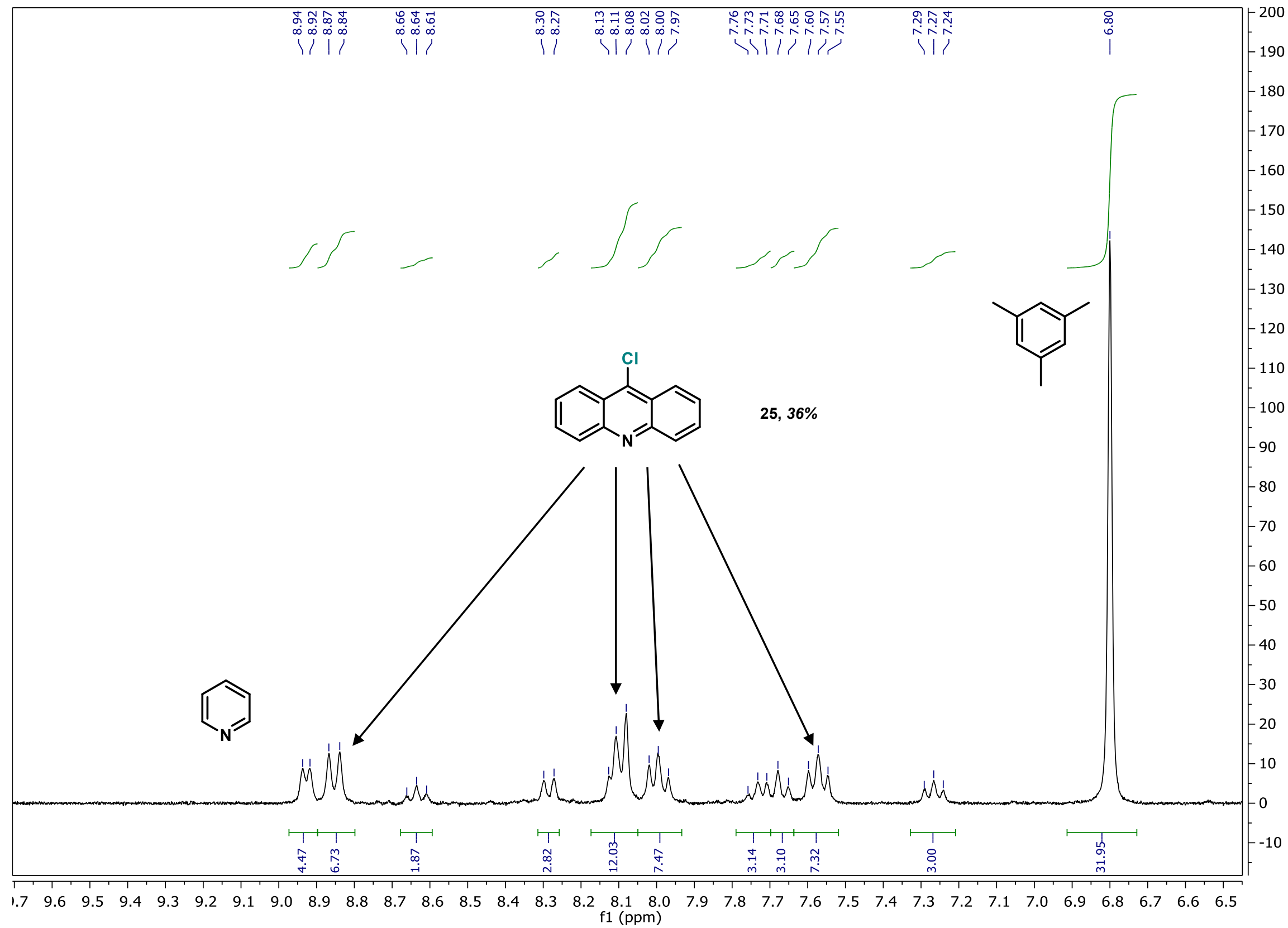


${ }^{1} \mathrm{H}$ NMR

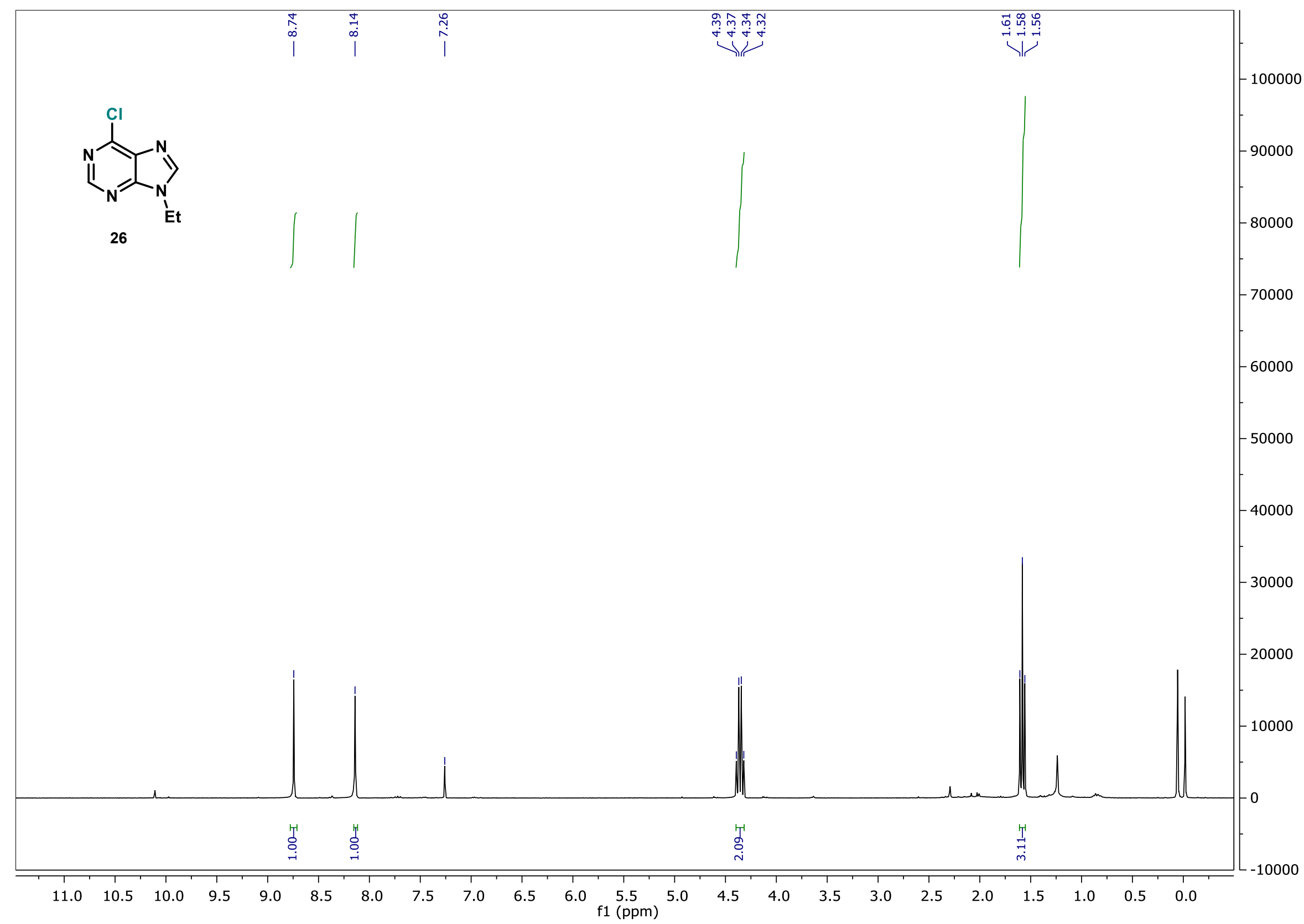




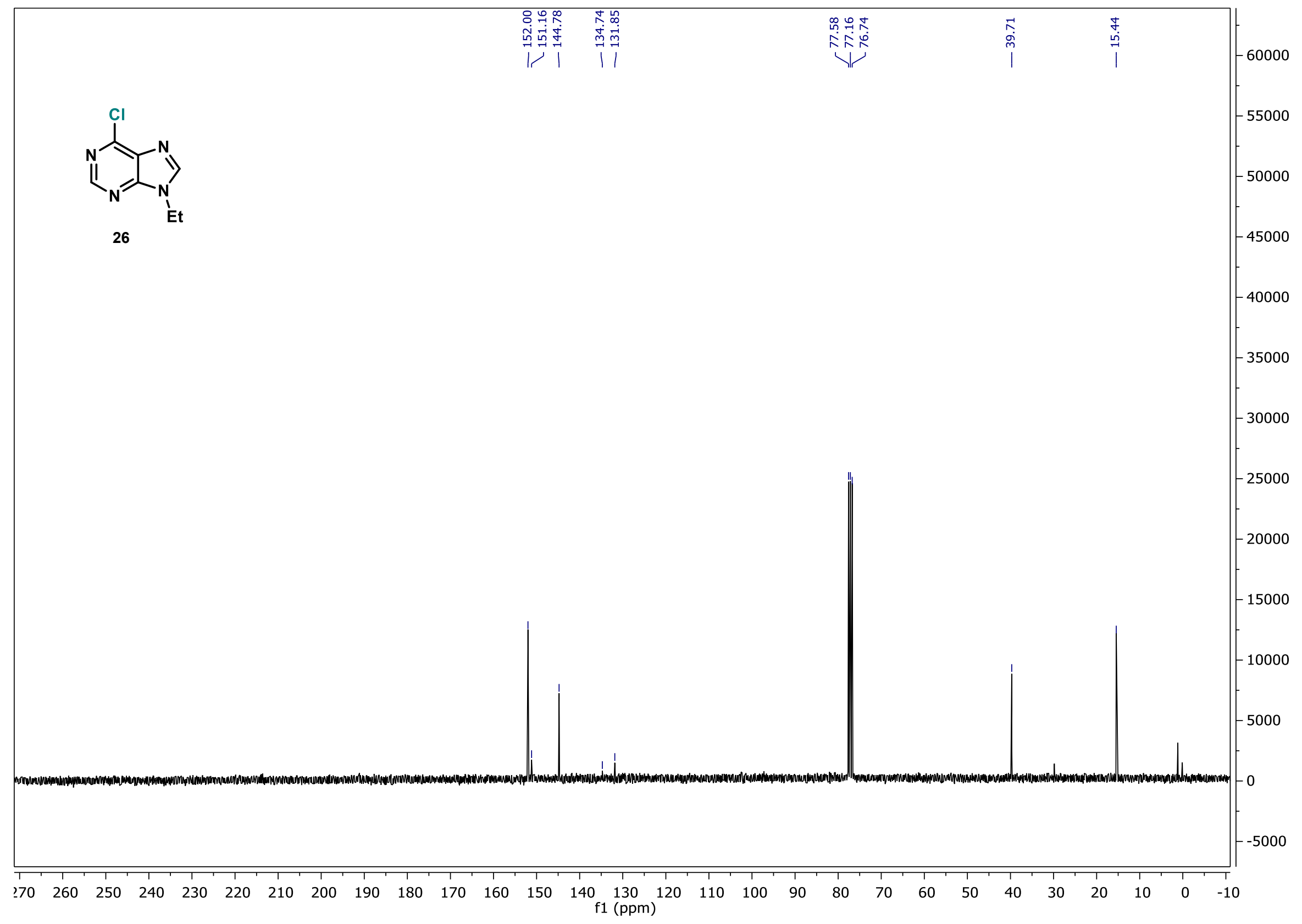


Mass to be matched $(\mathrm{m} / \mathrm{z}): 183.043180$ Charge: 1

Mass Tolerance: \pm 0.005000

Restriction of atom numbers:

$\begin{array}{llll}\mathrm{C} & \mathrm{H} & \mathrm{Cl} & \mathrm{N} \\ 1-100 & 1-100 & 1-1 & 2-4\end{array}$

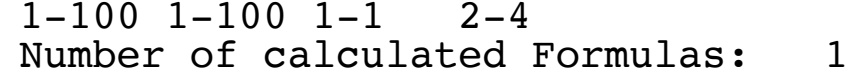

$\begin{array}{lrr}\text { Formula } & \text { Diff. }(\mathrm{ppm}) & \text { theor. } \mathrm{m} / \mathrm{z} \\ \text { C7 H8 Cl1 N4 } & 0.10 & 183.043198\end{array}$

\begin{tabular}{ll}
$\begin{array}{l}\text { Datum } \\
\text { Analyse: }\end{array}$ & 24.07 .2020 \\
& $148346 \mathrm{c}-00$ \\
\hline $\begin{array}{l}\text { Sigel: } \\
\text { LIS: Dr. Gosh, }\end{array}$ & SHS-GA-224-01 \\
\hline Messung: & HRMS \\
Methode: & ESIpos \\
Lösungsmittel: & CH2Cl2+CH3OH \\
Spektrometer: & Exactive \\
\hline Auswerter: & Kampen (2242)
\end{tabular}

Suggestion:

C7H7Cl1N4 MW 182

characteristical ion

$183=[182+\mathrm{H}]+$ 
${ }^{1} \mathrm{H} N M R$ - in situ

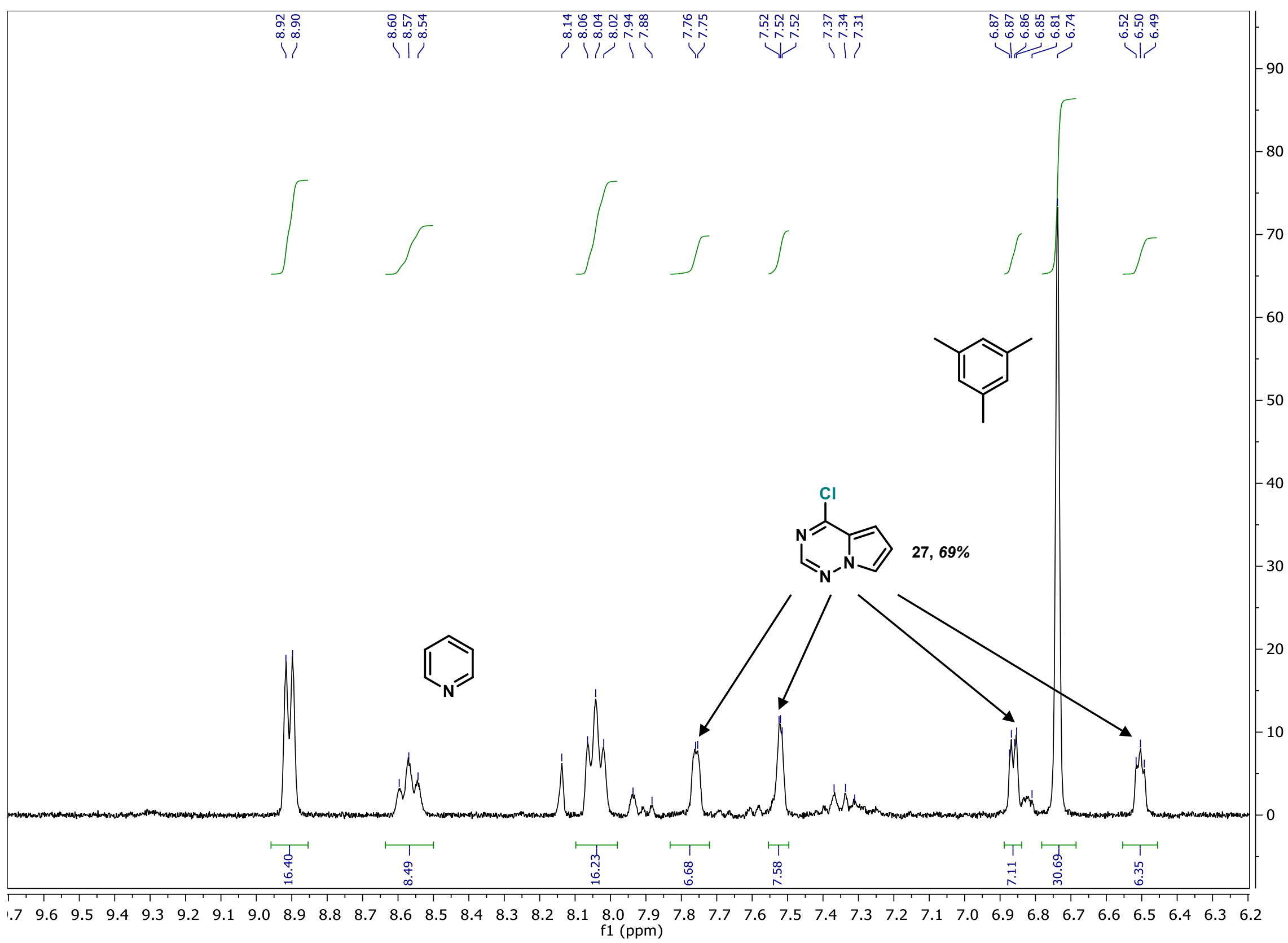




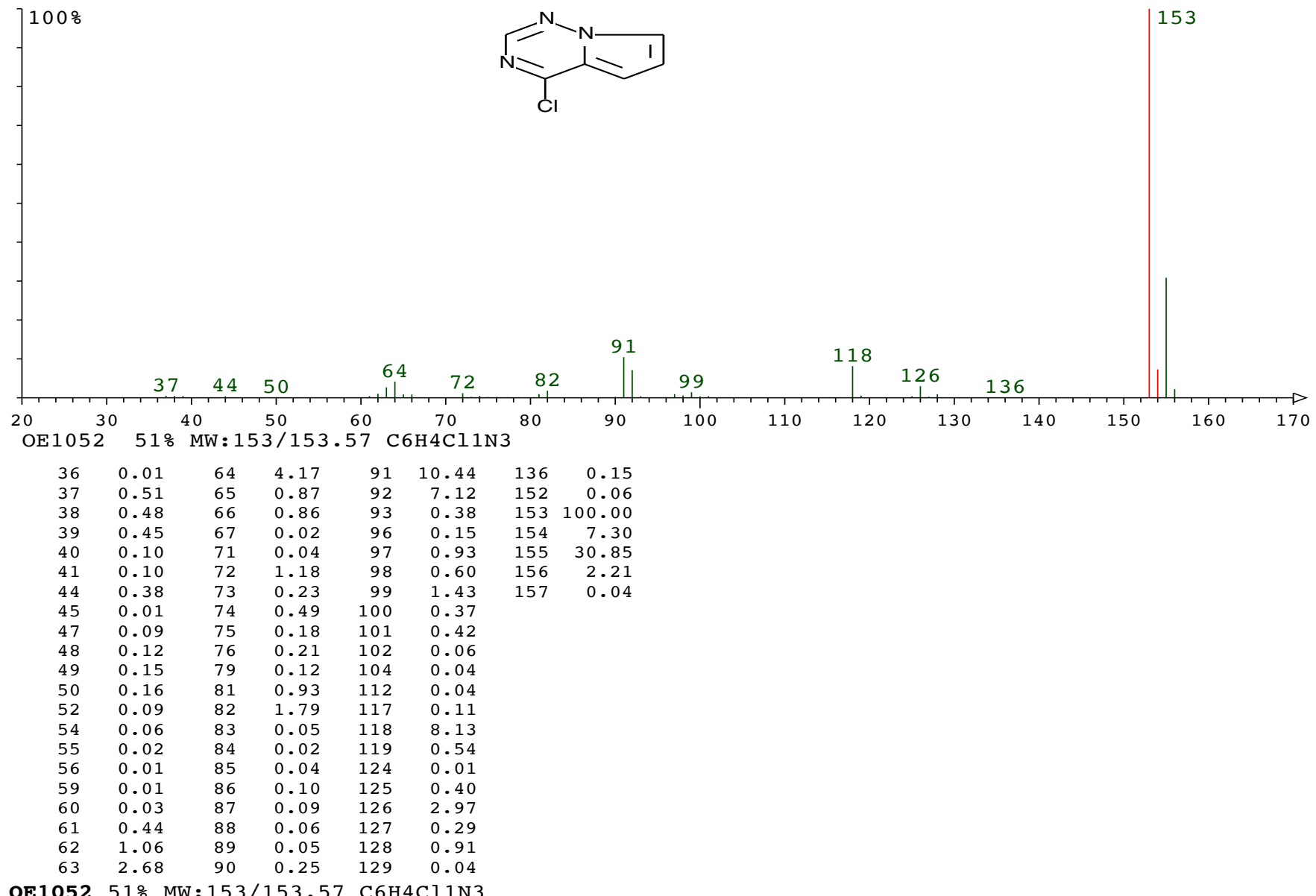

Mass to be matched $(\mathrm{m} / \mathrm{z}): 153.008950$ Charge: 1

Mass Tolerance: \pm 0.005000

Restriction of atom numbers:

$\begin{array}{llll}\mathrm{C} & \mathrm{H} & \mathrm{N} & \mathrm{Cl} \\ 1-110 & 1-100 & 1-3 & 1-1\end{array}$

Number of calculated Formulas: 1

Formula

C6 $\mathrm{H} 4$ N3 $\mathrm{Cl} 1$ $\begin{array}{rr}\text { Diff. (ppm) } & \text { theor. } \mathrm{m} / \mathrm{z} \\ -0.82 & 153.008824\end{array}$
9.10 .2020

File: 149786a-00.raw

Analyse: GHC-GA-372-01

COP: Dr. Clement Ghiazza

\begin{tabular}{ll}
\hline Messung: & GC-MS \\
Ionisierung: & GC-EI \\
Spektrometer: & QExactiveGC \\
Säule: & MS 50 TX1+VS \\
Länge: & $30+7$ \\
Temp.: & $35-10-285-5$ \\
GC-Nr.: & -
\end{tabular}

Auswerter: Margold 
${ }^{1} \mathrm{H}$ NMR

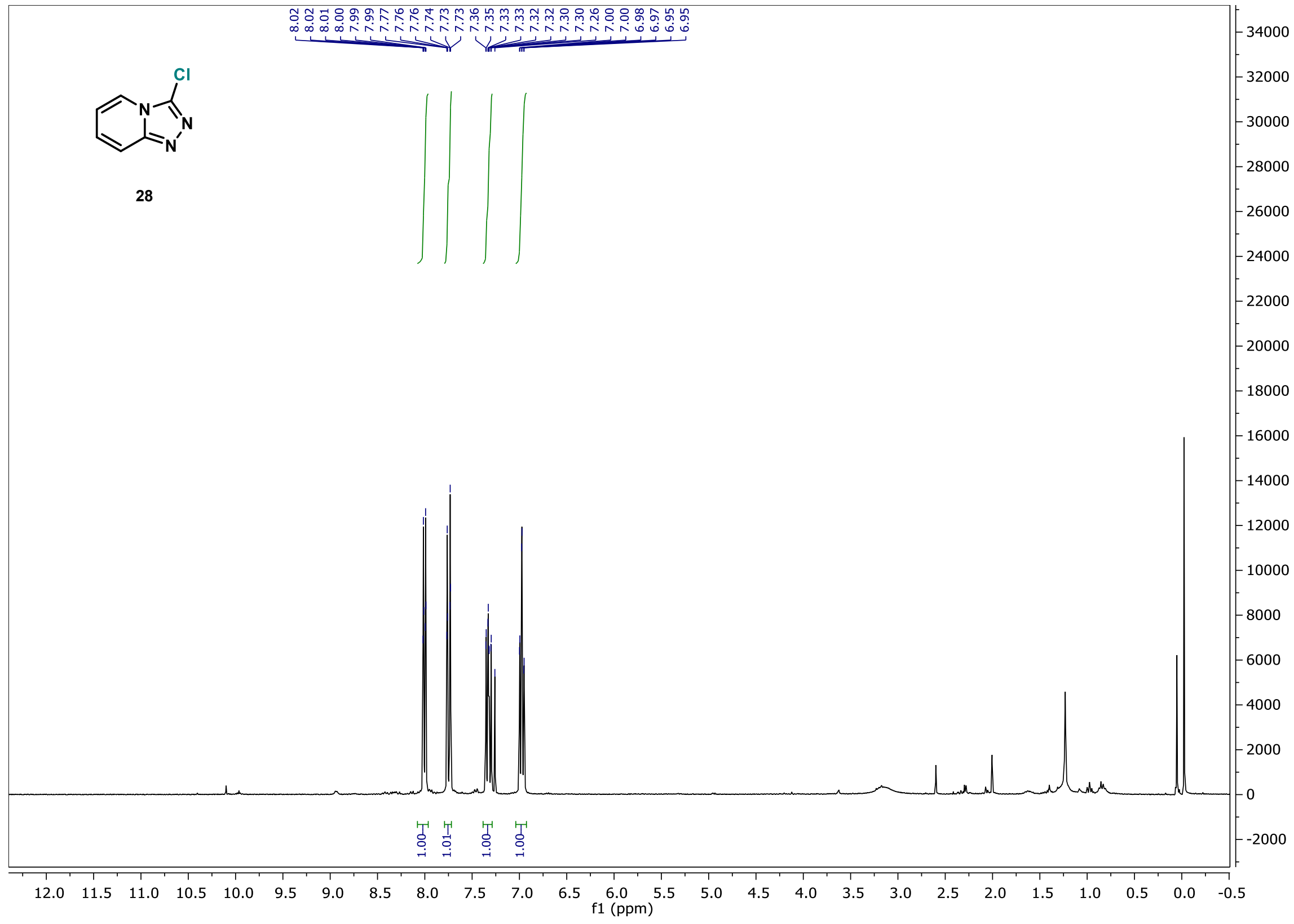




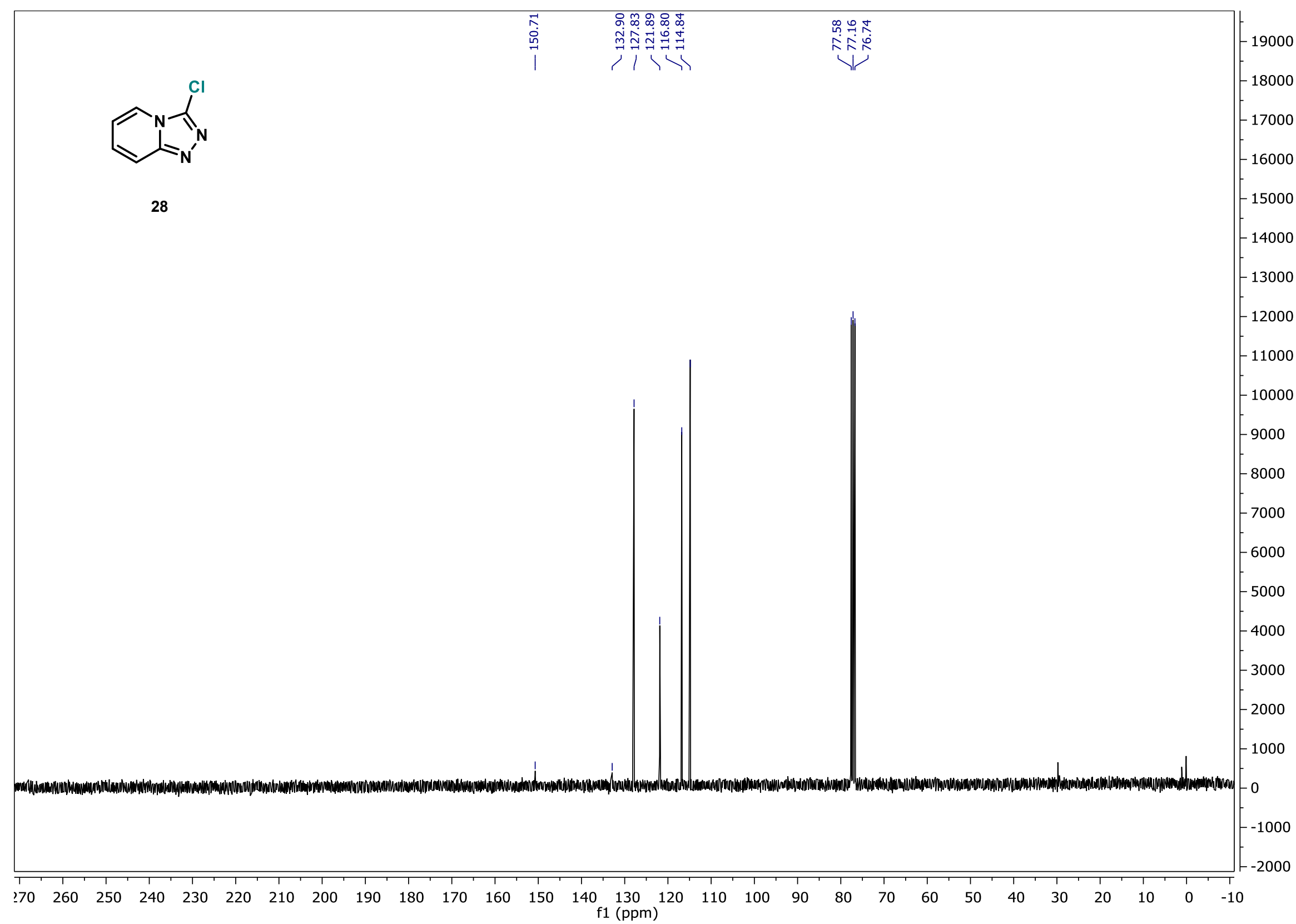


Mass to be matched $(\mathrm{m} / \mathrm{z}): 153.009070$ Charge: 1

Mass Tolerance: \pm 0.005000

Restriction of atom numbers:

$\begin{array}{llll}\mathrm{C} & \mathrm{H} & \mathrm{N} & \mathrm{Cl} \\ 1-110 & 1-100 & 1-3 & 1-2\end{array}$

Number of calculated Formulas: 2

Formula Diff. (ppm) theor. $\mathrm{m} / \mathrm{z}$

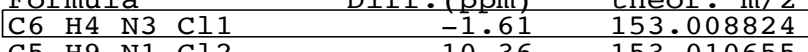

7.10 .2020

File: 149750a-00.raw

Analyse: GHC-GA-370-01

COP: Dr. Clement Ghiazza

Messung:

GC-MS

Ionisierung: GC-EI

Spektrometer: QExactiveGC

Säule:

MS $50 \mathrm{TX} 1+\mathrm{VS}$

Länge: $\quad 30+7$

Temp.: 35-10-285-5

$\mathrm{GC}-\mathrm{Nr}$. :

Auswerter: Margold 
${ }^{1} \mathrm{H}$ NMR

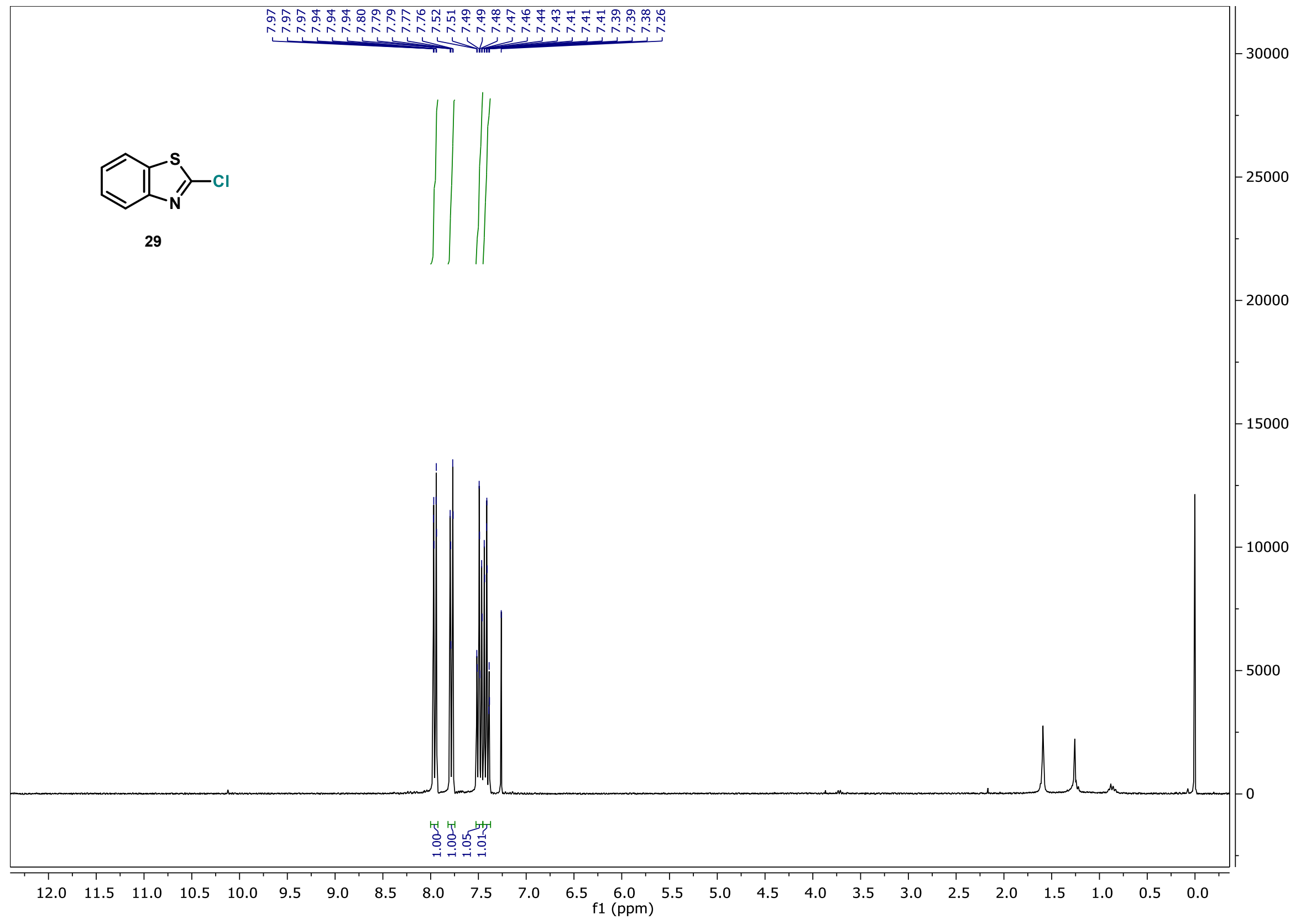


${ }^{1} \mathrm{H}$ NMR

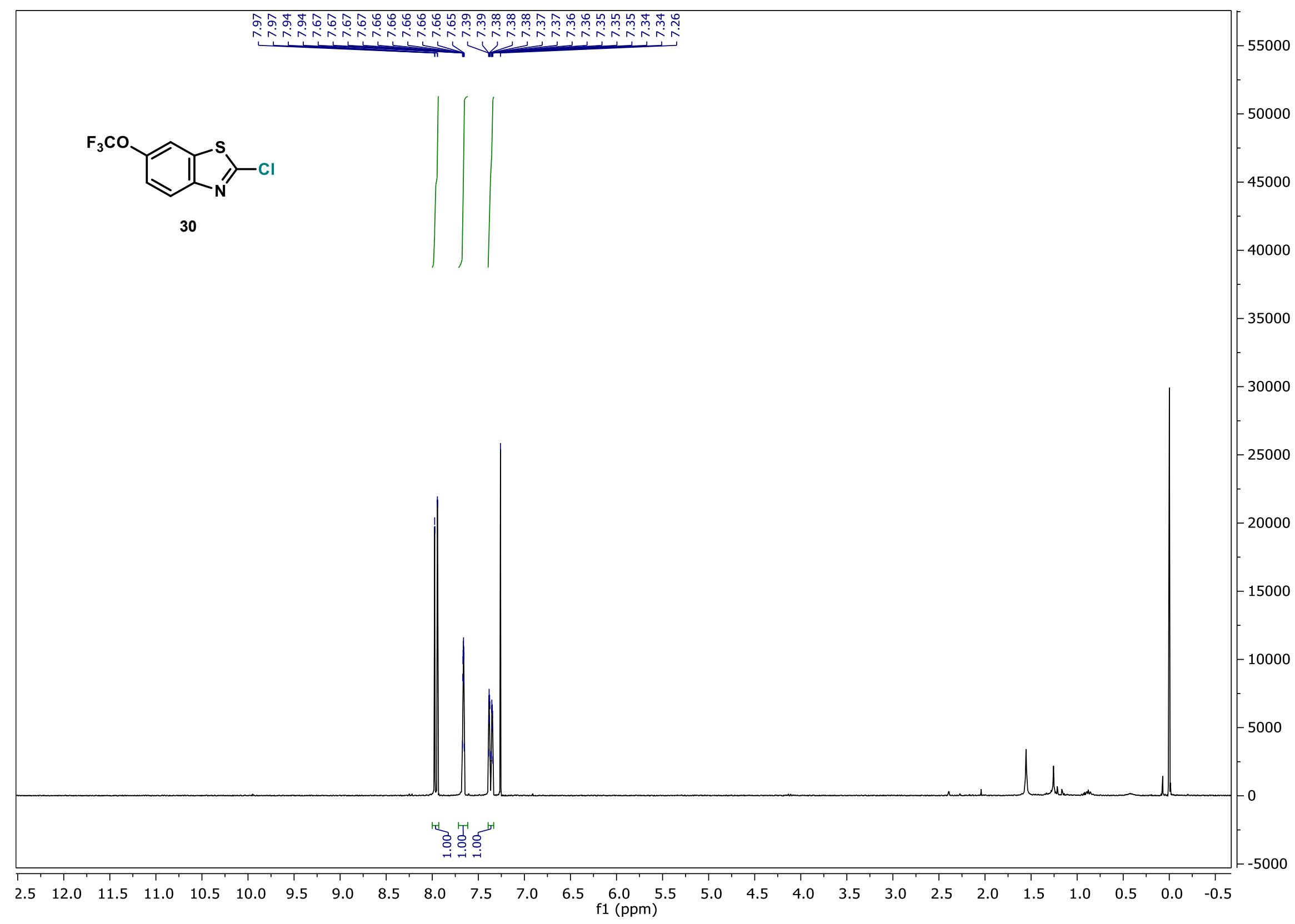




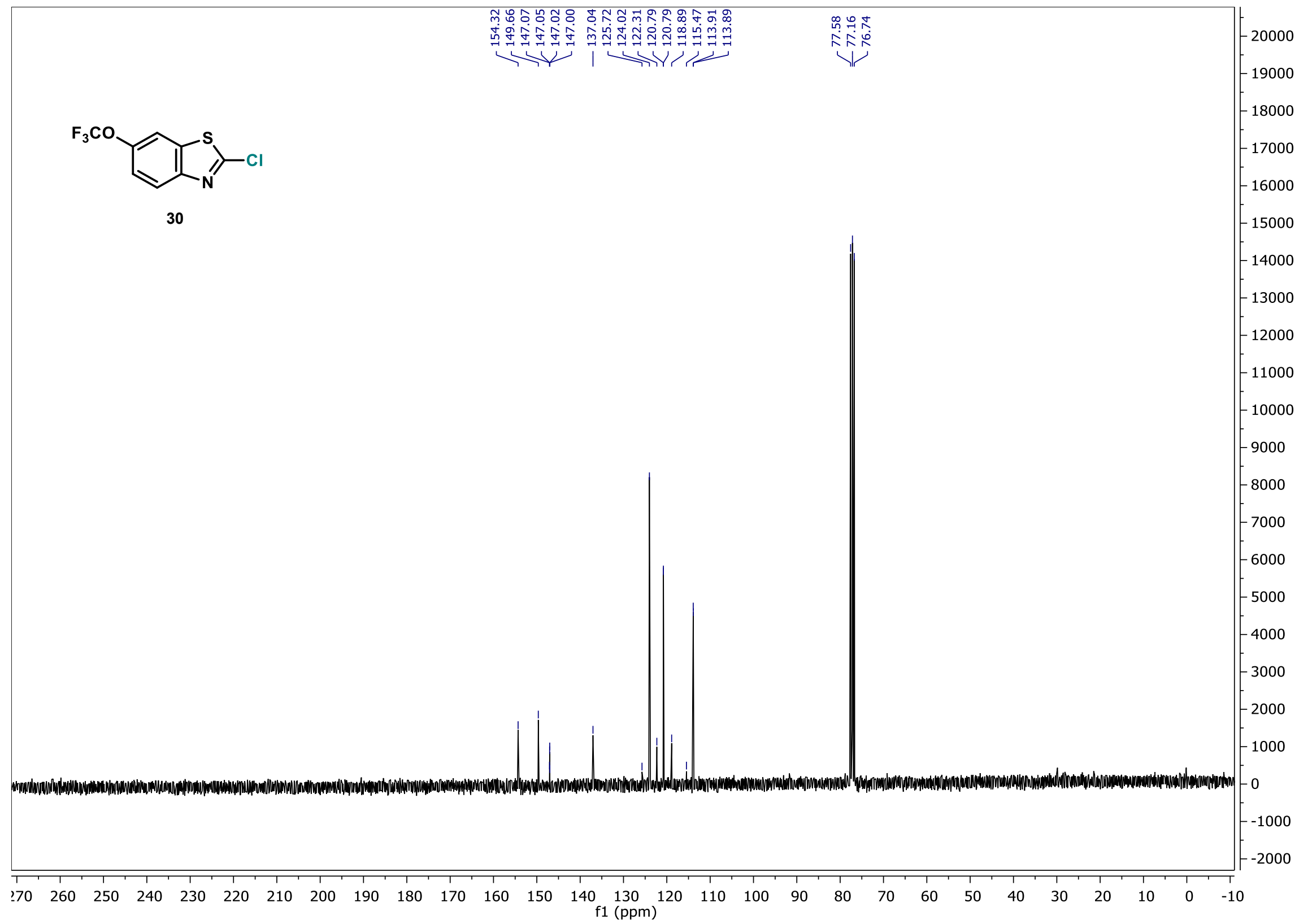


${ }^{19}$ F NMR

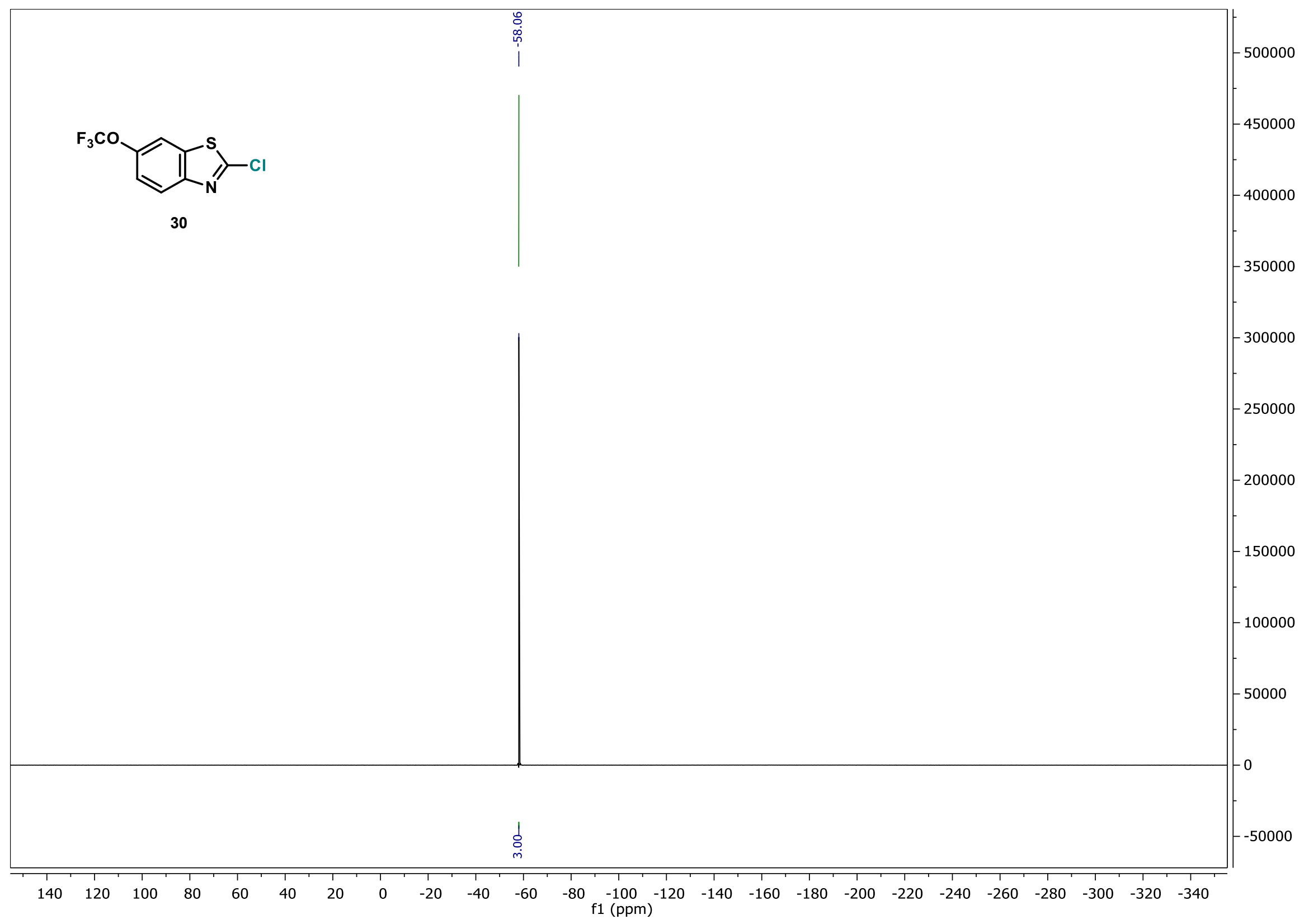


Mass to be matched $(\mathrm{m} / \mathrm{z}): 252.957470$ Charge: 1

Mass Tolerance: \pm 0.005000

Restriction of atom numbers:

$\begin{array}{lllllll}\mathrm{C} & \mathrm{H} & \mathrm{N} & \mathrm{O} & \mathrm{S} & \mathrm{Cl} & \mathrm{F} \\ 1-100 & 1-100 & 1-5 & 1-10 & 1-1 & 1-1 & 3-3\end{array}$

Number of calculated Formulas: 2

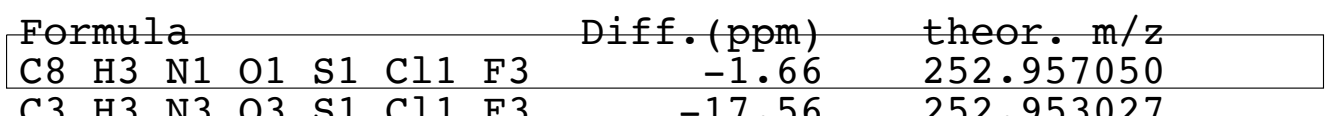

$\begin{array}{rrrrrrrrr}\text { C8 } & \text { H3 } & \text { N1 } & \text { O1 } & \text { S1 } & \text { Cl1 } & \text { F3 } & -1.66 & 252.957050 \\ \text { C3 } & \text { H3 } & \text { N3 } & \text { O3 } & \text { S1 } & \text { Cl1 } & \text { F3 } & -17.56 & 252.953027\end{array}$

\begin{tabular}{lr} 
Datum: & 6.08 .2020 \\
Analyse: & $148532 \mathrm{c}-00$ \\
\hline
\end{tabular}

$\begin{array}{ll}\text { Sigel: } & \text { GHC-GA-262-01 } \\ & \text { COP: Dr. Clement Ghiazza }\end{array}$

Method: HR-MS

Ionis. : GC-EI

Spectrometer: Q-Exactive

Auswerter: Marcus, Tel:2243

suggestion:

C8H3N101S1Cl1F3 MW: 253 
${ }^{1} \mathrm{H}$ NMR

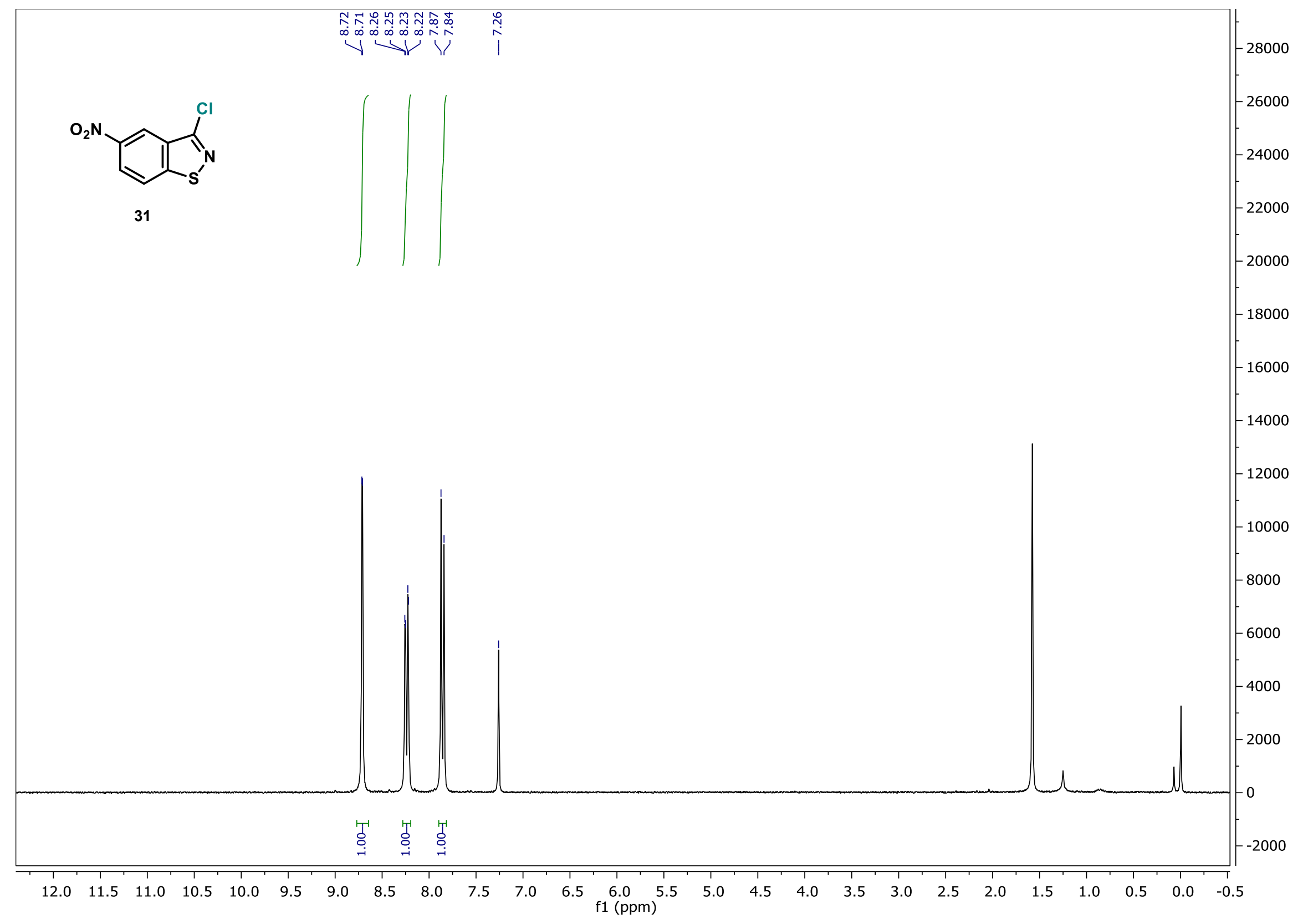




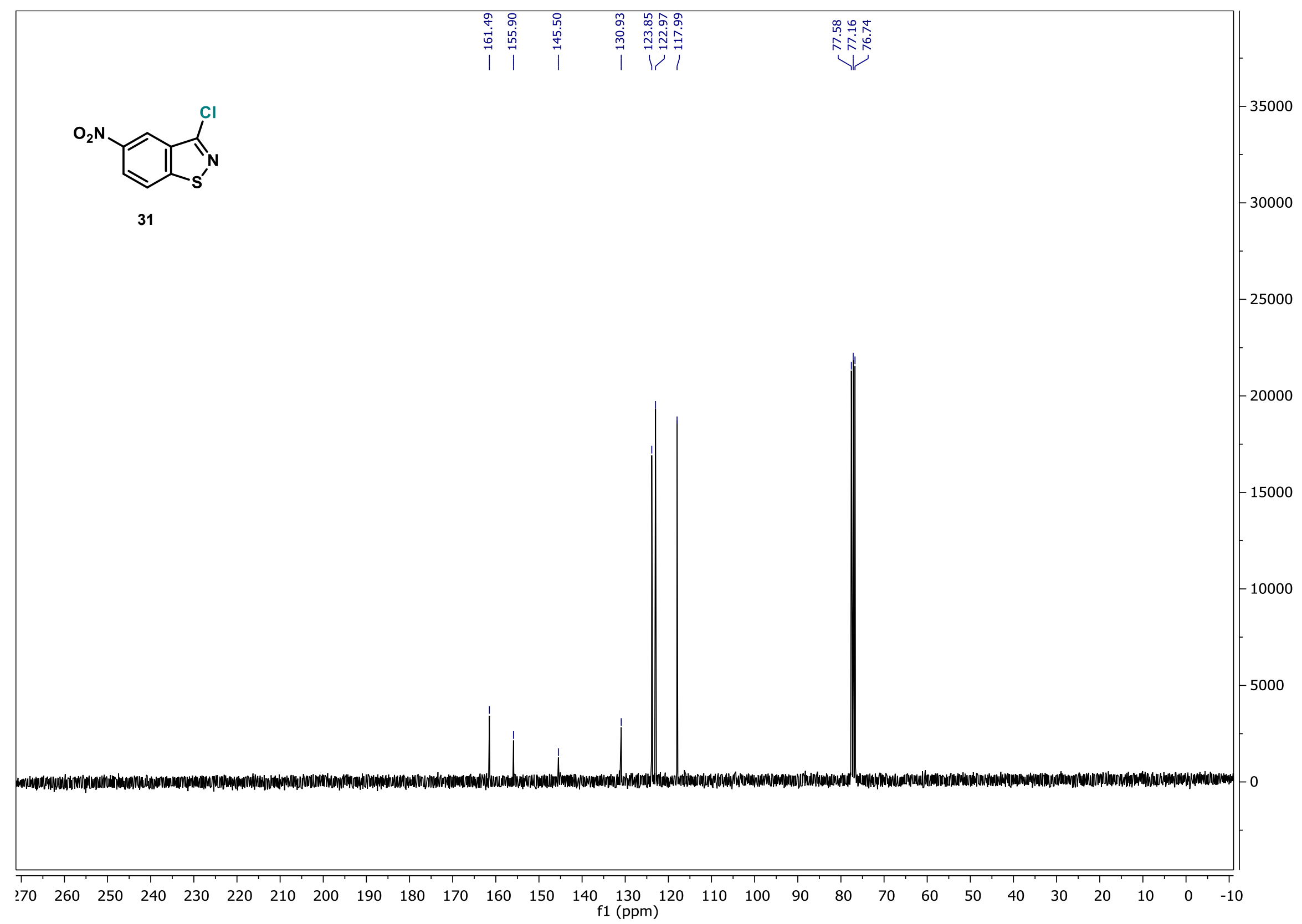


Mass to be matched $(\mathrm{m} / \mathrm{z}): 214.967750$ Charge: 1

Mass Tolerance: \pm 0.005000

Restriction of atom numbers:

$\begin{array}{llllll}\mathrm{C} & \mathrm{H} & \mathrm{N} & \mathrm{O} & \mathrm{S} & \mathrm{Cl} \\ 1-100 & 1-100 & 1-5 & 1-10 & 1-1 & 1-1\end{array}$

Number of calculated Formulas:

Formula Diff. (ppm) theor. $\mathrm{m} / \mathrm{z}$

$\begin{array}{rrrrrrrr}\mathrm{C} 7 & \mathrm{H} 4 & \mathrm{~N} 2 & \mathrm{O} 2 & \mathrm{~S} 1 & \mathrm{Cl} 1 & -0.45 & 214.967653\end{array}$

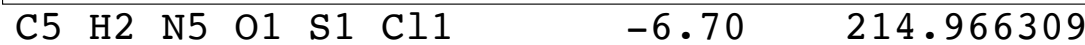

$\begin{array}{llllllll}\mathrm{C} 4 & \mathrm{H} 6 & \mathrm{~N} 1 & \mathrm{O} 5 & \mathrm{~S} 1 & \mathrm{Cl} 1 & -12.91 & 214.964974\end{array}$

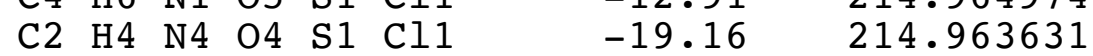

\begin{tabular}{ll}
$\begin{array}{ll}\text { Datum: } \\
\text { Analyse: }\end{array}$ & 24.07 .2020 \\
& $148347 \mathrm{C}-00$ \\
\hline Sigel: & GHC-GA-192-01 \\
& COP: Dr. Clement Ghiazza \\
\hline Method: & HR-MS \\
Ionis: : & ESIPos \\
solvent : & CH2Cl2 + CH3OH \\
Spectrometer: & Exactive \\
\hline Auswerter: & Marcus, Tel:2243
\end{tabular}

suggestion:

C7H3N2O2S1Cl1 MW: 214

Characteristic Ions:

$215=[214+\mathrm{H}]$ 
${ }^{1} \mathrm{H}$ NMR

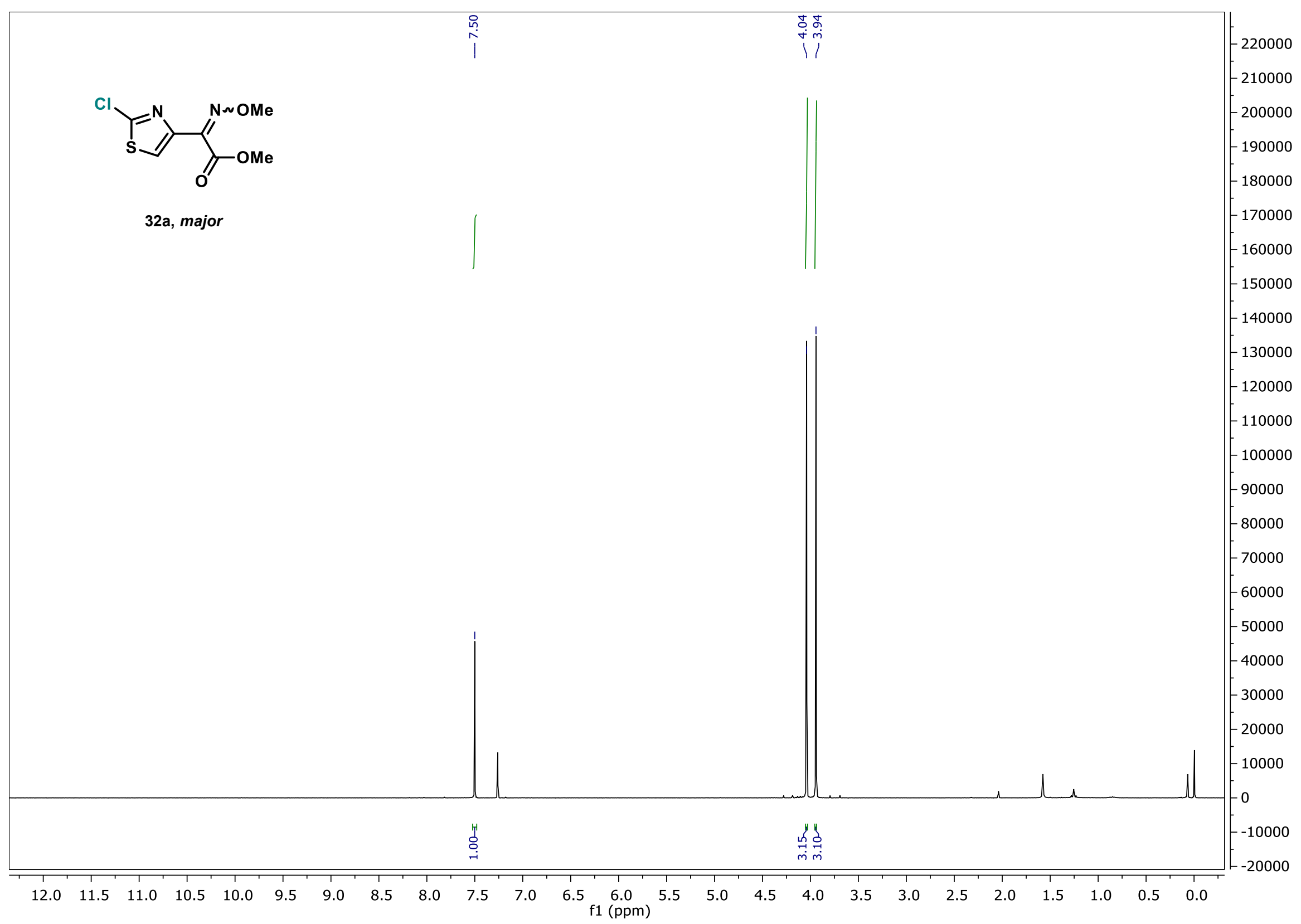




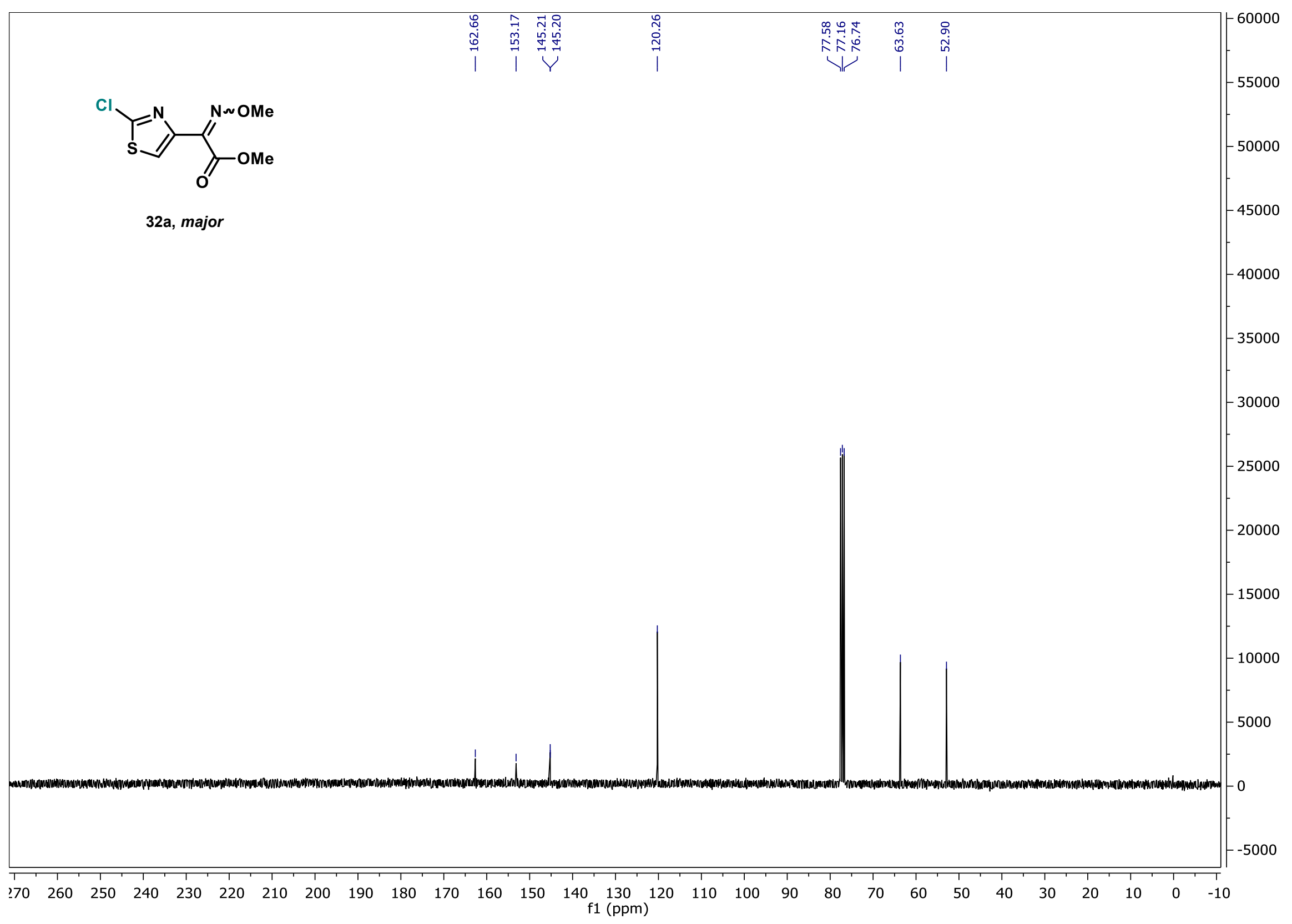


${ }^{1} \mathrm{H}$ NMR

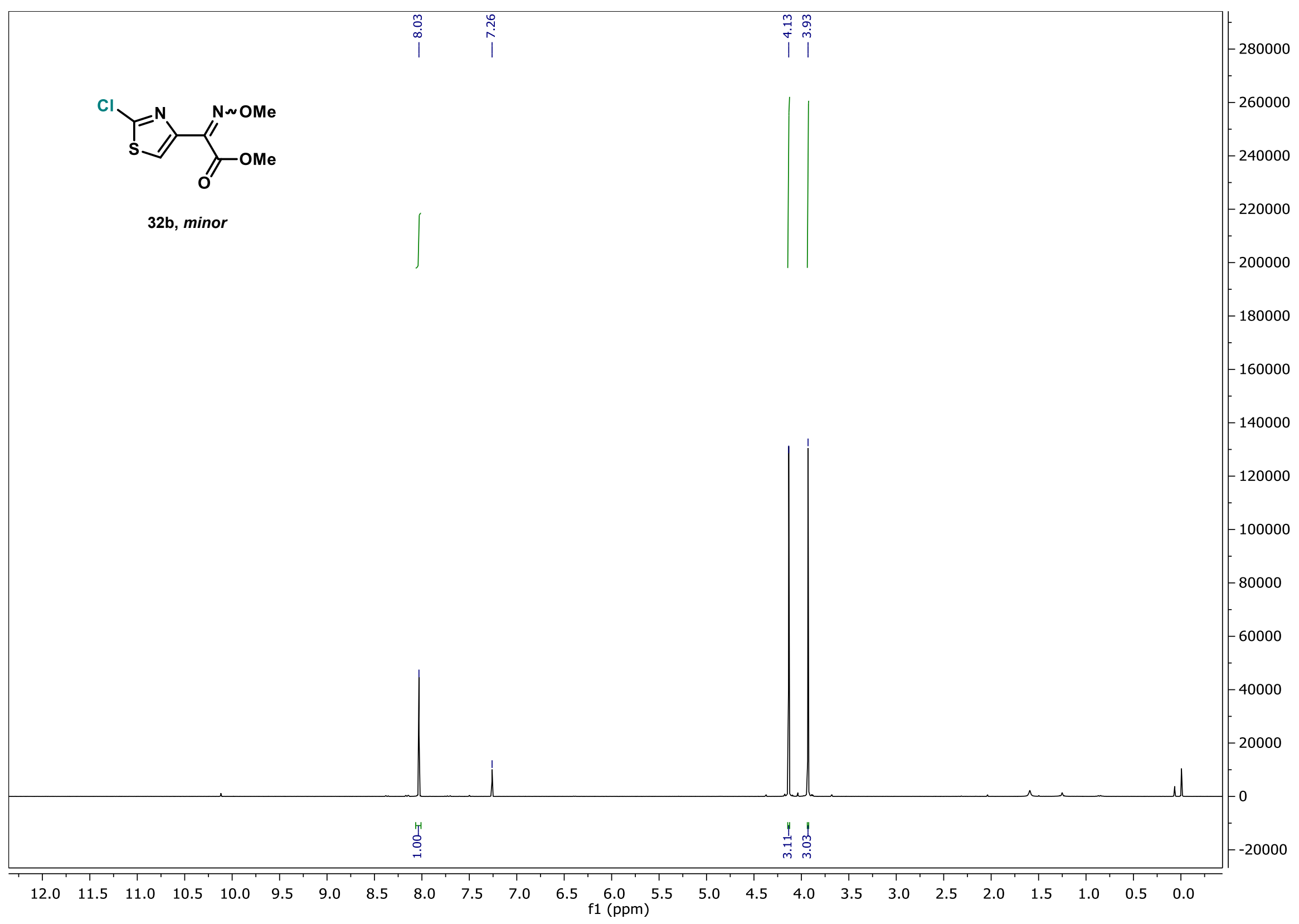




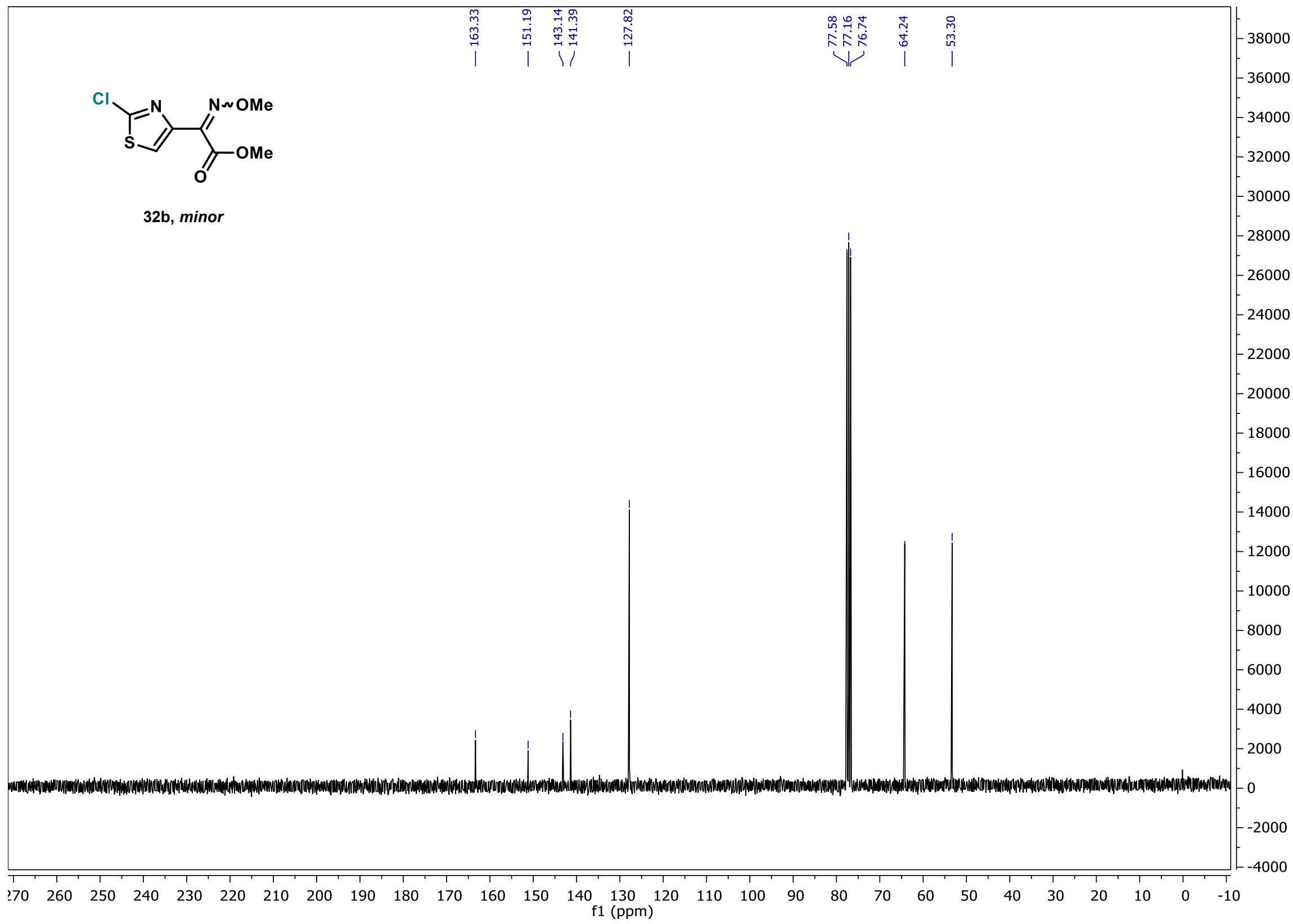


Mass to be matched $(\mathrm{m} / \mathrm{z}): 256.975680$ Charge: 1

Mass Tolerance: \pm 0.020000

Restriction of atom numbers:

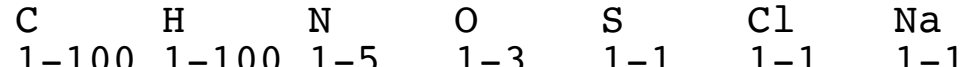

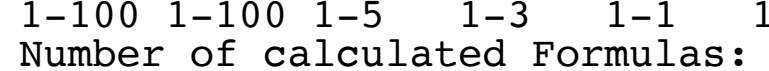
6

Formula

$\begin{array}{lllllll}\mathrm{C} 7 & \mathrm{H} 7 & \mathrm{~N} 2 & \mathrm{O} 3 & \mathrm{~S} 1 & \mathrm{Cl} 1 & \mathrm{Na} 1\end{array}$

C5 $\mathrm{H} 5$ N5 02 S1 Cl1 Na1

C11 H5 N1 O1 S1 Cl1 Na1

C6 H7 N4 02 S 1 Cl1 Na1

$\begin{array}{lllllll}\mathrm{C} 6 & \mathrm{H} 5 & \mathrm{~N} 3 & \mathrm{O} 3 & \mathrm{~S} 1 & \mathrm{Cl} 1 & \mathrm{Na} 1\end{array}$

$\begin{array}{lllllll}\mathrm{C} 8 & \mathrm{H} 9 & \mathrm{~N} 1 & \mathrm{O} 3 & \mathrm{~S} 1 & \mathrm{Cl} 1 & \mathrm{Na} 1\end{array}$
Diff. (ppm) 0.51 $-4.72$ $-32.77$

44.22

$-48.43$

49.45
Datum:

Analyse:

Sigel:

\section{Method:}

Ionis. :

solvent :

Spectromete (256.975812 256.974468

256.967258

256.987044

256.963236

256.988388

Auswerter:
22.07 .2020

$148260 \mathrm{c}-00$

GHC-GA-209-02

COP: Dr. Clement Ghiazza

HR-MS

ESIpos

$\mathrm{CH} 2 \mathrm{Cl} 2+\mathrm{CH} 3 \mathrm{OH}$

Marcus, Tel:2243

suggestion:

C7H7N2O3S1Cl1 MW: 234

Characteristic Ions:

$257=[234+\mathrm{Na}]$ 


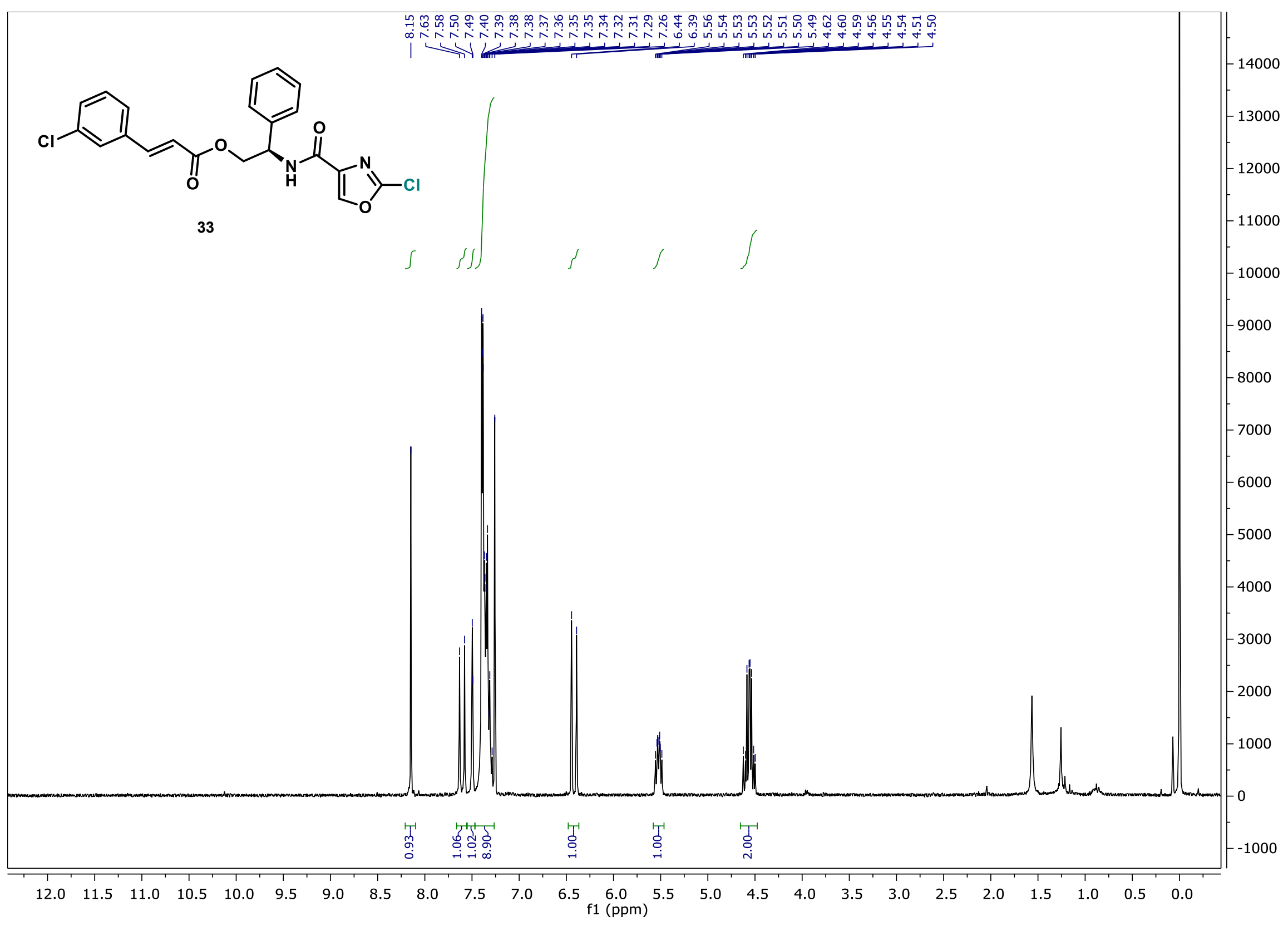




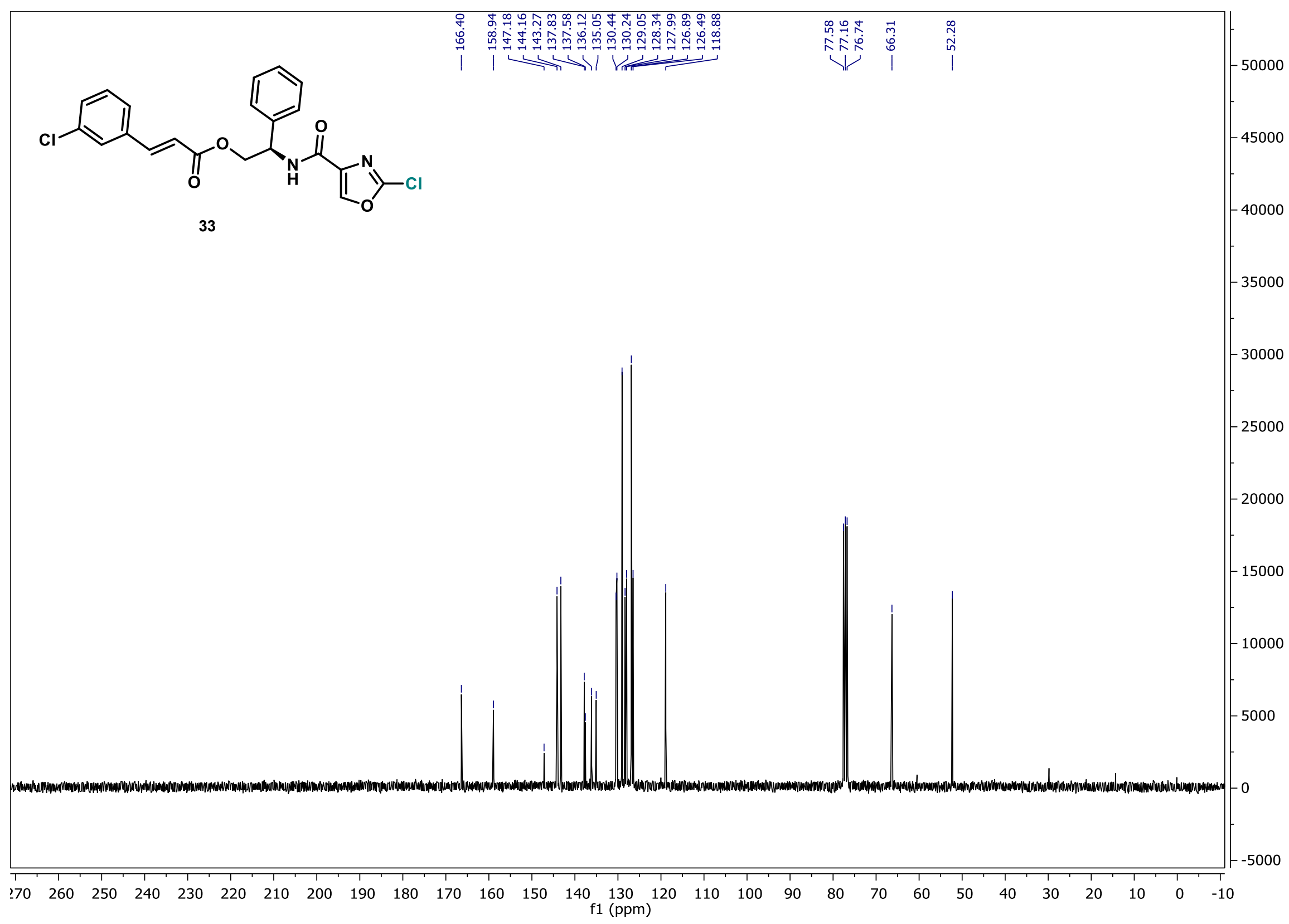


Mass to be matched $(\mathrm{m} / \mathrm{z}): 453.038660$ Charge: 1

Mass Tolerance: \pm 0.005000

Restriction of atom numbers:

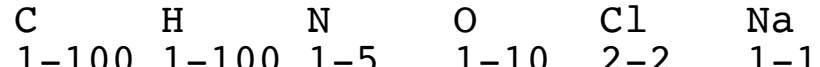

$1-100$
Number of calculated Formulas:

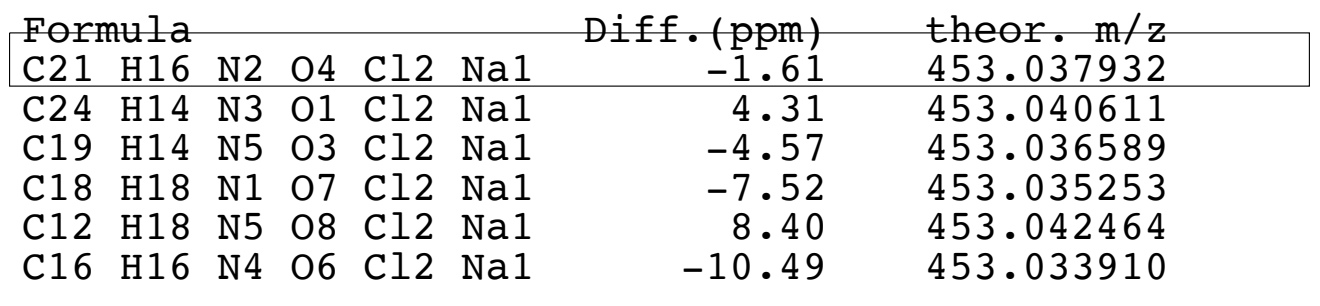

$\begin{array}{ll}\text { Datum: } & 15.10 .2020 \\ \text { Analyse: } & 149874 \mathrm{c}-00\end{array}$

Sigel: $\quad$ GHC-AA-058-0

COP: Dr. Clement Ghiazza

Method: HR-MS

Ionis. : ESIpos

solvent : $\mathrm{CH} 3 \mathrm{OH}$

Spectrometer: Exactive

Auswerter: Marcus, Tel:2243

suggestion:

C21H16N2O4Cl2 MW: 430

Characteristic Ions:

$453=[430+\mathrm{Na}]$ 
${ }^{1} \mathrm{H}$ NMR

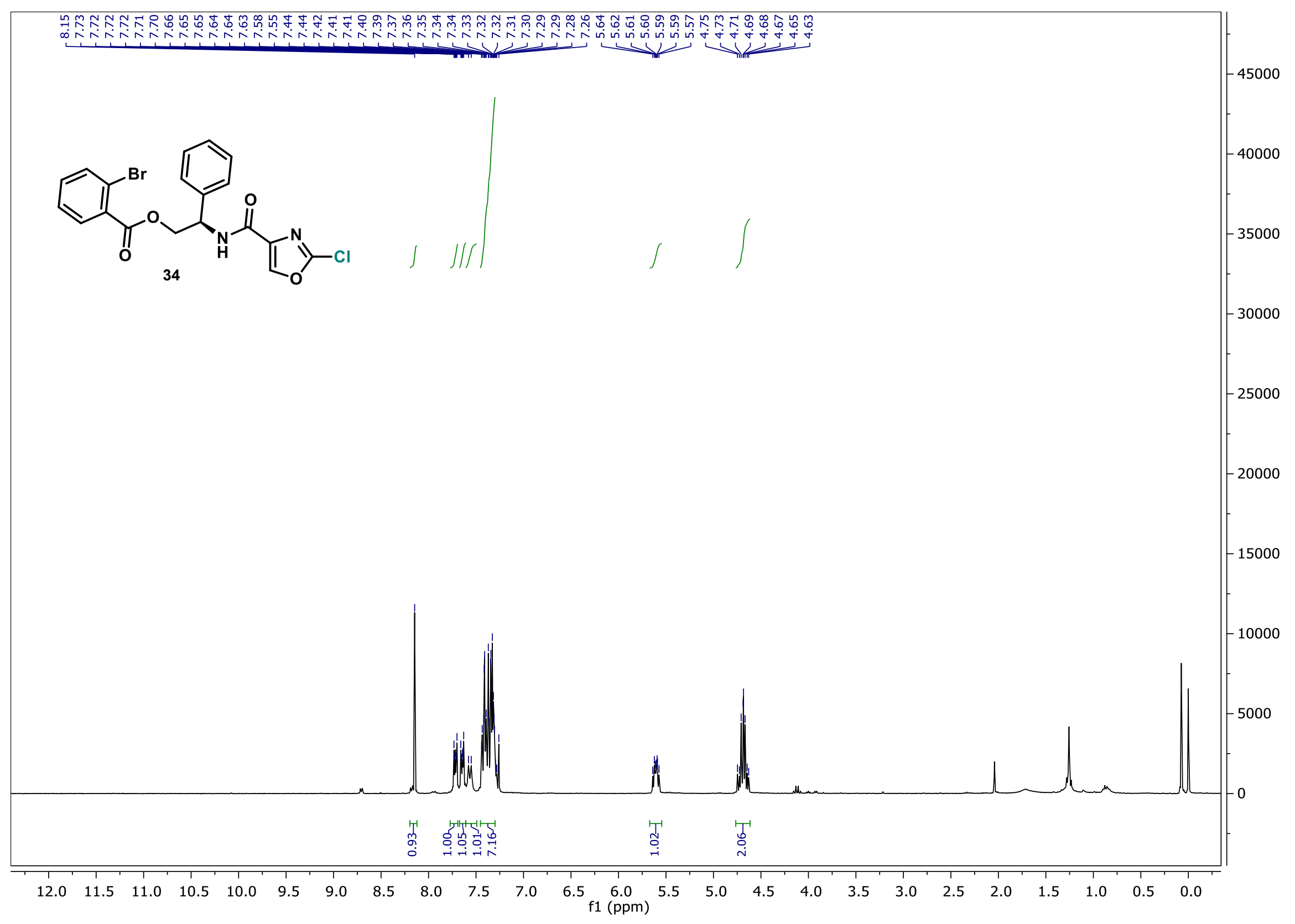




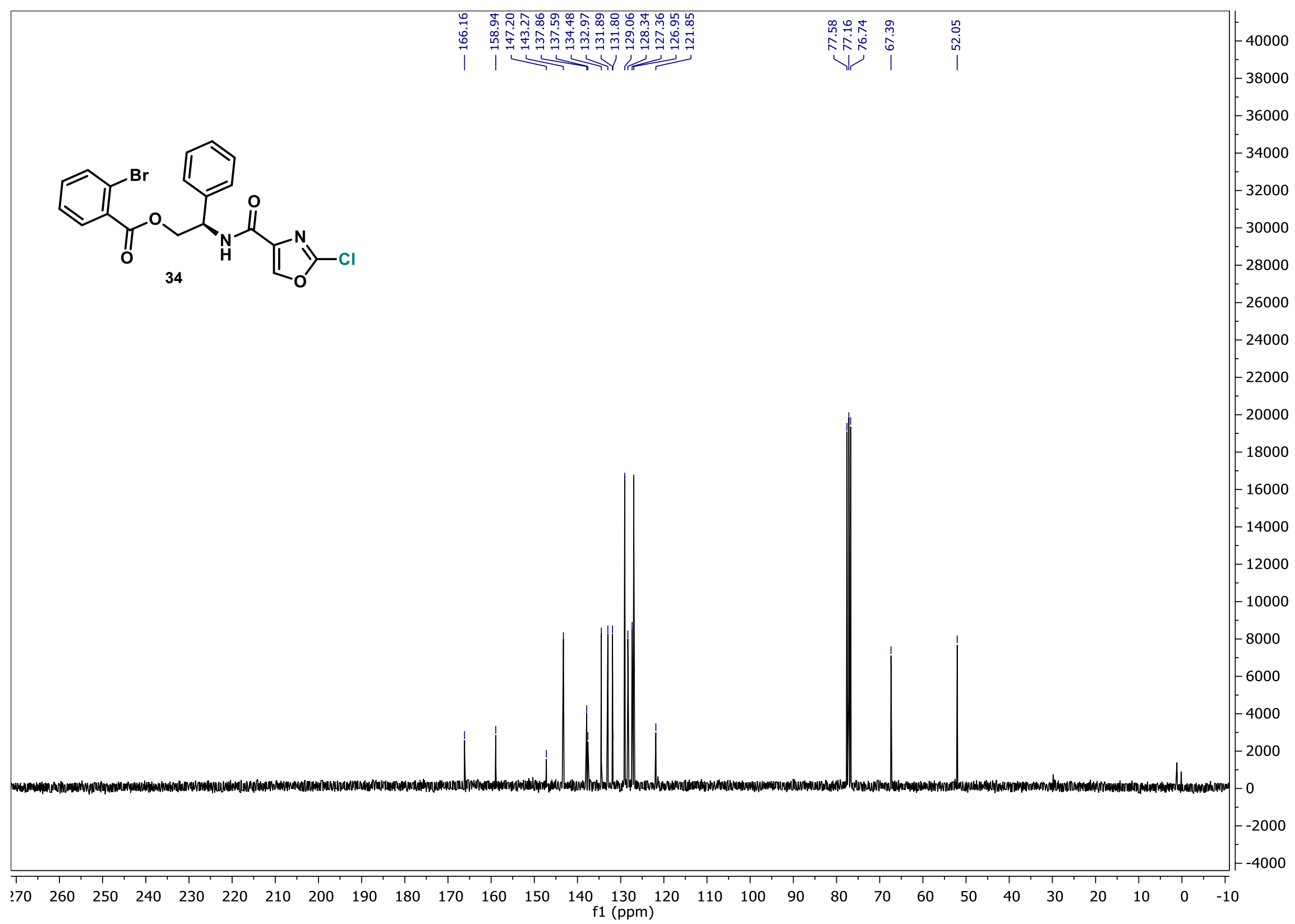


Mass to be matched $(\mathrm{m} / \mathrm{z}): 470.972260$ Charge: 1

Mass Tolerance: \pm 0.005000

Restriction of atom numbers:

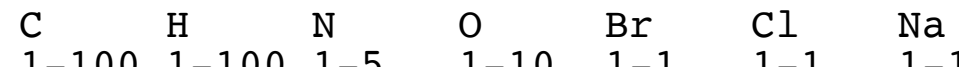

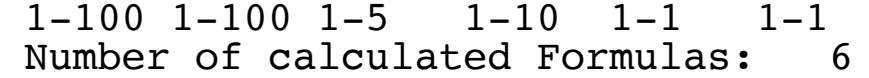

Formula

Diff. (ppm)

$\begin{array}{lllllll}\mathrm{C} 19 & \mathrm{H} 14 & \mathrm{~N} 2 & \mathrm{O} 4 & \mathrm{Br} 1 & \mathrm{Cl} 1 \mathrm{Na}\end{array}$ $-1.02$ theor $\mathrm{m} / \mathrm{z}$
470.971780

C17 H12 N5 O3 Brl Cl1 Na1

$-3.87$

470.970436

$\begin{array}{lllllll}\mathrm{C} 22 & \mathrm{H} 12 & \mathrm{~N} 3 & \mathrm{O} 1 & \mathrm{Br} 1 & \mathrm{Cl} 1 & \mathrm{Na}\end{array}$

C16 H16 N1 O7 Br1 Cl1 Na1

C10 H16 N5 08 Brl $\mathrm{Cl1}$ Nal

$\begin{array}{ll}4.67 & 470.974458\end{array}$

C14 H14 N4 O6 Br1 Cl1 Na1

470.969101

$-9.56 \quad 470.967757$

\begin{tabular}{ll}
$\begin{array}{ll}\text { Datum: } \\
\text { Analyse: }\end{array}$ & 15.10 .2020 \\
& $149897 \mathrm{~d}-00$ \\
Sigel: & GHC-AA-061-01 \\
& COP: Dr. Clement Ghiazza \\
\hline Method: & HR-MS \\
Ionis. : & ESIpos \\
solvent : & CH3OH \\
Spectrometer: Exactive \\
\hline Auswerter: & Marcus, Tel:2243
\end{tabular}

suggestion:

C19H14N2O4Br1Cl1 MW: 448

Characteristic Ions:

$471=[448+\mathrm{Na}]$ 


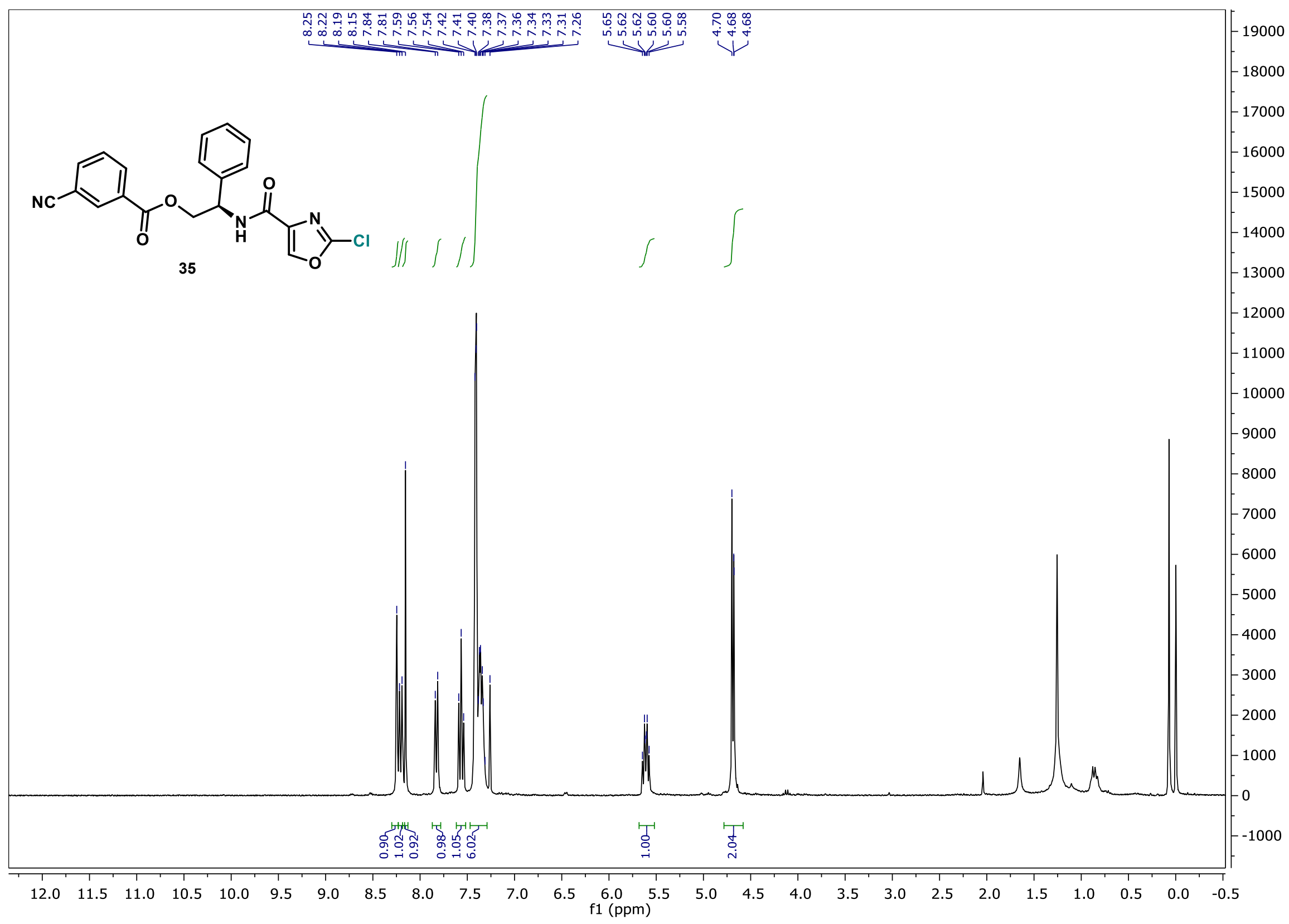




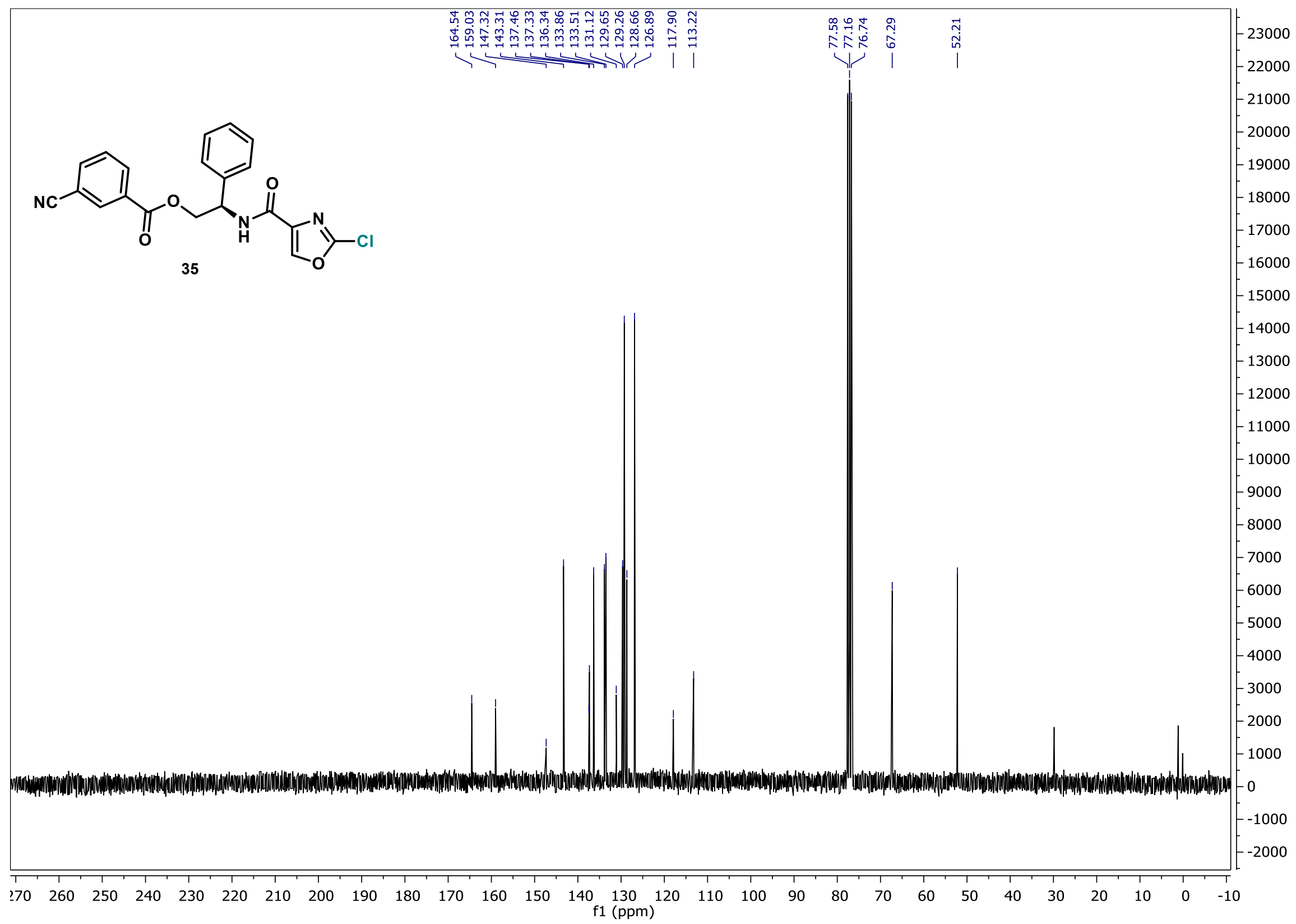




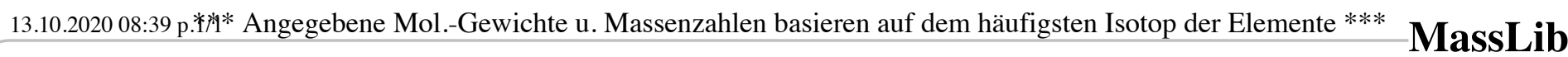

Mass to be matched $(\mathrm{m} / \mathrm{z}): 418.056640$ Charge: 1

Mass Tolerance: \pm 0.005000

13.10 .2020

Restriction of atom numbers :

$\begin{array}{llllll}\mathrm{C} & \mathrm{H} & \mathrm{N} & \mathrm{O} & \mathrm{Cl} & \mathrm{Na} \\ 1-110 & 1-100 & 1-3 & 1-4 & 1-2 & 1-1\end{array}$

Number of calculated Formulas: ${ }^{1-1} 4$

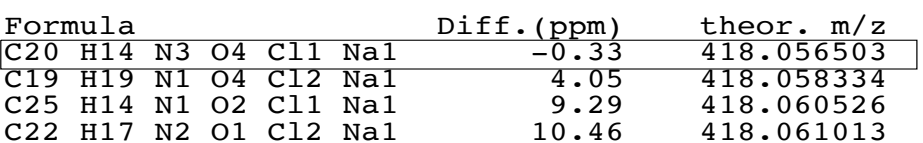

File: $149822 \mathrm{c}-00$

Analyse: GHC-AA-056-01

COP: Dr. Clement Ghiazza

Messung: HRMS ESIpos

Lösemittel: $\mathrm{CH} 3 \mathrm{OH}$

Spektrometer: Exactive

C22 H17 N2 O1 Cl2 Na1 $10.46 \quad 418.061013$

Auswerter: Kohler (2243)

Suggestion :

C20h14N304C11 MW 395

Characteristicial ions:

$418=[395+\mathrm{Na}]+$ 


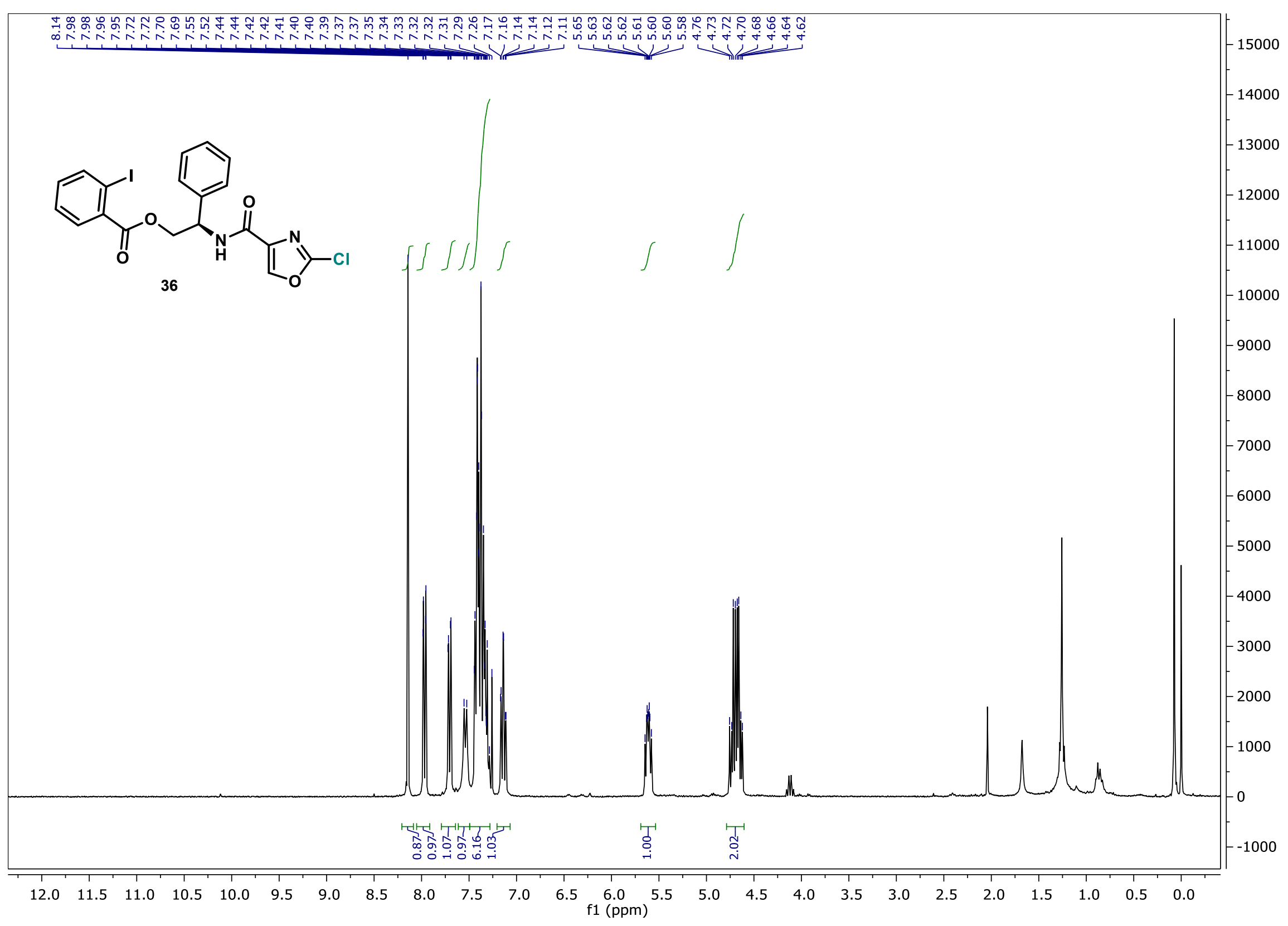




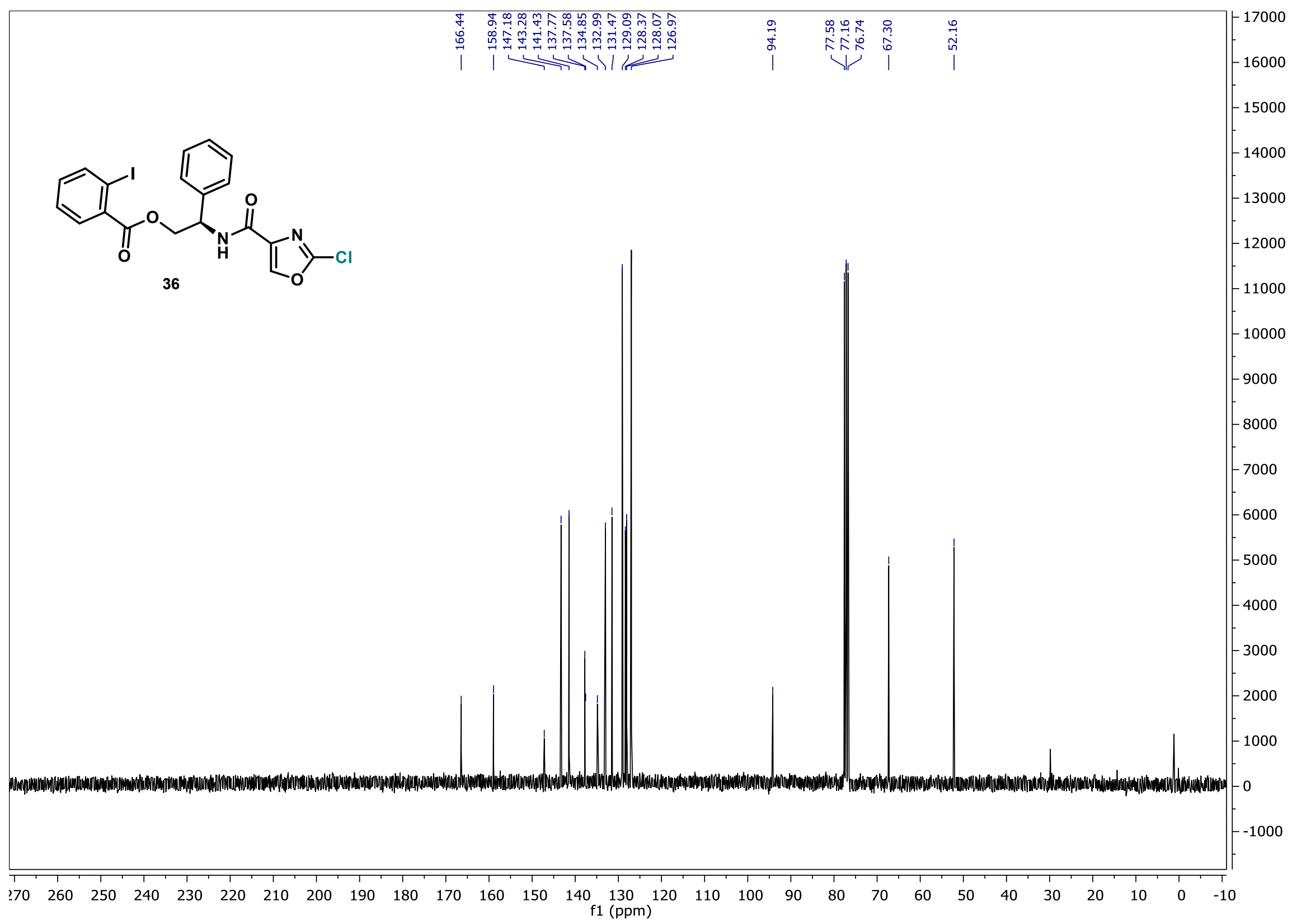


Mass to be matched $(\mathrm{m} / \mathrm{z}): 518.957980$ Charge: 1

Mass Tolerance: \pm 0.005000

Restriction of atom numbers:

$\begin{array}{lllllll}\mathrm{C} & \mathrm{H} & \mathrm{N} & \mathrm{O} & \mathrm{Cl} & \mathrm{I} & \mathrm{Na} \\ 1-100 & 1-100 & 1-5 & 1-10 & 1-1 & 1-1 & 1-1\end{array}$

Number of calculated Formulas: 6

Formula

$\begin{array}{lllllll}\mathrm{C} 19 & \mathrm{H} 14 & \mathrm{~N} 2 & 04 & \mathrm{Cl} 1 & \mathrm{I} 1 & \mathrm{Na} 1\end{array}$

C17 H12 N5 03 Cl1 I1 Na1

C22 H12 N3 O1 Cl1 I1 Na1

C16 H16 N1 07 Cl1 I1 Na1

C14 H14 N4 O6 Cl1 I1 Nal

C10 H16 N5 08 Cl1 I1 Na1
Diff. (ppm) $-0.15$ $-2.74$

5.01

$-5.31$

$-7.90$

8.58 theor. $\mathrm{m} / \mathrm{z}$ 518.957902

518.956558

518.960581

518.955223

518.953879

518.962433

\begin{tabular}{ll} 
Datum: & 30.10 .2020 \\
Analyse: & $150172 \mathrm{c}-00$ \\
\hline
\end{tabular}

Sigel: GHC-AA-051-01 COP : Dr. Clement Ghiazza

Method: HR-MS

Ionis. : ESIpos

solvent : $\mathrm{CH} 3 \mathrm{OH}$

Spectrometer: Exactive

Auswerter: Marcus, Tel:2243

suggestion:

C19H14N2O4I1Cl1 MW: 496

Characteristic Ions:

$519=[496+\mathrm{Na}]$ 
${ }^{1} \mathrm{H}$ NMR

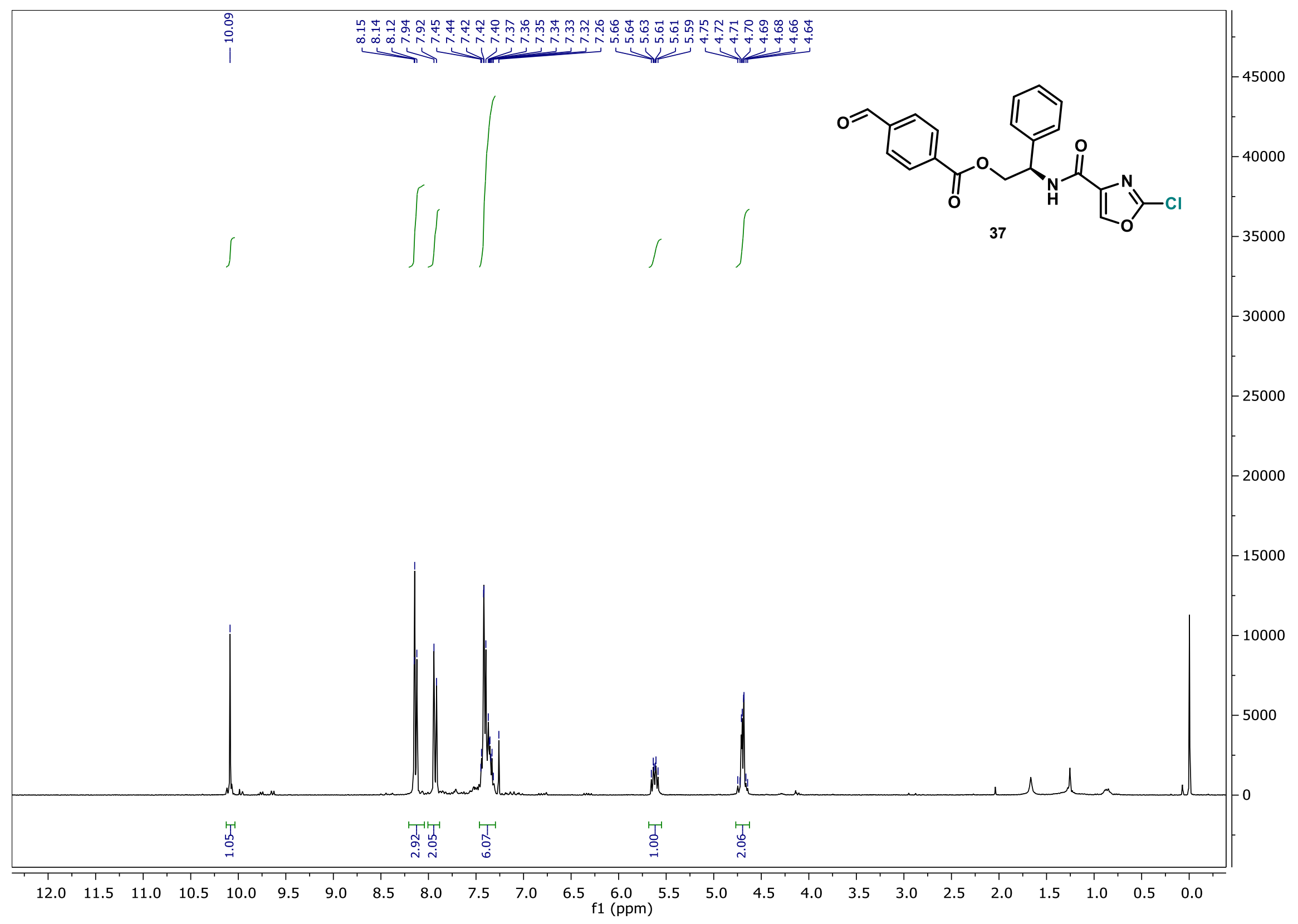




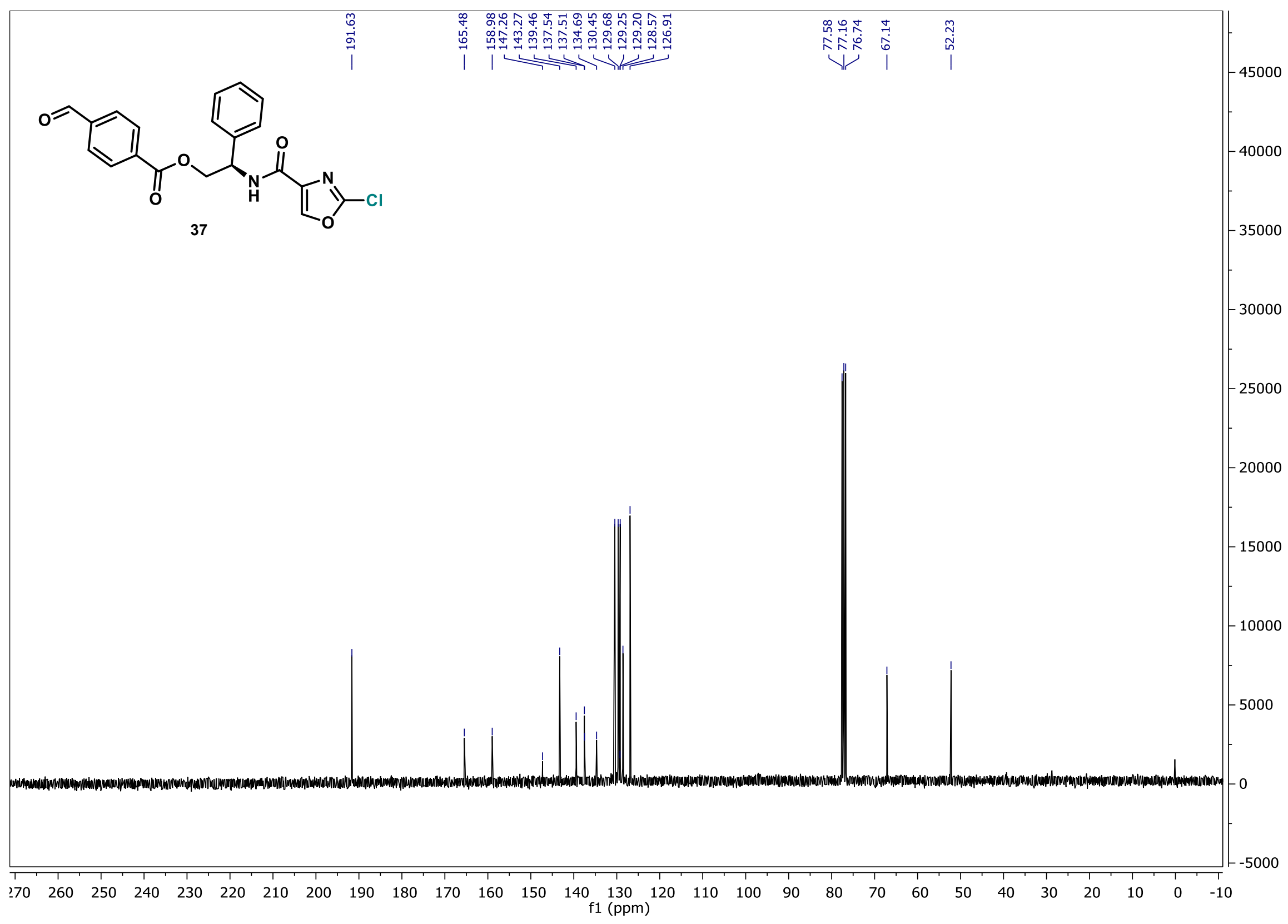


Mass to be matched $(\mathrm{m} / \mathrm{z}): 421.056580$ Charge: 1

Mass Tolerance: \pm 0.005000

Restriction of atom numbers :

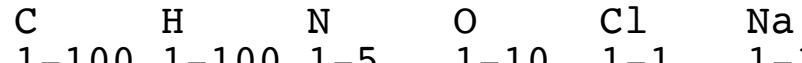

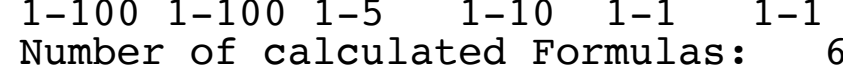

\begin{tabular}{|llllllrr|}
\multicolumn{2}{c}{ Formula } \\
C20 & H15 & N2 & O5 & Cl1 & Na1 & Diff. (ppm) & theor. $\mathrm{m} / \mathrm{z}$ \\
C18 & H13 & N5 & O4 & Cl1 & Na1 & -0.98 & 421.056169 \\
C23 & H13 & N3 & O2 & Cl1 & Na1 & -4.17 & 421.054826 \\
C17 & H17 & N1 & O8 & Cl1 & Na1 & 5.39 & 421.058848 \\
C11 & H17 & N5 & O9 & Cl1 & Na1 & -7.34 & 421.053491 \\
C15 & H15 & N4 & O7 & Cl1 & Na1 & -10.79 & 421.060700 \\
\end{tabular}

$\begin{array}{ll}\text { Datum: } & 15.10 .2020 \\ \text { Analyse: } & 149877 \mathrm{c}-00\end{array}$

Sigel: $\quad$ GHC-AA-065-01

COP: Dr. Clement Ghiazza

$\begin{array}{ll}\text { Method: } & \text { HR-MS } \\ \text { Ionis. : } & \text { ESIpos }\end{array}$

solvent : $\mathrm{CH} 3 \mathrm{OH}$

Spectrometer: Exactive

Auswerter: Marcus, Tel:2243

suggestion:

C20H15N2O5Cl1 MW: 398

Characteristic Ions:

$421=[398+\mathrm{Na}]$ 


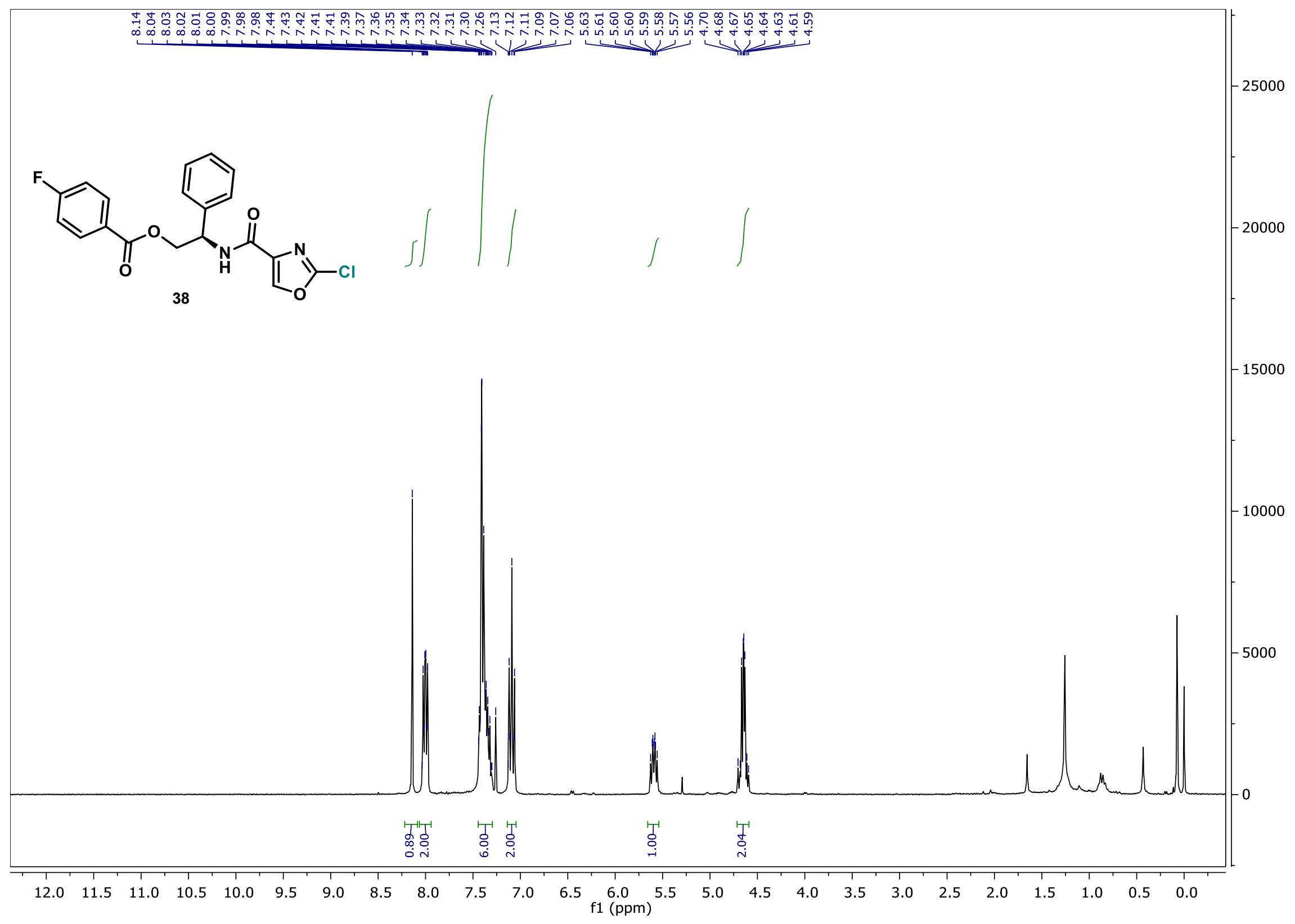




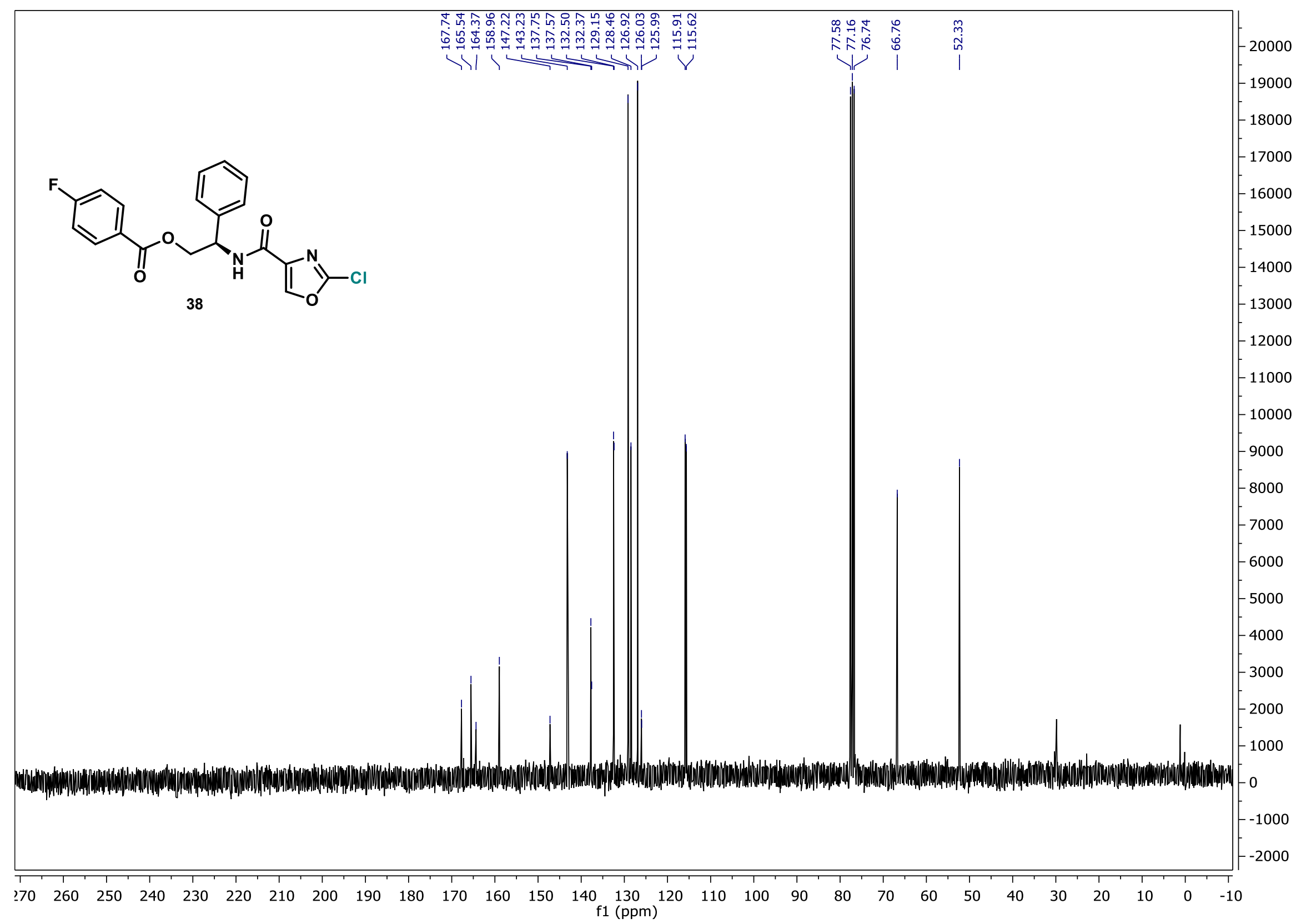




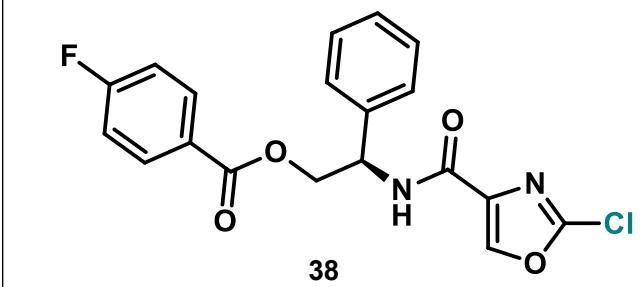


Mass to be matched $(\mathrm{m} / \mathrm{z}): 411.052650$ Charge: 1

Mass Tolerance: \pm 0.005000

Restriction of atom numbers:

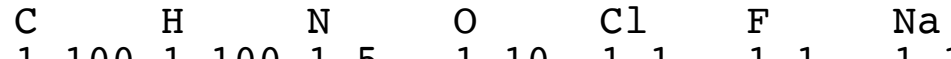

$\begin{array}{llllll}1-100 & 1-100 & 1-5 & 1-10 & 1-1 & 1-1 \\ \text { Number of calculated Formulas: } & 1-1\end{array}$ 6

Formula Diff. (ppm) $-1.99$

1 Datum:

15.10 .2020

Analyse:

$149871 \mathrm{c}-00$

$\begin{array}{lllllll}\mathrm{C} 19 & \mathrm{H} 14 & \mathrm{~N} 2 & \mathrm{O} 4 & \mathrm{Cl} 1 \mathrm{~F} 1 & \mathrm{Na} 1\end{array}$

Sigel:

GHC-AA-0 48-01

C22 112 N3 01 Cl1 F1 Na1

4.53

$-5.26$

$-8.50$

9.04

$-11.77$ 411.051833 411.054512

411.050489

C16 H16 N1 07 Cl1 F1 Na1

C10 H16 N5 08 Cl1 F1 Na1

411.049154

COP : Dr. Clement

Method: HR-MS

Ionis. : ESIpos

solvent : $\quad \mathrm{CH} 3 \mathrm{OH}$

Spectrometer: Exactive

$\begin{array}{lllllll}\mathrm{C} 14 & \mathrm{H} 14 & \mathrm{~N} 4 & \mathrm{O} 6 & \mathrm{Cl} 1 & \mathrm{~F} 1 & \mathrm{Na} 1\end{array}$

411.056364

Auswerter:

Marcus, Tel:2243

411.047810

suggestion:

C19H14N2O4Cl1F1 MW: 388

Characteristic Ions:

$411=[388+\mathrm{Na}]$ 


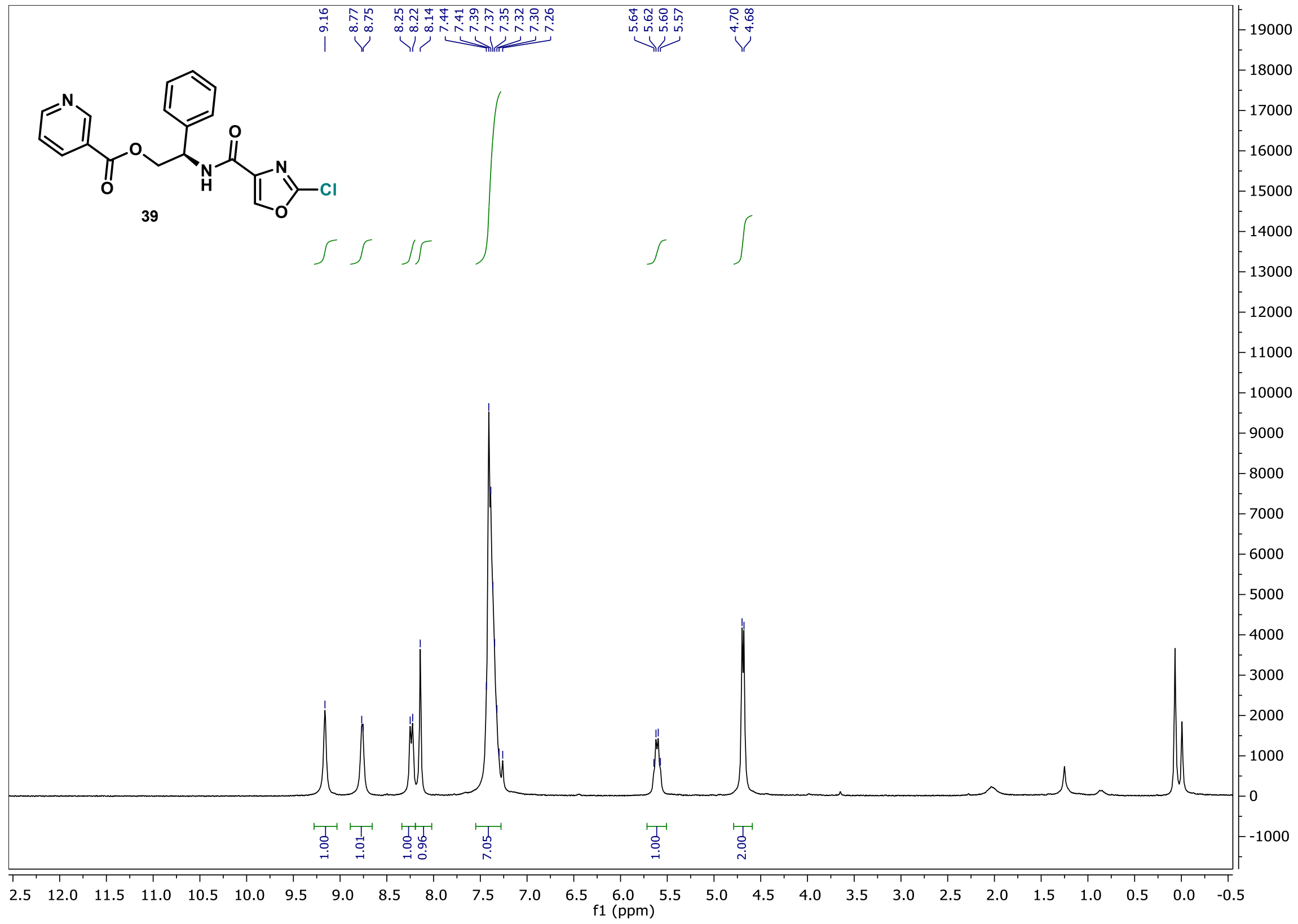




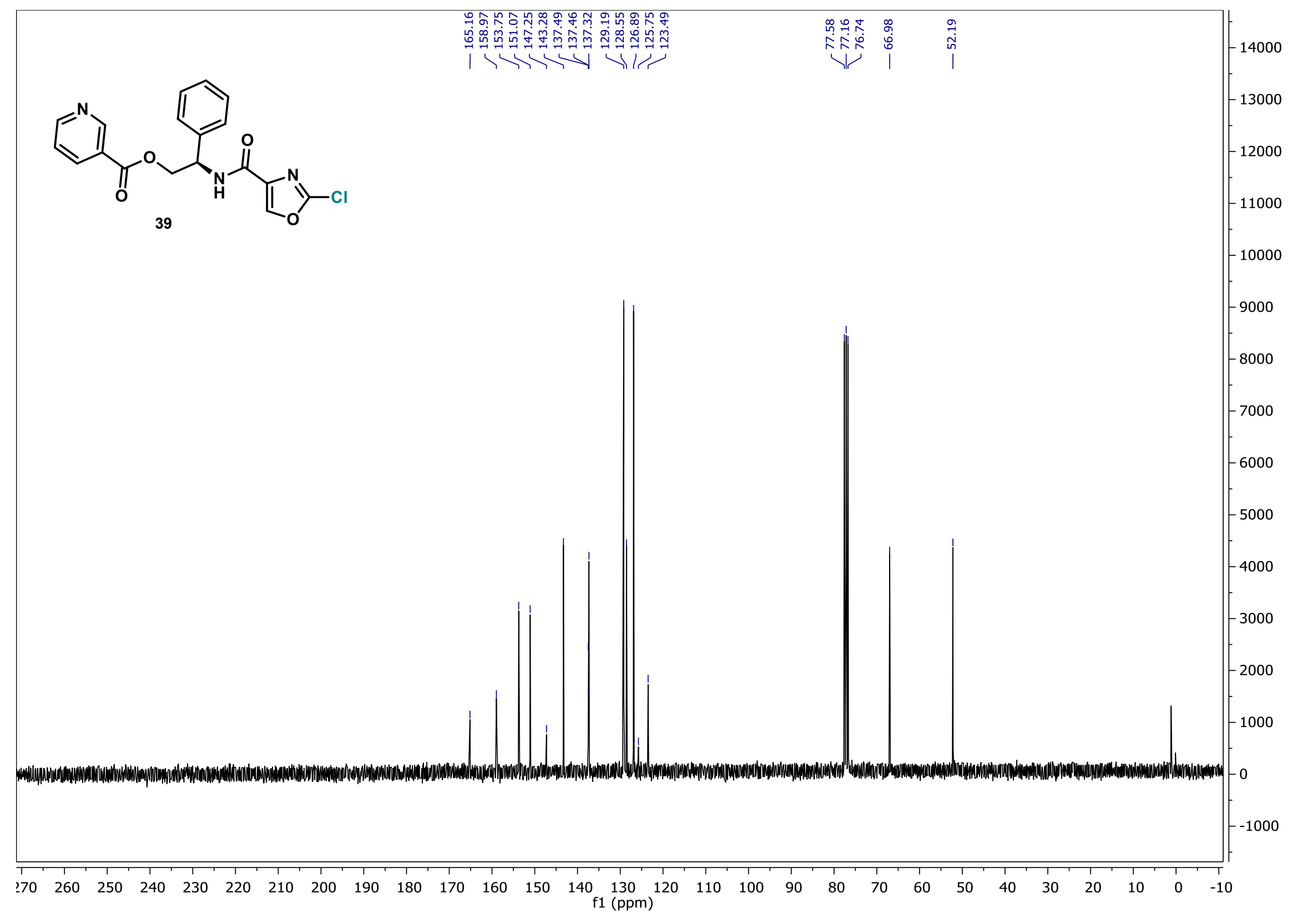


Mass to be matched $(\mathrm{m} / \mathrm{z}): 394.056660$ Charge: 1

Mass Tolerance: \pm 0.005000

Restriction of atom numbers:

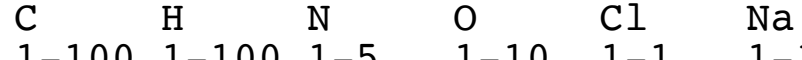

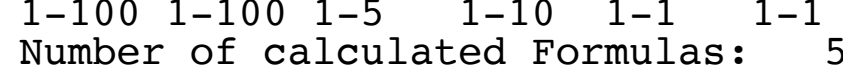

\begin{tabular}{|llllllrr|}
\multicolumn{2}{c}{ Formula } & \multicolumn{1}{c|}{ Diff. (ppm) } & theor. $\mathrm{m} / \mathrm{z}$ \\
C18 & H14 & N3 & O4 & Cl1 & Na1 & -0.40 & 394.056503 \\
C21 & H12 & N4 & O1 & Cl1 & Na1 & 6.40 & 394.059182 \\
C15 & H16 & N2 & O7 & Cl1 & Na1 & -7.20 & 394.053824 \\
C23 & H14 & N1 & O2 & Cl1 & Na1 & 9.81 & 394.060526 \\
C13 & H14 & N5 & O6 & Cl1 & Na1 & -10.61 & 394.052481
\end{tabular}

\begin{tabular}{|c|c|}
\hline $\begin{array}{l}\text { Datum: } \\
\text { Analyse: }\end{array}$ & $\begin{array}{l}15.10 .2020 \\
149898 c-00\end{array}$ \\
\hline Sigel: & $\begin{array}{l}\text { GHC-AA-066-01 } \\
\text { COP: Dr. Clement Ghiazza }\end{array}$ \\
\hline $\begin{array}{l}\text { Method: } \\
\text { Ionis. : } \\
\text { solvent : } \\
\text { Spectrometer: }\end{array}$ & $\begin{array}{l}\text { HR-MS } \\
\text { ESIpos } \\
\text { CH3OH } \\
\text { Exactive }\end{array}$ \\
\hline Auswerter: & Marcus, Tel:2243 \\
\hline
\end{tabular}

suggestion:

C18H14N304Cl1 MW: 371

Characteristic Ions:

$394=[371+\mathrm{Na}]$ 
${ }^{1} \mathrm{H}$ NMR

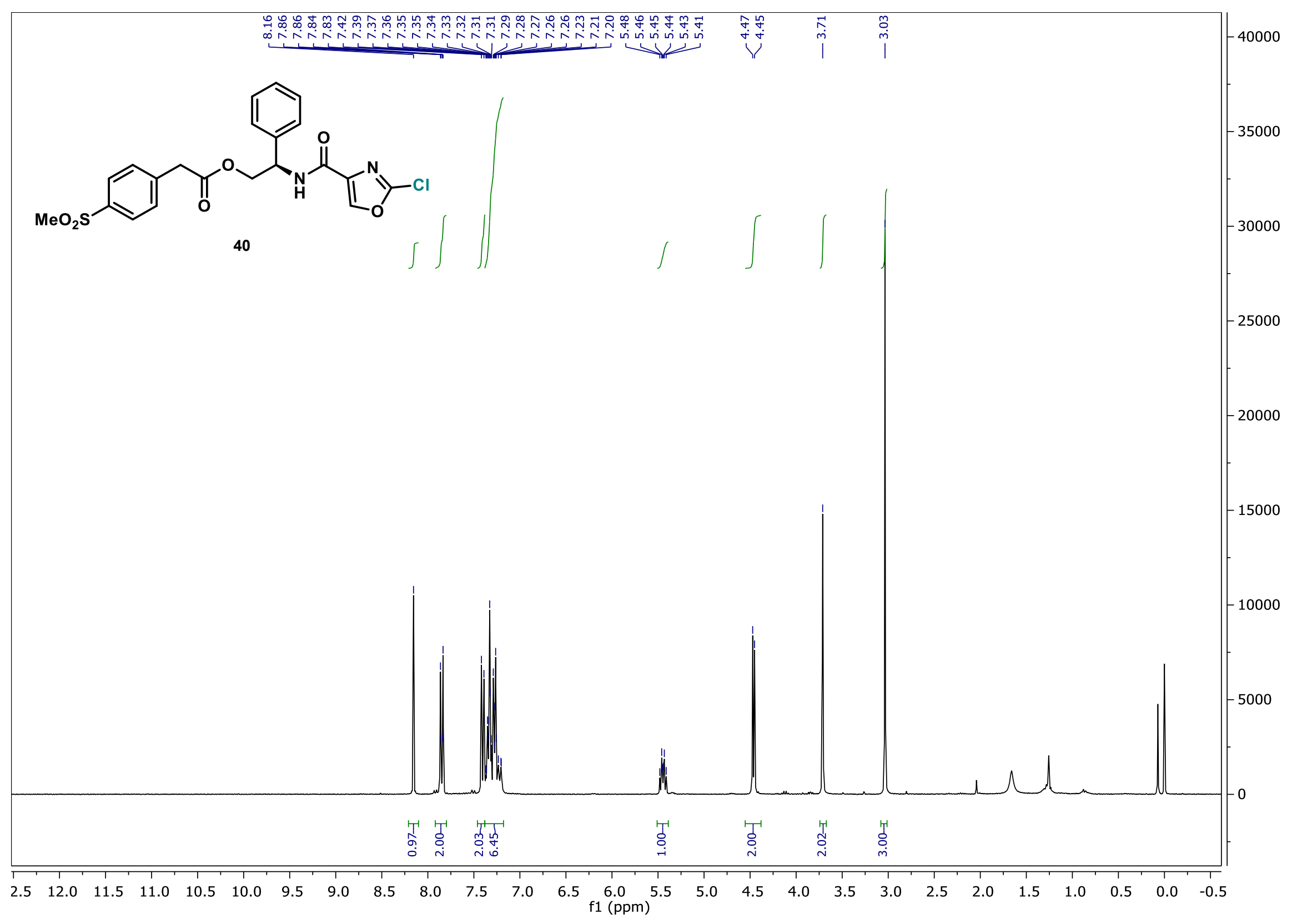




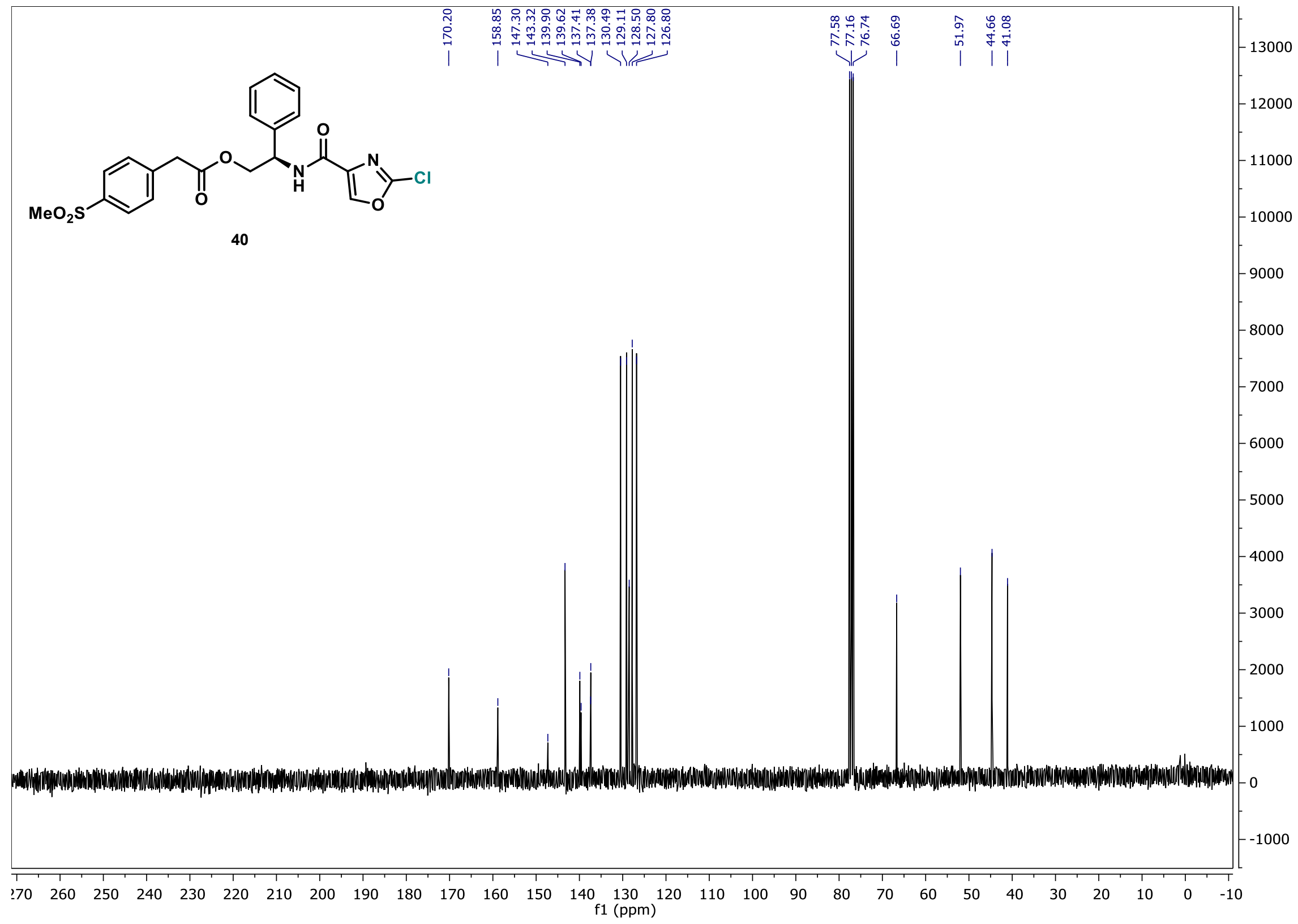


Mass to be matched $(\mathrm{m} / \mathrm{z}): 485.055210$ Charge: 1

Mass Tolerance: \pm 0.005000

Restriction of atom numbers:

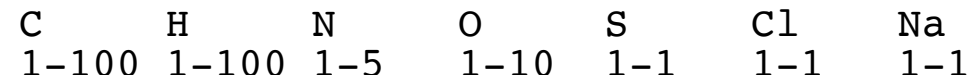

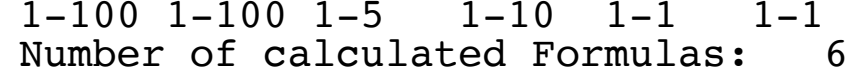

Formula Diff. (ppm) theor. $\mathrm{m} / \mathrm{z}$

C21 H19 N2 O6 S1 C11 Na1 $\quad-1.55 \quad 485.054457$

C24 H17 N3 O3 S1 Cl1 Na1 $\quad 3.97 \quad 485.057135$

C19 H17 $\mathrm{N} 5$ O5 $\mathrm{S} 1 \mathrm{Cl1} \mathrm{Na} 1$

$-4.32 \quad 485.053113$

C18 H21 N1 O9 S1 Cl1 Na1

485.053113
485.051778

C12 H21 N5 010 S1 Cl1 Na1

$-7.08$

485.051778

C16 H19 N4 08 S1 Cl1 Na1

$-9.85 \quad 485.050434$

\begin{tabular}{ll} 
Datum: & 15.10 .2020 \\
Analyse: & $149873 \mathrm{C}-00$ \\
\hline Sigel: & GHC-AA-057-01 \\
& COP: Dr. Clement Ghiazza \\
\hline Method: & HR-MS \\
Ionis. : & ESIpos \\
Solvent : & CH3OH \\
Spectrometer: Exactive \\
\hline Auswerter: & Marcus, Tel:2243
\end{tabular}

suggestion:

C21H19N206S1Cl1 MW : 462

Characteristic Ions:

$485=[462+\mathrm{Na}]$ 
${ }^{1} \mathrm{H} N M R$ - in situ

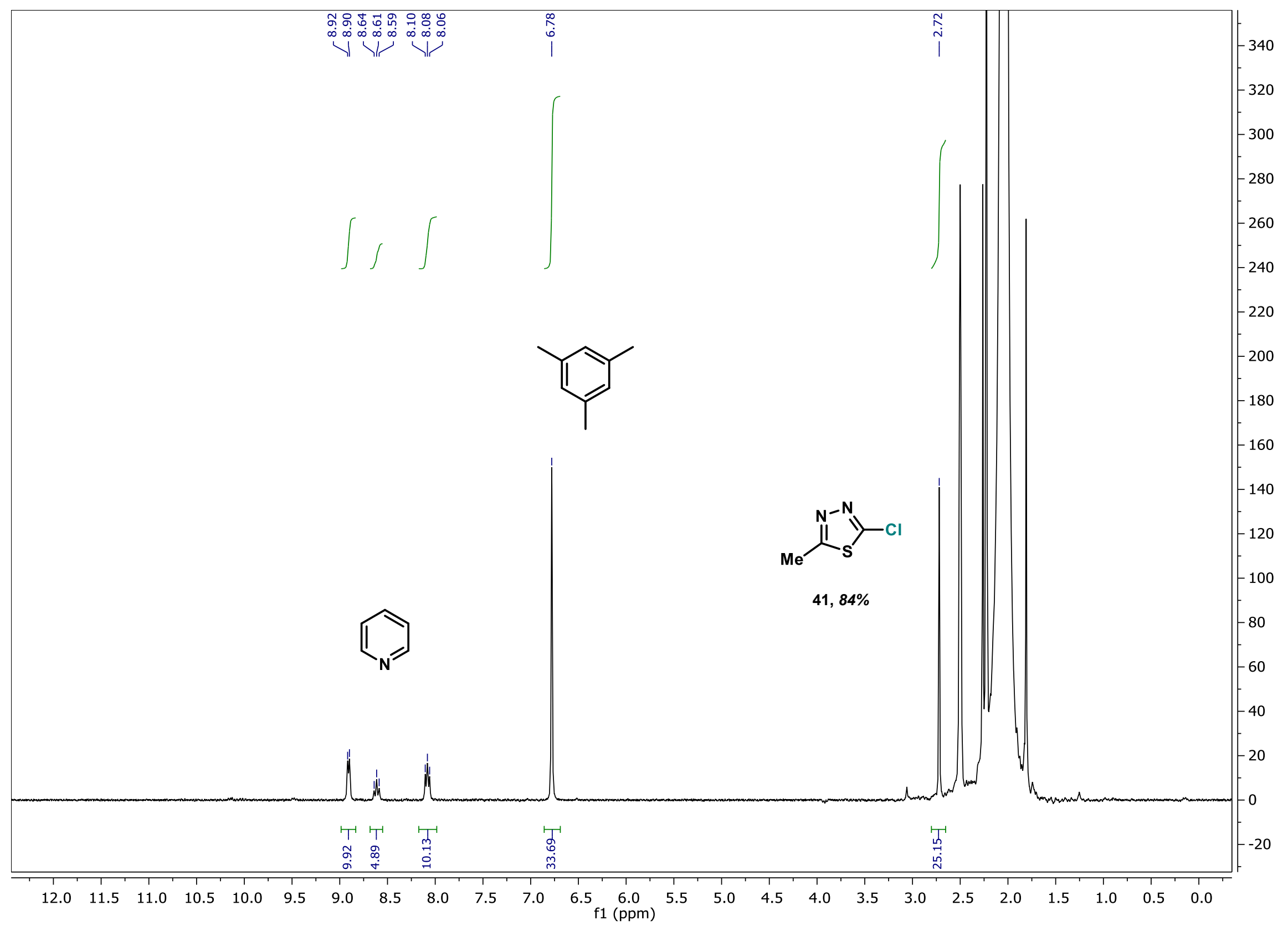




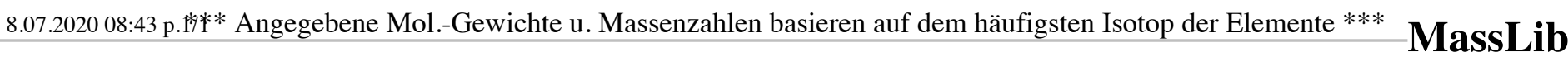

Mass to be matched $(\mathrm{m} / \mathrm{z}): 133.970270$ Charge: 1

Mass Tolerance: \pm 0.050000

Restriction of atom numbers:

$\begin{array}{lllll}\mathrm{C} & \mathrm{H} & \mathrm{N} & \mathrm{Cl} & \mathrm{S} \\ 1-100 & 1-100 & 1-2 & 1-2 & 1-1\end{array}$

Number of calculated Formulas: 3

Formula $\quad$ Diff. (ppm) theor. $\mathrm{m} / \mathrm{z}$

$\begin{array}{rrrrrrr}\mathrm{C} 3 & \mathrm{H} 3 & \mathrm{~N} 2 & \mathrm{Cl} 1 & \mathrm{~S} 1 & -2.03 & 133.969998 \\ \mathrm{C} 1 & \mathrm{H} 6 & \mathrm{~N} 1 & \mathrm{Cl} 12 & \mathrm{~S} 1 & -82.24 & 133.959252\end{array}$

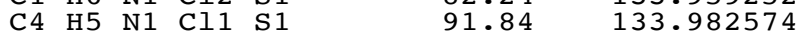

Suggestion:

C3H3N2Cl1S1 MW: 134
8.07 .2020

File: 147977c-00.raw

Analyse: GHC-GA-191-01

COP: Dr. Clement Ghiazza

Messung: GC-MS

Ionisierung: GC-EI

Spektrometer: Q Exactive GC Orbitrap

Säule: MS 75 ZB-5HT 30+5

Länge: $\quad 30+5$

Temp.: $\quad 35-10-285-5$

$\mathrm{GC}-\mathrm{Nr}$ : :

ELNA-Nr.: $\quad 25986$

Auswerter: Haupt (2243) 
${ }^{1} \mathrm{H} N M R$ - in situ

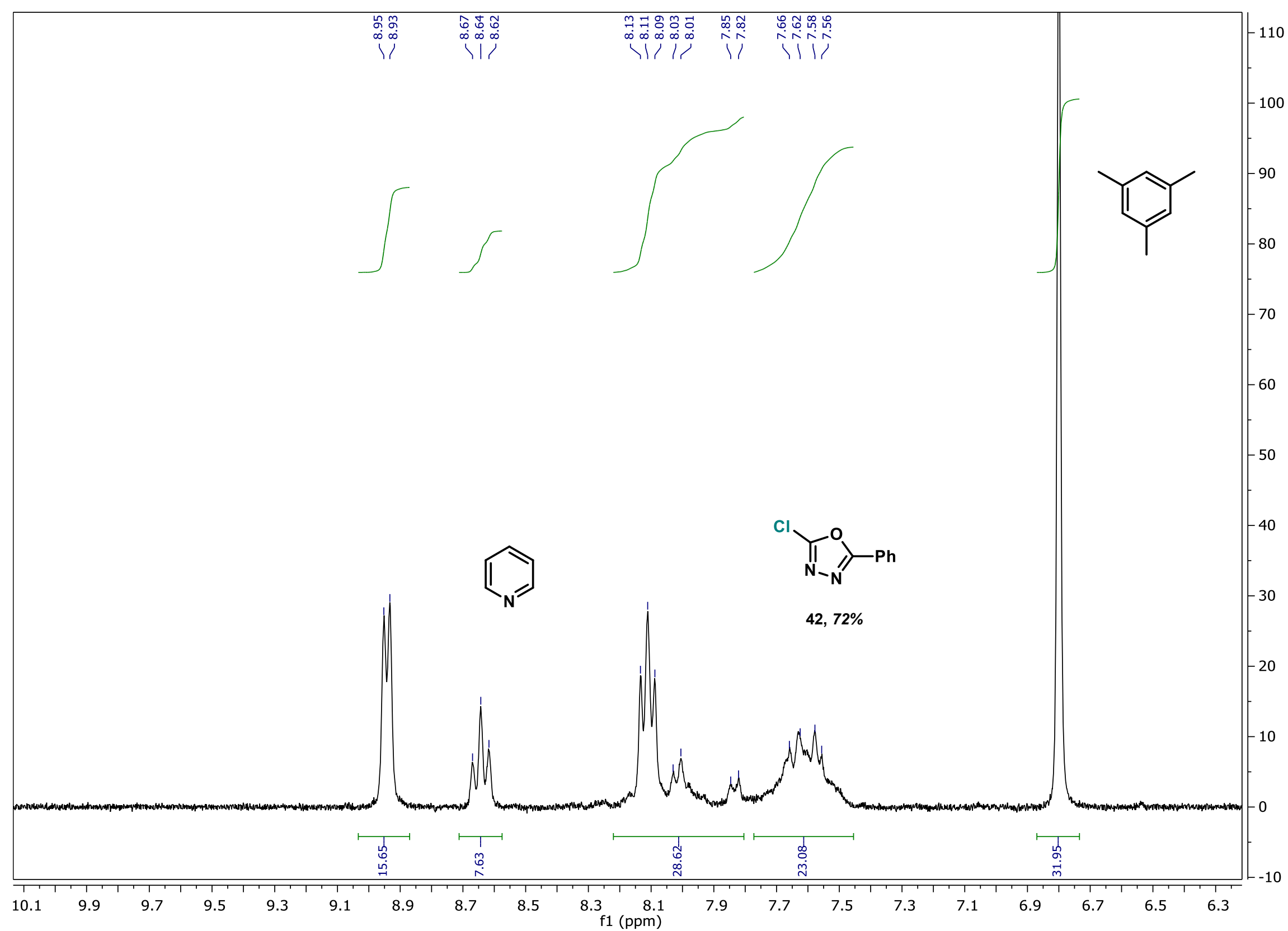




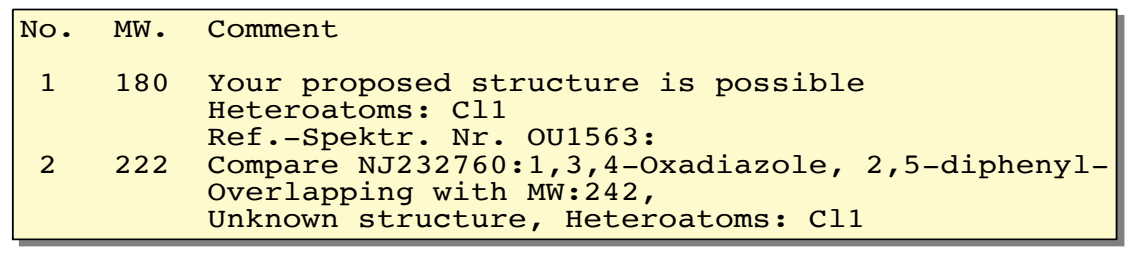

6.10 .2020

File: 149714a-00.raw

Analyse: GHC-GA-366-01

COP: Dr. Clement Ghiazza

Messung: GC-MS

Ionisierung: GC-EI

Spektrometer: QExactiveGC

Säule:

MS $50 \mathrm{TX} 1+\mathrm{VS}$

Iänge: $\quad 30+7$

Temp.: 35-10-285-5

$\mathrm{GC}-\mathrm{Nr}$. :

$-$

Auswerter: Margold
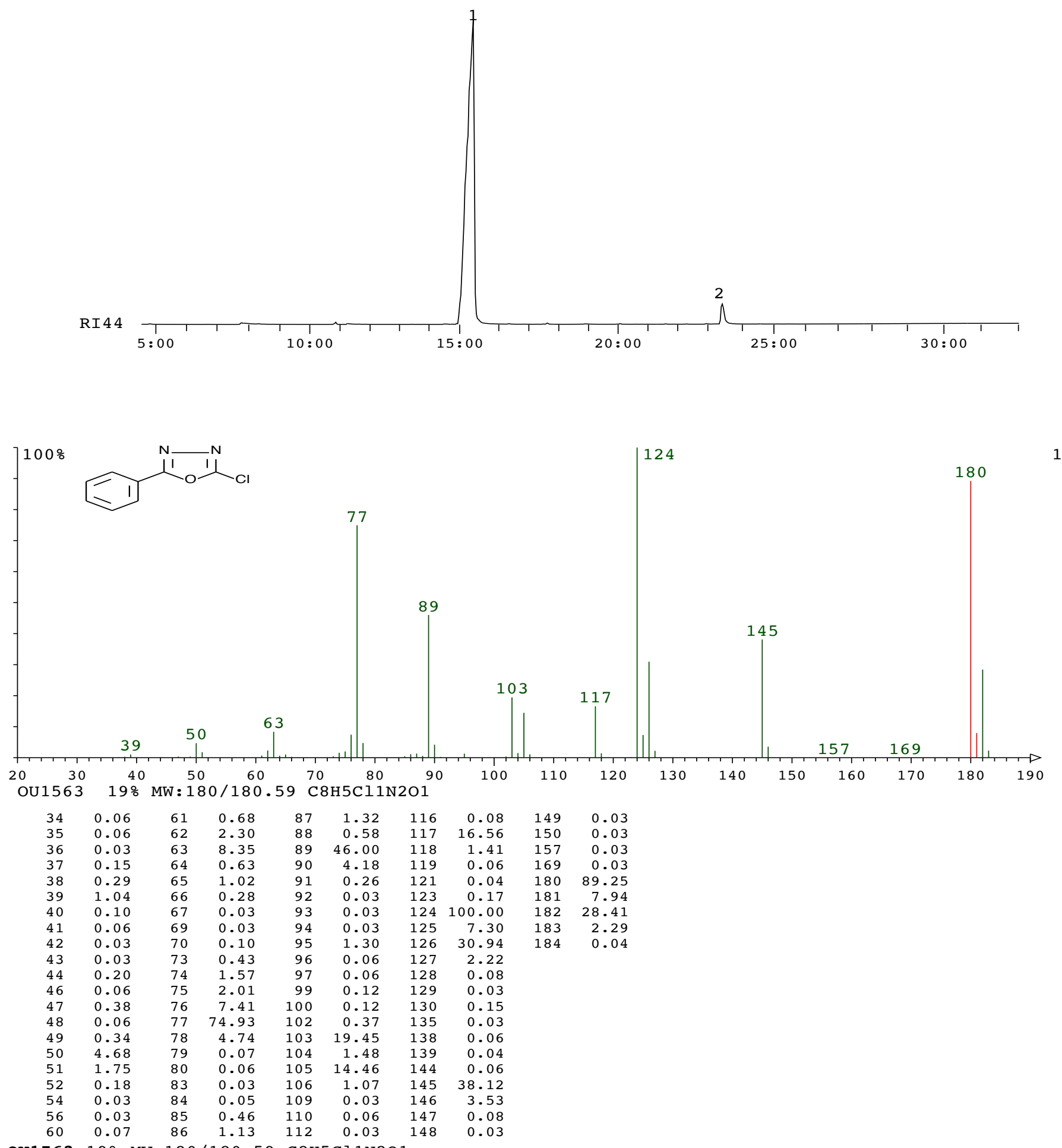

OU1563 19\% MW: $180 / 180.59$ C 8 H5Cl1N2O1 


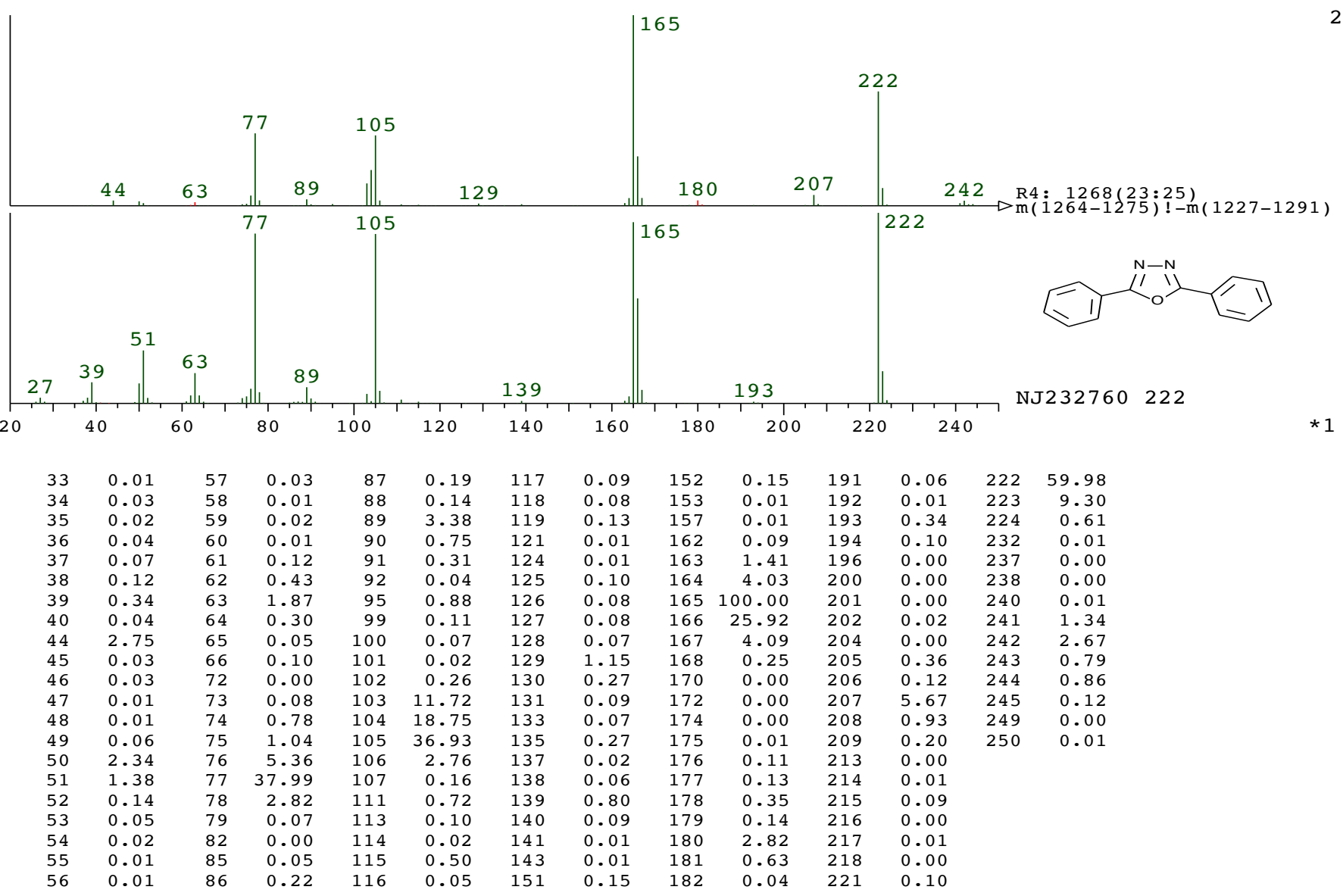

R4 : $1268(23: 25) \mathrm{m}(1264-1275)$ 149714a-00! -m(1227-1291) 14361 27\% 149714a-00 * GHC-GA-366-01

Mass to be matched $(\mathrm{m} / \mathrm{z}): 180.008840$ Charge: 1

Mass Tolerance: \pm 0.005000

Restriction of atom numbers:

$\begin{array}{lllll}\mathrm{C} & \mathrm{H} & \mathrm{N} & \mathrm{O} & \mathrm{Cl} \\ 1-110 & 1-100 & 1-2 & 1-5 & 1-1\end{array}$

Number of calculated Formulas: 2

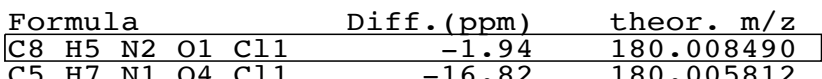

6.10 .2020

File: $149714 a-00$. raw

Analyse: GHC-GA-366-01

COP: Dr. Clement Ghiazza

\begin{tabular}{ll}
\hline Messung: & GC-MS \\
Ionisierung: & GC-EI \\
Spektrometer: & QExactiveGC \\
Säule: & MS 50 TX1+VS \\
Länge: & $30+7$ \\
Temp.: & $35-10-285-5$ \\
GC-Nr.: & - \\
\hline Auswerter: & Margold
\end{tabular}




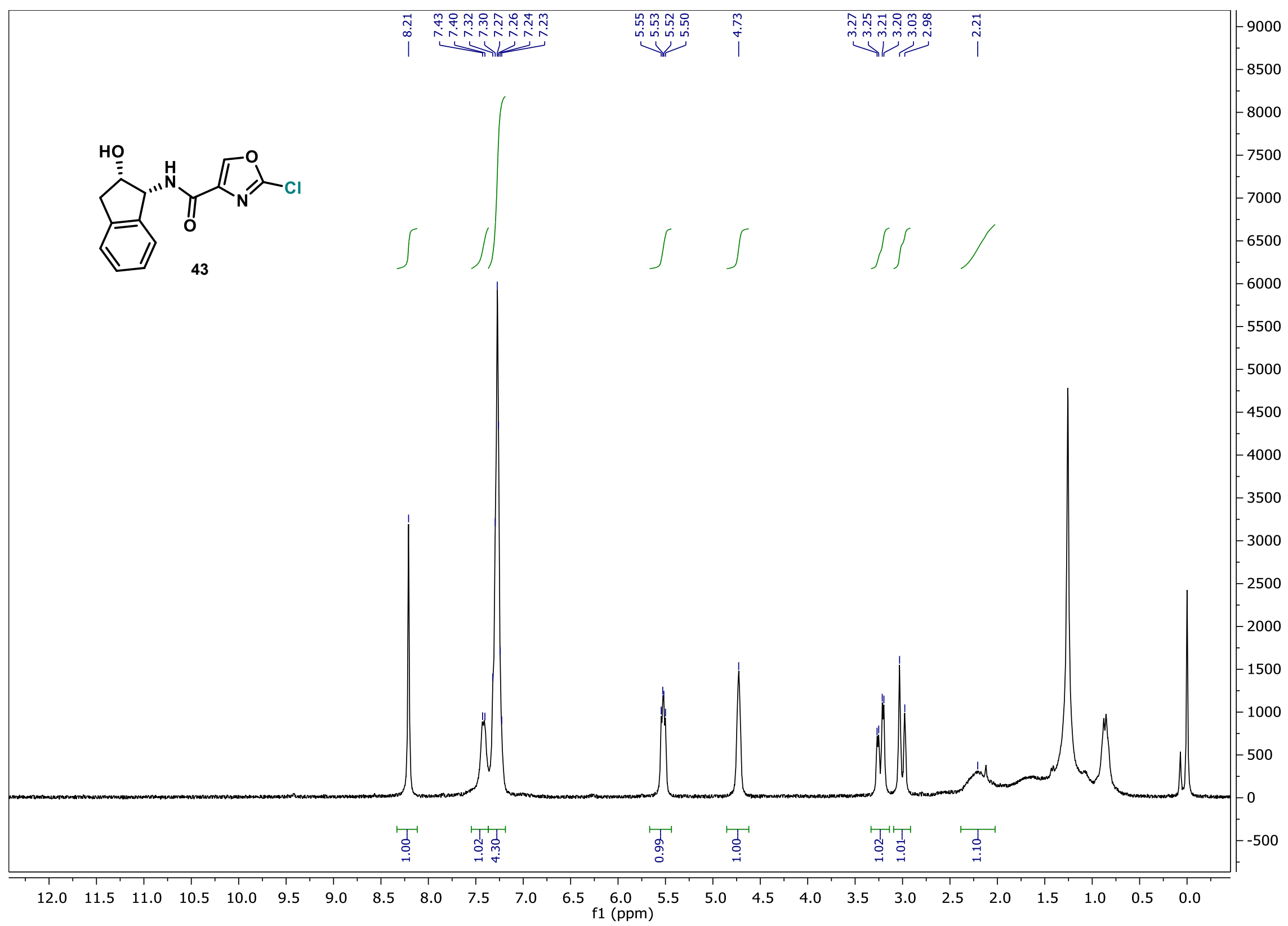




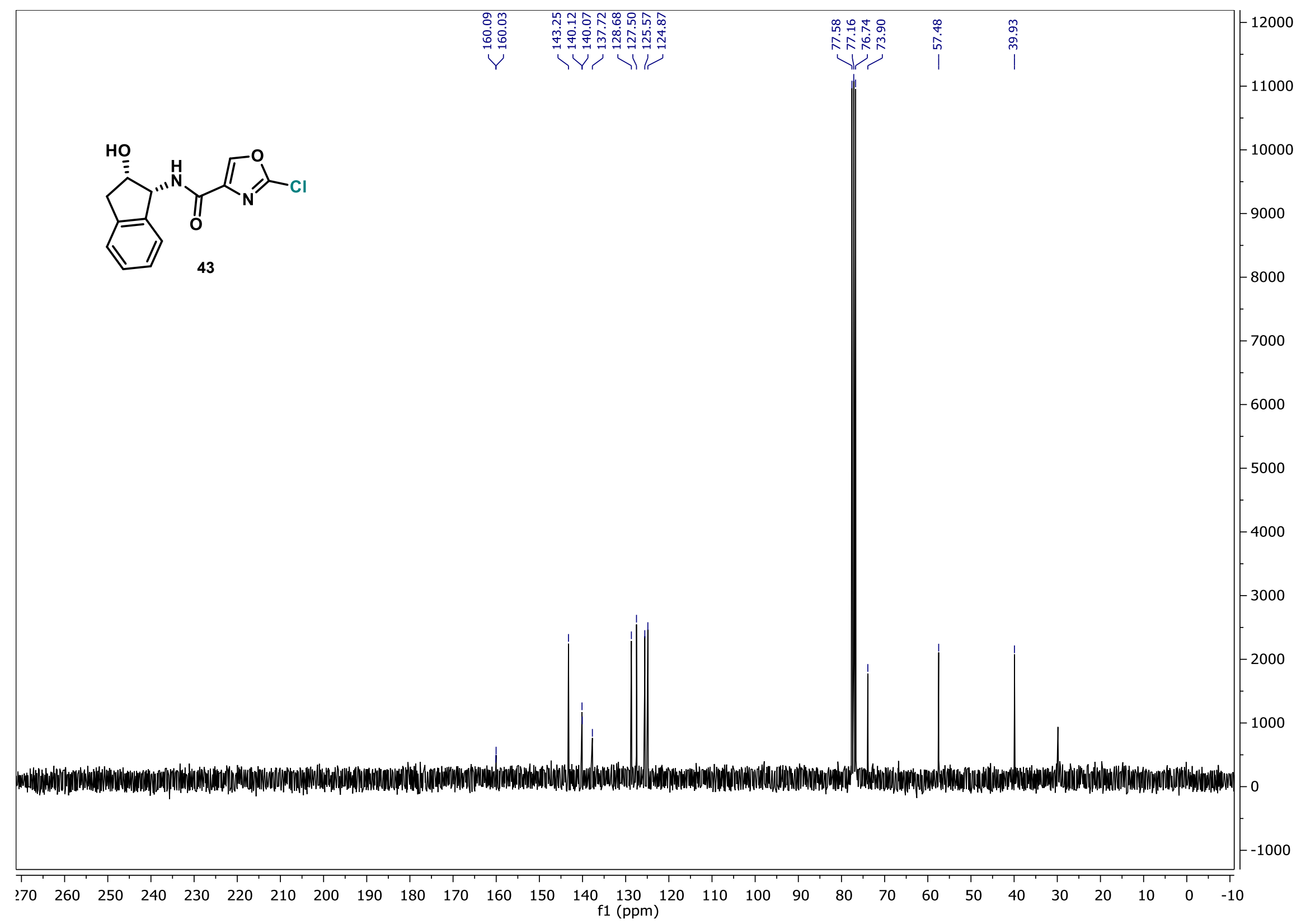


Mass to be matched $(\mathrm{m} / \mathrm{z}): 301.034780$ Charge: 1

Mass Tolerance: \pm 0.005000

Restriction of atom numbers:

$\begin{array}{lllllll}\mathrm{C} & \mathrm{H} & \mathrm{Cl} & \mathrm{N} & \mathrm{O} & \mathrm{Na} \\ 1-100 & 1-100 & 1-1 & \max 2 & \max 10 & 1-1\end{array}$

Number of calculated Formulas: 3

Formula

$\begin{array}{lllllll}\text { C13 } & \text { H11 } & \text { Cl1 } & \text { N2 } & 03 & \mathrm{Na1}\end{array}$

Diff.(ppm)

0.86

theor. $\mathrm{m} / \mathrm{z}$

C10 $\mathrm{H} 13 \mathrm{Cl} 1 \mathrm{~N} 1 \mathrm{O} \mathrm{Na}$

C18 H11 Cl1 O1 Na1
$-8.04301 .032361$

301.039062

\begin{tabular}{|c|c|}
\hline $\begin{array}{l}\text { Datum } \\
\text { Analyse: }\end{array}$ & $\begin{array}{l}19.10 .2020 \\
149943 c-00\end{array}$ \\
\hline Sigel: & GHC-AA-069-01 \\
\hline COP: Dr. Clement & t Ghiazza \\
\hline Messung: & HRMS \\
\hline Methode: & ESIpos \\
\hline Lösungsmittel: & $\mathrm{CH} 3 \mathrm{OH}$ \\
\hline Spektrometer: & Exactive \\
\hline Auswerter: & Kampen (2242) \\
\hline
\end{tabular}

Suggestion:

C13H11Cl1N2O3 MW 278

characteristical ion

$301=[278+\mathrm{Na}]+$ 
${ }^{1} \mathrm{H}$ NMR

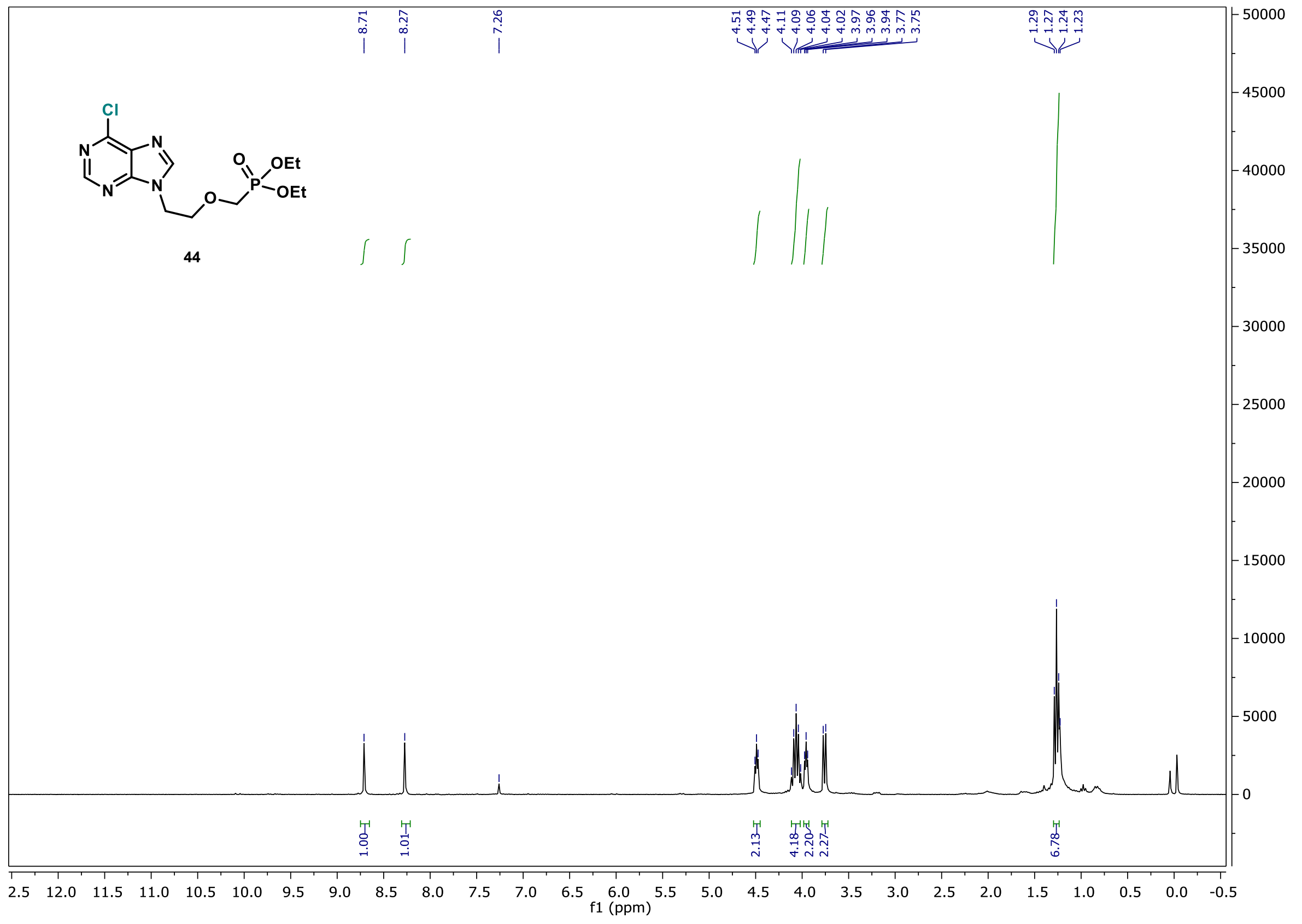




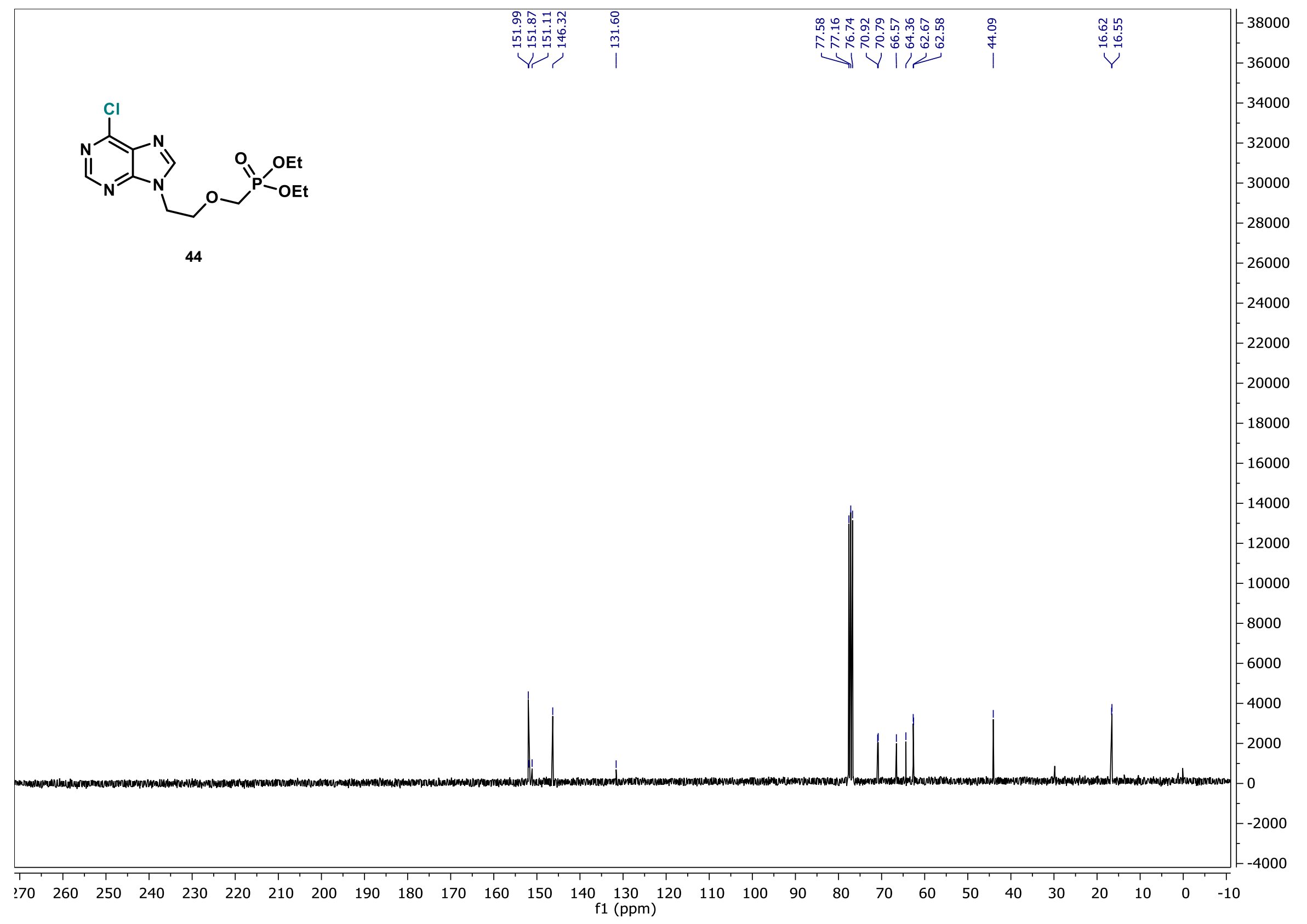




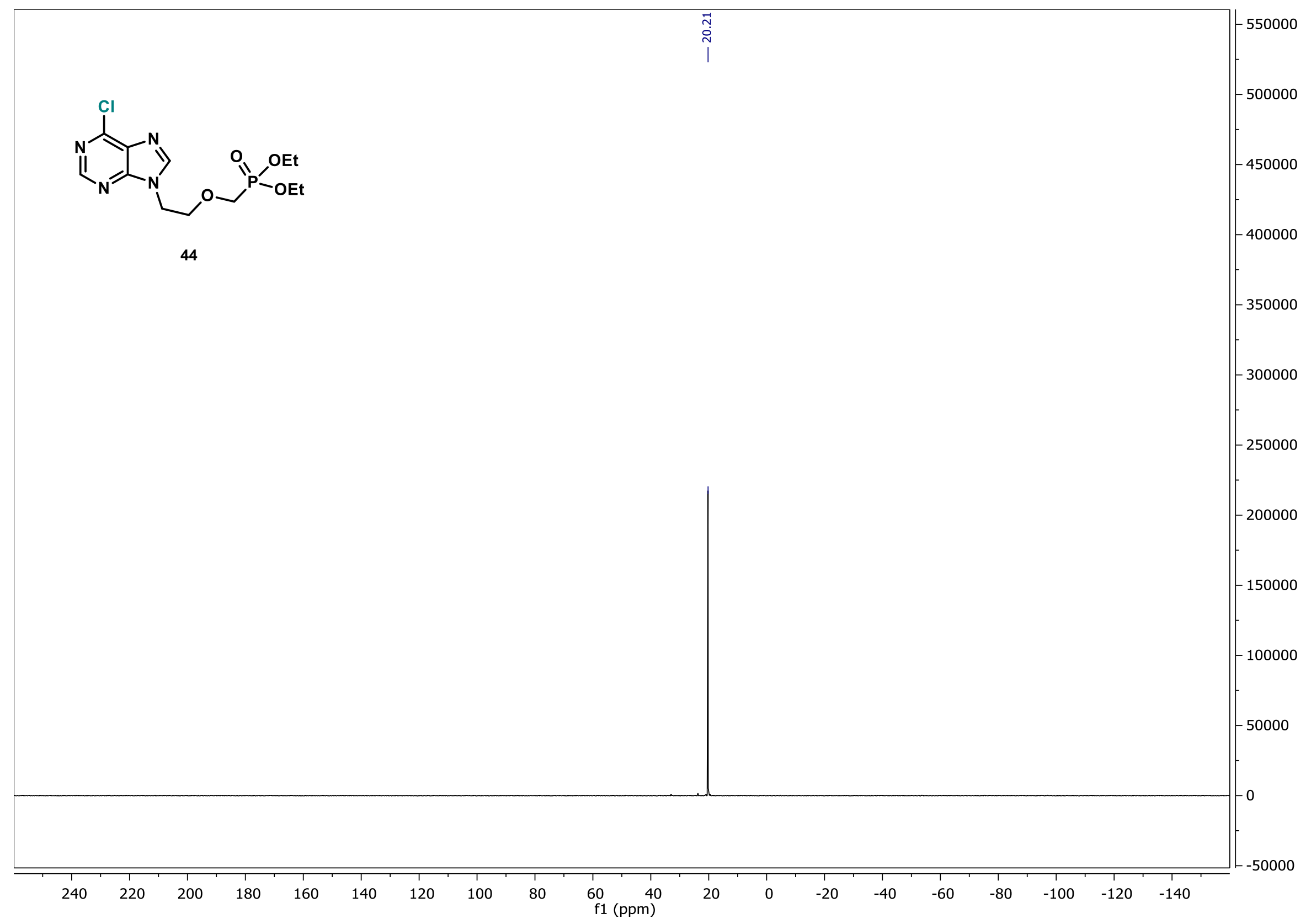


Mass to be matched $(\mathrm{m} / \mathrm{z}): 371.064630$ Charge: 1

Mass Tolerance: \pm 0.005000

Restriction of atom numbers:

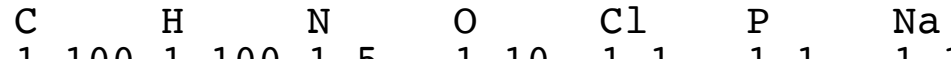

$1-100 \quad 1-1001-5$
Number of calculated Formulas:

Formula Diff. (ppm)

C12 H18 N4 04 Cl1 $\mathrm{P} 1 \mathrm{Na1}$

C14 H20 N1 O5 Cl1 P1 Na1

C9 H20 N3 O7 Cl1 P1 Na1

C15 H16 N5 O1 Cl1 P1 Na1

C17 H18 N2 O2 Cl1 P1 Na1

Datum: $\quad 16.10 .2020$

Analyse: $\quad 149929 \mathrm{~b}-00$

$\begin{array}{ll}\text { Sigel: } & \text { GHC-GA-380-01 } \\ & \text { COP : Dr. Clement Ghiazza }\end{array}$

Method: HR-MS

Ionis. : ESIpos

solvent : $\mathrm{CH} 2 \mathrm{Cl} 2+\mathrm{CH} 3 \mathrm{OH}$

Spectrometer: Exactive

Auswerter: Marcus, Tel:2243

suggestion:

C12H18N404C11P1 MW: 348

Characteristic Ions:

$371=[348+\mathrm{Na}]$ 
${ }^{1} \mathrm{H}$ NMR

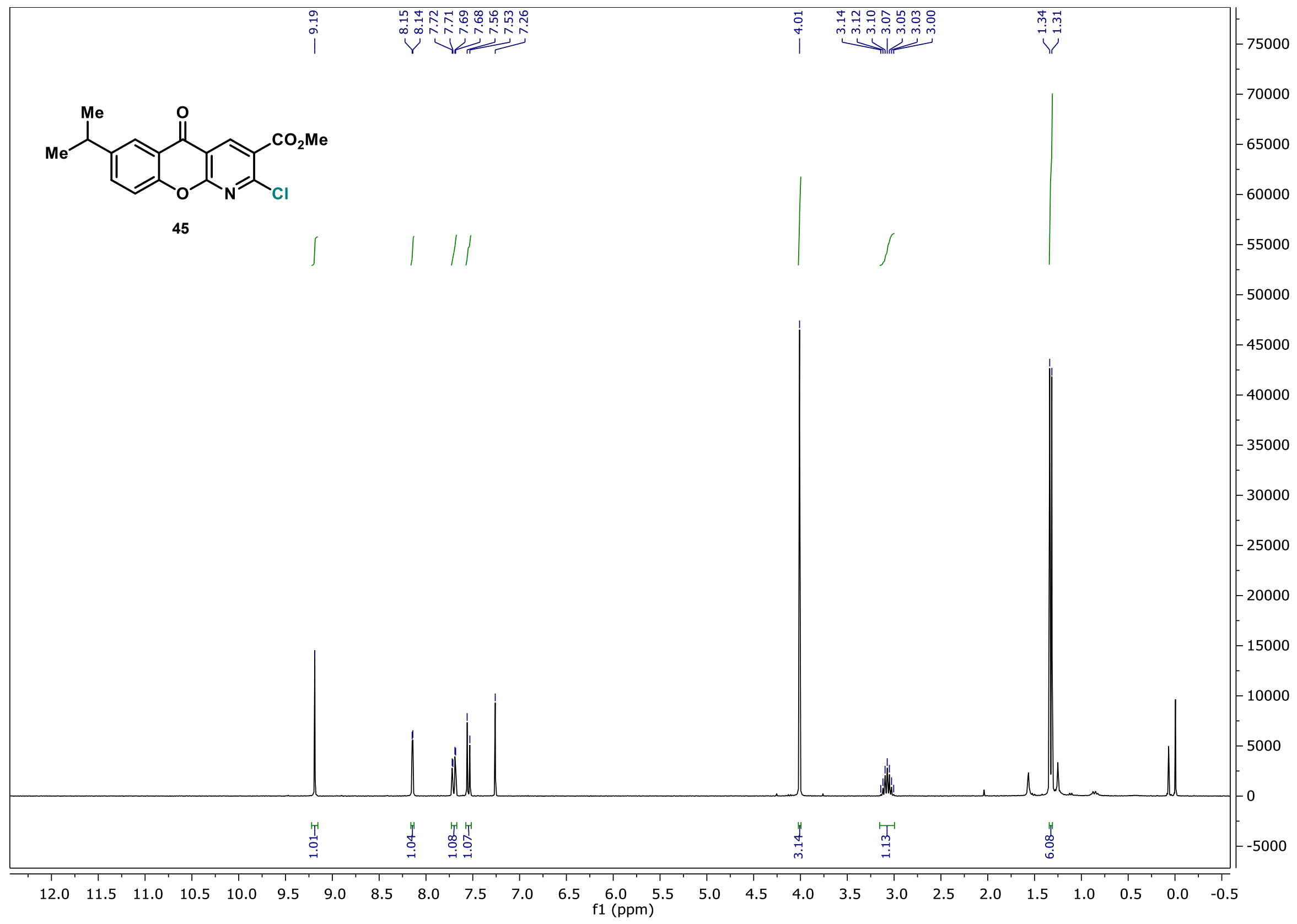




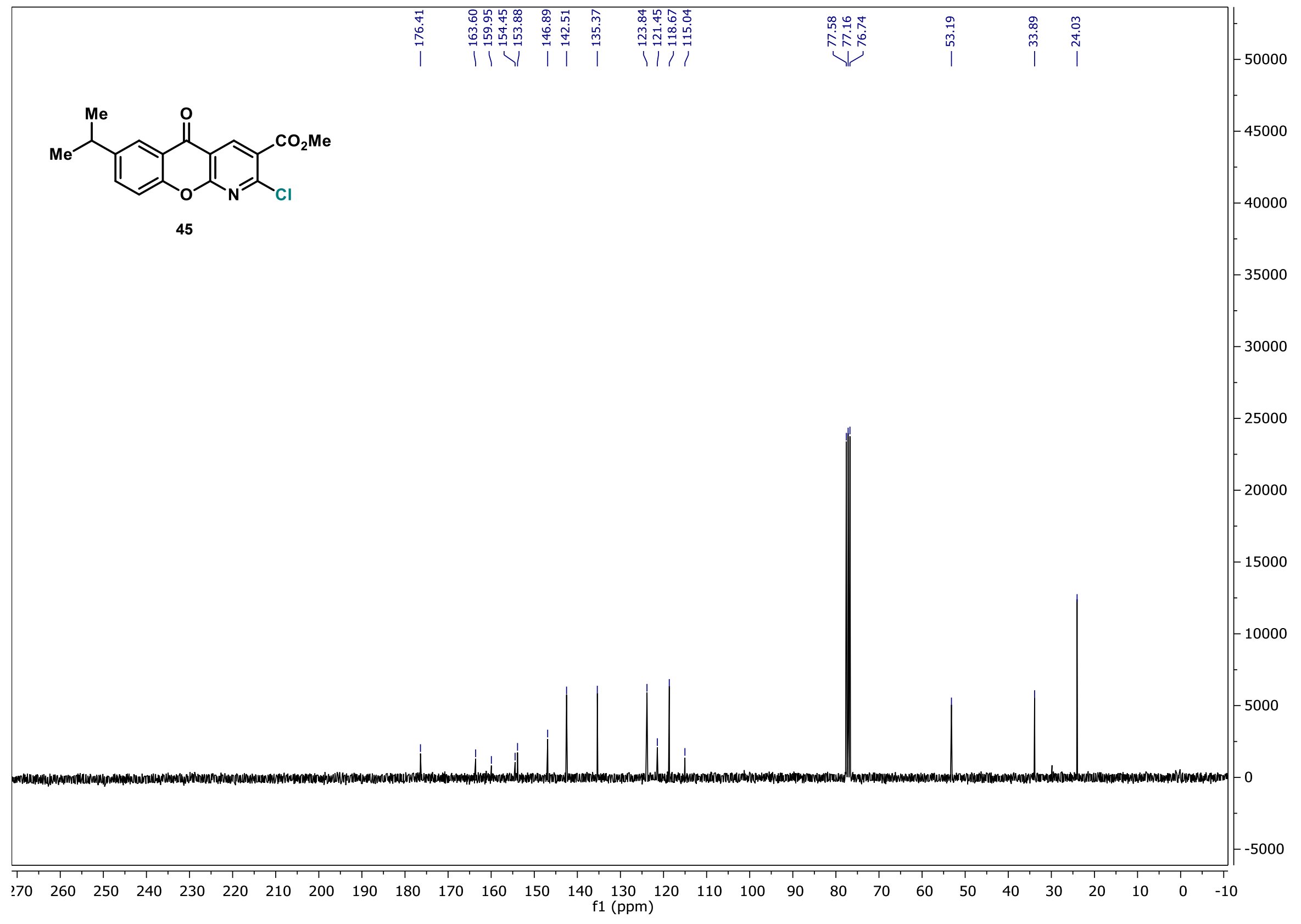


Mass to be matched $(\mathrm{m} / \mathrm{z}): 331.060640$ Charge: 1

Mass Tolerance: \pm 0.005000

Restriction of atom numbers:

$\mathrm{C} \quad \mathrm{H} \quad \mathrm{N} \quad \mathrm{O} \quad \mathrm{Cl}$

$1-100 \quad 1-100 \quad 1-5 \quad 1-10 \quad 1-1$
Number of calculated Formulas:

Formula Diff. (ppm) theor. $\mathrm{m} / \mathrm{z}$

$\begin{array}{rrrrrrr}\mathrm{C} 17 & \mathrm{H} 14 & \mathrm{~N} 1 & 04 & \mathrm{Cl} 1 & -0.16 & 331.060587\end{array}$

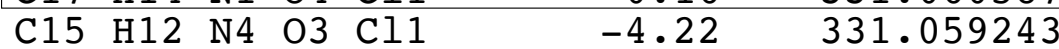

$\begin{array}{lllll}\mathrm{C} 20 \mathrm{H} 12 & \mathrm{~N} 2 & \mathrm{O} 1 \mathrm{Cl} 1 & 7.93 & 331.063265\end{array}$

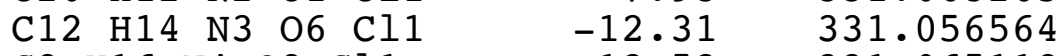

$\begin{array}{llll}\text { C } 8 \text { H16 N4 O8 Cl1 } & 13.53 & 331.065118\end{array}$

\begin{tabular}{ll} 
Datum: & 7.08 .2020 \\
Analyse: & $148567 \mathrm{C}-00$ \\
\hline Sigel: & GHC-GA-272-01 \\
& COP: Dr. Clement Ghiazza \\
\hline $\begin{array}{l}\text { Method: } \\
\text { Ionis : }\end{array}$ & HR-MS \\
Spectrometer: & GC-EI \\
\hline
\end{tabular}

Auswerter: Marcus, Tel:2243

suggestion:

C17H14N104Cl1 MW: 331 
${ }^{1} \mathrm{H}$ NMR

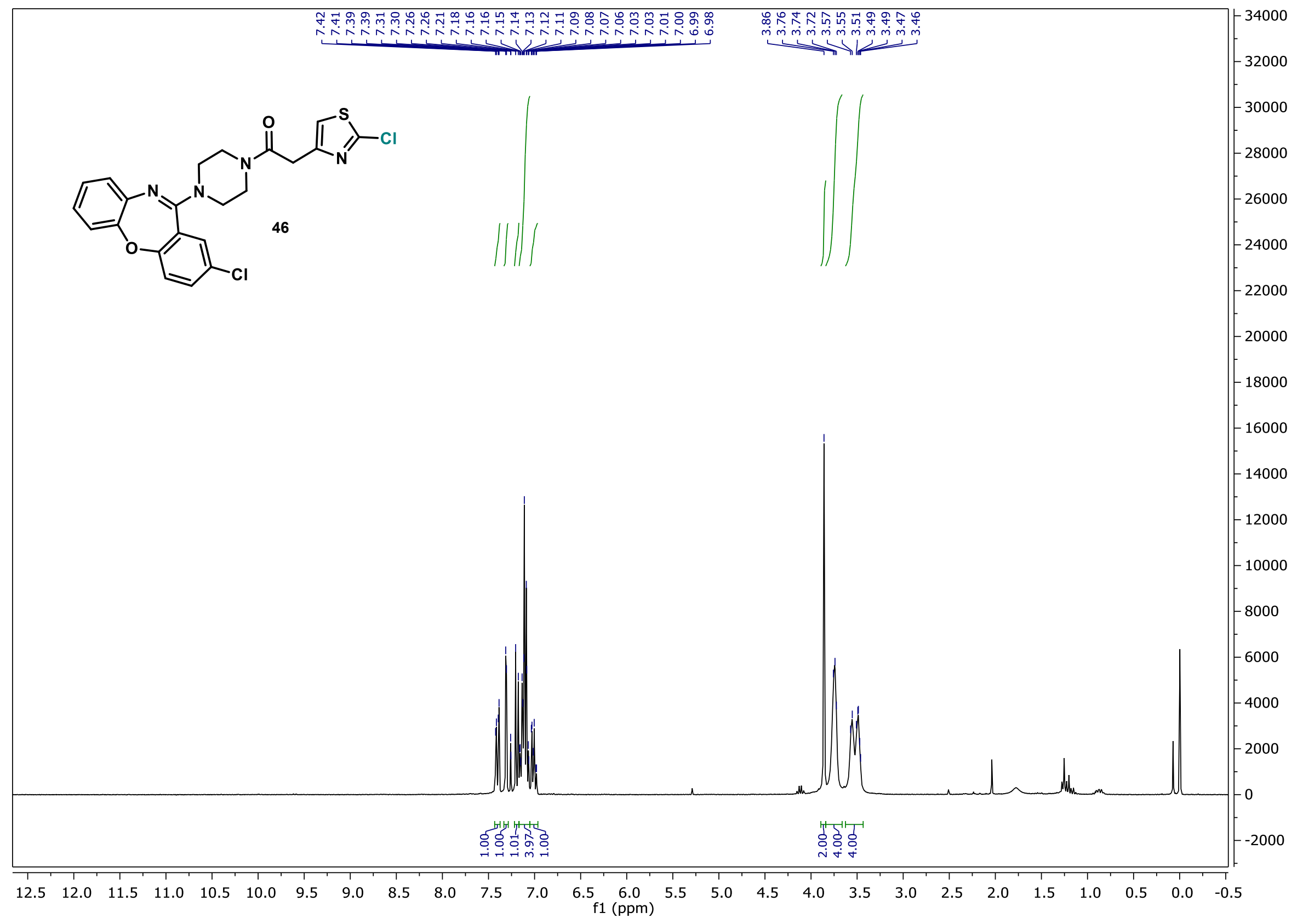




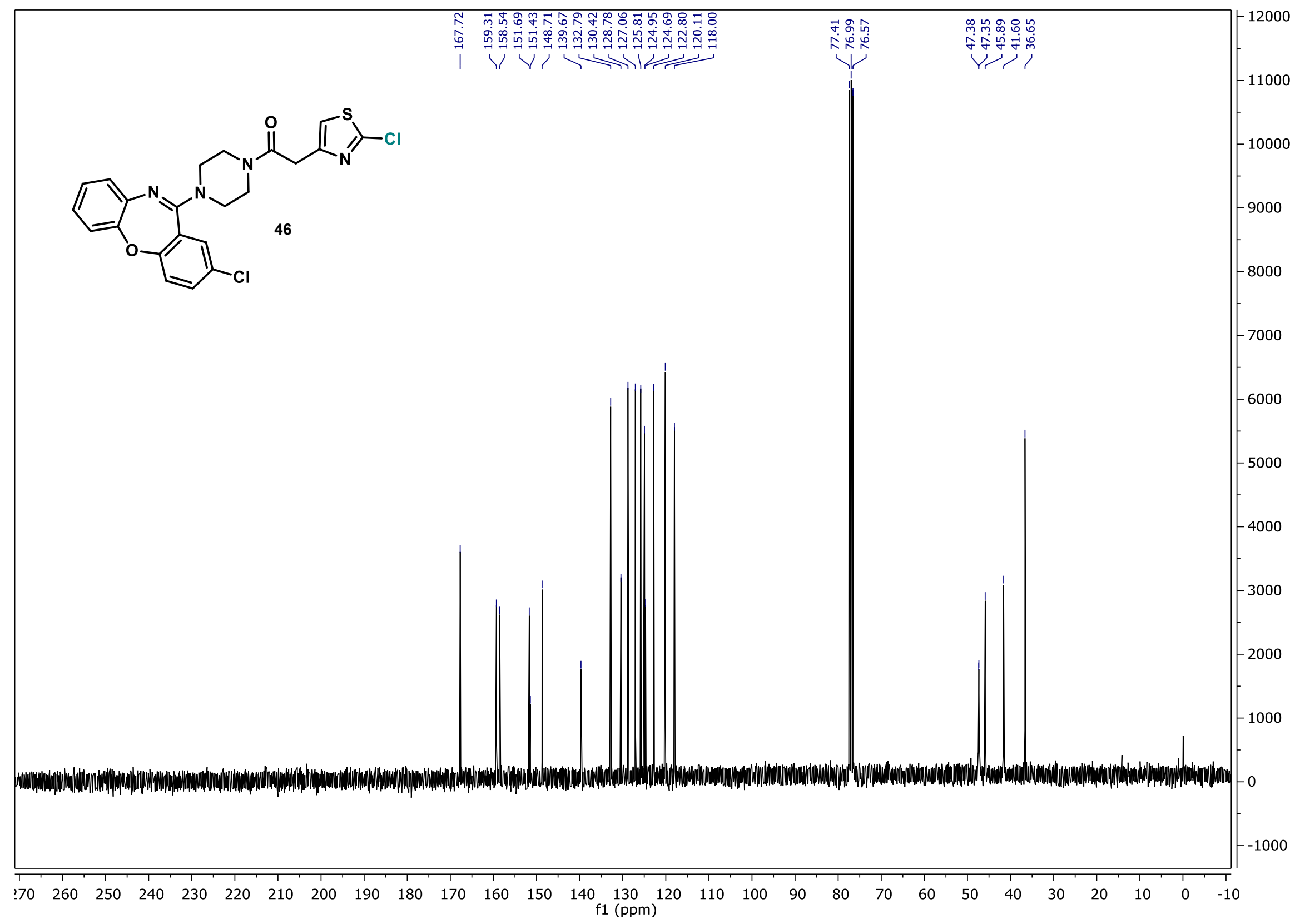


Mass to be matched $(\mathrm{m} / \mathrm{z}): 473.059970$ Charge: 1

Mass Tolerance: \pm 0.005000

Restriction of atom numbers:

$\begin{array}{llllll}\mathrm{C} & \mathrm{H} & \mathrm{N} & \mathrm{O} & \mathrm{S} & \mathrm{Cl} \\ 1-100 & 1-100 & 1-5 & 1-10 & 1-1 & 2-2\end{array}$

Number of calculated Formulas:

\begin{tabular}{|llllllrl|}
\multicolumn{2}{c}{ Formula } & & & Diff. (ppm) & theor. $\mathrm{m} / \mathrm{z}$ \\
C22 & H19 & N4 & O2 & S1 C12 & 0.12 & 473.060028 \\
C24 H21 & N1 & O3 & S1 C12 & 2.96 & 473.061372 \\
C19 & H21 & N3 & O5 S S S C12 & -5.54 & 473.057350 \\
C12 & H25 & N3 & O10 S1 C12 & 6.88 & 473.063225
\end{tabular}

\begin{tabular}{ll}
$\begin{array}{ll}\text { Datum: } \\
\text { Analyse: }\end{array}$ & $\begin{array}{l}30.10 .2020 \\
150219 \mathrm{C}-00\end{array}$ \\
\hline Sigel: & GHC-GA-410-01 \\
& COP: Dr. Clement Ghiazza \\
\hline Method: & HR-MS \\
Ionis. : & ESIpos \\
solvent : & CH3OH \\
Spectrometer: & Exactive \\
\hline Auswerter: & Marcus, Tel:2243
\end{tabular}

suggestion:

C22H18N4O2S1Cl2 MW: 472

Characteristic Ions:

$473=[472+\mathrm{H}]$ 
${ }^{1} \mathrm{H}$ NMR

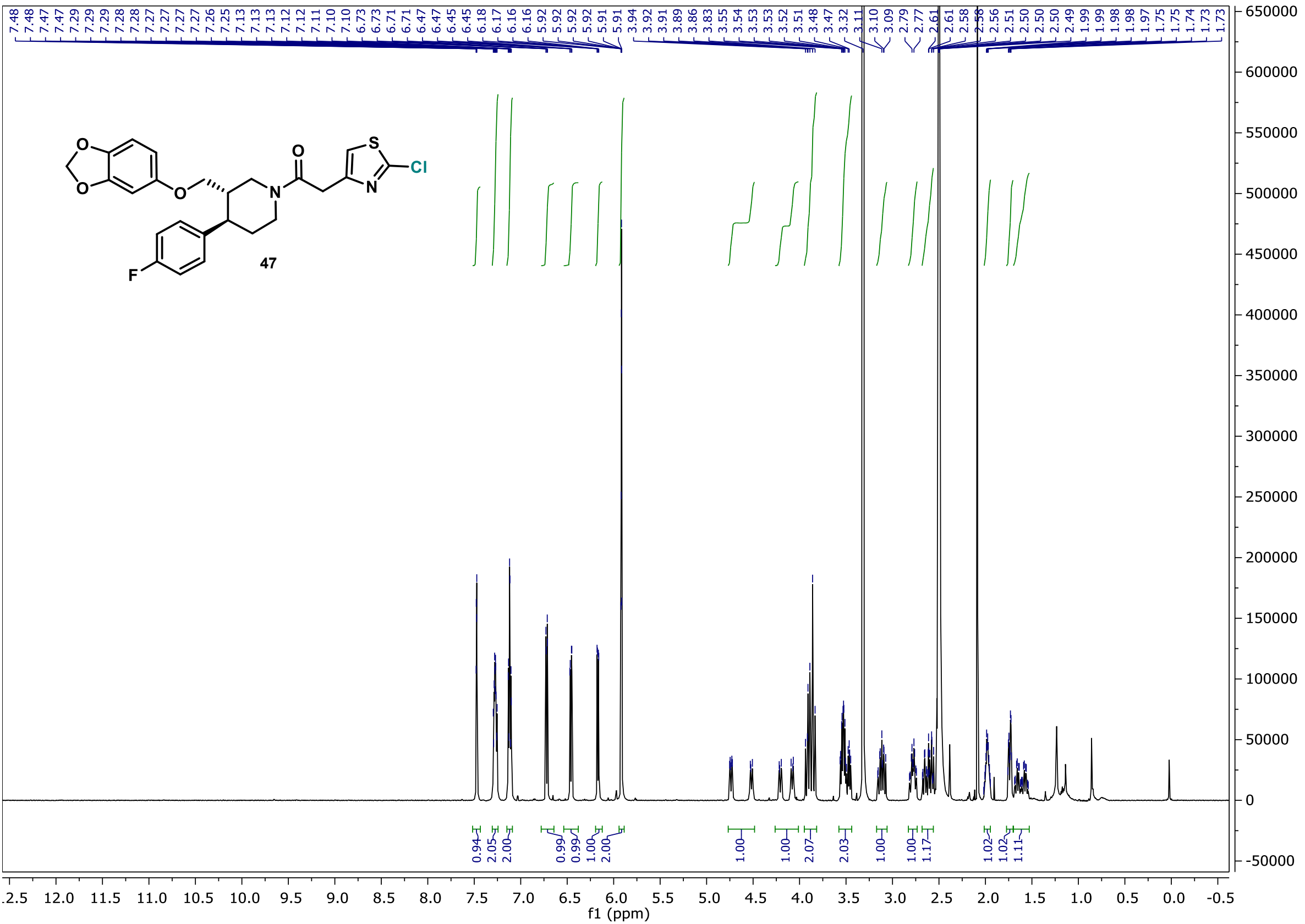




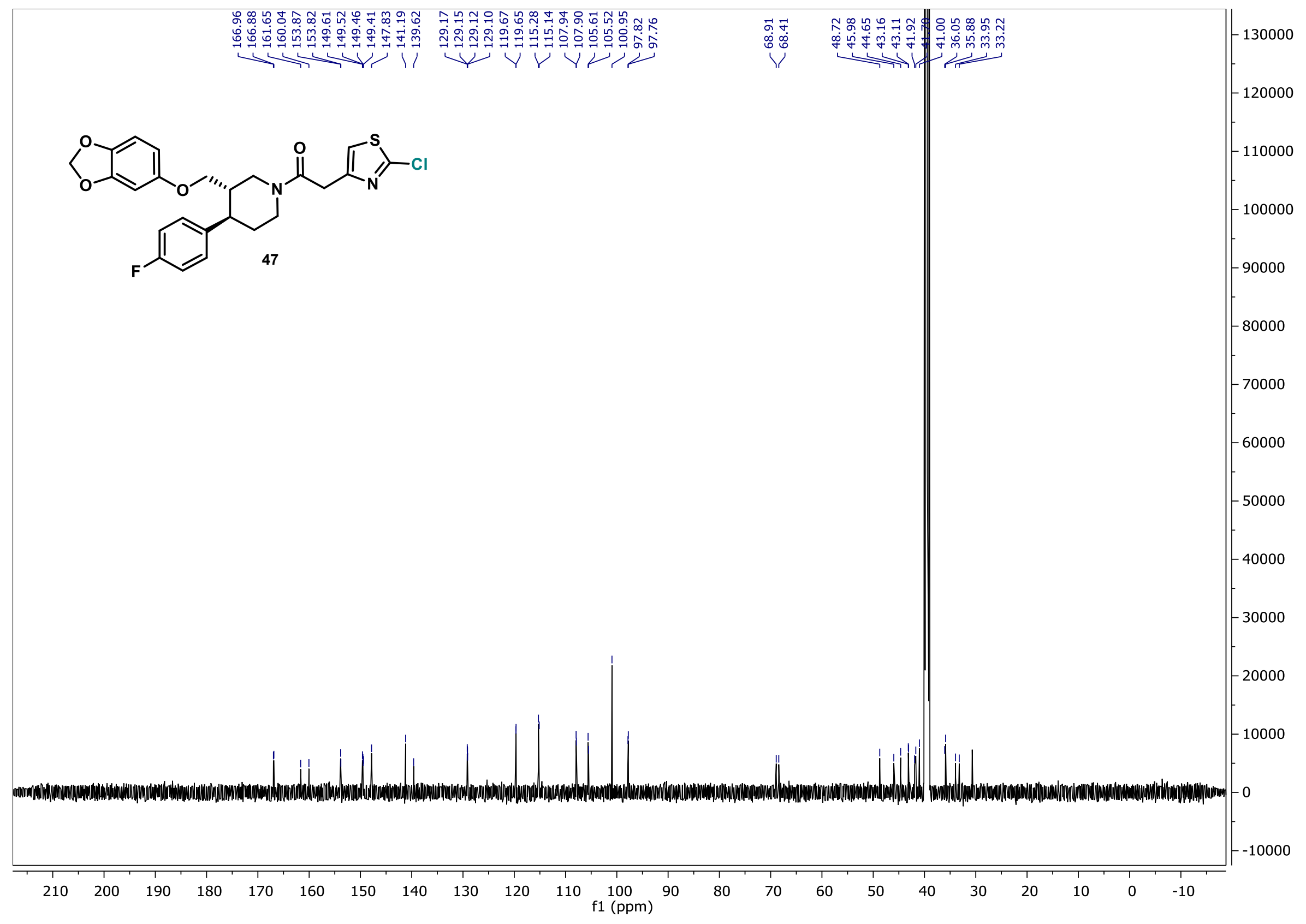


${ }^{19} \mathrm{~F}$ NMR<smiles></smiles>

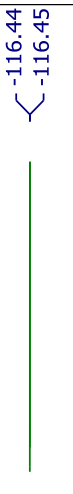


Mass to be matched $(\mathrm{m} / \mathrm{z}): 511.086620$ Charge: 1

Mass Tolerance: \pm 0.005000

Restriction of atom numbers:

$\begin{array}{llllllll}\mathrm{C} & \mathrm{H} & \mathrm{Cl} & \mathrm{F} & \mathrm{N} & \mathrm{O} & \mathrm{S} & \mathrm{Na}\end{array}$

$1-100$ 1-100 1-1 $1-1 \quad \max 2 \max 5$ 1-1 $1-1$

Number of calculated Formulas:

\section{Formula}

C24 H22 Cl1 F1 N2 O4 S1 Na1

C29 H22 Cl1 F1 O2 S1 Na1

Diff. (ppm)

$-0.22$

theor. $\mathrm{m} / \mathrm{z}$

511.086506

511.090528

\begin{tabular}{|c|c|}
\hline $\begin{array}{l}\text { Datum } \\
\text { Analyse: }\end{array}$ & $\begin{array}{r}2.03 .2021 \\
152006 b-00\end{array}$ \\
\hline Sigel: & GHC-GA-618-01 \\
\hline \multicolumn{2}{|c|}{ COP: Dr. Clement Ghiazza } \\
\hline Messung: & HRMS \\
\hline Methode: & ESIpos \\
\hline Lösungsmittel: & $\mathrm{CH} 2 \mathrm{Cl} 2+\mathrm{CH} 3 \mathrm{OH}$ \\
\hline Spektrometer: & Exactive \\
\hline Auswerter: & Kampen (2242) \\
\hline
\end{tabular}

Suggestion:

C24H22Cl1F1N2O4S1 MW 488

characteristical ion

$511=[488+\mathrm{Na}]+$ 
${ }^{1} \mathrm{H}$ NMR

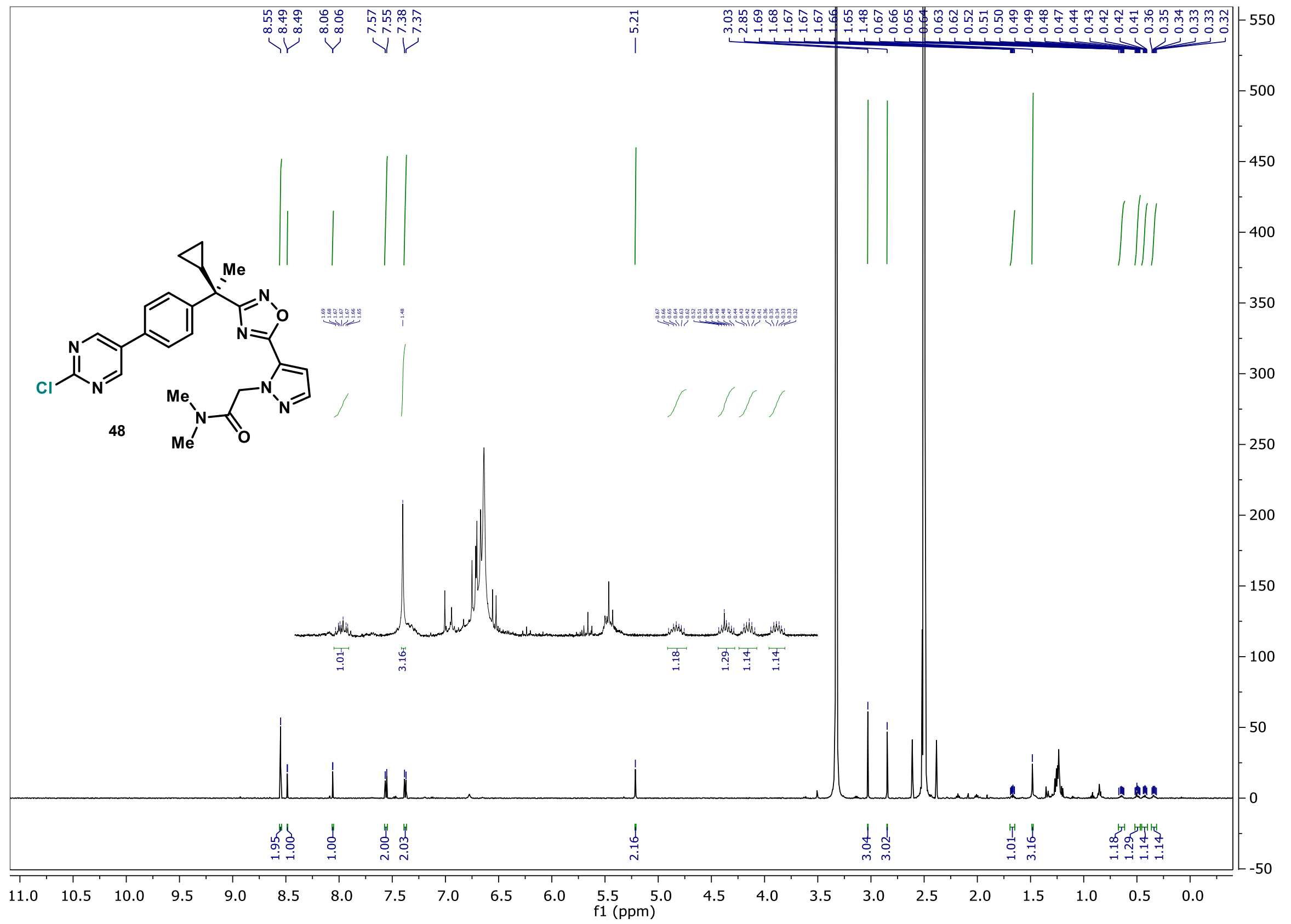




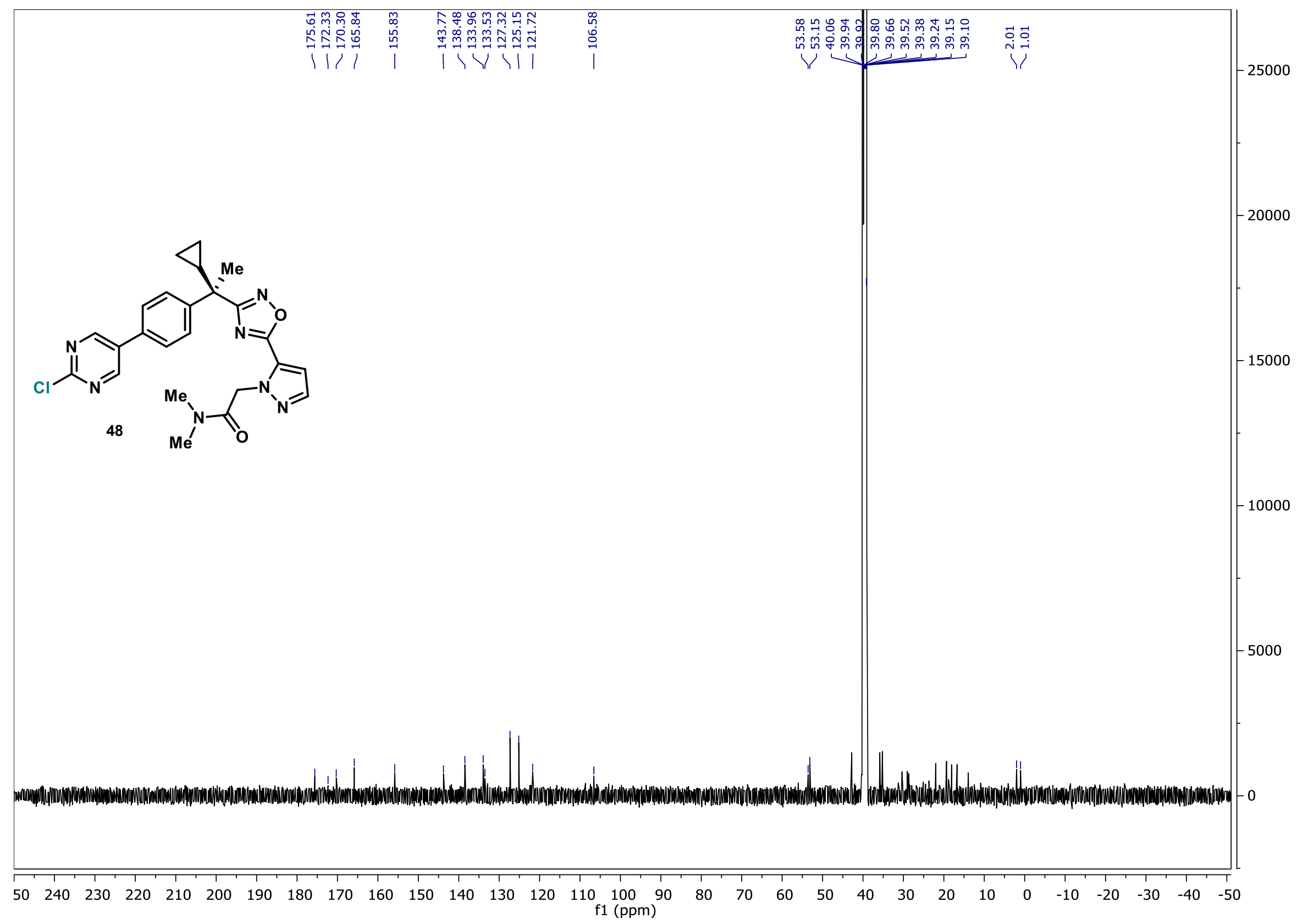


12.11.2020 07:28 p.肃* Angegebene Mol.-Gewichte u. Massenzahlen basieren auf dem häufigsten Isotop der Elemente *** MassLib

Mass to be matched $(\mathrm{m} / \mathrm{z}): 478.174910$ Charge: 1

Mass Tolerance: \pm 0.050000

Restriction of atom numbers:

$\begin{array}{lllll}\mathrm{C} & \mathrm{H} & \mathrm{N} & \mathrm{O} & \mathrm{Cl} \\ 1-100 & 1-100 & 7-7 & 1-3 & 1-2\end{array}$

Number of calculated Formulas: 6

Formula

Formula
\begin{tabular}{|lllll|}
\hline C24 & H25 & N7 & O2 & Cl1 \\
C22 & H30 & N7 & O1 & Cl2
\end{tabular}

Diff. (ppm) 0.76

$\begin{array}{lllll}\mathrm{C} 21 & \mathrm{H} 26 & \mathrm{~N} 7 & \mathrm{O} 2 & \mathrm{Cl} 2\end{array}$

C19 $\mathrm{H} 34$ N7 $\mathrm{O} 3 \mathrm{Cl} 2$

C23 H21 N7 O3 Cl1

C25 H29 N7 O1 Cl1
478.175274

478.18833

$72.27 \quad 478.151952$

478.209467

$\begin{array}{rr}-75.33 & 478.138889 \\ 76.85 & 478.211659\end{array}$
12.11 .2020

File: $150394 \mathrm{c}-00$

Analysis: GHC-GA-419-01

COP: Dr. Clement Ghiazza

Messung: HR-MS

Ionisierung: ESIpos

Lösungsmittel: $\mathrm{CH} 2 \mathrm{Cl} 2+\mathrm{CH} 3 \mathrm{OH}$

Spektrometer: Exactive

ELNA :

28360

Auswerter:

Haupt (2243)

Suggestion:
C24H24Cl1N7O2 MW: 477
Characteristic ions:
$478=[477+\mathrm{H}]+$

$478=[477+\mathrm{H}]+$ 
${ }^{1} \mathrm{H}$ NMR

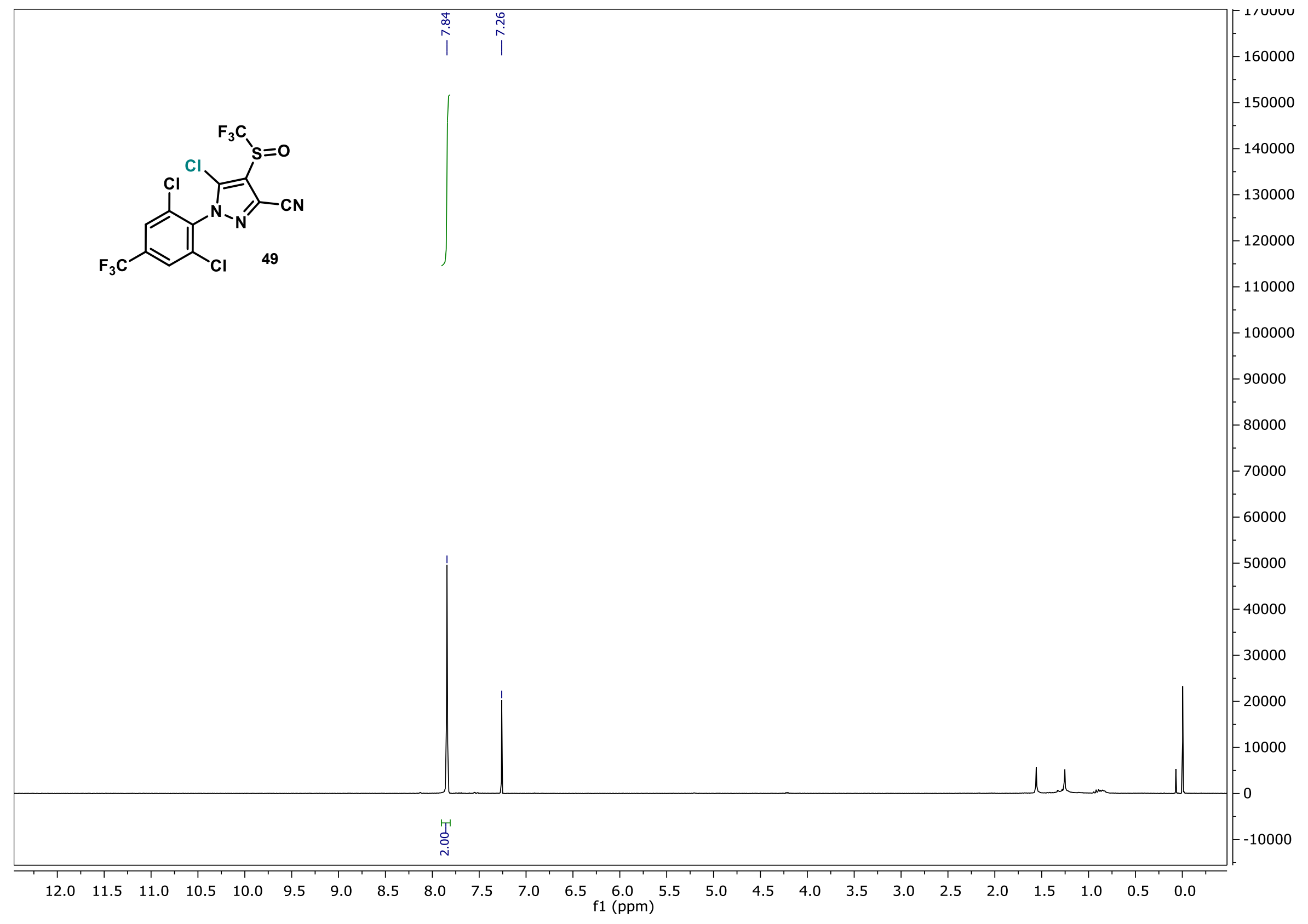




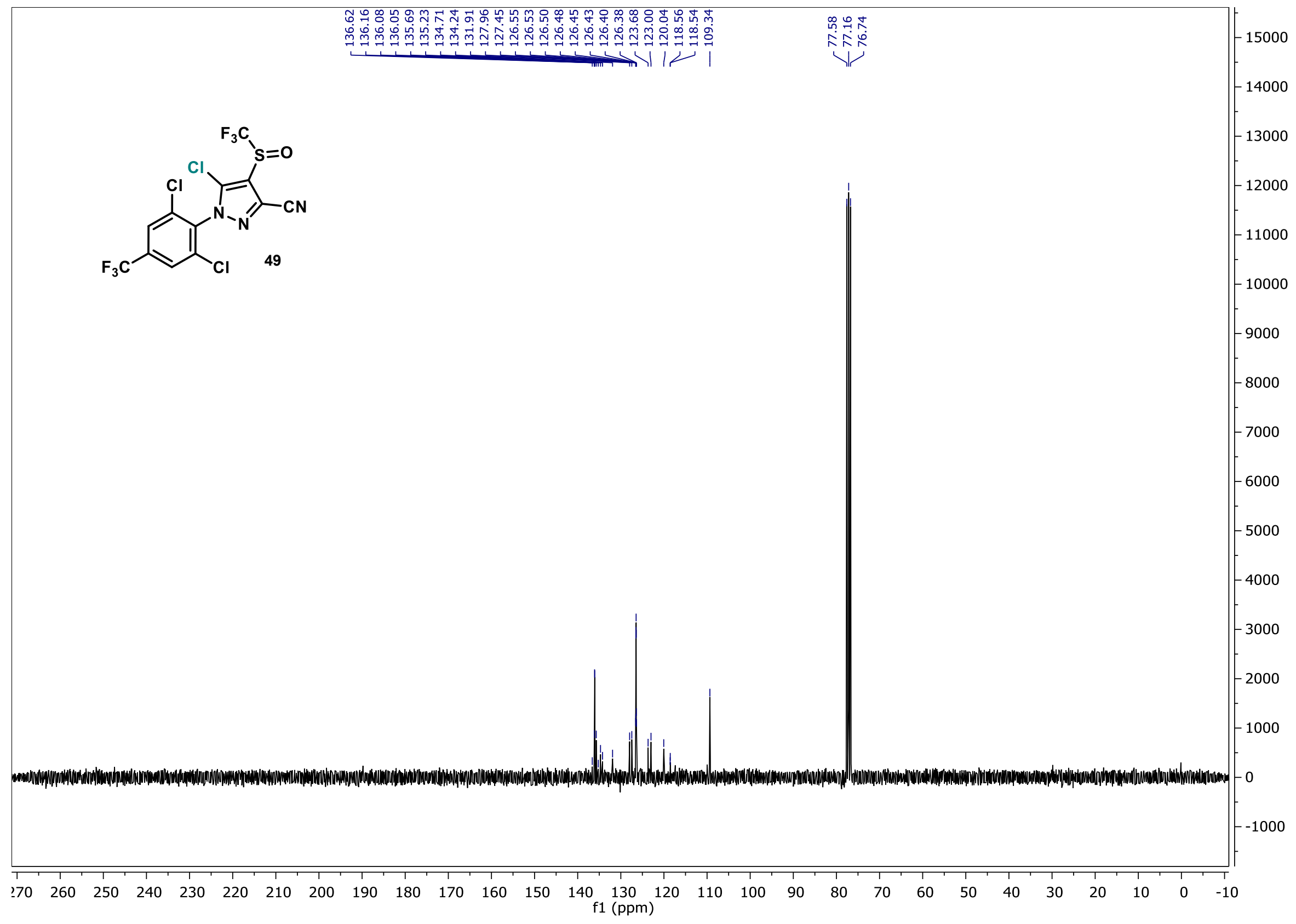


${ }^{19} \mathrm{~F}$ NMR

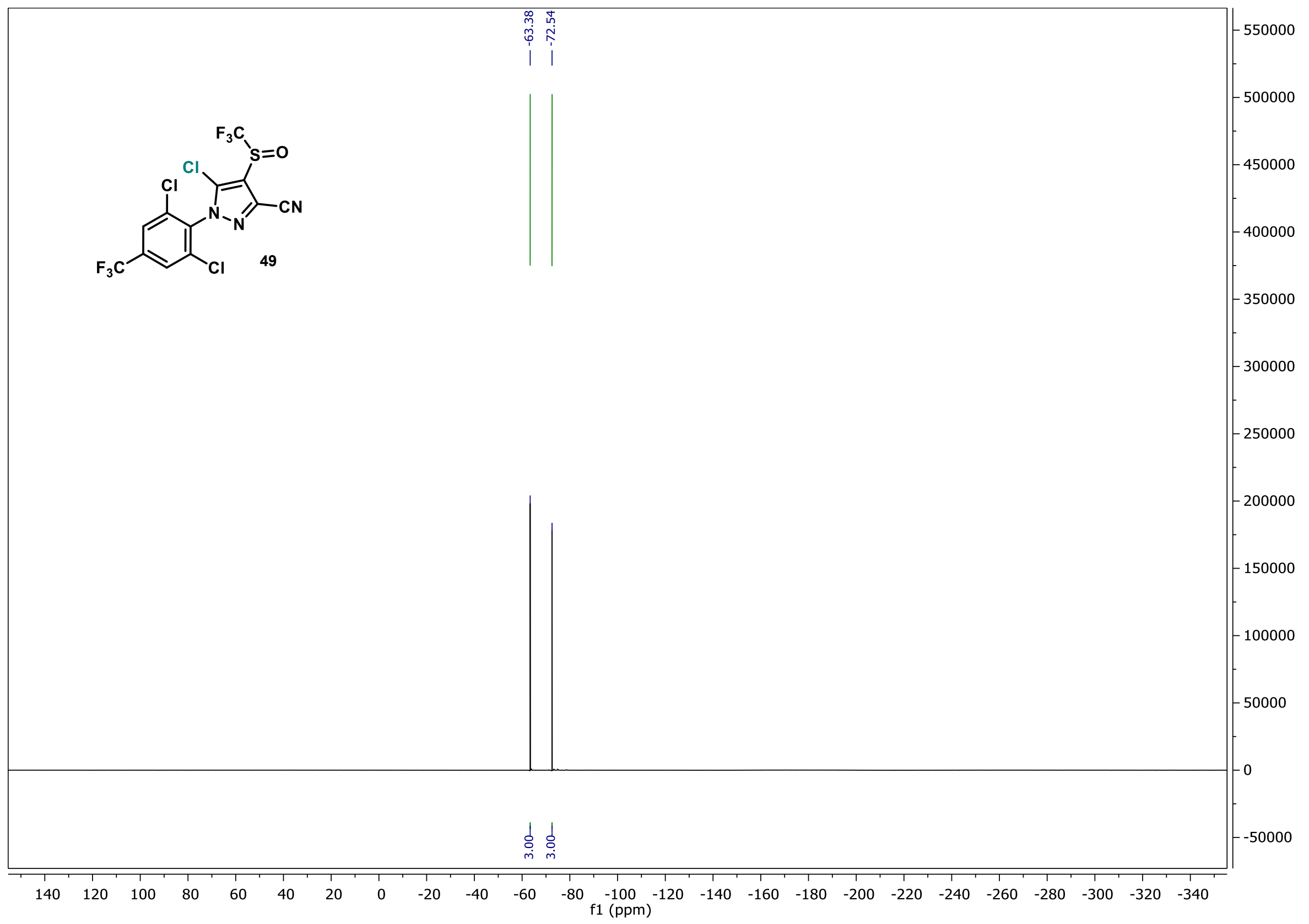


Mass to be matched $(\mathrm{m} / \mathrm{z}): 477.877890$ Charge: 1

Mass Tolerance: \pm 0.005000

Restriction of atom numbers:

$\begin{array}{llllllll}\mathrm{C} & \mathrm{H} & \mathrm{Cl} & \mathrm{F} & \mathrm{N} & \mathrm{O} & \mathrm{S} & \mathrm{Na} \\ 1-100 & 1-100 & 3-3 & 6-6 & 1-3 & \max 5 & 1-1 & 1-1\end{array}$

Number of calculated Formulas:

2

$\begin{array}{ll}\text { Datum } & 31.07 .2020 \\ \text { Analyse: } & 148457 \mathrm{~b}-00 . \text { raw } \\ \text { Sigel: } & \text { GHC-GA-243-01 }\end{array}$

Formula

$\begin{array}{llllllll}\mathrm{C} 12 & \mathrm{H} 2 & \mathrm{Cl} & \mathrm{F} 6 & \mathrm{~N} 3 & \mathrm{O} & \mathrm{S} 1 \mathrm{Na} 1\end{array}$

Diff.(ppm)

theor. $\mathrm{m} / \mathrm{z}$

C9 H4 Cl3 $\mathrm{F} 6$ N2 04 S1 Nal

0.35 477.878058 477.875379

GHC-GA-243-01

COP: Dr. Clement Ghiazza

Messung: HRMS

Methode: ESIpos

Lösungsmittel: $\mathrm{CH} 2 \mathrm{Cl} 2+\mathrm{CH} 3 \mathrm{OH}$

Spektrometer:

LTQ FT

Auswerter:

Kampen (2242)

Suggestion:

C12H2Cl3F6N301S1 MW 455

characteristical ion

$478=[455+\mathrm{Na}]+$ 
${ }^{1} \mathrm{H}$ NMR

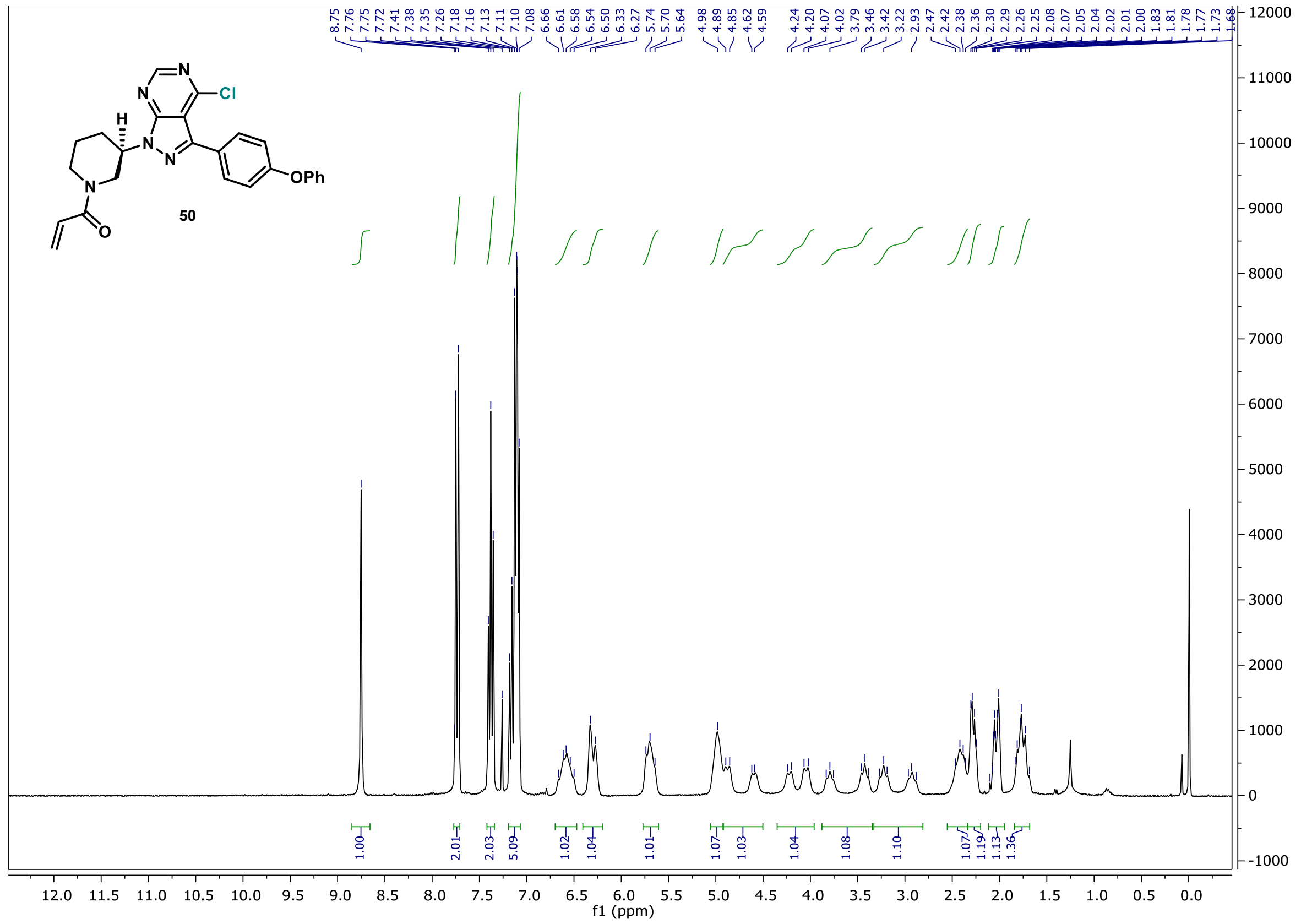




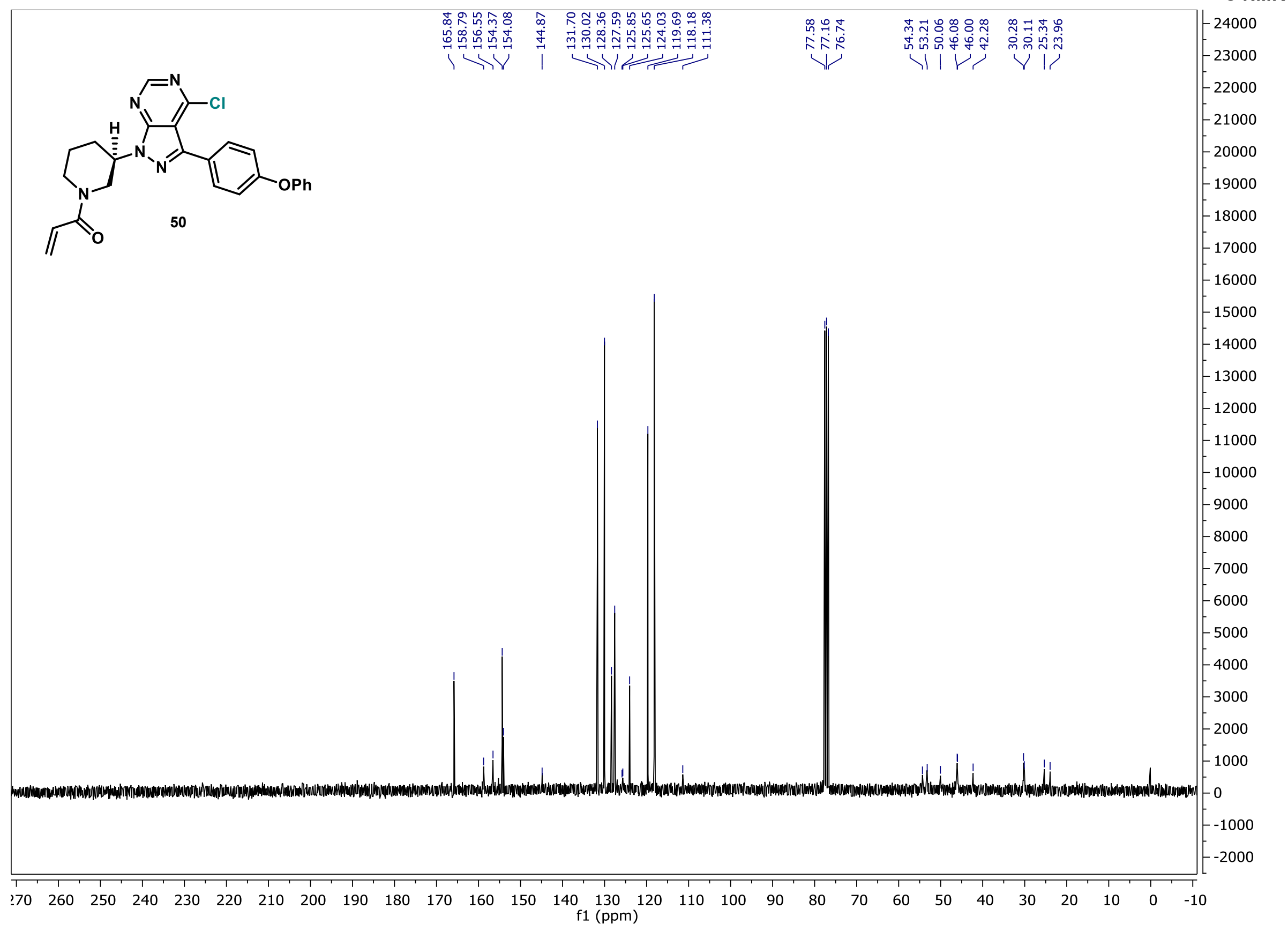


Mass to be matched $(\mathrm{m} / \mathrm{z}): 460.153380$ Charge: 1

Mass Tolerance: \pm 0.005000

Restriction of atom numbers:

$\begin{array}{lllll}\mathrm{C} & \mathrm{H} & \mathrm{Cl} & \mathrm{N} & \mathrm{O} \\ 1-100 & 1-100 & 1-1 & 1-5 & \max 5\end{array}$

Number of calculated Formulas: 4

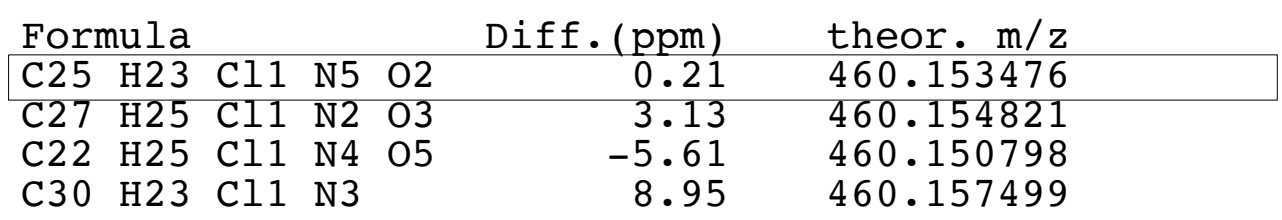

\begin{tabular}{ll} 
Datum & 11.08 .2020 \\
Analyse: & $148633 \mathrm{~b}-00$ \\
\hline
\end{tabular}

Sigel: GHC-GA-268-01

COP: Dr. Clement Ghiazza

\begin{tabular}{ll} 
Messung: & HRMS \\
Methode: & ESIpos \\
Lösungsmittel: & CH2Cl2+CH3OH \\
Spektrometer: & Exactive \\
\hline Auswerter: & Kampen (2242)
\end{tabular}

Suggestion:

C25H22Cl1N5O2 MW 459

characteristical ion

$460=[459+\mathrm{H}]+$ 


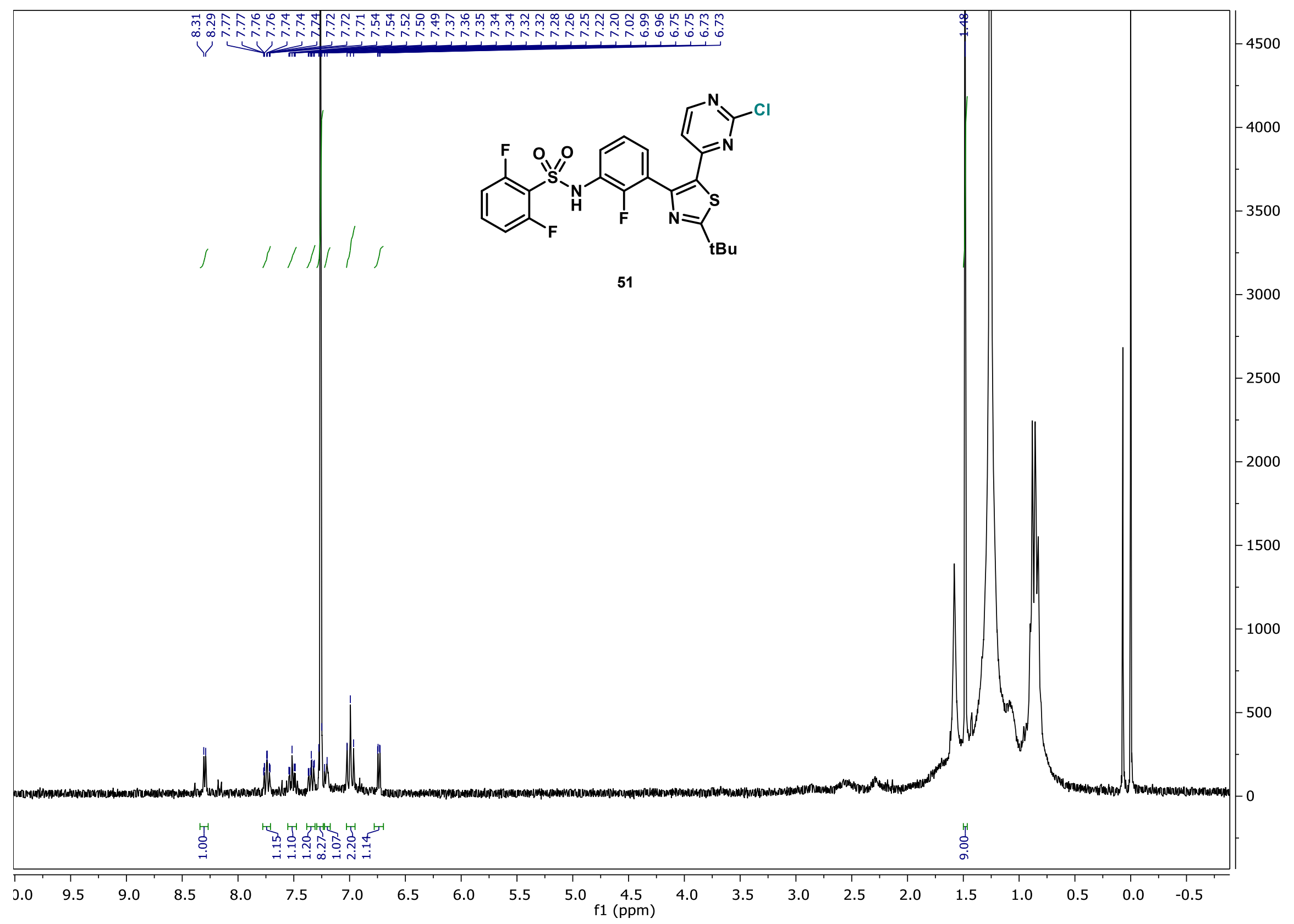




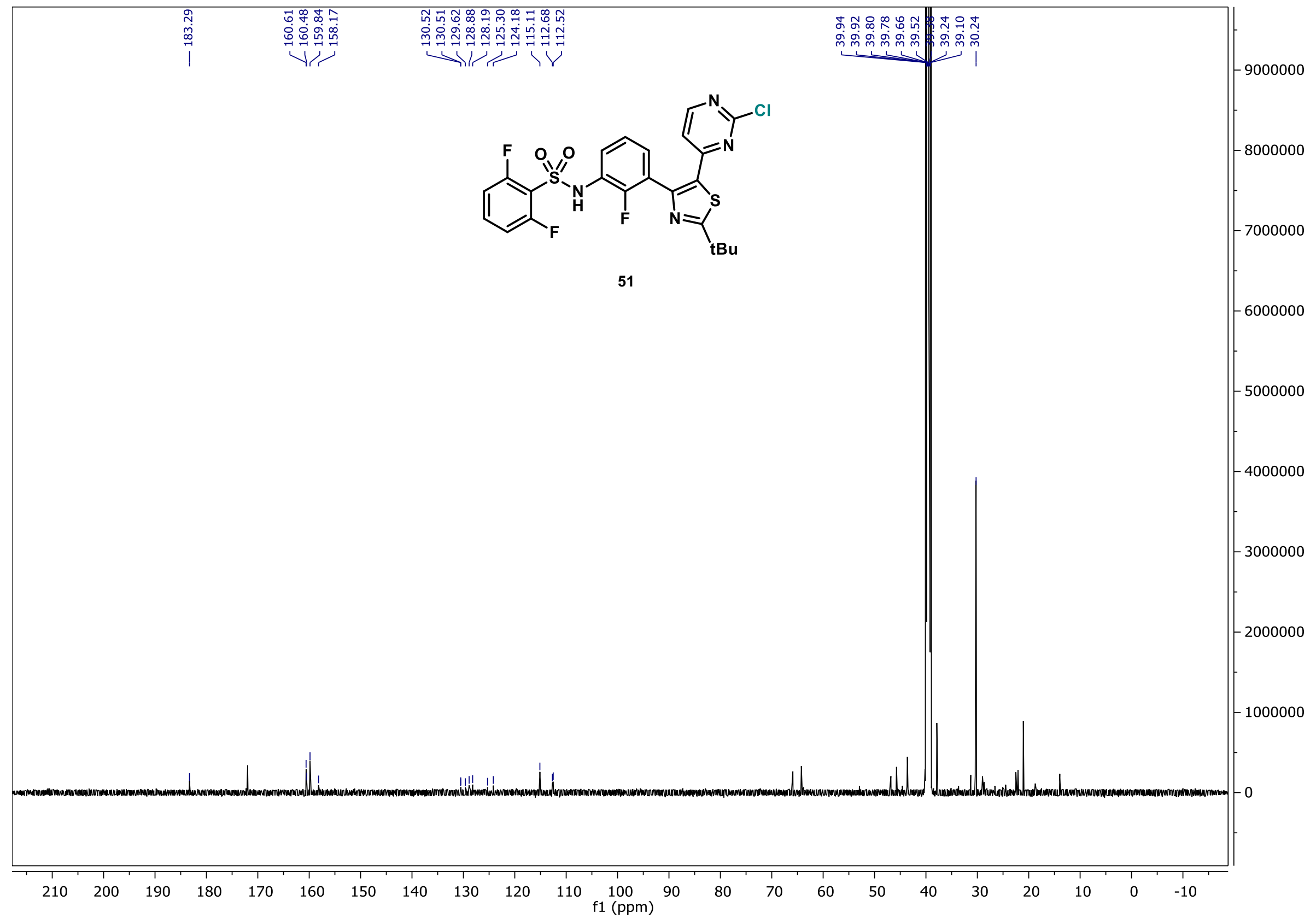




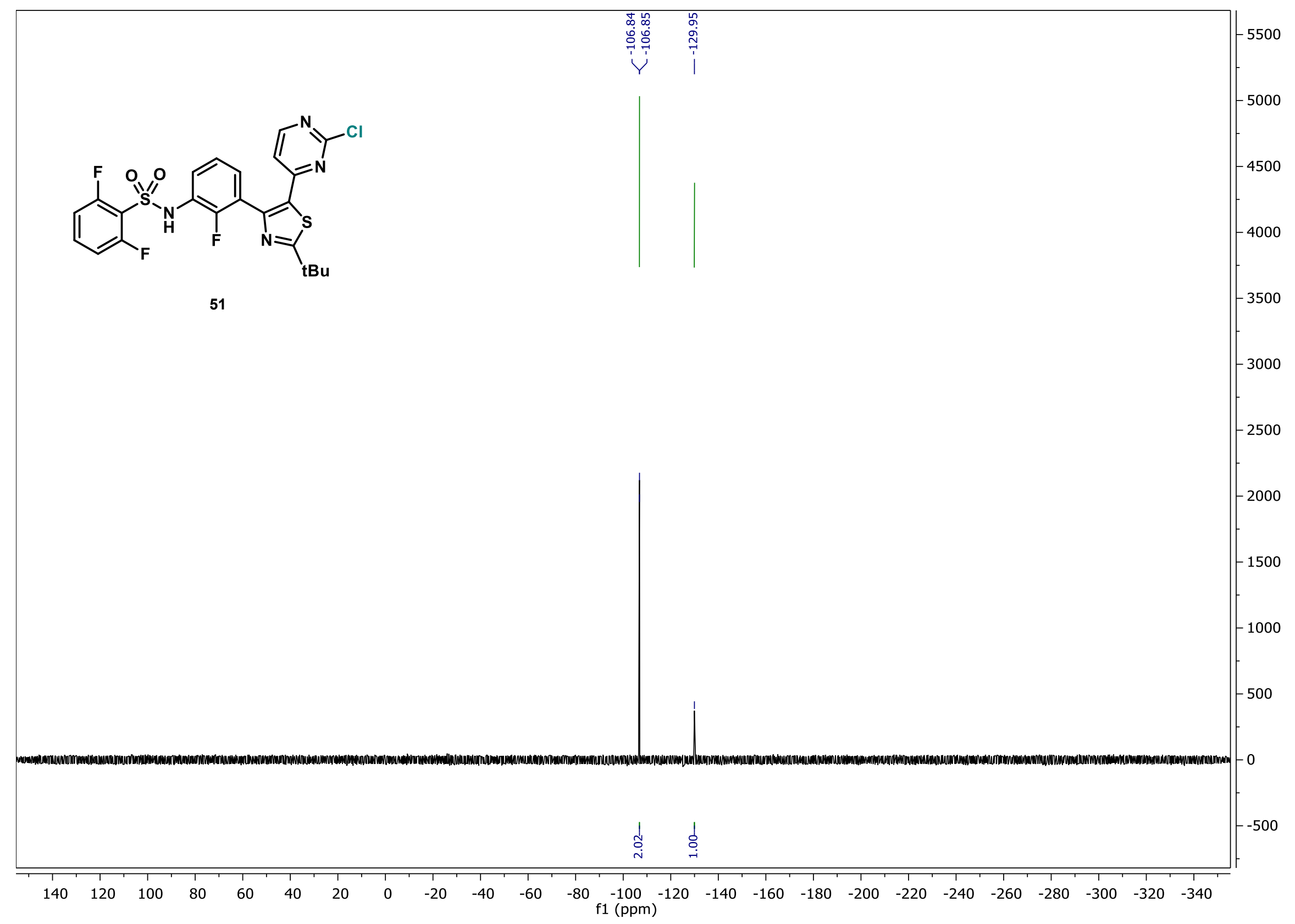


Mass to be matched $(\mathrm{m} / \mathrm{z}): 539.058050$ Charge: 1

Mass Tolerance: \pm 0.005000

Restriction of atom numbers:

$\begin{array}{lllllll}\mathrm{C} & \mathrm{H} & \mathrm{Cl} & \mathrm{F} & \mathrm{N} & \mathrm{O} & \mathrm{S} \\ 1-100 & 1-100 & 1-1 & 3-3 & 2-4 & \max 5 & 2-2\end{array}$

Number of calculated Formulas:

3

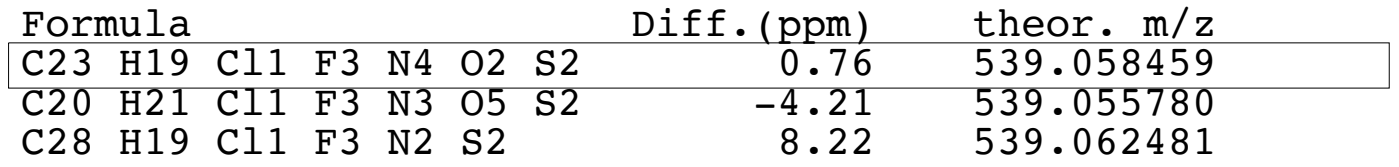

$\begin{array}{lr}\text { Datum } & 4.03 .2021 \\ \text { Analyse: } & 152063 \mathrm{~b}-00\end{array}$

Sigel: GHC-GA-629-01

COP: Dr. Clement Ghiazza

\begin{tabular}{ll} 
Messung: & HRMS \\
Methode: & ESIpos \\
Lösungsmittel: & CH2Cl2+CH3OH \\
Spektrometer: & Exactive \\
\hline Auswerter: & Kampen (2242)
\end{tabular}

Suggestion:

C23H18Cl1F3N4O2S2 MW 538

characteristical ion

$539=[538+\mathrm{H}]+$ 
${ }^{1} \mathrm{H}$ NMR

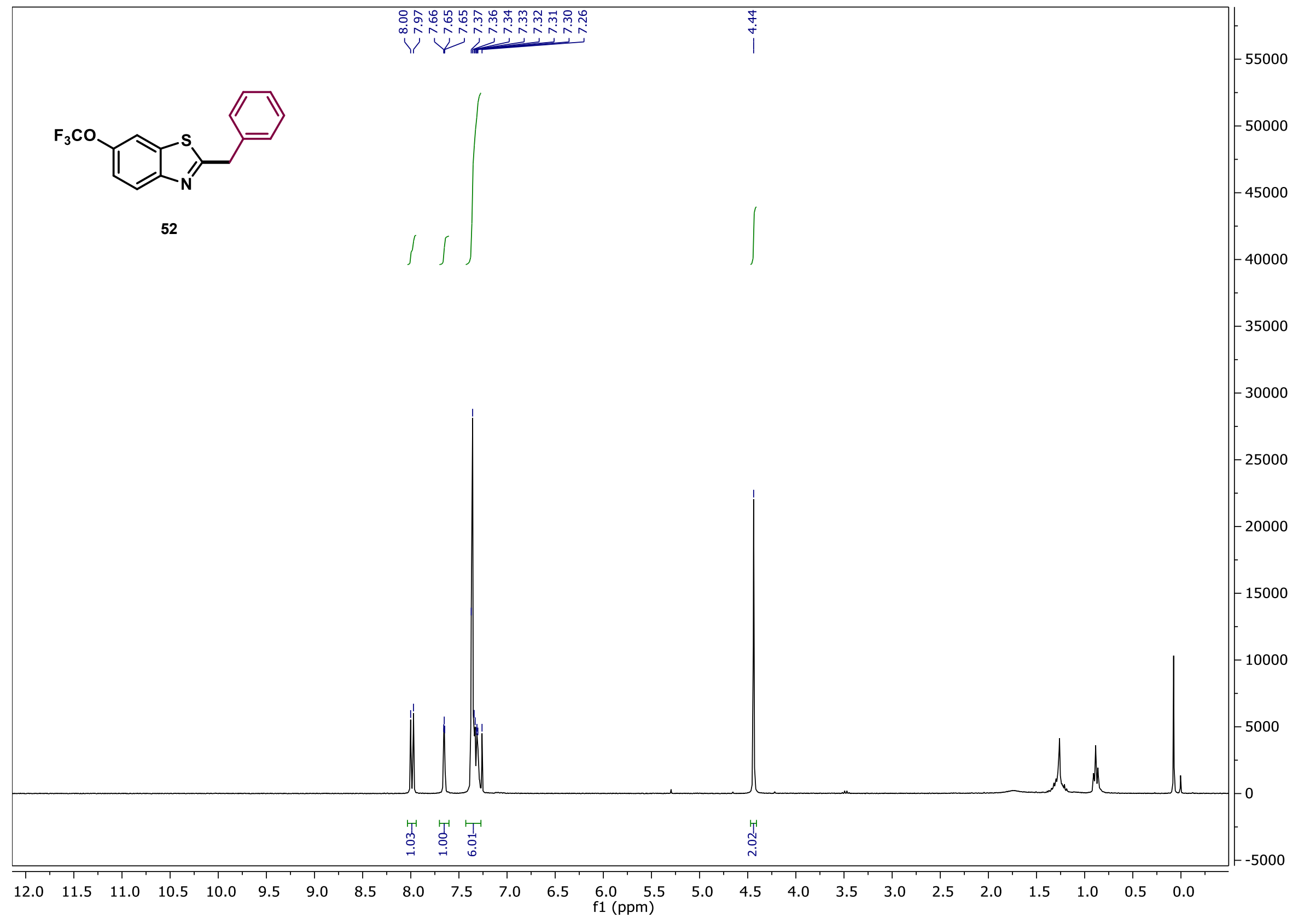




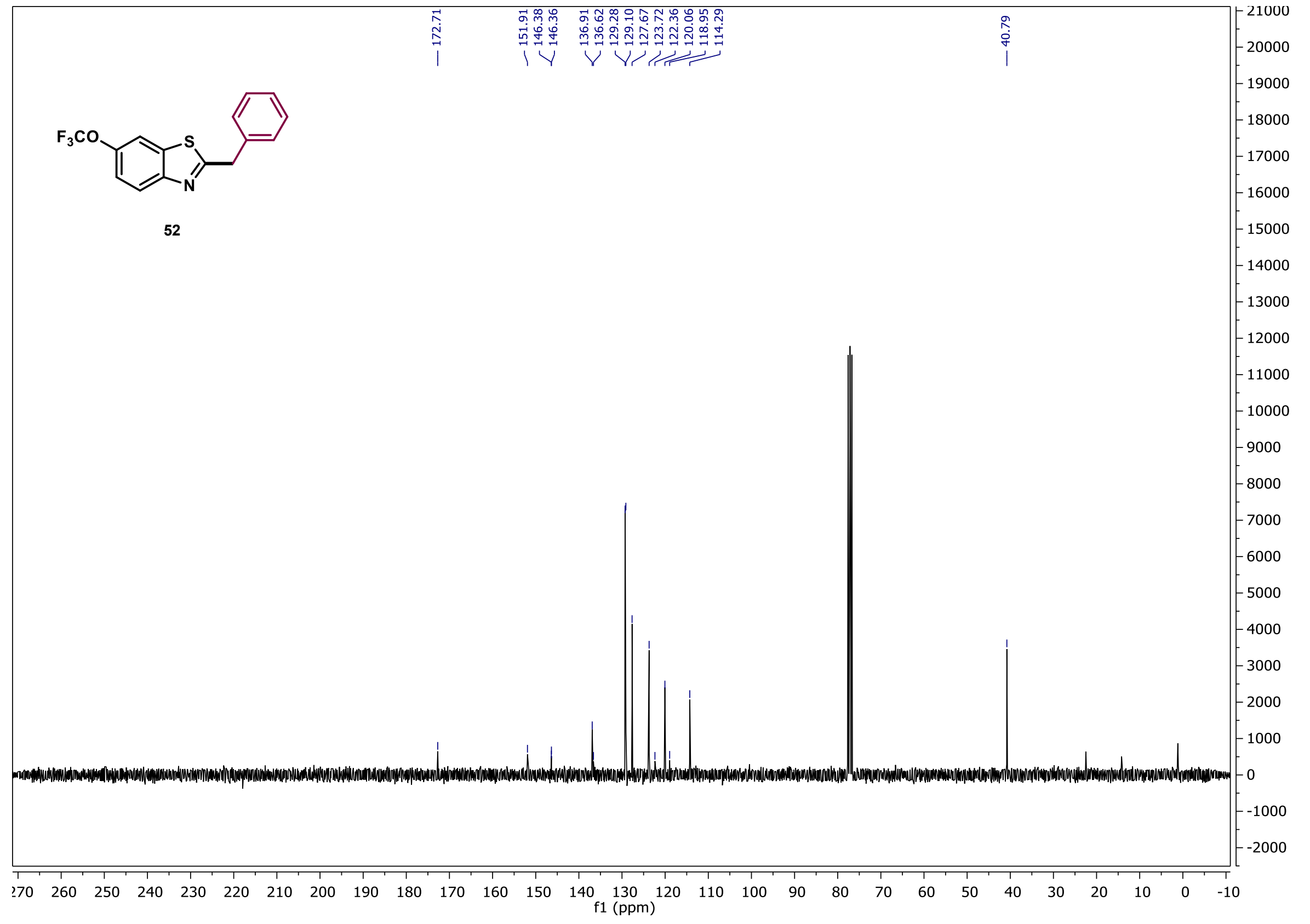


${ }^{19} \mathrm{~F}$ NMR

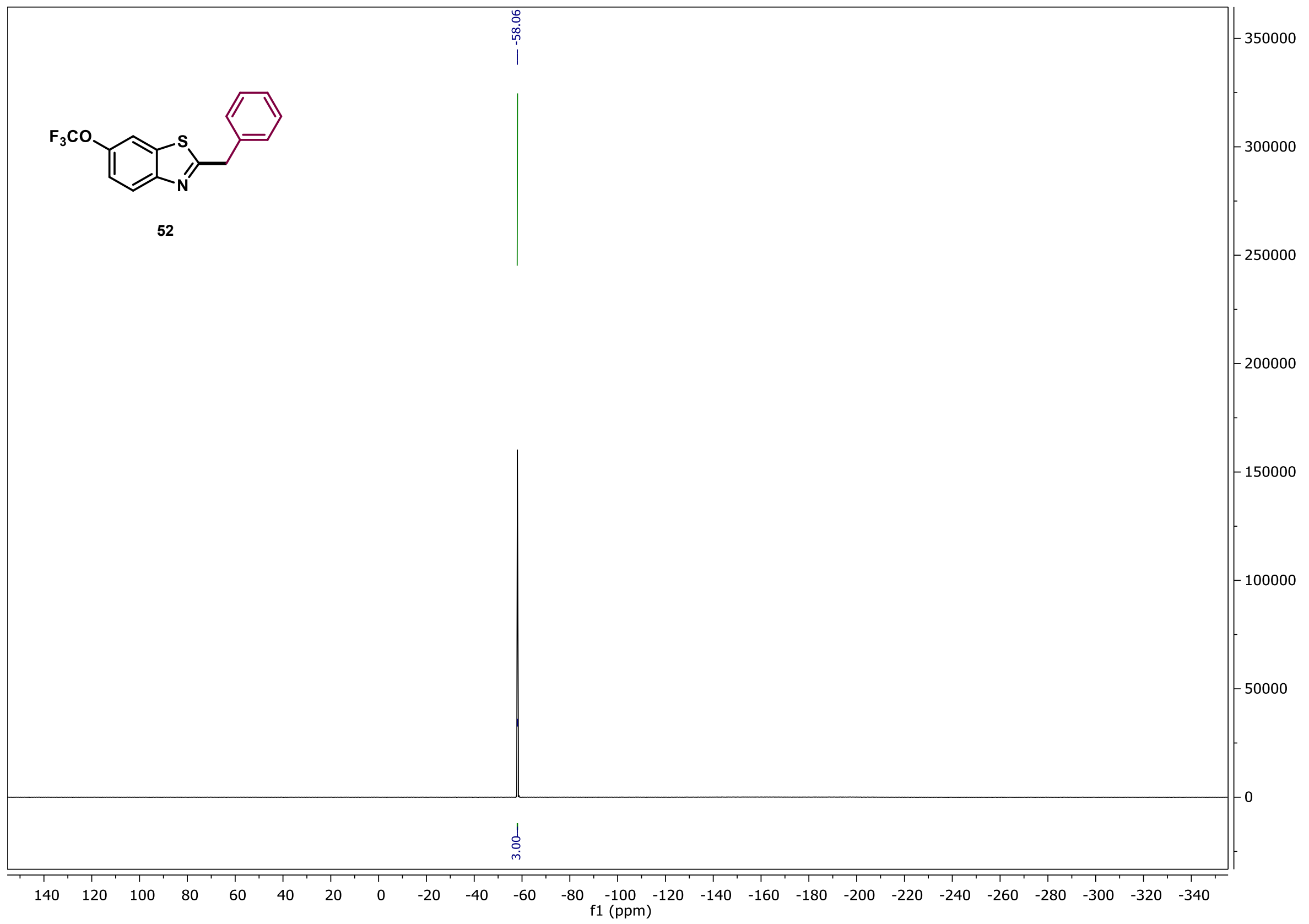


No. MW. Comment

1309 Your proposed structure is possible Ref.-Spektr. Nr. OU1617:
6.11 .2020

File: 150300a-00.raw

Analyse: GHC-GA-426-01

COP: Dr. Clement Ghiazza

Messung: GC-MS

Ionisierung: GC-EI

Spektrometer: QExactiveGC

Säule:

MS $50 \mathrm{RTX} 1+\mathrm{VS}$

Länge: $\quad 30+7$

Temp.: 35-10-285-5

$\mathrm{GC}-\mathrm{Nr} \cdot:$

MS-Nr.: $\quad 28258$

Auswerter: Margold (2242)

RI 50
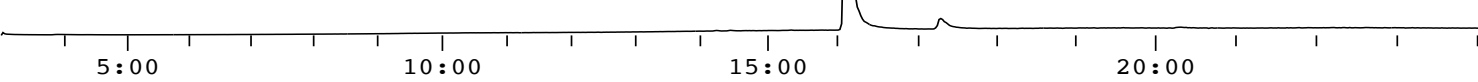

$100 \%$<smiles>FC(F)(F)Oc1ccc2nc(Cc3ccccc3)sc2c1</smiles>

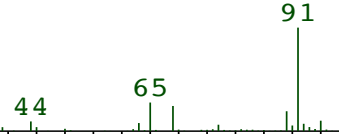

121 154

184
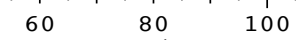

$20 \quad 140$

160

$180 \quad 200$

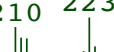

240

\begin{tabular}{|c|c|c|c|c|c|c|c|c|c|c|c|c|}
\hline 0.76 & 80 & 0.14 & 106 & 0.13 & 134 & 0.80 & 169 & 0.08 & 206 & 0.10 & 241 & 1.30 \\
\hline 0.09 & 81 & 0.37 & 107 & 0.31 & 135 & 0.30 & 171 & 0.25 & 207 & 0.07 & 242 & 0.56 \\
\hline 1.86 & 82 & 0.27 & 108 & 0.50 & 136 & 0.20 & 173 & 0.07 & 208 & 0.16 & 249 & 0.15 \\
\hline 0.77 & 83 & 0.27 & 109 & 0.41 & 139 & 0.70 & 177 & 0.36 & 209 & 0.56 & 252 & 2.32 \\
\hline 0.45 & 84 & 0.11 & 110 & 0.19 & 140 & 0.41 & 178 & 1.07 & 210 & 6.15 & 253 & 0.30 \\
\hline 0.15 & 85 & 0.19 & 111 & 0.23 & 141 & 0.21 & 179 & 0.67 & 211 & 4.12 & 254 & 0.09 \\
\hline 0.07 & 87 & 0.10 & 112 & 0.96 & 146 & 0.49 & 180 & 0.94 & 212 & 3.97 & 264 & 0.34 \\
\hline 0.38 & 88 & 0.13 & 113 & 0.10 & 148 & 0.15 & 181 & 0.13 & 213 & 0.72 & 275 & 0.07 \\
\hline 1.55 & 89 & 3.81 & 114 & 0.12 & 150 & 0.21 & 183 & 0.31 & 214 & 0.20 & 276 & 0.09 \\
\hline 0.17 & 90 & 1.08 & 115 & 0.32 & 151 & 0.43 & 184 & 1.38 & 221 & 0.15 & 277 & 0.15 \\
\hline 5.48 & 91 & 19.83 & 116 & 1.48 & 152 & 1.03 & 185 & 0.47 & 222 & 1.52 & 281 & 0.38 \\
\hline 0.23 & 92 & 1.41 & 117 & 0.19 & 153 & 0.40 & 186 & 0.15 & 223 & 7.98 & 282 & 0.13 \\
\hline 4.82 & 93 & 0.78 & 120 & 0.21 & 154 & 1.21 & 187 & 0.07 & 224 & 2.44 & 283 & 0.32 \\
\hline 0.29 & 94 & 0.41 & 121 & 2.75 & 155 & 0.23 & 188 & 0.15 & 225 & 0.46 & 294 & 0.17 \\
\hline 0.08 & 95 & 2.00 & 122 & 0.62 & 160 & 0.17 & 190 & 0.36 & 226 & 0.07 & 306 & 0.08 \\
\hline 0.25 & 96 & 0.30 & 123 & 1.33 & 162 & 0.11 & 191 & 0.25 & 230 & 0.16 & 307 & 7.84 \\
\hline 0.25 & 97 & 0.07 & 125 & 0.27 & 164 & 0.35 & 192 & 0.09 & 232 & 1.20 & 308 & 100.00 \\
\hline 0.36 & 102 & 0.44 & 126 & 0.14 & 165 & 0.21 & 195 & 0.25 & 233 & 0.20 & 309 & 50.05 \\
\hline 1.23 & 103 & 0.71 & 127 & 0.16 & 166 & 0.60 & 196 & 0.17 & 238 & 1.05 & 310 & 12.97 \\
\hline 0.23 & 104 & 0.10 & 128 & 0.29 & 167 & 1.00 & 197 & 0.28 & 239 & 2.93 & 311 & 2.93 \\
\hline 0.11 & 105 & 0.38 & 133 & 0.20 & 168 & 0.71 & 205 & 0.33 & 240 & 5.85 & 312 & 0 . \\
\hline
\end{tabular}

OU1671 33\% MW: $309 / 309.28$ C15H10F3N1O1S 1 


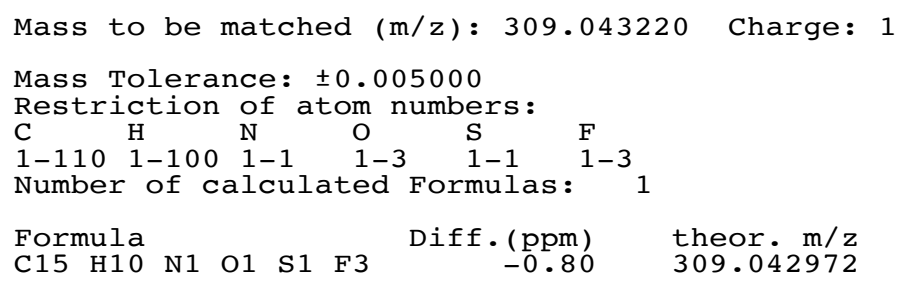

Auswerter: Margold (2242) 
${ }^{1} \mathrm{H}$ NMR

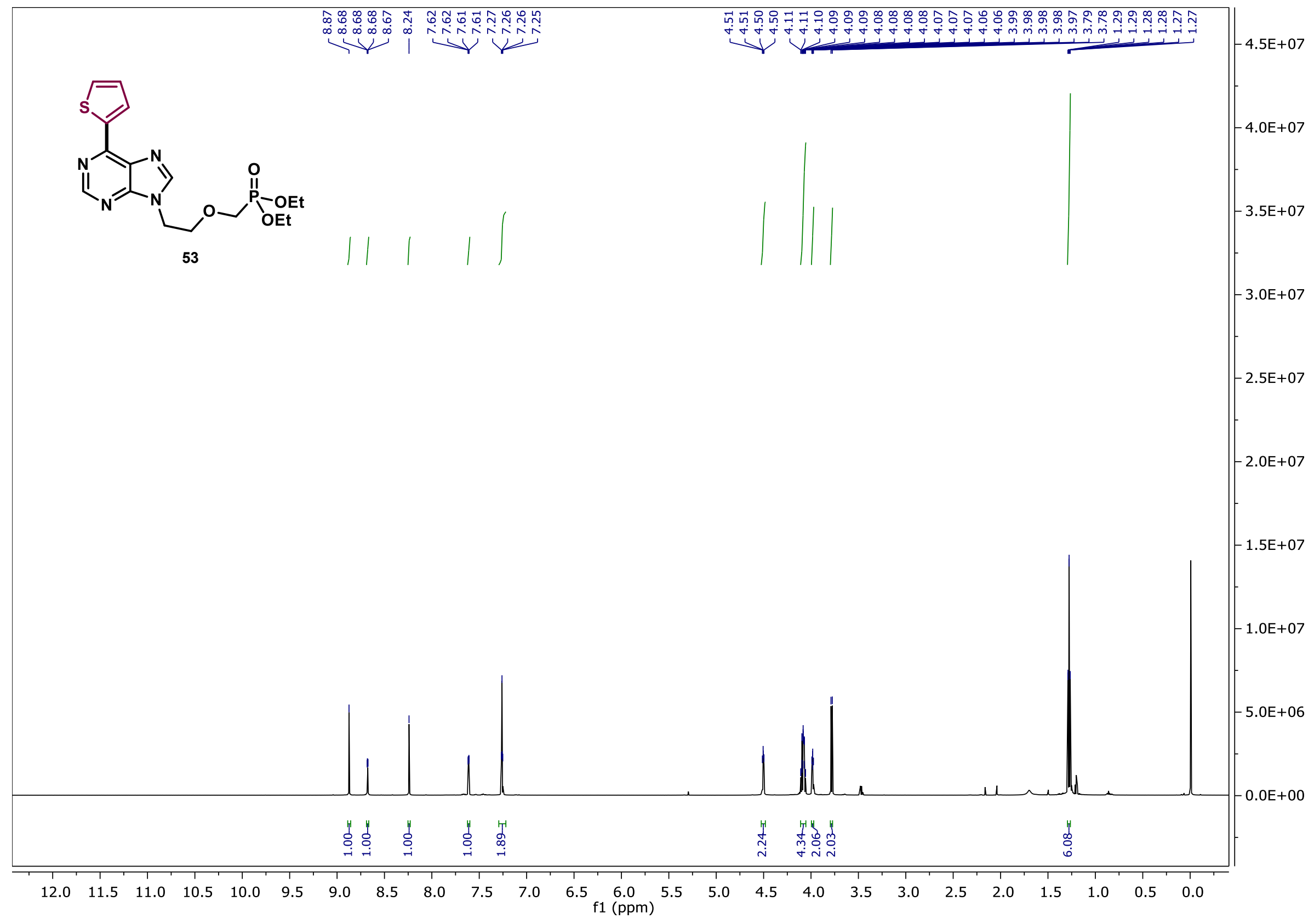




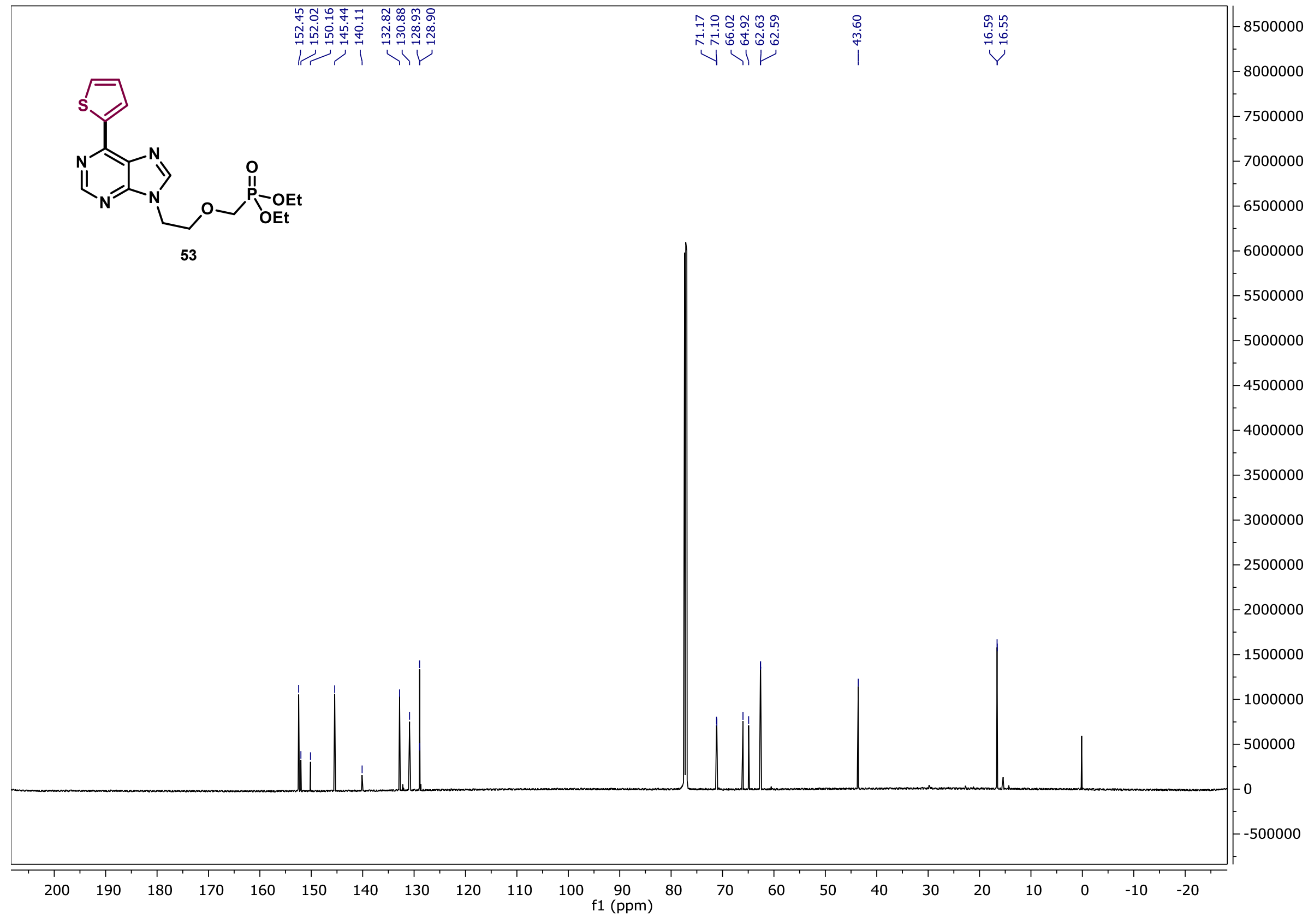




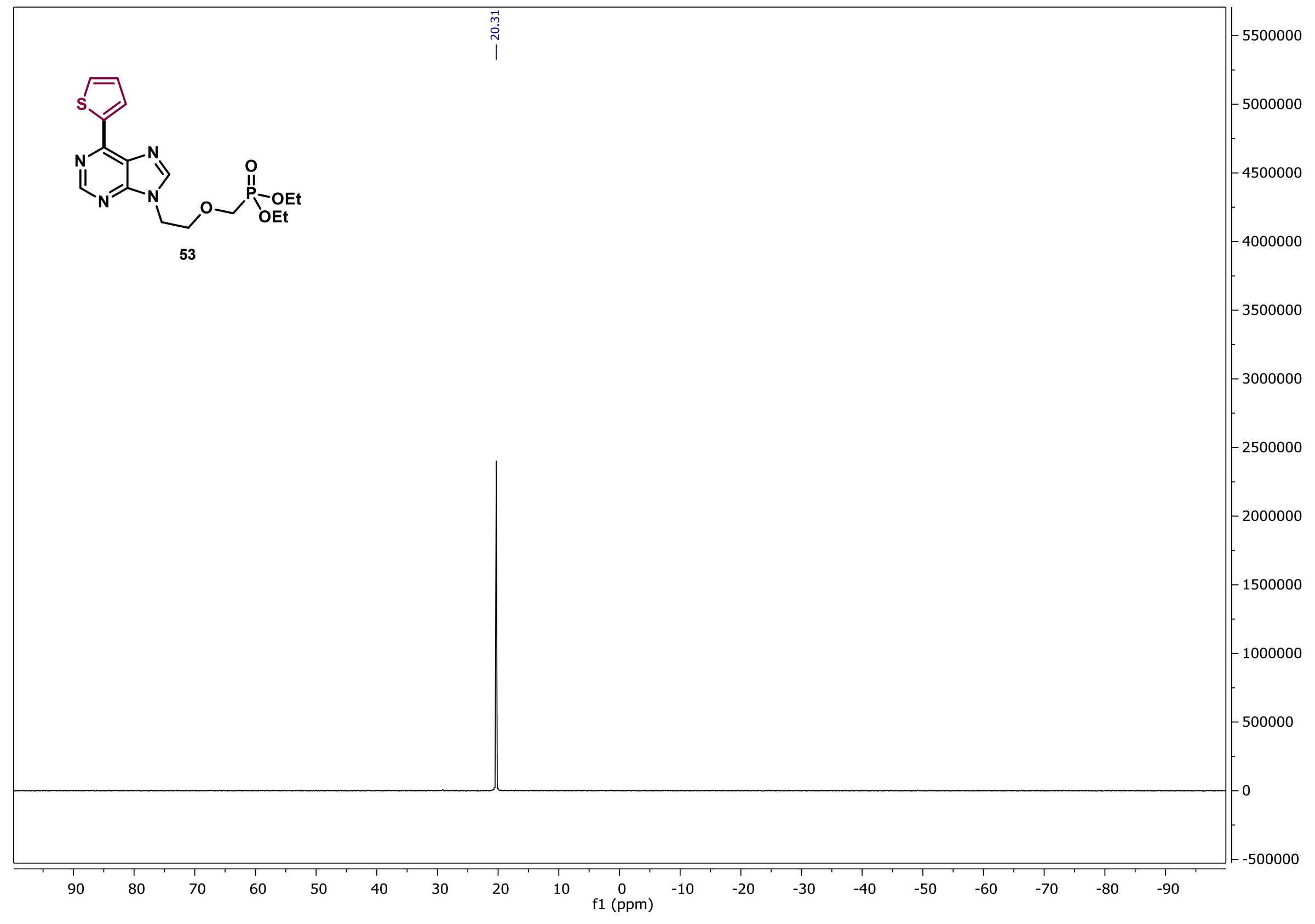


Mass to be matched $(\mathrm{m} / \mathrm{z}): 419.091270$ Charge: 1

Mass Tolerance: \pm 0.005000

Restriction of atom numbers:

$\begin{array}{lllllll}\mathrm{C} & \mathrm{H} & \mathrm{N} & \mathrm{O} & \mathrm{P} & \mathrm{S} & \mathrm{Na} \\ 1-100 & 1-100 & 2-4 & \max 10 & 1-1 & 1-1 & 1-1\end{array}$

Number of calculated Formulas: 3

Formula

$\begin{array}{lllllll}\mathrm{C} 16 & \mathrm{H} 21 & \mathrm{~N} 4 & 04 & \mathrm{P} 1 & \mathrm{~S} 1 & \mathrm{Na} 1\end{array}$

Diff. (ppm) 0.16

theor. $\mathrm{m} / \mathrm{z}$

$\begin{array}{llllll}\mathrm{C} 21 \mathrm{H} 21 & \mathrm{~N} 2 & \mathrm{O} 2 \mathrm{P} 1 & \mathrm{~S} 1 \mathrm{Na} 1 & 9.76 & 419.095358\end{array}$

\begin{tabular}{ll} 
Datum & 23.10 .2020 \\
Analyse: & $150104 \mathrm{~b}-00$ \\
\hline
\end{tabular}

Sigel:

GHC-GA-395-01

COP: Dr. Clement Ghiazza

$\begin{array}{ll}\text { Messung: } & \text { HRMS } \\ \text { Methode: } & \text { ESIpos }\end{array}$

Lösungsmittel: $\mathrm{CH} 2 \mathrm{Cl} 2+\mathrm{CH} 3 \mathrm{OH}$

Spektrometer:

Exactive

Auswerter:

Kampen (2242)

Suggestion:

C16H21N404P1S1 MW 396

characteristical ion

$419=[396+\mathrm{Na}]+$ 
${ }^{1} \mathrm{H}$ NMR

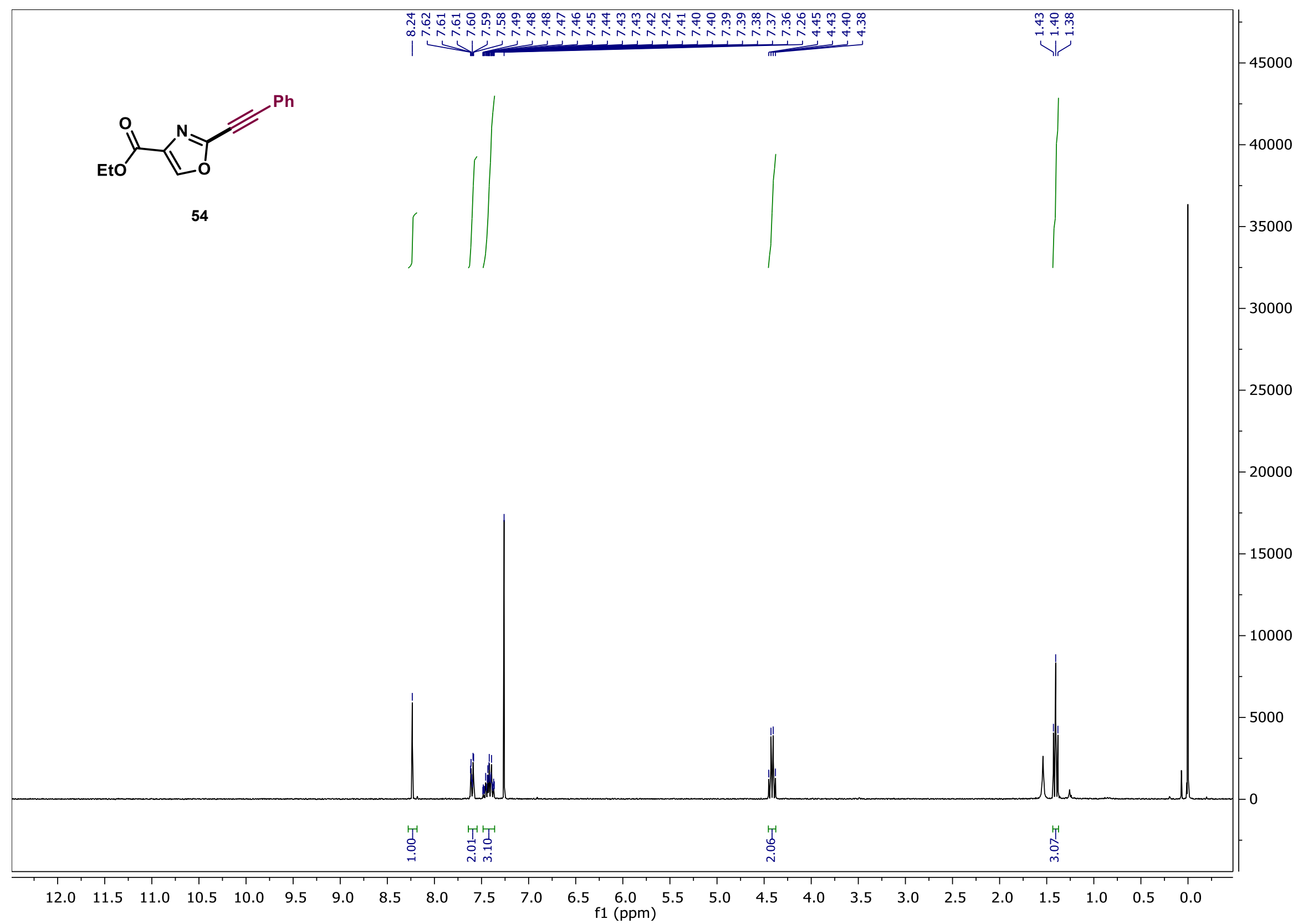




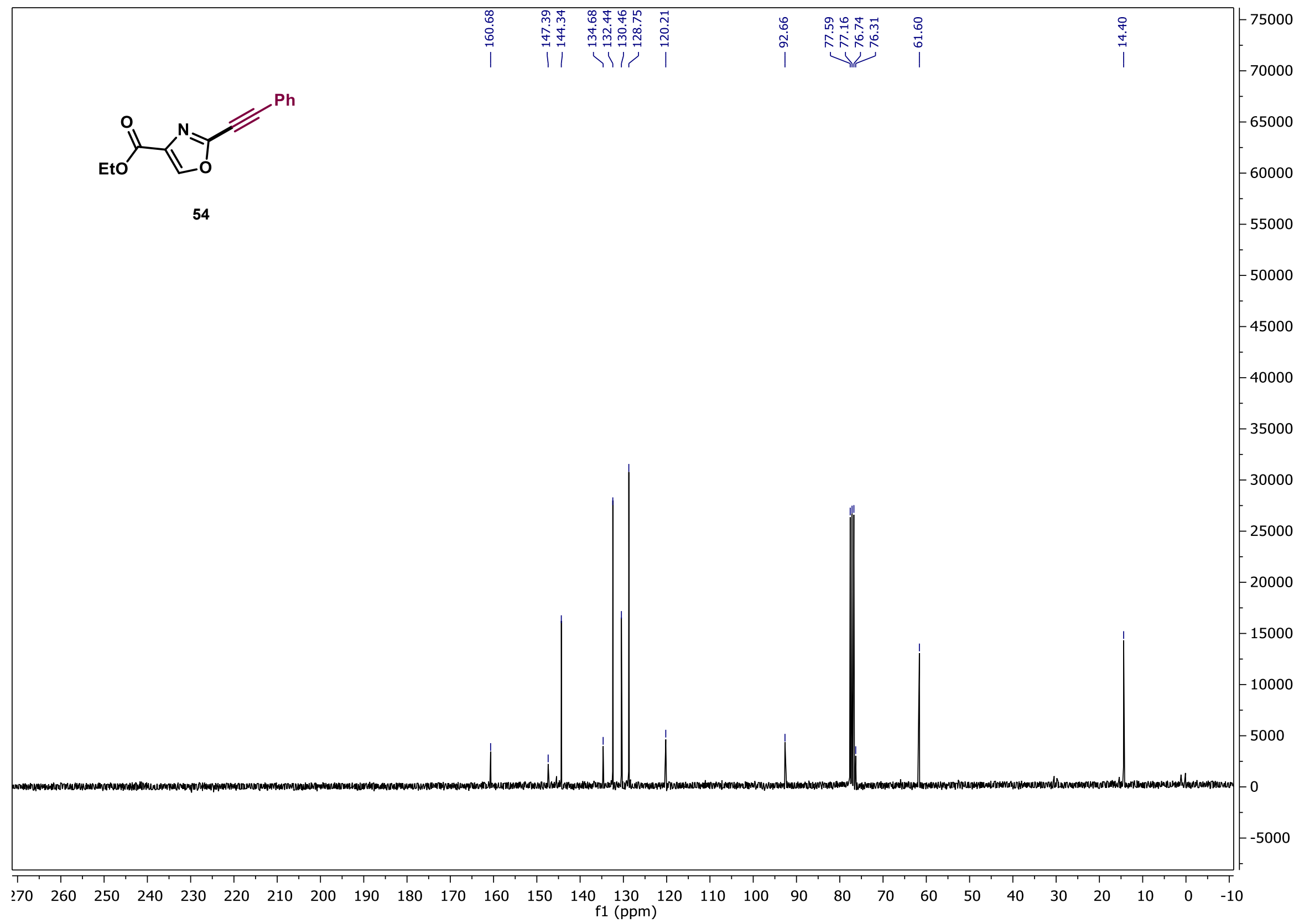


Mass to be matched $(\mathrm{m} / \mathrm{z}): 241.073490$ Charge: 1

Mass Tolerance: \pm 0.050000

Restriction of atom numbers:

$\begin{array}{llll}\mathrm{C} & \mathrm{H} & \mathrm{N} & \mathrm{O} \\ 1-100 & 1-100 & 1-2 & 1-5\end{array}$

Number of calculated Formulas: 11

Formula

$\begin{array}{llll}\mathrm{C} 14 & \mathrm{H} 11 & \mathrm{~N} 1 & \mathrm{O} 3 \\ \mathrm{C} 10 & \mathrm{H} 13 & \mathrm{~N} 2 & \mathrm{O} 5\end{array}$

$\mathrm{C} 10 \mathrm{H} 13 \mathrm{~N} 2 \mathrm{O}$

$\mathrm{C} 13 \mathrm{H} 9 \mathrm{~N} 2 \mathrm{O} 3$

$\begin{array}{llll}\mathrm{C} 11 & \mathrm{H} 15 & \mathrm{~N} 1 & \mathrm{O} 5\end{array}$

$\begin{array}{llll}\mathrm{C} 17 & \mathrm{H} 7 & \mathrm{~N} 1 & \mathrm{O} 1 \\ \mathrm{C} 14 & \mathrm{H} 13 \mathrm{~N} 2 & \mathrm{O} 2\end{array}$

$\begin{array}{llll}\mathrm{C} 14 & \mathrm{H} 13 & \mathrm{~N} 2 & \mathrm{O} 2 \\ \mathrm{C} 16 & \mathrm{H} 5 & \mathrm{~N} 2 & \mathrm{O} 1\end{array}$

$\begin{array}{llll}\mathrm{C} 15 & \mathrm{H} 15 & \mathrm{~N} 1 & \mathrm{O} 2\end{array}$

$\begin{array}{llll}\mathrm{C} 13 & \mathrm{H} 7 & \mathrm{~N} 1 & \mathrm{O} 4\end{array}$

$\begin{array}{llll}\mathrm{C} 11 & \mathrm{H} 17 & \mathrm{~N} 2 & \mathrm{O} 4\end{array}$

$\begin{array}{llll}\mathrm{C} 12 & \mathrm{H} 5 & \mathrm{~N} 2 & \mathrm{O} 4\end{array}$

\begin{tabular}{rl} 
Diff. (ppm) & theor. $\mathrm{m} / \mathrm{z}$ \\
-0.61 & 241.073344 \\
\hline 34.88 & 241.081898 \\
-52.77 & 241.060768 \\
87.04 & 241.094474 \\
-88.26 & 241.052214 \\
98.15 & 241.097153 \\
-140.42 & 241.039637 \\
150.32 & 241.109729 \\
-151.54 & 241.036959 \\
185.80 & 241.118282 \\
-203.70 & 241.024382
\end{tabular}

Suggestion:

C14 $111 \mathrm{~N} 103$
25.01 .2021

File: $151335 \mathrm{~b}-00$

Analyse: GHC-GA-552-01

COP: Dr. Clement Ghiazza

Messung: (HRMS)

Ionisierung: $\mathrm{EI}$

Spektrometer: Q Exactive GC Orbitrap

Säule:

MS50 RTX-1+VS

Iänge: $\quad 30+7$

Temp.: 35-10-285-5

GC-Nr : :

ELNA-Nr . :

29288

Auswerter:

Haupt (2243) 


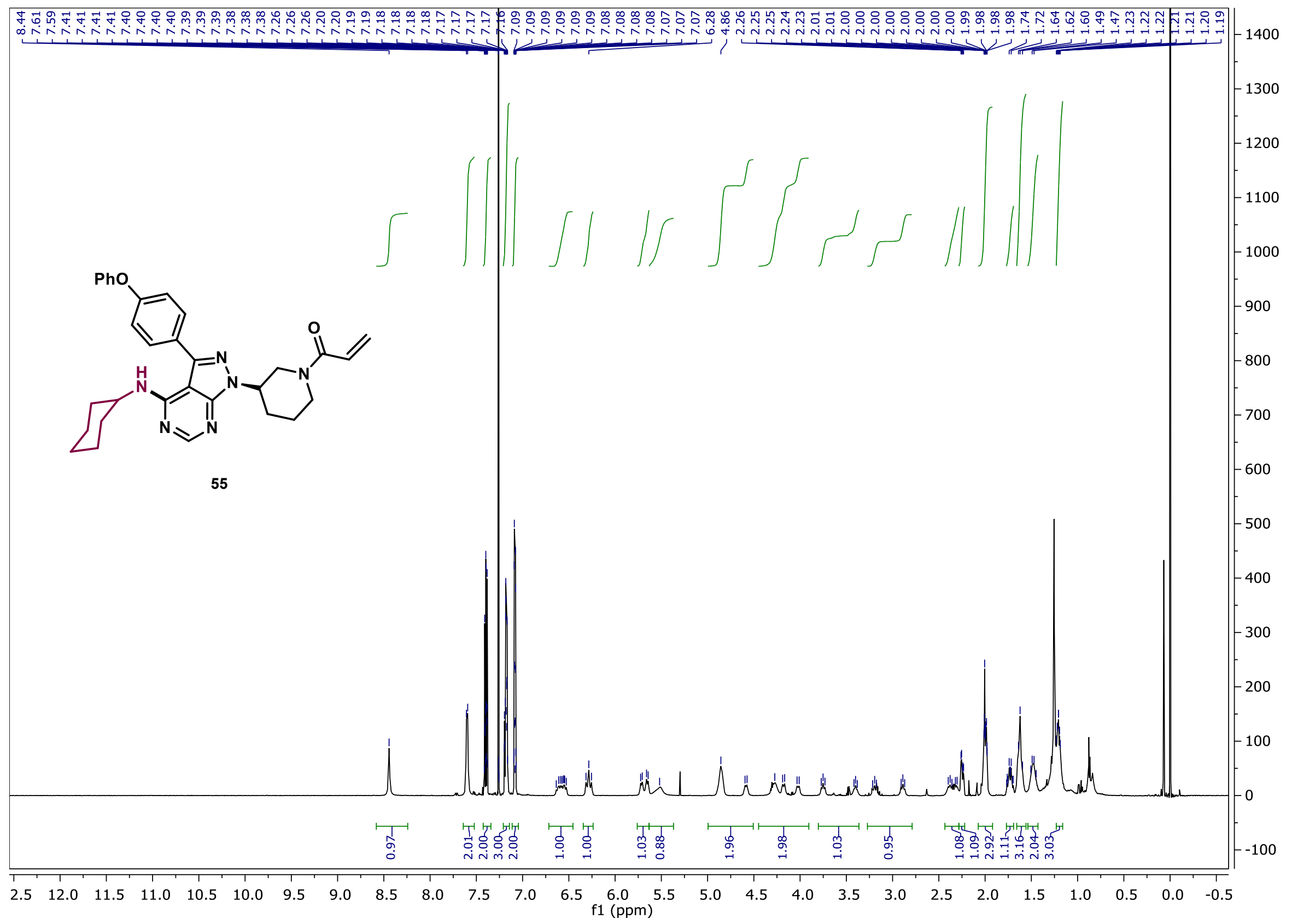




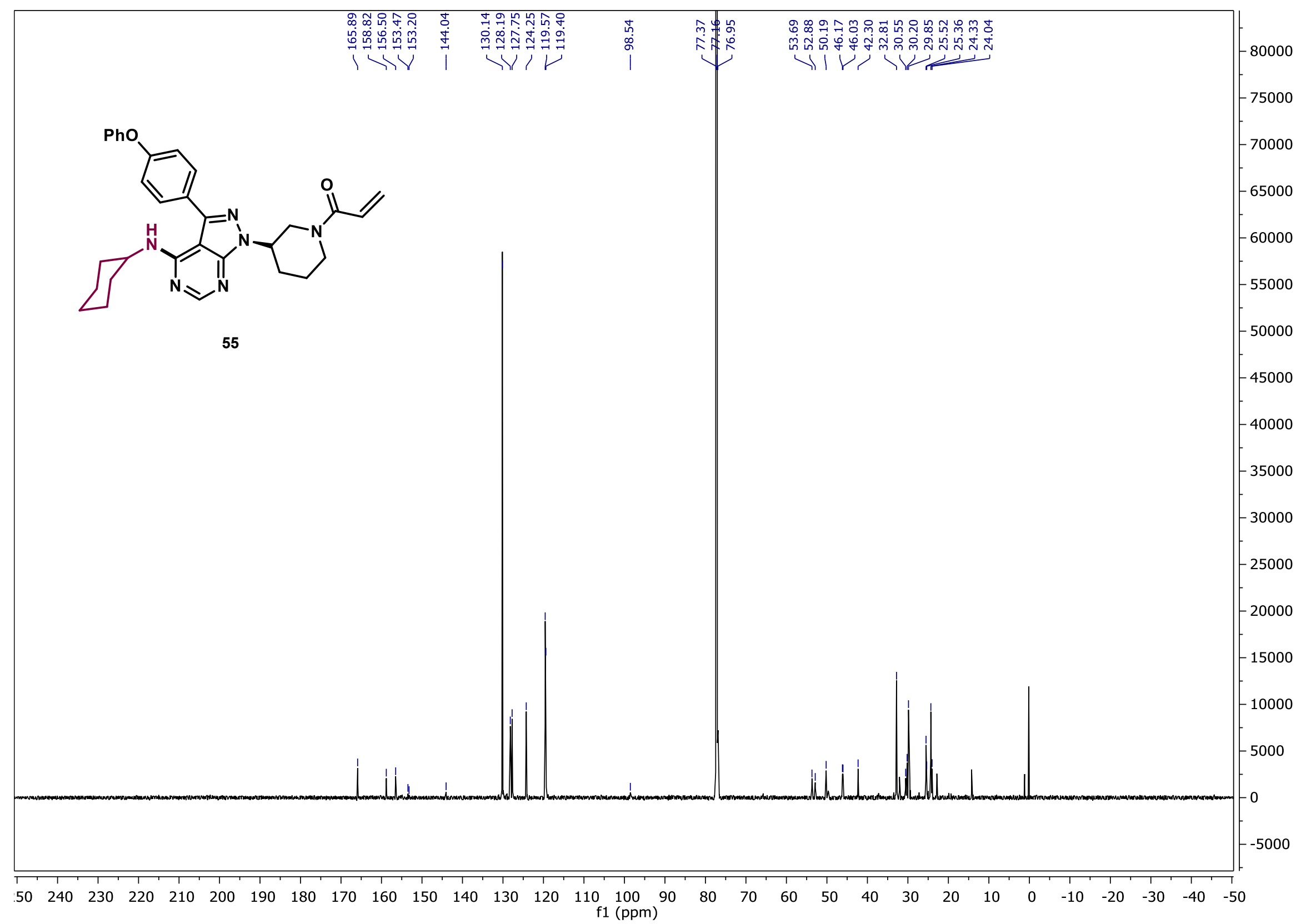


Mass to be matched $(\mathrm{m} / \mathrm{z}): 523.281660$ Charge: 1

Mass Tolerance: \pm 0.005000

Restriction of atom numbers:

$\begin{array}{lllll}\mathrm{C} & \mathrm{H} & \mathrm{N} & \mathrm{O} \\ 1-100 & 1-100 & 4-6 & \max & 10\end{array}$

Number of calculated Formulas:

\section{Formula}

$\begin{array}{llll}\mathrm{C} 31 & \mathrm{H} 35 & \mathrm{~N} 6 & \mathrm{O} 2 \\ \mathrm{C} 28 & \mathrm{H} 37 & \mathrm{~N} 5 & 05\end{array}$

C28 H37 N5 05

C21 H4 1 N5 010

Diff. (ppm)

$-0.12$

$-5.24$

5.99

7.57

$\mathrm{m} / \mathrm{z}$ 523.281597

C 36 H35 N4

523.278919

523.284793

523.285620

\begin{tabular}{ll} 
Datum & 19.11 .2020 \\
Analyse: & $150555 \mathrm{c}-00$ \\
\hline
\end{tabular}

Sigel:

GHC-GA-453-01

COP: Dr. Clement Ghiazza

\begin{tabular}{ll}
\hline Messung: & HRMS \\
Methode: & ESIpos
\end{tabular}

Methode: ESIpos

Lösungsmittel: $\mathrm{CH} 2 \mathrm{Cl} 2+\mathrm{CH} 3 \mathrm{OH}$

Spektrometer:

Exactive

Auswerter:

Kampen (2242)

\author{
Suggestion: \\ C31H34N6O2 MW 522 \\ characteristical ion \\ $523=[522+\mathrm{H}]+$
}




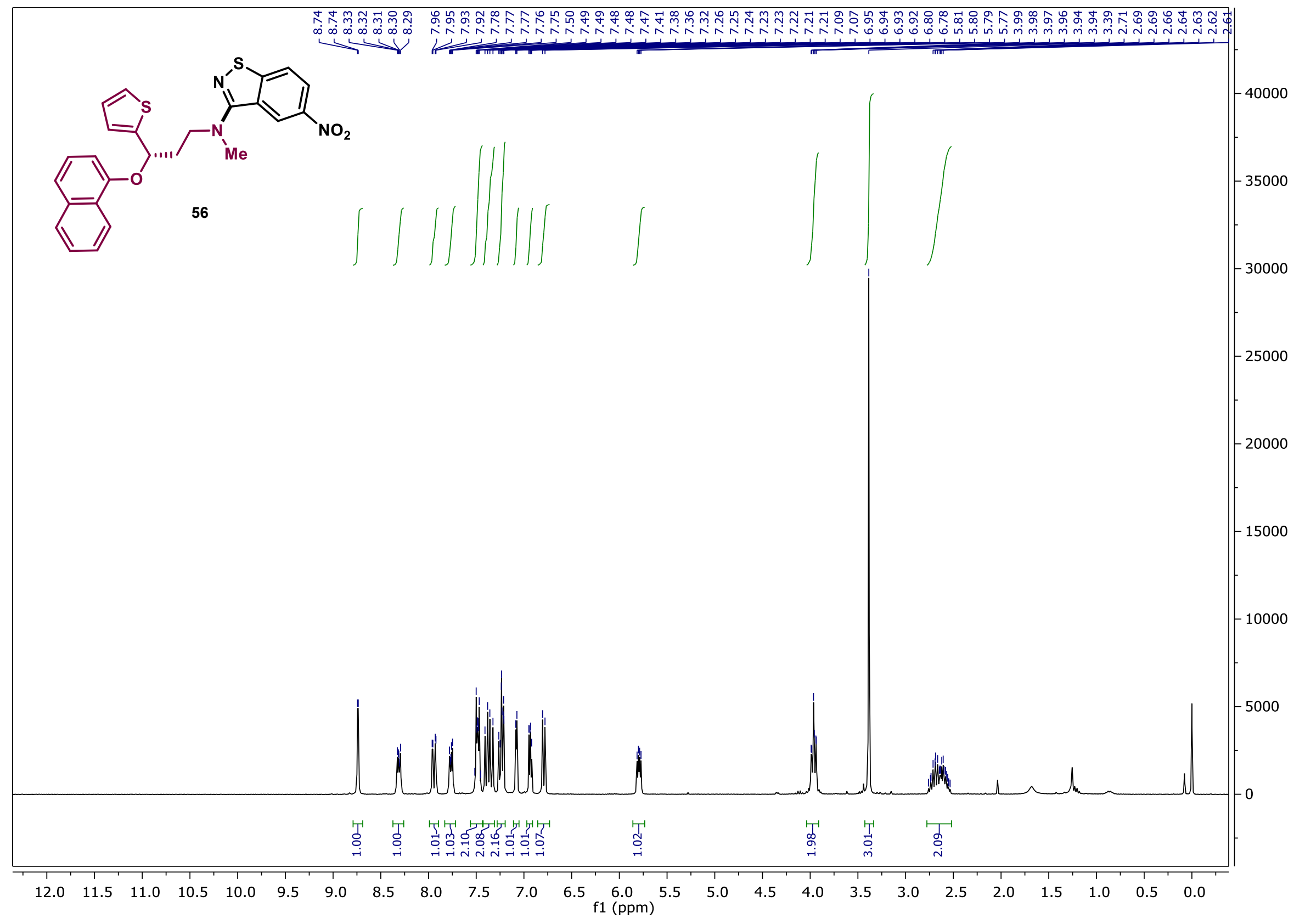




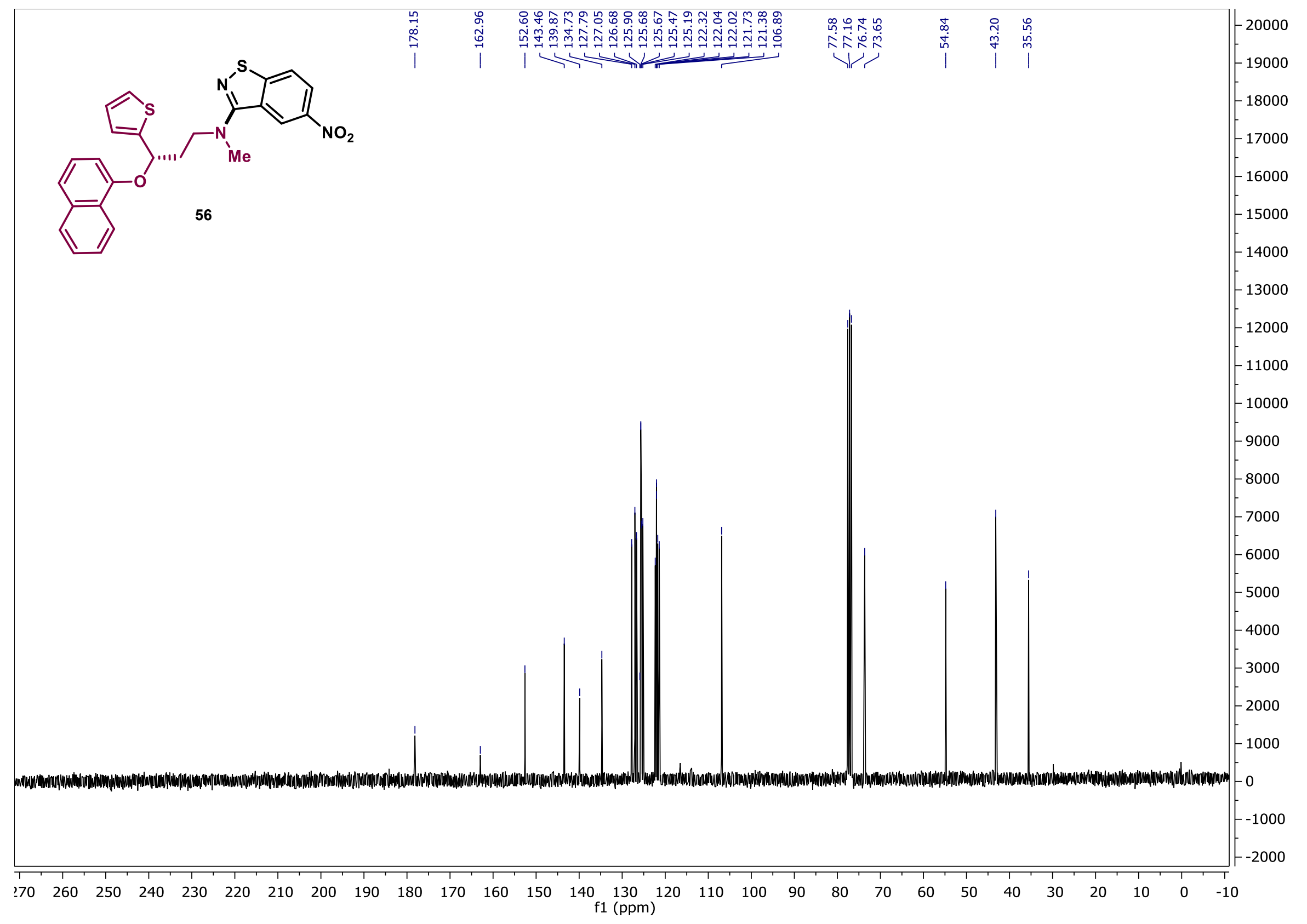


Mass to be matched $(\mathrm{m} / \mathrm{z}): 476.109480$ Charge: 1

Mass Tolerance: \pm 0.005000

Restriction of atom numbers:

$\begin{array}{lllll}\mathrm{C} & \mathrm{H} & \mathrm{N} & \mathrm{O} & \mathrm{S} \\ 1-100 & 1-100 & 1-3 & \max 5 & 2-2\end{array}$

Number of calculated Formulas: 2

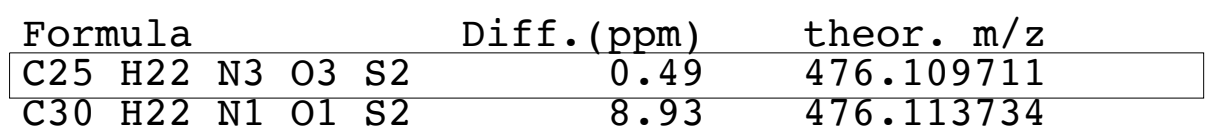

\begin{tabular}{|c|c|}
\hline $\begin{array}{l}\text { Datum } \\
\text { Analyse: }\end{array}$ & $\begin{array}{r}3.11 .2020 \\
150251 \mathrm{~b}-00\end{array}$ \\
\hline $\begin{array}{l}\text { Sigel: } \\
\text { COP: Dr. Clemer }\end{array}$ & $\begin{array}{l}\text { GHC-GA-417-01 } \\
\text { Ghiazza }\end{array}$ \\
\hline $\begin{array}{l}\text { Messung: } \\
\text { Methode: } \\
\text { Lösungsmittel: } \\
\text { Spektrometer: }\end{array}$ & $\begin{array}{l}\text { HRMS } \\
\text { ESIpos } \\
\text { CH2Cl2+CH } 30 \mathrm{H} \\
\text { Exactive }\end{array}$ \\
\hline Auswerter: & Kampen (2242) \\
\hline
\end{tabular}

Suggestion:

C25H22N3O3S2 MW 475

characteristical ion

$476=[475+\mathrm{H}]+$ 


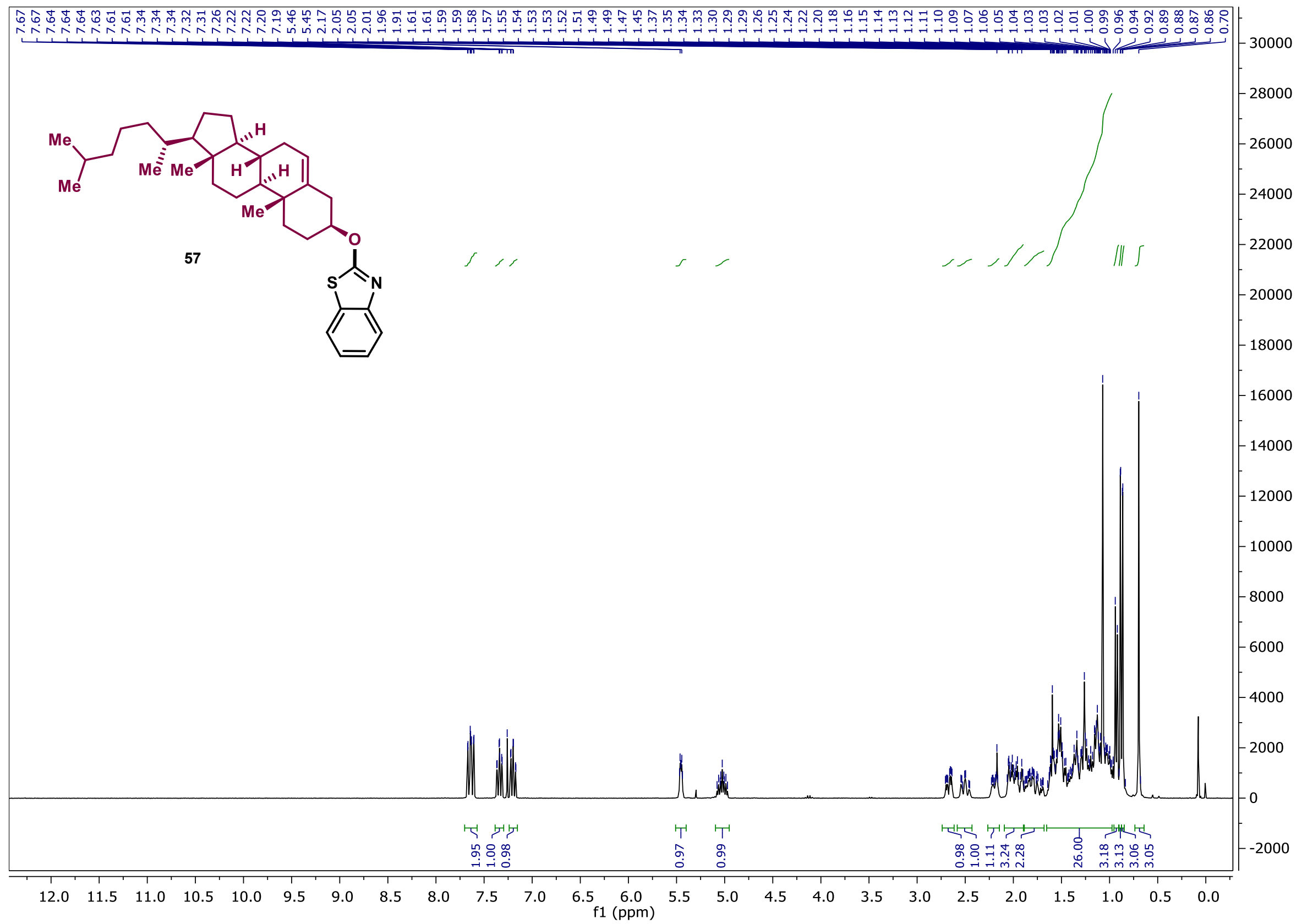




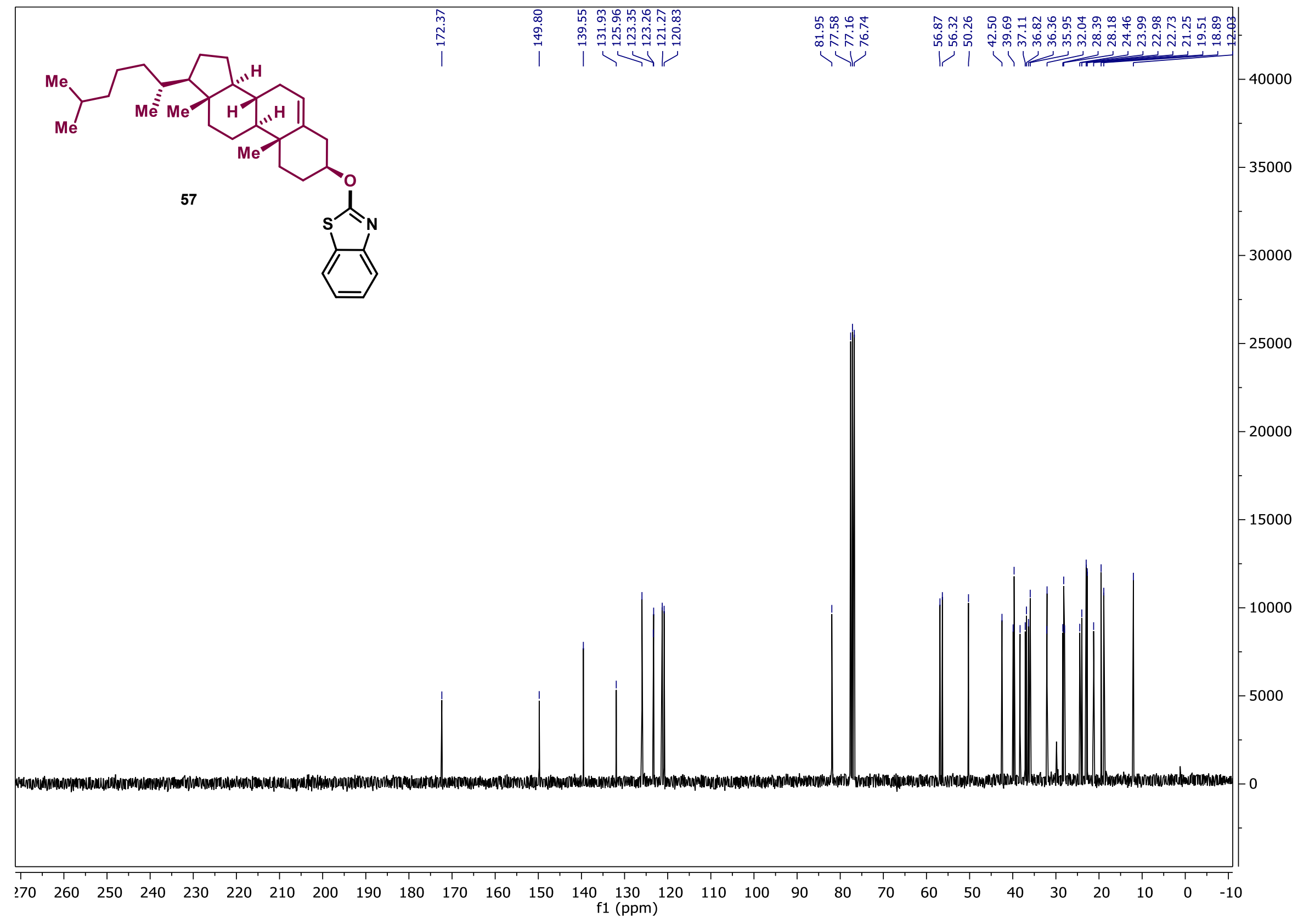


Mass to be matched $(\mathrm{m} / \mathrm{z}): 542.342660$ Charge: 1

Mass Tolerance: \pm 0.005000

Restriction of atom numbers:

$\begin{array}{llllll}\mathrm{C} & \mathrm{H} & \mathrm{N} & \mathrm{O} & \mathrm{S} & \mathrm{Na} \\ 1-100 & 1-100 & 1-3 & \max 5 & 1-1 & 1-1\end{array}$

Number of calculated Formulas: 2

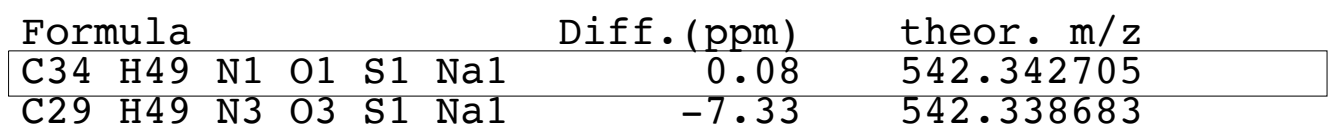

\begin{tabular}{lc} 
Datum & 19.11 .2020 \\
Analyse: & $150538 \mathrm{c}-00$. RAW \\
\hline $\begin{array}{l}\text { Sigel: } \\
\text { COP: Dr. Clement Ghiazza }\end{array}$
\end{tabular}

Messung: HRMS

Methode: ESIpos

Lösungsmittel: $\mathrm{CH} 2 \mathrm{Cl} 2+\mathrm{CH} 3 \mathrm{OH}$

Spektrometer:

Auswerter:

Exactive

Kampen (2242)

Suggestion:

C34H49N1O1S1 MW 519

characteristical ion

$542=[519+\mathrm{Na}]+$ 
${ }^{1} \mathrm{H}$ NMR

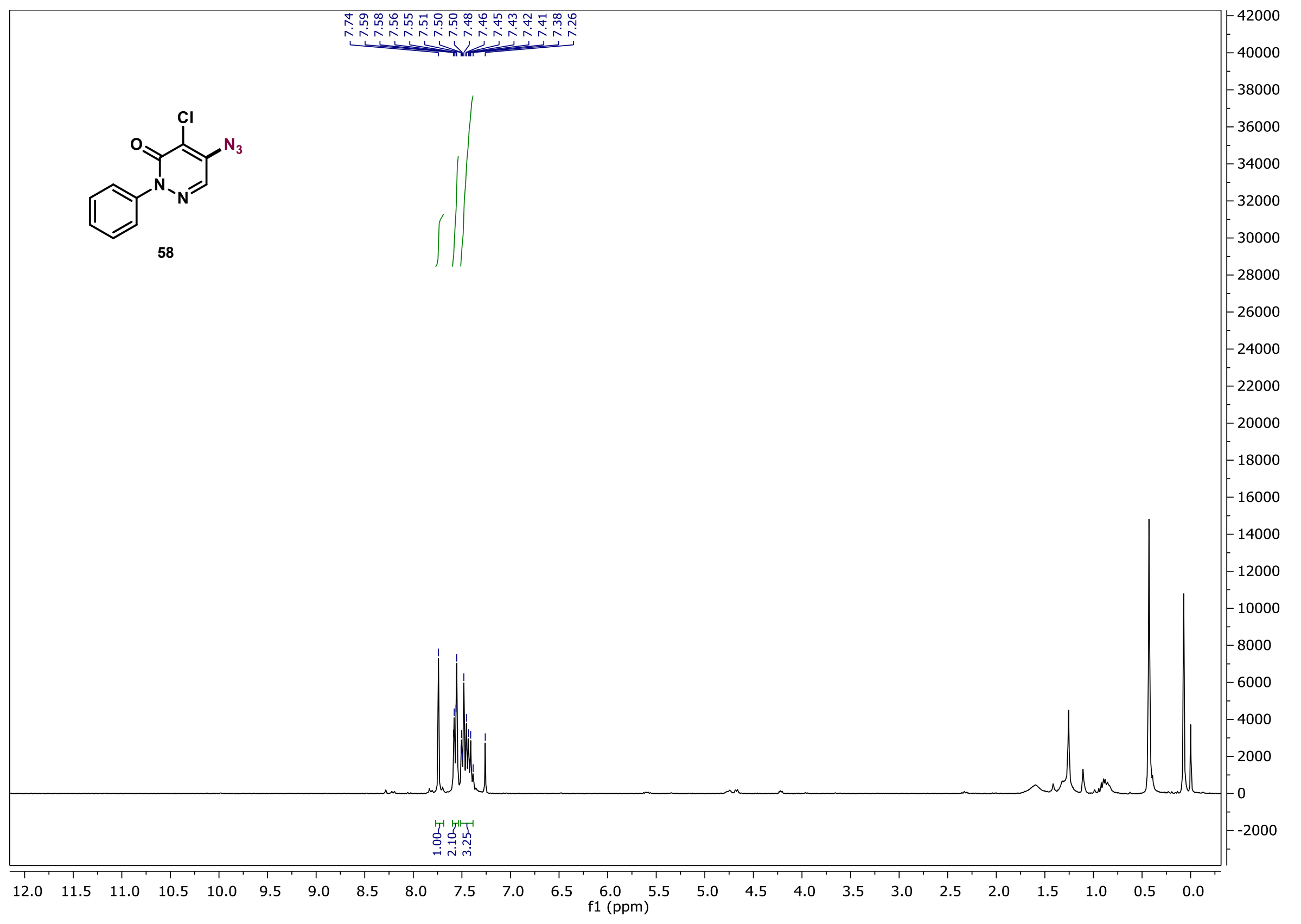


Mass to be matched $(\mathrm{m} / \mathrm{z}): 270.015390$ Charge: 1

Mass Tolerance: \pm 0.005000

Restriction of atom numbers:

$\begin{array}{llllll}\mathrm{C} & \mathrm{H} & \mathrm{Cl} & \mathrm{N} & \mathrm{O} & \mathrm{Na} \\ 1-100 & 1-100 & 1-1 & 1-5 & \max 105 & 1-1\end{array}$

Number of calculated Formulas: 4 max 105 1-1

Formula Diff. (ppm) theor. $\mathrm{m} / \mathrm{z}$

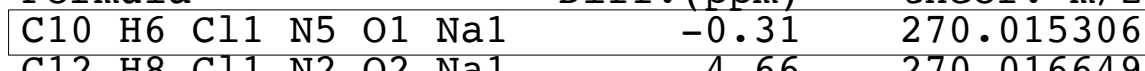

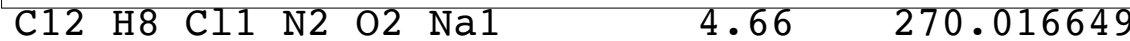

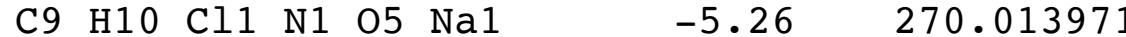

C7 H8 Cl1 N4 O4 Nal $\quad-10.23 \quad 270.012627$

\begin{tabular}{|c|c|}
\hline $\begin{array}{l}\text { Datum } \\
\text { Analyse: }\end{array}$ & $\begin{array}{l}23.10 .2020 \\
150103 \mathrm{~b}-00\end{array}$ \\
\hline Sigel: & GHC-AA-089-01 \\
\hline COP: Dr. Clement & t Ghiazza \\
\hline Messung : & HRMS \\
\hline Methode: & ESIpos \\
\hline Lösungsmittel: & $\mathrm{CH} 2 \mathrm{Cl} 2+\mathrm{CH} 3 \mathrm{OH}$ \\
\hline Spektrometer: & Exactive \\
\hline Auswerter: & Kampen (2242) \\
\hline
\end{tabular}

\footnotetext{
Suggestion:

C10H6C11N501 MW 247

characteristical ion

$270=[247+\mathrm{Na}]+$
} 
${ }^{1} \mathrm{H}$ NMR

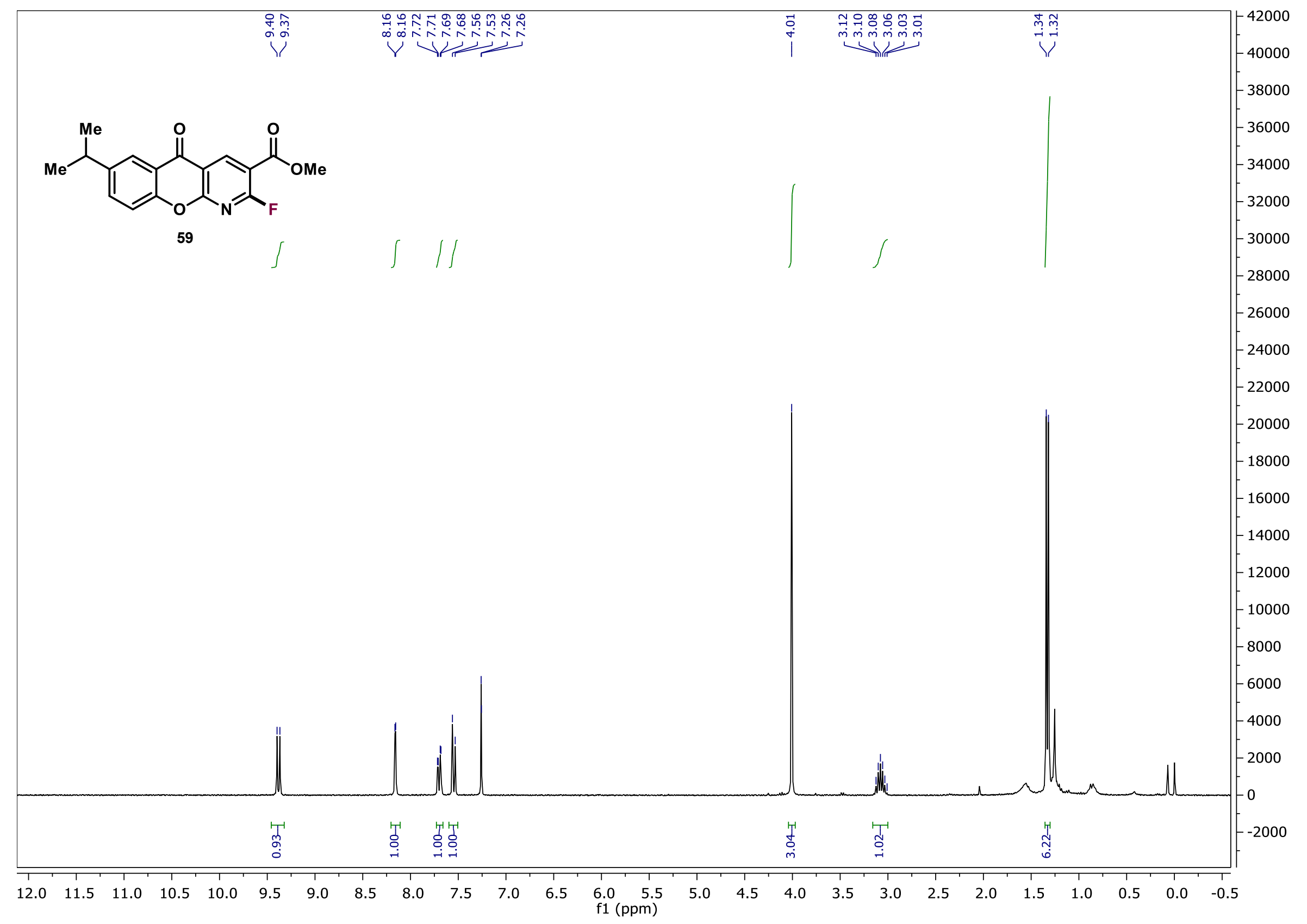




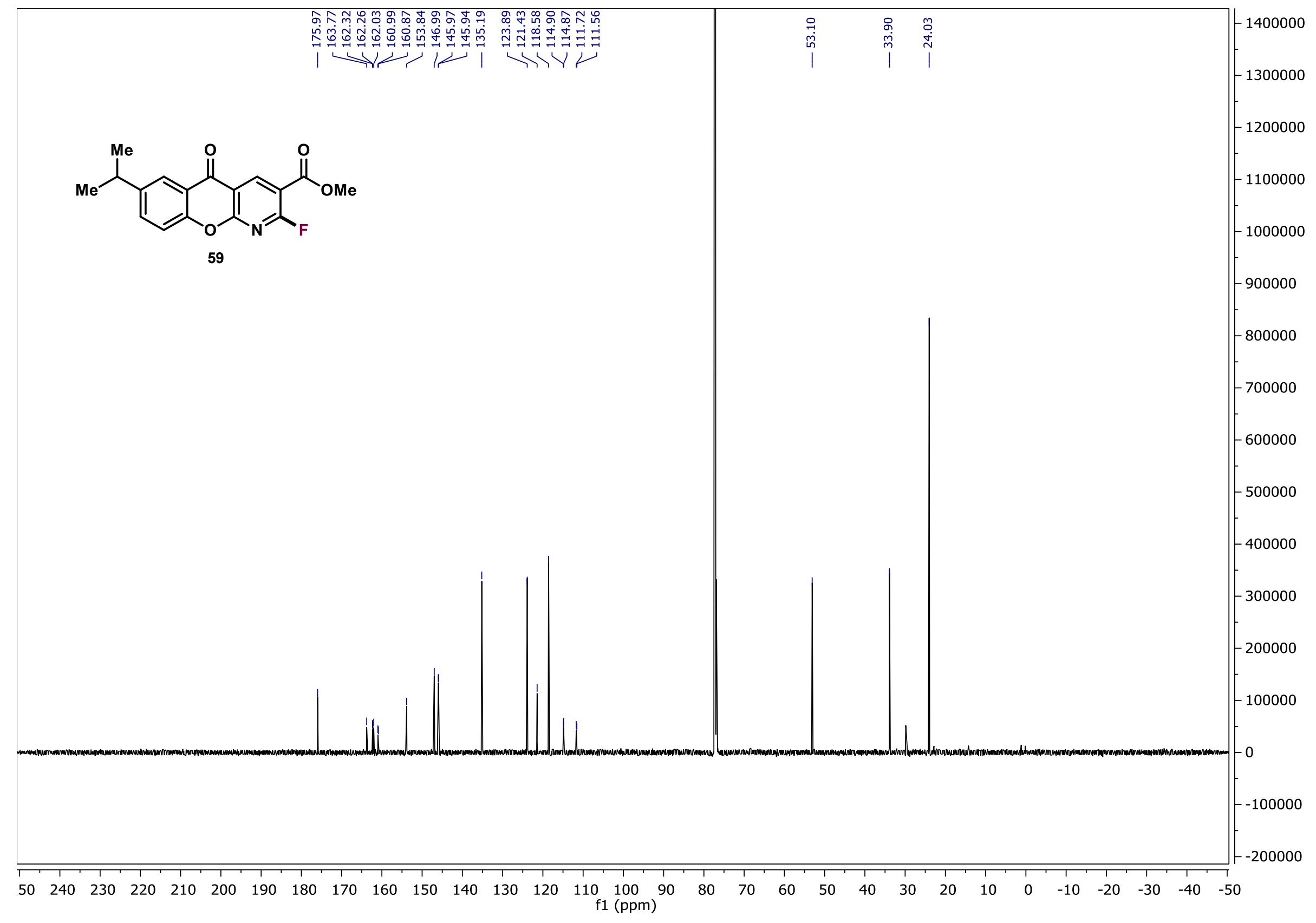


${ }^{19}$ F NMR

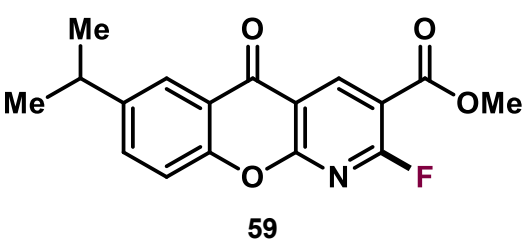

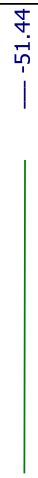

22000

21000

20000

19000

$-18000$

17000

$-16000$

15000

14000

13000

12000

11000

10000

9000

8000

$-7000$

6000

5000

4000

3000

2000

$-1000$

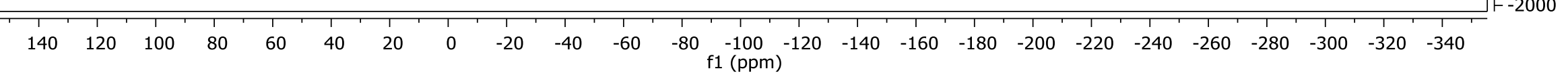


11.11.2020 10:45 p.判* Angegebene Mol.-Gewichte u. Massenzahlen basieren auf dem häufigsten Isotop der Elemente *** MassLib

Mass to be matched $(\mathrm{m} / \mathrm{z}): 315.090100$ Charge: 1

11.11 .2020

File: 150390d-00

Analyse: GHC-GA-435-01

Restriction of atom numbers:

$\begin{array}{lllll}\mathrm{C} & \mathrm{H} & \mathrm{N} & \mathrm{O} & \mathrm{F} \\ 1-100 & 1-100 & 1-2 & 1-4 & 1-1\end{array}$

Number of calculated Formulas: 8

Formula

\begin{tabular}{|c|c|c|}
\hline & $E f .(p p m)$ & theor. \\
\hline O4 F1 & 0.12 & 315.090137 \\
\hline O1 F1 & 8.62 & 315.092816 \\
\hline O4 F1 & -39.79 & 315.077561 \\
\hline O1 F1 & 48.53 & 105 \\
\hline $\mathrm{O} 2 \mathrm{~F} 1$ & -66.94 & 315.069007 \\
\hline $\mathrm{O} 3 \mathrm{~F} 1$ & 75.68 & 315.113946 \\
\hline $\mathrm{O} 2 \mathrm{~F} 1$ & -106.86 & 315.056431 \\
\hline O3 F1 & 115 & 315 . \\
\hline
\end{tabular}

COP: Dr. Clement Ghiazza

Messung: (HRMS)

Ionisierung: $\mathrm{EI}$

Spektrometer: Q Exactive GC Orbitrap

Säule:

MS50 RTX-1+VS

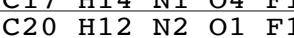

$\begin{array}{lllll}\mathrm{C} 16 & \mathrm{H} 12 & \mathrm{~N} 2 & \mathrm{O} 4 & \mathrm{~F} 1\end{array}$

Länge :

$30+7$

Temp.:

$35-10-285-5$

C20 1140

C2 17 H 16 N2 $\mathrm{O} 3$ F 1

C17 19 H8 N2 O2 F1

GC-Nr . :

ELNA-Nr.:

28353

C18 H18 N1 O3 F1 $115.59 \quad 315.126522$

Auswerter:

Haupt (2243) 
${ }^{1} \mathrm{H}$ NMR

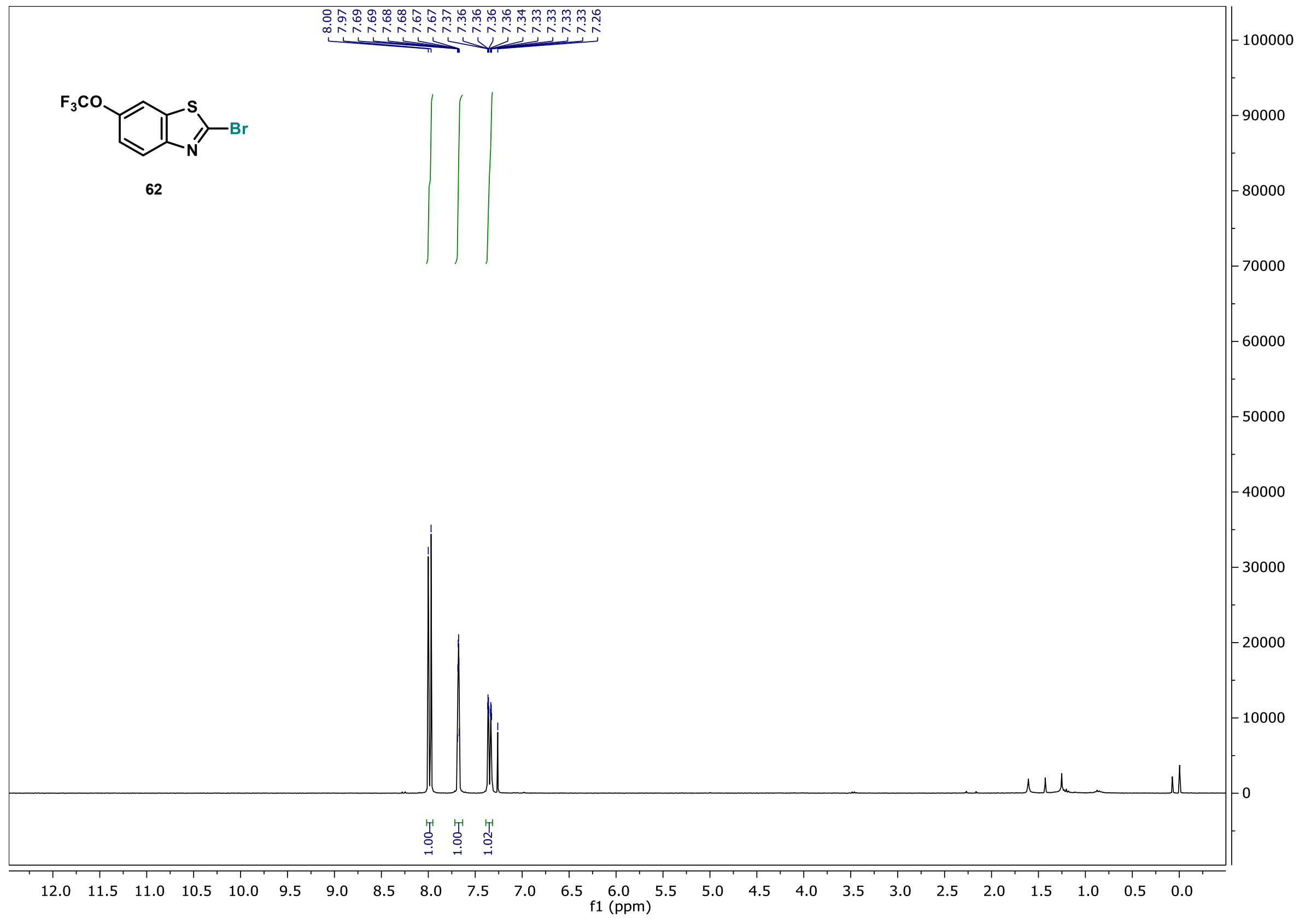


${ }^{13} \mathrm{C}$ NMR

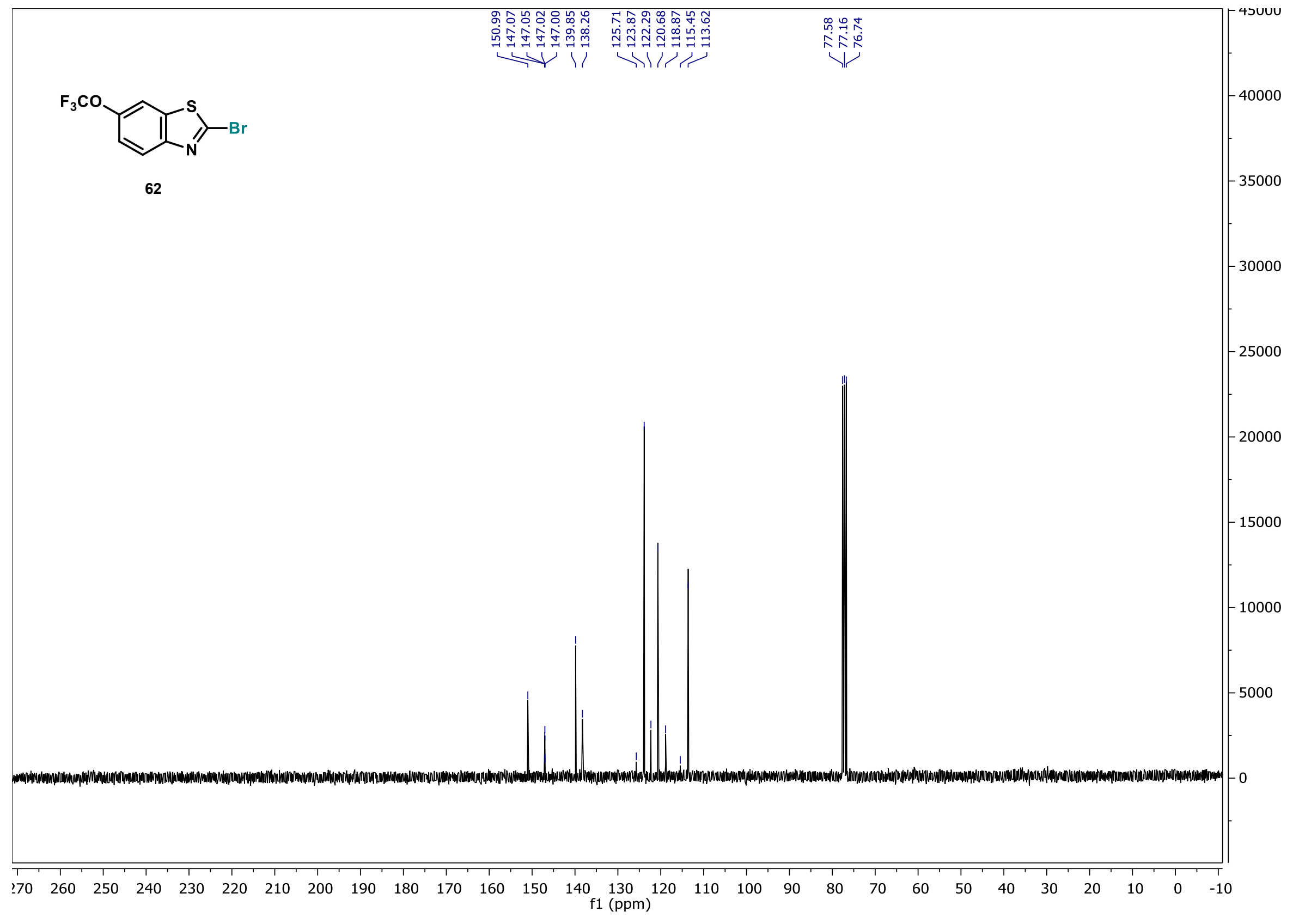


${ }^{19} \mathrm{~F}$ NMR

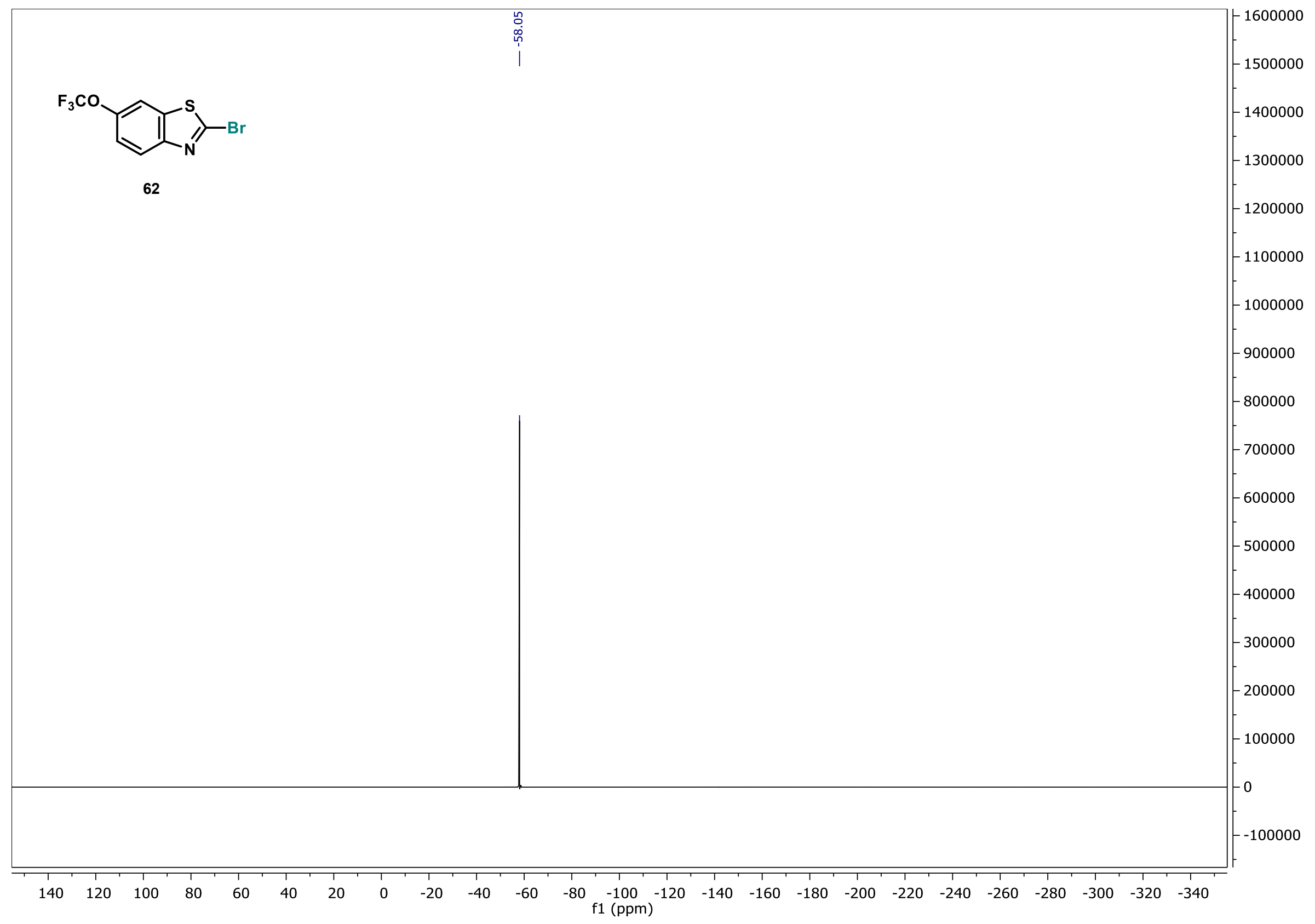




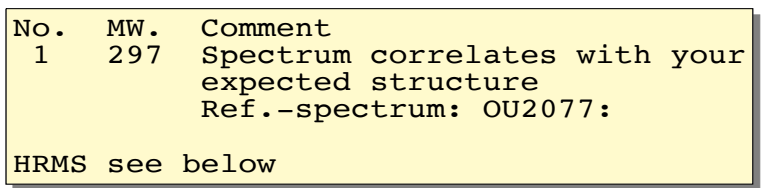

\begin{tabular}{|c|c|}
\hline \multicolumn{2}{|c|}{$\begin{array}{l}17.03 .2021 \\
\text { File: } 152336 a-00 . \text { raw } \\
\text { Analyse: GHC-GA-645-01 } \\
\text { CoP: Dr. Clement Ghiazz }\end{array}$} \\
\hline Messung: & GC-MS \\
\hline Ionisierung: & $\mathrm{GC}-\mathrm{EI}$ \\
\hline Spektrometer: & Q Exactive GC Orbitrap \\
\hline Säule: & MS $81 \mathrm{zB} 1 \mathrm{~ms}$ \\
\hline Länge: & 30 \\
\hline Temp.: & $35-15-300-3$ \\
\hline GC-Nr.: & - \\
\hline ELNA-Nr . : & 30257 \\
\hline
\end{tabular}
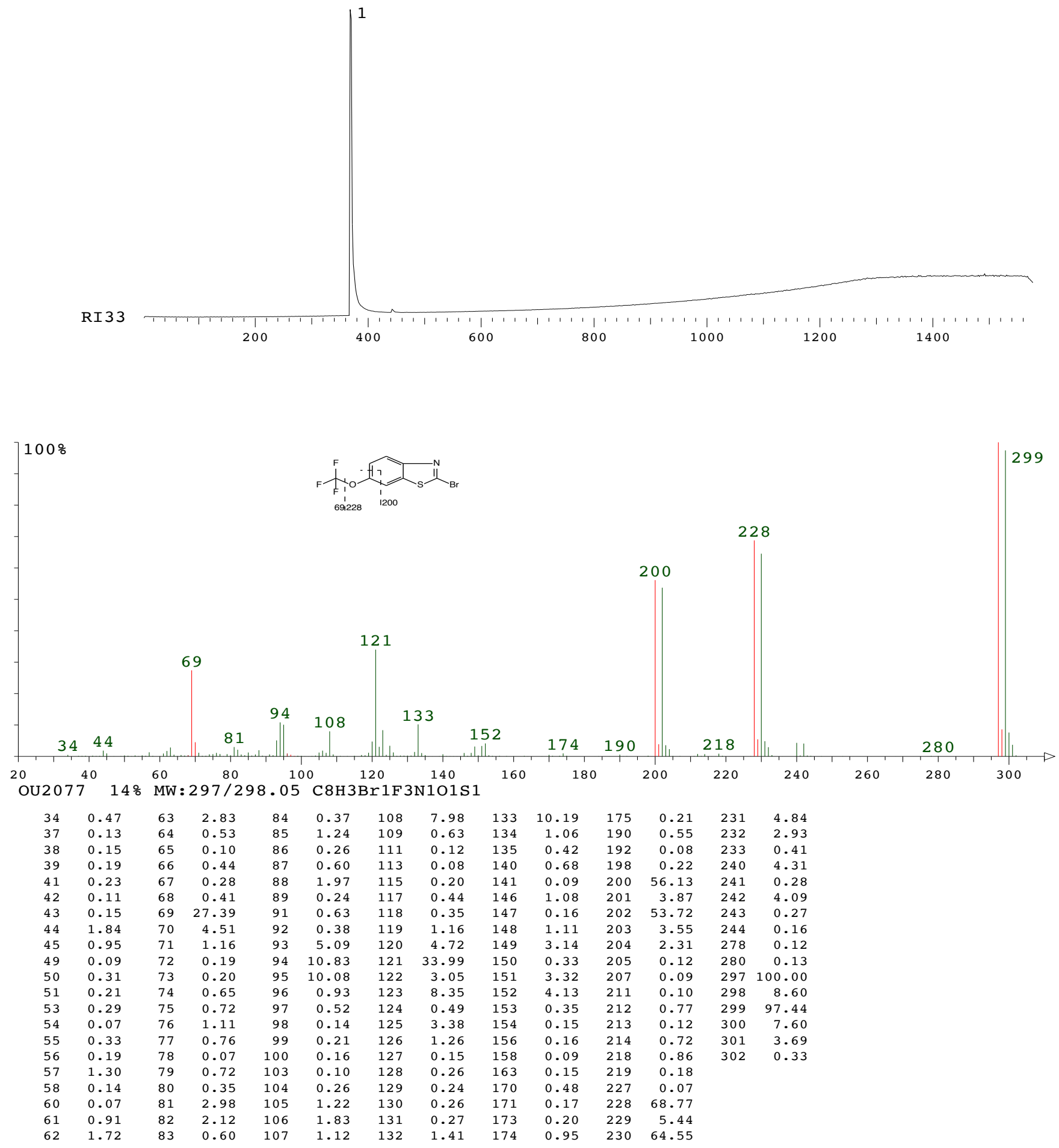

OU207174\% MW: $297 / 298.05$ C 8 H 3 Br 1 F $3 N 101 S$

$\lim : 0.07 \%$ 
Mass to be matched $(\mathrm{m} / \mathrm{z}): 296.906890$ Charge: 1

Mass Tolerance: \pm 0.001000

Restriction of atom numbers:

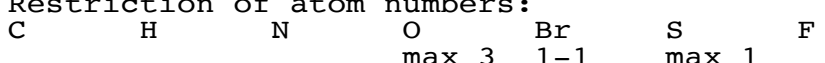

Number of calculated Formulas: $\quad 5 \quad \max 1$

Formula Diff. (ppm) theor. $\mathrm{m} / \mathrm{z}$

C8 H3 N1 O1 Br1 S1 F3 $\quad-1.15 \quad 296.906547$

C3 H2 N4 O1 Br1 S1 F4 $\quad-1.83 \quad 296.906346$

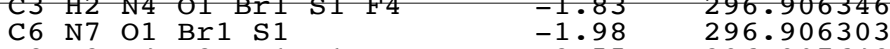

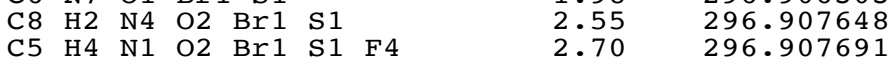
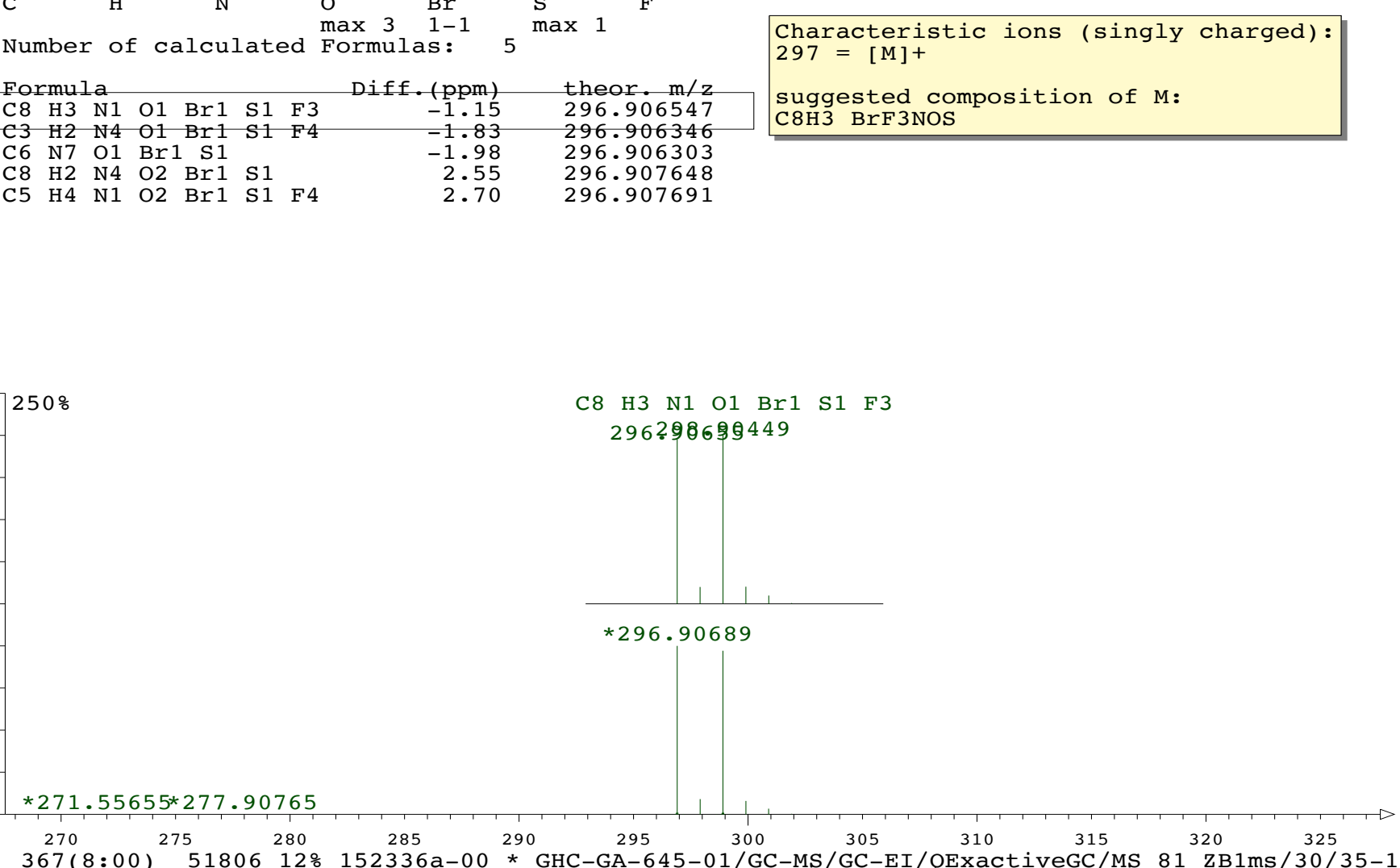


\section{${ }^{1} \mathrm{H}$ NMR}

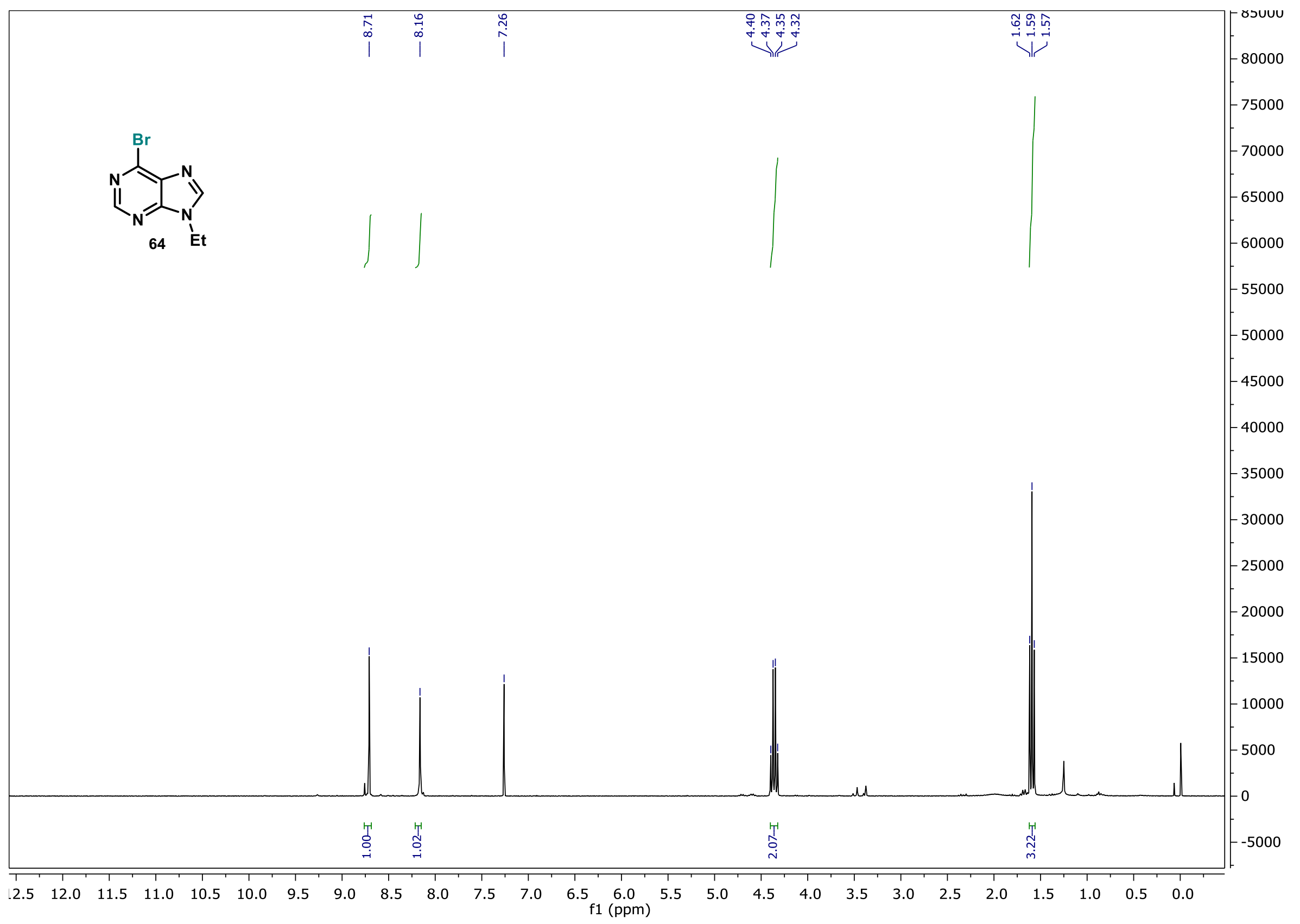




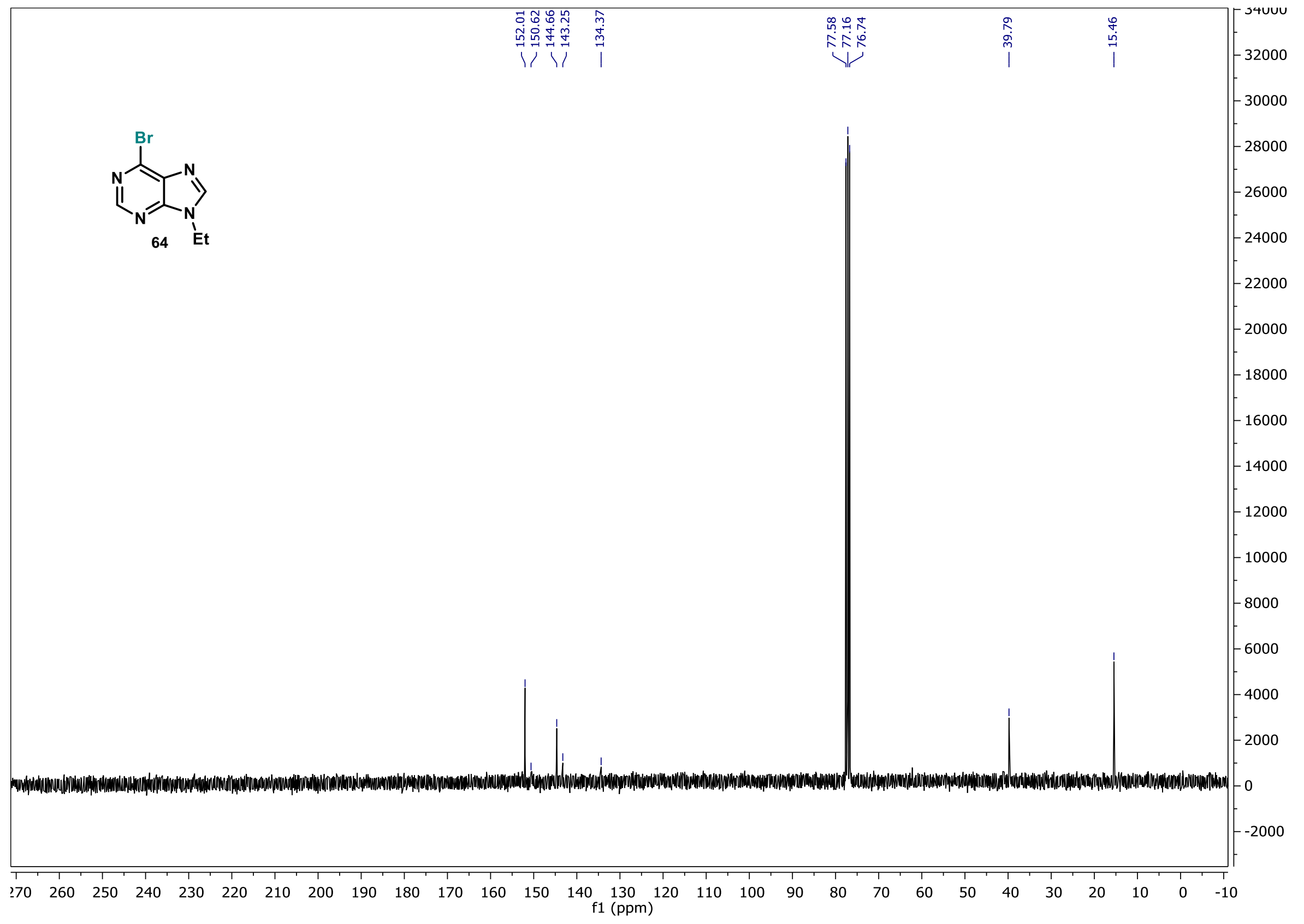


Mass to be matched $(\mathrm{m} / \mathrm{z}): 225.984890$ Charge: 1

Mass Tolerance: \pm 0.050000

Restriction of atom numbers:

$\begin{array}{llll}\mathrm{C} & \mathrm{H} & \mathrm{N} & \mathrm{Br} \\ 1-100 & 1-100 & 1-4 & 1-1\end{array}$

Number of calculated Formulas: 4

Formula

C7 $\begin{array}{lll}\text { H7 } & \text { N4 } & \text { Br } 1\end{array}$

C8 $\mathrm{H} 9$ N3 Br1

C9 H11 N2 Br 1

C10 H13 N1 Br
Diff. (ppm) $-0.09$

theor. $\mathrm{m} / \mathrm{z}$ 225.984870

225.997446

226.010023
22.03 .2021

File: 152395b-00.raw

Analyse: GHC-GA-653-01

COP: Dr. Clement Ghiazza

Messung: GC-MS

Ionisierung: GC-EI

Spektrometer: Q Exactive GC Orbitrap

Säule: MS 81 zBlms

Länge: $\quad 30$

Temp.: $\quad 35-15-300-3$

$\mathrm{GC}-\mathrm{Nr}$.:

ELNA-Nr .: $\quad 30330$

Auswerter: Haupt (2243) 

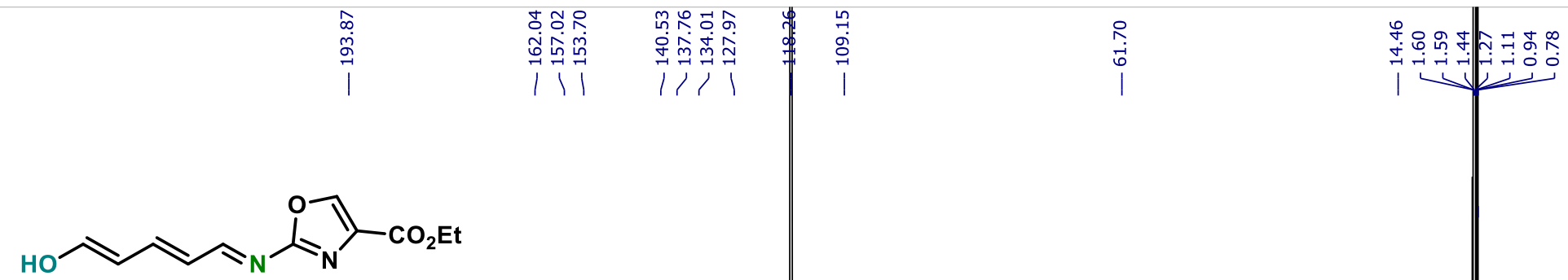
Mass to be matched $(\mathrm{m} / \mathrm{z}): 259.068840$ Charge: 1

Mass Tolerance: \pm 0.005000

03.12 .2020

Restriction of atom numbers:

$\begin{array}{lllll}\mathrm{C} & \mathrm{H} & \mathrm{N} & \mathrm{O} & \mathrm{Na} \\ 1-110 & 1-100 & 1-3 & 1-5 & 1-1\end{array}$

Number of calculated Formulas: 2

File: $150769 \mathrm{c}-00$

\begin{tabular}{|lrrrr|} 
Formula & & & Diff. $(\mathrm{ppm})$ & theor. $\mathrm{m} / \mathrm{z}$ \\
\hline C11 H12 & N2 & O4 Na1 & 0.33 & 259.068926
\end{tabular}

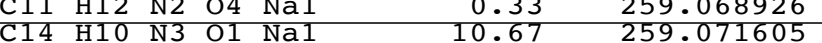

Analyse: GHC-GA-464-03

COP: Dr. Clement Ghiazza

Messung: HRMS ESIpos

Lösemittel: $\mathrm{CH} 2 \mathrm{Cl} 2+\mathrm{CH} 3 \mathrm{OH}$

Spektrometer: Exactive

Auswerter: Kohler (2243)

Suggestion:

C11 12 N2O 4

MW 236

Characteristicial ions:

$259=[236+\mathrm{Na}]+$ 